\title{
MONOGRAPH
}

INTERNATIONAL

\section{SOCIO-ECONOMIC AND MANAGEMENT CONCEPTS}

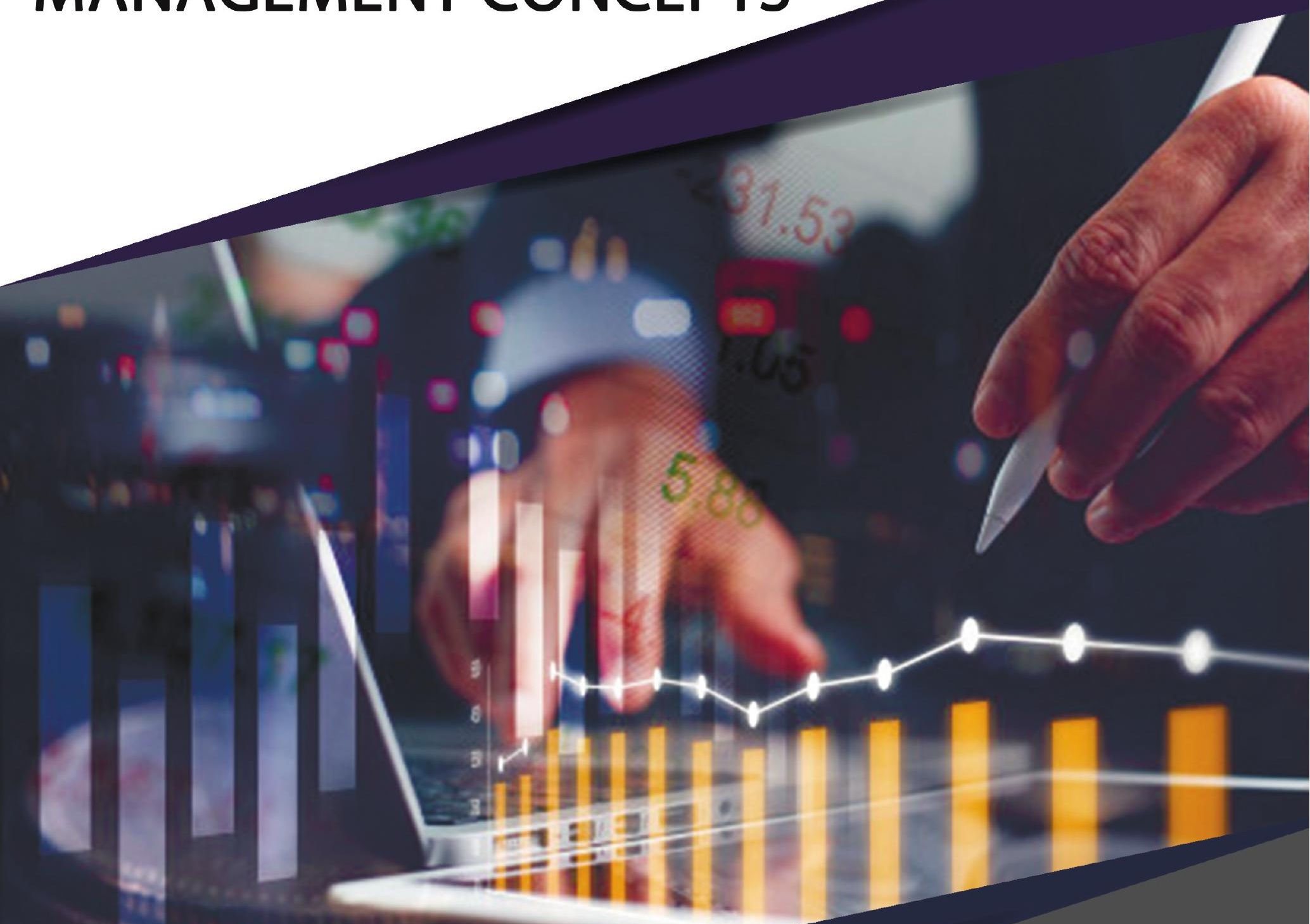

DOI 10.46299/ISG.2021.MONO.ECON.I

ISBN 978-1-63684-341-4

BOSTON (USA) - 2021

ISG-KONF.COM 
ISBN - 978-1-63684-341-4

DOI - 10.46299/ISG.2021.MONO.ECON.I

\section{Oacia-econamic and}

\section{management cancepts}

Gollective monograph

Boston 2021 
Library of Congress Cataloging-in-Publication Data

ISBN - 978-1-63684-341-4

\section{DOI- 10.46299/ISG.2021.MONO.ECON.I}

Authors - Krupelnytska I., Panasyuk V., Sokhatska О., Бєляєва Л., Пеняк Ю., Ментей О., Йолтуховська О., Ковалевська Н., Нестеренко І., Соколова Є., Лопін А., Лобачева I., Коцеруба Н., Сакун А., Цегельник H., Derkach O., Horbas I., Metoshop O., Moroz L., Амосов С., Ващенко В., Клебан О.Д., Устиновська Т.С., Галушка Н.О., Храбко М.I., Заріцька О.С., Савенко О., Mazurkevich I., Postova V., Moroz S., Кобилюх О.Я., Гірна О.Б., Краснодєд Т., Захарченко О., Попова Т., Почерніна Н., Псарьова I.С., Ромашко І.С., Пішенін І., Шевченко I.,

Тихонюк Д., Шевченко О.М., Чижевська М.Б., Жовнір Н.М., Шекета Є., Казюка H., Kobzev I., Kosenko V., Latynin M., Melnikov A., Pankova O., Shastun A., Kasperovich A., Soliar V., Zastavetska L., Zastavetskyi T., Taranova N., Балабанова Л.В., Германчук А.Н., Вдовенко Н., Герасимчук В., Коробова Н., Денисенко М.П., Бреус С.В., Коваль Л.А., Ліщук Н.В., Козак С.В., Онофрійчук О.П., Близнюк С.В., Морозов О.В., Кіріяк Ю.П., Морозов В.В., Козленко С.В., Морозова O.C., Boguslavskyу O., Nikitina T., Klochko V., Kulynych T., Kunicheva T., Postolna N., Holovanova O., Mishchenko V., Drougova O., Domnina I., Nikonenko U., Khalina O., Mandzinovska K., Балабанова Л.В., Сардак Е.В., Горященко Ю., Ільченко В., Гуртова Н., Жидовська Н., Прокопишин О., Журавська Н., Стефанович П., Стефанович І., Краснодєд Т., Бакіна Т., Попова Т., Захарченко О., Наливайко Н., Сухоняк С., Тельнов А., Решміділова С., Ткаченко І.П., Ніколаєва С.П., Буткевич О.В., Гора А.В., Штець Т.Ф., Alieksieiev I., Mazur A., Demchenko I., Yakusheva I., Havryliuk V., Khalatur S., Masiuk Y., Solodovnikova I., Protsun А., Лащик I., Віблий П, Мороз Н.В., Бондаренко Л.П., Третякова О., Харабара В., Грешко Р., Чорненька О.Б., Dehtyarova I., Melnyk L., Kubatko O., Karintseva O., Matsenko O., Gliebova N., Kovalova V., Kozyreva O., Svitlychna K., Koliada T., Yzik L., Максимов O., Пічугіна Ю., Максимова Ю., Сідельник О., Грудзевич У., Руденко 3., Фроленкова Н., Андрійцьо-Рузаєва А., Prokofieva O., Samoshkina I., Kudyrko L., Samsonova L., Panasyuk V., Brodovska O., Buchynska T., Плотніков O., Belei S., Dymchenko O., Rudachenko O., Patrizia G., Khailo Y., Khailo T., Yarova I., Аксьонова Т.С., Оболенський О.Ю., Громоздова Л.В., Леонтович С.П., Маляревський В.М., Косяк М.В., Шаравара Р.І., Боруцька Ю.З., Живко 3.Б., Прокопишин О.С., Лесик I.I., Кирчата I.M., Напольських К., Kaplin M., Bilan T., Makarov V., Amosova L., Bocheliuk V., Panov M., Uvarova A., Zinovchuk V., Kurovska N., Tsyganok V., Muhammad U.A., Martyn O., Zhyvko Z., Leskiv H., Rodchenko S., Іващенко M.B. 


\section{REVIEWER}

Kvasnytska Raisa Doctor of Economics, Professor of Finance, Banking and Insurance, Khmelnytsky National University

Dovgal Olena Dr.Sc. of Economics, Professor (Full), Professor of the Department of International Economic Relations of V.N.Karazin Kharkiv National University.

Breus Svitlana Doctor of Economic Sciences, Associate Professor, Professor of the Department of Management and Public Administration, Kyiv National University of Technologies and Design.

Published by Primedia eLaunch

https://primediaelaunch.com/

Text Copyright (C) 2021 by the International Science Group(isg-konf.com) and authors.

Illustrations (C) 2021 by the International Science Group and authors.

Cover design: International Science Group(isg-konf.com). C

Cover art: International Science Group(isg-konf.com). (C)

All rights reserved. Printed in the United States of America. No part of this publication may be reproduced, distributed, or transmitted, in any form or by any means, or stored in a data base or retrieval system, without the prior written permission of the publisher. The content and reliability of the articles are the responsibility of the authors. When using and borrowing materials reference to the publication is required.

The collection of scientific articles published is the scientific and practical publication, which contains scientific articles of students, graduate students, Candidates and Doctors of Sciences, research workers and practitioners from Europe and Ukraine. The articles contain the study, reflecting the processes and changes in the structure of modern science.

The recommended citation for this publication is:

Socio-economic and management concepts: collective monograph / Krupelnytska I., - etc. - International Science Group. - Boston : Primedia eLaunch, 2021. 660 p. Available at : DOI- 10.46299/ISG.2021.MONO.ECON.I 
TABLE OF CONTENTS

\begin{tabular}{|c|c|c|}
\hline \multirow{2}{*}{$\begin{array}{c}1 . \\
1.1\end{array}$} & \multicolumn{2}{|l|}{ ACCOUNTING AND AUDIT } \\
\hline & $\begin{array}{l}\text { Krupelnytska I. } \\
\text { INTANGIBLE DIGITAL ASSET IN ACCOUNTING: } \\
\text { PROBLEMS OF RECOGNITION AND ACCOUNTING }\end{array}$ & 13 \\
\hline 1.2 & $\begin{array}{l}\text { Panasyuk V., Sokhatska O. } \\
\text { FINANCIAL INSTRUMENTS IN THE WORLD AND IN } \\
\text { UKRAINE: ACCOUNTING AND ANALYTICAL CONCEPTS }\end{array}$ & 18 \\
\hline 1.3 & $\begin{array}{l}\text { Бєляєва Л., Пеняк Ю., Ментей О. } \\
\text { КОНЦЕПТУАЛЬНІ ПІДХОДИ } \quad \text { ОБЛІКУ } \\
\text { ОДЕРЖАНИХ ОСНОВНИХ ЗАСОБІВ }\end{array}$ & 27 \\
\hline 1.4 & $\begin{array}{l}\text { Йолтуховська О. } \\
\text { СОЦІАЛЬНІ ГАРАНТІЇ ПІДПРИЄМСТВА: ОБЛІКОВИЙ } \\
\text { ВИМІР }\end{array}$ & 34 \\
\hline 1.5 & $\begin{array}{l}\text { Ковалевська Н., Нестеренко І., Соколова Є., Лопін А. } \\
\text { ШЛЯХИ УДОСКОНАЛЕННЯ БУХГАЛТЕРСЬКОГО ОБЛІКУ } \\
\text { ЕЛЕМЕНТІВ ПРИРОДНОГО КАПІТАЛУ }\end{array}$ & 43 \\
\hline 1.6 & $\begin{array}{l}\text { Лобачева І., Коцеруба Н. } \\
\text { ОРГАНІЗАЦІЯ ТА ПЛАНУВАННЯ АУДИТУ РЕАЛІЗАЦІЇ } \\
\text { ПРОДУКЦІЇ ПІДПРИЄМСТВА }\end{array}$ & 48 \\
\hline 1.7 & 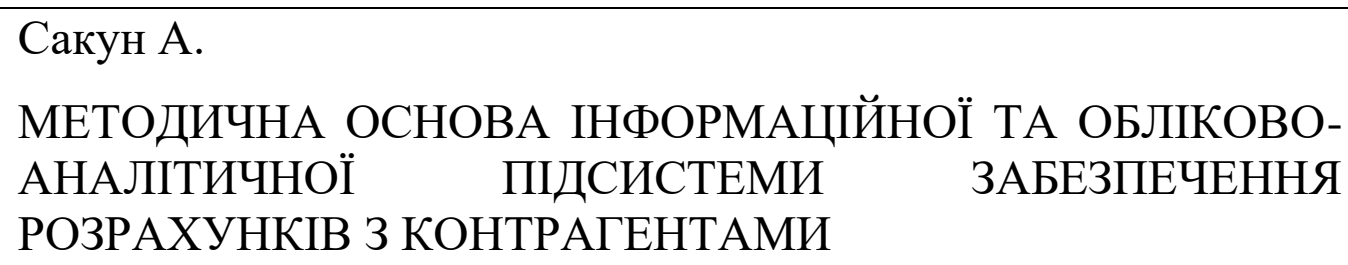 & 54 \\
\hline 1.8 & $\begin{array}{l}\text { Цегельник Н. } \\
\text { ДІДЖИТАЛІЗАЦІЯ } \quad \text { БУХГАЛТЕРСЬКОГО } \\
\text { ЕФЕКТИВНИЙ ЕЛЕМЕНТ УПРАВЛІННЯ }\end{array}$ & 60 \\
\hline 2. & ADMINISTRATIVE REGION AND BUDGET & \\
\hline 2.1 & $\begin{array}{l}\text { Derkach O., Horbas I., Metoshop O. } \\
\text { MODERN CONTROLLING: EVALUATION OF EFFICIENCY } \\
\text { AND DIRECTIONS OF IMPROVEMENT }\end{array}$ & 65 \\
\hline
\end{tabular}




\begin{tabular}{|c|c|c|}
\hline 3. & DEMOGRAPHY, ECONOMY, SOCIAL POLICY & \\
\hline 3.1 & $\begin{array}{l}\text { Moroz L. } \\
\text { FEATURES OF PERSONNEL MANAGEMENT OF THE } \\
\text { ENTERPRISE IN THE CONDITIONS OF CORONAVIRUS }\end{array}$ & 73 \\
\hline 3.2 & $\begin{array}{l}\text { Амосов С. } \\
\text { МОДЕЛІ ДЕРЖАВНОГО РЕГУЛЮВАННЯ ЗАЙНЯТОСТІ } \\
\text { НАСЕЛЕННЯ }\end{array}$ & 79 \\
\hline 3.3 & $\begin{array}{l}\text { Ващенко В. } \\
\text { ТЕОРЕТИЧНІ ТА ПРАКТИЧНІ АСПЕКТИ } \text { ПРИ } \\
\text { ФОРМУВАННЯ КАДРОВОГО РЕЗЕРВУ НА ПІДПРИЄМСВІ }\end{array}$ & 85 \\
\hline 3.4 & $\begin{array}{l}\text { Клебан О.Д., Устиновська Т.Є., Галушка Н.О., Храбко М.І., } \\
\text { Заріцька О.С. } \\
\text { КОВОРКІНГ ЯК СПОСІБ ВДОСКОНАЛЕННЯ ПРАКТИЧНИХ } \\
\text { НАВИКІВ СТУДЕНТІВ В НАВЧАЛЬНИХ ЗАКЛАДАХ } \\
\text { УКРАЇНИ }\end{array}$ & 94 \\
\hline 3.5 & $\begin{array}{l}\text { Савенко О. } \\
\text { УДОСКОНАЛЕННЯ } \quad \text { СИСТЕМИ } \\
\text { ПЕРСОНАЛОМ ПІДПРИСМСТВА }\end{array}$ & 99 \\
\hline 4. & ECONOMICS OF INDUSTRIES & \\
\hline 4.1 & $\begin{array}{l}\text { Mazurkevich I., Postova V. } \\
\text { THEORETICAL FOUNDATIONS OF } \quad \text { FORMING } \\
\text { COMPETITIVENESS OF THE } \\
\text { ESTABLISHMENTS }\end{array}$ & 106 \\
\hline 4.2 & $\begin{array}{llll}\text { Moroz S. } & & & \\
\text { INTEGRATED } & \text { INFORMATION } & \text { SYSTEMS } & \text { FOR } \\
\text { MANAGEMENT } & \text { OF AGRICULTURAL } & \text { ENTERPRISES } & \text { OF } \\
\text { UKRAINE } & & & \end{array}$ & 116 \\
\hline 4.3 & $\begin{array}{l}\text { Кобилюх О.Я., Гірна О.Б. } \\
\text { ТРЕНДИ ЦИФРОВІЗАЦІЇ } \quad \text { ЛОГІСТИКИ } \\
\text { COMMЕRСЕ }\end{array}$ & 121 \\
\hline 4.4 & $\begin{array}{l}\text { Краснодєд Т., Захарченко О., Попова Т., Почерніна Н. } \\
\text { СОЦІАЛЬНО-ЕКОНОМІЧНИЙ } \text { РОЗВИТОК } \text { ТУРИЗМУ } \\
\text { УКРАЇНІ }\end{array}$ & 128 \\
\hline
\end{tabular}




\begin{tabular}{|c|c|c|}
\hline 4.5 & $\begin{array}{l}\text { Псарьова І.С., Ромашко І.С. } \\
\text { МЕТАЛУРГІЙНА ГАЛУЗЬ УКРАЇНИ НА СВІТОВОМУ } \\
\text { РИНКУ: ПРОБЛЕМИ ТА ПРІОРИТЕТИ }\end{array}$ & 133 \\
\hline 4.6 & $\begin{array}{l}\text { Пішенін І. } \\
\text { СОЦІАЛЬНО-ЕКОНОМІЧНІ } \quad \text { ПРОБЛЕМИ } \\
\text { ОСВІТНІХ ЦИФРОВИХ ТЕХНОЛОГІЙ }\end{array}$ & 140 \\
\hline 4.7 & $\begin{array}{l}\text { Шевченко I., Тихонюк Д. } \\
\text { ПАНДЕМІЯ COVID-19 VS ТУРИСТИЧНА } \\
\text { УКРАЇНИ: КРИЗА ЧИ ГРАНД ШАНС? }\end{array}$ & 144 \\
\hline 4.8 & $\begin{array}{l}\text { Шевченко О.М., Чижевська М.Б., Жовнір Н.М. } \\
\text { ФІНАНСОВІ ТЕХНОЛОГІЇ: ПОТЕНЦІАЛ ТА РИЗИКИ } \\
\text { ВИКОРИСТАННЯ В УМОВАХ ЦИФРОВІЗАЦІЇ ЕКОНОМІКИ }\end{array}$ & 149 \\
\hline 4.9 & $\begin{array}{l}\text { Шекета Є., Казюка Н. } \\
\text { ОСОБЛИВОСТІ ІНВЕСТУВАННЯ } \quad \text { В } \quad \text { СІЛЬСЬКЕ } \\
\text { ГОСПОДАРСТВО УКРАЇНИ }\end{array}$ & 156 \\
\hline 5. & ECONOMY AND MANAGEMENT OF STATE GRATITUDE & \\
\hline 5.1 & $\begin{array}{l}\text { Kobzev I., Kosenko V., Latynin M., Melnikov A. } \\
\text { PROFESSIONAL TRAINING OF CIVIL SERVANTS: } \\
\text { DEVELOPMENT, FUNCTIONS AND PRINCIPLES }\end{array}$ & 161 \\
\hline 5.2 & $\begin{array}{l}\text { Pankova O., Shastun A., Kasperovich A. } \\
\text { SOCIAL AND LABOR SPHERE IN THE FACE OF } \\
\text { CHALLENGES OF THE COVID-19 PANDEMIC: PROBLEMS } \\
\text { AND OPPORTUNITIES OF ANTI-CRISIS REGULATION IN } \\
\text { UKRAINE }\end{array}$ & 169 \\
\hline 5.3 & $\begin{array}{l}\text { Soliar V. } \\
\text { FACTORS AND PHASE OF ECONOMIC COMPETITIVENESS - } \\
\text { THEIR MANIFESTATION IN UKRAINE }\end{array}$ & 174 \\
\hline 5.4 & 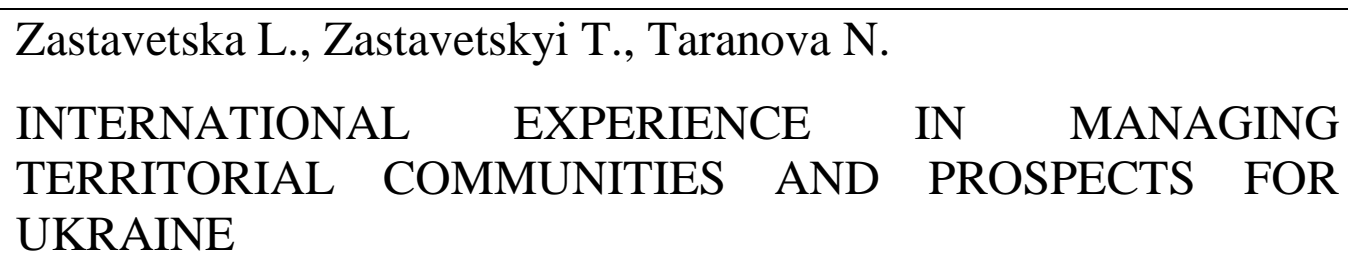 & 179 \\
\hline
\end{tabular}




\begin{tabular}{|c|c|c|}
\hline 5.5 & $\begin{array}{l}\text { Балабанова Л.В., Германчук А.Н. } \\
\text { ТРЕЙД-МАРКЕТИНГ КАК СОВРЕМЕННАЯ КОНЦЕПЦИЯ } \\
\text { СОВЕРШЕНСТВОВАНИЯ СИСТЕМЫ РАСПРЕДЕЛЕНИЯ }\end{array}$ & 187 \\
\hline 5.6 & $\begin{array}{l}\text { Вдовенко Н., Герасимчук В., Коробова Н. } \\
\text { ПРИКЛАДНІ РІШЕННЯ ДЛЯ РОЗРОБКИ ЕКОНОМІЧНОГО } \\
\text { МЕХАНІЗМУ РЕГУЛЮВАННЯ СТАЛОГО РОЗВИТКУ } \\
\text { ГАЛУЗЕЙ НАЦІОНАЛЬНОЇ ЕКОНОМІКИ }\end{array}$ & 192 \\
\hline 5.7 & $\begin{array}{l}\text { Денисенко М.П., Бреус С.В. } \\
\text { ПРОТИДІЯ } \quad \text { ДЕРЖАВИ } \quad \text { «ТІНІЗАЦЇ̈» } \quad \text { ЕКОНОМІКИ } \\
\text { ЧИННИК ПІДВИЩЕННЯ РІВНЯ ІІЇ ЕКОНОМІЧНОЇ БЕЗПЕКИ }\end{array}$ & 197 \\
\hline 5.8 & $\begin{array}{l}\text { Коваль Л.А., Ліщук Н.В., Козак С.В., Онофрійчук О.П., } \\
\text { Близнюк С.В. } \\
\text { ЕЛЕКТРОННИЙ БІЗНЕС В УКРАЇНІ: СТАН, ПЕРСПЕКТИВИ } \\
\text { ТА ПРОБЛЕМИ РОЗВИТКУ }\end{array}$ & 205 \\
\hline 5.9 & $\begin{array}{l}\text { Морозов О.В., Кіріяк Ю.П., Морозов В.В., КозЛенко С.В., } \\
\text { Морозова О.С. } \\
\text { АДАПТАЦІЯ АГРОТЕХНОЛОГІЙ ДО ЗМІН КЛІМАТУ В } \\
\text { УМОВАХ ПІВДЕННОГО СТЕПУ УКРАЇНИ }\end{array}$ & 217 \\
\hline 6. & $\begin{array}{l}\text { ECONOMY OF MANAGEMENT AND ADMINISTRATION OF } \\
\text { RADIO TECHNOLOGY }\end{array}$ & \\
\hline 6.1 & $\begin{array}{l}\text { Boguslavskyy O., Nikitina T. } \\
\text { THE DYNAMICS OF DEVELOPMENT OF THE MAIN TYPES } \\
\text { OF FOOD AND BEVERAGE SERVICES IN THE HOTEL AND } \\
\text { RESTAURANT ENTREPRENEURSHIP }\end{array}$ & 233 \\
\hline 6.2 & $\begin{array}{l}\text { Klochko V., Kulynych T., Kunicheva T., Postolna N., } \\
\text { Holovanova O. } \\
\text { WAYS TO IMPROVE THE CAREER MANAGEMENT SYSTEM } \\
\text { THROUGH STAFF MOTIVATION IN THE CONTEXT OF } \\
\text { TRENDS IN THE IT FIELD }\end{array}$ & 239 \\
\hline 6.3 & $\begin{array}{l}\text { Mishchenko V., Drougova O., Domnina I. } \\
\text { MODERN INNOVATIVE CONCEPT OF ANTI-CRISIS } \\
\text { ENTERPRISE MANAGEMENT }\end{array}$ & 243 \\
\hline
\end{tabular}




\begin{tabular}{|c|c|c|}
\hline 6.4 & $\begin{array}{l}\text { Nikonenko U., Khalina O., Mandzinovska K. } \\
\text { THEORETICAL AND METHODOLOGICAL PRINCIPLES OF } \\
\text { ASSESSMENT OF THE LEVEL OF FINANCIAL SECURITY OF } \\
\text { THE ENTERPRISE }\end{array}$ & 252 \\
\hline 6.5 & $\begin{array}{l}\text { Балабанова Л.В., Сардак Е.В. } \\
\text { КОНЦЕПТУАЛЬНЫЕ } \quad \text { ОСНОВЫ } \\
\text { ПОТЕНЦИАЛОМ ПРЕДПРИЯТИЯ }\end{array}$ & 263 \\
\hline 6.6 & $\begin{array}{l}\text { Горященко Ю., Ільченко В., Гуртова Н. } \\
\text { КОНЦЕПТУАЛЬНІ ЗАСАДИ ЗАБЕЗПЕЧЕННЯ СТІЙКОГО } \\
\text { ЕКОНОМІЧНОГО РОЗВИТКУ ПІДПРИСМСТВ }\end{array}$ & 268 \\
\hline 6.7 & $\begin{array}{l}\text { Жидовська Н., Прокопишин О. } \\
\begin{array}{lr}\text { ОБГРУНТУВАННЯ } & \text { СИСТЕМИ } \\
\text { ЕФЕКТИВНОСТІ } & \text { ПОКАЗНИКІВ } \\
\text { БУРЯКОЦУКРОВОГО ПІДКОМПЛЕКСУ }\end{array}\end{array}$ & 277 \\
\hline 6.8 & $\begin{array}{l}\text { Журавська Н., Стефанович П., Стефанович I. } \\
\text { АНАЛІЗ ВИРОБНИЧОГО РИЗИКУ } 3 \text { ДОПОМОГОЮ } \\
\text { ЕКСПЕРТНОЇ ОЦІНКИ }\end{array}$ & 283 \\
\hline 6.9 & $\begin{array}{l}\text { Краснодєд Т., Бакіна Т., Попова Т., Захарченко О. } \\
\text { ЕКОНОМІЧНИЙ МЕХАНІЗМ РОЗРАХУНКУ ВАРТОСТІ ТА } \\
\text { ПРОСУВАННЯ ТУРУ В КОНТЕКСТІ ТУРОПЕРАТОРСЬКОЇ } \\
\text { ДІЯЛЬНОСТІ ПІДПРИЄМСТВА }\end{array}$ & 297 \\
\hline 6.10 & 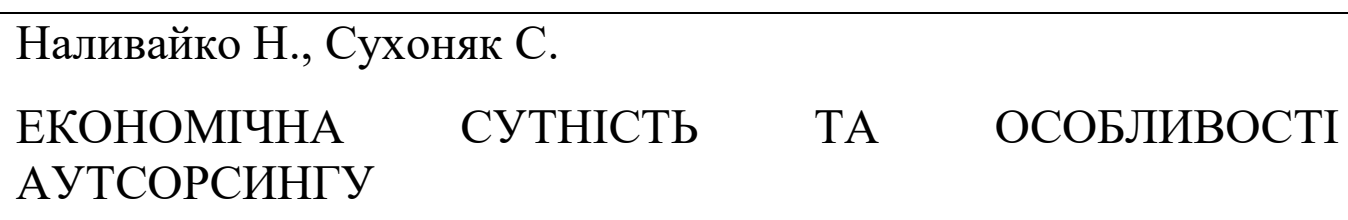 & 302 \\
\hline 6.11 & $\begin{array}{l}\text { Тельнов А., Решміділова С. } \\
\text { МАРКЕТИНГОВІ } \quad \text { ІНСТРУМЕНТИ } \\
\text { ПІДПРИСМСТВ ЛЕГКОЇ ПРОМИСЛОВОСТІ }\end{array}$ & 309 \\
\hline 6.12 & $\begin{array}{l}\text { Ткаченко І.П., Ніколаєва С.П., Буткевич О.В., Гора А.В., } \\
\text { Штець Т.Ф. } \\
\text { ОБЛІКОВА ПОЛІТИКА ЯК ФАКТОР УПРАВЛІННЯ } \\
\text { ДОХОДАМИ І ФІНАНСОВИМИ РЕЗУЛЬТАТАМИ } \\
\text { ДІЯЛЬНОСТІ ПІДПРЕМСТВА }\end{array}$ & 315 \\
\hline
\end{tabular}




\begin{tabular}{|c|c|c|}
\hline \multirow{2}{*}{$\frac{7 .}{7.1}$} & \multicolumn{2}{|l|}{ FINANCE, PENNILESS AND CREDIT } \\
\hline & $\begin{array}{l}\text { Alieksieiev I., Mazur A. } \\
\text { PROVIDING SUSTAINABLE FINANCE: THE ROLE OF } \\
\text { FINANCIAL INSTITUTIONS }\end{array}$ & 323 \\
\hline 7.2 & $\begin{array}{l}\text { Demchenko I., Yakusheva I. } \\
\text { UKRAINE'S POSITION ON THE WORLD FINANCIAL } \\
\text { MARKET }\end{array}$ & 332 \\
\hline 7.3 & 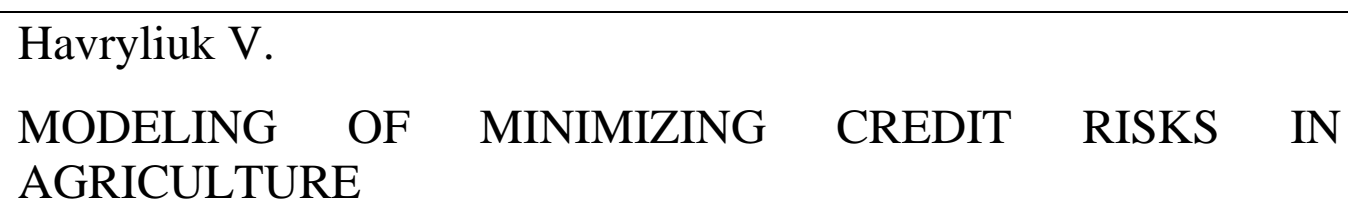 & 337 \\
\hline 7.4 & $\begin{array}{l}\text { Khalatur S., Masiuk Y., Solodovnikova I., Protsun A. } \\
\text { MANAGEMENT AND FORMATION OF CASH FLOWS IN } \\
\text { AGRICULTURAL ENTERPRISES }\end{array}$ & 342 \\
\hline 7.5 & $\begin{array}{l}\text { Лащик І., Віблий П. } \\
\text { СУЧАСНІ ТЕНДЕНЦІЇ ТА ПРОБЛЕМИ ФОРМУВАННЯ } \\
\text { ФІНАНСОВИХ РЕСУРСІВ КОМЕРЦІЙНИХ БАНКІВ }\end{array}$ & 351 \\
\hline 7.6 & $\begin{array}{l}\text { Мороз Н.В., БонДаренКо Л.П. } \\
\text { БАНКІВСЬКА СИСТЕМА УКРАЇНИ: ТЕНДЕНЦІЇ РОЗВИТКУ } \\
\text { ТА НАСЛІДКИ КРИЗИ СОVID-19 }\end{array}$ & 358 \\
\hline 7.7 & $\begin{array}{l}\text { Третякова О., Харабара В., Грешко Р. } \\
\text { СУЧАСНІ ЦИФРОВІ ТЕХНОЛОГІЇ В БАНКІВСЬКІЙ СФЕРІ } \\
\text { УКРАЇНИ }\end{array}$ & 376 \\
\hline 7.8 & $\begin{array}{l}\text { Чорненька О.Б. } \\
\text { РИЗИК-МЕНЕДЖМЕНТ } \quad \text { В } \quad \text { СИСТЕМІ } \\
\text { ЗАБОРГОВАНІСТЮ ПІДПРИСМСТВА }\end{array}$ & 382 \\
\hline 8. & INNOVATIVE ECONOMY & \\
\hline 8.1 & $\begin{array}{l}\text { Dehtyarova I., Melnyk L., Kubatko O., Karintseva O., Matsenko O. } \\
\text { DISRUPTIVE TECHNOLOGIES FOR GREEN ECONOMY } \\
\text { FORMATION IN CONDITIONS OF THE FOURTH } \\
\text { INDUSTRIAL REVOLUTION: THE EU EXPERIENCE }\end{array}$ & 390 \\
\hline
\end{tabular}




\begin{tabular}{|c|c|c|}
\hline 8.2 & $\begin{array}{l}\text { Gliebova N., Kovalova V., Kozyreva O., Svitlychna K., Koliada T. } \\
\text { INTELLECTUAL ASSETS OF HUMAN POTENTIAL IN A } \\
\text { DIGITAL ECONOMY }\end{array}$ & 395 \\
\hline 8.3 & $\begin{array}{l}\text { Yzik L. } \\
\text { THE CONCEPTUAL BASIS OF INNOVATION MANAGEMENT } \\
\text { IN SOCIALLY-ORIENTED MARKETING INCLUDES }\end{array}$ & 412 \\
\hline 8.4 & $\begin{array}{l}\text { Максимов О., Пічугіна Ю., Максимова Ю. } \\
\text { СУЧАСНІ } \quad \text { ПІДХОДИ } \\
\text { ІНФОРМАЦІЙНИХ ПОТОКІВ НА ПІДПБКИ } \\
\text { ВЕЛИКИХ }\end{array}$ & 418 \\
\hline 8.5 & $\begin{array}{l}\text { Сідельник О., Грудзевич У., Руденко } 3 . \\
\text { СУЧАСНІ ТЕХНОЛОГІЇ У БАНКІВСЬКОМУ БІЗНЕСІ }\end{array}$ & 423 \\
\hline 8.6 & 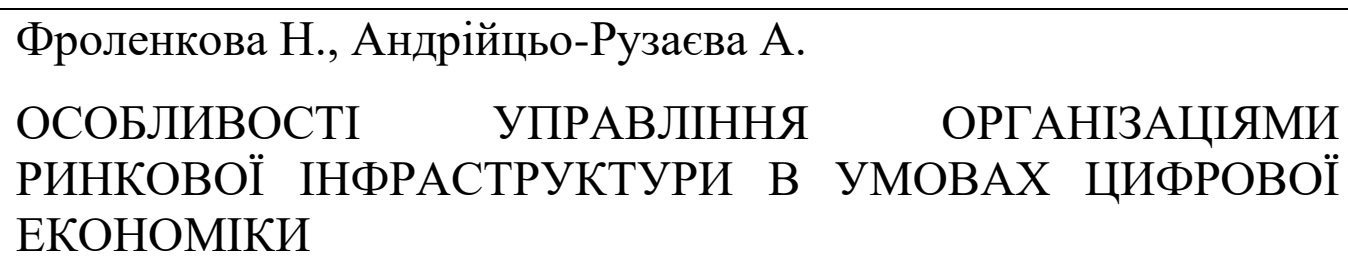 & 432 \\
\hline 9. & INSURANCE & \\
\hline 9.1 & $\begin{array}{lllll}\text { Prokofieva } \mathrm{O} . & & & & \\
\text { PROSPECTS } \quad \text { FOR } \quad \text { THE } & \text { DEVELOPMENT } & \text { OF } & \text { THE } \\
\text { REINSURANCE MARKET OF UKRAINE } & & \end{array}$ & 438 \\
\hline 9.2 & $\begin{array}{l}\text { Samoshkina I. } \\
\text { PROBLEMS OF LIFE INSURANCE DEVELOPMENT IN } \\
\text { UKRAINE }\end{array}$ & 442 \\
\hline \multicolumn{3}{|c|}{$10 . \quad$ INTERNATIONAL ECONOMIC NEWS } \\
\hline 10.1 & $\begin{array}{l}\text { Kudyrko L., Samsonova L. } \\
\text { NON-EQUITY MODES (NEMS) OF PRODUCTION IN ASEAN } \\
\text { COUNTRIES IN CONDITIONS OF GVCS REORGANIZATION }\end{array}$ & 452 \\
\hline 10.2 & 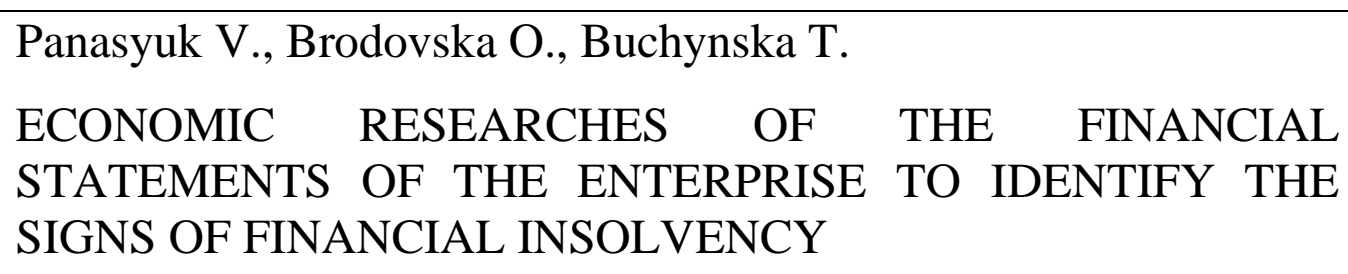 & 460 \\
\hline 10.3 & $\begin{array}{l}\text { Плотніков О. } \\
\text { ФІНАНСОВА ГЛОБАЛІЗАЦІЯ В КОНТЕКСТІ СУЧАСНОГО } \\
\text { РОЗВИТКУ СВІТОВОЇ ЕКОНОМІКИ }\end{array}$ & 483 \\
\hline
\end{tabular}




\begin{tabular}{|c|c|c|}
\hline \multicolumn{3}{|c|}{ 11. MECHANISMS OF REGULATION OF THE ECONOMY } \\
\hline 11.1 & $\begin{array}{l}\text { Belei S. } \\
\text { EVOLUTION OF SCIENTIFIC UNDERSTANDING OF "RURAL } \\
\text { DEVELOPMENT" IN THE CONTEXT OF THE CONCEPT OF } \\
\text { ORGANIZATIONAL AND ECONOMIC MECHANISM OF } \\
\text { RURAL DEVELOPMENT }\end{array}$ & 491 \\
\hline 11.2 & $\begin{array}{l}\text { Dymchenko O., Rudachenko O., Patrizia G., Khailo Y., Khailo T. } \\
\text { ENTREPRENEURIAL ADAPTATION OF PUBLIC UTILITIES: } \\
\text { UKRAINIAN EXPERIENCE }\end{array}$ & 499 \\
\hline 11.3 & 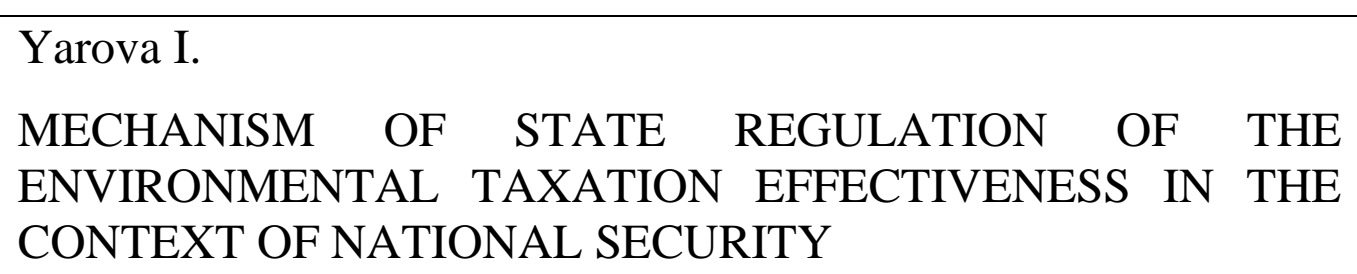 & 505 \\
\hline 11.4 & $\begin{array}{lll}\text { Аксьонова Т.С. } & & \\
\text { ДЕРЖАВНЕ РЕГУЛЮВАННЯ } & \text { ТА } & \text { ПРИНЦИПИ } \\
\text { ЗАБЕЗПЕЧЕННЯ } & \text { ФІНАНСОВОЇ } & \text { СКЛАДОВОЇ } \\
\text { ЕКОНОМІЧНЇ БЕЗПЕКИ УКРАЇНИ } & \end{array}$ & 515 \\
\hline 11.5 & 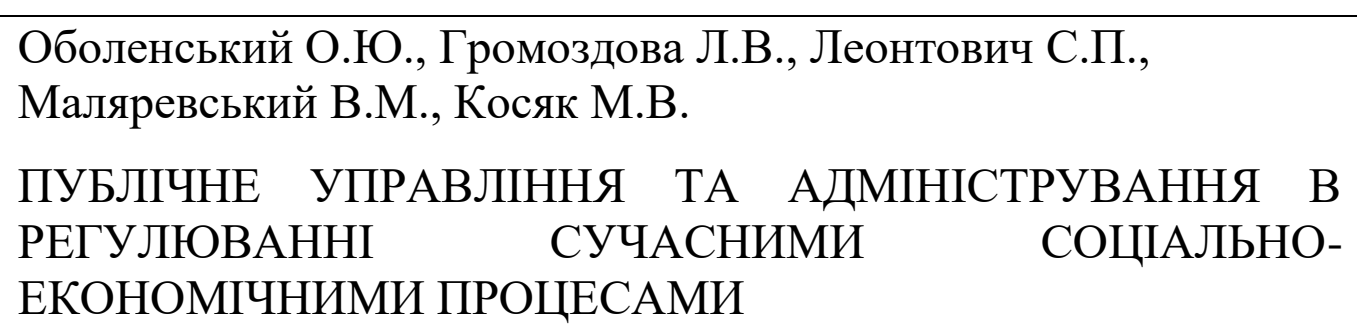 & 521 \\
\hline 11.6 & $\begin{array}{lc}\text { Шаравара Р.І. } & \\
\text { МЕХАНІЗМИ } & \text { ФОРМУВАННЯ }\end{array}$ & 528 \\
\hline 12. & MICRO AND MACRO ECONOMY & \\
\hline 12.1 & $\begin{array}{l}\text { Боруцька Ю.З., Живко З.Б., Прокопишин О.С., Лесик І.І. } \\
\text { ОСОБЛИВОСТІ РЕЛЬЕФУ БАСЕЙНУ РІКИ СТРИЙ ТА ЇХ } \\
\text { ВПЛИВ НА ЕКОНОМІКУ РЕГІОНУ }\end{array}$ & 533 \\
\hline 12.2 & 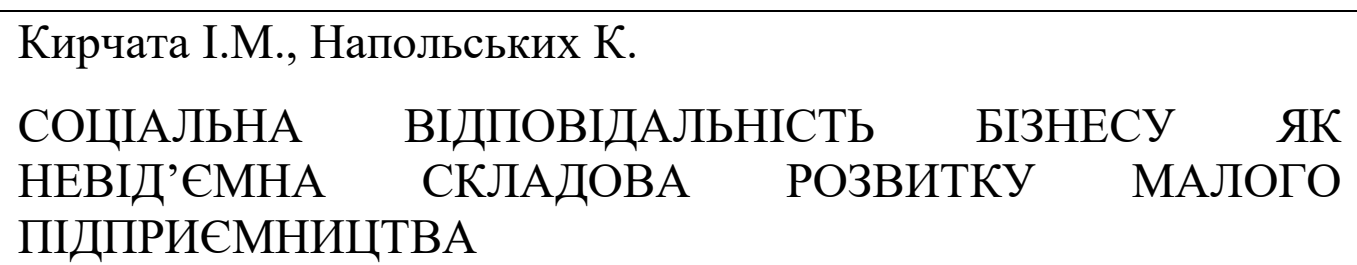 & 541 \\
\hline
\end{tabular}




\begin{tabular}{|c|c|c|}
\hline \multicolumn{3}{|c|}{ 13. QUANTITATIVE METHODS IN ECONOMICS } \\
\hline 13.1 & $\begin{array}{l}\text { Kaplin M., Bilan T., Makarov V. } \\
\text { OPTIMIZATION APPROACH TO DETERMINING CHANGES } \\
\text { IN OUTPUT AND EQUILIBRIUM PRICES }\end{array}$ & 551 \\
\hline \multicolumn{3}{|c|}{$\begin{array}{ll}14 . & \text { SOCIOLOGY }\end{array}$} \\
\hline 14.1 & $\begin{array}{l}\text { Amosova L. } \\
\text { MODÈLE DE COMPÉTENCES DE LA FONCTION PUBLIQUE } \\
\text { FRANÇAISE }\end{array}$ & 557 \\
\hline 14.2 & $\begin{array}{l}\text { Bocheliuk V., Panov M., Uvarova A. } \\
\text { SOCIO-PSYCHOLOGICAL FEATURES OF THE } \\
\text { DEVELOPMENT OF IDEAS ABOUT THE WORLD IN THE } \\
\text { CHILDREN WITH SPECIAL EDUCATIONAL NEEDS }\end{array}$ & 562 \\
\hline 14.3 & $\begin{array}{l}\text { Zinovchuk V., Kurovska N., Tsyganok V. } \\
\text { SOCIAL RESPONSIBILITY AND ETHICS OF MARKETING }\end{array}$ & 571 \\
\hline \multicolumn{3}{|c|}{ 15. $\quad$ THEORY AND HISTORY } \\
\hline 15.1 & $\begin{array}{l}\text { Muhammad U.A., Zhyvko Z., Leskiv H., Rodchenko S., Martyn O. } \\
\text { LOCAL ELECTIONS AND CAPITAL INVOLVEMENT IN } \\
\text { SOUTH KALIMANTAN }\end{array}$ & 582 \\
\hline 15.2 & $\begin{array}{l}\text { Іващенко М.В. } \\
\text { АНОМАЛІЇ ТА ЕФЕКТИ В ЕКОНОМІЧНІЙ ПОВЕДІНЦІ } \\
\text { ІСТОРІЯ ДОСЛІДЖЕНЬ ТА ПРОЯВИ В СУЧАСНИХ } \\
\text { ЕКОНОМІЧНИХ ВІДНОСИНАХ }\end{array}$ & 591 \\
\hline & REFERENCES & 603 \\
\hline
\end{tabular}




\section{SECTION 1. ACCOUNTING AND AUDIT}

\subsection{Intangible digital asset in accounting: problems of recognition and accounting}

In Ukraine, the real popularity of cryptocurrencies began in 2014, when enthusiasts created a public organization for the distribution, development and study of bitcoins and other virtual currencies in our country - Bitcoin Foundation Ukraine $(\mathrm{BFU})$. Around this time, the first companies and agencies appeared that offered the physical exchange of cryptocurrencies for cash, as well as money transactions on the Internet. Recently, BFU together with several foreign clearing companies conducted an interesting study on the popularity and use of bitcoins in Ukraine. The data turned out to be very interesting - Ukraine was among the top ten countries in the world that used nodes or bitcoin nodes. About $40 \%$ of all transactions with this cryptocurrency were concluded on exchanges with Ukrainian roots. Experts explain this fact by the fact that Ukraine is also one of the first in terms of quantity and quality of training of IT specialists.

Despite this, the general public still knows little about cryptocurrency, including bitcoins. The reason for this is the fact that in Ukraine there are no actual and de jure payment systems that work with cryptocurrencies. The National Bank of Ukraine even commented on the use of this type of currency: "... virtual currency bitcoin is considered a monetary surrogate that has no real value and cannot be used by individuals and legal entities in Ukraine as a means of payment, as it contradicts Ukrainian law." [1] According to one of the founders of the BFU, this is not correct, because then there will be no foreign exchange market in our country, but it does not prevent Ukrainians from buying or selling foreign exchange.

For this reason, one of the strategic directions of the BFU's work can be considered the development and implementation of regulations and other normative documents of a legislative nature that would bring bitcoin market participants out of the shadows. 
On December 19, 2016, the Ukrainian Stock Exchange began trading in futures contracts on the bitcoin index. The contract specification is registered with the NSSMC. This is actually the first regulated market in the world to offer bitcoin futures. [2]

In 2016, the law firm Axon Partners became the first Ukrainian company to add bitcoins to its authorized capital. The National Bank of Ukraine (NBU) did not recognize bitcoin as a currency or a means of payment.

While the hryvnia exchange rate is unstable, the most popular cryptocurrency is steadily gaining momentum. Due to the rapid growth of the exchange rate, "bitcoin fever" is spreading around the world - the high demand for virtual money stimulates the growth of the exchange rate almost at the speed of light and has already reached a record level of more than 7 thousand dollars.

Bitcoin is the first virtual currency that is protected from hacking by a number of cryptographic methods. The concept of the currency was voiced in 2008 by a person or group of people nicknamed Satoshi Nakamoto. [3] This electronic currency is actually a mathematical code that, according to the authors, cannot be counterfeited or stolen. With it you can make purchases and other transactions, exchange other currency and much more.

Bitcoin itself is not essentially a currency, as it does not have an issuance center in which it is issued, ie structures such as the National Bank. In fact, it is a mathematical code that has certain properties. Instead, it is useful that bitcoin cannot be stolen and all related transactions can be easily tracked. Bitcoin is programmed for a limited amount, which makes it invulnerable to inflation. One of the main advantages is decentralized support. However, there is no structure in which bitcoins can be "printed", and there is no single server on which the entire currency would "lie". Instead, it is a database that is supported and synchronized by thousands of computers at the same time. For example, to block a transaction, you need to do it simultaneously on thousands of devices around the world.

The peculiarity of transactions is that the transmissions take place in a network without intermediaries - this eliminates the possibility of blocking. Transactions always 


\section{SOCIO-ECONOMIC AND MANAGEMENT CONCEPTS}

have a low fixed fee regardless of the number of bitcoins transferred. When a transaction takes place online, information about it remains open to all and forever. However, the network does not collect names, only bitcoin code.

Bitcoins are stored in an open database - a blockchain, which is a decentralized public registry. It's basically a type of e-book that is stored on thousands of computers at once. The blockchain contains only the address of bitcoins in the form of a code. To delete them or make a transaction, you need special access - a private key that belongs only to the owner of the asset. So you can keep track of absolutely every transaction that has ever taken place in the system.

How exactly can cryptocurrencies be reflected in accounting if the company works with them and wants these transactions to be legal from the point of view of Ukrainian legislation?

The main problem of legalization of cryptocurrency in Ukraine is that many entrepreneurs and companies in Ukraine create, exchange intangible digital assets (hereinafter "cryptocurrencies") without creating a business unit, proper accounting and tax accounting. Entrepreneurs, companies engaged in such activities, often do not comply with current legislation of Ukraine, although they make a profit from the sale or creation of "cryptocurrencies", due to lack of financial accounting and understanding of the activity as a whole.

Now the crypto business is an established industry with its own producers, sellers and users of information. Therefore, legalization is already acute for our entrepreneurs. [4]

In this regard, all legal entities have a question how to conduct business on the production and exchange of "cryptocurrency" in Ukraine in accordance with current legislation. The joint declaration of financial supervisors on the state of cryptocurrencies in Ukraine dated November 30, 2017 states: "The complex legal nature of cryptocurrencies does not allow recognizing them as cash, currency and means of payment of another country, currency value, electronic money or securities , nor a monetary surrogate. "The letter further concludes that the nature of cryptocurrencies is perfectly legal, although there is no practice of regulating them. [5] 


\section{SOCIO-ECONOMIC AND MANAGEMENT CONCEPTS}

We note that for the conduct of business activities of a legal entity, the registration of a business unit is not enough, as in any other case, to be able to keep proper records.

We propose to consider aspects of accounting and tax accounting for the creation and exchange of "cryptocurrencies" - intangible digital assets for legal entities

Criteria for recognizing an intangible digital asset:

- can be identified and sold separately;

- is a non-monetary asset;

- do not have a physical shape;

- they are likely to bring future economic benefits.

The cost of an intangible digital asset created by an entity in accordance with paragraph 11 of IAS 8, intangible assets, includes direct labor costs, direct material costs and other costs directly attributable to the creation of the intangible asset and benefits from it. [6]

Due to the fact that the price of "cryptocurrency" is unstable, which means that it changes rapidly, the only method of accounting after recognition is accounting for revalued value.

Paragraph 19 of IAS 8 Intangible Assets allows an entity to revalue an intangible digital asset at fair value at the balance sheet date of the intangible assets for which there is an active market. In this case, we recommend revaluing such an asset at each balance sheet date and creating a bank statement that should include a reference to the price of such an asset from the official cryptocurrency exchange.

Accounting and tax accounting for the creation of an intangible digital asset "Bitcoin" includes the accumulation of costs associated with the acquisition of the account "Acquisition (creation) of intangible assets" and subsequent commissioning on the account "Intangible assets"

It should be noted that all costs included in the initial costs must be documented in order to determine (calculate) tax liabilities. The income taxpayer uses accounting data on income and expenses in accordance with the section of the Tax Code. [4] 


\section{SOCIO-ECONOMIC AND MANAGEMENT CONCEPTS}

To document the above processes of creating a "cryptocurrency" of an intangible digital asset, and then putting it into operation, you need to develop an internal local document: "Act of putting an intangible digital asset into operation", which is approved by the commission. [7] To justify the cost of creating such an intangible digital asset, process cards must be issued and approved in the company's accounting policies for items and calculation methods. The above documents are approved by the director of the enterprise and submitted for signature for review by material persons.

Accounting for the revaluation of the intangible digital asset "Bitcoin" is reflected in the revaluation as income (account "Other income"), the discount is reflected as an expense on the account "Other expenses"

In order to sell (exchange) "cryptocurrency" to the company, you must first transfer the NCA to non-current assets held for sale. Depreciation ends on the month following such transfer. NCAs are then transferred to the agent in accordance with the document "Act of transfer of intangible digital assets". Under the agreement, the agent undertakes to convert the digital asset into a foreign currency and transfer it to the account of the company that transferred the intangible digital asset.

Accounting and tax accounting for the exchange of intangible digital asset "Bitcoin" is carried out as a regular sale or exchange of intangible assets

As we see above, the intangible digital asset Bitcoin is completely legal, ie it can be created legally, accounted for as an intangible asset in the company, revalued at the balance sheet date and exchanged for cash. 


\subsection{Financial instruments in the world and in Ukraine: accounting and analytical concepts}

На розвинутих ринках уже більше двадцяти років фінансова інженерія $є$ визнаною, високо оплачуваною, престижною професією. Команди фінансових інженерів працюють над розробкою нових фінансових інструментів, схем фінансування, інвестиційним проектуванням у державних та комерційних банках, страхових компаніях, на фондових та ф’ючерсних біржах, інвестиційних та грошових фондах і у звичайних корпораціях, які належать до нефінансового сектору економіки.

Для всіх, хто займається бізнесом, отримання кредитних коштів у банківських установах є досить складним та багатогранним процесом, який вимагає значних витрат робочого часу, наявності певного виду забезпечення, в основному надійного (депозити, нерухоме майно), та додатково витрачених коштів на побічні обслуговуючі операції, такі як експертна оцінка, страхування, оплата послуг нотаріуса, юриста тощо.

У свою чергу, комерційні банки неохоче йдуть на кредитування новостворених підприємств, не бажаючи поділяти ризики, пов'язані з початком бізнесу. Так само важко видаються інвестиційні кредити. Враховуючи високі ризики, породжені недосконалістю законодавчої бази, відсутністю надійної системи правового захисту кредиторів, банки скоріше відмовляють у видачі даних кредитів, вважаючи, що краще втратити певний рівень прибутку, ніж отримати доволі реальний збиток. Окрім цього існуюча проблема із строковістю ресурсної бази та коефіцієнту її покриття, змушує провідні банки скорочувати строки кредитування юридичних осіб.

Для нейтралізації впливу інфляції було створено нові кредитні деривативи, тенденції сек'юритизації призвели до використання свопів на випадок дефолту, введення єврооблігацій, пов'язаних з індексами акцій тощо. Уже звичними фінансовими інструментами $є$ ф’ючерси на погоду, за допомогою яких страхуються від втрат, спричинених температурними коливаннями, інструменти, 
за допомогою яких одночасно прогнозується ціна та дохід, синтетичні контракти, які поєднують ф’ючерси, свопи та опціони тощо.

В України названі процеси поки що маловідомі. В економічній літературі, як і у законотворчому процесі, методологічні аспекти цього сегмента ринку майже не досліджуються, термінологічний понятійний апарат не визначений, для ідентифікації понять та категорій використовуються кальки англомовних термінів. В той же час банківська практика уже має приклади застосування фінансових інновацій i, особливо, фінансових схем для оптимізації оподаткування з використанням офшорів.

Варто зазначити, що і у країнах розвинутого ринку, де строковий ринок функціонує особливо успішно, зберігається невизначеність у його дефініціях. Більшість визнаних зарубіжних вчених-теоретиків фінансових ринків, та ф’ючерсних зокрема, як правило, не дають визначення цим поняттям, сприймаючи їх як давно відомі, або такі, сутність яких не потребує пояснень. Такий підхід може бути прийнятним для підручників та монографій зарубіжних авторів, де уже впродовж багатьох десятиліть формується та удосконалюється законодавча база, іє зовсім не прийнятним для наших умов, коли основні ринкові відносини лише починають втілюватися у законах.

У США та Великобританії, де немає законодавчого визначення цінних паперів, строкові інструменти пов'язують з термінами security, виділяючи їх на практиці та у економічній літературі вживанням терміну derivatives. Звідси і походять україномовні кальки деривативи та переклад цього терміну похідні изіні папери.

У країнах континентальної Свропи строкові контракти не належать до цінних паперів, де суть останніх формалізовано у законодавчих актах. Показовим у цьому аспекті є досвід Франції, де для ф’ючерсних ринків поряд 3 термінами строковий ринок (le marche a terme ou future) широко використовується термін ринок деривативів (les marches derives), а ринок цінних паперів має свої терміни, причому категорію цүінні папери поділено на ринок боргових зобов'язань, куди відносять акції та облігації (marches des valeurs 
mobiliers) та ринок інших комериійних паперів, як правило короткострокових, тобто паперів грошового ринку (marches des titres).

В Україні процес становлення фінансового та товарного ринків відбувається з використанням законодавства та торговельної практики різних країн, які не завжди є сумісними. Законодавство у сфері фондового ринку, а саме Закон України «Про цінні папери і фондову біржу», що був чинним з 1991 до 2006 року, та нова редакція Закону України «Про цінні папери і фондовий ринок» 2006 року із змінами і доповненнями від 02.09.2020 року трактує суть як цінних паперів, так і їхніх похідних (що є запозиченням із англо-американського законодавства).

Так, з 06.11.2017 року у новому законі фінансові інструменти трактуються як «цінні папери, строкові контракти (ф’ючерси), відсоткові строкові контракти (форварди), строкові контракти на обмін (на певну дату в майбутньому) у разі залежності ціни від відсоткової ставки, валютного курсу або фондового індексу (відсоткові, курсові чи індексні свопи), опціони, що дають право на купівлю або продаж будь-якого із зазначених фінансових інструментів, у тому числі тих, що передбачають грошову форму оплати (курсові та відсоткові опціони)» [9].

Однак тепер, після прийняття лише у першому читанні Закону України «Про строкові фінансові інструменти» та Закону «Про фінансові послуги та державне регулювання ринку фінансових послуг» [10], в яких використано елементи європейського права, методологічна визначеність щодо ідентифікації строкових фінансових інструментів набуває особливої гостроти. Підготовлені різними відомствами-регуляторами нормативні акти, якщо не прямо суперечать одне одному, то ніяк не утворюють єдину нормативну базу, що, в свою чергу, створює суттєві проблеми для учасників ринку.

У цьому контексті варто звернути увагу на дві важливі характеристики, на основі яких можна здійснити змістовну класифікацію інструментів даного ринку. До них належать строковість та похідність. Обидві ці характеристики $є$ самостійними. Строковість грунтується на зсуві строків укладання угоди та розрахунків за нею. Саме ця характеристика є основою поділу ринку на ринок $з$ негайною поставкою (spot, cash) та з строковою (future). 
Похідність (вторинність) грунтується на залежності цін цих інструментів безпосередньо або опосередковано від ціни або зміни ціни базового активу, який лежить в основі похідного. Отже, терміни деривативи та похідні фінансові інструменти є тотожними. Доцільнішим, на наш погляд, є вживання терміна похідні фінансові інструменти. Однак, враховуючи попередній досвід (у дореволюційній біржовій літературі вживався термін строкові ринки та угоди), ми схиляємося до того, щоб визначити зв'язок між термінами строкові ринки та ринки похідних фінансових інструментів, а лише потім визначитися з категорією $\phi$ 'ючерсні ринки. Тим більше, що перші кроки у цьому напрямі було здійснено на законодавчому рівні.

На наш погляд, вітчизняне законодавство повинне оформляти уже існуючі економічні відносини, але не допускати суттєвого відставання. В Україні, особливо у сфері фінансового ринку та всіх його складових (фондового, валютного), спостерігається тенденція щодо випередження безпосереднього застосування строкових фінансових інструментів у торговельній практиці перед створенням законодавчих норм, що призводить до суттєвих помилок.

Закони повинні прийматися на досить тривалий термін, бути достатньо виваженими, обгрунтованими, доповнювати один одного. У нашому випадку необхідно досягти повного логічного зв'язку між Цивільним Кодексом України, прийнятим Верховною Радою у 2003 році [11], Законом України «Про цінні папери та фондовий ринок» [9], Законом України «Про бухгалтерський облік та фінансову звітність в Україні» [12] та законами, які мають регулювати ринок фінансових послуг [10], строковий фінансовий ринок [13] та біржовий товарний ринок $[14,15]$.

При узгодженні названих документів було б доцільно в першу чергу звернути увагу на трактування категорій цінний папір та сертифікат цінного nanepy, який є похідним цінним папером. Як уже зазначалося, практика становлення фондового ринку відбувається у нас за законодавчими актами, запозиченими із досвіду США. За європейським правом, сертифікат не є цінним 
папером, за американським - це підтверджуючий документ, який засвідчує певні права його володаря.

Українське право, як і європейське, контракт цінним папером не вважає. У Цивільному Кодексі України поняття контракт відсутнє, однак є його синонім договір, який, на відміну від версії колишнього кодексу, трактується не як дія, а як «домовленість двох або більше сторін на встановлення, зміну або припинення цивільних прав та обов’язків», а строк договору - як «час, протягом якого сторони можуть здійснити свої права та виконати свої обов’язки відповідно до договору», що повністю відповідає процедурам укладання ф’ючерсних та опціонних контрактів як строкових договорів.

Вважаємо за доцільне звернути увагу на трактування угод (строкових та з негайною поставкою) у Цивільному Кодексі, а також на дефініції строковий ринок та строкова угода, або строковий фінансовий інструмент, оскільки вони є ширшими від понять ринок похідних фінансових інструментів та похідні фінансові інструменти.

Інтегруючи теоретичні погляди зарубіжних та вітчизняних вчених, а також власне бачення цієї проблеми, пропонується визначення категорії строкового ринку як системи міжнародних економічних відносин між основними учасниками щодо укладання угод (контрактів) із завчасною поставкою реальних активів (форвардів) або їх обміном (свопів), зобов’язань (ф’ючерсів) та прав (опціонів, варантів) на ці активи за цінами та курсами, погодженими в момент їх укладання, а також 3 різноманітними комбінаціями цих угод (синтетичних, гібридних) 3 метою виявлення майбутніх цін, підвищення інформаційної ефективності та насиченості, отримання доходів та трансферту ризику.

Існує так званий список Дж. Фінерті, в якому відомий фінансовий інженер США систематизував всі наявні фінансові інструменти (їх уже налічується понад сто і їх кількість постійно зростає) [16]. Він вперше класифікував ці фінансові інструменти за потребами їх користувачів, виділивши власне інструменти споживчого типу (цінні папери, як традиційні так i абсолютно нові типу одноіпотечних акцій 3 коректованою ставкою та облігацій із змінною 
відсотковою ставкою), фінансові процеси (дисконтний брокер, термінал на місці продаж, Internet-трейдинг) та фінансові стратегії і рішення (свопи акцій, проєктне фінансування тощо).

В Україні 19.06.2020 року було прийнято Закон України «Про внесення змін до деяких законодавчих актів України щодо спрощення залучення інвестицій та запровадження нових фінансових інструментів», в якому зазначено, що з 01 липня 2021 року Закон «Про цінні папери та фондовий ринок» замінить комплексний Закон України «Про ринки капіталу та організовані товарні ринки».

У цьому новому законі у статті 7 зазначено, що фінансовими інструментами є:

1) цінні папери, у тому числі цінні папери інститутів спільного інвестування;

2) інструменти грошового ринку;

3) опціони, ф'ючерси, свопи, контракти на майбутню відсоткову ставку та будь-які інші деривативні контракти, базовим активом яких є цінні папери, валюта або інші деривативні контракти, базовим показником яких є процентні ставки, дохідність, індекси або курс та які можуть бути виконані у вигляді фізичної поставки (поставні деривативні контракти) або розрахунків (розрахункові деривативні контракти);

4) опціони, ф'ючерси, свопи, форварди та інші деривативні контракти, базовим активом яких є продукція, які мають або можуть бути виконані у вигляді розрахунків за вибором однієї із сторін (змішані деривативні контракти), крім випадків неплатоспроможності або інших випадків припинення зобов'язань;

5) опціони, ф'ючерси, свопи та інші деривативні контракти, базовим активом яких $є$ продукція, що укладаються на торговельних майданчиках та які можуть бути виконані у вигляді фізичної поставки (поставні деривативні контракти), крім контрактів (договорів), передбачених частиною другою цієї статті;

6) опціони, ф’ючерси, свопи, форварди та інші деривативні контракти, базовим активом яких $є$ продукція, які можуть бути виконані у вигляді фізичної поставки (поставні деривативні контракти) та які не зазначені у пункті 5 цієї 
частини, укладаються не в комерційних цілях та мають характеристики іншого деривативного фінансового інструменту;

7) деривативні фінансові інструменти, що передбачають передачу кредитного ризику, зокрема кредитні ноти та кредитні дефолтні свопи;

8) фінансові контракти на різницю цін;

9) опціони, ф’ючерси, свопи, контракти на майбутню відсоткову ставку та будь-які інші деривативні контракти, що стосуються кліматичних параметрів, ставок фрахту, показників інфляції або інших показників економічної статистики, які мають бути виконані у вигляді розрахунків (розрахункові деривативні контракти) або можуть бути виконані у вигляді розрахунків за вибором однієї із сторін (змішані деривативні контракти), крім випадків неплатоспроможності або інших випадків припинення зобов'язань;

10) деривативні контракти, що стосуються активів, прав, зобов'язань, індексів, курсів, які не зазначені у цій частині та які мають характеристики іншого деривативного фінансового інструменту, у тому числі які укладаються на регульованому ринку, організованому торгівельними майданчиками (ОТМ) або багатосторонніми торгівельними майданчиками (БТМ).

Не є фінансовими інструментами:

1) контракти (договори) щодо оптових енергетичних продуктів, що укладаються на ОТМ, поза організованим ринком або на будь-якому торговельному майданчику/місці (централізованому чи децентралізованому організованому ринку), які не є БТМ чи регульованим ринком, та щодо яких поставка є обов’язковою, у тому числі контракти на різницю цін щодо енергетичних продуктів/послуг;

2) поставні опціони, ф’ючерси, свопи, форварди та інші деривативні контракти, базовим активом яких є продукція, не зазначені у пункті 6 вищезгаданої статті, що укладаються в комерційних цілях та не мають характеристики іншого деривативного фінансового інструменту;

3) товарні спот-контракти незалежно від майданчика/місця торгівлі (ринку, на якому вони торгуються); 
4) товарні форвардні контракти (договори) з фізичною поставкою, торгівля якими здійснюється на майданчиках/ринках інших, ніж БТМ та регульований ринок.

Отже, на нашу думку, фінансові інструменти слід класифікувати на такі групи:

1) цінні папери: акції та інвестиційні сертифікати; облігації, зобов'язання та векселі Казначейств країн світу; депозитні сертифікати банків; інструменти ринку капіталу;

2) інструменти грошового ринку та валюта: відсоткові ставки за депозитами провідних банків світу; валюта (британський фунт, євро, японська єна, мексиканське песо, австралійський та канадський долари, євродолари, долари США, російський рубль); фондові та товарні індекси провідних бірж та світових ринків;

3) строкові і похідні (деривативи) фінансові інструменти: форварди, ф'ючерси, опціони, свопи;

4) гібридні комбінації фінансових інструментів: гібрид процентних i валютних інструментів: двовалютна облігація;

5) синтетичні (структуровані) інструменти: опціон на ф'ючерсний контракт 3 пшеницею;

6) екзотичні фінансові інструменти: ф’ючерс на погоду; ф’ючерс на індекс ринку нерухомості.

Інструменти грошового ринку - це казначейські зобов'язання України, ощадні сертифікати банків, депозитні сертифікати банків, векселі, а також інші інструменти (в тому числі цінні папери), що мають усі з таких характеристик:

1) вартість, що може бути визначена у будь-який момент часу;

2) не є деривативними фінансовими інструментами;

3) мають період до погашення в момент емісії (видачі) 397 днів або менше. 
На наш погляд, ці поняття уже точніше визначають сутність фінансових інструментів та їх класифікацію, а також проведене розмежування 3 нефінансовими інструментами дає можливість виконати відповідні корективи щодо їх обліку.

При позитивних моментах цього нового закону, є i неузгодженості, які мають стати предметом дискусій з залученням науковців та учасників ринків.

Виходячи 3 вищевикладеного, пропонуємо наступну методологічну послідовність у розв'язанні наукових та законодавчих проблем: по-перше, віднести ф'ючерси та опціони до фінансових інструментів; по-друге, розширити класифікацію фінансових інструментів, особливу увагу звернувши на такі класифікаційні ознаки, як форма обігу та бухгалтерського обліку, характер контрактних відносин, місце обертання, строковість та похідність. Ця класифікація дозволить серед фінансових інструментів виділити такі, що обертаються на ринку у вигляді цінних паперів, та такі, що існують у вигляді контрактів як 3 негайною поставкою, так і поставкою або ліквідацією у конкретно визначені строки. Цей поділ $є$ досить важливим, оскільки саме тут і спостерігаються різні підходи англо-американського та європейського права до трактування строкових та похідних фінансових інструментів. 


\section{3 Концептуальні підходи обліку безоплатно одержаних основних засобів}

Відповідно до П(с)БО 7, основні засоби - матеріальні активи, які підприємство або установа утримує 3 метою використання їх у процесі виробництва і діяльності або постачання товарів, надання послуг, здавання в оренду іншим особам або для здійснення адміністративних і соціальнокультурних функцій, очікуваний строк корисного використання (експлуатації) яких більше одного року (або операційного циклу, якщо він довший за рік) [19].

Суб'єкти підприємницької діяльності можуть отримувати основні засоби на безоплатній основі, тому виникають питання щодо їх юридичного статусу, обліку та оподаткування.

У Податковому кодексі України п.14.1.13 визначається, що безоплатно надані товари - товари, що надаються згідно з договорами дарування, іншими договорами, за якими не передбачається грошова або інша компенсація вартості таких товарів чи їх повернення, або без укладення таких договорів [20].

Більш детальна інформація, 3 юридичної точки зору, про безоплатно отримані активи надається у ЦКУ, де безоплатне отримання активів розглядається, як дарування майна:дарунком можуть бути рухомі речі, в тому числі гроші та цінні папери, а також нерухомі речі (ст. 718), що не перечить сутності основних засобів;за договором дарування одна сторона (дарувальник) передає або зобов'язується передати в майбутньому другій стороні (обдаровуваному) безоплатно майно (дарунок) у власність (ст. 717 ЦКУ);сторонами у договорі дарування можуть бути фізичні особи, юридичні особи, держава Україна, Автономна Республіка Крим, територіальна громада. Підприємницькі товариства можуть укладати договір дарування між собою, якщо право здійснювати дарування прямо встановлено установчим документом дарувальника (ст. 720 ЦКУ);договір дарування нерухомої речі укладається у письмовій формі і підлягає нотаріальному посвідченню. Договір дарування рухомих речей, які мають особливу цінність, укладається у письмовій формі. 
Передання такої речі за усним договором є правомірним, якщо суд не встановить, що обдаровуваний заволодів нею незаконно (Ст. 719 ЦКУ) [21].

Але договір лише передбачає здійснення господарської операції, а в обліку відображаються операції, які дійсно відбулися і які оформлені відповідно заповненими первинними документами.

Використання первинних бухгалтерських документів залежить від того фізична або юридична особа надає безкоштовно основні засоби і від того чи були вони у використанні і нараховувався на них знос або надійшли нові від виробника або торгівельної організації. Від дарувальника, юридичної особи, надходження основних засобів, які були у використанні, передають за Актом приймання-передачі основних засобів ф.№ О3-1. Нові безкоштовні основні засоби (для визначення адресності) можуть надходити на підприємство при наявності одного з документів: накладної, ТТН, товарного або фіскального чеку.

Після надходження безкоштовних основних засобів, підприємству необхідно ввести їх в експлуатацію, поставити на баланс, щоб мати змогу використовувати у господарській діяльності .При цьому оформлюють типовою формою - Акт приймання-передачі основних засобів ф.№ О3-1, постійно діючою комісією, створеною за наказом по підприємству для огляду та введення в експлуатацію основних засобів, яка визначає призначення основних засобів (виробнича- невиробнича діяльність), визначення вартості що амортизується і при необхідності ліквідаційної вартості, строк корисного використання 3 урахуванням положень статті 138 ПКУ (де передбачено розподіл основних засобів за групами та встановлені мінімально допустимі строки), метод амортизації, а також наявність технічної документації та визначення матеріально-відповідальної особи. Податкове і бухгалтерське законодавство не вимагає документального оформлення основних засобів тільки у типових затверджених формах.

Об'єкт основних засобів визнається активом, якщо існує імовірність того, що підприємство отримає в майбутньому економічні вигоди від його використання та вартість його може бути достовірно визначена [19].Тому, перш 
ніж відобразити в обліку (поставити на баланс) об'єкт основних засобів, отриманий безоплатно, його слід оцінити за первісною вартістю.

Первісною вартістю основних засобів, отриманих безоплатно від інших осіб, визнається їх справедлива вартість на дату отримання з урахуванням витрат, передбачених пунктом 8 П(с)БО 7:реєстраційні збори, державне мито та аналогічні платежі, що здійснюються у зв'язку з придбанням (отриманням) прав на об’єкт основних засобів;суми ввізного мита;суми непрямих податків у зв'язку 3 придбанням (будівництвом) основних засобів (якщо вони не відшкодовуються підприємству);витрати зі страхування ризиків доставки основних засобів;витрати на транспортування, установку, монтаж, налагодження і пуск основних засобів;інші витрати, безпосередньо пов'язані з доведенням основних засобів до стану, у якому вони придатні для використання із запланованою метою [19].

Справедлива вартість це сума, за якою можна продати актив або оплатити зобов'язання за звичайних умов на певну дату [22]. Для підтвердження справедливої вартості можуть використовуватися дані про ринкові ціни на аналогічні об'єкти з тим же рівнем зношеності, по сумі залишкової вартості або здатності їх до експлуатації. Доцільною буде інформація про пропозицію і попит на ринку таких основних засобів у бізнес-виданнях, рекламі, прайсах i пропозиціях постачальників, а також будь-які інших документальних джерелах інформації про ціни. За потреби можна запросити незалежного оцінювача майна й отримати від нього звіт про оцінку, але ЗУ «Про оцінку майна, майнових прав та професійну оціночну діяльність в Україні» не вимагає обов'язкового залучення професійних оцінювачів для визначення справедливої вартості безоплатно отриманих основних засобів [23].

Якщо безоплатно отриманий об'єкт не вимагає додаткових витрат щодо оформлення, монтажу, його справедлива вартість зараховується відразу до статті балансу основних засобів, при цьому оформлюють Акт ф.№ O3-1 та складають бухгалтерську проводку Дт 10 Кт 424. 
На практиці частіше виникає ситуація коли безоплатне отримання основних засобів вимагає додаткових витрат, як пов'язаних з реєстрацією об'єкту, так і 3 підготовкою до введення в експлуатацію. На жаль на сьогодні не існує єдиного погляду на методологію відображення цих витрат в обліку, що пов'язано 3 невизначеністю даної ситуації у нормативних актах. Якщо визначати первісну вартість на рахунку 15, то вона буде складатися з справедливої вартості на момент надходження (безоплатна складова) та з витрат які сплачуються не за рахунок юридичних осіб, що передають основні засоби, а за рахунок підприємства - який отримує основні засоби (платна складова).

При цьому слід розуміти що в бухгалтерському обліку вартість безоплатно отриманих основних засобів відноситься до додаткового капіталу (Дт 10 Кт 424), а додатково понесені витрати не можуть збільшувати додатковий капітал (Дт 15 Кт 63,20,66,65 ... потім Дт 10 Кт 15).

Якщо у підприємства витрати виникають (монтаж, пусконалагоджувальні та інші роботи), то пропонується створювати окремий об'єкт і враховувати витрати на рахунку 15, тобто окремо від вартості безоплатно отриманого об'єкта, яка вже значиться на рахунку 10.

При цьому виникає невідповідність вимогам П(С)БО 7, оскільки не можна зарахувати до статті основних засобів об'єкт, який не можна вважати придатним до експлуатації (при відсутності акту вводу в експлуатацію) або таким, що вже експлуатується.

Під безоплатним отриманням основних засобів розуміється отримання об'єктів готових до експлуатації, а безоплатне отримання об'єктів у тому стані, в якому вони ще не є придатними до експлуатації - це безоплатне отримання капітальних інвестицій. В даному випадку субрахунок 152 "Придбання (виготовлення) основних засобів" можливо використовувати в кореспонденції 3 рахунком 424 "Безоплатно одержані необоротні активи".

При суворому дотриманні діючого на сьогодні п.8 П(с)БО 7, коли ми збираємо всі витрати з вартості об'єкта та витрат і вважаємо це справедливою вартістю, яка і буде амортизуватися протягом відповідного строку корисного 
використання, то виникає питання правильного відображення доходу від одержання безоплатного основного засобу у розмірі нарахованої амортизації. Пунктом 4 П(с)БО 7 встановлено, що під амортизацією розуміється систематичний розподіл вартості, яка амортизується, необоротних активів протягом строку їх корисного використання (експлуатації).Тож відповідно до пункту 21 П(с)БО 15 «Дохід», якщо безоплатно отриманий актив забезпечує надходження економічних вигод протягом кількох звітних періодів, то доходи визнають на систематичній основі протягом тих звітних періодів, коли надходять відповідні економічні вигоди (наприклад, у сумі нарахованої амортизації) [24].

Нарахування амортизації основних засобів проводиться помісячно починаючи з місяця, що настає за місяцем введення об'єкта основних засобів в експлуатацію, та зупиняється на період його реконструкції, модернізації, добудови, дообладнання, консервації й інших видів поліпшення та консервації

Безоплатно отримані виробничі основні засоби підлягають амортизації і впливатимуть на визначення об’єкта оподаткування з податку на прибуток.

Згідно з вимогами Плану рахунків залишок додаткового капіталу на субрахунку 424 зменшується на суму визнаного доходу протягом строку корисного використання безоплатно одержаних об’єктів необоротних активів та при їх вибутті. Дохід у бухгалтерському обліку визнається на субрахунку 745 «Дохід від безоплатно одержаних активів» в сумі амортизації такого основного засобу одночасно з ї нарахуванням. У бухгалтерському обліку нарахування амортизації основних засобів відображається таким чином на суму нарахованого зносу: Дт $23(91,92,93,94)$ — Кт 131 «Знос основних засобів» і зменшення капіталу з одночасним визнанням доходу в частині амортизаційних відрахувань Дт 424 «Безоплатно одержані необоротні активи» - Кт 745 «Дохід від безоплатно одержаних активів».

Порядок обчислення податку на прибуток залежить від суми річного доходу від будь якої діяльності, визначеного за правилами бухгалтерського обліку, до якого включається дохід (виручка) від реалізації продукції (товарів, робіт, послуг), інші операційні доходи, фінансові доходи та інші доходи. 
Дана інформація визначається на підставі положень НСБО 1 «Загальні вимоги до фінансової звітності» ( або МСФЗ) і надається у Звіті про фінансові результати [25].

Якщо річний обсяг доходу не перевищує 20 млн. грн., то підприємства розрахунок амортизації всіх безоплатно отриманих основних засобів, незалежно від дати їх придбання, здійснюють відповідно до національних положень (стандартів) бухгалтерського обліку або міжнародних стандартів фінансової звітності. При такому розрахунку можуть застосовуватися всі методи нарахування амортизації, передбачені національними положеннями (стандартами) бухгалтерського обліку і мають право не коригувати на податкові різниці визначений фінансовий результат.

Якщо річний обсяг доходу перевищує 20 млн. грн., то підприємства зобов'язані проводити корегування фінансового результату до оподатковування на різниці, передбачені ПКУ, які виникають при нарахуванні амортизації необоротних активів (ст. 138 ПКУ) і застосовують методи нарахування амортизації, передбачені національними положеннями (стандартами) бухгалтерського обліку, крім "виробничого" методу [20].

При безоплатному отриманні основних засобів немає факту їх виготовлення або придбання, тому, отримуючи безоплатні основні засоби, підприємство не має права на податковий кредит з ПДВ за такою операцією.

Оформлений акт з додатковою технічною документацією, що відноситься до об'єкта безоплатно одержаних основних засобів, передається в бухгалтерію на підпис головному бухгалтеру та для оформлення інвентарної картки, затверджується керівництвом організації чи уповноваженими на те особами.

Аналітичний облік об’єктів основних засобів ведеться в Інвентарних картках ф. О3-6, Інвентарні картки реєструють в Інвентарних описах ф. О3-7. Зареєстровані картки зберігаються у картотеці основних засобів. На місцях експлуатації аналітичний облік ведуть в Інвентарних списках основних засобів ф. ОЗ-9. Згідно даних інвентарних карток складають Картки руху основних засобів ф. ОЗ-8.Синтетичний облік ведеться в журналі № 4, в якому вказується 
назва об'єкта, що вибув, первісна вартість, знос, залишкова вартість, а формування первісної вартості відбувається у Відомості 4.1.

При відсутності достатньої нормативної та методологічної бази, головному бухгалтеру необхідно вирішувати дані питання самостійно на свій ризик.

Якщо підприємство звітує за національними стандартами бухгалтерського обліку, то можна звернутися до системи міжнародних стандартів, тому як у самому визначенні національного стандарту, наведеному в Законі України «Про бухгалтерський облік та фінансову звітність в Україні», $є$ прив'язка до міжнародних стандартів (принципи і методи національних стандартів не можуть суперечити міжнародним стандартам), або використовувати практику аналогічних ситуацій [26].

Загальні положення МСФЗ, дозволяють зробити висновок про те, що на всю вартість безоплатно отриманого активу треба збільшити дохід у періоді його отримання. Існують всі ознаки ідентифікації доходу у цій операції: є приріст активів, що несе економічні вигоди, і він не супроводжується відповідним приростом зобов'язань. Отже, цей приріст активів відображає збільшення власного капіталу. А це означає, що підприємство згідно 3 визначеннями параграфа 7 МСБО 18 [27] та параграфа 4.25 Концептуальних основ фінансової звітності отримало дохід [28].

При безоплатному отримані основних засобів головному бухгалтеру також слід визначити облікову політику стосовно його оцінки та сформувати облікову модель на основі положень, які не суперечать МСФЗ та грунтується на досвіді системи П(с)БО та закріпити в наказі про облікову політику підприємства.

Причину відсутності методичного забезпечення в обліку безоплатного надходження основних засобів можна пояснити тим, що дана господарська операція відбувається досить рідко і не $є$ характерною для господарської діяльності виробничого підприємства (частіше для неприбуткових підприємств), а всі стандарти побудовані для типових господарських операцій i тому на сьогодні дане питання необхідно вирішити на законодавчому рівні. 


\section{4 Соціальні гарантії підприємства: обліковий вимір}

Соціальна орієнтація економіки передбачає здійснення значних видатків як в масштабах держави через державний бюджет, так і в масштабах підприємств із використанням прибутку та інших матеріальних ресурсів. Здійснення соціальних видатків має корелюватися з ефективністю здійснення соціальної політики, яка б забезпечила пошук невикористаних резервів і можливість звітування перед власниками задіяних ресурсів та іншими зацікавленими особами. Основним шляхом розв'язання даної проблеми є функціонування інформаційної системи, в якій можуть узагальнюватись дані про всі економічні процеси від рівня суб’'єктів господарювання до економіки в цілому. Поставлені вимоги найбільшою мірою задовольняє система обліку за умови врахування соціальної спрямованості (компоненти) кінцевої інформації. Адже іiї користувачами мають бути не лише власники та керівництво підприємства, а й держава, суспільство та суб’єкти соціально-трудових відносин.

Соціальна складова обліку спрямована на аналіз інформації про здійснення підприємством соціальної діяльності та визначення ступеня ії впливу на результати господарювання.

Вирішення соціальних питань завжди потребує глибокого аналізу та розуміння політичних, фінансових, моральних та етичних аспектів, які з ними тісно пов'язані. «Розвиваючись в напрямі створення цивілізованого суспільства, слід налагоджувати відповідні взаємовідносини між найманими працівниками, підприємцями та урядовими інституціями...» [29, с. 73]. Провідну роль у контролі за вирішенням цих питань, у фінансовому забезпеченні соціальної діяльності підприємств, відіграє облік, адже, його раціональна організація та надання об'єктивної звітності в необхідних розрізах, дає змогу провести детальний аналіз усіх аспектів забезпечення соціальних гарантій.

Соціальна політика працюючих громадян здійснюється і з боку держави, i 3 боку підприємства. Економічна політика України на сучасному етапі спрямована на перехід до соціально орієнтованої ринкової економіки, яка припускає проведення такої соціальної політики, що, сприяючи розвитку економіки, враховувала б інтереси всіх соціально-демографічних груп населення країни. 


\section{SOCIO-ECONOMIC AND MANAGEMENT CONCEPTS}

Реформування соціальної сфери відповідно до вимог ринкової економіки в Україні вимагає вирішення проблем, що стоять на шляху створення соціально орієнтованої економіки, здатної забезпечити добробут і соціальний захист населення країни.

Підприємство, використовуючи систему обліку, в змозі реалізувати потреби соціальних партнерів. Для якнайкращого виконання запитів всіх користувачів, у тому числі і соціальних партнерів, суб’єкти ведення обліку мають бути ознайомлені з їхніми інтересами для вдосконалення процесу ведення та організації обліку.

3 позиції Т.О. Стрибулевича, такі вдосконалення можуть стосуватися розробки облікової політики підприємства, створення звітних форм безпосередньо для певної групи користувачів інформації, застосування новітніх комп’ютерних технологій у веденні бухгалтерського обліку [30].

Інтереси кожного iз соціальних партнерів $\epsilon$ досить широкими та різносторонніми, але збігаються вони здебільшого в одному - підприємство, навколо якого вони згуртувалися, має розвиватися і працювати й надалі. Важливою ж передумовою подальшої ефективної діяльності підприємства є досягнення повної згоди між соціальними партнерами та прагнення до вирішення існуючих між ними протиріч.

Система обліку є найбільш достовірним джерелом необхідної інформації і втілює цілий комплекс дій, направлених на накопичення, обробку даних та надання користувачам інформації у необхідному для них розрізі. Для повноцінного здійснення соціального партнерства його учасники мають бути поінформованими щодо усіх аспектів, які їх можуть зацікавити. Таким чином, можна стверджувати, що які б питання не поставали в системі соціального партнерства, але до їх вирішення в більшості випадків готові приступити всі соціальні партнери. У даному випадку така одностайність може бути пояснена ступенем впливу на особисті інтереси кожного із учасників і, відповідно, прагненням їх задовольнити.

Поряд з соціальними гарантіями, що надаються працівникам, відповідно до чинного законодавства, значної актуальності набувають соціальні виплати та пільги, які надаються роботодавцями. Як зауважує Ф.Ф. Бутинець, - «такі 


\section{SOCIO-ECONOMIC AND MANAGEMENT CONCEPTS}

виплати здійснюються виходячи з фінансових можливостей підприємства, як частина сукупного доходу працівників підприємства, що підвищує їх трудову активність і прихильність інтересам підприємства» [31, с. 273]. Вони розглядаються як винагороди, не пов’язані з кількістю і якістю праці; працівники одержують їх за факт роботи на даному підприємстві.

Для досягнення високого рівня мотивації через виплати соціальних гарантій працівникам слід створити відповідний фонд у системі обліку, адже діюче законодавство не регламентує акумулювання ліквідних активів для здійснення соціальної політики. Пропонований алгоритм коригування валового прибутку, що спрямовується на створення фонду виплат соціальних гарантій, на підставі даних ф. № 2 «Звіт про фінансові результати (Звіт про сукупний дохід)» зображено на рис. 1.

Відповідно до поданого порядку величина фонду виплат соціальних гарантій працівникам визначається за наступною формулою (1):

$$
\Phi_{\mathrm{CГ}}=\left(\mathrm{BП}-\mathrm{B}_{\text {зб }}-\mathrm{B}_{\text {адм }}-\mathrm{IHOПВ} \mathrm{без} \mathrm{соц}\right) \mathrm{K}_{\text {змінПП, }}
$$

де $\Phi_{\text {Сг }}-$ сума фонду виплат соціальних гарантій;

ВП - валовий прибуток;

$\mathrm{B}_{\text {зб }}$ - витрати на збут;

$\mathrm{B}_{\text {адм }}$ - адміністративні витрати;

ІнОпВ без соц - інші операційні витрати за виключенням витрат на продуктивні та непродуктивні соціальні гарантії згідно соціального пакету;

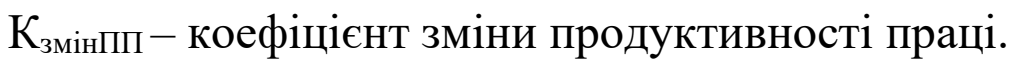




\section{SOCIO-ECONOMIC AND MANAGEMENT CONCEPTS}

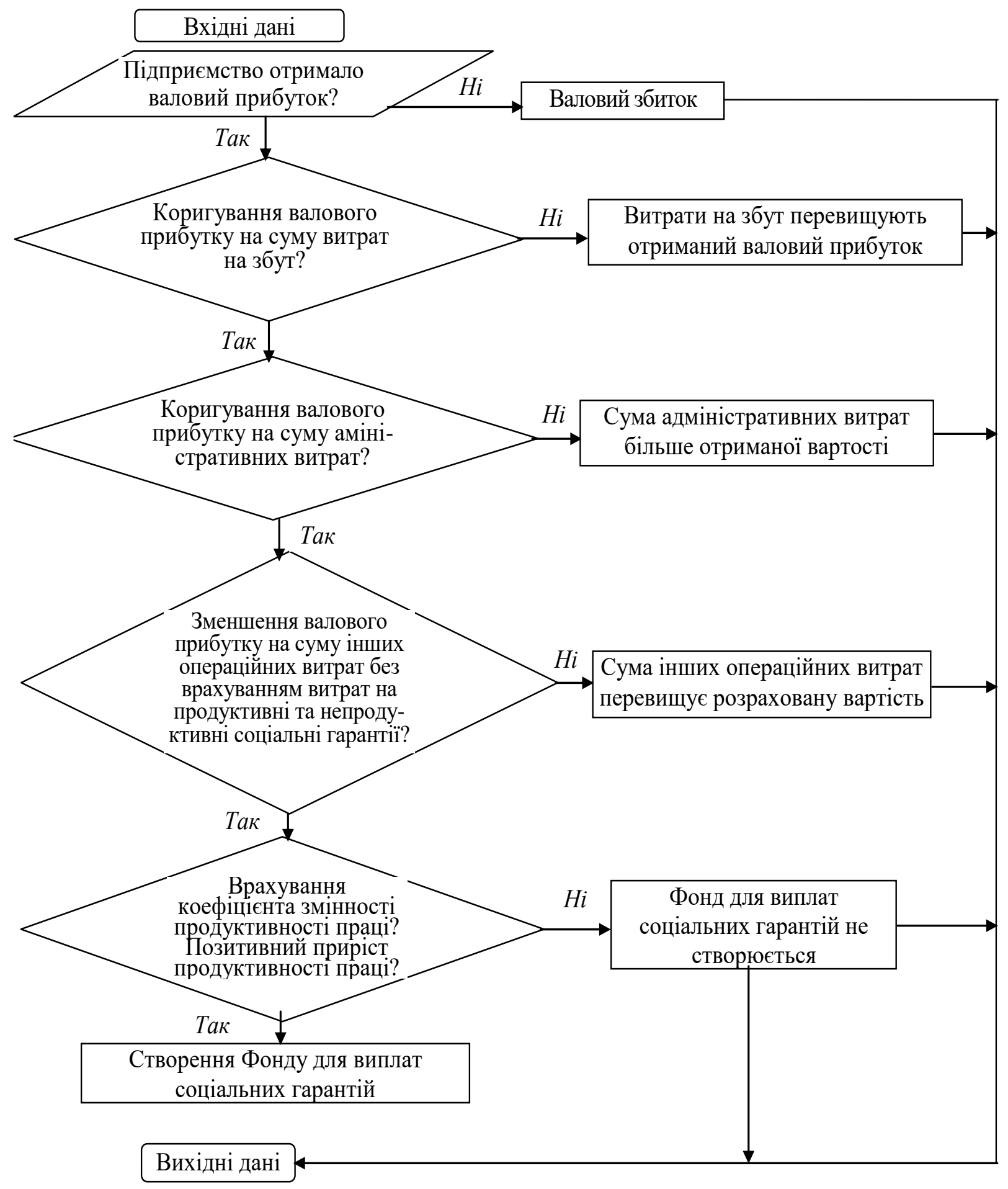

Рисунок 1. Алгоритм створення фонду виплат соціальних гарантій

Коефіцієнт зміни продуктивності праці дозволяє визначити динаміку зміни продуктивності праці за певні періоди (формула (2):

$$
\kappa_{\text {зиінПII }}=\frac{\Pi \Pi_{\text {зв }}-\Pi \Pi_{\text {nопер }}}{\Pi \Pi_{\text {nопер }}} \times 100 \%
$$

де $П_{\text {зв }}$ і ПП попер - продуктивність праці у звітному та попередньому 
періодах відповідно.

За умови недостатнього підвищення продуктивності праці у звітному періоді, тобто отримання iї від’ємного значення, фонд виплат соціальних гарантій не створюється:

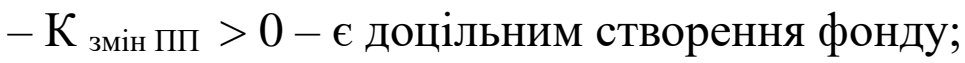

- К змін пп $<0$ - недоцільно створювати фонд.

Для удосконалення відображення в обліку створення та використання фонду виплат соціальних гарантій та аналітичного обліку при розрахунку виплат працівникам пропонується створити додаткові субрахунки систематизації інформації, які дозволять підвищити інформативність обліку та зменшити трудомісткість розрахунків при іiї наданні в напрямі запитів користувачів різних груп в комп’ютерному середовищі (табл. 1).

Таблиця 1

Діюча та запропонована система рахунків обліку для відображення виплат соціальних гарантій працівникам

\begin{tabular}{|c|c|}
\hline Діюча система & Запропонована система рахунків обліку \\
\hline $\begin{array}{l}377 \text { «Розрахунки } 3 \\
\text { різними дебіторами» }\end{array}$ & $\begin{array}{l}377.1 \text { «Розрахунки з працівниками підприємства за товари, роботи, } \\
\text { послуги» }\end{array}$ \\
\hline $\begin{array}{l}443 \text { «Прибуток, } \\
\text { використаний } \\
\text { звітному періоді» }\end{array}$ & $\begin{array}{l}443.1 \text { «Напрями використання прибутку» } \\
443.11 \text { «Спрямування частини прибутку на соціальні гарантії } \\
\text { відповідно до умов колективного договору» } \\
443.12 \text { «Спрямування частини прибутку для виплати дивідендів } \\
\text { простими та привілейованими акціями працівникам підприємства» }\end{array}$ \\
\hline $\begin{array}{l}472 \text { «Додаткове пен- } \\
\text { сійне забезпечення» }\end{array}$ & 472 «Фонд виплат соціальних гарантій» \\
\hline $\begin{array}{l}654 \text { «Розрахунки за } \\
\text { індивідуальним } \\
\text { страхуванням» }\end{array}$ & 654.1 «Недержавне медичне страхування» \\
\hline $\begin{array}{l}663 \text { «Розрахунки зі } \\
\text { іншими виплатами» }\end{array}$ & $\begin{array}{l}663.1 \text { «Виплати соціальних гарантій» } \\
663.11 \text { «Продуктивні соціальні гарантії» } \\
663.12 \text { «Непродуктивні соціальні гарантії» }\end{array}$ \\
\hline $\begin{array}{l}671 \text { «Розрахунки за } \\
\text { нарахованими } \\
\text { дивідендами» }\end{array}$ & $\begin{array}{llll}671.1 \text { «Розрахунки за нарахованими дивідендами } & \text { зовнішнім } \\
\text { акціонерам» } & & \\
671.2 \text { «Розрахунки за нарахованими дивідендами } & \text { внутрішнім } \\
\text { акціонерам (працівникам)» } & & \end{array}$ \\
\hline
\end{tabular}


Продовження таблиці 1

\begin{tabular}{|c|c|}
\hline $\begin{array}{l}949 \text { «Інші операційні } \\
\text { витрати» }\end{array}$ & 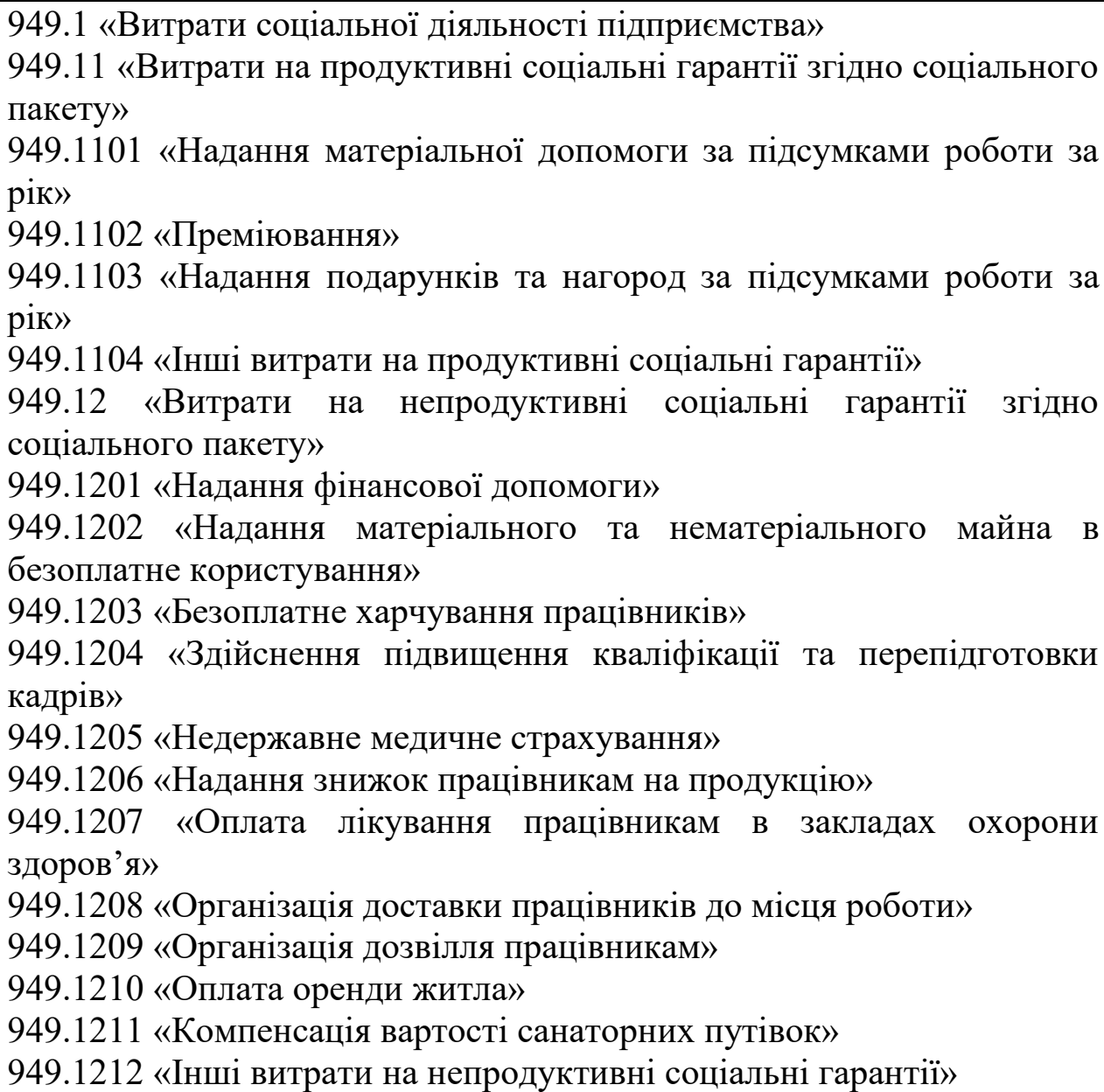 \\
\hline
\end{tabular}

Запропонована система рахунків обліку надає змогу оптимальніше планувати соціальну діяльність підприємствам, тобто можливість наперед забезпечувати джерела додаткових соціальних виплат, які значно підвищують лояльність та ефективність роботи персоналу. До того ж, розподіляючи такі витрати на рівні частки протягом року, уникнути проблем негативного впливу на фінансову результативність підприємства та різких коливань собівартості продукції.

Пропонуємо для обліку акумулювання коштів у вигляді фонду та його використання передбачити у Плані рахунків бухгалтерського обліку активів, капіталу, зобов'язань і господарських операцій підприємств і організацій рахунок 472 «Фонд виплат соціальних гарантій». Облікове відображення процесу створення даного фонду та відображення його використання має певні відмінності від діючої на сьогодні практики (табл. 2.). 
Таблиця 2

Методика відображення в обліку операцій за виплатами соціальних гарантій працівникам

\begin{tabular}{|c|c|c|c|c|c|}
\hline \multirow{2}{*}{$\begin{array}{l}\text { № } \\
3 / \Pi\end{array}$} & \multirow{2}{*}{ Зміст операції } & \multicolumn{2}{|c|}{ Діючий порядок } & \multicolumn{2}{|c|}{ Запропоновані зміни } \\
\hline & & Дебет & Кредит & Дебет & Кредит \\
\hline 1 & 2 & 3 & 4 & 5 & 6 \\
\hline \multirow[t]{3}{*}{1.} & \multicolumn{5}{|c|}{ Відображено понесені витрати на соціальні гарантії для формування фонду: } \\
\hline & - продуктивні & 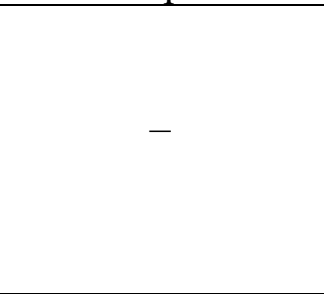 & 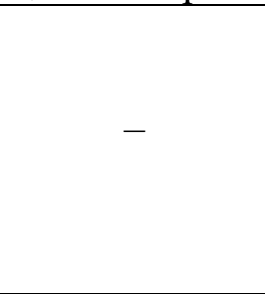 & $\begin{array}{l}949.11 \text { «Витрати } \\
\text { на продуктивні } \\
\text { соціальні } \\
\text { гарантії згідно } \\
\text { соціального } \\
\text { пакету» }\end{array}$ & $\begin{array}{l}472 \quad \text { «Фонд } \\
\text { виплат } \\
\text { соціальних } \\
\text { гарантій» }\end{array}$ \\
\hline & $\begin{array}{l}\text { - } \\
\text { непродуктивні }\end{array}$ & - & - & $\begin{array}{l}949.12 \text { «Витрати } \\
\text { на } \\
\text { непродуктивні } \\
\text { соціальні } \\
\text { гарантії згідно } \\
\text { соціального } \\
\text { пакету» }\end{array}$ & $\begin{array}{l}472 \quad \text { «Фонд } \\
\text { виплат } \\
\text { соціальних } \\
\text { гарантій» }\end{array}$ \\
\hline 2. & $\begin{array}{l}\text { Спрямування } \\
\text { частини коштів } \\
\text { на формування } \\
\text { фонду виплат } \\
\text { соціальних } \\
\text { гарантій } \\
\text { грошовому у } \\
\text { виразі }\end{array}$ & - & - & $\begin{array}{l}315 \text { «Поточний } \\
\text { рахунок для } \\
\text { забезпечення } \\
\text { виплат } \\
\text { соціальних } \\
\text { гарантій» }\end{array}$ & $\begin{array}{l}311 \text { «Поточні } \\
\text { рахунки в банку } \\
\text { в національній } \\
\text { валюті» }\end{array}$ \\
\hline \multirow[t]{3}{*}{3.} & \multicolumn{5}{|c|}{$\begin{array}{l}\text { Відображено використання фонду виплат соціальних гарантій на фактично спожиті } \\
\text { соціальні гарантії: }\end{array}$} \\
\hline & - продуктивні & ( & 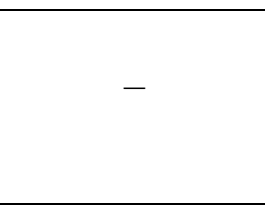 & $\begin{array}{l}472 \quad \text { вФонд } \\
\text { виплат } \\
\text { соціальних } \\
\text { гарантій» }\end{array}$ & $\begin{array}{l}663.11 \\
\text { «Продуктивні } \\
\text { соціальні } \\
\text { гарантії» } \\
\end{array}$ \\
\hline & - & - & - & $\begin{array}{l}472 \text { «Фонд } \\
\text { виплат } \\
\text { соціальних } \\
\text { гарантій» } \\
\end{array}$ & $\begin{array}{l}663.12 \\
\text { «Непродуктивні } \\
\text { соціальні } \\
\text { гарантії» } \\
\end{array}$ \\
\hline 4. & $\begin{array}{l}\text { Відображено } \\
\text { суму } \\
\text { використаного } \\
\text { прибутку у } \\
\text { звітному } \\
\text { періоді }\end{array}$ & $\begin{array}{l}441 \text { «Прибуток } \\
\text { нерозподілений» }\end{array}$ & $\begin{array}{l}443 \\
\text { «Прибуток, } \\
\text { використаний } \\
\text { у звітному } \\
\text { періоді» }\end{array}$ & - & $x_{1}$ \\
\hline
\end{tabular}


Продовження Таблиці 2

\begin{tabular}{|c|c|c|c|c|c|}
\hline 5. & $\begin{array}{l}\text { Відображено } \\
\text { роз-поділу } \\
\text { прибутку між } \\
\text { працівниками } \\
\text { підприємства } \\
\text { згідно умов } \\
\text { колективного } \\
\text { договору }\end{array}$ & - & - & $\begin{array}{l}443.11 \\
\text { «Спрямування } \\
\text { частини } \\
\text { прибутку } \\
\text { соціальні } \\
\text { гарантії } \\
\text { відповідно до до } \\
\text { умов } \\
\text { колективного } \\
\text { договору» }\end{array}$ & $\begin{array}{l}663.11 \\
\text { «родуктивні } \\
\text { соціальні } \\
\text { гарантії» } \\
663.12 \\
\text { «Непродуктивні } \\
\text { соціальні } \\
\text { гарантії» }\end{array}$ \\
\hline 6. & $\begin{array}{lr}\text { Відображено } \\
\text { спрямування } \\
\text { частини } \\
\text { прибутку } \\
\text { виплату } \\
\text { дивідендів } \\
\text { простими } \\
\text { привілейованими } \\
\text { акціями } \\
\text { за } \\
\end{array}$ & $\begin{array}{l}443 \\
\text { «Прибуток, } \\
\text { використаний } \\
\text { у звітному } \\
\text { періоді» }\end{array}$ & $\begin{array}{l}671 \\
\text { «Розрахунки } \\
\text { за } \\
\text { нарахованими } \\
\text { дивідендами» }\end{array}$ & $\begin{array}{l}443.12 \\
\text { «Спрямування } \\
\text { частини } \\
\text { прибутку для } \\
\text { виплати } \\
\text { дивідендів } \\
\text { простими та } \\
\text { привілейованими } \\
\text { акціями } \\
\text { працівникам } \\
\text { підприємства» }\end{array}$ & $\begin{array}{l}671.2 \\
\text { «Розрахунки за } \\
\text { нарахованими } \\
\text { дивідендами } \\
\text { внутрішнім } \\
\text { акціонерам } \\
\text { (працівникам)» }\end{array}$ \\
\hline
\end{tabular}

Для обліку формування та використання фонду виплат соціальних гарантій працівникам вважаємо доцільним введення наступних рахунків: 315 «Поточний рахунок для забезпечення виплат соціальних гарантій» та 472 «Фонд виплат соціальних гарантій». Методика використання фонду виплат соціальних гарантій передбачає раціональне здійснення соціальної діяльності суб’єктом господарювання за рахунок вилучення високоліквідних активів, витрат операційної діяльності та розподілу прибутку. Обгрунтовуємо доцільність відкриття рахунку 315 «Поточний рахунок для забезпечення виплат соціальних гарантій» внаслідок необхідності здійснення моніторингу можливості проведення виплат працівникам в межах сформованого фонду відповідними грошовими коштами. Операцію 3 резервування коштів на даному рахунку не можна вважати їх вилученням з обігу, тому що формування будь-якого фонду, зокрема, фонду виплат соціальних гарантій носить виключно цільовий характер його використання.

Вважаємо доречним коригування фонду виплат соціальних гарантій працівникам на суму фактично спожитих та документально затверджених соціальних гарантій, що призводить до зменшення відрахувань на соціальні заходи. 
Запропоновані зміни до Плану рахунків бухгалтерського обліку активів, капіталу, зобов'язань і господарських операцій підприємств і організацій сприятимуть підвищенню аналітичності обліку через можливість відкриття аналітичних рахунків до рахунку другого порядку 472 «Фонд виплат соціальних гарантій» в розрізі структурних підрозділів, окремих працівників та напрямів використання коштів фонду. 


\section{5 Шляхи удосконалення бухгалтерського обліку елементів природного капіталу}

Система бухгалтерського обліку $€$ основним джерелом формування достовірної й своєчасної інформації для зовнішніх та внутрішніх користувачів. При цьому, бухгалтерська інформація використовується внутрішніми користувачами в цілях управління ланцюгом додавання вартості. Тому керівники та власники, часто більше зацікавлені в оптимізації оподаткування шляхом мінімізації або відстрочення податкових зобов'язань і не стосуються суб'єкта господарювання [32]. За таких умов глобальні питання сталого розвитку економіки та необхідність визначення внеску суб'єкта господарювання у досягнення цілей сталого розвитку екологічної сфери залишаються поза увагою керівного персоналу, а відповідно не знаходять свого відображення в організації бухгалтерського обліку. Крім того, окремі екологічні аспекти господарської діяльності є досить складними з точки зору їх спостереження, оцінювання та фіксації в первинних документах.

3 точки зору організації бухгалтерського обліку, зважаючи на суттєві відмінності в обліковому відображенні як елементів природного капіталу так і інших об'єктів бухгалтерського обліку, доцільно підприємства харчової індустрії за специфікою діяльності розділити на чотири групи: сільське господарство, виробництво продуктів харчування, торгівля продуктами харчування, ресторанний бізнес. Крім того, згідно Закону про бухгалтерський облік та фінансову звітність в Україні на організацію бухгалтерського обліку суттєво впливає розмір підприємства, які можуть належати до мікропідприємств, малих, середніх або великих[33]. Норми статті 2 визначають, що до певної групи відносяться підприємства, показники яких на дату складання річної фінансової звітності за рік, що передує звітному, відповідають щонайменше двом із критеріїв, наведеним в таблиці 1. 
Ранжування підприємств за розміром в цілях

організації бухгалтерського обліку

\begin{tabular}{|c|c|c|c|}
\hline Розмір підприємства & $\begin{array}{c}\text { Балансова вартість } \\
\text { активів }\end{array}$ & $\begin{array}{c}\text { Чистий дохід від } \\
\text { реалізації продукції } \\
\text { (товарів, робіт, послуг) }\end{array}$ & $\begin{array}{c}\text { Середня кількість } \\
\text { працівників }\end{array}$ \\
\hline Мікропідприємства & до 350 тисяч євро & до 700 тисяч євро & до 10 осіб \\
\hline Малі підприємства & до 4 мільйонів євро & до 8 мільйонів євро & до 50 осіб \\
\hline Середні підприємства & до 20 мільйонів євро & до 40 мільйонів євро & до 250 осіб \\
\hline Великі підприємства & понад 20 мільйонів євро & понад 40 мільйонів євро & понад 250 осіб \\
\hline
\end{tabular}

Дослідження форм організації облікової служби за розміром підприємств вибіркової сукупності показало, що високий показник наявності внутрішньої облікової служби досягнуто здебільшого за рахунок великих та середніх підприємств харчової індустрії (табл. 2). Малим та мікро підприємствам більш притаманна організація облікової служби на засадах аутсорсінгу або змішане ведення обліку, за якого функції первинного обліку виконуються обліковоекономічним персоналом підприємства, а формування звітності та податкові розрахунки переносяться на консультаційні центри, аудиторські фірми або приватних консультантів.

Таблиця 2.

Форма організації облікової служби за розміром

підприємств вибіркової сукупності

\begin{tabular}{|c|c|c|c|c|c|}
\hline \multirow{2}{*}{$\begin{array}{c}\text { Форма організації } \\
\text { облікової служби }\end{array}$} & \multicolumn{3}{|c|}{ Розмір підприємств вибіркової сукупності } & \multirow{2}{*}{ Разом } \\
\cline { 2 - 5 } & Мікропідприємства & $\begin{array}{c}\text { Малі } \\
\text { Відприємства }\end{array}$ & $\begin{array}{c}\text { Середні } \\
\text { підприємства }\end{array}$ & $\begin{array}{c}\text { Великі } \\
\text { підприємства }\end{array}$ & \\
\hline \multirow{2}{*}{ Зовнішня } & - & 6 & 7 & 5 & 18 \\
\cline { 2 - 5 } & - & 11 & 12 & 10 & 33 \\
\hline \multirow{2}{*}{ Змішана } & 8 & 8 & - & - & 16 \\
\cline { 2 - 5 } & 14 & 14 & - & - & 28 \\
\hline Разом & 2 & 30 & 6 & - & 39 \\
\cline { 2 - 6 } & 10 & 31 & 11 & 5 & 57 \\
\hline
\end{tabular}

Дослідження форм організації облікової служби за видом діяльності підприємств вибіркової сукупності показало, що високий показник наявності внутрішньої облікової служби досягнуто здебільшого підприємствами, що здійснюють виробництво продуктів харчування та торгівлю продуктами 
харчування. Підприємствам, які займаються сільськогосподарським виробництвом та ресторанним бізнесом більш притаманна організація облікової служби на засадах аутсорсінгу або змішане ведення обліку.

Ефективна організація бухгалтерського обліку елементів природного капіталу на підприємстві передбачає виділення специфічних елементів обліку як інформаційної системи, визначення та налагодження взаємозв'язків між ними та обгрунтування складу i структури внутрішніх регламентів документування господарських операцій пов'язаних 3 природоохоронною діяльністю підприємств харчової індустрії. Налагодження дієвої системи документування господарських операцій є основою ефективного функціонування та розвитку бухгалтерського обліку природного капіталу.

Перелік внутрішніх регламентів організації обліку природного капіталу, які мають бути прийняті на підприємстві харчової індустрії є специфічним і напряму залежить від галузевої належності. В системі внутрішніх організації обліку природного капіталу слід виділяти чотири блоки документів, які згруповано у два класи: 1. Регламентація організації та обліку охорони навколишнього середовища (Блок 1. Документи в частині організації екологічної служби та Блок 2. Документи в частині охорони атмосферного повітря); 2. Регламентація організації та обліку природокористування (Блок 3. Документи у сфері водокористування та Блок 4. Документи у сфері поводження з відходами).

Харчова індустрія відноситься до найбільш матеріалоємних галузей, тому раціональне використання сировини має особливо важливе значення. Утилізація відходів виробництва поряд 3 комплексним використання сировини $\epsilon$ найважливішими напрямами зниження матеріалоємності i відповідно собівартості виробленої продукції (товарів, робіт та послуг).

На думку В.А. Кулик та М.О. Любимова, дієвість і ефективність організації бухгалтерського обліку залежить від взаємовідносин між людьми та результатами їх трудової діяльності; політики керівництва i методів, що використовуються для впливу на персонал; повноважень та функцій працівників підприємства на різних рівнях управління [34]. Відносно природного капіталу це 
означає, що весь персонал підприємства, починаючи від управлінської ланки, повинен бути зацікавлений в екологоорієнтованій господарській діяльності, дбати про раціональне використання природних ресурсів, залученні до виробничого ланцюжка найбільш ефективних 3 точки зору охорони навколишнього середовища засобів та предметів праці. Для налагодження ефективної системи документування на першому етапі необхідно сформувати аналітичну картку складових природного капіталу, які використовуються в господарській діяльності підприємства харчової індустрії за напрямами такої діяльності.

Таким, чином доведено, що природний капітал потребує адаптації загальноприйнятих методів для достовірного відображення інформації про нього в обліково-аналітичній системі та звітності, що має досягатися розкриттям їх в обліковій політиці. Обгрунтовано, що в розпорядчому документі про облікову політику підприємства харчової галузі мають наводитися методи оцінки вибуття запасів; облік транспортно-заготівельних витрат; метод амортизації основних засобів та нематеріальних активів природоохоронного призначення; періодичність та об’єкти проведення інвентаризації.

Для раціональної організації обліку природного капіталу на підприємствах харчової галузі визначено процедурні питання облікової політики, які включають: розробку робочого плану рахунків обліку природного капіталу та форми відповідних первинних документів; формування графіків документообігу операцій 3 обліку екологічних аспектів бізнесу; опис порядку організації матеріальної відповідальності за порушення екологічних норм; визначення порядку ведення управлінського обліку та формування екологічної звітності.При формуванні робочого плану рахунків необхідно враховувати не лише вимоги своєчасності та повноти заповнення форм фінансової, статистичної та податкової офіційної звітності, а також потенційну необхідність подання інформації про досягнення підприємством цілей сталого розвитку екологічної сфери. В основу розробленого робочого плану рахунків природного капіталу підприємств харчової індустрії доцільно покласти фасетну класифікація екологічних аспектів 


\section{SOCIO-ECONOMIC AND MANAGEMENT CONCEPTS}

діяльності. Для формування добровільної звітності про досягнення цілей сталого розвитку екологічної сфери підприємствам харчової індустрії відповідно до чинної облікової практики та специфіки їх діяльності рекомендуємо використовувати вільні шифри забалансових рахунків.

Використання адекватних оцінок для різних елементів природного капіталу $є$ основою для нормування збереження стійкості екосистем та створює нові передумови для застосування запобіжних, а не компенсаційних економічних механізмів у сфері природокористування підприємств харчової індустрії. При цьому, окремі екологічні аспекти господарської діяльності є досить складними 3 точки зору їх спостереження, оцінювана та фіксації в первинних документах. 3 метою ефективної організації бухгалтерського обліку елементів природного капіталу на підприємстві пропонуємо застосовувати комплексну модель організації бухгалтерського обліку природного капіталу, яка враховує специфічні елементи обліку як інформаційної системи, взаємозв'язки між ними та склад і структуру внутрішніх регламентів документування господарських операцій пов'язаних з природоохоронною діяльністю підприємств харчової індустрії. 


\section{6 Організація та планування аудиту реалізації продукції підприсмства}

Як відомо, від якості інформації залежить рівень інформаційного ризику користувачів такою інформацією. Викривлена узагальнююча інформація щодо отриманих підприємством фінансових результатів передбачає спотворення макроекономічних показників та зниження ефективності прийняття управлінських рішень не тільки на рівні підприємства, а й на рівні держави. Саме тому, важливим аспектом є проведення аудиту, на якість якого неабиякий вплив має чітка організація та планування такого роду перевірки на підприємстві.

Вивченню питань, які стосуються організації та планування аудиту присвячено чимало праць вітчизняних науковців, серед яких Андрейцева I., Бескоста Г., Ватуля І., Корінько М., Корягін М., Коцеруба Н., Лобачева І.Ф. та інші. Проте, різноманітність дискусій навколо даного питання зумовлює вивчення його аспектів, а також внесення власних корективів та стверджень.

Суть аудиту реалізації продукції полягає в аудиторській перевірці достовірності формування дохідної та витратної частин в розрізі видів діяльності господарюючого суб’єкта та повноти визнання сум щодо собівартості реалізації продукції. Аудит реалізації продукції розпочинається із визначення мети, якої прагне досягти виробник - чи то максимізувати прибуток, чи втриматись на ринку тощо. «Лише після цього можна здійснити обгрунтований конкретний аналіз i підготувати достовірні аудиторські висновки», вважає науковець Тарнавська М.О. [39, c. 90$]$.

Мета аудиту реалізації продукції полягає у вивченні відповідності даних, відображених у фінансовій звітності та бухгалтерському обліку, діючим нормативно-правовим документам, які регламентують порядок ведення бухгалтерського обліку та складання фінансової звітності.

Згідно НСБО № 1 «Загальні вимоги до фінансової звітності» головними напрямками аудиту реалізації продукції є перевірка достовірності відображення в обліку фактичної виручки від реалізації продукції, фактичних витрат на виробництво та реалізацію продукції, визначення сум податкового доходу від 
реалізації продукції та підтвердження сум податкових витрат для достовірної суми визнання бази оподаткування податком на прибуток та ПДВ [36].

Як відомо, аудит реалізації продукції підприємства складається з трьох етапів (рис. 1) та починається 3 його планування, а саме 3 укладання договору на проведення аудиторської перевірки, а також 3 «перевірки обгрунтованості плану реалізації продукції та цін на неї, повноти визначення валової та товарної продукції, показників якості, відповідності останніх вимогам державних стандартів, технічних умов.

\begin{tabular}{|c|c|}
\hline I ЕТАП & ОРГАНІЗАЦІЯ АУДИТОРСЬКОЇ ПЕРЕВІРКИ \\
\hline & $\begin{array}{l}\text { Передбачається документально-правове забезпечення аудиту, визначення } \\
\text { відповідальних за проведення аудиту (групи аудиторів або одного аудитора) }\end{array}$ \\
\hline II ЕТАП & МЕТОДИЧНЕ ЗАБЕЗПЕЧЕННЯ ПРОВЕДЕННЯ АУДИТУ \\
\hline & 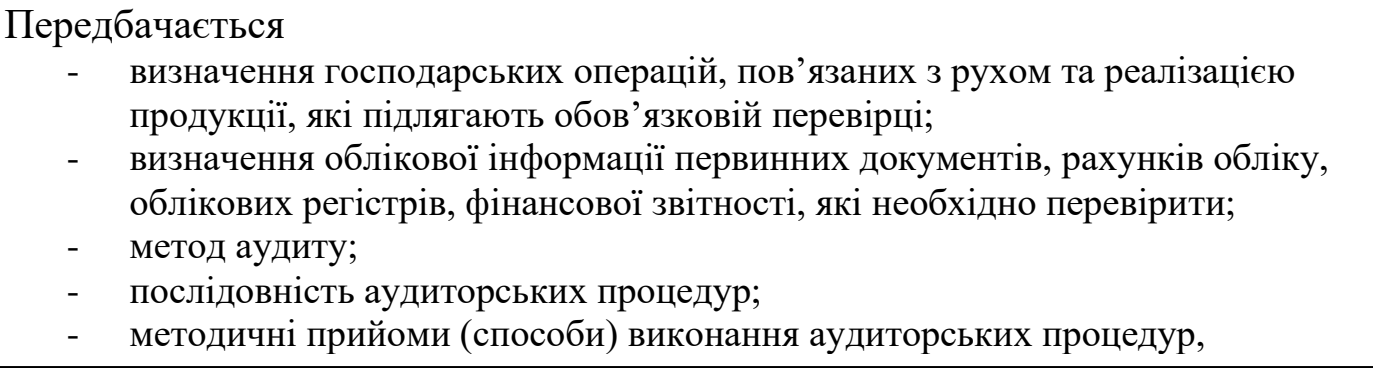 \\
\hline III ЕТАП & УЗАГАЛЬНЕННЯ РЕЗУЛЬТАТІВ АУДИТУ (АУДИТОРСЬКИЙ ВИСНОВОК) \\
\hline
\end{tabular}

Рисунок 1. - Етапи проведення аудиту реалізації продукції

Після підписання договору на здійснення аудиторської перевірки складається загальний план аудиту. У зарубіжній практиці аудиторів він охоплює перевірку в розрізі окремих етапів. Натомість, вітчизняна практика свідчить про складання такого плану відповідно до аудиторських процедур, які складають програму аудиту. Ми вважаємо, що загальний план аудиту необхідно складати відповідно до етапів без виділення аудиторських процедур. 3 метою досягнення мети та виконання завдань, а також покращення якості проведення аудиторської перевірки виникає потреба в чітко та раціонально сформованій організації та методиці аудиту реалізації продукції (рис. 2.) [37]. 


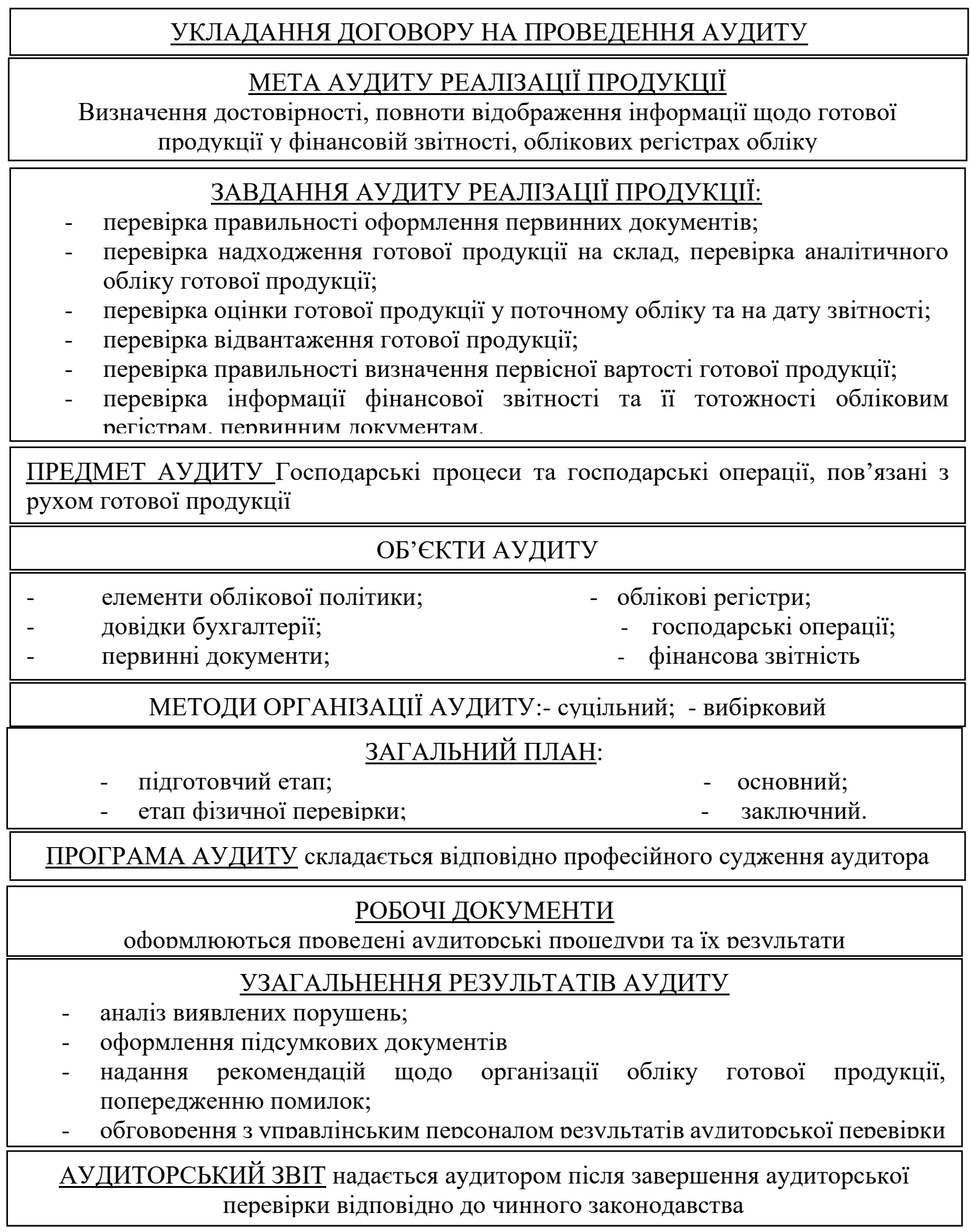

Рисунок 2. - Головні організаційно-методологічні аспекти аудиту реалізації продукції

Слід зауважити, що така схема може використовуватися для проведення аудиту будь-якого облікового процесу. 3 метою забезпечення правдивості даних бухгалтерського обліку та фінансової звітності, в загальному плані аудиту 
реалізації продукції завжди є місце для проведення інвентаризації. Завдання інвентаризації готової продукції на підприємстві полягають у перевірці стану, наявності та зіставленні фактичної готової продукції з даними бухгалтерського обліку, а також оцінці обліку готової продукції на складі.

Результати аналізу інвентаризаційних документів аудитор оформлює у довільній формі, 3 обов'язковим підтвердженням якості інвентаризаційної перевірки. Не менш важливим в процесі аудиту реалізації є перевірка фактичного обсягу відвантаження продукції покупцям. Така перевірка проводиться згідно відомості, складеної на основі даних рахунку 36 «Розрахунки з покупцями та замовниками», що дає змогу встановити як загальний обсяг постачання продукції по підприємству, так і обсяг відвантаження в розрізі кожного покупця окремо. Так, першочергово, аудитор перевіряє достовірність відображення у відомості даних первинних бухгалтерських документів по відвантаженню готової продукції, зокрема наявність всіх сум у відомості. У разі виявлення розбіжностей між ними аудитор встановлює причини їх виникнення. Аудитор перевіряє достовірність та своєчасність складання рахунків та платіжних документів на відвантажену продукцію, а також приділяє велику увагу поступленню коштів на банківські рахунки підприємства. Перевірці на відповідність залишків готової продукції на складах підприємства підлягають суми по статтях Балансу «Готова продукція» $\mathrm{i}$ «Товари».

Одним із найважливіших аспектів перевірки достовірності бухгалтерських та звітних даних щодо реалізації продукції $є$ детальне вивчення банківських виписок та додатків до них, платіжних документів, які є основою для внесення до відповідних реєстрів (журналів) бухгалтерського обліку по кредиту рахунку 701 «Дохід від реалізації готової продукції» в кореспонденції з дебетом рахунку 311 «Поточні рахунки в національній валюті», рахунку 301 «Каса», рахунку 313 «Інші рахунки в банках», рахунку 333 «Грошові кошти в дорозі в національній валюті» [35].

В процесі перевірки операцій з обліку готової продукції аудитор порівнює сальдо кінцеве попереднього звітного періоду із сальдо початковим наступного 
звітного періоду. 3 метою виявлення розбіжностей та одержання результативних значень аудитор вводить вхідну інформацію до попередньо розроблених таблиць, які містять задані алгоритми розрахунку необхідних показників, порівнює свої дані з бухгалтерськими, таким чином перевіряє достовірність проведених бухгалтером розрахунків.

В ході перевірки аудитор складає протокол, який $є$ вихідною інформацією для аудиторського висновку. Разом з тим, застосовує режим автоматизованого документування вихідної інформації. Вихідні дані для відображення результатів аудиту реалізації продукції можуть відрізнятися за формою їх представлення та залежать від потреб аудитора. Це дає змогу аудитору зробити аналіз абсолютних відхилень, виявити причини їх виникнення та шляхи їх усунення. Інформація про відхилення «...дає можливість керівникам підприємства ...впливати на виробничий процес з метою економного використання матеріальних, трудових та грошових засобів» [38].

Як відомо, сьогодні чимало підприємств практикують попередню оплату за реалізовану продукцію, таким чином аудитор змушений виводити суми попередньої оплати та перевіряти належність проведення розрахунків окремо по кожному покупцеві. Разом з тим, деякі господарюючі суб'єкти під видом попередньої оплати здійснюють перерахунок сум, які не обкладаються податком на додану вартість. Перед аудитором постає завдання вивчення випадків невключення таких сум ПДВ до податкового зобов'язання, визначення рівня обгрунтованості перерахованих сум, а саме «...чи вся сума включена в обсяг реалізації, чи обкладалася вона ПДВ, в яких цінах здійснювався бартерний обмін». Після того аудитор проводить аналіз правильності визначення оподаткованого обороту для обкладення ПДВ.

В процесі перевірки руху готової продукції аудитор може виявити наступні порушення: невідповідність оцінки готової продукції методу оцінки, обраного в обліковій політиці підприємства; неповне відображення в обліку випущеної продукції; несвоєчасне відображення в обліку відвантаженої та реалізованої 
продукції; відсутність налагодженого аналітичного обліку готової продукції за місцями її зберігання та окремими видами [39].

Крім того, аудиторською перевіркою контролюється списання позавиробничих витрат на собівартість реалізованої продукції. Зрештою, аудитор аналізує правильність визначення результатів реалізації готової продукції по кожній номенклатурній одиниці, а також правильність відображення їх в реєстрах бухгалтерського обліку і в звітних даних форм 1 «Баланс підприємства» та форми 2 «Звіт про фінансові результати» річної і квартальної звітності. 


\section{7 Методична основа інформаційної та обліково-аналітичної підсистеми забезпечення розрахунків 3 контрагентами}

Ухвалення управлінського рішення, оперативного та стратегічного напряму має базуватися на достовірній інформації в необхідних показниках. Учасники підприємницьких відносин зацікавлені в прозорості інформації, сформованої за єдиними принципами. Результативність управління в значній мірі визначається рівнем організації процесу і якістю його інформаційного забезпечення. При цьому інформаційне забезпечення управління організацією тісно корелюється з його обліково-аналітичним забезпеченням.

В економічній літературі використовуються різні визначення: "інформація для прийняття рішень", "інформаційне забезпечення" (Х. Андерсон, М.А. Вахрушина, К. Друрі, Д. Кондуелл, М.І. Кутер, Б. Нидлз, Дж. Фостер, Ч.Т. Хорнгрен, А .Д. Шеремет); "інформаційне поле підприємства" (М.I. Маниліч, Г.Д. Шутак, В. І. Борисова, Л. М. Баранова); "обліково-інформаційна система" (Л.І. Хоружий); "аналітичне забезпечення" (Н.В. Гойло, С.В. Мочерний, О.С. Іванілов); "обліково-аналітичне забезпечення" (С.Ф. Голова, М.Ф. Огійчук, І.В. Орлов, С.А., Бороненкова, М.А. Вахрушина, К. Уорд), - з яких, на нашу думку, найбільш точним є останнім. Провівши дослідження економічної літератури, систематизуємо існуючі в даний час визначення обліково-аналітичного забезпечення процесу управління підприємства (таблиця 1).

Необхідно відмітити, що система обліково-аналітичного забезпечення $є$ складовою загальної системи управління, вона базується тільки на даних бухгалтерського обліку і здійснюється працівниками бухгалтерії. 
Поняття обліково-аналітичного забезпечення процесу управління

підприємства

\begin{tabular}{|c|c|}
\hline Автор & Зміст поняття \\
\hline $\begin{array}{c}\text { М.А. } \\
\text { Вахрушина }\end{array}$ & $\begin{array}{l}\text { Збір, обробка та передача фінансової та нефінансової інформації, } \\
\text { використовуваної менеджерами для плануванні ня і контролю за ходом } \\
\text { діяльності ввірених їм підрозділів, вимірювання та оцінки отриманих } \\
\text { результатів }\end{array}$ \\
\hline M.I. Куттер & $\begin{array}{l}\text { Взаємозв'язок оперативного, бухгалтерського (фінансового та } \\
\text { управлінського) і статистичного обліків за рахунок спільності } \\
\text { методології обліку в усьому господарстві держави, а також показників } \\
\text { прогнозування, обліку та звітності }\end{array}$ \\
\hline $\begin{array}{c}\text { С.В. } \\
\text { Івахненков }\end{array}$ & $\begin{array}{l}\text { Результат інтерпретації користувачем даних, представлених у } \\
\text { бухгалтерській звітності, що обумовлено рядом суто суб'єктивних } \\
\text { факторів: наприклад, особистим сприйняттям користувача стану справ } \\
\text { на підприємстві до читання бухгалтерської звітності і після її аналізу }\end{array}$ \\
\hline Ю.А.Мишин & $\begin{array}{l}\text { Сукупність інформаційних ресурсів і способів їх організації, } \\
\text { необхідних і придатних для реалізації аналітичних процедур, що } \\
\text { забезпечують фінансову сторону діяльності компанії }\end{array}$ \\
\hline $\begin{array}{l}\text { M.C. } \\
\text { Пушкар }\end{array}$ & $\begin{array}{l}\text { інформація - це субстрат, необхідний і обов'язковий для того, } \\
\text { щоб оцінити ситуацію, виробити можливі альтернативи управлінських } \\
\text { рішень та відібрати найдоцільнішу з них для практичного використання }\end{array}$ \\
\hline B.B.Con & $\begin{array}{l}\text { Процес збору вихідних даних від джерел формування первинних } \\
\text { аналітичних даних з подальшою процедурою обробки сформованих } \\
\text { аналітичних даних і використанням отриманої аналітичної інформації } \\
\text { в оцінці і контролі за виробничою діяльністю }\end{array}$ \\
\hline І.В. Орлов & $\begin{array}{l}\text { Частина процесу управління підприємством, що включає } \\
\text { наступні елементи: } \\
\text { 1) спеціальну методику (технологію) системних записів, } \\
\text { об'єктивно відображають доконаний факт господарського життя } \\
\text { підприємства, яка дозволяє об'єднати їх в єдину модель "облік - аналіз } \\
\text { - аудит"; } \\
\text { 2) аналітичні показники; } \\
\text { 3) аудиторські докази }\end{array}$ \\
\hline $\begin{array}{r}\text { Ч.Т. } \\
\text { Хорнгрен }\end{array}$ & $\begin{array}{l}\text { Система інформації, яка виходить із основи організаційної } \\
\text { структури управління - ієрархії функцій або совокупності бізнес- } \\
\text { процесів }\end{array}$ \\
\hline С.Ф. Голов & $\begin{array}{l}\text { Система даних різних видів обліку (фінансового, управлінського, } \\
\text { стратегічного) і інших позаоблікового відомостей }\end{array}$ \\
\hline $\begin{array}{r}\text { А.Д. } \\
\text { Шеремет }\end{array}$ & $\begin{array}{l}\text { Сукупність внутрішніх і зовнішніх потоків прямого і зворотнього } \\
\text { інформаційного зв'язку економічного об'єкта, методів засобів, фахівців, } \\
\text { що беруть участь в процесі обробки інформації і виробленні } \\
\text { управлінських рішень }\end{array}$ \\
\hline Г.Д. Шутак & $\begin{array}{l}\text { Сукупність інформаційного (планові, облікові та позаоблікове } \\
\text { джерела) і методичного забезпечення (методи і методики аналізу) } \\
\text { діяльності організації }\end{array}$ \\
\hline
\end{tabular}

Джерело: складено автором за [41-53] 
Суть цієї системи полягає в об’єднанні облікових та аналітичних операцій в один процес, проведення оперативного мікроаналізу, забезпеченні безперервності даного процесу і використанні його результатів при формуванні рекомендацій для прийняття управлінських рішень. При цьому загальна методологія і нормативні положення обліку і аналізу удосконалюються для раціонального використання в єдиній обліково-аналітичній системі [40].

Потік бухгалтерської інформації починається 3 фактичних економічних подій і дозволяє здійснювати збір та переміщення економічних даних від одного періоду до наступного. Послідовний процес дозволяє зацікавленим сторонам зрозуміти фінансовий стан організації та покластись на неї.

Базовою в обліково-аналітичному забезпеченні є облікова підсистема, оскільки саме вона забезпечує постійне формування, накопичення, класифікацію і узагальнення необхідної інформації [54]. Отже, виникає потреба розробки принципів і процедур, складових методичної основи підсистеми обліковоаналітичного забезпечення розрахунків з контрагентами.

Вивчивши існуючі визначення категорії "системи обліково-аналітичного забезпечення", можемо розкрити деякі трактування цього поняття стосовно до розрахунків $з$ контрагентами. Вважаємо, "підсистема обліково аналітичного забезпечення розрахунків з контрагентами - це сукупність взаємодіючих i взаємопов'язаних елементів, що сприяють формуванню бізнес-процесу за допомогою збору, реєстрації, оцінки, узагальнення і аналізу всіх видів інформації, яка використовується для планування діяльності, розробки, прийняття і реалізації управлінських рішень, а також здійснення контрольних дій 3 метою зниження ризиків суттєвого її спотворення" [55].

Виходячи з проведеного дослідження, підсистему обліково-аналітичного забезпечення розрахунків з контрагентами можна розглядати як багатофакторну модель взаємодії підрозділів економічного суб'єкта в ході здійснення бізнеспроцесу. При цьому слід врахувати, що на організаційну структуру даної моделі найбільш істотний вплив роблять три блоки факторів: 
1) структура ієрархії формування інформації (організація в цілому, іï структурних підрозділів, центри відповідальності);

2) діюча нормативно-правова база в області бухгалтерського обліку та оподаткування у зв'язку з можливими галузевими особливостями;

3) інформаційні потреби внутрішніх зовнішніх користувачів.

Отже, модель обліково-аналітичної системи забезпечення розрахунків 3 контрагентами повинна носити індивідуальний характер в залежності від специфіки діяльності конкретного економічного суб'єкта. Також в основу подібної системи повинна бути покладена економічна сутність категорії операцій за розрахунками, які, в свою чергу, супроводжують процесу обміну, за допомогою якого розрізнені, господарсько відокремлені виробники і споживачі товарів, робіт, послуг передають у власність результати виробничої діяльності, спрямовані не для власного споживання, а для задоволення суспільних потреб.

Досить важливою і значущою проблемою на сьогоднішній момент для підприємств, можна вважати перевищення кредиторської заборгованості над дебіторською. При виникненні даних обставин виникає ситуація неплатоспроможності і розрахунки 3 контрагентами як правило порушуються. Негативність стану неплатоспроможності господарюючого суб'єкта спричинить затримку оплати, за договорами 3 постачальниками та підрядниками, також можуть бути припинені поставки, котрі мають право нарахувати пені за певні прострочення і зрив договірних зобов'язань[56]. Необхідно відзначити, що невірне оформленні платіжні доручення можуть бути причиною прострочення розрахунків. Для вирішення проблем 3 кредиторської заборгованістю необхідний iі моніторинг, аналіз і періодичне порівняння 3 показником попередніх періодів або середньозваженими показником. У свою чергу результат моніторингу, дозволяє оперативно реагувати на ситуацію і сприяє прийняттю ефективних управлінських рішень в частині управління за кредиторською заборгованістю.

На жаль, через складність сприйняття бухгалтерами нового об'єкта бухгалтерського обліку - "договірних зобов'язань, що не має майнового 
наповнення, розробники MCФЗ (IFRS) 15 не позначали їх як об'єкти бухгалтерського обліку, проте нехай навіть побічно використовують для позначення договірних зобов'язань такі терміни: "актив за договором" i "зобов'язання за договором", але не забороняють організації використовувати альтернативні назви для цих статей у звіті про фінансовий стан [56].

Бухгалтерська служба підприємства, зобов'язана своєчасно відстежувати виконання всіх термінів і умов договорів поставок, що сприятиме виявленню недобросовісних і відповідальних постачальників. Такий підхід до управління кредиторської та дебіторської заборгованістю дозволить саме підприємствам уникнути прострочення в постачанні ресурсів, також скоротити кількість відсутніх документів, необхідних для формування достовірної звітності [58]. Головний бухгалтер зобов'язаний тримати на контролі рівень кредиторської заборгованості і точно розставляти пріоритети оплати. У свою чергу працівники бухгалтерської служби не повинні допускати помилки при відправленні платіжних поручнів. Неякісне проведення навіть елементарних операцій сприяє несвоєчасного проходження оплати через банк.

До облікової інформації відносяться всі дані, які містяться в документах бухгалтерського, оперативного і статистичного обліку, первинної облікової документації. На підставі даних джерел складається фактична інформація про стан і видах дебіторської і кредиторської заборгованості. Ретельне виконання всіх етапів організації обліку, аналізу та аудиту розрахунків дасть змогу побудувати на підприємстві ефективну систему, за допомогою якої можна ефективно керувати дебіторською i кредиторською заборгованістю підприємства. Така система не тільки покращить розрахунки 3 контрагентами, але й наддасть більші можливості до ефективного залучення коштів у грошовий обіг на підприємстві, що відобразиться на результатах його діяльності в цілому Значна роль в інформаційному забезпеченні аналізу відводиться бухгалтерському обліку та звітності, оскільки в них досить повно відбиваються господарські явища, процеси і їх результати. Бухгалтерська інформації включає первинні документи, регістри і внутрішню звітність і бухгалтерську звітність. 
Дані перших двох груп мають обмеження в доступі до них. У зв'язку з чим, перераховані документи утворюють інформаційну базу, що дозволяє проводить внутрішній аналіз в інтересах керівників і власників організації [59]. До основних джерел інформації для аналізу дебіторської i кредиторської заборгованості підприємства відносяться наступні форми бухгалтерської звітності: бухгалтерський баланс організацій; звіт про фінансові результати; інші додатки до бухгалтерського балансу і звіту про фінансові результати. Детальне уявлення інформації в бухгалтерській (фінансової) звітності про діяльність підприємства може дати можливість зацікавленим користувачам визначити реальний фінансовий стан підприємства, оцінити ризики господарської діяльності, яким вона схильна до, для прийняття рішень про перспективну співпрацю з контрагентами. Коли бухгалтери ретельно стежать за процесом, фінансова звітність підприємства за своєю суттю буде порівнянною, послідовною та надійною з часом. Це дозволяє підприємству, іï зацікавленим сторонам бути краще поінформованими та мати можливість приймати рішення на основі фінансових показників організації [60].

У свою чергу, ефективне управління дебіторською та кредиторською заборгованістю сприяє зниженню ризиків неплатоспроможності і фінансової залежності економічного суб'єкта від зовнішніх джерел фінансування, що в свою чергу відбивається на його фінансовий стан. Проведене дослідження визначає важливість того, що питання інформаційного забезпечення аналізу взаємодії 3 контрагентами для будь-якої організації є досить важливими і актуальними. Підсистема обліково-аналітичного забезпечення розрахунків з контрагентами $€$ процес безперервних, взаємопов'язаних дій, що утворюють замкнутий цикл управління, ядром якого виступає система бухгалтерського обліку. Вважаємо за необхідне розглядати підсистему обліково-аналітичного забезпечення розрахунків $з$ контрагентами як багатофакторну модель взаємодії підрозділів економічного суб'єкта в ході здійснення бізнес-процесу. 


\section{8 Діджиталізація бухгалтерського обліку як ефективний елемент управління}

У сучасних ринкових умовах, коли темп життя постійно набирає обертів, відбувається збільшення інформації і це призводить до пошуку нових підходів до використання та обробки даних, системи автоматизації для ефективного управління господарською діяльністю кожного підприємства. Сьогодні кожна компанія прагне підвищити свою конкурентоспроможність і вимагає швидких змін та використання новітніх технологій, щоб зберегти, збільшити інтегрований розвиток для стабільного майбутнього. Економічне зростання та трансформація відбуваються за рахунок розширення та більш зручного використання цифрових технологій. Отже, швидкі зміни неминучі для розвитку та конкурентоспроможності підприємства щодо використання цифрових перетворень.

Діджиталізація (цифровізация) є основою для розвитку сучасного бізнесу. В умовах нової економіки, під час жорсткої конкуренції, швидкого старіння технологій, професій, ідей, проникнення Інтернету в усі частини економіки, діджиталізація вийшла на новий рівень важливості для бізнесу, суспільства та держави.

Сьогодні діджиталізація в Україні тільки розвивається, на жаль, набагато повільнішими темпами ніж в розвинутих країнах. Дослідження та аналіз даної проблеми ще досконало не опрацьовано українськими науковцями, проте окремі теоретичні аспекти діджиталізації висвітлені в наукових доробках вчених, таких як: О. Абакуменко, О. Грибіненко, О. Гудзь, М. Дубина, О. Козлянченко, С. Король, Т. Лазоренко, Л. Лігоненко, М. Устенко, С. Федюнін та інші.

Л. Лігоненко вважає, що діджиталізація є необхідним процесом розвитку сучасних підприємств в умовах неоекономіки. Вона покликана спростити та прискорити роботу з великими базами даних, забезпечити автоматизацію усіх видів діяльності (основної та допоміжної операційної, інвестиційної, фінансових), покращення комунікації з клієнтами, постачальниками та партнерами та усіма інститутами зовнішнього середовища, формування нових засад взаємодії в межах 


\section{SOCIO-ECONOMIC AND MANAGEMENT CONCEPTS}

підприємства — між підрозділами, працівниками, менеджментом, перехід до нових організаційних форм господарювання (мережева та віртуальна економіка) [61, c.21].

На думку, А. Гуренко, нині головними чинниками розвитку процесів діджиталізації стають: поява новітніх цифрових технологій, формування нових потреб та запитів споживачів (орієнтація на економію часу, пошук і придбання товарів за чіткими параметрами); створення нових цінностей, властивостей товарів; зміна умов конкурентного середовища [62, с.740].

Термін «діджиталізація» («digitalization») прийшов до нас 3 США та перекладається, як оцифровування. Тобто, дослівно в перекладі «діджиталізація» — це процес перенесення інформації у цифрову форму, тобто перетворення паперових книжок у електронні, фотографії у зображення на екрані тощо [61 ,с.21].

Поняття «діджиталізації» інтерпретується ученими як процес використання, застосування, перенесення та переведення інформації у цифровий формат; система збору, зберігання, аналізу даних, застосування штучного інтелекту; трансформація проникнення цифрових технологій, щодо оптимізації бізнес-процесів. Під дефініцією діджиталізація, на нашу думку, слід розуміти процес систематизації, використання, обробки інформації у цифровий формат з використанням Інтернету, 3 одночасним поліпшенням системи обслуговування клієнтів у бізнес-середовищі [63].

Основна мета діджиталізації полягає у досягненні цифрової трансформації існуючих та створенні нових галузей економіки, а також трансформації сфер життєдіяльності у нові більш ефективні та сучасні. Такий приріст є можливим лише тоді, коли ідеї, дії, ініціативи та програми, які стосуються цифровізації, будуть інтегровані, зокрема, в національні, регіональні, галузеві стратегії і програми розвитку [64].

Перші кроки до процесів діджиталізації (цифровізації) наразі вже зроблено. Про це свідчить діджиталізація роботи державних служб, контроль за державними фінансами, електронні аукціони, онлайн-послуги. Наразі понад 100 онлайн-послуг дають можливість отримання якісного сервісу без втручання людини. 
В 2019 році 76\% органів виконавчої влади розміщують дані на Єдиному державному веб-порталі відкритих даних data.gov.ua; впроваджено понад 120 загальнодержавних е-послуг та 10 тис. онлайн зареєстрованих підприємств. Щорічне зростання IT-сфери зафіксовано на рівні 22\% [65].

Звичайно, нововведення впливають на всю інформаційну систему, що підтримує процес управління, а отже, і на іï центральну ланку - бухгалтерську інформаційну систему, де вона збирає, обробляє, зберігає, збирає та узагальнює інформацію про діяльність підприємства в хронологічному та систематичному порядку. Аналіз публікацій показав, що якісний розвиток діджиталізації в бухгалтерському обліку спрямований не тільки на мінімізацію людського фактора при прийнятті рішень, а й на своєчасне отримання якісної інформації про процеси господарських операцій. Водночас діджиталізації $є$ інструментом створення, впровадження та використання переваг системи бухгалтерського обліку, збагаченої Digital технологіями в бухгалтерському обліку [66].

Діджиталізація бухгалтерського обліку можлива за умови взаємодії між новими концепціями обробки та передачі інформації за допомогою Digital технологій (табл. 1) [67].

Таблиця 1

IT-сервіси обробки та передачі інформації бухгалтерському обліку при діджиталізації

\begin{tabular}{|c|c|}
\hline IT-сервіси & Призначення \\
\hline RTA & ведення бухгалтерського обліку в реальному часі \\
\hline EDI & електронний обмін даними від первинного до звітного \\
\hline XBRL & $\begin{array}{c}\text { розширена мова фінансової, управлінської та податкової } \\
\text { звітності з різних сфер бізнесу }\end{array}$ \\
\hline $\begin{array}{l}\text { cloud technologies (хмарні } \\
\text { технологіï) }\end{array}$ & для обчислень, хмарні бухгалтерські операції \\
\hline АI (штучний інтелект) & $\begin{array}{c}\text { модернізація математичного моделювання за допомогою } \\
\text { сучасних технологічних інновацій (оцінка рівня запасів за } \\
\text { допомогою програмно керованих безпілотників) }\end{array}$ \\
\hline BigData & $\begin{array}{c}\text { використання в розрахунках для підвищення ефективності, } \\
\text { точності та швидкості }\end{array}$ \\
\hline Blockchain & систематизація та ефективний контроль \\
\hline $\begin{array}{l}\text { м'яка цифрова } \\
\text { інфраструктура }\end{array}$ & $\begin{array}{c}\text { інфраструктура ідентичності та довіри, інфраструктура } \\
\text { відкритих даних, інфраструктура сумісності, інфраструктура } \\
\text { електронних рахунків та транзакцій, інфраструктура } \\
\text { електронної комерції та взаємодія бізнесу в Інтернеті }\end{array}$ \\
\hline
\end{tabular}


Розвиток системи обліку вимагає всеохоплюючого використання розповсюдження та покриття ІТ-технологіями не лише підприємств, а i ïx контрагентів, використовуючи при цьому новітні засоби інформатизації та трансформації уже існуючих. Оскільки діючі технології, які апробовані та довели свою ефективність, можуть використовуватись у діяльності підприємств.

Найпопулярнішими автоматизованими бухгалтерськими системами, які застосовуються в Україні, є такі: «1С: Підприємство»; «Fin Expert»; «Інфобухгалтер»; «АУБІ»; «AВACUS Professional»; «БЕСТ»; «Дебет Плюс»; «ХепіБух»; «Галактика»; «Супер Менеджер»; «Фоліо»; «БОСС»; «Audit Expert.» та ін. [65].

В процесі організації системи бухгалтерського обліку доведеться переформатовувати облікову політику підприємства, переглянути значний масив операцій, поставити під сумнів використання на практиці окремих із них. Окрім цього, у процесі використання принципів діджиталізації необхідно визначитись зі змістом та значенням понять, пов'язаних із цією сферою, можливості їх використання в процесі удосконалення системи обліку.

Основна ідея використання діджитал-інструментів полягає, в першу чергу, у спрощенні облікового процесу, виконанні властивих йому функцій 3 максимальною ефективністю, оскільки діджиталізація нерозривно пов'язана 3 інформацією. На нашу думку, першочерговими та необхідними у функціонуванні системи обліку в майбутньому є інструменти (рис. 1). 


\section{SOCIO-ECONOMIC AND MANAGEMENT CONCEPTS}

Діджитал-інструменти для спрощення облікового процесу

Максимальне використання електронного документообігу в системі обліку - "must have" для будь-якого підприємства

Зростання ефективності облікового процесу прямо залежить від обсягу перетвореної інформації за допомогою використаних діджитал-інструментів

Трансформація діючої технології та розширення у процесі використання хмарних сервісів та систем взаємодії між об'єктами обліку

Розвиток принципів використання чат-ботів, як одного із інструментів у технології облікового процесу, за допомогою автоматизації повторюваних процесів та інтерактивному спілкуванні з користувачами

Розширення можливостей системи для користувачів за допомогою розміщення облікових сервісів на одній платформі, що визначатиме іiі економічність

Рисунок 1. Діджитал-інструменти для спрощення облікового процесу

Усе вище перелічене не $є$ виключним набором інструментів, які сприятимуть удосконаленню системи обліку. Це швидше іiі філософія, сучасне наповнення та розвиток, що полягає у спрощенні та пришвидшенні бізнеспроцесів підприємства. Проте, їх свідоме ігнорування - це неминуча поразка перед конкурентами.

Таким чином, діджиталізація дає можливість прискорити традиційні для облікової системи процеси вимірювання, реєстрації, документування, відображення, перетворення, зберігання. Тобто, удосконалення технічної й технологічної складової обліку з урахуванням діджитал-інструментів сприятиме подальшому розвитку іï досконалішої організації з метою управління при прийнятті ефективних управлінських рішень. 


\section{SECTION 2. ADMINISTRATIVE REGION AND BUDGET}

\subsection{Modern controlling: evaluation of efficiency and directions of improvement}

At the present stage, the social situation of development of most countries is characterized by changes in all spheres of society in general and the functioning of organizations in particular. Accordingly, there is a need to implement various aspects of business process management in the enterprise, which becomes one of the main reasons for the emergence of controlling as a new effective concept. The concept of controlling is based on the need to ensure the successful operation of the enterprise in the long run with the help of certain tools. An integral part of successful controlling in the enterprise is the successful implementation of personnel controlling, because human resources and their intellectual potential occupy a key place in modern organizations.

Numerous researches of domestic and foreign authors, such as Balabanova L., Evseeva S., Eronina V., Kovaleva S., Mikhailova A., Mirinyuk I., Mishchenko O., Nikonova T., Panchenko G., Petenko I., Polozova A., Utkina E., Stanczyk I., Stuss M., Szejniuk A., Schlendera P. etc., are devoted to the problem of controlling as an element of the enterprise management system. Scientific development of this topic, however, is quite limited. Much attention in the works of scientists is paid to defining the essence, highlighting the basic principles, objectives and goals of controlling staff. At the same time, the practical aspects of the implementation and application of personnel controlling in management activities remain insufficiently disclosed, which determines the relevance of this work.

The purpose of the study is to develop a general procedure for evaluating the effectiveness of personnel controlling in the enterprise using a balanced scorecard that contains quantitative and qualitative parameters for evaluation.

Based on the understanding of the concepts of "personnel controlling" and "human resources controlling" defined in and the purpose of controlling [68, 69], we note that personnel controlling is focused on supporting decision-making processes in 
the field of personnel management by supporting and coordination of planning, information support, control and adaptation to changes in the external environment. The effectiveness of the personnel controlling system at the enterprise is determined by its contribution to the achievement of organizational goals [70,71], so assessing its effectiveness is extremely important. Yes, this process is quite complex, as not all results of such activities are quantifiable. To assess the effectiveness of personnel controlling at the enterprise often the following methods are used:

-Expert evaluation, when the experts are actually the heads of the personnel department of the same company, who are asked questions about the effectiveness of the personnel controlling system at the enterprise and a certain scale of evaluation. Experts usually evaluate the personnel controlling system based on the analysis of personnel activities and personnel management services in general. The advantage of such evaluation is the simplicity of its implementation and relatively low costs, but the disadvantage is the inevitable subjectivity of evaluation and not taking into account the overall performance of the enterprise for the period under study.

- Calculation of the rate of return on investment in personnel (ROI on Human Capital), calculated by formula (1):

$$
R O I=\frac{\text { Income }- \text { Costs }}{\text { Costs }} \times 100 \%,
$$

This method is quite time consuming, because it is necessary to take into account the cost of a particular event and the indirect costs associated with its implementation [72]. Accurate calculation of income from this event is unlikely and difficult, because it is not removed from other management and production processes in the enterprise, which also affect the income of the period.

-Benchmarking method in the field of personnel management allows to compare indicators in the field of personnel management and personnel controlling with the results of other companies. According to this methodology, consultants conduct research in the companies participating in such a project to collect the necessary quantitative and qualitative indicators. The survey is conducted confidentially, and as a result, companies are provided with generalized statistics in the field, which can be 
compared with their own performance of personnel controlling. The disadvantages of this method are the lack of flexibility, the inability to identify problems and reduce competitive advantages between companies in the industry.

-Jack Phillips method is designed to evaluate the human resources department, but it can also be used to assess the personnel controlling in the enterprise using five formulas to determine the effectiveness of human resources: evaluation of investment in HR-department, abseitism, employee satisfaction, a criterion that determines the unity and harmony in the organization. The disadvantage of this methodology is the lack of coverage of the selected indicators of all necessary processes to determine the effectiveness of personnel controlling in the enterprise.

-Methodology Suvorova O. Yu. is based on a balanced system of indicators, the main functions are determined, according to which performance evaluation indicators are set and their evaluation is carried out by experts. Functions and indicators for personnel management of the enterprise are: implementation of personnel management policy, organization of personnel work and motivation, meeting the need for staff management personnel; staff adaptation, staff development, staff appraisal, staff training, corporate culture development. Within each of the indicators, detailed criteria are determined, which can be evaluated by experts. Based on the evaluation results, the calculation of the integrated indicator is proposed.

The method of assessing the state of staff controlling which is proposed by the authors Balabanova L. V., Likhoyedova O. V [72] is based on 5 areas: assessment of the completeness and quality of the implementation of information support processes for personnel controlling; analysis of the completeness and quality of the implementation of the processes of methodological support of personnel controlling; analysis of the completeness and effectiveness of the implementation of the processes of resource provision of controlling personnel; analysis of completeness and quality of implementation of technical support processes for personnel controlling; analysis of the completeness, quality and effectiveness of the organization of organizational support processes for personnel controlling. The authors propose to evaluate these areas with a set of individual indicators, each of which has its own evaluation scale. 
The proposed indicators are evaluated by an expert method. Based on this, we understand that this technique is quite cumbersome, and the results are not objective.

According to the BI TO BE consulting group, there are currently several leading performance management techniques, the most effective of which is the Business Performance Management methodology, the main element of which is the Balanced Scorecard. Therefore, after analyzing the selected methods, their main advantages and disadvantages, the author's method of evaluating the effectiveness of personnel control system based on a system of balanced scores, using quantitative and qualitative indicators, which will objectively and comprehensively assess the effectiveness of personnel controlling in the enterprise is proposed.

Before you begin to format your paper, first write and save the content as a separate text file. Complete all content and organizational editing before formatting. Please note sections A-D below for more information on proofreading, spelling and grammar. The process of evaluating the effectiveness of the personnel controlling service according to the author's method consists of 8 stages (Fig. 1).

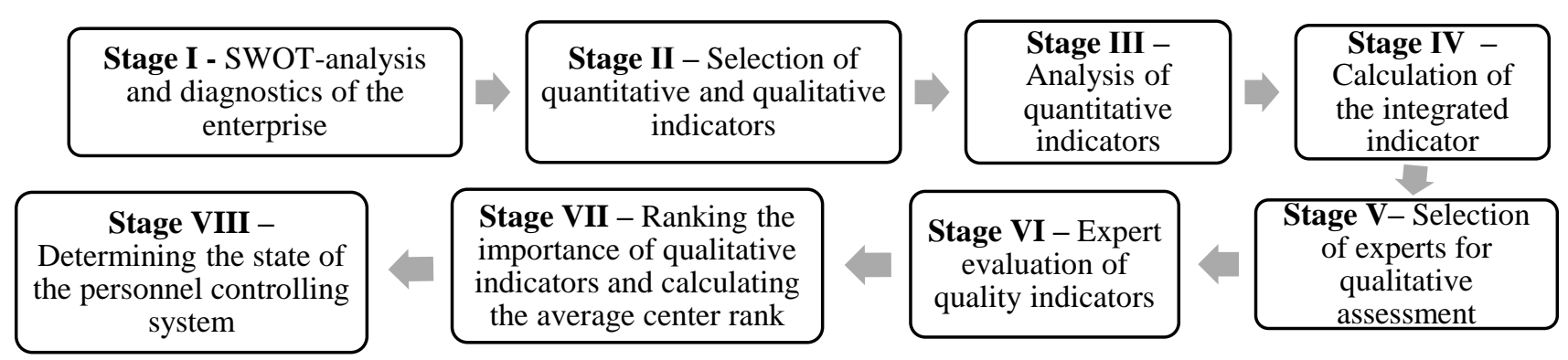

Fig. 1.Stages of evaluating the effectiveness of the personnel controlling system

Evaluation of the effectiveness of personnel controlling is based on the criteria expressed in quantitative indicators, which are presented in table. 1. 
Table 1.

Quantitative indicators of the efficiency of the personnel controlling system at the

enterprise*

\begin{tabular}{|l|l|}
\hline \multicolumn{1}{|c|}{ Research/Direction } & \multicolumn{1}{c|}{ Indicator } \\
\hline Productivity & Sales volume per employee; The amount of net income per employee \\
\hline Staff costs & $\begin{array}{l}\text { The total cost of the enterprise for staff; The share of enterprise costs for } \\
\text { staff in sales for the period; Costs per employee; The growth of the } \\
\text { average monthly wage }\end{array}$ \\
\hline $\begin{array}{l}\text { Training and staff development } \\
\text { costs }\end{array}$ & $\begin{array}{l}\text { Proportion of persons who improved their skills during the year in the } \\
\text { total number of staff }\end{array}$ \\
\hline $\begin{array}{l}\text { The level of satisfaction and } \\
\text { working conditions of staff }\end{array}$ & $\begin{array}{l}\text { Staff turnover ratio; The amount of social benefits per employee; } \\
\text { Investments in labor protection }\end{array}$ \\
\hline
\end{tabular}

Qualitative indicators include: the level of creativity of employees; level of initiative; level of self-realization; level of communication; the level of adaptability of the personnel controlling system; the level of employee culture; ability to selfdiscipline; ability to withstand stressful situations; educational and qualification level of specialists; the level of support for employees of the corporate culture of the enterprise. Note that the number of selected quantitative and qualitative indicators for evaluation by this method should be optimal, which will control the quality of their provision and notice changes. The next step is to analyze the dynamics of the selected quantitative indicators using an integrated indicator. Partial indices of quantitative indicators are calculated as the ratio of the actual value of the $\mathrm{j}$-th indicator to the best value of the same indicator for the last 3 years, i-e rationing of indicators $(2,3)$ and calculate the products of partial indices that characterize the i-th block of quantitative indicators of personnel controlling.

- for stimulant indicators: $\mathrm{K}_{\text {part.i }}=\frac{X_{\mathrm{i} j}}{X_{i j \max }}$

- for destimulant indicators: $\mathrm{K}_{\text {part.i }}=\frac{X_{\mathrm{ijmin}}}{X_{i j}}$

At the third stage, the calculation of group integral indices is carried out, which characterize certain aspects of the personnel controlling system according to the formula of the geometric mean partial coefficients (4) included in the i-th block.

$$
K_{i=} \sqrt[m]{K_{\text {part } 1} * K_{\text {part } 2} * \ldots K_{\text {part. }} m}
$$

The calculation of the consolidated integrated index of personnel controlling by quantitative indicators is carried out according to the formula of the geometric mean of 
the group integrated indices. Based on this indicator, the level of efficiency of the personnel controlling system at the enterprise is determined. For each quality indicator, experts are offered a rating scale with the appropriate levels of "high", "medium" or "low". After the evaluation, the significance of each of the qualitative indicators is ranked in relation to its impact on the effectiveness of personnel controlling at the enterprise. The results obtained on qualitative indicators are reduced by the method of the average central rank (5).

$$
\overline{\mathrm{X}}_{\text {якісне }}=\sum R_{j} \times n_{j} \times f_{j},
$$

where $R_{j}$ values of 1,0 , or -1 , given to "high", "medium" and "low" levels, respectively; $\mathrm{n}_{\mathrm{j}}$ - the number of indicators of the corresponding level with the same weight; $f_{j}$ - the weight of the relevant indicator.

If the value obtained is positive, then the personnel controlling for quality indicators is at a high level, for a negative value - for a low level, and for a value of zero - at a medium level. Based on the above methodology, the assessment of personnel controlling at state-owned enterprises, in particular NJSC "Naftogaz of Ukraine", JSC "Ukrgazvydobuvannia", PJSC "Ukrnafta”, JSC "Ukrtransgaz", was assessed. The integrated indicator of personnel controlling at these enterprises ranges from 0.60 to 0.95 , which indicates its average and high efficiency. Based on the analysis of the impact of each of the selected indicators on the integrated, it is established that there are some aspects of the activities of enterprises in the field of personnel management and controlling, which remained unaccounted for. Therefore, it is advisable to offer the following recommendations that will help improve the system of controlling personnel in state-owned enterprises.

-Introduction of HR-analytics into the personnel controlling system. HRanalytics is a dynamic in time and content-filled process of human resource management monitoring, in which data processing methods and business analytics are applied to HR-data processing in order to positively influence management decisions in the enterprise [73]. According to research by ASUG, American SAP User Group $[74,75]$, HR professionals spend an average of $70-90 \%$ of their time on administrative operations, document management and current functionality, and only about $10 \%$ on 
HR analytics and HRM development strategy. In conditions of constant change leads to an increase in business risks and calls into question not only the success but also the existence of enterprises. It is advisable to focus on the ability to identify and process the most relevant and previously unavailable (insider) information, based on which to predict the optimal algorithms for maximizing investment in human capital of the organization. Thus, HR-analytics allows to create personalized sets of indicators and their dashboards [76], to convert ordinary, banal and "raw" data into business metrics to model the production or organizational behavior of employees.

-Activation of the process of digitalization of HR-functions is the introduction of a holistic talent management system that will create a comfortable digital environment for managers and employees in order to implement management processes and opportunities for employee development and potential of the company as a whole. The talent management system includes performance management for each employee, search and adaptation of employees, training and career management; will facilitate the interaction of managers at all levels and employees of the company, as it will manage the setting of goals, their relationship and track progress. Building a talent management system based on a cloud solution will not require significant capital investment in IT infrastructure, so it can be relatively easily implemented in state-owned enterprises.

-Improving the process of staff training - access to online courses to improve the professional level and competence development. Each employee will be able to track the stages of their own career growth and receive training for further advancement within the company. An important step in staff training should be the introduction of a distance learning system. Due to the epidemiological situation, as well as the trends towards digitalization, this practice is one of the key in all enterprises, offering online training courses for employees of a wide range of specializations.

-Introduce systematic feedback between management and employees. Personnel controlling is not possible without sufficient information support and a wellestablished system of submitting, receiving and processing information. And if the already implemented processing and analysis systems help to cope with the latter, the information about the level of staff satisfaction, their wishes or comments on the work 
of management, working conditions or corporate culture is best obtained directly from the employees themselves. That is why feedback will be a good tool for establishing the process of collecting information to improve the system of personnel control.

The proposed measures will help to regulate the effectiveness of the personnel controlling system and ensure its support at a high level. There is now a lot of researches in the field of controlling, but most of them are limited. In particular, considerable attention is paid in the works to the theoretical principles and methods of controlling, and in most of them there is no comprehensive, systematic approach to the process of evaluating the effectiveness of the existing controlling system. The imperfection of the proposed assessment methods is due to their subjective nature, failure to take into account all the essential elements of the analysis, excessive or insufficient number of indicators, which together make it impossible to develop relevant recommendations for adjusting the system to changes in internal and external environments. Further research on this issue should focused on the analysis of factors that affect the possibility of implementing the proposed author's methodology and areas for improving the system of personnel controlling in the enterprise. 


\section{SECTION 3. DEMOGRAPHY, ECONOMY, SOCIAL POLICY}

\subsection{Features of personnel management of the enterprise in the conditions of coronavirus}

In the face an urgent need to overcome the economic crisis caused by the global pandemic, the efficiency of domestic enterprises depends on the effective use of available human resources, and, first of all, on the work of the leader, who bears the greatest responsibility.

Personnel management, which is carried out by the head, should unite, coordinate, interconnect and integrate all other functions of the enterprise into a single whole.

The modern personnel strategy of the enterprise in a pandemic provides for the development of measures for the development of personnel and their adaptation to these conditions.

Thus, the personnel policy of the enterprise in relations with personnel should be carried out on the following principles:

- a special system of labor motivation for employees who have had coronavirus;

- creation of a democratic atmosphere, which is based on openness, mutual respect and promotion of the disclosure of the abilities of each worker, in particular, and the team as a whole;

- transparency and objectivity of the system of remuneration and labor motivation;

- periodic increase in wages in connection with an increase in labor productivity;

- the use of flexible bonus systems in order to take into account the individual labor contribution of the employee;

- creating safety and comfort in the workplace in a pandemic [77-79].

Today, the activities of any enterprise are constantly under the influence of internal and external factors that can cause this or that situation in production and economic activities and cause deviations from the planned program, therefore, the emerging production and economic situations can be predictable or arise accidentally 
due to unforeseen circumstances of a quarantine period. In this case, the reaction of the leader to this situation plays a significant role.

Making specific management decisions in a pandemic is the main component of the activities of the leaders of today's enterprise, therefore, understanding all the intricacies of the decision-making process in the current environment, knowledge and application of various methods and models of decision-making play a significant role in improving the efficiency of a modern enterprise [80,81].

A professional-manager is always more competent in solving the problems of the enterprise, it is easier and easier to solve the assigned tasks with him. In addition, today he must be a psychologist, flexible and compliant, since people have a subconscious need to repay for what is good done for them.

Analyzing the current situation in a pandemic, we can determine the list of economic consequences of deteriorating health of the working population, which can be classified into the following socio-economic groups:

- increase in the cost of social insurance for the payment of sick leave for temporary disability with increasing morbidity due to the epidemic;

- increase in the cost of social benefits for workers who have suffered an illness;

- increase in the cost of social insurance for the payment of pensions with increasing disability due to complications from a serious illness;

- increasing the cost of socio-economic (material) measures for health care with increasing morbidity and disability.

Today, the management of enterprises must also remember that normal working conditions are a factor in increasing productivity and efficiency and are achieved as organizational and technical measures, and factors that affect the physiological state of the worker's body and his mental processes, which include socio-psychological climate in the team, living conditions, moral and material incentives, etc.

Діяльність сучасного працівника в умовах третьої хвилі коронавірусу пред’являє високі вимоги до його психіки i, насамперед, до іï емоційновольового компоненту, та характеризується низкою факторів, які впливають на його емоційний стан і поведінку [82]. 
The activity of a modern worker in the third wave of the coronavirus places high demands on his psyche and, above all, on its emotional and volitional component, and is characterized by a number of factors that affect his emotional state and behavior [82].

In a pandemic, high results are achieved by those who have a strong and steadfast will and strength of spirit. The struggle to achieve this goal requires employees of both the company and any organization to overcome many of the most difficult obstacles, but, above all, to overcome themselves, their weaknesses. To solve the problems of emotional and volitional training of modern workers, it is advisable to use all means to improve human capabilities.

Therefore, employees need:

- individual planning of own business;

- individual approach to the person based on studying of his individual features;

- interest and self-belief in the fight against the disease;

- the ability to control oneself and do what is needed, not what is wanted;

- constant personal improvement.

The professional suitability of man for work in modern conditions depends on the peculiarities of the development of functional states and its resistance to extreme forms (stress, fatigue, desynchrony), which necessitates the study of psychophysiological mechanisms of regulation of these states, especially the problem of human selfregulation [83]. People with a predominance of emotional type of self-regulation in a pandemic are characterized by a high level of personal and situational anxiety, the highest rates of neuroticism, tension in activity and communication, low adaptive capacity and instability to extreme factors.

Individuals with well-developed volitional regulation successfully reduce the level of emotional tension during the illness, they are more productive, active, and as a result, quickly deplete their reserves. The most resistant to the influence of adverse factors of the disease are people with developed volitional regulation and established methods of self-regulation aimed at restoring psychophysiological resources. 
When starting work, employees do not have the same ability to work, which depends on both human health and moral and material incentives that may create interest in achieving the purpose of its activities.

Psycho-emotional stress under conditions of coronavirus can cause not only different types of fatigue, but also psychological stress, which arises due to excessive mental stress and changes in worker behavior.

As a result of hard or long work, workers may experience temporary changes in physiological and psychological state, which are manifested in varying degrees of fatigue [84]:

- errors in performing precise movements with little muscle effort (first degree fatigue);

- a slight decrease in efficiency and endurance, which is manifested in an increase in the number of errors in the performance of work (fatigue of the second degree);

- a significant decrease in the overall performance and endurance of the musculoskeletal system, which is manifested in an increase in reaction time, slowing down the speed of working reactions and reducing muscle effort (third-degree fatigue);

- non-perception by the employee of positive signals leading to errors and accidents (fatigue of the fourth degree).

Chronic fatigue and overfatigue, as signs of coronavirus disease, can lead to loss of employee interest in work and their own behavior, but even more harmful and disorganized is the psychological stress that can occur suddenly and permanently upset a person. After the illness, the employee must both psychologically and physically mobilize their resources for work in order to further perform work tasks and return it to a stable functional working condition. This is significantly influenced by personal character traits, which are different for each person. They affect his activities, relationships, methods of action, etc. $[85,86]$. Under conditions of stress, a person may experience isolation, alienation, even jealousy of the well-being of others, meticulousness, propensity to argue, pettiness. It is clear that in stressful conditions a person can experience an extraordinary strengthening of certain character traits, when 


\section{SOCIO-ECONOMIC AND MANAGEMENT CONCEPTS}

there are deviations in human psychology and behavior, which may not go beyond its normative behavior, but may be a pathology (accentuation of character). This accentuation of human character traits is manifested only under certain critical conditions in which he found himself. In a calm state, these people can be calm, sensible.

The modern worker must be ready to deal with stress and have the habit of relaxing (daily walks, watching quiet movies, reading fiction, periodic massage sessions), which will help keep the brain healthy for a long time.

The most effective way to teach employees to control stress and anxiety in the coronavirus is to develop self-confidence. To this end, it is advisable to create a positive human environment and foster a constructive attitude to mistakes and failures.

That is, the human factor, namely its moral and subjective characteristics include emotional and volitional qualities, temperament, tastes, preferences, which determine human behavior in the sphere of production and life. Based on this, the state of mental readiness of the company's staff to work in quarantine should include the following components:

- optimal level of emotional arousal;

- sober self-confidence;

- ability to control their actions and personal behavior in extreme situations;

- high resistance to obstacles in relation to adverse external and internal influences;

- the desire to fight to the end for the best result.

It takes time to recover from an illness emotionally, physically and psychologically, and to return to normal work in all areas of life.

Today, leaders need to be sensitive and calm, but act decisively. The employee must remain a competitive person who is able to quickly and painlessly adapt to constant changes in social conditions, scientific and technological progress and new activities and forms of communication, while maintaining a positive internal psychoenergy potential and harmony. He must return to effective activity, communication, self-awareness. 
Thus, the study of the nature and main socio-economic problems of the personnel of the enterprise in the conditions of epidemic diseases are timely and extremely relevant and should be the basis for further practical research in health care and improving the efficiency of employees under the coronavirus. 


\section{2 Моделі державного регулювання зайнятості населення}

Зайнятість населення доцільно розглядати в якості одного з найважливіших елементів соціально-економічної системи суспільства. У загальному розумінні, зайнятість можна визначити як залучення населення до процесу трудової діяльності, включаючи навчання, ведення домашнього господарства, службу в армії, догляд за дітьми. Безумовно, всі ці види діяльності повинні бути обмежені рамками законодавчо-правової бази, що прийнята в даному суспільстві, i підлягати державному регулюванню.

Державна політика зайнятості населення це комплекс заходів прямого й опосередкованого впливу держави на соціально-економічний розвиток суспільства в цілому, і на кожного індивідуума окремо з метою оптимізації соціально-трудових відносин.

Дослідники виділяють п'ять базових моделей регулювання зайнятості та ринку праці:

- Американська (США);

- Шведська (скандинавські країни);

- Континентальна (Німеччина, Австрія, Бельгія, Нідерланди, Швейцарія, Франція);

- Англосаксонська (Великобританія, Канада, Ірландія);

- Японська.

Базовими принципами американської моделі є такі: - мінімізація втручання держави в процеси регулювання зайнятості; - ефективна законодавча база, яка гарантує правову захищеність працівників; - прагнення нівелювати будь-які види дискримінації на ринку праці, що пов'язані 3 расовими, гендерними стереотипами, політичними поглядами, релігійними переконаннями тощо [88, с. $3]$.

Для американської моделі характерні відносно високі показники безробіття, i, зокрема, значна питома вага фрикційного безробіття, що пояснюється високою динамічністю ринку праці, на якому працівники активно змінюють не тільки 
місце роботи, а й професію. Так, близько 10\% працівників країни змінюють професію протягом року. Крім того, ця держава на протязі багатьох років утримувала перше місце в світі за кількістю створюваних щорічно робочих місць.

В державній політиці регулювання зайнятості США питома вага приділяється проблемі вибору професії. Створена широка мережа як приватних агентств, так і спеціальних центрів профорієнтації при коледжах і університетах. При міністерстві праці США створено 1200 державних центрів профорієнтації та профвідбору, через які щорічно проходить понад 1 млн. підлітків [89, с. 111]. Реалізація цієї моделі призводить до виникнення досить численної категорії громадян, трудовий дохід яких не забезпечує мінімального споживчого стандарту і нерідко є нижчим рівня соціальної допомоги. Головними жертвами безробіття в США стають працівники з низькою кваліфікацією, а робочі місця, які створюють безпосередньо для них, характеризуються досить низьким рівнем оплати праці. Тому одним з основних векторів сучасної політики зайнятості крани є підвищення якості робочих місць в аспекті підвищення рівня оплати праці, перспектив професійного зростання і збагачення змісту праці.

Резюмуючи, слід відмітити, що в США державна політика зайнятості на ринку робочої сили орієнтована: - на прискорене перенавчання працівника, підвищення його професійно-кваліфікаційної конкурентоспроможності на протязі всього трудового життя; - на активну територіальну й професійну мобільність робочої сили; - на високу частку нетрадиційних форм зайнятості та режимів робочого часу; - на нетривалий період виплати допомоги по безробіттю.

Шведська модель регулювання зайнятості населення ставить перед собою три основні завдання: - досягнення повної зайнятості економічно-активного населення; - державне гарантування рівних стартових можливостей; - надання соціальних гарантій населенню.

Практично це реалізується в переважанні активної політики зайнятості: боротьба з безробіттям в рамках цієї моделі носить превентивний характер.

При розробці програми соціальної політики підвищена увага держави приділяється заходам, що спрямовані: - на створення нових робочих місць, 
переважно в державному секторі економіки; - на стимулювання позитивної внутрішньої міграції робочої сили через пропозиції субсидій і кредитів; - на переїзд сімей із районів із надлишком робочої сили в райони, де є дефіцит кадрів.

У Швеції функціонують державні регіональні компанії, які беруть пайову участь у реконверсії підприємств і організації виробництва нових товарів, підтримують малі й середні підприємства, що значною мірою сприяє вирішенню проблем зайнятості [89, с. 111].

Важливим досягненням політики зайнятості скандинавських країн $\epsilon$ забезпечення рівного доступу населення до інформації про вакансії й ефективна актуалізація інформаційних баз.

Англосаксонську модель відрізняє акцент на пасивних заходах у державному регулюванні зайнятості, питома вага приватних підприємств i громадських організацій у наданні соціальних послуг. Практичну реалізацію принципів цієї моделі найзручніше розглядати на прикладі Великобританії.

Сучасна модель регулювання зайнятості Великобританії являє систему взаємопов'язаних елементів:

- Інституційний блок, що представлений Департаментом $з$ питань зайнятості та Комісією з робочої сили (дорадчий орган при уряді). - Служба зайнятості молоді, до функціонального апарату якої входить більш ніж 3,6 тис. консультантів та їхніх помічників. - Інформаційна база, яка містить дані про наявні вакансії та структуру попиту на них. - Комплекс програм професійного навчання та перепідготовки з метою підвищення конкурентоспроможності на ринку праці соціально незахищених верств населення. - Розвиток системи соціального забезпечення, розробка цільових програм громадських робіт, розвиток фондів страхування від безробіття.

У країнах континентальної моделі проблемам зайнятості та безробіття приділяється пріоритетна увага в першу чергу, з причин соціально-політичного характеру, зокрема через наявність великої кількості трудових іммігрантів, що призводить до дисбалансу рівноваги на ринку праці. Для боротьби з негативними наслідками цього чинника у Франції розроблено програму зайнятості «Нові 
послуги - нові робочі місця». Ї̈̈ головне завдання - забезпечити постійні (не менше 5 років) робочі місця для молоді, яка не має трудового досвіду. Приватним компаніям, що готові надати роботу молодому працівнику, держава відшкодовує до 80\% мінімального розміру оплати праці на кожне нове місце [90, с. 45]. У 2016 році уряд Франції розробив комплекс законодавчих заходів щодо зниження податків на ФОП, щоб стимулювати роботодавців до розширення штату. Крім цього, компаніям, які працевлаштовують молодих спеціалістів, надаються податкові пільги [90, с. 47].

Система соціального страхування в країнах цієї моделі є досить розвиненою і забезпечує реалізацію державних гарантій щодо громадян, які залишилися без роботи, пенсіонерів, інвалідів, матерів тощо. Також існують розвинені системи професійної підготовки і перепідготовки безробітних і працюючих громадян. Франція є одним з лідерів у світі за розмірами виплат по безробіттю: вони становлять до 70\% від заробітку. Допомога по безробіттю виплачується в тому випадку, якщо заявник відпрацював мінімум 122 дня до закінчення терміну дії трудового договору і перебуває на біржі праці [90, с. 49].

У Німеччині широко застосовується концепція дуального навчання. В процесі навчання майбутні працівники мають можливість застосувати на практиці отримані теоретичні знання без відриву від навчання і отримувати матеріальну винагороду за роботу на підприємстві. Ця система значно знижує ризик не отримати роботу через брак досвіду і практичних навичок. Також у Німеччині існує програма допомоги з працевлаштування людей, яким за 50 років ( «50+», «50 ТОР» тощо). Основна частина субсидій направляється кооперативам, що утворилися на базі підприємств-банкрутів із безробітних, які мають певні знання, але не мають навичок в організації бізнесу [89, с. 112].

Активну роль на ринку праці Франції і Німеччини відіграють профспілки, які використовують різні заходи відстоювання своєї позиції - від прийняття галузевих колективних угод до страйків, проведення яких дозволено законом. Наприклад, в Німеччині профспілки безпосередньо беруть участь в управлінні підприємствами, коли до складу ради директорів компанії входять представники 
профспілкової організації в кількості, необхідній для прийняття або відхилення тих чи інших рішень.

Політика зайнятості в цих країнах включає в себе чотири основних елементи: 1) обмежувальну фіскальну політику, яка спрямована на підтримку менш прибуткових підприємств і стримування прибутку високоприбуткових компаній для зниження інфляційної конкуренції між ними в підвищенні заробітної плати; 2) політику солідарності в заробітній платі, яка має на меті досягнення рівної оплати за рівну працю незалежно від фінансового становища роботодавця або галузевої приналежності фірми; 3) стимулювання створення нових робочих місць, а також центрів 3 професійної підготовки та перепідготовки кадрів; 4) селективну підтримку в секторах економіки, що мають низькі економічні показники, але при цьому забезпечують вирішення важливих соціальних завдань.

Японська модель має ряд специфічних рис із обмеженим потенціалом реалізації в іншому соціокультурному середовищі. Головною ії характеристикою $\epsilon$ концепція «довічного найму», яка забезпечує робоче місце на весь період трудової активності, аж до граничного віку працівника (55-60 років). В Японії внутрішній ринок праці переважає над зовнішнім. Кар'єрне зростання працівників відбувається за допомогою переміщення по кар'єрних сходах всередині одного підприємства. Кожна компанія визначає свою стратегію розвитку й організаційну структуру. Відповідно до неї відбувається навчання, підвищення кваліфікації, розробка заходів з утримання кваліфікованих кадрів всередині підприємства. Орієнтація японських роботодавців на довічне використання трудового потенціалу визначила розвиток у працівників творчого ставлення до своєї праці і високої якості в роботі. Ця особливість японської моделі праці дає можливість підприємцям не скорочувати штат під час спаду виробництва, а переводити працівників на дочірні підприємства або на інші фірми згідно взаємної домовленості.

Таким чином, аналіз зарубіжного досвіду дозволяє виділити основні напрями державного регулювання зайнятості населення, а саме: 
- інформаційне забезпечення суспільства про актуальне співвідношенні попиту й пропозиції на ринку праці;

- узгоджена система професійного навчання i перекваліфікації безробітних;

- система державних гарантій, субсидій i пільг для стимулювання створення нових робочих місць;

- формування регіональних програм зайнятості населення і цільових програм громадських робіт;

- розвиток системи державних гарантій і соціального забезпечення.

Існування різних моделей державного регулювання зайнятості означає відсутність єдиного вектора розвитку ринку праці. На їх формування i функціонування впливають традиційні особливості соціально-економічного розвитку країни і ступінь її інтеграції до міжнародного ринку праці. 


\section{3 Теоретичні та практичні аспекти при формування кадрового резерву на підприємсві}

Підготовка кадрового резерву є стратегічним пріоритетом для більшості підприємств країн, що розвиваються. Наявність компетентних, підготовлених фахівців, готових до просування на ключові для підприємства посади, гарантуе кадрову безпеку бізнесу і впевненість у завтрашньому дні. 3 огляду на масштаб i складність завдання робота зі створення кадрового резерву вимагає від HRменеджера комплексного підходу і ретельного планування. Неправильна певна послідовність дій у роботі з резервом або пропуск важливого етапу ставить під загрозу якість і результативність усієї роботи. [91]

Зупинимося на кожному етапі більш детально.

Етап 1. Визначення ключових посад для підготовки резерву дії:

1. Аналіз організаційної структури і штатного розпису підприємства.

Мета: визначення кадрової укомплектованості структурних підрозділів компанії.

2. Віковий аналіз поточного керівного складу підприємства.

Мета: виявлення найбільш критичних менеджерських позицій з точки зору строковості підготовки резерву (керівники пенсійного або передпенсійного віку).

3. Експертний аналіз менеджерських позицій вищим керівництвом підприємства.

Мета: виявлення найбільш пріоритетних керівних позицій з точки зору їх внеску в бізнес-результат і перспектив вивільнення посади. Критерії експертного аналізу посад (приклад): внесок у досягнення бізнес-результату компанії; перспектива вивільнення - посаду не планується вивільняти в найближчі 3-5 років (не планується вихід співробітника на пенсію, підвищення або ротація);кількість працівників у підпорядкуванні (наявність / відсутність заступників, кадрова укомплектованість відділу / департаменту). Відділи, в яких 
недоукомплектований штат співробітників, є дефіцитними щодо потенційних резервістів.

Окремо варто зазначити менеджерські посади, які на підприємстві планується створити в перспективі (наприклад, при формуванні нових підрозділів у рамках розширення бізнесу). При складанні списку цільових посад також необхідно проаналізувати 3 точки зору важливості й терміновості підготовки резерву.[91]

Результат етапу: визначено посади, які потребують пріоритетної формування кадрового резерву.

Етап 2. Планування оптимальної чисельності резервістів під кожну цільову позицію.

Мета: здійснювати кадрову безпеку для ключових посад підприємства (знизити кадрові ризики, пов'язані з відмовою / звільненням / вибуванням резервістів).

З урахуванням важливості та ії пріоритетності необхідно визначити, скільки резервістів потрібно підготувати для кожної цільової посади.

Оптимальною кількістю резервістів на посаду є 2-3 людини. 3 одного боку, це «страхує» цільову посаду від ризику втрати резервіста (через його відхід із підприємства або вибування з програми підготовки резерву). 3 іншого боку, наявність декількох претендентів на одну посаду, при грамотній HR-політиці, створює здорову конкуренцію між резервістами, підвищуючи їхню мотивацію до саморозвитку (тема про те, як не допустити негативних наслідків конкуренції за місце, заслуговує на окреме обговорення).

Етап 3. Профілювання цільових посад.

Проведення аналізу ключових посад і складання карти компетенцій (профілю посади).

Мета: визначити основні вимоги до професійних і ділових якостей, знань i навичок, якими необхідно володіти співробітнику для успіху на тій чи іншій посаді. Додатково: визначити додаткові критерії для відбору кандидатів у резерв (вік, стаж роботи і т. п.). Джерела інформації: посадові інструкції на цільові 
позиції; положення та бізнес-плани підрозділів; результати інтерв'ю $з$ топменеджментом і носіями цільових посад.

Результат етапу: для кожної цільової посади складено профіль, що включає перелік найбільш важливих компетенцій (професійних і ділових), необхідних успішному власникові позиції.

Етап 4. Підготовка та проведення заходів з інформаційного супроводження програми підготовки кадрового резерву.

Однією 3 поширених помилок при впровадженні програми кадрового резерву є те, що вона розробляється і обговорюється дуже вузьким колом осіб (як правило, керівництво підприємства + представники HR-підрозділу) i доходить до співробітників у вже готовому вигляді як якесь «спущене зверху» нововведення, обов'язкове до виконання. Це викликає серед більшості персоналу природну захисну реакцію й різко знижує ефективність роботи програми.

У зв'язку з цим, необхідно дотримуватися трьох простих принципів у ході розробки нового проекту та його впровадження:

1. Інформування. Співробітникам важливо бути в курсі розробки, запуску i роботи програми підготовки кадрового резерву. Перш за все, їм необхідно дізнатися цілі й завдання програми, зрозуміти, чим вона може бути корисна підприємству в цілому i особисто кожному співробітнику. Недостатнє інформування персоналу про нововведення може послужити причиною появи негативних чуток, побоювань і призвести до неприйняття програми резерву частиною співробітників.

2. Залучення. Для того, щоб уникнути появи помилкових уявлень і очікувань від програми підготовки резерву, крім інформування, необхідно цілеспрямовано залучати персонал в обговорення проекту, надавати можливість відкрито висловлювати свою думку про програму, задавати питання i висувати пропозиції.

3. Посилення значущості. Участь у проведенні інформаційних заходів топменеджерів і неформальних лідерів підприємства здатне істотно підвищити значимість програми і підкреслити іiі важливість для підприємства. Відомі 
випадки, коли проведення інформаційних заходів доручалося рядовому співробітникові відділу персоналу, оскільки вважалося, що це досить просте завдання.

Однак персонал підприємства не сприймав слова про значущість програми 3 вуст людини, яка не мала в їхніх очах достатнього авторитету. Реалізація програми істотно затягнулася, оскільки було витрачено додатковий час на проведення повторних зустрічей за участі вищого керівництва компанії.[91]

Дії:

1. Підготовка інформаційних матеріалів про проект кадрового резерву.

Мета: інформаційне висвітлення програми підготовки резерву на всіх етапах ії роботи.

2. Розробка плану інформаційного супроводу програми.

Перший етап - підготовчий (за 1-2 місяці до запуску програми). Інформування співробітників про цілі і завдання впровадження програми, іii переваги для підприємства і співробітників. Завдання - сформувати загальне розуміння важливості програми серед співробітників, подолати можливий опір і скептичне ставлення до нововведення за рахунок своєчасного і максимально повного інформування персоналу.

Другий етап - основний (запуск програми та іiі функціонування). Інформування працівників про хід роботи програми. Завдання - підтримувати увагу персоналу до програми, виключити появу негативних чуток і помилкових уявлень.

Третій етап - підсумковий (результати роботи програми за період). Інформування персоналу про результати роботи програми, досягнення іiі учасників (кращі наставники, кращі резервісти), незначних резервістів i подальшої роботи програми. Завдання - висвітлити результативність програми, підкреслити відповідність поставлених цілей i завдань 3 отриманими результатами.

Етап 5. Розробка положення про кадровий резерв дії:

1. Складання проекту положення про кадровий резерв. 


\section{SOCIO-ECONOMIC AND MANAGEMENT CONCEPTS}

По-перше, положення про кадровий резерв допомагає структурувати етапи програми, документально зафіксувати зони відповідальності учасників програми, чітко визначити їх права та обов'язки. Крім того, положення буде важливим джерелом інформації для персоналу про цілі, завдання і механізм роботи програми підготовки кадрового резерву.

По-друге, положення, будучи офіційним документом підприємства, підкреслює важливість кадрового резерву для підприємства та серйозність намірів керівництва щодо нововведення. Документальне підтвердження намірів керівництва для багатьох співробітників автоматично підвищує статус проекту, це корисно пам'ятати.

2. Узгодження проекту положення про кадровий резерв 3 керівниками підрозділів.

На даному етапі дуже важливо залучити менеджмент підприємств у процес доопрацювання і узгодження положення про кадровий резерв. Це буде сприяти не тільки отриманню цінних доповнень до положення з боку керівників, а й зніме ефект «нав'язаного зверху» рішення.

3. Затвердження положення вищим керівництвом підприємства.

Після того, як пройшов процес узгодження на рівні менеджерів, він приймає статус офіційного документа компанії.

Етап 6. Відбір докадрового резерву (пошук і оцінка кандидатів).

Висування кандидатів у резерв може проводитися, як мінімум, трьома способами: 1)висування співробітника його безпосереднім керівником; 2)висування співробітника вищим керівником (через один або кілька організаційних рівнів);3) самовисування співробітника.

Співробітники, чиї кандидатури були заявлені на зарахування до резерву, проводять стандартизовану процедуру відбору, мета якого - виявити управлінський потенціал співробітника і його готовність до проходження програми підготовки.

Відбір доцільно проводити у два етапи: 


\section{SOCIO-ECONOMIC AND MANAGEMENT CONCEPTS}

1. Попередній відбір. Формальна відповідність кандидата вимогам зарахування до кадрового резерву (приклад використовуваних критеріїв);

2. Основний відбір. Оцінка менеджерського потенціалу (професійно-ділові якості) проводиться відповідно до складеного профілем посади для кожної позиції.

Методи оцінки: асесмент-центр, аналіз результатів роботи, кейс-тестинг, інтерв'ю за компетенціями, тестування (професійне, особистісне).

Джерела додаткової інформації: експертна оцінка колег, керівника, підлеглих (за наявності) співробітника за методом 360 градусів.

У результаті даного етапу формується підсумковий список кандидатів на зарахування до кадрового резерву.

Етап 7. Підготовка резервістів (реалізація програми розвитку професійних та управлінських компетенцій).

Дiї:

1. Розробка спільної програми розвитку резервістів.

Мета: розвиток менеджерських компетенцій резервістів, які можна застосувати для всіх цільових посад.

У даному випадку йдеться про складання загальної для всіх резервістів програми менеджерської підготовки, яка включає в себе групові форми навчання (тренінги, семінари, майстер-класи i т. ін.), спрямовані на розвиток універсальних менеджерських компетенцій, важливих для будь-якої управлінської посади на підприємстві.

Як правило, програма загальної підготовки планується на 1 рік i реалізується в рамках внутрішнього навчального центру (силами внутрішніх тренерів) або із залученням зовнішніх тренінгових компаній (чи поєднання обох способів).

2. Розробка індивідуальної програми підготовки для кожного резервіста (індивідуальний план розвитку).

Мета: забезпечити підготовку резервіста під вимоги цільової посади 3 урахуванням його індивідуальних особливостей, сильних і слабких сторін. 
Складання для кожного резервіста індивідуального плану розвитку (як правило, на 1 рік), в якому поєднуються різні методи розвитку професійних $\mathrm{i}$ ділових якостей, необхідних для успішної роботи на цільову посаду.

3. Закріплення за кожним резервістом наставника з числа більш досвідчених колег / вищого керівника.

Завдання, яке необхідно вирішити на даному етапі, - це створити ефективну систему мотивації самих наставників на виконання своїх функцій.

Варіанти: регулярна надбавка за наставництво (щомісячна / квартальна); заохочення наставників, чиї резервісти продемонстрували кращі результати підготовки за підсумками проходження програми розвитку (або у ході проміжної оцінки).

За потреби корисно провести внутрішнє навчання наставників навичкам передачі досвіду й допомоги в розвитку резервістів.

4. Моніторинг ефективності підготовки резервістів.

Підведення регулярних проміжних зустрічей резервістів та їх наставників зі співробітниками служби персоналу для оцінки прогресу в розвитку. Своєчасне коригування індивідуального плану розвитку резервіста в разі потреби.

Результат етапу: розвиток необхідних компетенцій резервістів.

Етап 8. Оцінка результатів підготовки резервістів

1. Проведення комплексної оцінки якості підготовки резервістів.

Напрямки оцінки: оцінка виробничих результатів - як змінилася продуктивність праці і результативність резервіста за підсумками підготовки (збільшилася / зменшилася / залишилася без змін); оцінка результатів проходження загальної програми підготовки та індивідуальних планів розвитку - наскільки покращилися професійні та управлінські якості резервіста порівняно 3 показниками первинної оцінки (при відборі); оцінка результатів проектної роботи - які результати отримані за підсумками виконання розвиваючих проектів, визначення внеску резервіста в досягненні результату.

Методи оцінки: аналіз виробничих результатів і досягнень резервіста; отримання зворотного зв'язку від наставника резервіста; повторна оцінка 
резервіста (див. Етап 6, пункт «Основний відбір»);аналіз результатів проектної діяльності.

2. Підбиття підсумків програми підготовки резервістів.

За результатами оцінки якості підготовки резервістів, прийняття рішення про: заохочення успішних резервістів, що продемонстрували зростання результативності й підвищення рівня розвитку професійних і менеджерських компетенцій; виключення 3 резерву співробітників, що продемонстрували зниження виробничих показників і / або відсутність прогресу в розвитку професійних та управлінських компетенцій.

Результат етапу: визначено резервістів з високим рівнем готовності для заміщення вакантних керівних посад.

Етап 9. Планування подальшої роботи з кадровим резервом.

1. За наявності на підприємстві відкритих цільових вакансій, розгляд кандидатів на заміщення з числа успішних резервістів.

2. Планування і організація адаптаційних заходів для резервіста при входженні в нову посаду. Складання плану адаптації на новій посаді. Закріплення за резервістом на період адаптації / випробувального терміну наставника з числа вищих керівників для забезпечення необхідної підтримки.

3. За відсутності на момент закінчення програми підготовки резервістів відкритих цільових вакансій, планування заходів з утримання перспективних співробітників на підприємстві.

Резервісти, які успішно пройшли програму підготовки та підвищили свій професійний рівень, часто «виростають» зі своєї поточної посади. Цей факт і відсутність кар'єрного просування може серйозно знизити мотивацію співробітника і у крайніх випадках послужити причиною відходу з підприємства та пошуку більш перспективної роботи. Для мінімізації цього ризику корисно спланувати програму щодо утримання резервістів на підприємстві.

Програма може включати в себе такі способи утримання (залежать від можливостей і кадрової політики підприємства): розширення функціональних обов'язків співробітника, розширення зони його відповідальності й рівня 
прийняття рішень (за потреби, додавання частини менеджерських функцій, наприклад, керівництво будь-яким відповідальним проектом);надбавка до заробітної плати; надання додаткових соціальних пільгорганізація тимчасових заміщень керівника (на час відпустки, відрядження, хвороби та ін.); можливість стати наставником для менш досвідчених співробітників тощо.

Результат етапу: просування підготовлених резервістів на вакантні цільові посади, збереження кадрового потенціалу підприємства за рахунок утримання перспективних співробітників у кадровому резерві.[91]

Розглянувши сучасні підходи до навчання і розвитку кадрового резерву, можна зробити висновок про те, що українським підприємствам варто використовувати комплексну систему навчання і розвитку, а не обмежувати свою роботу з персоналом типовими методами розвитку. Використання сучасних технологій для підготовки резервістів дає підприємству можливість отримати реальну конкурентну перевагу за рахунок накопичення i примноження людського капіталу. 


\section{4 Коворкінг як спосіб вдосконалення практичних навиків студентів в навчальних закладах України}

Соціологічні опитування говорять про те, що переважна більшість студентів після закінчення закладу освіти планують змінити місце проживання, і навіть країну, у зв язку з відсутністю роботи. Ніхто не заперечує, що система освіти в такому вигляді, якою вона є зараз, потребує істотних та грунтовних змін. Ці зміни повинні стосуватися не лише змісту освіти, освітнього середовища та обладнання, а й зміни сучасного педагога. Такі зміни та модернізацію можна запровадити шляхом реалізації такого проєкту, як коворкінг.

Отже, коворкінг це (ㅅгл. Co-working - спільно працџювати) у широкому сенсі модель організації роботи людей, найчастіше фрилансерів, з різним типом зайнятості у єдиному робочому просторі; у вузькому- колективний офіс. Коворкінги характеризує гнучка організація робочого простору і прагнення до формування спільноти резидентів та внутрішньої культури. Учасники залишаються незалежними і вільними, мають можливість спілкуватися, обмінюватися ідеями та допомагати один одному, на відміну від роботи вдома. Ідея коворкінгу включає в себе телеворкінг, фриланс, деякі принципи аутсорсингу[93].

У 2017p. Інститут громадянського суспільства ініціював, а Міністерство освіти та науки України підтримав ідею - змінити концепцію національного фіналу Олімпіади: окрім традиційної оцінки від журі учасники отримали грошову оцінку своїх виробів на онлайн аукціоні. Експеримент вдався і надихнув на кардинальні зміни навчальної програми. Довкола інноваційної ідеї сформувалася спільнота активних вчителів - група у фейсбуці Трудове навчання в українській школі (стартувавши з десятка активістів, на сьогодні налічує 3900 учасників). На сьогодні нові моделі трудового навчання за сприяння Європейського Союзу проходить апробацію в Баранівській ОТГ [92].

Чим повинен стати коворкінг в системі сучасного навчального закладу? Перш за все коворкінг може бути місцем, де можна створювати авторський 
продукт на продаж, для особистого споживання та для реалізації соціальних проєктів.

На прикладі Вишнянського коледжу Львівського НАУ, коворкінг можна розглядати, як практичну базу, де студенти разом з викладачем роблять певні речі для громади. Наприклад:

- в теплиці - вирощування рослин для озеленення, продуктів харчування для спеціальності «Агрономія»;

- на фермі великої рогатої худоби - виробництво молочної продукції та надання послуг з лікування тварин для населення, спеціальність «Ветеринарна медицина»;

- надання дорадчих, консультаційно-правових та бухгалтерських послуг студентами спеціальності «Облік та оподаткування» і «Право»;

- допомога в відкритті власної справи та складанні бізнес-планів для студентів спеціальності «Менеджмент» та інші.

3 метою реалізації даного проєкту, з 2016 року на сайті Вишнянського коледжу Львівського НАУ було створено такі відділи навчально практичної роботи для студентів, як «Юридична консультація» та «Фінансово-бухгалтерські послуги». Це означає, що будь-яка людина, яка потребує юридичної допомоги, розяснення чи консультації, може зареєструвати своє питання на сайті за відповідним посиланням та одержати грунтовну відповідь. Слід зазначати, що такі послуги надаються тільки під керівництвом викладача і є безкоштовними, тобто здійснюються на громадських засадах. Це є способом набуття студентами практичних навиків, які будуть необхідними для них в майбутньому працевлаштуванні за обраним фахом.

Найчастішими юридичними проблемами, з якими звертаються громадяни є земельні питання, питання оформлення і вступання в дію спадщини, проблеми оформлення позовів. Після реєстрації такого звернення громадян, студенти, під керівництвом викладача, вивчають дане питання, досліджуть нормативноправову базу, на яку можна посилатися і протягом двох днів надають грунтовну відповідь з посиланням на законодавчі акти та положення. Керівництвом таких 
юридично-дорадчих послуг у Вишнянському коледжі займаються викладачі Заріцька Ольга та Галушка Наталія при залученні студентів спеціальності «Право».

В середньому в місяць поступає 10-20 таких звернень та запитань від громадян, що $є$ непоганим стартом для студента, щоб вдосконалити свої знання i практичні навики, навчитися швидко знаходити законодавчі акти, що регулюють дане питання і давати правильну і обгрунтовану відповідь на відповідне звернення. Що стосується географії звернень, то в основному це $є$ місцеві жителі міста Рудки Самбірського району, Львівської області, а також жителі сусідніх населених пунктів Городоцького району, Львівської області та Старосамбірського району Львівської області.

Крім юридичної консультації, з 2019 року у Вишнянському коледжі Львівського НАУ використовується «Фінансово-бухгалтерська консультація». Це означає, що будь-який субє'кт підприємницької діяльності або фізична особа може звернутися за роз'ясненням 3 питань ведення бухгалтерського обліку на загальних засадах, при спрощеній формі, для бюджетних установ, нарахування i сплати податків, оформлення пенсії та інші. Керівництвом такого фінансовобухгалтерського проєкту займаються викладачі Вишнянського коледжу Львівського НАУ Клебан Оксана і Устиновська Тетяна.

Найчастішими проблемами, з якими звертаються громадяни по «Фінансовобухгалтерській консультації» $\epsilon$ порядок оформлення податкового відшкодування, застосування податкових соціальних пільг, порядок оформлення пенсій та допомога в складанні бізнес-плану для новостворений суб'єктів підприємницької діяльності. Так як такі послуги є безкоштовними і звернення громадян відбуваються досить часто, для опрацювання кожного питання потрібне залучення додаткового людського ресурсу і часу.

До роботи проєкту «Фінансово-бухгалтерської консультації» залучаються студенти Вишнянського коледжу Львівського НАУ спеціальностей «Облік та оподаткування», «Фінанси, банківська справа та страхування» а також «Менеджмент». 3 цією метою створена робоча група студентів у формі гуртка 


\section{SOCIO-ECONOMIC AND MANAGEMENT CONCEPTS}

(Малюнок 1), яка під керівництвом викладачів надає послуги з консультування та дорадчої діяльності.

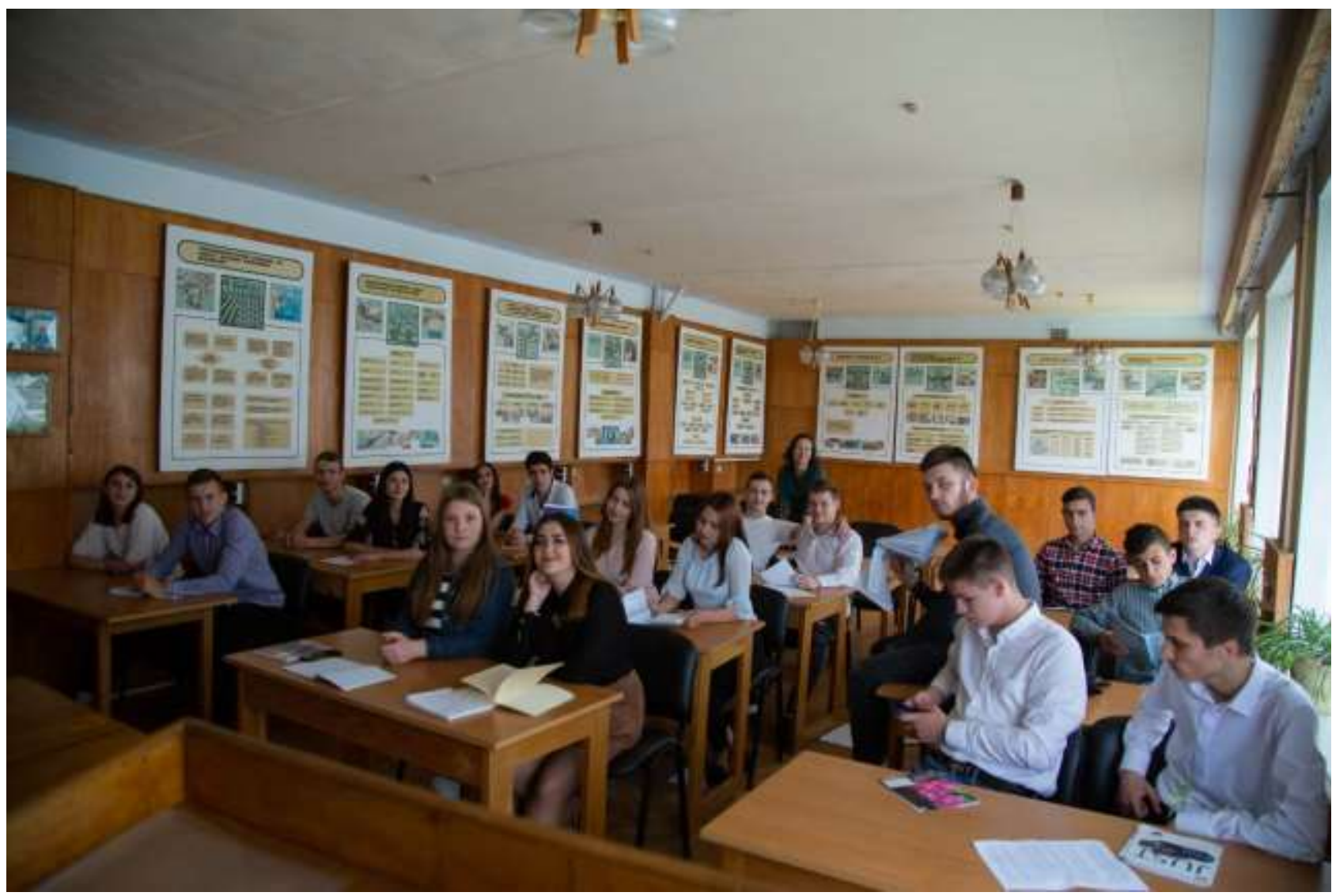

Малюнок 1 Склад студентського гуртка по наданні фінансовобухгалтерських послуг

Отож, з усією впевненістю можна сказати, що такий проєкт, як короркінг буде свого роду базою для «набивання гуль» при створенні і реалізації стартапів або проєктів для студентів в майбутньому.

Якщо розглянути це явище в тривалій перспективі, то однозначно такий проєкт буде допомогою студенту при самовизначенні та самореалізації а також способом пов'язання свого майбутнього із майбутнім громади, приєднання до стратегії іï розвитку. Також паралельне навчання та застосування практичних навиків для студента покращить якість знань 3 акцентом на розвиток бізнескомпетенцій. Це в певній мірі буде сприяти розкриттю підприємницького та лідерського потенціалу молоді, залучення їх до соціальних і економічних змін в місцевій громаді, а в подальшому буде запорукою створення нових робочих місць в аграрному та інших секторах економіки України[92]. 


\section{SOCIO-ECONOMIC AND MANAGEMENT CONCEPTS}

У міру розвитку індустрії коворкінгу та загострення конкуренції багато провайдерів у всьому світі починають сегментувати свій бренд. Зосередившись на нішах, середовища коворкінгу можуть створити спільноти однодумців, які підтримують одне одного та розвивають спільну економіку. Спільна робота у спільних просторах та середовищах, природно, розвиває взаємні можливості, часто виявлені випадково, для додаткових потоків доходу та підтримки для членів[93].

Як підсумок, можна зазначити, що коворкінг - це потужний інструмент всестороннього розвитку громади, ii економічного зростання, запобігання відтоку молоді в великі міста та за межі держави. Якщо кожен об єкт громади спільно з закладами освіти буде реалізовувати такі проєкти, то через 10 років ми не впізнаємо свою державу. 


\section{5 Удосконалення системи управління персоналом підприємства}

Розвиток економіки країни, функціонування підприємств, а особливо сільськогосподарських та будь-які інші процеси суспільного життя $\epsilon$ неможливими без залучення персоналу. Людський ресурс є визначальним стержнем, який започатковує і веде бізнес, а з іншого боку, людина є важливим стимулятором, що формує попит на кінцевий продукт. Персонал підприємства на сучасному етапі, розглядають, не безпосередньо як склад працівників, що задіяні у виробничому процесі, а як сукупність системо пов'язаних робітників 3 їх індивідуальними характеристиками, знаннями, майстерностями, навиками роботи, які вони застосовують у трудовій діяльності. Індивідуальний ступінь персоналу є сукупністю наявних у зазначеної особистості рекомендацій, які є особистими i, які важко змінити. До таких головних рекомендацій віднесено:

1) вік, ситуація зі здоров'ям, фізичний розвиток - це дійсно звичайні характеристики робітника, які встановлюють фізичну здібність особистості виконувати певну роботу;

2) інтелектуальні здібності, морально-ціннісні орієнтації, виховання, психологічний стан - це вирішальні ознаки людини, що отримані в процесі останніх років життя в визначеному соціальному середовищі, які людина, не схильна перетворювати для чіткого буденного місця;

3) одержані теоретичні знання в процесі отримання освіти, ділові навички, здібності працівника, стаж і досвід роботи - це високоякісні характеристики, які набуваються протягом визначеного часу і мерщій вплинути на їх переміну в короткий термін не можливо;

4) сила волі та бажання до саморозвитку -вагома характеристика працівника, яка пов'язана з моральною можливістю і бажанням особі до змін задля самореалізації та досягнення високих результатів.

5) ступінь фінансової забезпеченості грамотності особи - це набуті характеристики особи, що визначають ставлення особистості та іï бажання до певного виду роботи, зацікавленість у самовіддачі в трудовому процесі. Це сукупність рекомендацій, які вміють змінюватись [94]. 
Визначальну роль відіграє також відбір персоналу. Методологічною основою відбору кадрів $є$ психодіагностика або професійний відбір направлений на відбір кандидатів на вакантні посади або формування резерву висування на посаду з величезним обсягом робіт, з урахуванням їх потенціалів і ступінню розвитку професійно важливих якостей, необхідних для успішного виконання конкретної роботи. Психодіагностичну роботу на виробництвах України не вживають всеохопною мірою, у зв'язку з тим, що неприсутні способи для створення певних служб, немає досить розвиненої правової бази. Певну роботу використовують в окремих великих корпораціях, що зацікавлені у відбиранні вправних топ-менеджерів i професіоналів високого рівня, підходящих виконувати власну роботу на високому рівні продовж робочого дня і давати дохід власному підприємству [95].

Істотна ціль психодіагностики - це формулювання відповідності індивідуально-психофізиологічних рекомендацій кандидата основним вимогам, які вимагаються до службовців підприємства, а також їх професійної придатності. Крім того, психодіагностика виявляє психологічні проблеми співробітників підприємства, допомагає правильно розставити штат i спрогнозувати успішність його подальшої діяльності і дає можливість визначити психологічний стан окремої групи колективу.

Для об'єктивної оцінки кандидата перед початком психодіагностики необхідно використовувати бібліографічний метод дослідження, використовуючи вивчення його анкетні дані, враховуючи невербальні характеристики кандидата (зовнішній вигляд, вираз очей, манеру спілкування)[96].

Проведення психодіагностики символічно можна розділити на кілька етапів. Спершу проводиться всебічна формалізована бесіда 3 кандидатом 3 метою виявлення стану його психічних і психофізіологічних особливостей особи. Вслід реалізується його детальне обстеження за допомогою стандартного набору методик. Всі результати носять узагальнюючий характер. Даний етап припиняється складанням експертного висновку про придатність або непридатність даного кандидата до реалізація конкретної роботи. Оцінка якостей 
кандидатів здійснюється на базі стандартних репрезентативних критеріїв оцінювання результатів психологічного тестування.

Діяльність працівників підприємства пов'язана 3 підвищеною відповідальністю за результати роботи як в моральному, так і юридичному плані. В ході роботи можливі ситуації, коли від професіоналізму менеджера підприємства залежатиме успішність здійснення поставлених перед підприємством завдань і планів.

У ході роботи працівник підприємства постійно випробовує емоційну напругу, перебуваючи в ситуаціях між особових взаємодій з суб'єктами підприємницької діяльності, а також ситуаціях, коли необхідно ухвалювати швидкі і раціональні управлінські рішення.

Окрім фахових знань і умінь треба посідати конкретними професійно важливими якостями, передусім ці якості природно пов'язані 3 особливостями центральної нервової системи або темпераментом людини. В зв'язку з цим варто на підставі професіографічного розглядові і дослідних психологічних оглядів менеджерів виробництва скласти інформаційну професіограму, де чітко розписати соціально-економічні, виробничі характеристики професії. Підготувати комплекс методичних прийомів для оцінки особистих і професійно важливих якостей менеджера [96].

Таким чином, варто професійно підходити до підбору персоналу, використовуючи ретельно підібрані методи дослідження особи, щоб вакантну посаду міг посісти професіонал $з$ відповідними параметрами. При підборі персоналу активне використання психодіагностики дає можливість створювати колективи з високим рівнем продуктивності праці, а також формувати ділову обстановку i згуртованість колективу. Крім того, використання психодіагностики дає можливість виявляти професійно непридатних фахівців для роботи на даному підприємстві [94].

Відомо, що на тих підприємствах, де між керівниками і підлеглими існують гарні взаємини, ефективність виробництва і рівень кваліфікації співробітників вище, а кількість прогулів і плинність робочої сили значно нижче. Установлення гарних виробничих відносин жадає від керівництва визначених витрат (фізичних, 
матеріальних, моральних). Для здійснення на практиці політики нормальних виробничих відносин у багатьох організаціях і корпораціях створюються спеціальні психологічні групи. Колектив стає могутнім засобом формування особистості тільки тоді, коли він характеризується позитивним (або оптимальним) психологічним кліматом.

Психологічний клімат створюється та проявляється в процесі спілкування, на фоні якого реалізуються групові потреби, виникають та поширюються між особистісні та групові конфлікти [95].

Психологічна сумісність - ефект поєднання людей, який надає максимальний результат діяльності при мінімальних психологічних витратах взаємодіючих осіб. Якщо група досягає високих результатів у сумісній діяльності при великих витратах психічної енергії, за рахунок нервових зривів - це вже змушує сумніватися у наявності психологічної сумісності їі членів, і як наслідок - в присутності позитивного психологічного клімату.

Таким чином соціально-психологічний клімат колективу залежить від особистості керівника, компетентності виконавців і їх сумісності, яка проявляється під час виконання колективної роботи.

Проблема вивчення морально - психологічного клімату на підприємстві є дуже важливою і актуальною. Якраз морально - психологічний клімат колективу безпосередньо впливає на формування особистості робітників, помагає успішному подоланню професійної деформації.

Психологічний клімат $є$ комплексною психологічною характеристикою, що відображає стан взаємин і ступінь задоволеності співробітників різними чинниками життєдіяльності колективу служб і підрозділів підприємства. Доцільно відзначити, що серед основних чинників психологічного клімату називають відносини людей і умови спільної діяльності.

Сприятливий морально-психологічний клімат в $\mathrm{C}(\Phi) \Gamma$ «СТКОЛОС» - це важлива умова розкриття здібностей особистості працівників підприємства та підвищення продуктивності праці.

При проведенні досліджень морально-психологічного клімату в колективі С(Ф)Г «СТОКОЛОС» спеціалістами підприємства можуть бути використані різні методи: анкетування, тестування, опитування, інтерв'ювання, 


\section{SOCIO-ECONOMIC AND MANAGEMENT CONCEPTS}

спостереження та ін. При цьому різними є витрати праці на їх проведення, собівартість та результативність. Для більшої об'єктивності результатів рекомендовано використовувати 2-3 методи. В той же час одним із завдань цього процесу є i мінімізація бюджету досліджень для підприємства-замовника за умови дотримання всіх якісних параметрів. Необхідно знайти оптимальне вирішення конфлікту цілей.

При виконанні такого завдання за допомогою методу лінійного програмування за змінні може бути прийнято:

X1 - витрати праці на суспільне анкетування, люд-год.;

X2 - витрати праці на групове анкетування, люд-год.;

X3 - витрати праці на вибіркове анкетування, люд-год.;

X4 - витрати праці на суспільне тестування, люд-год.;

X5 - витрати праці на групове тестування, люд-год.;

Х6 - витрати праці на вибіркове тестування, люд-год.;

X7 - витрати праці на суспільне опитування, люд-год.;

X8 - витрати праці на групове опитування, люд-год.;

X9 - витрати праці на вибіркове опитування, люд-год.;

Х10 - витрати праці на суспільне інтерв’ювання , люд-год.;

X11 - витрати праці на групове інтерв’ювання, люд-год.;

Х12 - витрати праці на вибіркове інтерв'ювання, люд-год.;

Х12 - витрати праці на вибіркове інтерв’ювання, люд-год.;

X13 - витрати праці на суспільне спостереження, люд-год.;

X14 - витрати праці на групове спостереження, люд-год.;

Х15 - витрати праці на вибіркове спостереження, люд-год.

Таблиця 1

Мінімальні витрати праці при проведенні соціально-психологічних досліджень різними методами

\begin{tabular}{|c|c|}
\hline Метод & Витрати праці, люд-год \\
\hline Суспільне анкетування+тестування+опитування & 91 \\
\hline Групове анкетування+тестування+опитування & 76 \\
\hline Вибіркове анкетування+тестування+опитування & 65 \\
\hline Суцільне+групове+вибіркове інтерв'ювання & 112 \\
\hline Суцільне+групове+ вибіркове спостереженя & 134 \\
\hline
\end{tabular}




\section{SOCIO-ECONOMIC AND MANAGEMENT CONCEPTS}

Згідно з умовами через графік завантаженості по інших замовленнях спеціалістів С $(\Phi) \Gamma$ «СТОКОЛОС» не можуть працювати над таким завданням у підприємства-замовника більше, ніж 480 люд-год.

Таблиця 2

Ймовірність отримання достовірної інформації при проведенні соціальнопсихологічних досліджень різними методами

\begin{tabular}{|c|c|}
\hline Метод & Ймовірність, $\%$ \\
\hline Суцільне анкетування & 85 \\
\hline Групове анкетування & 80 \\
\hline Вибіркове анкетування & 80 \\
\hline Суцільне тестування & 85 \\
\hline Групове тестування & 80 \\
\hline Вибіркове тестування & 50 \\
\hline Суцільне опитування & 60 \\
\hline Групове опитування & 55 \\
\hline Вибірове опитування & 45 \\
\hline Суцільне інтервювання & 50 \\
\hline Групове інтервювання & 45 \\
\hline Вибіркове інтервюваня & 40 \\
\hline Суцільне спостереження & 100 \\
\hline Групове спостереження & 95 \\
\hline Вибіркове спостереження & 90 \\
\hline
\end{tabular}

Загальна ймовірність має скласти не менше 80\%

Таблиця 3

Вартість 1 люд-год. Проведення соціально-психологічних досліджень різними методами

\begin{tabular}{|c|c|}
\hline Метод & Вартість, грн.. \\
\hline Суцільне анкетування & 220,00 \\
\hline Групове анкетування & 160,00 \\
\hline Вибіркове анкетування & 102,00 \\
\hline Суцільне тестування & 95,00 \\
\hline Групове тестування & 104,00 \\
\hline Вибіркове тестування & 80,00 \\
\hline Суцільне опитування & 120,00 \\
\hline Групове опитування & 98,00 \\
\hline Вибірове опитування & 130,00 \\
\hline Суцільне інтервювання & 80,00 \\
\hline Групове інтервювання & 70,00 \\
\hline Вибіркове інтервюваня & 75,00 \\
\hline Суцільне спостереження & 60,00 \\
\hline Групове спостереження & 75,00 \\
\hline Вибіркове спостереження & 50,00 \\
\hline
\end{tabular}




\section{SOCIO-ECONOMIC AND MANAGEMENT CONCEPTS}

Обмеження матриці економіко-математичної моделі задачі можуть бути об’єднані у чотири групи.

Перша група обмежень по максимальних витратах праці при проведенні соціально-психологічних досліджень:

$$
\begin{aligned}
& X 1+X 4+X 7>=91 \\
& X 2+X 5+X 8>=76 \\
& X 3+X 6+X 9>=65 ; \\
& X 10+X 11+X 12>=112 ; \\
& X 13+X 14+X 15>=134
\end{aligned}
$$

Друга група обмежень по ймовірності отримання достовірної інформації при проведенні соціально-психологічних досліджень різними методами:

$$
(0,85 \times 1+0,80 \times 2+0,80 \times 3+0,85 \times 4+0,80 \times 5+0,50 \times 6+0,60 \times 7+0,55 \times 8+0,45 \times 9+
$$
$0,50 \mathrm{X} 10+0,45 \mathrm{X} 11+0,40 \mathrm{X} 12+0,105 \mathrm{X} 13+0,95 \mathrm{X} 14+0,90 \mathrm{X} 15) /(\mathrm{X} 1+\mathrm{X} 2+\mathrm{X} 3+\mathrm{X} 4+\mathrm{X} 5+$ $\mathrm{X} 6+\mathrm{X} 7+\mathrm{X} 8+\mathrm{X} 9+\mathrm{X} 10+\mathrm{X} 11+\mathrm{X} 12+\mathrm{X} 13+\mathrm{X} 14+\mathrm{X} 15)>=0,80$;

Третя група обмежень по невід ємних значеннях змінних:

$\mathrm{X} 1>=0 ; \mathrm{X} 2>=0 ; \mathrm{X} 3>=0 ; \mathrm{X} 4>=0 ; \mathrm{X} 5>=0 ; \mathrm{X} 6>=0 ; \mathrm{X} 7>=0 ; \mathrm{X} 8>=0 ; \mathrm{X} 9>=0$; $\mathrm{X} 10>=0 ; \mathrm{X} 11>=0 ; \mathrm{X} 12>=0 ; \mathrm{X} 13>=0 ; \mathrm{X} 14>=0 ; \mathrm{X} 15>=0$.

Четверта група обмежень по максимальному використанню витрат праці спеціалістів С(Ф)Г «СТОКОЛОС» на соціально-психологічні дослідження:

$$
\mathrm{X} 1+\mathrm{X} 2+\mathrm{X} 3+\mathrm{X} 4+\mathrm{X} 5+\mathrm{X} 6+\mathrm{X} 7+\mathrm{X} 8+\mathrm{X} 9+\mathrm{X} 10+\mathrm{X} 11+\mathrm{X} 12+\mathrm{X} 13+\mathrm{X} 14+\mathrm{X} 15<=480 .
$$

Цільова функція - мінімум вартості проведення соціально-психологічних досліджень різними методами для підприємства:

$$
\mathrm{F}=12,4 \mathrm{X} 1+11,6 \mathrm{X} 2+10,2 \mathrm{X} 3+\ldots . .4,5 \mathrm{X} 15 \text { => мінімум. }
$$

В результаті вирішення задачі на ПЕОМ стане відомо, що при проведенні досліджень морально-психологічного клімату колективу підприємства найдешевшою комбінацією буде наступна: 65 люд-год. доцільно віднести на вибіркове анкетування; 91 люд-год. - на суцільне тестування; 76 люд-год.- на групове тестування; 67,5 люд-год. - на суцільне інтерв’ювання; 44,5 люд-год.- на вибіркове інтерв’ювання; 134 люд-год. - на суцільне спостереження.

Мінімальні витрати при цьому будуть дорівнювати 35833 грн. 


\section{SECTION 4. ECONOMICS OF INDUSTRIES}

\subsection{Theoretical foundations of forming the competitiveness of restaurant business establishments}

The restaurant business is one of the most significant components of the service sector. All over the world, it is one of the most profitable types of small businesses, so these institutions always compete for an optimal position in the market and its most promising segments, as well as for finding new and retaining regular consumers of these services.

Today, restaurants, more than ever before, offer a wide range of services to consumers of products and services of restaurant establishments. This business became one of the first sectors of the Ukrainian economy to switch to market relations. But the functioning of this sphere at the macro level is impossible without its functioning at the local level, since all restaurant establishments are located and operate in certain localities.

Fundamental and applied aspects of the development of restaurant establishments were considered in the works of domestic and foreign authors: A. Avetisova, V. Antonova, V. Arkhipov, V. Varfolomeeva, K. Egerton-Thomas, V. Naidyuk, L. Nechayuk, V. Pivovarov, G. Pyatnitskaya, O. Svatyuk, N. Telesh, T. Stahl and others.

The restaurant industry is one of the most profitable sectors of the world economy of the XXI century and is becoming a leading direction of economic and social development. Today, it is the service sector that shapes the economy of many countries and becomes an important factor in the stable development of the global hospitality industry.

The main purpose of the restaurant industry is to provide the population with culinary products, organize a high level of service in accordance with their needs, as well as organize leisure activities.

Understanding the concept of competitiveness requires taking into account all the main elements of the competition mechanism. Since competitiveness is formed at 


\section{SOCIO-ECONOMIC AND MANAGEMENT CONCEPTS}

different levels: services, restaurant establishments, market, region, country, it is necessary to distinguish it and divide it into different types [97].

To understand the essence of the competitiveness of restaurant enterprises, it is necessary to take into account the features of the enterprise as a system, characterized by the presence of input and output of the system, communication with the external environment, feedback, and internal structure. The complexity of the process is also determined by the influence of many factors of ensuring competitiveness [98].

The complexity of the process is also determined by the influence of many factors of ensuring competitiveness. In the field of restaurant management, they are characterized by an internal atmosphere (not noticeable to the consumer), material and non-material quality of service, the creation of comfortable psychological conditions for visitors, as well as the time spent on their service [99].

The concept of enterprise competitiveness is widely used and at the same time ambiguous. The theoretical justification of the concept of "competitiveness" is determined by scientists in different ways, without providing a single definition, putting different content into this concept.

The competitiveness of restaurant establishments is an opportunity to use their strengths and concentrate their efforts in the production of relevant services, where they can take an offensive position in the domestic and foreign markets.

Analyzing the definition of the essence of "competitiveness of restaurant establishments", we can distinguish the following three features of this concept (fig. 1) [100]. 


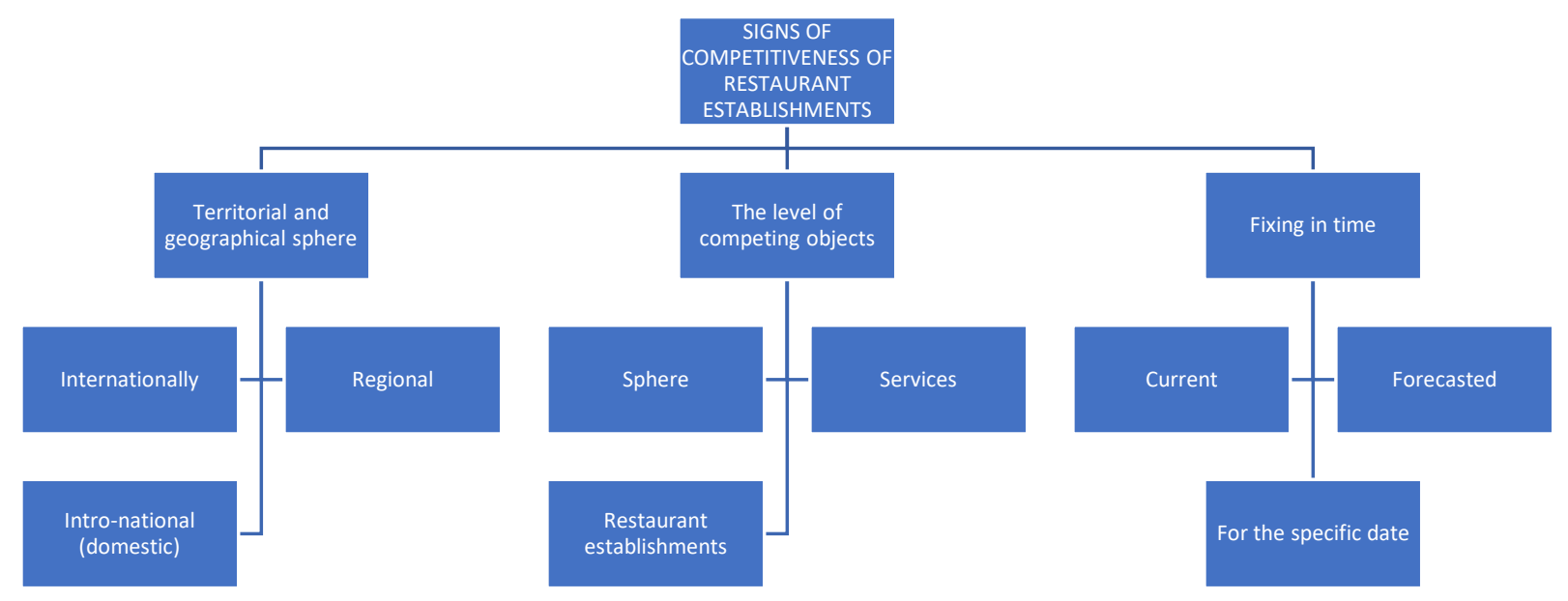

Figure 1. Classification of signs of competitiveness of restaurant establishments

So, competitiveness is a market category that has a dynamic and changeable character. Thus, with the same quality characteristics of services provided by restaurant establishments, its competitiveness can vary widely depending on market conditions, competitors actions, price changes, advertising events, and so on.

The competitiveness of restaurant establishments should be ensured by such indicators as high production efficiency, which is realized thanks to modern equipment, technologies, qualified employees and the ability to win and maintain a stable position in the market for a long time, which is ensured by the effective use of marketing management principles [101].

The main conditions for ensuring the competitiveness of restaurant establishments are:

- application of scientific approaches to Strategic Management in restaurant establishments;

- to ensure the adjacency of Technology, economics and management development;

- application of modern research and development methods in the field of restaurant business; 
- analysis of the interrelationships of management functions of any process at all stages of the life cycle of restaurant establishments;

- the formation of a system of measures to ensure the competitiveness of various institutions in the service sector [102].

So, the following conclusions can be drawn from the above:

- the competitiveness of restaurant establishments is a relative concept and, accordingly, can have different levels in relation to different competitors;

- the higher the competitiveness of restaurant establishments, the better their results in international markets;

- the competitiveness of restaurant establishments is the result of effective economic activity of these establishments in a competitive market;

- the competitiveness of restaurant establishments is considered as a complex comparative characteristic of the institution, reflecting the totality of advantages over competitors, the harmony of development of these establishments;

- an integral component of the competitiveness of restaurant establishments in the service sector market is the marketing component, namely: customer satisfaction, a positive image of the institution, the presence of a strong brand, etc.;

-the competitiveness of restaurant establishments is based on the competitiveness of the services they provide, but these categories, although interrelated, are not identical.

Therefore, competitiveness is a property of an object that characterizes the degree of actual or potential satisfaction of a specific or emerging need in comparison with similar objects in a given market. Competitiveness is one of the main factors in the ability to compete to meet the needs compared to similar facilities. The object shows its competitiveness in a specific market or a specific group of consumers, which is part of a strategic market segment. In the absence of a market where the object can be competitive, it means that this object has no analogues and is in this particular period of time the world's best object (sample). Based on the analysis of existing definitions and approaches to the concept of "competitiveness of restaurant establishments", we grouped these approaches (fig. 2). 


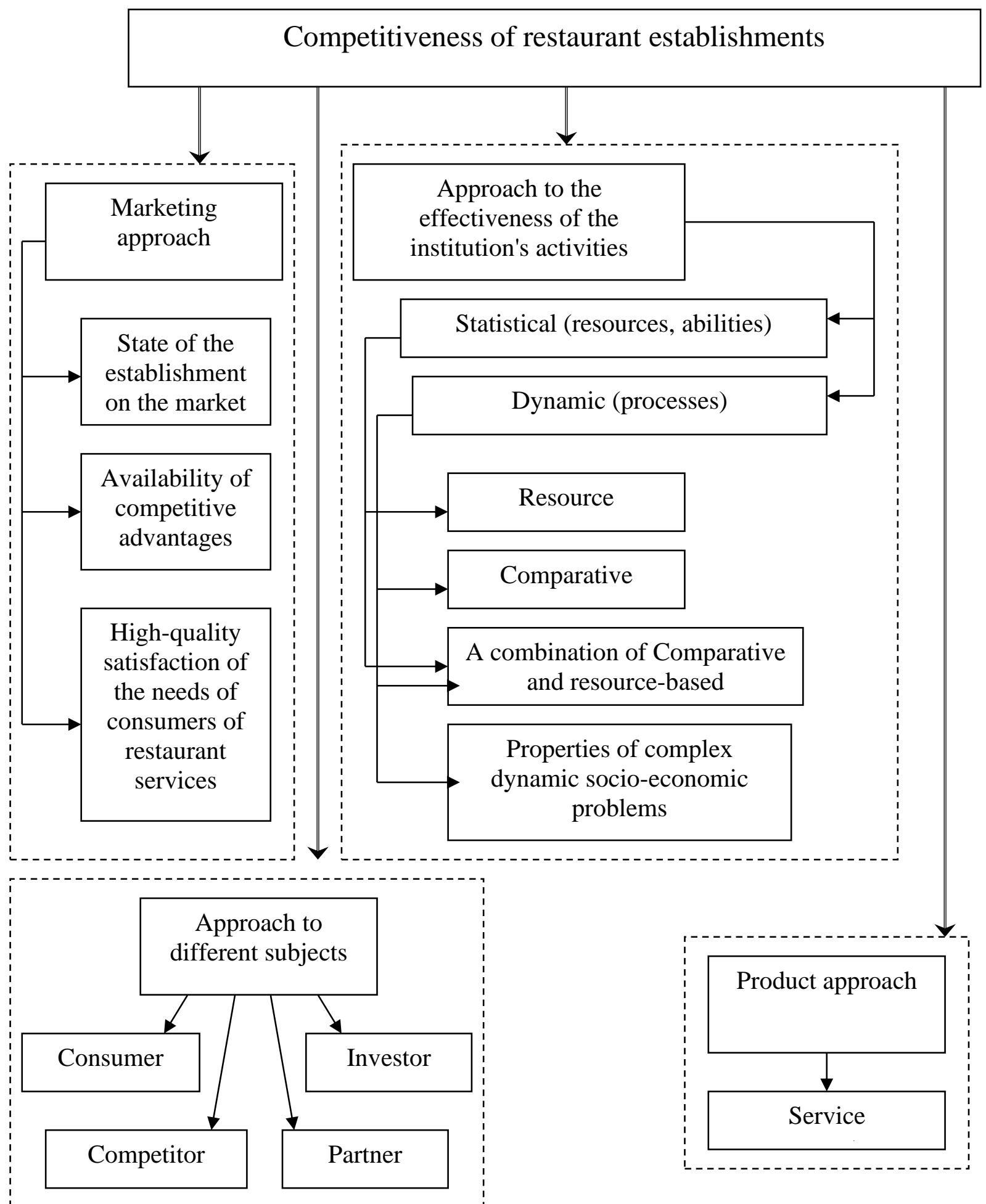

Figure 2. Grouping of approaches to defining the term " competitiveness of restaurant establishments"

The grouping of these approaches, in our opinion, is based on four main ones: the marketing approach, the product position, the efficiency and effectiveness of restaurant establishments, and the definition of various subjects. All other approaches are based on these groups. When considering the economic category "competitiveness of 


\section{SOCIO-ECONOMIC AND MANAGEMENT CONCEPTS}

restaurant establishments", it is necessary to take into account approaches to the general definition and features of these restaurant establishments.

Restaurant establishments are characterized by the presence of certain characteristics that differ from establishments in other industries. At the same time, the definition of the concept of "competitiveness of restaurant establishments" should be based on the characteristics of the object of competition.

Analyzing the definition of restaurant establishments, it is determined that in accordance with the activities carried out, these establishments are industrial, commercial and providing services. Therefore, to define the essence of the concept of "competitiveness of restaurant establishments", it is necessary to take into account the definition of the concepts "competitiveness of trade, production and service enterprises".

In accordance with the types of enterprises that are included in restaurant establishments, we suggest dividing them according to their functional purpose into the following groups (fig. 3).

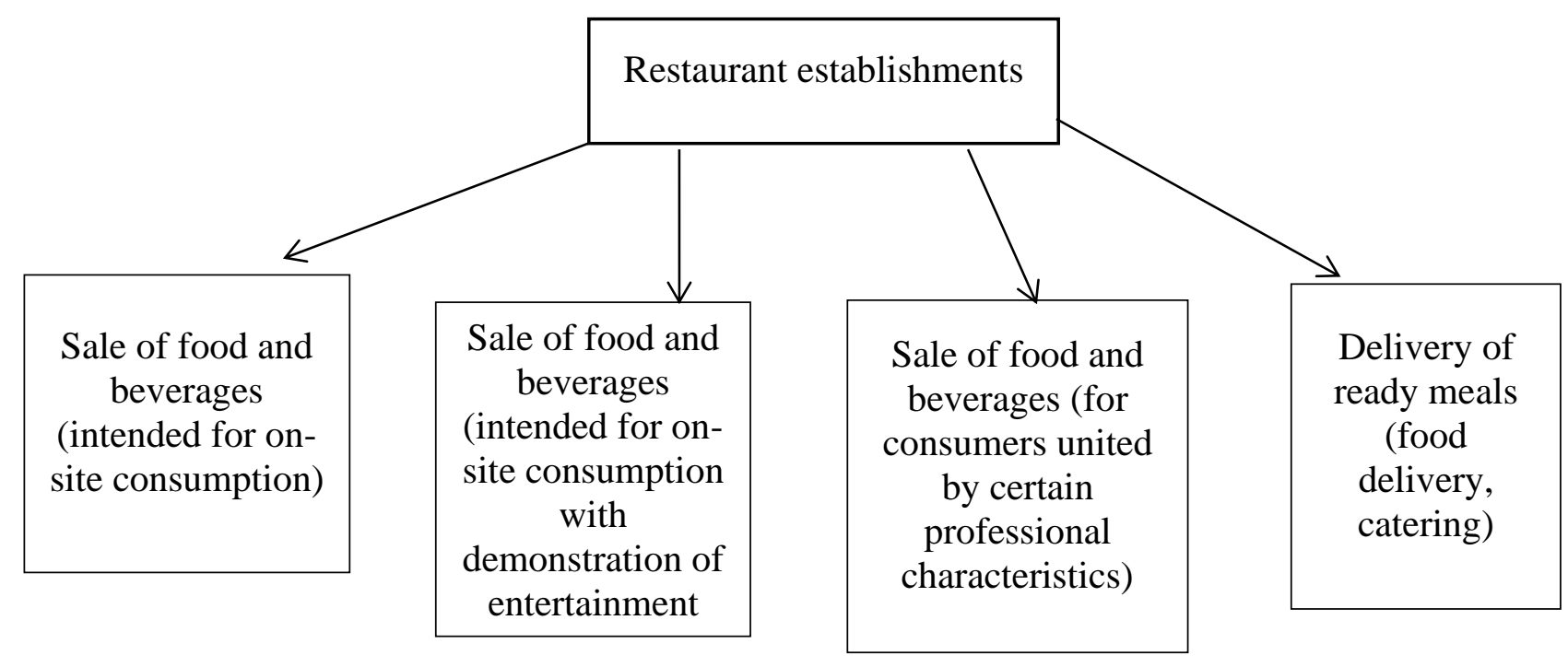

Figure 3. Characteristics of restaurant establishments by functional purpose

So, according to Fig. 3, each type of restaurant industry will have its own segment in the market. Based on previous research, each market segment will be characterized by a certain competitiveness. Therefore, the difference between these types of enterprises lies in the different demand for the services that they will provide. 
In our opinion, the competitiveness of restaurant establishments is a characteristic of an enterprise that reflects the specifics of its activities in a certain segment of the food market in a certain period, relative to existing competing enterprises, and depends on the influence of factors of the external and internal environment, as well as affects the satisfaction of the needs of consumers of services.

The competitiveness indicator is a kind of element that reflects the results of the work of all its services and divisions, which characterize the state of stability of the internal environment to the external one.

The course of economic processes over a certain period of time is dynamic. This encourages enterprises to adapt to the rapidly changing conditions of the external and internal environment in conditions of intense competition. In this situation, the company that adapts faster than others to the realities of time and adapts to new operating conditions wins.

Adaptation of restaurant establishments to market conditions often depends on the effectiveness of the current management system, the ability of the management team to create and implement a system of short-and long-term goals.

According to the analysis of the activities of domestic restaurant establishments, most of them were unable to study the market or produce certain services that would meet the needs of this market, and therefore were not ready for the realities of intense competition. Thus, according to statistical studies, $34.8 \%$ of Ukrainian restaurant establishments, unable to withstand the competition, became unprofitable [98].

The most significant reasons for the unstable position of restaurant establishments in the market are:

1) lack of assessment of the purpose and intentions of competing institutions;

2) insignificant response to the requests of consumers of restaurant services;

3) inaccuracies in identifying priority areas of development;

4) fierce competition in the industry;

5) uniformity in the implementation of the company's product strategy;

6) lack of opportunities for conducting price competition;

7) financial instability of the institution; 
8) inefficient long-term planning system;

9) application of outdated methods of managing a restaurant establishment;

10) use of outdated equipment and equipment;

11) inefficient methods of organizing the promotion and implementation of services.

Thus, the ability of a restaurant establishment to compete in the domestic and global markets was embodied in the category of "competitiveness".

The analysis of the economic literature indicates a sufficient variety of interpretations of the term "competitiveness".

The formation of the theory of competitive advantages is inextricably linked with the steady transformation of the market economy. In the field of international competition, the formation of competitive advantages was first explained by the achievement of relatively lower costs in the production of goods (services) (D. Ricardo), later - the effective use of excess factors of production (E. Heckscher, B. Olin), and then - the corresponding conditions that are created in the country where the production of products (services) is based, the so-called determinants of the "National Diamond" (M. Porter) [101].

For quite a long time, the theory related to the use of resources has been dominant in the field of strategy, but over the past three decades, several new ones have emerged that explain the features of the competitive advantages of restaurant establishments with such opportunities:

- ability to balance the efficient use of resources and increase consumer values (attractiveness) of restaurant services for the consumer;

- effectiveness in global markets;

- high adaptability in hyper-competitive conditions;

- ability to perceive and use new knowledge;

- ability to carry out environmentally safe activities (production of own ecoproducts).

In the modern period, the approach proposed by M. Porter is methodically developed for quantitative assessment. Studying its features, it is necessary to pay 
attention to three main problems that will arise before the analyst, due to the fact that their solution is provided more in the theoretical aspect than in the applied one [101]:

1) selection of an indicator for assessing the level of resource efficiency;

2) selection of basic objects for comparison;

3) availability of reliable and comprehensive information on the state of competition in a higher-order economic organization.

The competitiveness of a restaurant establishment is ensured by the achievement and development of competitive advantages that arise in the economic, technical, and organizational spheres of the enterprise's activity.

Competitive advantages - the results of legal actions to win consumer preferences that ensure the company's superiority over competitors and which can be measured by economic indicators.

The competitive advantage that various competitors (competitors) have in specific markets is a significant factor in the competitive situation in the service market. Competitive advantage is characterized by a list of characteristics, properties of services or brands, which forms a certain advantage for a restaurant establishment over its direct competitors [99].

Competitive advantages are a pronounced manifestation of leadership over competitors in the economic, organizational, and technical spheres of the institution's activity. It is worth noting that competitive advantage is not synonymous with the potential of the institution. Unlike opportunities, this is a real fact that occurs due to obvious advantages on the part of service consumers.

Competitive advantage is comparative, i.e. relative, not absolute, since it can only be estimated by comparing certain characteristics that affect the economic efficiency of selling services. The second characteristic feature of a competitive advantage is its ability to be ambiguously influenced by a large number of different factors. In order for a restaurant establishment to achieve competitive advantages, comprehensive efforts are needed. Sometimes they are not enough due to the influence of external, uncontrolled factors. After all, the same factors can both strengthen and weaken a competitive advantage. 
Competitive advantages are characterized by different levels of hierarchy, they can belong to a service in the service sector, institution, industry, economy as a whole, be based on price and non-price factors, be long-term and short-term, stable and unstable, unique and imitated, and so on.

So, the conducted research gives grounds to assert that the term "competitiveness of restaurant establishments" is based on the main approaches to the general definition of enterprise competitiveness, and approaches to determining the specific properties of restaurant enterprises. 


\subsection{Integrated information systems for management of agricultural enterprises of Ukraine}

Conditions of global competition, growing societal requirements for product quality and environmental friendliness, encourage Ukrainians agricultural enterprises to seek various means to improve the efficiency of production and marketing activities. One of the obvious ways is adaptive management and rapid response to changes in production and market factors based on reliable and timely information. Currently, this is possible due to the use of modern management methods, computer information systems, special business and mobile applications.

It is known that the larger the scale of the enterprise, the more information is needed to manage it. Therefore, farms and small agricultural enterprises mainly use accounting automation systems to compile mandatory financial and tax reporting, as there is no need for an automated system to calculate several units of equipment.

For great enterprises with a large number of structural divisions, including geographically dispersed, it is very important to streamline information flows to coordinate the decisions of management at all levels and structural units and the actions of employees. This is possible through the formation of integrated information systems, which combine specialized, namely automated accounting systems, production process management systems, trade and warehousing systems, etc., into a single complex.

Domestic and foreign scientists have paid enough attention to various aspects of the functioning of integrated information systems (IIS). Among them Guzhva V. M, Ilyenko R. V, Hopkins D., $\quad$ Morehart M., Sokol K. M., $\quad$ Plekhanova G. O., Riznichenko L. V., Rybalko L. P., Tatarchuk M. I., Titova O. P., Udovik A. S., Ushakova I. O. But not enough attention was paid to the analysis of software solutions for the agricultural sector, which determined the purpose of this research.

The key properties of IIS are the modular principle of construction, inheritance of systems of different profile, integration, long life cycle software, scalability, use of equipment of different generations and quality characteristics, etc. 


\section{SOCIO-ECONOMIC AND MANAGEMENT CONCEPTS}

The modular principle of construction allows completing the system for your own needs and the ability to gradually increase functionality.

Under the integration of information systems understand the combination of a single whole subsystems and components of different systems in order to form the information space of the enterprise. That is, the purpose of integration is to combine information arrays and business process automation programs. There are several types of integration in integrated systems: vertical (between management levels), horizontal (between production units) and information (at the level of databases and knowledge bases).

System integrators solve the problems of integration of various specialized enterprise management programs, namely specialists and firms that analyze the software used, evaluate the software available on the market and based on the tasks and financial capabilities of the client, offer a set of hardware and software, configure programs and transition modules, train employees.

The term "corporate" is often used in Ukrainian educational and scientific publications, thus emphasizing the scale of the tasks to be solved and the approximate consumer of the product.

In world practice, the recognized international standards in the construction of integrated systems in recent years are ERP, ERPII and CSRP. ERP - Enterprise Resource Planning includes modules: procurement, sales, orders, supplies, accounting, human resources, fixed assets, warehousing, business planning, etc. In ERPII Enterprise Resource \& Relationship Processing in addition to the previous expanded capabilities for manipulating external relations based on Internet protocols, including benchmarking subsystems (information about competitors) and CRM - Customer Relations Management. CSRP - Customer Synchronized Resource Planning involves the inclusion of the customer in the business planning system of the enterprise.

Recently, the term EAS - Enterprise Application Suite has become widespread. One of the reasons for this was the widespread use of Data Mining technology and Business Intelligence (BI). 
In the practice of using integrated information systems, there are two main ways to create integrated information systems: acquisition and self-development.

According to the scale of the tasks to be solved, integrated systems are divided into several groups: small (1C), medium (Galaxy, Parus, Micosoft Axapta, Microsoft Navision) and large (SAP R / 3, Oracle Applications, Baan IV).

Acquisition and implementation of ready-made solutions. This is quite a costly and time-consuming process, which requires the integration of the implemented information system with the organizational structure of the enterprise and the possible reengineering of his business processes.

Integrated information systems on the market are represented by foreign, Russian and domestic developments.

Among the big integrated systems the most widespread in the world and in Ukraine are the developments of companies: SAP AG, Oracle, Infor Global Solutions, J.D. Edwards \& Co, PeopleSoft and Platinum. The proposed libraries of functional modules allow you to complete the system on a single platform, removing the problem of data compatibility. The main users of large IIS in Ukraine are the industrial, energy, trade and telecommunications sectors.

Ukrainian agricultural enterprises are offered a specialized solution based on SAP Business One. The system includes modules: Basic registers, Equipment, Crop production, Livestock, Specialized industry solutions (Cotton, Coffee, Fisheries), Maintenance of machines and mechanisms, Manpower, Stocks and supplies, Planning and cost [107].

Agricultural enterprises of Ukraine use software products of mainly Russian origin in the construction of enterprise management information systems, which is due to the aggressive distribution policy of companies (especially 1C products) with a branched structure of implementation centers and a common historical past and lack of language barrier. Between the Russian-language and English-language interface and lower costs, the first choice will be the obvious choice for the average user. 
One of the first Russian products for agricultural holdings were ERP-systems "CPS: AgroHolding based on 1C: Management of the production enterprise" (CenterProgramSystem) and "1C Agricultural Enterprise" (Voronezh).

CenterProgramSystems offers 1C: Enterprise 8. Agricultural Enterprise Accounting and GeoGovernment Geographic Information System (GIS) on the 1C: Enterprise platform for the agricultural sector. Among the company's clients are domestic Veres Group of Companies, AGROTRADE Group, Freedom Pharm International, UkrTransAgro LLC, Zelena Dolina Agrocomplex, Agricor Holding, Agrodim JV LLC, international with production areas in Ukraine AS Trigon Agri Group and SigmaBleyzer [108].

In response to the state's restrictive sanctions against Russian software, ITEnterprise offered Ukrainian MASTER: Agro for agricultural enterprises in 2015. Like all ERP-based IT products, the system consists of interconnected functional modules that cover management, accounting and organizational functions. Agricultural components of the system are represented by modules: Crop production, Livestock, Transport, Land lease. Specialized add-ons MASTER: Technical and economic planning, MASTER: Threshing floor and MASTER: Agronomy contribute to the expansion of crop management functionality [109].

It should be noted that the system is offered in stationery and cloud solutions. The latter helps reduce equipment and administration costs, but will not allow adjustments to be made to the system. For the most part, cloud-based solutions of this type are unacceptable to large data security and control companies. For farmers and small agricultural enterprises, the deterrent is mainly the financial aspect.

The advantage of using domestic developments is full compliance with national accounting standards and timely updating of the system (adjustment by the developer of software algorithms) when changing legislation.

Independent development of an integrated information system is an extremely complex, time-consuming and costly process. Even with an information technology division, this method is inefficient for this class of systems, as the market advantage of 
IIS market leaders is the use of SMART components, namely intelligent components and science-intensive algorithms in data analysis and decision support.

In our opinion, the most promising is a combined approach, when the company combines different standard systems and creates insufficient subsystems to solve its own specific problems.

An example of this approach is the experience of AgroGeneration, which did not find in the market programs for automation of relationships with shareholders, and therefore in 2011 developed a management system of contracts with shareholders "Land Accounting", which included a document management module on platform 1C: Enterprise 8. The next step was to create a management system to display the spatial characteristics of land on the ArcGIS platform. To automate settlements with shareholders in the accounting system, a subsystem "Accounting for land resources" was created in parallel, which combined financial and management data. External information resources are also used in the information system of the enterprise. In particular, the control of land use accounting data is carried out on the basis of free images from the Landsat 8 and Modis satellites [110].

An important feature of integrated information systems is their configuration depending on the needs of the enterprise. Thus, in the agricultural holding "Ukrlandfarming" the integrated information system of production process management includes: in the field of distribution and transportation the Tele Track system for monitoring the location and operation of road transport; in crop production, the equipment of the precision farming system Auto Track from John Deere - for compiling programs for growing in specific areas, managing field units, generating reports; at processing plants and elevators weight control system [111].

In summary, the success of the implementation and use of integrated information systems largely depends on the interest of management and the willingness of professionals to work with information and use and develop software products, namely the availability of information culture. 


\section{3 Тренди цифровізації логістики ринку е-commerce}

В результаті закриття у 2020 р. оф-лайн магазинів на карантин у зв'язку із пандемією Covid-19 глобальна електронна торгівля досягла рекордного рівня в 16,4\% від загальних світових роздрібних продажів. За даними опитування EVO, $84 \%$ споживачів здійснювали покупки в інтернеті під час пандемії. Найбільше зростання е-commerce в 2020 р. відбулося в країнах Центральної та Східної Європи - 21,5\% [112]. Як очікується, після пандемії глобальне зростання електронної комерції сповільниться, перш ніж знову почне зростати в 2022 році.

В 2020 р. загальний обсяг продажів в Інтернет-магазинах по всьому світу досяг \$4 трлн. У зв’язку з тим, що після подолання пандемії значна кількість торгівельних підприємств не повернеться до стаціонарних продажів, прогнозується ще один рік стрімкого зростання електронної комерції у всьому світі, очікується, що в 2021 р. ця цифра збільшиться до $\$ 4,5$ трлн. [112].

Ринок електронної комерції в Україні за 2020 р. склав 107 млрд. грн., що на 41\% більше, ніж у 2019 р. (за даними EVO). Тепер майже 9\% всіх покупок в Україні відбувається онлайн - на маркетплейсах, в онлайн-магазинах і соцмережах. До Китаю, де понад 30\% всіх покупок в онлайні, ще далеко, але приріст за рік чималий [113].

Пандемія також посилила зростаюче прагнення споживачів до зручності, швидкості і простоти. Так, 64\% споживачів вважають вагомою причиною купити товар в інтернеті, якщо буде пряма доставка додому, а 57\% - якщо буде нижча ціна. Для половини респондентів виявилися також важливі більш зручний спосіб покупки (54\%), цілодобова доступність (50\%) і більший асортимент для вибору (47\%) [114]. Тому торгівельні підприємтсва повинні адаптуватися, інакше вони ризикують втратити актуальність. Багато що буде залежати від ступеня задоволення клієнтів новим цифровим досвідом. Напр., в Італії 60\% опитаних купували в Інтернеті під час пандемії, але менше 10\% залишилися задоволені цим досвідом, в той час як у Фінляндії покупці готові продовжувати онлайнпокупки. Але так чи інакше зміни будуть йти і повного відкату назад не буде. 
Існуючі умови диктують нові тенденції розвитку логістики на ринку еcommerce. Сьогодні для підтримки сервісу на стабільно високому рівні логістичним операторам необхідно все гнучкіше адаптувати набір стандартних логістичних послуг під конкретні потреби замовника. У світі тренд на «переродження» логістики 3 перевезення в повноцінний сервіс став активніше розвиватися в останні кілька років. Пандемія Covid-19 тільки посилила вплив ринку е-соmmerce на розвиток логістичного сервісу. За час самоізоляції в сфері логістики зародилося кілька позитивних трендів - рітейлери стали переходити в онлайн, серйозний стимул до розвитку отримали Інтернет-магазини і сервіси доставки. В квітні-травні 2020 р. великим маркетплейсам вдалося наростити обсяг замовлень в 2-3 рази [115]. При цьому логістика деяких омніканальних рітейлерів сегмента non food виявилася не готова до різкого сплеску замовлень через Інтернет-майданчики. Наприклад, виявилася не готова інфраструктура: не вистачало кур'єрів, складів, фулфілмент-центрів, потужностей автопарку та ін. Внаслідок чого, середні терміни доставки замовлень по країні виросли до тижня і більше.

Карантинні заходи змінили поведінку споживачів, а це, в свою чергу, запустило процеси трансформації логістики в роздрібній торгівлі, основні тренди, якої представлено нижче, де цифровізація і ще більше проникнення ITсистем з оцифрування та автоматизації всього логістичного ланцюга займають перше місце.

По-перше, посилення проникнення цифрових технологій. Це торкнеться i нового підходу до управлінських рішень, включаючи хмарні технології, i роботизацію бізнес-процесів, i впровадження ITC (інтелектуальних транспортних систем). Цифрова трансформація до новітнього рівня Business 5.0 дає можливість використовувати технології нового часу (штучний інтелект, системи обробки великих обсягів даних), а також автоматизувати виробничі процеси. Основні тенденції цифровізації сфери логістики такі:

1. Технологія блокчейна, яка відома своєю прозорістю, буде широко застосовуватися в світовій логістиці (як блокчейн ланцюга поставок). 
Дослідження показують, що тільки в сфері продуктів харчування та напоїв до 2024 р. блокчейн може заощадити \$ 31 млрд. [116]. У світових ланцюгах поставок обмін безпечними даними $\epsilon$ однією 3 проблем. Використання блокчейна дозволяє обмінюватися даними в ланцюжку поставок від початку до кінця з усіма зацікавленими сторонами.

2. Збільшення використання Інтернету речей (Internet of Things, IoT), який об'єднує взаємопов'язані фізичні пристрої, які можуть відстежувати, складати звіти, відправляти і обмінюватися даними, в ланцюгах поставок. Пристрої IоT можуть відстежувати і аутентифікувати продукти та поставки за допомогою GPS та інших технологій. Вони також можуть відстежувати умови зберігання продуктів, покращуючи управління якістю та прозорістю всього ланцюга поставок. Використання IоT на складах і в торгових точках також може покращити прозорість виробництва, управління запасами і профілактичного обслуговування.

3. Створення гнучкості ланцюга поставок, що в основному досягається за рахунок швидкості, вартості та ефективності. Гнучкість ланцюга поставок базується на чутливості до споживчого попиту. Структура гнучкою ланцюжка поставок відповідає основним складовим, включаючи віртуальну інтеграцію, узгодження процесів, мережу, чутливість до ринку та ін. Персоналізація поставок вважається ще одним аспектом гнучкості в ланцюгу поставок.

4. Хмарні рішення - запорука гнучкості бізнесу. В рамках стратегії орієнтації на хмарні рішення, інвестиції спрямовуються на три моделі хмарних сервісів: програмне забезпечення як послуга (SaaS), інфраструктура як послуга (IaaS) і платформа як послуга (PaaS). У складних умовах виживає той бізнес, який швидше адаптується до викликів, і події останнього року твердо доводять - для ефективного управління сьогодні необхідні хмарні сервіси. Міграція даних в «хмари» стабільно зростає по всьому світу. Ще в 2019 р. попит на такі ITпослуги як IaaS i PaaS зріс більше ніж на 38\%, і тенденції зростання стабільні, як ніколи раніше - навіть не зважаючи на цілком зрозумілий стрибок попиту в березні-квітні 2020 р. Відповідно до звітів Gartner, до 2025 р., щонайменше 50\% 
великих підприємств успішно реалізують комплексну стратегію в хмарі SaaS [116].

5. Діджиталізація процесів доставки. Сьогодні клієнт хоче, щоб відправку в будь-яку точку світу можна було здійснити максимально просто і легко. Але основний запит, який раніше не надавали логістичні компанії, а тепер це необхідність часу - можливість управляти посилкою в режимі реального часу, тобто в процесі самої доставки, напр., коли клієнт може в режимі реального часу змінити маршрут i кінцеву адресу своєї доставки. А це потребує повну діджиталізацію процесу всього шляху доставки. Більшість існуючих систем адаптовані до роботи в режимі реального часу 3 застосуванням моделі маршрутизації за рахунок фіксованої концепції часових вікон. Більш досконалі і «розумні» системи, що визначають тенденції розвитку маршрутизації в майбутньому, застосовують алгоритми з гнучкими тимчасовими вікнами, які змінюються в реальному часі, що дозволяє миттєво коригувати маршрути. Все частіше впроваджуються цифрові платформи і сервіси збору даних про стан на дорогах. Застосування сучасних систем динамічного визначення маршрутів дозволяє скоротити терміни і зменшити часовий інтервал доставки вантажів. Для переважної більшості інтернет-магазинів швидкість і «вікно» доставки представляють собою велику проблему. Це саме ті фактори, які зберігають інтерес до офлайн-торгівлі і впливають на вибір інтернет-рітейлера.

Зменшення терміну доставки та можливість вибору конкретного часу доставки є ще одним трендом крім управління посилкою в процесі самої доставки. Можливість вибору конкретного часу доставки - тренд актуальний як для міжнародної доставки, так i для локальної. Він буде очевидною конкурентною перевагою для тих логістичних компаній, які впровадять його найближчим часом.

За період дії карантину обсяг кур'єрської доставки «до дверей» виріс в 2,5 рази [115]. До такого різкого зростання попиту, який перевищував в рази навіть передноворічні піки, ринок виявився не готовий. При зростанні частки забору i доставки вантажів на 40\% обсяг одного перевезення міг знизитися до 6 разів, а 
середній чек зменшився в середньому на $30 \%$. Зниження обсягів перевезення в деяких напрямках загрожувало збільшенням інтервалів і термінів доставки. Щоб цього уникнути, багато рітейлерів спільно зі своїми логістичними провайдерами, змінили динаміку рейсів: завдання було зберегти колишню собівартість і своєчасність доставки. Для стабілізації термінів доставки, рітейлери, по-перше, залучали додаткові потужності логістичних операторів, а по-друге, оптимізували маршрути доставки між містами і доставку «до дверей».

Бум автоматизованої останньої милі стосується як онлайн-покупок, так і безконтактної доставки. Вимушений захід обернувся вигодою для покупця: рівень сервісу для нього виріс в рази. Зручність доставки по місту, вузькі таймслоти, комунікація з водієм, відстеження замовлення онлайн - вже той мінімум, на який погодиться покупець. Тепер стандартом $є$ прагнення клієнтів до отримання комплексного логістичного сервісу від забору вантажу до його доставки «до дверей». Тому фінансову кризу легше переживуть ті, хто вже налагодив та автоматизував свої процеси останньої милі.

Трансформація рітейлу та «останньої милі» в логістиці ставить непрості завдання перед власниками бізнесу: управління процесами вимагає більше ресурсів, в той час як клієнти очікують нових підходів в технологіях і сервісі. Раніше часовий проміжок доставки кур'єром розтягувався на пів дня або кілька годин, зараз потрібно пропонувати такий сервіс, який дозволить вашому клієнтові вибрати конкретне часове вікно в 15 хв. Якщо ж клієнт хоче отримати свою посилку протягом двох годин у зручний йому поштомат або відділення запропонувати таку можливість. Так, компанія Meest розробила і втілила рішення, яке, стане незамінним інструментом в логістиці та рітейлі, ERP-систему і відкрите API, на базі яких бізнес може автоматизувати процеси управління офлайн-локаціями, а клієнти отримують доступ до постійно оновлюваної бази даних локацій. Такий персоналізований підхід- безумовний тренд і конкурентна перевага для кожної логістичної компанії [117].

Одним із головних трендів сучасності стає безконтактна кур'єрська доставка. Кінцевому споживачу пропонується найширший асортимент товарів 3 
безконтактною доставкою додому. 3 метою уникнення громадських місць, в умовах пандемії, покупці готові переплачувати 5-10\% від вартості за товари 3 швидкою доставкою (1-3 дні) [118]. Продовженням ідеї безконтактної кур'єрської доставки вантажів є розвиток доставки посилок за допомогою «дронів» або «автопілотної» доставки. Все більше дронів розглядається для цілей доставки невеликих пакетів. Пересування по повітрю, незалежність від пробок, висока вантажопідйомність, автономність і досить низькі амортизаційні витрати зроблять дрони повсюдно поширеним типом доставки. Уже через 10-15 років очікується поява серійних важких безпілотників, здатних переміщувати по повітрю великі вантажі на великі відстані.

Перехід від офлайн торгівлі до е-commerce вплинув на ринок складських приміщень. Конкурентною відмінністю сьогодення на ринку е-commerce стає фулфілмент. Компанії все частіше вдаються до фулфілменту, щоб боротися зі зростаючими витратами i відповідати очікуванням споживачів. Оскільки створення своїх мереж фулфілмента коштує дорого, очікується, що попит на послуги 3PL операторів в першій половині цього десятиліття виросте майже вдвічі і складе \$408 млрд. [119].

На ринку з'явилося безліч нових програмних продуктів, при тому, що до 2019p. їх кількість була незначна. Йдеться про модернізацію WMS і TMS-систем, з їх адаптацією під запити роздробу та складів, розробці спеціальних рішень для фулфілмент, з'явилися програми розрахунку завантаження транспортних засобів та розрахунку замовлень. Одним 3 технологічних трендів, які змінюють логістику досить швидко, стає штучний інтелект. Допоміжні, доповнені й автономні системи ШІ вирішують i/або допомагають вирішувати такі завдання: аналіз колосальної кількості онлайн-замовлень 3 миттєвим отриманням результатів про напрямки транспортування і прогнозуванням часу доставки на основі даних про погоду, обстановку на дорогах та ін.,; застосування комплексних систем управління (ERP); автоматизація систем управління складами з адресним зберіганням (WMS); алгоритми розрахунку раціональних маршрутів вантажоперевезень і аналізу ефективності логістичних схем; 
автоматизація систем управління парком транспорту (TMS); управління складськими роботами й іншими засобами автоматизації складу.

Впровадження цифрових технологій управління і автоматизації бізнеспроцесів в логістиці - це новий, обов'язковий і неминучий тренд розвитку та збільшення прибутковості компанії на найближчі п’ять років. 


\section{4 Соціально-економічний розвиток туризму в Україні}

Туризм та соціально-культурний сервіс сьогодні розвиваються швидко та успішно по всьому світу, в тому числі і в Україні. Незважаючи на окремі бар'єри розвитку, країна має всі природні та економічні передумови для розвитку туріндустрії, що в першу чергу характерне для внутрішнього та в’їзного туризму. Тому дослідження питань соціально-економічного розвитку в туристичній сфері та напрямів туристських потоків $є$ актуальним напрямом дослідження. Водночас для визначення туристського потенціалу України важливо мати уявлення про іiї місце на світовому ринку відповідних послуг.

Україна - дуже приваблива країна з туристичної точки зору. Це пояснюється наявністю на ії туристичних дестинаціях різноманітних туристичних ресурсів. Найголовнішими компонентами природно-рекреаційних ресурсів країни $\epsilon$ курорти, бальнеологічні рекреації, повітря і кліматичні умови на площах українських лісів та гір. Щодо соціально-економічних туристичних ресурсів, то слід відмітити, що Україна вона має вигідне географічне положення, зручне транспортне сполучення і морські шляхи, достатню кількість працездатного населення, зайнятого в соціально-культурному сервісі та сфері туризму, наявну туристичну інфраструктуру в межах туристичної індустрії. Водночас обслуговування туристів відбувається за міжнародними стандартами, а рівні добробуту та розвитку господарства в країні дозволяють приймати як вітчизняних, так і іноземних гостей на належному рівні.

У зв'язку 3 наявністю туристично-ресурсного потенціалу соціальноекономічних розвиток туризму в Україні характеризується існуванням позитивних, так і негативних ефектів - зростання ВВП, податкових надходжень і надходжень іноземної валюти за рахунок розвитку туризму, зміни на ринку праці, погіршення екологічно-рекреаційного становища, продовольчі труднощі. На думку дослідників, позитивних факторів від розвитку туризму в нашій країні значно більше, ніж породжуваних ним проблем. 


\section{SOCIO-ECONOMIC AND MANAGEMENT CONCEPTS}

Туристична індустрії в Україні на сучасному етапі характеризується розвитком відповідних подій та зростанням більшості показників. Отже, в 2019 році в Україні функціонувало 4664 суб’єкта туристичної діяльності. До цієї цифри входять як юридичні, так і фізичні особи. Це туристичні агенти, туроператори, суб'єкти, що здійснюють екскурсійну діяльність та інші суб'єкти, що забезпечують функціонування соціально-культурного сервісу та туризму в країні. Зазначений показник на 34,4\% більше, ніж в 2017 році та майже на 9,0\%, ніж в попередньому 2018. 3 усіх суб'єктів туристичного бізнесу основну частину займають турагенти - 83,7\%. Частка туроператорів практично в 7 разів менше. Це пояснюється тим, що до них відносяться лише юридичні особи. Щодо тенденції зміни їх кількості протягом 2017-2019 р.p., то тут також можна відмітити щорічне зростання. Витрати суб'єктів туристичної діяльності на послуги сторонніх організацій, що використовуються при виробництві туристичного продукту в 2019 році становили 32404332,1 тис. грн. Це на 76,2\% більше, ніж в 2017 році та на 42,4\% порівняно з попереднім 2018 роком. Аналогічна тенденція спостерігалася 3 кількістю реалізованих туристичних путівок туроператорами і турагентами. Зростання за 2017-2019 р.р. склало 113,2\%. При цьому вартість їх також відповідно зростала. Кількість туроднів за реалізованими туристичними путівками зросла більше, ніж в 1,5 рази. Слід зазначити, що за аналізований період темпи зростання кількості реалізованих туристичних продуктів не надто відрізняються від темпів зростання їх вартості. Це свідчить про лояльну цінову політику вітчизняних туроператорів по відношенню до споживачів. Щорічне зростання вказаних показників говорить про невпинне зростання кількості туристів протягом аналізованого періоду, які обслуговувалися туроператорами та турагентами (без екскурсантів). Так, за два роки воно склало 220,5\%, що у натуральному виразі - становить 6187869 осіб. У відповідності до такого зростання туристів в Україні останнім часом виникає потреба у нарощуванні кількості колективних засобів їх розміщування та харчування. Щорічне зростання кількості таких та інших інфраструктурних об'єктів відбувалося помірними темпами. Наприклад, кількість колективних 
засобів розміщування туристів за 2017-2019 р.р. зросла на 29,6\% і в 2019 році їх в Україні було вже 5335 од. Основна частина 3 них - це готелі та аналогічні засоби розміщення (59,3\%), інше - це різноманітні оздоровчі заклади, табори праці та відпочинку, громадські засоби транспорту, конгрес-центри, облаштовані житлові місця для відпочинку, площадки для кемпінгу тощо (40,7\%). Кількість туристів, що припадає на один колективний засіб розміщення в 2019 році становила 1686 осіб, що в 2,5 рази більше, ніж в 2017 році. Тому і кількість місць у колективних засобах розміщення туристів збільшується. За неофіційними даними таке положення можна в повній мірі віднести і до індивідуальних закладів розміщення туристів.

Переважну частину споживачів туристичного продукту, обслугованих туроператорами та турагентами, складають туристи, що мандрують 3 метою, відпочинку та гарного проведення дозвілля. Їх питома вага в загальній кількості туристів перевищує 90\%. I це цілком логічно з огляду на той факт, що туризм по своїй сутності передбачає наявність у людини вільного часу, проведеного в мандрах із задоволенням, отримуючи фізичну користь та цікаві туристські враження. На відміну від відпочивально-розважального туризму інші цільові види туризму, як правило, викликані об’єктивною необхідністю у людини до поїздки, тому не носять масовий характер. Це лікувальний, діловий, навчальний, спеціалізований туризм та інші. Тому їх масова доля у загальній кількості туристів набагато менше. Наприклад, питома вага ділового туризму трохи більше 5\%, а спортивного - не перевищує і 1\%. Водночас слід зазначити, що за останні три роки кількість туристів, обслугованих туроператорами та турагентами України, по кожному напрямку туризму зросла. Соціальноекономічний розвиток туристичної галузі характеризують такі основні показники, як: кількість туристів, обслугованих туроператорами і турагентами України; кількість громадян України, які виїжджали за кордон, але не обслуговувались туроператорами та турагентами України; кількість іноземців, які відвідали Україну, але не обслуговувались турпідприємствами України; обсяги експорту-імпорту туристських послуг тощо. 
За 2012-2019 p.p. серед загальної кількості туристів, що обслуговувались туроператорами і турагенствами України, основну питому вагу займають виїзні туристи - 82,0\%. Найменша частина - в'їзні туристи (2,9\%). На внутрішніх туристів припадає відповідно $15,1 \%$. Ситуація з виїзним туризмом пояснюється декількома причинами. По-перше, більшість українців потребують туристських вражень, не пов'язаних з наявними туристичними ресурсами України. Певна частина достатньо добре вже ознайомлена 3 вітчизняними туристичними дестинаціями країни або зацікавлена мандрами та новими, екзотичними відчуттями. Водночас, цінова політика та політика якості розвинутих туристичних курортів інших країн має оптимальніше, ніж в Україні, співвідношення «ціна-якість». Слід також відмітити, що часто рівень вітчизняного соціально-культурного сервісу не влаштовує українців 3 високим або вище середнього рівнем доходу. За більшості цих причин і багато іноземців не бажають відвідувати українські курорти та знакові історичні пам'ятки. Крім того, економіко-політичні події 2014 року та відповідні кризові тенденції в межах країни значним чином вплинули на показник в’їзного та інших видів туризму. Далі, незважаючи на зазначені диспропорції в структурі загальної кількості туристів, тенденція до ії зростання має чітко позначений характер, за деяким виключенням. Тобто, молода індустрія туризму в Україні динамічно розвивається, але не такими швидкими темпами, як на деяких туристичних азіатських та європейських територіях. На думку авторів, наведена статистична інформація не зовсім відображує реальної картини та має ймовірність відхилення за рахунок показника внутрішнього туризму. Це можна пояснити тим, що даний вид туризму здійснюється в межах країни ії громадянами і переміщення туристів не фіксуються державними органами, на відміну від в’їзного та виїзного видів туризму. Але мандрівники при цьому продовжують вважатися туристами. Тобто, реальна кількість внутрішніх туристів та загальна їх кількість в Україні ймовірно більше, особливо сьогодні, в умовах всесвітньої пандемії вірусу COVID-19, коли багато кордонів до зарубіжних країн періодично зачиняються. Тенденція щодо кількості туристів, які не обслуговувались туроператорами та 
турагентами України, за 2012-2017 р.p. має аналогічний характер - зростання кількості виїзжаючих туристів (на 23,3\%) та зменшення в’їзних іноземних відвідувачів (на 38,2\%).

Слід зазначити, що найбільш всього за останні роки громадяни України відвідували Польщу, Росію, Угорщину, Молдову, Білорусь, Туреччину, Румунію, Словаччину, Сгипет, Німеччину, Італію, Арабські Емірати. Україну відвідали іноземні громадяни переважно Молдови, Білорусі, Росії, Польщі, Угорщини, Румунії, Словаччини, Туреччини, Ізраїлю, Німеччини та США.

Таким чином, соціально-економічні показники туристичної діяльності в Україні свідчать про різноспрямованість тенденцій в галузі туризму та наявність певних проблемних аспектів. Покращення перспектив України на зовнішньому ринку туризму автори вбачають в наявності трьох складових на внутрішньому ефективного сприяння держави розвитку якісного українського туризму; пред'явлення споживачем об'єктивної вимоги щодо отримання якісної туристської послуги; створенням турвиробником комплексного, креативного, відповідного своїй вартості туристичного продукту. 


\section{5 Металургійна галузь України на світовому ринку: проблеми та пріоритети}

Останнім часом котирування практично усього металу, має виражений різноспрямований характер. У високому ступені схильний до спекулятивних настроїв ринок сталі завжди відрізнявся помітною волатильністю, але тепер зміни цін на нім набувають характеру важкопрогнозованих різких обвалень $\mathrm{i}$ моментальних стрибків вгору.

Одним з основних чинників, що продовжують потужно впливати на рівень світових цін, залишається виробництво сталевого прокату, що збільшується, в країнах Азії і передусім в Китаї (рис. 1). За даними World Steel Association, до якого включено 64 країни і припадало приблизно 99\% всього виробництва сталі в 2019 р., за січень 2021 року Китай виробив 90,2 млн тонн сталі, Індія - 10 млн тонн сталі, Японія - 7,9 млн тонн сталі, в той час, як США виробили 6,9 млн тонн, Росія - 6,7 млн тонн сталі.

За даними World Steel Association [124], в перший місяць 2021 року на азіатський регіон припало близько 119 млн тонн зробленої сталі, що складає 73,05\% відносно до загальносвітового об'єму в 162,9 млн тонн. Безперечним лідером у даній сфері є Китай, його частка відносно до світового ринку сталі у січні 2021 року склала більш ніж половину всього світового випуску, а саме $55,37 \%$.

На графіку (рис.1) порівнюється випуск нержавіючої сталі ПівденноСхідної Азії (основні виробники Китай, Індія та Японія) та СС (основні виробники Іспанія, Італія та Франція), з нього видно, що азіатський регіон випереджає ЄС більше ніж в 10 разів. 


\section{SOCIO-ECONOMIC AND MANAGEMENT CONCEPTS}

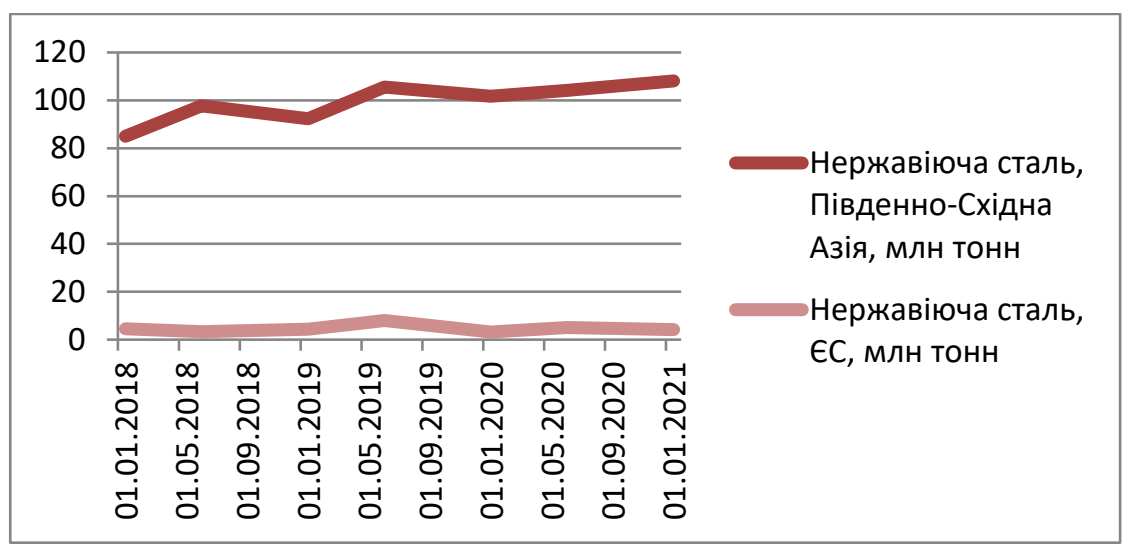

Рис. 1. Порівняльна характеристика виробництва нержавіючої сталі [124]

Вітчизняна металургія, 3 одного боку, удержується однією 3 основних галузей промислової діяльності, та забезпечує до 16\% загального обсягу реалізованої промислової продукції, 1/5 від товарного експорту та більш 10 млрд доларів виручки експорту, та 200 тисяч робочих місць та близько 10\% загальної середньооблікової кількості штатних працівників у промисловому виробництві. Виходячи 3 цього можна сказати, що металургія стратегічно важлива для подальшого розвитку української економіки. Але є і свої недоліки: дана сфера різниться недостатнім рівнем екологічності виробництва - приблизно 1/3 викидів шкідливих речовин, які згубно впливають на навколишнє середовище, приходиться на металургійну діяльність, а також характеризується від'ємною, або зовсім низькою рентабельністю операційною діяльністю підприємств, а це в свою чергу не сприяє «влиттю» прямих іноземних інвестицій. Необхідним є підштовхнути металургію до кардинальних змін щодо підвищення ефективності виробництва.

Основною тенденцією розвитку української металургії за останні роки є безперервне зниження обсягу виробництва металургійної продукції.

Географічна структура зовнішньої торгівлі товарами за перше півріччя 2020 p. характеризується лідируючими позиціями $\mathrm{CC}$, але його частка знизилась 3 42,3\% аналогічного періоду 2019 р. до 40,2\% (табл. 1). 
Таблиця 1.

Географічна структура зовнішньої торгівлі України, \% [125]

\begin{tabular}{|l|l|l|l|l|l|l|}
\hline Країни & \multicolumn{4}{l|}{ Перше півріччя 2019 р. } & \multicolumn{4}{l|}{ Перше півріччя 2020 p. } \\
\hline & Товарообіг & Експорт & Імпорт & Товарообіг & Експорт & Імпорт \\
\hline СС & 42,31 & 42,01 & 42,58 & 40,23 & 37,22 & 43,07 \\
\hline СНД & 17,67 & 13,32 & 21,52 & 14,19 & 12,33 & 15,94 \\
\hline Інші країни & 40,02 & 44,67 & 35,90 & 45,58 & 50,45 & 40,99 \\
\hline
\end{tabular}

Ці зміни здійснились через падіння товарообігу на 13,9 \%, експорт до СС більш скоротився, порівняно $з$ імпортом (рис. 2). За перше півріччя 2020 р. зменшення експорту склало 17\% (1,75 млрд дол. США), водночас відбулося скорочення імпорту на 11,2\% (1,33 млрд дол. США).

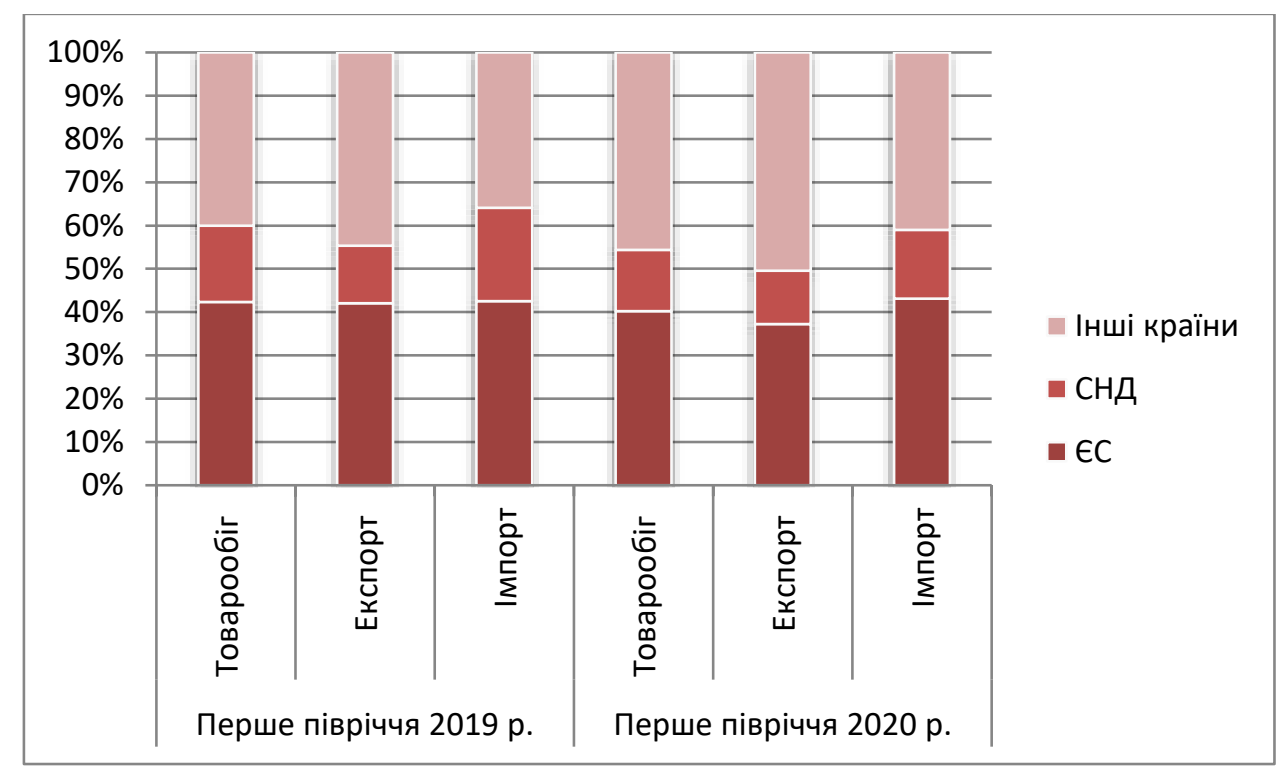

Рис. 2. . Географічна структура зовнішньої торгівлі України, \%

У 2019 році Україна наростила експорт до Китаю на 63,3\% (табл. 2), що склало в грошовому еквіваленті 3,6 млрд дол., до Єгипту на 44,8\% (2,3 млрд дол.), до Нідерландів (1,8 млрд дол.), до Німеччини (2,4 млрд дол.) та до Туреччини (2,6 млрд дол.) (рис. 3). 3 країнами $С С$ експорт зріс на 3\% і становив 20,8 млрд дол.. 
Таблиця 2.

Зовнішня торгівля товарами у 2019 році [125]

\begin{tabular}{|l|l|l|l|l|l|}
\hline Експорт & сума & приріст & Імпорт & сума & приріст \\
\hline Китай & 3,6 млрд дол & $+63,3 \%$ & Китай & 9,2 млрд дол & $+20,9 \%$ \\
\hline Польща & 3,3 млрд дол & $+1,2 \%$ & РФ & 7 млрд дол & $-13,6 \%$ \\
\hline РФ & 3,2 млрд дол & $-11,2 \%$ & Німеччина & 6 млрд дол & $+0,1 \%$ \\
\hline Туреччина & 2,6 млрд дол & $+11,3 \%$ & Польща & 4,1 млрд дол & $+12,6 \%$ \\
\hline Італія & 2,4 млрд дол & $-8 \%$ & Білорусь & 3,8 млрд дол & $-0,9 \%$ \\
\hline Німеччина & 2,4 млрд дол & $+7,9$ & США & 3,3 млрд дол & $+10,9 \%$ \\
\hline Сгипет & 2,3 млрд дол & $+44,8 \%$ & Туреччина & 2,4 млрд дол & $+37,4 \%$ \\
\hline Індія & 2 млрд дол & $-7 \%$ & Італія & 2,1 млрд дол & $+2,1 \%$ \\
\hline Нідерланди & 1,8 млрд дол & $+15,3 \%$ & Франція & 1,7 млрд дол & $+11,6 \%$ \\
\hline Угорщина & 1,6 млрд дол & $-5,1 \%$ & Швейцарія & 1,6 млрд дол & $-2,5 \%$ \\
\hline
\end{tabular}

$12 \%$ - саме на стільки відбулося просідання торгівлі металами та виробами 3 них, однак вона переважала у експорті (10,3 млрд дол.). Відбулося підвищення на 12,2\% і досягло 4,99 млрд експорту мінерального паливу, нафти та нафтопродуктів. Експортування українського обладнання, машин, механізмів та електротехнічного обладнання впало на 4,1\%.

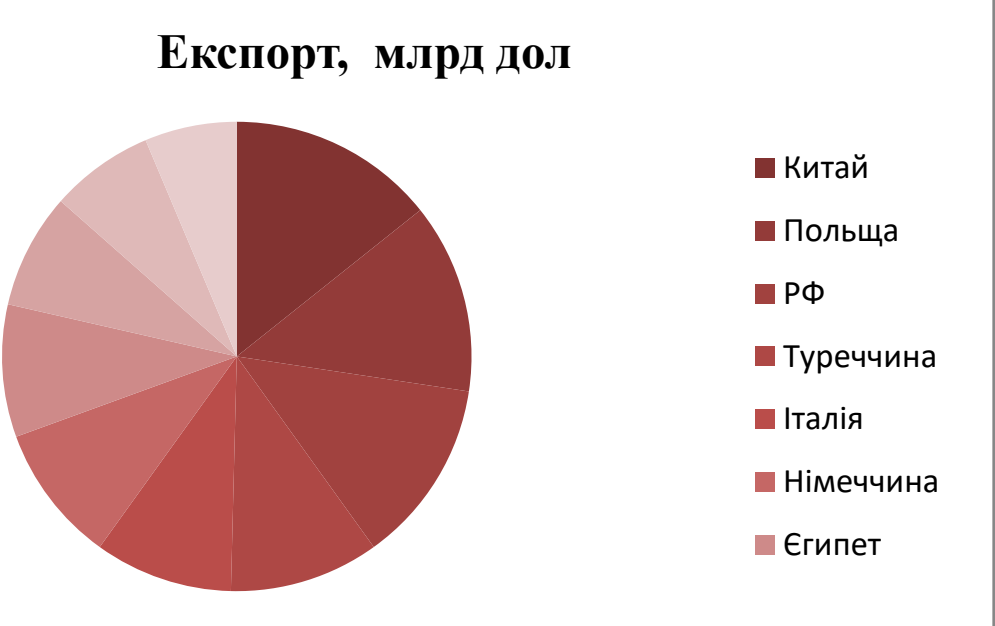

Рис. 3. Експорт товарів у 2019 році 


\section{SOCIO-ECONOMIC AND MANAGEMENT CONCEPTS}

У 2019 році найбільшу кількість товарів Україні імпортовано з Китаю (9,2 млрд), до того ж імпорт виріс майже на 21 \% , з Російською Федерацією - 7 млрд, імпорт зменшився на $13,6 \%$ (рис. 4).

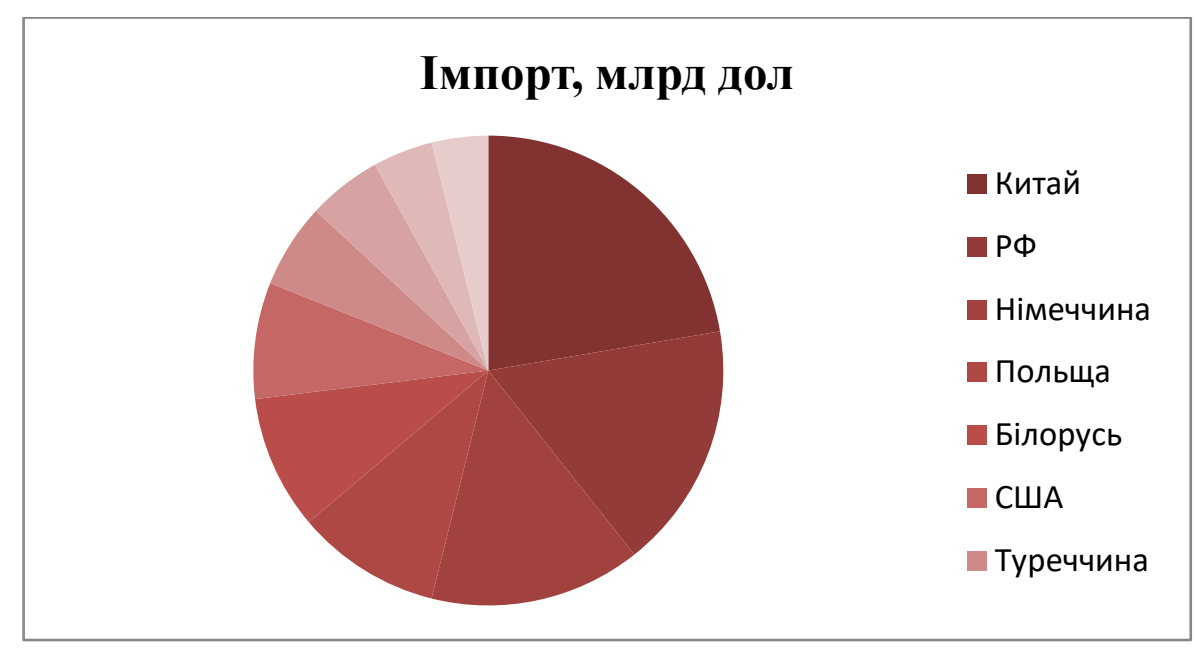

Рис. 4. Імпорт товарів у 2019 році

Основна проблема української металопродукції на світових металургійних ринках полягає у дефіциті попиту на вітчизняну продукцію. Розвинуті крани переважно закупають напівфабрикати для подальшої переробки у більш якісні вироби. Уряди кількох іноземних держав оповістили щодо планів збільшення виробництва сталі на наступні декілька років. Іран має плани щодо нарощення виробництва сталі до 2025 р. в чотири рази обсягом до 55 млн т, експортуватися буде 10 млн т.. Уряд Індії має намір збільшити сталеливарне виробництво, за допомогою чого у планах нарощення виробничих потужностей до 2025 року до 300 млн. т..

Недостатній рівень енергозбереження та зміни на ринку металургійної продукції накладають на галузь необхідність підіймати ціни, що робить і без того не дуже конкурентну продукцію вітчизняних підприємств, ще менш привабливою.

Щороку вітчизняною металургією споживається 6-7- млрд. кубічних метрів природного газу, в той час як багато світових виробників відступили від використання цим недешевим енергоносієм, впроваджуючи у виробництво 
технологію пиловугільного палива. Окрім цього, в Україні коксу на тону виплавки чавуну йде 500-550 кг, в той час як середня норма в світі 270-300 кг.

На сьогоднішній день спостерігається стагнація світового металургійного ринку, значні обсяги профіциту вітчизняних металів, відслідковується загальна негативна динаміка галузевої діяльності і відсталість ефективності виробництва порівняно 3 зарубіжними аналогами. Майбутній розвиток металургійної промисловості України треба будувати в таких напрямках:

- пріоритетний розвиток внутрішнього металургійного ринку, забезпечуючи цим стабільний збут виробленої продукції та зменшення залежності від коливань світової кон'юнктури;

- інтенсифікація провадження сучасних інноваційних розробок, створюючи нові техніко-технологічні металургійні рішення, які забезпечать внутрішній попит вітчизняних науково-технічних й інноваційних розробок, що спричинить зменшення собівартості продукції за рахунок зниження ресурсоємності та енергоємності всіх етапів виробництва, збільшення екологічної спрямованості виробництва, осучаснення номенклатури металургійної продукції, що випускається;

- підготовка спеціалістів сьогодення, які матимуть більш високий рівень цифрової культури, глибоке поєднання i всебічне застосування сучасних діджитал-технологій у праці та готові до постійного навчання і набуття нових навичок;

- державно-приватне партнерство, що посприяє визначенню стратегій розвитку металургії;

- поліпшення інституційних умов партнерства підприємств щодо співробітництва $з$ наукою й інвесторами;

- пріоритетні сфери щодо фінансування й держпідтримки для наукових, технічних, соціальних і економічних змін на шляху становлення вітчизняної металургії майбутнього.

Головними завданнями для осучаснення металургійного виробництва: зниження ресурсоємності та енергоємності, усунення викидів небезпечних 
речовин, покращення умов праці (підвищити соціальну захищеність працівників i знизити рівень травматизму на виробництві), переорієнтування до індивідуальних потреб й вимог споживачів задля того, щоб зайняти нові ринкові ніші та закріпитись на традиційних позиціях.

Щоб досягти цих результатів, необхідно технічно переозброїти виробництво у межах вже винайдених технологій: безповоротно вивести мартенівські печі з заміною на конвертори та електропечі, будувати нові; капітально відремонтувати доменні печі тощо. А також поєднати з сучаснішими «смарт» технологіями, наприклад, старт-пристроями, створити єдиний інформаційний управлінський простір, використовувати предикативну аналітику та ін.. 


\section{6 Соціально-економічні проблеми розвитку освітніх цифрових технологій}

Цифрові освітні технології радикально змінюють викладання дисциплін і сприяють з'єднанню теоретичного матеріалу та практичного. Сьогодні використання цифрових технологій в освітньому процесі - необхідна умова для підвищення результативності освітнього процесу.

Впровадження цифрових технологій, що забезпечують можливість поліпшення освіти, дозволяє удосконалювати навчальну роботу через інтеграцію теорії і практики. Новизна дослідницького підходу полягає у визначенні цифрових освітніх технологій, що використовуються у викладанні дисциплін.

Цифровизация освіти - це один із сучасних процесів, який зачіпає всі предметні області і йде швидкими темпами. Інтеграція цифрових технологій 3 предметними областями фахових дисциплін стає неминучим в сучасному освітньому процесі.

Досвід показує, що підготовка фахівців менеджерів неможлива без цифрових технологій. Інтегруючи предметні області викладач отримує можливість застосування цифрових освітніх технологій у викладанні дисциплін, які формують професійні компетенції майбутніх керівників. Сьогодні фахівці в галузі освіти сперечаються про те, які нові дисципліни включати в навчальну програму, а що виключити. Зрозуміло, що це глухий кут, причому такий підхід посилюється тією обставиною, що знання старіють дуже швидко. Зараз, поки студент навчається у вищому навчальному закладі і засвоює базові знання, вся елементна база істотно змінюється на іншу і всі знання, яким він навчався, стають неактуальними. Швидкість поновлення прикладної інформації досягає межі. Завдання освіти сьогодні навчити таких знань і навичок, які будуть затребувані через 5-10 років, тому що, коли буде закінчено процес навчання у ВНЗ, ці знання і навички повинні бути актуальними.

Інтенсивний розвиток цифрових технологій приводе сформовану систему освіти до необхідності постійного удосконалення і впровадження інновацій в освітній процес. Удосконалення процесу освіти шляхом впровадження цифрових 


\section{SOCIO-ECONOMIC AND MANAGEMENT CONCEPTS}

технологій передбачає використання найбільш компетентних викладачів, які постійно посилюють контент своїх лекцій, додатково організовують перегляд в процесі навчання відеоматеріалів, проводять тренінги 3 даної тематики, а також підсилюють практичні заняття включенням цифрових технологій доповненої реальності.

Перегляд відеолекцій хорошого викладача - це дуже важлива складова освітнього процесу, яка забезпечує більш високий якісний рівень освоєння навчального матеріалу. З'являється можливість повторного прослуховування складних тем, гнучкість в обговоренні дискусійних питань і більш ефективного використання часу навчання.

Однак ніякі дистанційні технології не зможуть замінити живе спілкування викладача і студента.

Відеоціфрові шаблони не замінять творчого підходу до вивчення матеріалів, тому можуть тільки доповнювати факторами змістовний контент. Також цифрові технології виключають самоконтроль. Відсутність зворотного зв'язку завжди зменшує ефективність освітнього процесу.

Формування навичок нестандартного рішення задачі, можливості знаходження правильного виходу 3 критичної ситуації - це головні драйвери сучасної підготовки фахівців. Формування осмисленої волі, сумлінності не входить в стандартні освітні послуги, посилені цифровізацією.

Для цього необхідно ефективні комунікації викладача і студентів, причому спілкування не тільки на лекціях та практичних заняттях. Це також вимагає вміння викладача взаємодіяти з аудиторією, надавати належну спрямованість спілкування і формувати у студентів відповідні навички [126, с. 191; 127$].$

Однією з основних причин застосування цифрових освітніх технологій в освітньому процесі є підготовка конкурентоспроможних фахівців для управління бізнесом, регіоном, державою.

Цифровізація навчального процесу має на меті підвищити конкурентоспроможність і ефективність випускників вищої школи за рахунок застосування проривних інформаційних технологій. Причому, включення в 


\section{SOCIO-ECONOMIC AND MANAGEMENT CONCEPTS}

навчальний процес інтеграцію систем Інтернету речей, технологій обробки великих даних, розподіленого цифрового моделювання і штучного інтелекту забезпечує формування необхідних навичок майбутнього керівника. При такому підході цифровізація освіти займає провідне місце і сприяє підготовці грамотних фахівців.

В умовах дистанційної форми навчання часто використовуються електронні підручники, які представляють собою комплексну програму. У таких навчальних посібниках вивчення матеріалу включає домашні завдання і практичні роботи, а також $\epsilon$ можливість переглянути відеоматеріали, які створюють доповнену реальність при вивченні нового матеріалу [128, с. 135].

Досвід використання електронних навчальних програм і підручників показує суттєве підвищення якості засвоєння навчального матеріалу. Це пов'язано з тим, що студенти в наочній і доступній формі швидше і краще розуміють суть нового матеріалу [129, с. 5].

Електронні підручники та навчальні програми мають ряд переваг, пов'язаних 3 новими інформаційними технологіями:

- використання ресурсів відео-конференцій дозволяє обробляти числову i текстову інформацію повніше;

- спрощення процесу взаємодії 3 цифровими технологіями дозволяє сформувати об'єктно-орієнтоване мислення;

- цифровізація реалізує сучасні технології інформаційного пошуку в написанні випускних робіт.

При використанні електронних підручників, викладач може виключити багато операцій і отримує можливість діагностувати знання студентів. Досвід показує, що динаміка навчання і розвитку практичних навичок, істотно збільшується за рахунок застосування цифрових технологій. Цифрові технології можуть бути: імітаційні та моделюючі, що демонструють; навчальні; тестуючи та контролюючі.

Особливу роль в підготовці фахівців відіграють імітаційні тренажери, які допомагають познайомитися 3 професійними компетенціями та набути навички. Імітаційний тренажер моделює конкретну ситуацію i дозволяє проводити управлінські поєдинки. Такі умови змушують студентів креативно підходити до 
ситуації, розробляти нестандартні рішення, пропонувати нові шляхи розвитку комунікацій. При вирішенні проміжної управлінської задачі можливий перехід на вирішення проблеми за різними схемами розвитку ситуації.

Все це дозволяє підготувати фахівців високого рівня, підвищити їх професійну мобільність, компетентність, яка гарантуватиме їм конкурентоспроможність на ринку праці.

3 упевненістю можна сказати, що майбутнє цифровізації освітнього процесу нерозривно пов'язане 3 інформаційними технологіями, тому викладання всіх фахових дисциплін має бути направлено на інтеграцію 3 предметною областю підготовки. Через інформаційні технології відбувається знайомство 3 професійними компетенціями і подальшим відпрацюванням професійних навичок.

В ході дослідження цифровізації освітнього процесу можна зробити наступні висновки.

1. В результаті різко зростаючого обсягу інформації в процесі навчання формується середовище поетапного оволодіння дисциплінами;

2. Формується творчий підхід у студентів до вирішення практичних завдань, що значно змінює якість навчання.

3. Впровадження цифрових технологій призводить до розвитку необхідних навичок в результаті активних дій студента.

4. Значно зростає мотивація процесу навчання.

5. Суттєво підвищується якість знань. 


\section{7 Пандемія COVID-19 vs туристична індустрія України: криза чи гранд шанс?}

Туризм є однією 3 найбільш високодохідних галузей господарства, адже туристична індустрія стимулює розвиток практично всіх галузей національної економіки, а саме: промисловості, торгівлі, будівництва, транспорту, сільського господарства, побутового обслуговування та багатьох інших, виступаючи потужним каталізатором соціально-економічного розвитку країни.

Вагомість внеску туристичної індустрії до розвитку національної економіки визначається традиційним і універсальним методом через аналіз: частки галузі у ВВП країни; частки населення країни, зайнятого у галузі.

Щодо України, то, судячи $з$ даних рис. 1-2, на жаль, вагомість туристичної індустрії у національному господарстві має тенденцію до зниження.

Внесок туристичної індустрії до ВВП України, \%

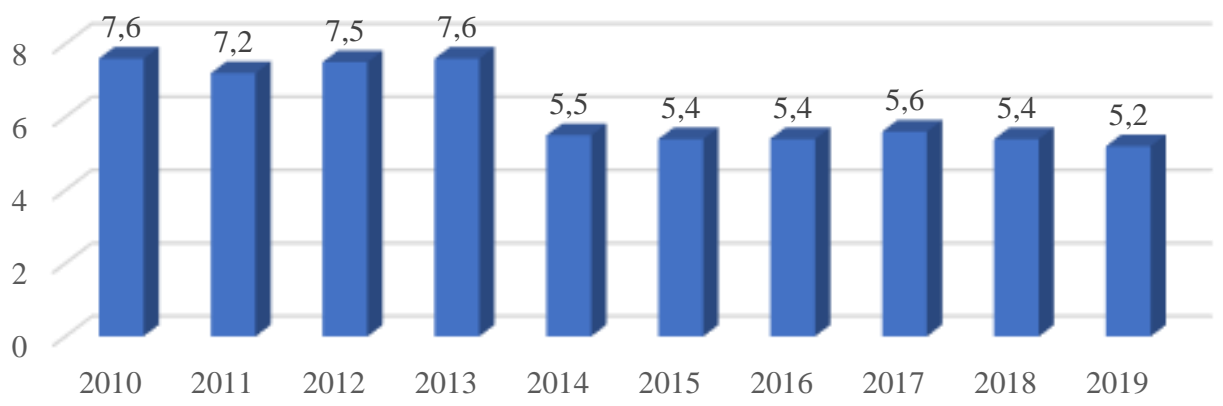

\section{Рисунок 1. Частка туристичної індустрії у ВВП України у 2010-2019 рр.} Джерело: побудовано авторами за даними [131] 
Внесок туристичної індустрії до зайнятості населення України, \%

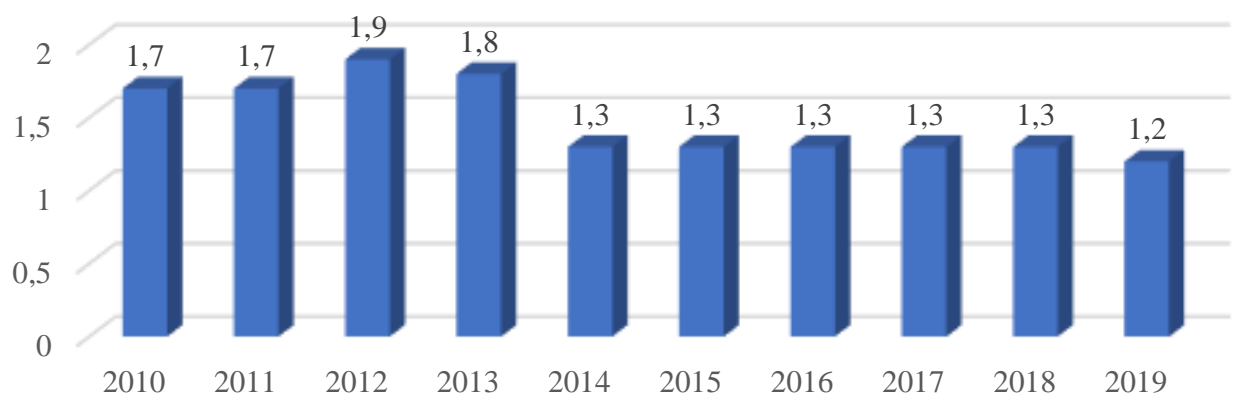

Рисунок 2. Частка населення України, зайнятого у туристичній індустрії, у 2010-2019 рр.

Джерело: побудовано авторами за даними [132]

Особливо прикрою ситуація, що склалася в туристичній індустрії України, виглядає 3 огляду на величезний туристичний потенціал країни: сприятливі кліматичні умови, наявність як морських, так і горнолижних курортів, річок, цілющих джерел, природних та історичних пам’яток, унікальних народних (в тому числі гастро-) традицій і багатьох інших об’єктивно сприятливих факторів для розвитку туристичної галузі. Але дані Державної служби статистики України невтішні: вітчизняні суб'єкти туристичного бізнесу програли боротьбу за клієнтуру зарубіжним гравцям туристичного ринку (рис. 3-5).

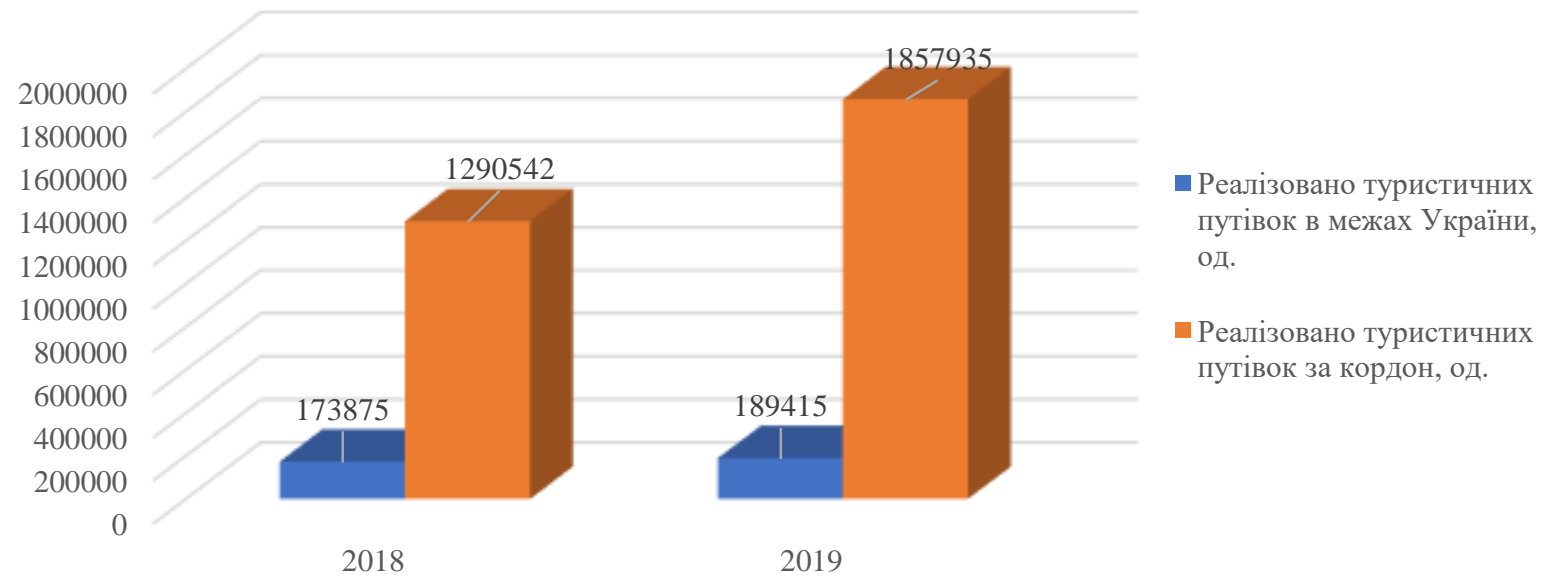

Рисунок 3. Кількість реалізованих туристичних путівок в Україні у 2018-2019 pp.

Джерело: побудовано авторами за даними [133] 


\section{SOCIO-ECONOMIC AND MANAGEMENT CONCEPTS}

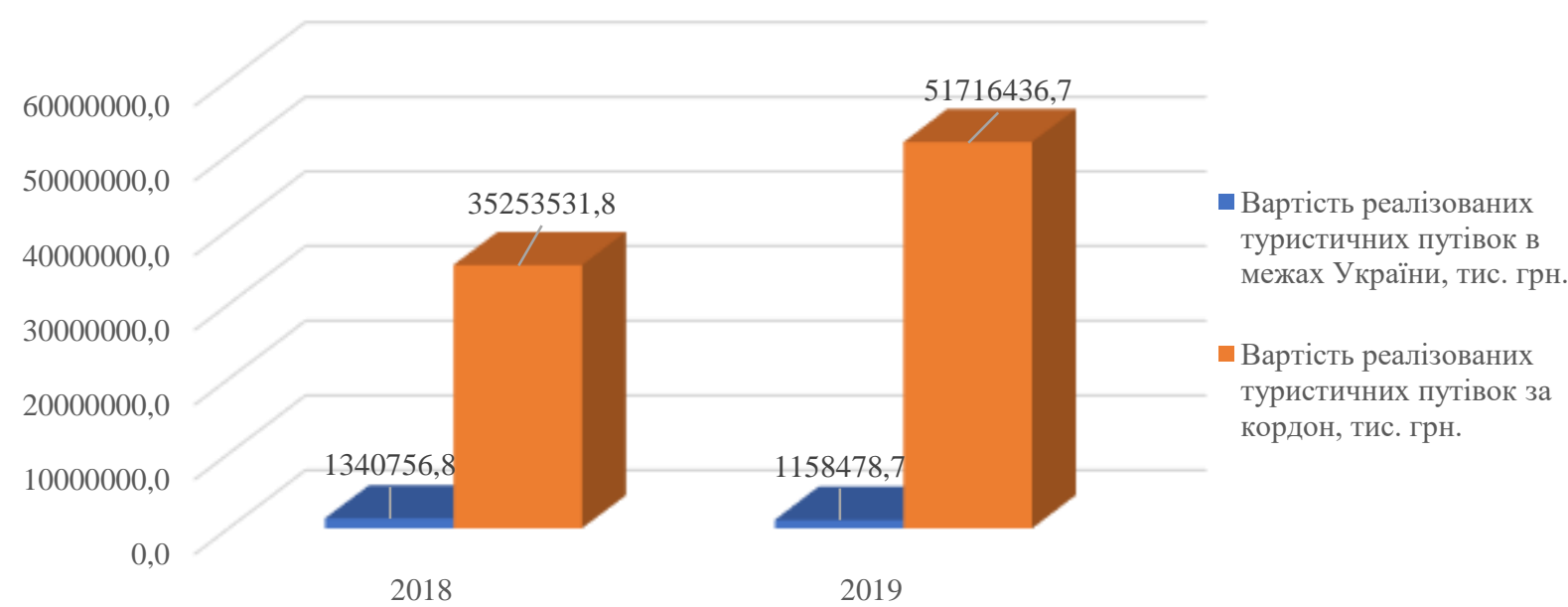

Рисунок 4. Вартість реалізованих туристичних путівок в Україні у 20182019 pp.

Джерело: побудовано авторами за даними [133]

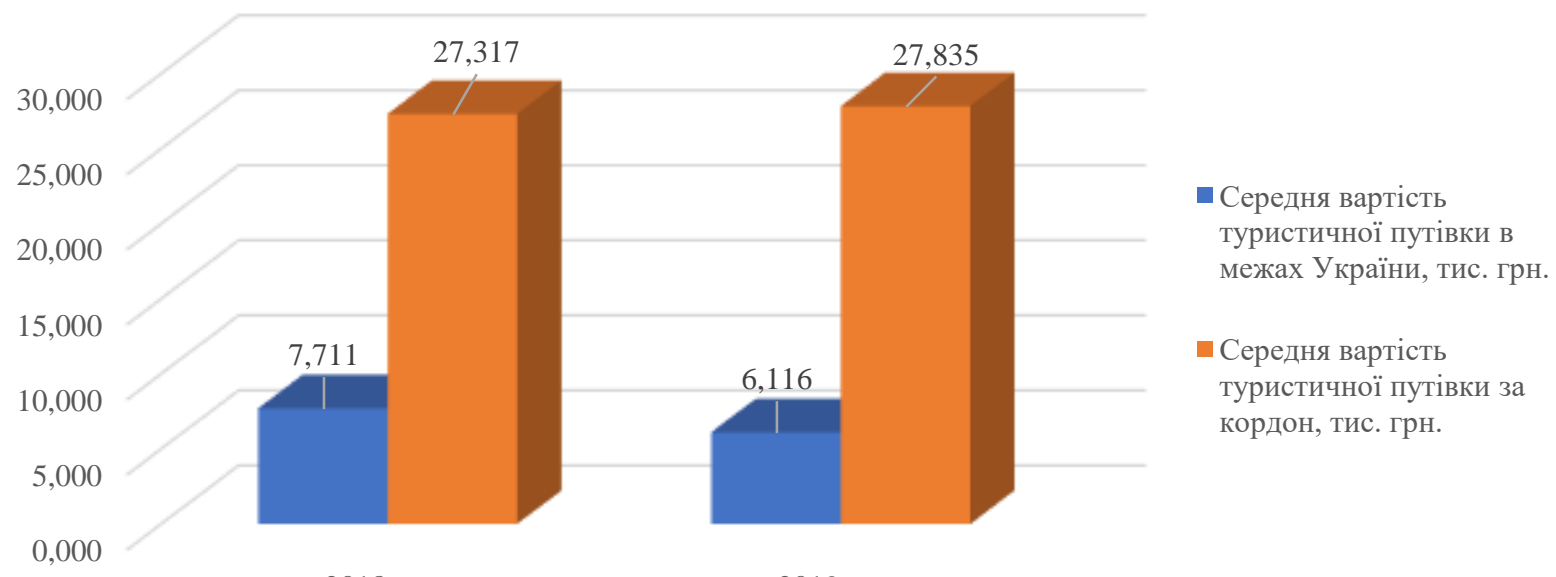

2019

\section{Рисунок 5. Середня вартість реалізованої туристичної путівки в}

\section{Україні у 2018-2019 pp.}

Джерело: побудовано авторами за даними [133]

Але 2020 рік, ознаменований початком пандемії COVID-19, змінив все: одна за одною «закривалися» країни, клієнти, що робили ранні бронювання путівок за кордон масово зіткнулися з неможливістю повернути кошти та були вимушені очікувати можливостей реалізувати придбану путівку або обміняти іiі на іншу. До того ж клієнти, які врешті-решт змогли дістатися на відпочинок на закордонні курорти зіткнулися з безліччю обмежень: закритими залишилися багато відомих туристичних об'єктів, а в готелях певна частина інфраструктури не працювала у 
зв’язку з карантинними обмеженнями. У додаток - деякі популярні туристичні країни відмовилися визнавати ПЦР-тести, які надавалися громадянами України по прильоту, та зобов'язали всіх до проходження в аеропорту нового тестування на наявність COVID-вірусу. При цьому до отримання результатів тестування громадяни мали знаходитися на самоізоляції у кімнаті готелю, що: у разі негативного тесту - скорочувало час відпочинку; у разі позитивного тесту фактично призводило до анулювання путівки. Всі ці незручності та ризики створили сприятливу платформу для того, щоб багато внутрішніх клієнтів у туристичному сезоні 2020 року віддали перевагу саме вітчизняним курортам.

Вітчизняні готельєри з ентузіазмом сприйняли підвищення попиту на свої послуги, що одразу отримало відображення у підвищенні цін на відпочинок. Це скорегувало попит у напрямку зменшення бюджетного сегменту та збільшення VIP-сегменту. Тим не менш, як зазначається в повідомленні прес-служби «Vodafone Україна», у 2020 році, судячи зі збільшення Інтернет-трафіку i кількості 4G-користувачів, внутрішній туризм на морських курортах Одеської, Миколаївської та Херсонської областей виріс на 30\% порівняно з аналогічним відрізком часу 2019 року [134]. Така ситуація видається цілком закономірною.

Але що ж очікувати далі? Піковий попит на внутрішній туризм у 2020 році - для багатьох це вимушена ситуація, особливо для найбільш платоспроможного сегменту клієнтури. Пандемія не може тривати вічно й обов'язково ситуація стабілізується та прийме звичний уклад. Тоді з дуже високою ймовірністю буде спостерігатися сплеск продажів туристичних путівок за кордон: повернуться до звичних курортів клієнти, для яких відпочинок за кордоном став доброю традицією; віддадуть перевагу зарубіжним курортам і клієнти «середнього» сегменту, котрі в інші часи чергували відпочинок за кордоном з відпочинком в Україні. Якщо щодо першої групи клієнтів прогноз не викликає особливих сумнівів, то поштовхом для прийняття відповідного рішення другою групою клієнтів буде не «ностальгія», а розчарування співвідношенням «ціна - якість» на вітчизняних курортах. 
Аналізуючи пропозиції готельєрів у 2020 році складається враження, що українські підприємці вирішили використати пандемічні обмеження 3 максимальною вигодою для себе: вартість путівок на курорти Азовського моря та Чорного моря подекуди ні в чому не поступалася та навіть перевищувала вартість аналогічних за тривалістю відпочинку путівок у 5-тизіркові готелі Туреччини та Єгипту. Але ж загальновідомим є факт, що «левову частку» закордонних путівок складає вартість авіаперельоту. Що ж тоді складає основу калькуляції собівартості та ціни вказаних туристичних путівок в Україні? Така цінова політика незмінно призведе до того, що клієнти почнуть почуватися обманутими, а вітчизняні курорти почнуть викликати у них негативні асоціації. А ми знаємо, що клієнти не повертаються туди, де, як гадають, їх обманули.

Тобто стратегія моментального заробітку може у майбутньому призвести до суттєвих втрат клієнтської бази та, як наслідок, - прибутку. Українські суб’єкти туристичної індустрії досі не прийшли до розуміння того, що найсуттєвіша втрата - репутаційна. Отже, найбільш вірним рішенням в умовах вимушеного підвищеного внутрішнього попиту на туристичні послуги має стати інвестування в покращення якості туристичної інфраструктури та сервісу. 


\section{8 Фінансові технології: потенціал та ризики використання в умовах цифровізації економіки}

Цифровізація економіки в сучасних умовах розглядається як ключовий чинник, що забезпечує розвиток в усіх сферах соціально-економічної діяльності як в усьому світі, так і в Україні. У галузі фінансових технологій на сучасному етапі відбуваються радикальні зміни, пов'язані 3 підвищенням рівня автоматизації, відкритості та орієнтованості на споживача. Значення даного інноваційного сектору вельми велике, оскільки глобальне впровадження фінансових технологій щорічно зростає на 15-20\%. Крім того в умовах поширення коронавірусної інфекції, карантину та вимушеної ізоляції актуальність використання цифрових технологій у фінансовій сфері в усьому світі стала підвищуватися. Стрімкий прогрес цифровізації в сфері фінансових технологій приводе до трансформації фінансово-економічної сфери, що відкриває широкий спектр можливостей і одночасно створює потенційні ризики.

Фінансові технології або фінтех (англ. мовою від «financial technology», скорочене «FinTech») являють собою порівняно нову галузь не тільки в Україні, але і у всьому світі. Фінансові технології являють собою синтез цифрових технологій та інновацій у фінансовій сфері, що використовуються для надання, розширення і розповсюдження фінансових послуг технологічними компаніями [135].

На сучасному етапі фінтех розглядають як екосистему, яка поєднує всіх учасників фінансового ринку, зокрема, фінтех-стартапи, регуляторів, банки, міжнародні платіжні системи, асоціації банкірів та фінансистів, інкубаторів, акселераторів, постачальників [136]. Отже, фінтех являє собою складну систему, що об’єднує сектори нових технологій i фінансових послуг, стартапи та відповідну інфраструктуру. 


\section{SOCIO-ECONOMIC AND MANAGEMENT CONCEPTS}

Фінтех відкриває величезні можливості для всіх суб’єктів фінансової сфери. Безумовно, фінтех мають незаперечні конкурентні переваги в умовах глобальної цифровізації. До числа таких переваг можна віднести [137, с. 795; 138, с. 206]:

1) гнучкість процесу з надання послуг, що відрізняються персоніфікованим підходом, доступністю, прозорістю, злагодженістю і рентабельністю. Фінансові технології дозволяють видавати кредити, продавати страхові поліси і товари, проводити будь-які розрахунки безперервно на високих швидкостях в будь-який час. Крім того, програмні продукти працюють швидше, ніж люди, вони і ще працюють без вихідних, свят і відпусток, 24 години на добу;

2) забезпечують клієнтам зниження витрат. Зниження рівня витрат на сучасному етапі розвитку пов'язано з переходом на електронну взаємодію між усіма учасниками ринку, що веде до зниження сукупної вартості фінансових послуг;

3) відкривають малим і середнім підприємствам шлях до нових механізмів залучення фінансування безпосередньо від інвесторів, за допомогою таких інструментів, як краудфандинг й краудлендинг;

4) сприяють розвитку ключових інформаційних послуг, які дозволяють інвесторам оцінити ризики своїх інвестицій. У той же час вони дозволяють клієнтам отримувати доступ до інших допоміжних послуг, наприклад, інвестиційного консультування;

5) активно використовують соціальні мережі для систематизації і контролю за споживчою та фінансовою поведінкою клієнта. Тому вони більш мобільні, більш чутливі до фінансових потреб клієнтів, але водночас і більш впливові на нього;

6) сприяють зростанню фінансової інклюзії та розширює доступ до фінансових послуг, використовуючи технологічні досягнення. Надаючи фінансові послуги вразливим групам, фінтех сприяє не тільки інклюзивному зростанню, а й економічної стійкості бідних верств населення в періоди економічних потрясінь. 


\section{SOCIO-ECONOMIC AND MANAGEMENT CONCEPTS}

Аналіз та вивчення наукової літератури свідчить, що дослідники, розкриваючи позитивний вплив фінансових технологій на фінансову-економічну сферу відзначають зростання конкуренції на ньому, консолідацію інформаційних технологій фінансовими організаціями для диверсифікації свого бізнесу, зменшення інформаційної асиметрії та підвищення ефективності ціноутворення, розширення набору фінансових послуг та кола потенційних клієнтів [139, с. 71]

Отже, фінансові технології є одним з основних інструментів підвищення прозорості бізнесу та економіки країни в цілому, сприяє підвищенню рівня життя населення і фінансової підтримки бізнесу.

Незважаючи на те, що фінтех має значний потенціал як для розвитку фінансової сфери, так й для економіки в цілому, він сприяє появі певних потенційних ризиків, які впливають на ефективність функціонування фінансової системи. До таких ризиків належать [140, с. 64; 141]:

- ринковий ризик, що передбачає негативні наслідки від істотної зміни ринкової кон'юнктури. Цей вид ризику пов'язаний не стільки 3 самим застосуванням технологій для здійснення фінансових операцій, скільки 3 вкладенням коштів у фінансові технології, які є різновидом співінвестування (ICO, карудсорсинг, краудфандинг). Застосування фінансових технологій для співінвестування істотно підвищує ризики здійснення відповідної діяльності, оскільки пов’язано з ще більшою віртуалізацією об’єкта вкладень;

- кібер-ризик, що виникає внаслідок специфіки середовища фінансових технологій. Джерело кібер-ризику може виходити як від самої організації (внутрішня загроза може виходити від співробітників, підрядників організації), так і розташовуватися за їі межами (кібер-злочинці, партнери-постачальники). Також не рідкісні ситуації умисних дій хакера або їх групи, що здійснює атаку 3 метою зараження інформаційних систем. Однак вони також можуть бути ненавмисними, наприклад, помилка користувача або системного адміністратора, яка робить систему тимчасово недоступною; 
-технологічний ризик, що передбачає порушення безперебійності надання послуг внаслідок збоїв чи помилок у діяльності сервісу. Логічним наслідком застосування будь-яких віддалених сервісів $є$ вироблення у клієнта звички їх використання. Отже, в разі несподіваного припинення можливості здійснення операції із застосуванням звичної технології для клієнта неминуче наступають негативні наслідки, в тому числі матеріального характеру;

- юридичний ризик, що стосуються недостатності захисту прав споживачів. Ризики в сфері захисту прав і законних інтересів користувачів - ймовірність настання несприятливих наслідків у зв'язку з неможливістю або з суттєвим ускладненням захисту прав користувачів послуг, що надаються з використанням фінансових технологій. Ці ризики зумовлені переважно віддаленим характером надання послуг, з використання фінансових технологій;

- соціальний ризик, тобто ризик пов'язаний зі зниженням числа робочих місць за рахунок використання технологій штучного інтелекту. Відбувається істотний вплив на трансформацію ринку праці. По-перше, створення для суспільства нових послуг шляхом автоматизації /роботизації існуючих процесів призводить до скорочення персоналу, який виконував ці функції раніше. Подруге, 3 точки зору залучення кадрів фінтех компанії орієнтуються на молоде покоління, що, в свою чергу, збільшує нерівність з точки зору доступності вакансій для населення старшої вікової групи.

Усі перераховані вищи ризики тісно взаємопов'язані між собою, тому посилення тієї чи іншої загрози призводить до виникнення міжгрупових ризиків: соціально-ринкових, ринково-технологічних або ринково-юридичних.

Вважаємо, що найсуттєвіший вплив на ефективне функціонування фінтех в умовах цифровізації є ризик кібератак, який зазнають останнім часом фінансові компанії. Так, опитування менеджерів з ризику фінансових послуг, показало, що $70 \%$ респондентів вважають найсуттєвішим вплив кібер-ризику на функціонування глобальної фінансової системи [142]. Проблема реалізації кіберризиків є загальносвітовою. Серед країн-лідерів за кількістю кібератак слід виділити США (57\% від загальної кількості кібер-інцидентів). За даними 
агентства Javelin Research, рівень шахрайства 3 персональними даними в 2019 році виріс на 13\% і досяг обсягу 16,9 млрд доларів; рівень шахрайства, пов’язаний з платежами з карти на карту, виріс у 2019 р. у порівнянні з 2016 р. на рекордні 74 \%, а заволодіння даними рахунку тільки в 2019 році стало більше на $72 \%[143]$.

Для посилення позитивних ефектів i пом'якшення можливих ризиків необхідно реалізація наступних заходів:

1. Поступова адаптація до міжнародних регуляторних правил і наглядових практик та модернізація організаційного-правового середовища щодо ефективного функціонування фінансових технологій, а також щодо виявлення $\mathrm{i}$ управління ризиками.

2. Створення та розвиток особливого страхового сегменту - кіберстрахування, який є об'єктивною умовою функціонування цифрової економіки. Важливу роль в цьому процесі має відігравати мегарегулятор в особі Національного банку України. Створення адекватного правового поля, об’єктивних вимог до капіталу, резервів, показників фінансової стійкості страхових компаній, дозволить мінімізувати витрати національної фінансовій системі від кібер-загроз. Своєчасне виявлення кібер-ризиків, достовірне і в повному обсязі отримання інформації о можливих кібер-інцидентах, передача сигналів контролюючим органам $є$ запорукою забезпечення інформаційної безпеки.

3. Забезпечення на законодавчому рівні прозорості сервісів, які залучають грошові кошти, майно або обробляють дані клієнтів шляхом встановлення вимог щодо розміщення на своїх ресурсах в мережі Інтернет певну інформацію, зокрема: про порядок надання послуг, про провайдера, про юридичні підстави надання відповідних послуг, про суб’єктів розгляду претензій користувачів тощо [141].

4. Удосконалення системи моніторингу нових ризиків на основі підвищення якості та гнучкості проведення постійної оцінки зміни самої фінансової індустрії, іï учасників, бізнес-моделей, ступеня взаємозв’язку і рівня 
концентрації ризиків. Створення нових можливостей і форумів для ведення діалогу та обміну досвідом як з усталеними, так і з новими учасниками фінтехіндустрії, допоможе регуляторам зібрати корисну інформацію для своєчасного здійснення заходів політики, спрямованих на усунення перешкод для впровадження інновацій.

5. Інтеграція фінтех-тематики у національні стратегії підвищення фінансової доступності та фінансової грамотності й вивчення можливості створення спеціального органу, який буде відслідковувати розвиток подій в галузі фінансових технологій, сприяти формуванню сприятливих умов для ведення бізнесу в цьому секторі.

6. Проведення просвітницької роботи та ліквідація розриву між багатими $\mathrm{i}$ бідними. Підвищення обізнаності щодо фінансових технологій шляхом надання фізичним особам, малим і середнім підприємствам інформації про найважливіші аспекти, включаючи ризики, а також інструменти, що полегшують прийняття обгрунтованих рішень. Підвищення цифрової грамотності, що здійснюються в ув'язці зі спеціальними програмами, адресованими цільовим сегментам населення.

7. Поступове переведення державних платежів в електронний формат. Це зміцнить довіру, збільшить глибину проникнення рахунків і підвищить ефективність платежів для сегментів населення, недостатньо охоплених фінансовими послугами. У поєднанні з цифровою ідентифікацією це також дозволить скоротити кількість випадків шахрайства та ухилення від сплати податків [144].

Таким чином, фінансові технології в умовах цифровізації економіки мають значний потенціал, який проявляється, перш за все, в позитивному ефекті на економічний розвиток країни й скорочення бідності за рахунок активізації процесу фінансового розвитку, а також підвищення доступності та ефективності фінансових послуг, але при цьому вони можуть створювати ризики як для споживачів й інвесторів, так і для стабільності й цілісності фінансової системи. Тому для подолання загроз та підвищення рівня безпечності функціонування 
фінансового сектору при застосуванні інструментів фінансових технологій слід модернізувати національне законодавство, адаптуватись до міжнародних регуляторних правил та наглядових практик, створити особливий страховий сегмент - кібер-страхування, удосконалювати систему моніторингу та прогнозування ризиків. 


\section{9 Особливості інвестування в сільське господарство України}

Питання вигідного і перспективного вкладення коштів завжди актуальне i більшість інвесторів тримають руку на пульсі та моніторять ринок 3 метою пошуку альтернативних напрямів спрямування своїх фінансових ресурсів. Варто відзначити, що аграрний бізнес у цьому напрямку займає далеко не останню позицію, та, на думку фахівців, однозначно заслуговує на увагу, адже відкриває перспективи та можливості інвестування в сільське господарство.

Аналізуючи інвестиційну складову аграрного сектору економіки, перш за все слід брати до уваги той факт, що попит на аграрну продукцію буде завжди. 3 кожним роком населення планети постійно збільшується, що спричиняє зростання попиту на продукти харчування. Останні кілька десятиліть у країнах Європи і світу гостро акцентуються екологічні проблеми планети та поширюється тенденція споживання якісних органічних продуктів харчування. Навіть пандемія Covid-19 не змогла повністю деструктуризувати аграрний сектор економіки (хоча i спричинила значний вплив), оскільки i в умовах карантинних обмежень існує попит на продукти харчування. Звісно агробізнес не відноситься до надприбуткових і швидкоокупних видів діяльності, проте він є привабливим для тих, хто віддає перевагу стабільності.

Розвиток вітчизняної економіки залежить, перш за все, від позицій та потенціалу аграрного комплексу, оскільки це базовий актив України. На етапі становлення та розвитку інноваційної економіки сільськогосподарським підприємствам необхідне широкомасштабне фінансування своєї діяльності, впровадження у виробничі процеси провідних результатів науково-дослідних та конструкторських розробок, страхування існуючих та прорахунок потенційних ризиків, побудови якісної транспортної та торговельної інфраструктури. Проаналізувавши нормативно-правове законодавство [145-147] у сфері регулювання аграрного сектору економіки, слід відзначити, що воно вкрай застаріле, носить поверхневий декларативний характер, а програми і концепції розвитку затверджені урядом, не містять чітких важелів i механізмів 
стимулювання розвитку фермерства, підтримки занедбаних сільських територій, розв'язання соціальних проблем сіл, їх сталого економічного розвитку, забезпечення зайнятості та підтримки рівня життя сільського населення.

Аналіз забезпеченості вітчизняних сільськогосподарських підприємств фінансовими ресурсами показує, що вони акумулюють здебільшого тільки власні кошти. Попри зростання масштабів самофінансування суб'єктів господарювання сільськогосподарської галузі проблема забезпечення всезростаючих потреб розвитку агропромислового комплексу залишається вкрай актуальною.

Практика розвитку сільського господарства різних країн засвідчує, що підприємства даного сектору забезпечують процеси розширеного відтворення за рахунок залучених фінансових коштів, серед яких важливе місце займає підтримка з боку держави. Специфіка розвитку агробізнесу обумовлює певні особливості накопичення фінансових активів, вибір інструментів, методів та форм їх використання у цьому секторі економічного розвитку.

Основною формою фінансування розвитку сільськогосподарських підприємств $є$ інвестиції. Попри істотне нарощування масштабів сільськогосподарського виробництва рівень інвестиційної активності підприємств агропромислового комплексу України все ще залишається достатньо низьким.

Аналізуючи показники Таблиці 1 варто відзначити, що серед продукції рослинництва в Україні у 2020 році переважали зернові та зернобобові культури, і незважаючи на зростання середньої ціни реалізації цих культур у порівнянні 3 2019 роком майже на 20\%, реалізовано їх було на $12,9 \%$ менше ніж у минулому році. Серед інших культур також збережена негативна динаміка реалізації, а саме: на $15 \%$ менше було реалізовано олійних культур, майже на $20 \%-$ цукрового буряку, на 27\% - продовольчих баштанних культур, на $40 \%$ винограду, на 31\% - плодово-ягідних культур. У 2020 році обсяг реалізації продукції тваринництва сукупно залишився практично незмінним у порівняні 3 


\section{SOCIO-ECONOMIC AND MANAGEMENT CONCEPTS}

минулим роком, проте на 13,6\% знизилася реалізація великої рогатої худоби, на $52 \%$ - вовни овець і кіз, на 5,7\% - яєць.

Таблиця 1

\section{Обсяги та середні ціни продукції сільського господарства України у}

2020 році* $^{*}$

\begin{tabular}{|c|c|c|c|c|}
\hline \multirow[b]{2}{*}{ Найменування продукції } & \multicolumn{2}{|c|}{ Реалізовано } & \multicolumn{2}{|c|}{ Середні ціни реалізації } \\
\hline & $\begin{array}{l}\text { тис. тонн } \\
\text { (тис. шт.) }\end{array}$ & $\begin{array}{c}\text { у \% до } \\
\text { відповідного } \\
\text { періоду } 2019\end{array}$ & $\begin{array}{c}\text { грн. за тонну } \\
\text { (тис. шт.) }\end{array}$ & $\begin{array}{c}\text { у \% до } \\
\text { відповідного } \\
\text { періоду } 2019\end{array}$ \\
\hline Культури зернові та зернобобові & 36871,7 & 87,1 & 4691,4 & 119,9 \\
\hline \multicolumn{5}{|l|}{3 них } \\
\hline пшениця & 14287,4 & 91,8 & 4970,7 & 121,6 \\
\hline кукурудза на зерно & 18434,2 & 80,3 & 4497,4 & 120,3 \\
\hline ячмінь & 3357,8 & 113,9 & 4314,7 & 109,1 \\
\hline жито & 138,7 & 111,2 & 4595,0 & 108,1 \\
\hline Насіння культур олійних & 12723,0 & 84,9 & 10417,0 & 124,2 \\
\hline \multicolumn{5}{|l|}{3 них } \\
\hline боби сої & 1946,1 & 69,5 & 10282,1 & 125,6 \\
\hline насіння ріпаку й кользи & 2122,5 & 77,1 & 10932,7 & 114,3 \\
\hline насіння соняшнику & 8632,4 & 91,8 & 10309,8 & 128,0 \\
\hline Буряк цукровий фабричний & 2800,9 & 80,4 & 837,4 & 112,9 \\
\hline Картопля & 220,8 & 106,3 & 5140,0 & 94,2 \\
\hline Культури овочеві & 970,3 & 113,0 & 4183,5 & 92,8 \\
\hline Культури баштанні продовольчі & 7,7 & 72,9 & 4318,7 & 152,3 \\
\hline Виноград & 46,8 & 59,2 & 6720,2 & 125,9 \\
\hline Культури плодові та ягідні & 165,8 & 68,8 & 8995,6 & 141,9 \\
\hline Тварини сільськогосподарські живі & 913,3 & 100,8 & 32110,9 & 97,7 \\
\hline \multicolumn{5}{|l|}{3 них } \\
\hline велика рогата худоба & 133,2 & 86,4 & 32722,9 & 112,6 \\
\hline свині & 381,1 & 100,4 & 37795,7 & 101,9 \\
\hline птиця свійська & 397,5 & 107,4 & 26426,2 & 88,0 \\
\hline Вовна овець і кіз & 51,7 & 48,0 & 12939,9 & 53,5 \\
\hline $\begin{array}{l}\text { Молоко від сільськогосподарських } \\
\text { тварин усіх видів, сире }\end{array}$ & 2370,0 & 102,2 & 8730,1 & 107,5 \\
\hline $\begin{array}{l}\text { Яйця птиці свійської в шкаралупі } \\
\text { свіжі, млн. шт. }\end{array}$ & 7166,1 & 94,3 & 1178,8 & 98,6 \\
\hline $\begin{array}{l}\text { Цукор білий кристалічний } \\
\text { буряковий }\end{array}$ & 652,7 & 94,7 & 9941,1 & 109,6 \\
\hline
\end{tabular}

\footnotetext{
* Побудовано на основі даних [146].
} 
Враховуючи вищенаведений аналіз бачимо, що аграрний потенціал вітчизняних суб'єктів господарювання не реалізований у повній мірі, а на макрорівні зменшення обсягів реалізації сільськогосподарської продукції вітчизняними підприємствами компенсується за рахунок імпорту продуктів харчування з країн-сусідів, переважно з Білорусії, Польщі, Туреччини, Італії.

Інвестиційна активність в сільське господарство пожвавлює національну економіку вцілому, оскільки сприяє створенню нових робочих місць, збільшує продовольчий запас країни, підвищує добробут населення, активізує діяльність суміжних галузей економіки: машинобудівної, біохімічної, енергетичного сектору, науково-дослідних установ тощо.

Процес інвестування в аграрну сфер в Україні супроводжується значними перспективами, оскільки тут наявні об'єктивні фактори для його зростання: це, передусім, оптимальне географічне розміщення та великі території; значна кількість потенційних споживачів; істотний обсяг сировинних ресурсів; близько $60 \%$ усіх чорноземів світу; достойний рівень освіти працівників при порівняно низькій оплаті праці; достатня інфраструктура та логістичний потенціал; ліберальне законодавство у сфері захисту навколишнього середовища; незначне податкове навантаження на юридичних та фізичних осіб; помірний клімат; членство в СОТ, наявність зони вільної торгівлі з СС та іншими країнами.

На рівень ефективності впровадження інвестиційних проектів в Україні впливає правильність вибору галузі, партнерів, топ-менеджерів та персоналу; можливість залучення до проектної діяльності іноземних спеціалістів. Також на розвиток проекту впливає забезпечення фінансовими та технологічними ресурсами із врахуванням рівня та масштабу проекту. При цьому проблема фінансових інвестицій не є єдиною. Важливе також впровадження нових технологій, використання продуктивних маркетингових стратегій та стратегій 3 розвитку кадрових ресурсів, оскільки зараз прослідковується конкуренція не тільки виробленого продукту, але й ефективної бізнес-моделі, яка дасть найоптимальніші та найочікуваніші результати. 
Активізація інвестиційної діяльності у вітчизняному агробізнесі є ключовим фактором розвитку національної економіки, оскільки наша країна характеризується значним запасом територій для здійснення сільськогосподарського виробництва та виготовлення сільськогосподарської продукції. У зв'язку з цим для посилення інвестиційних процесів в аграрній сфері потрібно здійснити розробку комплексу найбільш перспективних засобів державного впливу: забезпечити ефективні законодавчі акти щодо покращення інвестиційного клімату в країні; впроваджувати відповідне інформаційнометодичне забезпечення інвестиційних процесів; сприяти забезпеченню сільськогосподарських галузей висококваліфікованими кадровими ресурсами; розробляти інвестиційні регіональні та загальнодержавні програми у сфері сільського господарства, що сприятиме спрямованості фінансових активів на впровадження, перш за все, тих інвестиційних програм, реалізація яких забезпечить найсуттєвіший економічний та соціальний ефект. 


\section{SECTION 5. ECONOMY AND MANAGEMENT OF STATE GRATITUDE}

\subsection{Professional training of civil servants: development, functions and principles}

Considering the system of professional training of civil servants, it should be noted that the main purpose of this system is to increase the level of professionalism and competence of staff, ensure their continuing education, proper staffing of executive bodies and local governments, increase their efficiency, i.e. ensure the reliability of public administration [149-151].

The experience gained by mankind over the years of its existence is constantly enriched and disseminated, developing a system of training and retraining by intensifying training, introduction of its optimal technologies, system and information content of training content.

Therefore, in order to be a professional, you need to enrich and develop your knowledge, skills, abilities, and master the best experience. Professional activity is associated with a certain isolation of professionals in the circle of professional interests. Such isolation is natural in all spheres of human activity, which creates a certain limitation of personality development. The purpose of education is its comprehensive and harmonious development. This moves the system of training and retraining of civil servants in the direction of enriching their general culture, professional abilities and interests.

The above contradictions in the training of civil servants are the driving forces of its development, which improves the links between phenomena and processes that characterize the state of the system. Such links include:

-the dependence of the education system of civil servants on a set of objective and subjective factors of change in the socio-economic environment;

-enrichment in the process of teaching general cultural, professional and functional components of the overall culture of the specialist;

-improving the quality of education with active self-education, self-improvement of civil servants; 
-dependence of educational efficiency on expediently organized educational process;

-dependence of the content of education on public-state and individual educational needs.

Taking into account the links between the development of the civil service training system opens the way to optimize the management of this system [152].

The professional activity of a civil servant presupposes not only the availability of training in the field of public administration, but also awareness in the fields of science, culture, socio-political life, and the formation of a broad worldview. Therefore, the general cultural level of a civil servant is the basis on which his professional activity unfolds, the development of which contributes to raising the general cultural level of a civil servant [153].

The professional development of a civil servant is aimed at improving his professionalism and functional activity, and the general culture and education become the key to the effective performance of official duties.

Thus, the system of training of civil servants, as well as the system of their professional development, has general cultural, professional qualification and functional components that are interconnected. The structure of the system of training of civil servants is determined by its elements, purpose of functioning and functions that it performs. Function is a special way of operating this system. The subject of the function indicates the aspects, aspects, manifestations of the system of advanced training of civil servants, and the content of the functions reproduces the nature of managerial influence. The method of implementing the function reveals the possibility of preserving or transforming the relationships inherent in it. According to the content, nature and scope of influence, the functions are divided into general and specific. In the system of professional training of civil servants there are both general (planning, organization, regulation, staffing and control) functions, and specific. Specific functions can be divided into external and internal.

External functions affect the development of the system of training and retraining of civil servants indirectly. They determine the role and place of this system in society, characterize the links with other systems. These include: 


\section{SOCIO-ECONOMIC AND MANAGEMENT CONCEPTS}

-socio-economic function, which is to meet the needs of the state in highly qualified personnel, creating conditions for deepening the knowledge, skills and abilities of the specialist;

-adaptive function - acts as a means of adaptation of civil servants to rapid sociopolitical and economic changes, living conditions, etc.;

-prediction function - determines the need for advanced nature of education and provides a combination of results of socio-economic, scientific and technical, cultural and aesthetic, socio-political forecasting with forecasts in the field of public administration and education;

- coordination function - provides a rational combination of activities and comprehensive harmonious development of personality;

- organizing function - is to organize training, determine the timing and forms of training, control over its quality;

-production function - is the processing and accumulation of information, its adaptation to practical use and relates to public administration, civil service and civil servant activities;

-propaganda function - is implemented in the content of education, preparation of textbooks, teaching materials, etc.;

-experimental research function - is to organize and conduct research and experimental work, study of domestic and foreign experience of public administration and civil service. It covers research work on the application of forms, methods and content of training in practice;

-personnel function - aims at the selection and placement of teachers and methodological staff. It provides for the constant growth of scientific, methodological, pedagogical and general cultural level of the teaching staff of educational institutions, involvement in the educational process of statesmen and politicians, leading scientists, experienced practitioners, creating conditions for their work.

Internal functions of the system of professional training of civil servants are functions that directly affect the individual. They reveal the role of the system in the comprehensive development of the specialist, which includes professional, educational, cultural and spiritual components. Internal functions include: 
-adaptive - refers to the adaptation of a civil servant to his profession, new position, etc., gaining and enriching practical experience;

-compensatory - aimed at reproducing forgotten knowledge, expanding and updating knowledge within the education of a specialist;

-analytical - is to study and summarize the experience of professional activity of civil servants;

-transformative - is reduced to the transformation in the psychology of civil servants of outdated views and stereotypes of actions that prevent a change in thinking style in accordance with the theory and modern practice of management;

-developing - is the comprehensive harmonious development of civil servants;

-predictive - is to form the skills of a specialist to predict the results of their work, plan their activities, determine its goals and objectives, make optimal decisions;

-communicative - develops communicative properties and skills of a civil servant, promotes his self-education and self-improvement;

-incentive - increases the interest of civil servants in improving their skills, encourages them to education, development and improvement of professional skills.

All the functions of the vocational training system are closely interconnected, which can be traced not only within the groups of functions, but also between external and internal functions. External functions acquire their meaning due to internal, and vice versa, the implementation of internal due to external functions.

The system of professional training of civil servants is based on certain scientific principles. Finding out the principles of organization and functioning of this system is one of the important areas of research. Scientists distinguish the following organizational principles:

-the principle of systematization, which is that the system of training and retraining of civil servants is considered as a set of interrelated elements. According to him, the goals, objectives, principles and methods of teaching cannot be considered in isolation. This principle coordinates the interaction of the components of the educational process;

-principle of functionality implies the presence of a set of functions necessary for the functioning of the system; 
- the principle of unity determines the combination of all areas of personal development and indicates the dependence of the development of the specialist on the influence of state and public organizations;

-the principle of differentiation provides a differentiated approach to improving the structure, content, forms and methods of training, as well as determines the dependence of training on the status of public bodies, positions of civil servants, their level of education and training, civil service, etc.;

-the principle of obligatoryness consists in normative fixing of obligatory increase by civil servants of a professional level;

-the principle of continuity provides for the consideration of training as a continuous process, organically connected with the professional development and career advancement of a civil servant;

- the principle of advanced nature of education means that education must not only meet modern socio-state and individual educational needs, but also be advanced in content and take into account the high dynamism of social processes;

-the principle of planning is based on a systematic analysis of the composition of civil servants and the study of the training needs of public authorities and their specialists. It provides for the development of training plans for civil servants, drawing up training and thematic plans and training programs, planning the educational process;

- the principle of mutual rights, duties and responsibilities of civil servants, state bodies in the field of advanced training establishes the obligation of civil servants to maintain their level of qualification, and state bodies - to plan, organize and control the training of civil servants. Measures of disciplinary responsibility are applied both to the civil servants who refuse advanced training, and to heads of the state bodies which do not provide advanced training of the subordinates;

- the principle of legal consequences for trained persons is manifested in the relationship between training results and promotion, which may consist of appointment to a higher position, early assignment of the next rank, increase in allowances to the salary of a civil servant;

- the principle of ensuring the quality and efficiency of education provides a high level of quality training and retraining of civil servants, a rational ratio of forms and 
types of education, providing qualified scientific and pedagogical staff, methodological and information-analytical literature;

- the principle of continuity makes it possible to link the previous training and experience of the specialist with its further development in the learning process. It affects the content, forms and methods of teaching, based on the amount of knowledge, skills and abilities already possessed by the specialist;

-the principle of consistency is a rational structuring of the content of training, construction of training of experts according to their individual features and needs. This principle is important for the educational activities of students, the development of the necessary personality traits and qualities;

-the principle of scientificity requires relying on new achievements of science and practice, building the educational process on a scientific basis, the introduction into practice of new technologies and the use of technical teaching aids;

-the principle of providing a humanistic, democratic approach requires the development of intellectual and moral potential of students, comprehensive democratization of the educational process with their active participation;

-the principle of inseparable connection of theory and practice of state bodies allows civil servants on the basis of thorough theoretical training to navigate in complex, contradictory events of public life, analyze and assess the situation, focus on economic development, economic reforms, social stabilization of society;

-the principle of decentralization provides for a combination of mandatory and planned training of civil servants with the right of public authorities to choose the subject, content, forms, methods of training;

-the principle of taking into account domestic and foreign experience in training civil servants makes it possible to reveal the heredity of state and legal relations, understand development trends, solve modern problems of development of training and retraining of civil servants, taking into account previous experience.

In addition to the general principles of organization and functioning of the system of professional training of civil servants, there are androgynous principles of training, which include: 
-principle of taking into account individual experience and development of individual educational needs;

-the principle of level-qualification differentiation is that the purpose, tasks, content, forms and methods of training should be differentiated according to the interests, needs, knowledge and experience of civil servants. It makes it possible to most fully meet the individual educational needs of students;

-principle of age approach. This principle requires consideration when determining the purpose, content, forms and methods of teaching the age qualification of students, as well as the organization of the educational process, when outside intervention is replaced by introspection, self-awareness and self-control;

-the principle of freedom of choice allows choice in the educational process and includes freedom of choice regarding the purpose, content, forms, methods, means of organization and implementation of training, and does not narrow the variability of curricula;

- the principle of problem-situational organization of training requires the construction of training not on the subject, but on the problem and situational features. What is important for a specialist is not the discipline being studied, but its role in solving professional problems and life problems;

-the principle of stimulating self-education and independence in learning helps the specialist to follow the path of self-development, independent acquisition of new knowledge and their use in professional activities. The central figure in learning is not the teacher, but the listener, who assesses the importance of learning. This principle is realized through the forms and methods of teaching, evaluation of the results of the educational process;

-the principle of joint activity in the learning process is to change the role of the teacher, who becomes an assistant. Together with the student, the teacher determines the content of training, plans and manages the learning process to facilitate the assimilation of the material;

-the principle of development of creative potential and moral and educational sphere of personality provides stimulation of intellectual activity of listeners, development of emotional, moral and volitional sphere of personality; 
-the principle of taking into account life and job prospects makes it possible to specify the purpose of training, to harmonize the content, forms and methods of training with the general needs of the individual, the prospects for professional growth. It is quite natural for a person to strive to achieve the highest results in his work, to receive the recognition of colleagues, to hold a higher position, to have the prospect of promotion;

-the principle of updating learning outcomes implies the mandatory application of acquired knowledge, skills and abilities in practice. This method involves a variety of forms and methods of teaching.

The organizational and androgynous principles of the organization and functioning of the system of professional training of civil servants are closely interrelated. Partly they correlate, partly develop each other [154-156].

$\mathrm{n}$ conclusion, it can be argued that the system of professional training of civil servants has general cultural, professional and functional components that are interrelated. The general cultural component contains a set of individual qualities necessary for the performance of professional duties; professional qualification provides for the need to master a common set of knowledge, skills and abilities for all civil servants; functional - involves a set of first and second properties required to perform specific tasks in everyday activities.

The system of professional training of civil servants performs general and specific functions. Common functions include: planning, organization, regulation, staffing and control. Specific functions can be divided into interdependent external (determine the role and place of this system in the system of public relations) and internal (directly related to the development of professional qualities of civil servants). 


\subsection{Social and labor sphere in the face of challenges of the COVID-19 pandemic: problems and opportunities of anti-crisis regulation in Ukraine}

The end of December 2019 opens a new stage in the history of mankind - at least the history of the XXI century. This was the moment, first in China (Wuhan, Hubei Province), and later around the world, that human society faced the COVID-19 pandemic. The spread of COVID-19 disease has led to system changes in the sociolabor sphere and - actually - to the emergence of a new socio-economic reality. The "viral" factor of social progress-XXI began to change all components of life of people, communities, global society as a whole [157, p.16-17]. Economic activity, social organization of labor, the sphere of direct production, the labor market and much more concerning human, his life, well-being - all these aspects acquire a new format under the influence of new phenomena and processes. We are witnessing the formation of a new socio-economic reality caused by the COVID-19 pandemic. It exacerbates the challenges and threats of the pre-pandemic era and creates new ones, intensifies demographic and globalization factors and actualizes the demand for the development of digitalization of the economy and society, information and communication and other breakthrough technologies, etc [158, p.4]. The specific feature of the current global crisis is that it is both epidemiological, economic, social and geopolitical at the same time. The COVID-19 pandemic is a test of humanity's ability to counter global threats, to mobilize for solving urgent problems and to act purposefully. Therefore, the active and prompt response of each country to these challenges and threats, the development of a collective security system is the key to security of life and health of the people of each state and humanity as a whole.

COVID-19 caused a threefold negative impact on global human development negatively affecting the health care system, education, employment and income of people worldwide; it has also made significant changes to all components of global and national labor markets, affecting both the demand, supply and price of labor [157]. Therefore, measures already taken by national governments (including the Government of Ukraine) to counteract the spread of COVID-19 and avoid large-scale 
losses among the population have at least threefold consequences for the socioeconomic system.

One of the most significant negative consequences of the COVID-19 pandemic was the economic stagnation and large-scale rise of unemployment. Thus, in Ukraine, the COVID-19 pandemic and quarantine restrictions have significantly deepened the economic crisis - the economic activity of the people decreased significantly, the activity of a large number of sectors of the economy slowed down or even stopped, an unemployment has risen, poverty has spread, opportunities for full, quality education are being lost, the burden on medical institutions, state social services, law enforcement agencies, etc. has significantly increased. The socio-psychological condition of the people has deteriorated due to increased threats of losing health or even life, restrictions on freedom of movement, living conditions and livelihoods, etc. At the same time, internal negative processes deepened due to the spread of part-time, informal and "shadow" employment, declining productivity and efficiency of employment, loss of livelihoods, reduced use of labor potential [158, p.73].

A serious challenge for Ukrainian businesses and employees was the fact that the authorities actually removed the association of employers and trade unions from tripartite consultations and negotiations not only on the development and preservation of human potential, but also on labor market, economic and social policy [159]. The institution of social dialogue is, in fact, being dismantled, which, according to the International Trade Union Confederation, will have almost irreversible consequences for the Ukrainian economy and society [160], and this poses an additional threat in the face of the COVID-19 pandemic. Thus, Ukrainian experts V. Kostrytsia and T. Burlay point out that governments in recent years have intended "to liberalize radically " labor legislation without mandatory consultation with the social partners, instead of making it flexible enough to protect employment, both for employees and employers [161]. The processes of development of the labor sphere in Ukraine, its adaptation to the new conditions, active counteraction to the risks and threats of the pandemic are hindered by the lack of the Labor Code. Today, the Labor Code, adopted in 1971, is still in force, and it does not take into account current trends and the latest challenges regarding 
precarization, digitalization, shadowing, the spread of atypical forms of employment, etc. Therefore, all these factors must be taken into account in the processes of development and implementation of effective anti-crisis socio-economic state policy, which should include measures to stabilize the labor market and employment, taking into account the spread of remote forms of employment and necessity of providing social protection for people in a pandemic.

The low capacity of the subjects of social and labor relations to stabilize the situation in the socio-economic sphere leads to the understanding that its restoration requires not just the return of labor and employment to its previous state, but a significant renewal and increase of its resilience to force majeure situations, like the COVID-19 pandemic is. Accordingly, the search for mechanisms to ensure such sustainability is becoming perhaps the most urgent task and a necessary condition for the restoration of labor and employment in Ukraine [158, p.73].

In this context, an adequate steps taken were conducting of an economic audit of the country [162] and determining the Vectors of economic development of Ukraine until 2030 [163]. The country's economic audit has been dubbed RE: think to focus on rethinking Ukraine's potential. The results of the economic audit of the state were the impetus for the developing of the draft of "National Economic Strategy of Ukraine 2030" by the Ukrainian Government [164]. The positive fact is that representatives of all branches of government, think tanks, Ukrainian business, and scientists have united around the creation of the mentioned Strategy draft. The state of the socio-economic sphere of Ukraine, by the end of 2020, turned out to be slightly better than it was predicted at the beginning of the pandemic 2020. Thus, real GDP in 2020 decreased by $4,4 \%$. This is much less than expected at the beginning of the pandemic crisis (6\%). Ukraine's economy began to recover fairly quickly in the second half of 2020. After the hard phase of quarantine, the decline in real GDP slowed down (to 3,5\% in the third quarter of 2020) and continues to slow down. This recovery of the national economy is primarily due to growing consumption. The increase in wages and social budget expenditures kept consumer demand at a fairly high level. Unemployment also began to decrease. According to the forecast of the National Bank of Ukraine, in 2021 the 
economy will recover and almost return to pre-crisis (pre-pandemic) levels [165]. However, the paradox of the situation in the post-pandemic period is that the official unemployment rate may fall sharply, because during the border closure in the spring of 2020 , about $10 \%$ of the total number of migrant workers returned to Ukraine. However, when the borders are opened, the likely outflow of Ukrainian citizens will be much higher. Returning to an open Europe will lead to additional migration flows, and the outflow of labor (primarily skilled) can only accelerate. Such dynamics should be taken into account in the state anti-crisis regulatory policy of Ukraine, including in the above-mentioned draft of the National Economic Strategy of Ukraine 2030 (hereinafter - the Strategy draft).

The main priorities of the vision of the draft Strategy of Ukraine 2030 are as follows [164]:

1) create competitive conditions for business and investment and to restore trust in state institutions;

2) win competition for capital on the world market;

3) stimulate the development of innovations and modernization of economic sectors to ensure their competitiveness in the international market;

4) promote human development and win the competition for talents.

However, the priorities mentioned unjustifiably do not contain segments directly related to "development of the social and labor sphere and the labor market", "development of constructive social dialogue in the system of social and labor relations", "development of public-private partnership", etc. It seems impossible to create high opportunities for quality life of Ukrainians without providing conditions for socio-economic stability and post-pandemic recovery and without constructive social dialogue. Taking into account that the COVID-19 pandemic has dealt a devastating blow to the Ukrainian economy, with triple long-term negative consequences, it is necessary to supplement the structure of the Strategy draft with an additional chapter - "Overcoming the risks, threats and negative consequences of the COVID-19 pandemic on the national economy, labor and employment". This structural element of the Strategy should be built into the overall structure of the Strategy draft 
and taken into account in the further development of the Action Plan for its implementation. The content of the new chapter, which is proposed to be added, should be based on the ILO recommendations $[159$, p.120] on the implementation of effective anti-crisis policy in Ukraine.

Thus, under the new pandemic socio-economic reality, Ukraine faces complex urgent tasks in the socio-labor and economic spheres to implement an effective anticrisis regulatory policy. These tasks include both short-term and long-term ones. Efforts should be aimed at forming and ensuring of: 1) a stable macroeconomic environment; 2) stable functioning of socio-political and socio-economic spheres; 3 ) consistent improvement of living standards and welfare; 4) prevention of further loss of investment potential; 5) the formation of a favorable environment for business, especially small and medium; 6) strengthening financial stability as an important component of investment attractiveness and economic development; 7) strengthening and expanding the openness of the country [163].

None of these areas has a chance to be implemented if institutional capacity of the government is low; without the practical implementation of effective social dialogue and public-private partnership, without creating appropriate conditions for the restoration and development of small and medium-sized businesses and entrepreneurial activity in general. Such ambitious goals for the future can be achieved if the basis of the "National Economic Strategy of Ukraine-2030" will be laid risk-recovery model of economic and social and labor development [1, p.21; 10], which provides for the simultaneous maintenance of tight control over the COVID-19 pandemic and its consequences and the "launch" (recovery and development) of the national economy. An important component of the implementation of the risk-recovery model should be increasing of the role and responsibility of public authorities, transformation of their functions in the triad "market - state - business"; transition to an updated format of partnership with extensive use of digital, information, various breakthrough technologies, etc. 


\subsection{Factors and phase of economic competitiveness - their manifestation in Ukraine}

Change the paradigm of macroeconomic development in the formation of the knowledge economy, the growth of openness of national economies under the influence of globalization creates an urgent need to rethink the foundations of economic competitiveness, taking into account the transformation of its factors. In modern society, the relative importance of natural resources and labour is decreasing; the role of new factors of economic activity is growing, which depend on investment in innovation and the development of knowledge infrastructure.

In this context, the synthesis of neoclassical and institutional approaches to the analysis of the innovative foundations of the competitiveness of the modern economy seems productive. Within the neoclassical approach, the key ideas in the study area lie in line with M. Porter's theory of competitive advantage, according to which national competitiveness is associated primarily with the ability of enterprises to constantly innovate develop. The scientist identifies four stages of competitiveness of the national economy, which correspond to the driving drivers of growth of the competitiveness of the national economy. These are factors of production, investment, innovation and wealth [167].

The system of modern factors of competitiveness includes basic, progressive, general and specific factors. The main factors (natural resources, climatic conditions, geographical location of the country, unskilled and semi-skilled labour, etc.) exist objectively, or to create them requires small public and private investments. As a rule, the advantages created by them are unstable, and the profit from use is low.

Progressive factors (modern infrastructure, high technology, highly qualified personnel, etc.) are higher-order factors and need capital investment and human resources. In addition, the basic factors must be of sufficient quality so that complementary factors can be created on their basis, which is a reliable source of competitive advantage. 
Common factors can be used in a wide range of economic activities. In contrast, specialized factors are used in one or a limited number of industries, but form a more fundamental, long-term basis for competitiveness. Competitive advantages, which are based on a combination of basic and general factors, act as advantages of a lower order (extensive type), they are short-lived and unstable. To a greater extent, competitiveness can be increased due to developed and specialized factors; they are a prerequisite for innovation of economic entities.

Criteria for classifying factors as develop or specialized are strengthened under the influence of scientific and technological progress. Therefore, the resource factor as the basis of long-term competitive advantage is depreciated if it is not constantly improved. Thus, in modern conditions, the main factors of business competitiveness are its ability to innovate and modernize, achieve competitive advantage through innovation, creation and development of knowledge, which, accordingly, will contribute to the formation of innovative imperatives of competitiveness of the national economy.

In Ukraine, the problem of maintaining competitive positions in the world market is important, because in modern conditions the factors that could contribute to the growth of competitiveness in the future are lost: technical and technological, innovation and investment, system and other factors (Table 1).

Despite the growing importance of globalization, national competitiveness is determined by a set of factors that depend on specific, local conditions. Differences in the economies of countries, in their culture, population, infrastructure, governance, national values and even in history - all this to some extent affects the competitiveness of national companies. Country competition is the competition of laws, administrative procedures, taxes, as well as monetary, financial, trade, legal, educational, social, environmental and judicial systems. Each industry is constantly improved and updated. As the formation of the global economy is not yet complete, Ukraine has the opportunity to win a worthy place in global competition. To fully participate in the competition in world markets requires the creation of competitive production that can ensure the accelerated quality of economic growth. 
Factors of competitiveness and their manifestation in Ukraine

\begin{tabular}{|l|l|}
\hline $\begin{array}{c}\text { Factors of the } \\
\text { country's } \\
\text { competitiveness }\end{array}$ & \multicolumn{1}{|c|}{ Peculiarity of their manifestation in Ukraine } \\
\hline $\begin{array}{l}\text { Technical and } \\
\text { technological }\end{array}$ & $\begin{array}{l}\text { low technical and technological level of production; high level of physical and moral } \\
\text { depreciation of fixed capital. }\end{array}$ \\
\hline $\begin{array}{l}\text { Innovation and } \\
\text { investment }\end{array}$ & $\begin{array}{l}\text { innovation and investment passivity of enterprises; lack of investment for the } \\
\text { reconstruction of old capacities; deepening the innovative lag of production from global } \\
\text { trends; low "innovative" quality of investment in the development of national } \\
\text { competitive advantages. }\end{array}$ \\
\hline Internal demand & low real incomes; uneven distribution of income between different social groups. \\
\hline $\begin{array}{l}\text { The position of } \\
\text { the market } \\
\text { infrastructure }\end{array}$ & $\begin{array}{l}\text { underdeveloped infrastructure of commodity markets; low quality of corporate } \\
\text { governance; low efficiency of the financial system; low efficiency of the tariff regulation } \\
\text { system (insecurity of domestic producers in relation to "organized" importers); } \\
\text { insufficient development of modern information technologies; high transaction costs of } \\
\text { economic and investment activities of enterprises. }\end{array}$ \\
\hline Systemic & $\begin{array}{l}\text { low efficiency of methods of state regulation; lack of competitive business environment; } \\
\text { high transaction costs of economic and investment activities of enterprises; inconsistency } \\
\text { of the legal framework, including in the field of taxation. }\end{array}$ \\
\hline $\begin{array}{l}\text { Science and } \\
\text { education }\end{array}$ & $\begin{array}{l}\text { ineffective protection of property rights; low competitiveness of the educational system; } \\
\text { lack of proper financial state "support" for universities implementing innovative } \\
\text { programs; lack of a system of educational loans. }\end{array}$ \\
\hline $\begin{array}{l}\text { Social } \\
\text { production }\end{array}$ & $\begin{array}{l}\text { lack of sufficient funding for science, low share of knowledge-intensive products in } \\
\text { exports; suspension of the process of expanded reproduction; low quality of life; social } \\
\text { polarization of society (lack of equal right of access to socio-economic benefits); low } \\
\text { level of investment in health care. }\end{array}$ \\
\hline
\end{tabular}

In the ranking of the World Economic Forum for 2018, Ukraine took 83rd place among 140 participants in the ranking (57 points out of a possible 100), in 2017 Ukraine - 89th place among 135 participants. After a period of relative stability of the rating in 2006 - 2008 (69, 73 and 72nd places, respectively), the country was in the ninth ten countries where it was before [168]. In the 2019 ranking, Ukraine ranked 85th out of 141 .

You can also track the annual changes in a single indicator and component, which form the overall rating of the country in 2018-2019. Ukraine's position deteriorated compared to the previous year according to the new methodology in 11 components, and only one, "Business sophistication" recorded positive dynamics. Ukraine received the most points in such components as "Skills" (45th place), "Market size" (47th place), "Infrastructure" (57th place), and "Innovation" (58th place). And according to the "Quality electricity supply" indicator, Ukraine even managed to take the first place. However, Ukraine shared this first place with 66 participants in the ranking. 
The components that indicate the low level of Ukraine in the ranking were "Macroeconomic environment" (131st place), "Financial market development" (117th place) and "Institutions" (110th place). Compared to the data for 2019, the indicators of macroeconomic stability deteriorated from 131st to 133rd, the financial system - to 136th, health care - from 94th to 101st. At the same time, Ukraine managed to rise in the ranking of "Business sophistication"- from 86th to 85th, from "Labour market efficiency"- from 66th to 59th, from the "Market size" - from 73rd to 57th.

Indicators related to low indicators for Ukraine include: the impact of organized crime on the cost of doing business, inflation, debt dynamics based on the country's credit rating, terrorism, independence of the judiciary, protection of property rights, quality of roads, impact of taxes, subsidies and competition, wage flexibility, bank reliability, the share of problem loans, the growth rate of innovative companies.

The closest to Ukraine in the ranking are the Dominican Republic (82nd place) and Macedonia (84th place). Ukraine's geographical neighbours overtook it: Russia took 43rd place, Poland - 37th, Slovakia - 41st and Hungary - 48th, Romania - 52nd. Below was only Moldova (88th place), and Belarus has traditionally not been ranked. The United States topped the rankings, followed by Singapore and Germany. Last year's leader - Switzerland - took 4th place. Yemen and Chad have the lowest level of competitiveness [169].

Thus, for all three groups of components of the rating: basic requirements, efficiency enhancers and factors of innovative development, Ukraine has a negative trend. At the same time, the most important are the assessments of the first ten components of competitiveness, as the country is in the second stage of development according to the WEF methodology. With a low level of factors of production, institutions and measures of state influence that affect the level of the national economy, Ukraine has a low level of competitiveness of national business. According to WEF experts, Ukraine will not be able to rise in the rankings without institutional progress, as this is one of the main factors hindering its development [170].

In our opinion, this requires the introduction of a mechanism to stimulate economic activity and development of the internal market, which provides for 
institutional and regulatory changes. First of all, it is demonopolization and the formation of a competitive environment, the separation of big business from power (deoligarchization); reduction of the shadow economy, anti-corruption measures in the field of open e-government; reducing the tax burden on business.

The component of economic policy should be the selective support of the development of priority economic activities, technological modernization of production and introduction of innovations in order to increase energy efficiency and competitiveness of traditional sectors of the economy; support for the development of industries - potential leaders in import substitution and development in international markets; development of "strategic leaders" - science-intensive economic activities, stimulating entry into international production networks through the creation of new promising industries and related services through the development and optimization of its own research base, cooperation with global leaders, creating innovation clusters.

An important condition for the successful modernization of the national economy is the acceleration of the pace of reforms from the short-term cycle model to the longterm paradigm of sustainable development. To do this, it is necessary to use the classic built-in mechanisms to increase the investment activity of economic entities; increase in the working population; increase of labour productivity, quality of education, professional training, industrial culture and ethics; transition to new types of raw materials and energy. 


\subsection{International experience in managing territorial communities and prospects for Ukraine}

\section{Analysis of international experience in the development of territorial communities}

In every country, the way of organizing decentralized authority is connected with its history, political and managerial culture, economy and social experience. This makes it impossible to develop and implement one common and universal model. However, there are some similarities in approaches to solving a number of problems. First of all, it concerns the increased administrative role of the regional level. It has taken a long time for territorial parts (regions, states, lands) in federal or highly regionalized countries to resolve the issue of internal structure [171].

The experience of consolidation of municipal units has both positive and negative consequences. Firstly, it is impossible to apply a single quantitative criterion to all settlements (for example, a predetermined number of residents). Secondly, if the municipalities were united into a new administrative unit due to a command or administrative order (for example, in France), the reform was usually unsuccessful and does not give the expected results. Success was achieved due to the voluntary unification of local authorities (even if the state still initiated it), the use of the experience of municipal cooperation, monitoring of public opinion in order to identify preferences and take into account historical, cultural, economic ties of the population.

France made an attempt to implement forced territorial reform which involved the unification of communes (municipalities) created hundreds of years ago. This idea of the French government was not perceived by the population and it turned into cooperation of territorial communities.

A significant number of countries eliminate small and non-effective territorial formations. Concerning France, it remains quite conservative at this point. There are currently 36,568 communes in the country. However, about $80 \%$ of them have a population of less than 1000 inhabitants.

It is quite possible that due to the small size of the territory and a small number of the population, these territories cannot create conditions for performimng all the 
necessary duties [172]. To solve the problem of financial support and functioning of governing institutions, 2 approaches are used: 1) cooperation between communes to solve certain common problems; 2) uniting several small communes into a single one which is more powerful and financially capable to solve the functioning of all local government services.

In order to determine the new boundaries of new municipal territories, various criteria were taken into account, but all of them had a comprehensive, quantitative and qualitative principle. Thus, in Sweden, municipalities that carried out cooperation with each other were united around cities, taking into account the level of area development between settlements. In Denmark, a special research was carried out to determine the municipal boundaries, the results of which revealed areas that were naturally formed basing on different common spheres of activity. As a result, more than 40 trade zones, 123 centers of labor resources, etc. were identified. Many indicators were taken into account, among them even such as mail and press delivery. Therefore, a map of the interrelation and interdependences of territories was created. A detailed analysis of the "scale effect" was also carried out in order to optimize the way of providing the population with various services. Basing on the collected data, the legislation was changed, there were the proposals to create districts, which was discussed in municipalities and approved by the central government only after reaching an agreement with the areas to be united.

Today in Ukraine you can observe the reverse process. 136 rayons (districts) were created out of 480 existing rayons. The justification for this amount is not confirmed and explained to the population, the calculation relied only on the Polish experience of such a reform.

It should be said that Poland has had more than 300-year experience in the functioning of local government. Despite the positive results of decentralization in Poland, one of the negative aspects was failing in considering the difference between rural and urban povits (municipalities), in particular, the differences in resources that these locally governing units can use. For a significant number of under-developed regions of Poland, decentralization meant increasing the gap between them and the 
most successful Polish regions and the whole country. Regions which turned out to be without the state support after the administrative reform began to develop worse [173].

Unlike Poland, where the successful implementation of the decentralization reform was largely due to a single "reform headquarter" which included the parliament and government representatives, experts and non-governmental organizations, Ukraine has a large number of reform center situated in the country center that poorly coordinate their activities with the regional level authorities.

Territorial planning requires the unification of territories and the search for optimal options for their fair division (Table 1).

Table 1.

Number of local authorities

\begin{tabular}{|c|c|c|c|}
\hline Country name & local & intermediate & Regional \\
\hline France & 36786 & 101 & 13 \\
\hline Germany & 11252 & 295 & 16 \\
\hline United Kingdom & 433 & & 4 \\
\hline Poland & 2497 & 380 & 16 \\
\hline Ukraine & 10885 & 488 & 25 \\
\hline
\end{tabular}

In Finland, two decades ago, an attempt was made to significantly reduce the number of municipalities by command and administrative order. In the end, as a result of political changes, the volunteering principle won. At the same time, the state encourages the municipalities unification by providing additional subsidies. Administrative and territorial reform in Finland is not carried out in an administrative and command way, but due to the economic stimulation of local authorities to make voluntary decisions regarding the expediency of such an association.

In Italy, financial motivation is expected for the unification of communes with the population of less than five thousand inhabitants, or for their joining the larger communes. A similar experience was also introduced in Estonia.

In Latvia, taking several stages, both methods of consolidation - stimulation of voluntary unification and administrative consolidation - were used. Since the beginning 
of the reorganization, four years have been spared for the creation of voluntary unifications supported financially by providing a single subsidy (from the state budget) in the amount of 1 to $5 \%$ of the total budget of the municipality. A year after, administrative consolidation of the remaining municipalities was carried out.

Another problem that appears during the decentralization reform is the choice between equality and hierarchy in relations between different regional and local institutions. In the French constitution, for example, there is the principle that no local authority can exercise power or supervise other authorities, but this is mostly a formality than it works in practice.

Instead, in Germany, the hierarchy of relations between different levels of government is a priority: legislative acts approved by the land institutions are mandatory for local authorities located in their territories. Regional authorities have a high level of power: local authorities have the right to supervise the activities of the lower ones. Both the first and the second approaches have their drawbacks.

In the French system of formal equality, this does not correspond to the real practice of subordination between different levels of government, also it does not contribute to the development of cooperation between regions, departments or municipalities, and does not exclude the competition between them, which leads to unclear responsibilities.

The hierarchy chosen by Germany contributes to the re-concentration of power at the land level and contradicts the formal imperatives of decentralization. However, despite the national experience, the idea of ensuring a regional level of responsibility to maintain the unity of the system of local authorities finds more and more supporters [174].

Clear distinction of responsibilities between the state and various local and regional authorities is the main requirement for the effective public administration. The European Charter of Local Authorities states that "the main responsibilities and functions of local institutions are determined by the Constitution or the law.

However, this statement does not exclude providing responsibilities and obligations for local institutions for specific purposes in accordance with the law. Local 
authorities within the law have all rights to resolve any issue that is not removed from their competence and which is not appointed to any other institution. The Charter also emphasizes that the responsibilities provided for local authorities should be full and exclusive. They cannot be terminated or restricted by other central or regional authorities unless required by law.

The rule of clear competence is implemented in Belgium, where each power branch is in charge of its specific responsibilities: issues related to sovereignty are in the prerogative of federal institutions; cultural issues, health care and social welfare belong to the competence of communities, and the issues of housing and ommunal services are partly belong to the competence of regions. Clear competence means no interference from the federal government. The principle of common power was introduced in federal Germany. According to the Constitution, the Parliament of the Federation has exclusive responsibilities concerning certain spheres; lands are deprived of the power to approve of legislation in several areas [174].

Other types of reforms that have been carried out in Europe during the last decades of the twentieth century can be defined as organizational reforms. They took place mostly under the great influence of the central government and intended to change the internal structure of territorial units. They included the following points: strengthening the role of mayors and elected councils; making the process of reaching decisions more open, public and democratic; increasing the role of the public in decision-making; applying the obligatory "rational" planning methods; changes in the local staff, changes in local rules for organizing the activities of authorities, etc.

The measures meant to promote more active participation of local institutions in the social and political life of states and transform them into reliable leaders of public policy (Italy, Great Britain, etc.) [174]. Therefore, the European countries have carried out and are still working on providing the society with information about the decentralization reform, its positive aspects and the results of implementation. For example, in France there is a National Commission for Public Debate, which is responsible for providing citizens with information and taking into account their wishes in the process of making certain decisions. 
The study of the experience of foreign countries enables us to define the following ways to improve the decentralization reform in Ukraine:

1) separation of responsibilities, rights and obligations of different levels of government in accordance with the principles of a democratic state, making achieving a balance of interests in the system of public relations possible;

2) development and implementation of regional policy aimed at ensuring equal local and regional development;

3 ) ensuring the implementation of the principle of subsidy as a way to overcome conflicts of interest between local executive authorities and local institutions;

4) ensuring the growth of territorial communities' responsibilities to solve the problems vital for them;

5) implementation of budget reform taking into account state and local interests [175].

\section{Mechanisms for implementing the decentralization reform in Ukraine at the present stage}

At present, the process of forming communities in our country is mostly spontaneous, without involving the results of scientific research and specialists' conclusions. Ukraine has a number of initiatives to raise residents' awareness about the decentralization reform, but their effectiveness is doubtful.

As a result, newly formed territorial communities are quite different from each other in the main topological criteria - the size of the territory and the population, as well as they are quite different in their income and budget subsidies. If the consolidation of some territorial units took place by force, the measures should be taken to mitigate the implementation of the reform. They may include:

1. Time adaptation. Conversions take quite a long period of time. Thus, the reform in Poland from the very beginning of its implementation was estimated to last for 2030 years, in Lithuania, Latvia, Finland it essentially took place for 15-16 years.

2. Gradualism. The detailed preparation and research of the administrative territories state are required. 
3. Taking into account the population's preferences. There is a need to perform local referendums, do opinion polls not only during transformations, but also in the development of the reform concept, to involve the public, representatives of local institutions into the special centres for the processing and implementation of the reform.

4. Substantiation of the criteria for the creation of new administrative and territorial units without specifying quantitative and qualitative characteristics, the possibility of applying an individual approach to each region.

5. Terms and methods of consolidation to choose from: the process of municipalities unification or establishing an intermunicipal partnership.

On the one hand, these mechanisms mitigate the reform process, on the other hand, they may lead to its delay and, as a result, the need to apply husher administrative measures.

One of the main tasks of administrative and territorial reforms should be to increase the efficiency of providing services to the population and bringing the authorities closer to people. Reforms should be carried out comprehensively on the basis of scientifically based programs close to reality, taking into account foreign experience, our previuos mistakes, social and cultural characteristics and potential of the regions.

As experience shows, more effective administrative and territorial reforms are those initiated directly by communities, and not imposed by the administrative method. But, if the initiative comes from the ruling authorities, a wide discussion of this issue and considering citizens' opinion should preceded this process. Of course, natural voluntary unification of territorial communities can be stimulated by the state, providing certain preferences and incentives.

A problematic challenge for reformers is that in the areas of communities unification, the responsibilities and power of local authorities of OTG, district (rayon) councils and RDA are duplicated. At the same time, there is a rayon (district) state administration and a rayon council with appropriate expenditures for their maintenance, as well as executive bodies of OTG with powers and funding determined by law. Relevant district councils usually make decisions on monetary land estimation and redistribution of transfers from the state budget. Rayon state administrations are also 
deprived of a significant number of responsibilities, which are legally carried out by the executive institutions of the OTG council.

One of the problems arising from the reorganization of territorial communities is the problem of ensuring the real capacity of the newly formed community unification of the relevant administrative and territorial unit. The key here is the availability of appropriate human resources, financial support and infrastructure development.

In fact, in the process of community unification, 3 types of financial capacity can be identified.

1) the potential or estimated capacity that hromada (community) should have, as defined in accordance with the perspective plan;

2) capacity, which is legally recognized by the Cabinet of Ministers of Ukraine in accordance with Article 9 of the Law of Ukraine "On Voluntary Unification of Territorial Communities";

3) real (true) capacity, which is determined after the community unification is formed and shows certain results of activity.

As experience shows, potential, legally recognized and real capacity coincide, as a rule, only for those community unification that have arisen around district centers.

Conversely, the creation of rural community unifications around settlements that did not have the status of administrative centers immediately causes the problem of qualified personnel support. At the same time, there is a need for such personnel who would be able to work in the conditions of expanding the powers of local authorities and solving tasks that were not previously typical for local authorities.

Based on the first stages of the decentralization process in our country, taking into account foreign experience and opportunities that exist in Ukraine to solve the issue of ensuring the financial capacity of territorial communities, it is proposed to develop urban-type settlements and villages around large cities by providing jobs for young people, developing infrastructure, promoting investment for the implementation of promising innovative projects, which will increase their competitiveness, and thereby financial capacity. 


\section{5 Трейд-маркетинг как современная концепция совершенствования системы распределения}

Динамизм внешней среды и изменение условий хозяйствования предприятий обусловливает необходимость разработки новых подходов и технологий работы на рынке, связанных с необходимостью поиска резервов сокращения затрат в процессе доведения продукции до потребителя, оптимизации логистических бизнес-процессов, более полного удовлетворения потребностей и предпочтений потребителей.

Сегодня в отношениях между производителями, дистрибьюторами и ритейлерами происходит смена властных отношений, связанная с консолидацией розничных сетей, появлением новых форматов розничной торговли и жесткой конкуренцией в каналах распределения продукции. Необходимость совершенствования маркетинговой деятельности, усиливающаяся власть ритейлеров в переговорах и сильное влияние, которое они оказывают на процесс принятия решения о покупке конечным потребителем, заставили производителей искать новые направления в реализации своей маркетинговой стратегии, a также новые способы сотрудничества с посредниками канала для достижения своих целей продаж. В этих условиях трейд-маркетинг становится эффективной практикой для расширения сотрудничества и маркетингового взаимодействия в каналах распределения продукции, поскольку производитель рассматривает каждого участника канала как ценного уникального клиента, который является источником роста потребительской ценности товара.

Несмотря на значительное количество исследований в этом направлении, до сих пор отсутствует концептуальная ясность в теоретических и практических разработках, касающихся формирования системы трейд-маркетинга, что требует систематизации и существенной проработки данных вопросов. По нашему мнению, концепция трейд-маркетинга - это научно обоснованная система принципов, подходов и взглядов на процесс взаимодействия участников 
маркетинговой системы распределения по формированию уникального ценностного предложения, позволяющая обеспечить создание высокой потребительской ценности для потребителя, а также стимулировать рост рыночной активности. Теоретический базис формирования концепции, определяющий цели, задачи, принципы, объект, предмет и категории концепции трейд-маркетинга представлен на рисунке 1.

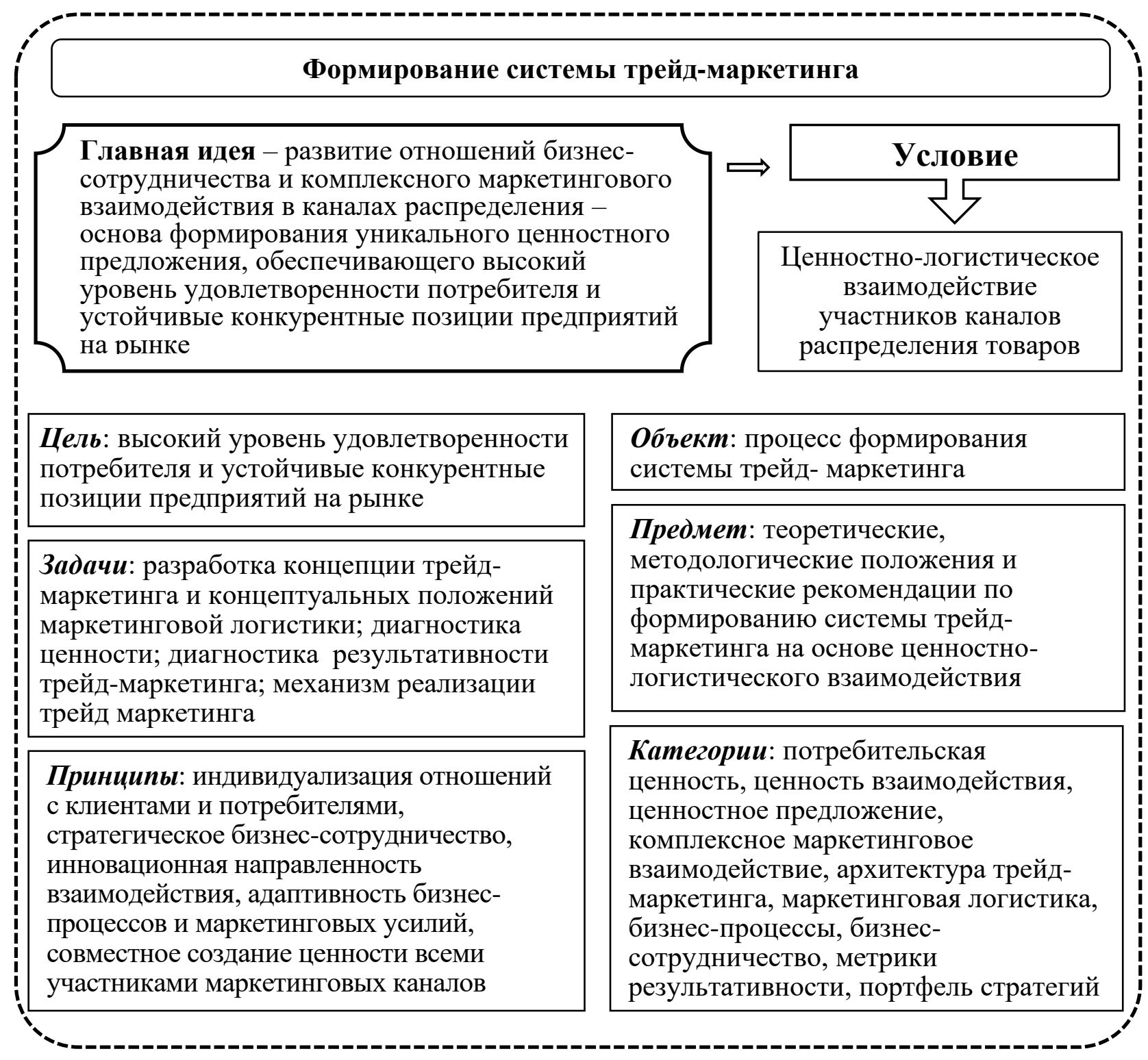

Рисунок 1. Теоретический базис формирования концепции трейд-маркетинга

Трейд-маркетинг предполагает совместную деятельность производителей, дистрибьюторов и ритейлеров в каналах распределения продукции, 
обеспечивающую достижение баланса интересов функционально связанных бизнес-субъектов в процессе доведения товаров от производителя до потребителя. Отметим, что содержание трейд-маркетинговой деятельности имеет свою специфику в зависимости от уровня маркетингового канала. Так, маркетинговые действия производителя направлены на формирование ассортимента товаров с ориентацией на спрос потребителей, разработку ценовой политики, организацию системы сбыта товаров и построение архитектуры каналов распределения продукции, разработку политики продвижения. Маркетинговые действия дистрибьютора - это выполнение функций физического перемещения товаров от производителя до потребителя, разработка и внедрение стандартов сервисного обслуживания, работа с торговыми представителями. Маркетинговые действия ритейлера связаны с организацией процесса продажи в магазинах, здесь особое значение имеет мерчендайзинг, программы лояльности потребителей, ценовое стимулирование покупателей, стимулирование сбыта и др.

Разнообразие маркетинговых действий в процессе осуществления трейдмаркетинга требует уточнения его структуры, поскольку многие предприятия используют трейд-маркетинг в качестве инструментария, направленного только на продвижение и реализацию товаров в местах продаж. Между тем, концепция трейд-маркетинга является более широкой, превратившись в модель партнерства между производителями и каналами распределения их продукции с использованием эффективной маркетинговой стратегии, логистического подхода, современных информационных технологий.

В настоящее время не существует единой точки зрения на содержание трейд-маркетинговой деятельности в каналах распределения. Так, Д.Моралес определил пять ключевых областей взаимодействия между производителями, дистрибьюторами и ритейлерами: создание базы данных о конкурентах (маркетинговая активность, рекламная политика, конкурентная стратегия), а также о предпочтениях и мотивациях покупок конечных потребителей; создание планов для достижения целей бренда через каналы дистрибуции; определение возможности увеличения мощности каналов распределения; разработка 


\section{SOCIO-ECONOMIC AND MANAGEMENT CONCEPTS}

креативных способов увеличения объема продаж с помощью ориентированных на потребителя рекламных акций; обеспечение экономической жизнеспособности всех видов действий в каналах сбыта продукции [180]. К.Шинардет, указывает, что основное содержание трейд-маркетинга проявляется в адаптации продукта к требованиям конкретного дистрибьютора, проведении стимулирующих акций по отношению к посредникам (брендинг, мерчендайзинг, маркетинговые мероприятия в точках продаж (акции, реклама, управление пространством)). Кроме того, автор подчеркивает, что основой такого взаимодействия должен выступать электронный обмен данными (EDI) между участниками каналов [178].

М. Дюпюи и Э. Тиссье-Десборд указывают, что трейд-маркетинг не заменяет специфику маркетинга поставщика или специализацию розничной торговли, а определяет области сотрудничества между ними в области управления брендом, логистики, мерчендайзинга и продвижения [179].

По нашему мнению, современный комплекс трейд-маркетинга должен охватывать основной, логистический и обеспечивающий функционалы. Основной функционал трейд-маркетинга предполагает обеспечение максимального удовлетворения потребностей покупателей и создание потребительской ценности, а также обеспечение эффективного взаимодействия между производителями, дистрибьюторами и ритейлерами. В рамках основного функционала традиционный комплекс маркетинга приобретает определенную специфику и включает категорийный менеджмент, маркетинговую ценовую политику, маркетинговую политику распределения, мерчендайзинг, сервис, комаркетинг, маркетинговый персонал (команды торговых представителей, супервайзеров, мерчендайзеров).

Логистический функционал трейд-маркетинга обеспечивает повышение эффективности маркетингового управления потоковыми процессами предприятия в сфере распределения. Его основой является маркетинговая логистика, направленная на оптимизацию информационных, материальных и сервисных потоков, сопровождающих маркетинговую деятельность предприятий 


\section{SOCIO-ECONOMIC AND MANAGEMENT CONCEPTS}

на рынке, которая позволит вывести систему распределения товаров на качественно новый уровень и будет способствовать рационализации структуры и параметров товарных потоков, обеспечению надлежащего сервисного обслуживания потребителей и оптимизации расходов.

Обеспечивающий функционал трейд-маркетинга направлен на создание необходимых условий для реализации основного и логистического функционалов на основе информационно-аналитической поддержки взаимодействия; создания совместных маркетинговых фондов; планирования, организации, мотивации, контроля и координации усилий участников взаимодействия; адаптивного развития маркетинговых каналов распределения. Формирование инструментария адаптивного развития предполагает обеспечение гибкости и адекватности реагирования действий участников маркетинговых каналов на изменения окружающей среды посредством прогнозирования возможных изменений и тенденций развития, создания информационно-аналитических систем поддержки принятия решений, формирования стратегических альянсов и партнерства, изменения организационной структуры в соответствии с изменяющимися условиями функционирования предприятий и др.

Таким образом, предложенная концепция трейд-маркетинга позволит оптимизировать бизнес-процессы в маркетинговых каналах распределения, обеспечить долгосрочное сотрудничество и эффективное взаимодействие бизнес-партнеров, направив все усилия на предоставление уникального ценностного предложения для потребителя. 


\section{6 Прикладні рішення для розробки економічного механізму регулювання сталого розвитку галузей національної економіки}

Питання сталого розвитку галузей національної економіки виникло не одразу і стало результатом розвитку суспільства фактично після другої світової війни, коли людство тривалий час уникало глобальних руйнівних військових конфліктів і почався всесвітній перехід до суспільства споживання та поширення впливу ідеології та засад функціонування такого суспільства не лише на постіндустріальні країни, а й на весь світ. Як показали дослідження, досить цікавий матеріал щодо становлення ідеології сталого розвитку міститься, зокрема і на українській сторінці Вікіпедії. Початок роботи над формулюванням ідеології почався у середині 60-х років. У 1987 році в доповіді «Наше спільне майбутнє» Міжнародна комісія з довкілля і розвитку (МКНСР) під головуванням екс-прем’єра Норвегії Гру Харлем Брундтланд приділила основну увагу необхідності «сталого розвитку», як розвитку, який забезпечує потреби нинішнього покоління без завдання шкоди можливості майбутнього покоління задовольнити свої власні потреби $[181$, с. 2$]$. Це формулювання поняття «сталий розвиток» зараз широко використовується як базове в багатьох країнах. Крім того, вона стверджувала, що основна ідея людських суспільств має полягати в активізації пошуку кращого життя, добробуту.

Термін сталий розвиток було уведено у широкий обіг рішеннями Усесвітньої конференції 1992 року у Ріо-де-Жанейро щодо Порядку денного на XXI століття. У рішеннях Конференції Ріо-XXI сталий розвиток визначили як «розвиток, що задовольняє потреби теперішнього часу, не ставлячи під загрозу здатність майбутніх поколінь задовольняти свої власні потреби», тобто фактично формулювання Комісії Брундтланд. Ця конференція розглядала оточуюче середовище i соціально-економічний розвиток як взаємопов'язані i взаємозалежні області. Тобто йдеться про те, що основними ознаками принципу, або ідеології, сталого розвитку, є гармонійне поєднання соціального та економічного розвитку у процвітаючому довкіллі. 
Незважаючи на визначення під час конференції цілей сталого розвитку певних цілей та термінів з їх досягнення, на Йоганнесбурзькому саміті ООН 2002 року, присвяченому 10-літтю Ріо-XXI, було констатовано, що більшість цілей, визначених Pio-XXI, не лише не досягнуто, але й фактично не розпочалась робота над реальними планами з їх реалізації.

У рішеннях Йоганнесбургу було виокремлено питання розвитку рибо- та морегосподарської діяльності - присвячено окремий розділ Океани та узбережжя. Окремим пунктом згадано і аквакультуру: пункт 31 (h) сприяння сталому розвиткові аквакультури, включаючи дрібномасштабну аквакультуру, 3 урахуванням зростання іiї важливості для продовольчої безпеки та економічного розвитку. Цілі і цього саміту не було досягнуто, крім помітного поступу, хоч і 3 значним запізненням - у вирішенні питання створення морських районів що охороняються, та відчутного посилення боротьби з незаконним, нерегульованим та непідзвітним рибальством на міжнародному рівні.

Оскільки поступ у досягненні цілей сталого розвитку явно недостатній, то Генеральна асамблея ООН 2015 року ухвалила Порядок денний з досягнення цілей сталого розвитку до 2030 року. У цьому переліку цілей до 2030 року рибному господарству присвячено лише ціль 14 - причому з наголосом на морях та океанах. Річки та озера, тобто водойми суходолу, лишились без прямої уваги - як рибальство так і аквакультура. На відміну від рішень Йоганнесбургу, у Цілі сталого розвитку, визначені70-ю сесією Генеральної асамблеї ООН, що ухвалила у вересні 2015 року Резолюцію під назвою «Перетворення нашого світу: Порядок денний у сфері сталого розвитку на період до 2030 року», - прямі згадки про аквакультуру, а ні у Ціль 2 щодо ліквідації голоду, ані у Ціль14 щодо морів та океанів, не потрапили. На це, зокрема, звернули увагу і провідні фахівці ФАО під час напрацювання останнього огляду з питань прісноводного рибальства (ФАО, 2018 рік). Як відомо, 30 вересня 2019 року Президент України підписано Указ № 722/2019 «Про цілі сталого розвитку України». Останнім абзацем пункту 1 Указу, у якому перераховано цілі сталого розвитку до 2030 року, виголошені у резолюції Генеральної асамблеї ООН, зазначено, що «Цілі сталого розвитку 
України на період до 2030 року є орієнтирами для розроблення проєктів прогнозних і програмних документів, проєктів нормативно-правових актів 3 метою забезпечення збалансованості економічного, соціального та екологічного вимірів сталого розвитку України.»

Незважаючи на проголошення необхідності врахування у проєкті Стратегії розвитку рибного господарства України на період до 2025 року узгодження та врахування інтересів окремих галузей, такого узгодженого підходу не спостерігається. Варто підкреслити, що обговорення питань сталого розвитку у цілому, всеохоплююче, відбувалось паралельно з обговоренням питання сталого розвитку рибного господарства. Зокрема вже 1992 року у Канкунській декларації, ухваленій під час Канкунської конференції з відповідального рибного господарства, було сформульовано визначення сталого (відповідального) рибальства та аквакультури. Концепція відповідального (сталого) рибного господарства «включає в себе стале використання рибних ресурсів у гармонії 3 довкіллям; використання практик рибальства та аквакультури, які не шкідливі для екосистем, ресурсів та їх якості; включення доданої вартості таких продуктів шляхом застосування процесів переробки, які відповідають необхідним санітарним стандартам; ведення комерційної практики у спосіб, який забезпечуватиме споживачам доступ до продуктів високої якості». На виконання рішень Канкунської конференції було напрацьовано Кодекс ведення відповідального рибного господарства ФАО, де, крім іншого, виокремлено Главу 9 «Розвиток аквакультури», яка присвячена саме розвиткові аквакультури на принципах сталості. У розвиток зазначеного Кодексу було напрацьовано як узагальнюючий роз'яснювальний матеріал у серії Технічних керівництв 3 відповідального рибного господарства під назвою «Аквакультура», і більш детальні посібники, один 3 яких присвячений якраз веденню сталої аквакультури. I зветься він Екосистемний підхід до аквакультури: це i $\epsilon$ використання принципів сталого розвитку в аквакультурі.

Як можна зрозуміти з викладеного, а також дещо заглибитись у дискусії щодо того, що є сталий розвиток, то стає зрозуміло, що для оцінки того, чи є 


\section{SOCIO-ECONOMIC AND MANAGEMENT CONCEPTS}

розвиток сталим, потрібні якісь критерії, методи оцінки, ті ознаки, на які варто орієнтуватись за оцінки правильності чи неправильності наших дій щодо спрямування розвитку за напрямом сталості. Цьому має сприяти сертифікація різних напрямів рибогосподарської діяльності, зокрема i сертифікація виробництва продукції аквакультури. Питання детально було обговорено під час сесії підомітету ФАО з аквакультури у Бангкоці 2010 року та потім ухвалено сесією Комітету з рибного господарства ФАО 2011 року.

Маємо зауважити і ще такий момент. Запровадження принципів сталої аквакультури, яке характеризується підвищеними вимогами до мінімального негативного впливу на довкілля, одразу обертається - практично без виключень саме до зменшення обсягів виробництва за таких самих витрат або збільшення витрат у великих обсягах з метою підтримання таких самих обсягів. Тобто розвиток будь-якого виробництва, у нашому випадку - аквакультури, - за принципами сталості неминуче має призвести до зменшення фізичних обсягів або стагнації виробництва. Адже у першу чергу сталий розвиток - це про екологізацію виробництва в галузях національної економіки.

Таким чином, для уникнення негативної реакції суспільства потрібно, перш за все, опрацювати національну стратегію сталого розвитку, причому, як радить посібник ФАО, така стратегія має охоплювати проміжки часу, які можна виміряти, 3 конкретними завданнями, аналізом отриманих результатів i визначенням подальших кроків. У цілому можна сказати, що ідеологія сталого розвитку - це ідеологія постіндустріального суспільства, доволі багатих країн, до яких, на жаль, не належить Україна. Якщо ж Україна у своїй стратегії розвитку рибного господарства прибере непотрібні та фактично порожні гасла про ліквідацію продовольчої небезпеки за рахунок розвитку аквакультури - адже досягти двох цілей одночасно неможливо - і сталість, і обсяги, - то абсолютно реальним $\epsilon$ просування щонайменше аквакультури за напрямом сталого розвитку, оптимізації виробництва продукції аквакультури, усталення на досягнутих обсягах виробництва та розширення спектру, наприклад, інших видів 
SOCIO-ECONOMIC AND MANAGEMENT CONCEPTS

послуг, крім забезпечення продовольством, як екологічних, рекреаційних, освітніх, які й надає аквакультура як галузь національної економіки. 


\section{SOCIO-ECONOMIC AND MANAGEMENT CONCEPTS}

\section{7 Протидія держави «тінізації» економіки як чинник підвищення рівня ії економічної безпеки}

Категорії «економічна безпека» та «національної безпека» мають тісний зв'язок. Найважливішим принципом формування в Україні цивілізованих ринкових відносин $є$ досягнення економічної безпеки держави, оскільки загроза економічній безпеці є загрозою економічному суверенітету [189].

Наявність тіньової економіки є однією 3 найбільш істотних перешкод економічному зростанню країни та загрозою економічній безпеці держави.

Високий рівень «тінізації» економіки переважно притаманний країнам 3 низькою ефективністю системи державного управління, ключовими ознаками якої у цьому випадку $є$ відсутність перспективного бачення, недостатня професійна підготовка керівних кадрів, низька мотивація відповідальних контролюючих установ, недосконалість правової системи. Він свідчить про реальні загрози національній безпеці держави, є наслідком неефективного функціонування суспільно-економічної системи i, у свою чергу, стимулює іiі подальше розбалансування. Однією з головних загроз, які несе в собі тіньова економіка національній безпеці, можна вважати блокування створення ефективних механізмів управління соціально-економічним розвитком. Криза в цій сфері, у свою чергу, стимулює розвиток широкого спектру суспільних проблем [190].

При цьому слід зазначити, що критичність економічної ситуації в сучасних умовах полягає у тому, що або руйнівні процеси стануть незворотними й призведуть до втрати державності або, в кращому випадку, забезпечать Україні роль другорядної держави й сировинного придатку високорозвинутих країн, або ж вдасться зупинити негативні процеси, домогтися економічного зростання та гідного місця у світі [191]. У цьому контексті розширення обсягів тіньової економіки справляє деструктивний вплив на забезпечення економічної безпеки держави і національної в цілому.

У державах сучасного світу національна безпека стала невід’ємним 
атрибутом, своєрідним категоричним імперативом їх зовнішньої, внутрішньої та військової політики. Незважаючи на це, поняття національної безпеки залишається терміном із багатьма значеннями. На розуміння поняття національної безпеки впливають історичний i політичний досвід держав, характер політичних режимів, особливості міжнародної ситуації в конкретний історичний період, цілі зовнішньої та військової політики тощо. Національна безпека є системою оптимізації взаємовідносин між усвідомленими загрозами та ресурсами, що має суспільство для протидії цим загрозам. Загрози для суспільства є завжди, а рівень захищеності від них ніколи не буває максимальним. Тому національна безпека $є$ динамічним засобом досягнення i підтримки балансу між реальними та потенційними загрозами, з одного боку, та здатністю суб'єкта протидіяти їм, з іншого [192].

Головною складовою національної безпеки є економічна безпека, до загроз їй відносять явні чи потенційні дії, що ускладнюють або унеможливлюють реалізацію національних економічних інтересів і створюють небезпеку для соціально-економічної та політичної систем, національних цінностей, життєзабезпечення нації та окремої особи. До основних принципів забезпечення економічної безпеки України відносять [191]: верховенство закону під час забезпечення економічної безпеки; додержання балансу економічних інтересів особи, сім’і, суспільства, держави; взаємна відповідальність особи, сім’ї, суспільства, держави щодо забезпечення економічної безпеки; своєчасність i адекватність заходів, пов'язаних із відверненням загроз і захистом національних економічних інтересів; пріоритет договірних (мирних) заходів у вирішенні як внутрішніх, так і зовнішніх конфліктів економічного характеру; інтеграція національної економічної безпеки з міжнародною економічною безпекою.

Економічна безпека забезпечується як суто економічними методами, так і засобами неекономічного характеру: політичними, юридичними, правовими, спеціальними, військовими й іншими, включаючи захист секретів. У свою чергу, варто підкреслити, що безпека в суміжних позаекономічних сферах забезпечується не тільки специфічними для них методами, але значною мірою й 
економічними засобами, зокрема завжди 3 залученням грошових та інших ресурсів економічного характеру. Крім того, економічна оцінка наслідків загроз безпеці в будь-яких сферах, як правило, забезпечує універсальний підхід, даючи можливість кількісно оцінити збиток і на цій основі визначити систему пріоритетів [193]. Тому, головні зусилля мають бути спрямовані не на спроби найточнішого визначення обсягів тіньової економіки, а на усунення причин i умов надзвичайного їі поширення, оскільки держава підійшла до межі, за якою при подальшій загальній «тонізації» економіки може втратити важелі реального впливу на ситуацію [194].

Тіньова економіка - незареєстрована в установленому порядку економічна діяльність суб’єкта господарювання, яка характеризується мінімізацією витрат на виробництво товарів, виконання робіт та надання послуг, ухиленням від сплати податків, зборів (обов'язкових платежів), статистичного анкетування та подання статистичної звітності, наслідком якого є порушення законодавчо встановлених норм (рівень мінімальної заробітної плати, тривалість робочого часу, умови і безпека праці тощо) [195].

Вона являє собою уклад економічних відносин, що охоплює невраховані, нерегламентовані й незаконні види господарської діяльності. У кожній країні $є$ така складова економічної діяльності, що не укладається в сформовані й узаконені норми. Цей сектор економіки в різних країнах називається по-різному: у Франції - «підземна», «неформальна» економіка; в Італії - «таємна», «підводна»; в Англії - «неофіційна», «підпільна», «схована»; у Німеччині «стіньова». За сферою діяльності до тіньової економіки різні автори відносять різні види діяльності. Одні вважають, що тіньова економіка охоплює насамперед кримінальну діяльність; інші зазначають, що тіньова економіка як особливий сектор утворюється тими, хто ухиляється від сплати податків. У Німеччині до тіньової економіки спочатку зараховували лише фінансові таємні угоди. В ООН фахівці, що займаються національними рахунками, тіньову економіку поділяють на три види діяльності: приховану (або тіньову), неформальну (або неофіційну) й нелегальну. Прихована діяльність характеризує дозволену законом працю, що 
офіційно не оголошується або їі результати занижуються з метою відсторонення від сплати податків. Неформальна діє на законній підставі й націлена на виробництво товарів та послуг для задоволення власних потреб домашніх господарств (наприклад, власними силами індивідуальне будівництво). Нелегальна - це діяльність, що здійснюється найманими робітниками без юридичного оформлення договору [196].

Найточніше сутність та природу виникнення нелегальної економіки встановив провідний перуанський економіст Ернандо де Сото, який сформулював такі принципові положення [196]: 1) нелегальна економіка (стихійна реакція народу на неспроможність держави задовольняти основні потреби зубожілих мас); 2) «чорний» ринок (реакція мас на систему, що традиційно ставить їх у положення жертв свого роду правового і економічного апартеїду. В існуючій системі приймаються закони, які роблять нездійсненним природне прагнення народу мати роботу й дах над головою. У цих умовах маси перестають дотримуватись законів, виходять на вулиці, щоб продати те, що можуть, створюють власні магазини, там, де немає роботи, вони знаходять їі, навчаючись ремеслам, про які більшість 3 них до тієї пори не мала поняття); 3) залучені до тіньової діяльності живуть більш благополучно, коли порушують закон, порівняно з тим, якщо поважають його. Можна стверджувати, що незаконна діяльність процвітає, якщо правові обмеження перевищують деякий соціально прийнятний рівень і при цьому держава не має достатньої силу щодо примушування; 4) особистості самі по собі не є «тінями», тіньовими є їхні дії й діяльність. Ті, хто діє нелегальним образом, не становлять певний сектор суспільства. Люди прагнуть попасти у тіньову економіку, коли витрати при дотриманні закону перевищують вигоди при його порушеннях.

Згідно 3 [195] причинами утворення тіньової економіки є: 1) обліковостатистичні: ухилення суб’єктів господарювання від звітування перед органами державної статистики та контролюючими органами; відсутність належної інформації, обумовлена недоліками методу статистичного охоплення діяльності суб’єктів господарювання та ведення статистичної звітності; 2) економічні: 
ухилення суб'єктів господарювання від державної реєстрації з метою уникнення від сплати податків, зборів (обов'язкових платежів); заниження суб'єктами господарювання відомостей про отримані доходи з метою зменшення суми сплачуваних податків, зборів (обов'язкових платежів).

Для інтегральної оцінки рівня тіньової економіки в Україні використовуються методи, усереднене значення результатів яких представляє характеристику стану та тенденцій розвитку тіньової економіки. Найбільш прийнятними для визначення обсягів тіньової економіки в умовах наявної статистичної бази $є$ такі методи: «витрати населення - роздрібний товарооборот», фінансовий, монетарний, електричний. Метод збитковості підприємств застосовується для оцінки мінімального та максимального коефіцієнтів, у межах яких знаходиться рівень тіньової економіки [195].

Розвиток неконтрольованої державою економічної діяльності сам по собі $є$ індикатором існування в державі певних деструктивних тенденцій [191].

До основних причин зростання тіньової економіки в Україні експерти відносять такі [194]: 1) високі податки і нерівномірність їх розподілу; 2) невиправдане звільнення значної частини суб'єктів господарювання від оподаткування; 3) недостатню прозорість податкового законодавства та постійне внесення змін до нього; 4) повільні та непрозорі приватизаційні процеси; корумпованість значної частини структур влади i особливо податкової адміністрації; 5) втручання влади у діяльність суб'єктів господарювання; соціально-економічна криза в країні, непослідовність економічних та соціальних реформ; 6) неврегульованість багатьох сторін суспільно-економічних та соціальних реформ; 7) відсутність стабільного законодавства, яке регламентує економічну діяльність; 8) прогалини в чинному законодавстві; 9) відсутність впевненості у гарантуванні захисту правоохоронними органами, підштовхує навіть законослухняних підприємців до рук злочинних угруповань 3 наступним укладанням «довгострокової угоди», яка стає звичайним інструментом здійснення платежів і усунення конкурентів. Розповсюджуються шахрайства, нав’язуються силові методи вирішення економічних питань, конкуренції. 
За даними [197] в Україні у першому кварталі 2020 року рівень тіньової економіки склав 31 \% від обсягу офіційного ВВП, що на 2 в.п. більше показника 2019 року. Зазначається, що досвід попередніх криз свідчить про очікування збільшення рівня тіньової економіки, адже в умовах значної невизначеності через поширення пандемії COVID-19 бізнес прагне зменшити ризики втрати ресурсів. У січні-квітні відбулось очікуване зменшення ділової та інвестиційної активності, як в середині країни, так і за їі межами. Також суттєво зросли збитки в економіці. Три з чотирьох методів, з використанням яких здійснюється оцінка рівня тіньової економіки, зафіксували таке [197]: метод «витрати населення роздрібний товарооборот і послуги» - 29 \% від обсягу офіційного ВВП; електричний метод - 27 \% від обсягу ВВП; монетарний метод - 29 \% від обсягу ВВП. Разом з тим метод збитковості підприємств показав збільшення рівня тіньової економіки до 38 \% від обсягу офіційного ВВП. В цілому рівень тіньової економіки у 2019 році склав 28 \% від обсягу офіційного ВВП України, що на 3 в.п. менше за показник 2018 року. За даними дослідження проведеного Ernst \& Young, у 33 країнах світу, серед яких Чеська Республіка, Польща, Словенія, Словаччина, Хорватія, Болгарія, Сербія, Боснія і Герцеговина. Історично рівень тіньової економіки серед зазначених країн коливався від 10,1\% до 26,9\% від обсягу ВВП [198]. Таким чином, слід зазначити, що позитивним слід вважати їі зменшення рівня тіньової економіки у 2019 році порівняно з 2018 роком, зважаючи при цьому на те, що рівень тіньової економіки в Україні фактично відповідає середньому їі рівню по цих країнах.

За оцінками Всесвітнього економічного форуму (ВЕФ) поширення тіньової економіки поряд з макроекономічною розбалансованістю визнано основними глобальними ризиками протягом найближчих десяти років на фоні обмеженості ресурсів. Обсяг ринків окремих нелегальних товарів та послуг, за даними ВЕФ, оцінюється на рівні: підроблених лікарських засобів - 200 млрд дол. США, проституції - 190, марихуани - 140, підробленої електроніки - 100, кокаїну - 80, піратського програмного забезпечення - 50, торгівлі людьми - 30, злочинів у сфері охорони навколишнього середовища та торгівлі природними ресурсами - 
20 млрд дол. США відповідно [199].

За оцінкою Фрідріха Шнайдера, тіньова економіка $\epsilon$ навіть кращим способом протидії рецесії, оскільки гроші, які люди заробляють нелегально, не відкладаються в банки, а витрачаються негайно, збільшуючи споживчий попит. Єдиною, хто програє, в даному випадку є держава [200].

Враховуючи зазначене можна констатувати, що в Україні необхідно посилювати роль держави, задля підвищення рівня іiі економічної безпеки, у формуванні комплексу заходів протидії «тінізації» економіки, основними з яких можуть бути такі:

1. Зменшення банківських ставок за кредитами для кредитування промисловості з урахуванням ії пріоритетності для забезпечення економічного зростання країни (для машинобудівного комплексу, будівельно-індустріального комплексу, легкої та харчової промисловості) та здешевлення послуг банківських установ.

2. Здійснення легалізації тіньових доходів. Б. Губський [195], зокрема, пропонує з метою прискорення легалізації «темно-сірої» економіки та переходу iï суб’ єктів на легальну, офіційну економіку здійснити: 1) економіко-правову інвентаризацію існуючих проявів так званих тіньових правопорушень i подальшою декриміналізацією більшості з них залежно від ступеня їх соціальноекономічної небезпеки; 2) пом'якшити та диференціювати штрафні санкції і покарання за несуттєві правопорушення; 3)підвищити ефективність захисту прав власності та інтересів підприємців з боку державної влади, усунути існуючі дискримінаційні елементи, що на цей час мають місце у чинному законодавстві; 4) суттєво спростити процедури реєстрації, звітності, врегулювання податкових і митних питань, скоротити мережу відповідних інстанцій, а також кількість обов'язкових відвідувань підприємців різноманітними комісіями та інспекціями; 5) створити правове поле цивілізованих відносин держслужбовців та підприємців, налагодити правову та організаційно-кадрову роботу 3 метою підвищення рівня професіоналізму та посилення відповідальності працівників державного апарату; 6) створити дійсно незалежної судово-слідчої системи, яка 
буде в змозі доводити кримінальні справи у сфері економічної злочинності до логічного завершення.

3. Підвищення рівня розвитку економіки за рахунок мобілізації фінансових ресурсів держави в розвиток пріоритетних секторів промисловості, зокрема виробничої діяльності тих підприємств, які спроможні здійснювати випуск продукції, що відноситься до 6-го та 7-го технологічних укладів. Особлива увага має бути приділена розвитку підприємств машинобудівного комплексу України, адже розвиток машинобудування може стати локомотивом подальшого розвитку економіки України [201-203]. 


\section{8 Електронний бізнес в Україні: стан, перспективи та проблеми розвитку}

Сьогодні ринок Інтернет-розрахунків розширюється 3 дивовижною швидкістю, адже звернувшись до інформаційної мережі можна отримати цілий спектр послуг.

Так, за даними Google в 2019 році, кількість українців, що мають постійний доступ в Інтернет, збільшується з кожним днем. За оцінками деяких експертів, на сьогодні вона складає близько 25 млн. чол. Цілком логічно, що разом із зростанням абонентської бази розвивається і вітчизняний сегмент Всесвітньої Мережі - стає більше Інтернет-магазинів, все частіше навіть не пов'язані 3 Мережею компанії ухвалюють рішення про прийом онлайн платежів за свої товари і послуги. Водночас стрімкий розвиток безготівкових розрахунків та розбудова інформаційного суспільства у нашій країні вимагає вирішення низки соціальних, організаційних, юридичних та інших проблем, що безпосередньо пов’язані із розвитком та становленням електронного бізнесу в Україні.

Якщо звернутись до Рейтингу "Електронної готовності країн світу», то необхідно відмітити, що згідно з цими статистичними даними Україна посідає лише 60 місце (рис.1.1.). Дані рейтингу свідчать наскільки сприятливі умови для розвитку електронного бізнесу в країні і яка готовність ринку до реалізації Інтернет-технологій, а також рівень споживання цифрових товарів і послуг компаніями і громадянами. За дослідженнями компанії ElVisti, індекс електронної готовності в першу чергу будується на загальному достатку громадян і країни та є похідним від економічного розвитку. 


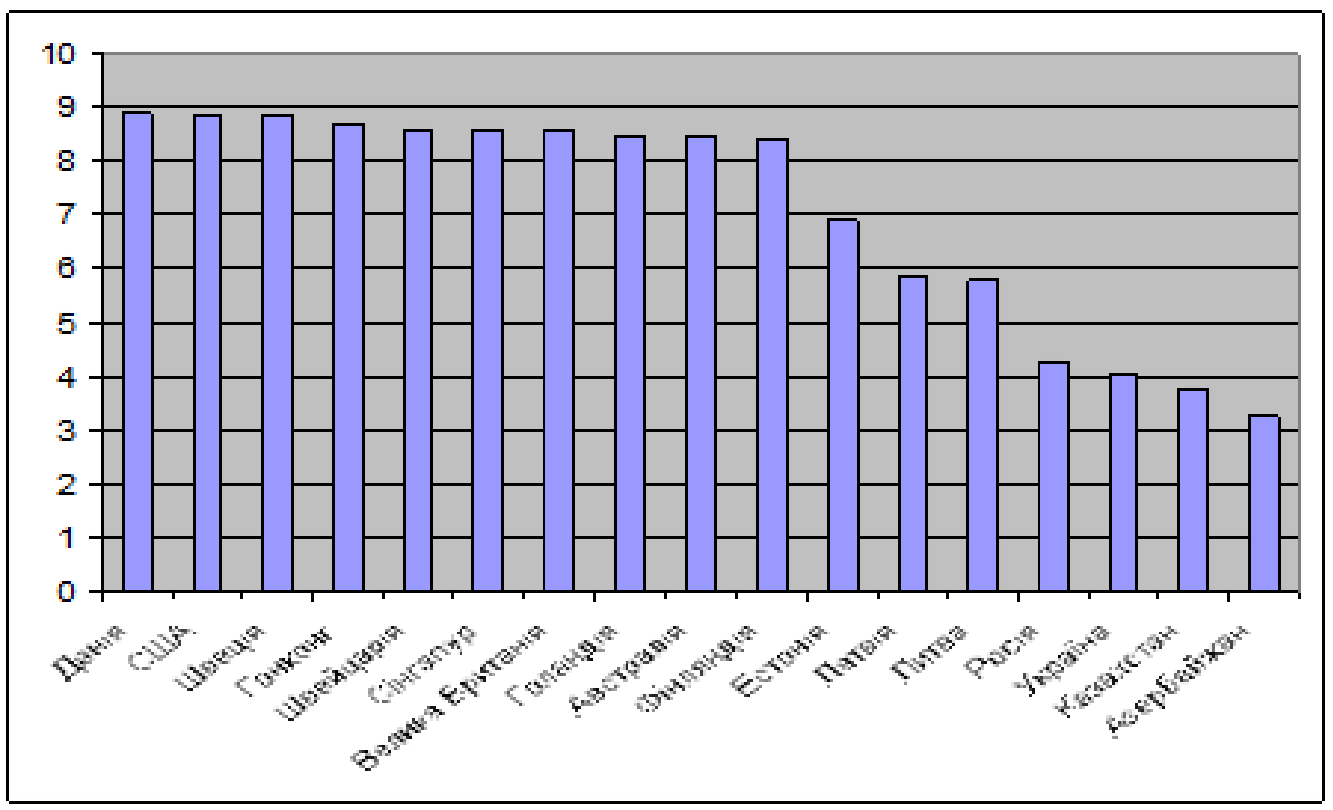

Рис. 1.1. Рейтинг "Електронної готовності країн світу-2018"

Протягом останніх декількох років ринок електронної комерції зростає і набуває глобальних масштабів. Безумовно, що тенденції Інтернет-торгівлі набувають все більшої популярності не лише у високо розвинутих країнах, але й у країнах, що розвиваються, а також країнах із перехідною економікою. Так чи інакше, на вітчизняному ринку електронна комерція та платежі стають дедалі частішим явищем. Так важливим кроком у переході на новий спосіб ведення економічної діяльності стало затвердження у 2017 р. Верховною Радою України Закону «Про електронну комерцію». Цей Закон визначає організаційно-правові засади діяльності у сфері електронної комерції в Україні, встановлює порядок вчинення електронних правочинів із застосуванням інформаційно телекомунікаційних систем та визначає права і обов'язки учасників відносин у сфері електронної комерції [204].

Важливо зауважити, що у більшості країн законодавчі акти щодо функціонування ринку електронної комерції були прийняті ще у кінці 90-их та на початку 2000-их років. Тому Україна чи не найпізніше регламентувала та затвердила законодавчу основу функціонування електронної комерції. Проте експерти все ж вважають, що говорити про чіткий регламент та контроль за 


\section{SOCIO-ECONOMIC AND MANAGEMENT CONCEPTS}

усіма суб’єктами електронної комерції говорити поки рано. Не зважаючи на кризові явища в країні та швидку девальвацію національної валюти, ринок електронної комерції в Україні продовжує зростати. Порівняно з 2016 роком у 2017 - зростання електронних замовлень та платежів відбулося на 20\%, у 2018 - близько 35 \% росту, і багато експертів прогнозують зростання частки електронної комерції у 2019 році аж до 45\%[205].

Глобальні тенденції розвитку електронної комерції та іiі поширення у глобальній мережі спонукає вітчизняний бізнес до реструктуризації та реінжинірингу основної діяльності та переходу до нових форм електронної торгівлі. Якщо наводити дані у грошовому вимірі, то обсяг продажів та замовлень в інтернеті на 2017 рік складав 25,5 млрд.грн, у 2018 - 34,2 млрд.грн, у 2019 аналітики прогнозують, що загальний обсяг замовлень складатиме близько 46 млрд.грн. [206]. Наразі найпопулярніша форма взаємодії економічних суб’єктів у реалізації будь-якої комерційної діяльності в Україні це В2С, тобто Бізнес до Споживача, елемент роздрібної торгівлі. Саме основним інструментом такої форми є спеціалізовані веб-сайти купівлі/продажу товарів, де економічні суб’єкти здійснюють свою комерційну діяльність. За статистичними даними організації UNCTAD, що займається моніторингом та аналізом електронного ринку та розвитком онлайн-торгівлі по всьому світі, у 2018 році Україна посіла 54 сходинку за розвитком електронної комерції зі 130 можливих. До слова, у 2016 році країна зайняла 58 сходинку [208].

Експерти стверджують, що беручи до уваги швидкі темпи розвитку та створення онлайн сервісів для продажу/купівлі товарів та послуг, до 2020 року цілком можливий вихід України до топ-30 країн світу з найшвидшими темпами розвитку електронної торгівлі. Позитивним моментом є рейтинг країн з різними типами економік, де у 2018 у категорії «Перехідні економіки» Україна увійшла в топ-10 країн з найвищим індексом електронної торгівлі та посіла 4 сходинку, після Македонії, Росії та Сербії. Також в Україні досить значна різниця між прогнозованою часткою онлайн-покупців серед усіх користувачів мережі Інтернет. За даними UNCTAD прогнозована частка онлайн- покупців складає 
$24,9 \%$, а фактична (реальна) досягає 44 . За величиною такої абсолютної різниці 19,1\%, а відносної - 77\%. [208] У 2017 році частка інтернет-покупців від всього населення складала 23\%, в той час як у Великобританії 74\%, а у США 69\%, у Норвегії показник сягає 79\%.

Окрім електронного ринку продажів товарів, зростає популярність послуг інтернет-банкінгу та платіжних операцій через інтернет. Сьогодні лідером за новітніми способами реалізації трансакцій є «Приватбанк», «Райффайзен Банк Аваль» та інші. Ці сервіси забезпечують здійснення будь-яких платежів через інтернет, а також створено додатки для мобільних телефонів, щоб зробити певну банківську операцію якомога зручнішою. Також перевагами електронної комерції користуються і служби доставки, без яких купівля електронної продукції практично не можлива. Сучасні служби доставки - 78 \% серед усіх способів доставки товару, вирізняються швидкістю передачі та оформлення платежів та товарів. I безумовно, що у своїй роботі вони використовують також комп’ютерні технології та новітнє програмне забезпечення. За даними української асоціації директ маркетингу найпотужнішою та найпопулярнішою комерційною (недержавною) службою доставки з Інтернет-магазинів є «Нова пошта», частка якої складає $21 \%$ зі загальної кількості доставки товарів, придбаних через Інтернет-сервіси [208]. Також все частішим явищем стає придбання авіаквитків чи залізничних квитків онлайн. «Укрзалізниця» 32015 року запустила продаж проїзних документів, придбаних в мережі Інтернет. Так за даними «Укрзалізниці» у 2016 році близько 5,8 млн. залізничних квитків було придбано за допомогою інтернету, а це складає близько $13 \%$ усіх продажів. Починаючи з 2018 року «Укрзалізниця» створила мобільну версію для купівлі квитків, яка одразу набула популярності.

Отже, до факторів, які певним чином перешкоджають повноцінному розвитку електронної комерції в Україні необхідно віднести:

- недостатній економічний потенціал і недовіра простого користувача;

- недостатній рівень державних гарантій і правових норм; 


\section{SOCIO-ECONOMIC AND MANAGEMENT CONCEPTS}

- нерозвиненість сервісу, доставки товарів і надання послуг;

Швидкість роботи сайтів і зручність використання у багатьох випадках залишає бажати кращого. Це визначається, мабуть, якістю устаткування, на якому працює компанія, і програмним забезпеченням.

Розвиток електронного бізнесу значною мірою буде залежати від політики держави у даній сфері діяльності, а саме: в першу чергу від встановлення нормативно-правової бази. Вирішення питань правового регулювання сфери Інтернет-послуг повинно стати основою для врегулювання наявних й потенційних ризиків, серед яких: ухилення від податків, шахрайство, порушення прав інтелектуальної власності та ін. Тому закріплення основ електронної комерції у Цивільному кодексі України та подальший розвиток правового регулювання сфери Інтернет-послуг повинні закласти фундамент для розквіту електронного бізнесу в нашій державі.

Також, на мою думку, держава повинна приділити більше уваги таким питанням, як: податкові пільги в сфері електронного бізнесу, вкладання коштів в освіту, високі технології, розвиток телекомунікацій, Інтернету, а також організацію їх інфраструктури.

Що стосується забезпечення безпеки даних та якості сервісу у сфері електронної комерції, то необхідно відзначити, що ці чинники в першу чергу залежать лише від діяльності самої організацій, що надає послуги у дані сфері бізнесу.

Можливо, використання електронного бізнесу в Україні не отримало такого масштабного розвитку як у таких країнах, як Данія, США, Швеція, Швейцарія та все одно наша держава має значні перспективи розвитку даної сфери діяльності, адже може врахувати досвід інших країн, які пройшли такий же шлях становлення та розвитку електронної комерції.

Українською владою визнається важливість застосування новітніх інструментів та належне функціонування ринку електронної комерції про що, зокрема, свідчить План заходів щодо дерегуляції господарської діяльності, затверджений Розпорядженням Кабінету Міністрів України № 615-р від 23 
серпня 2018 р. Згідно даного документу, передбачається прийняття актів, спрямованих на регулювання електронних правочинів, операцій 3 електронними грошима та електронного документообігу та інших нормативних документів у даній сфері.

Саме 3 метою визначення організаційно-правових засад діяльності у сфері електронної комерції, встановлення порядку вчинення електронних правочинів iз використанням інформаційно-телекомунікаційних систем парламентом прийнято основний нормативний документ у даній сфері - Закон України «Про електронну комерцію» № 675-VIII (далі - Закон № 675-VIII).

Донедавна визначення дефініції «електронна комерція» не існувало, однак цю прогалину було усунуто Законом № 675-VIII.

Так, відповідно п. 1 ч.1 ст. 3 Закону № 675-VIII, електронна комерція відносини, спрямовані на отримання прибутку, що виникають під час вчинення правочинів щодо набуття, зміни або припинення цивільних прав та обов'язків, здійснені дистанційно 3 використанням інформаційно-телекомунікаційних систем, внаслідок чого в учасників таких відносин виникають права та обов'язки майнового характеру.

Попри стрімкі темпи розвитку електронної комерції, вітчизняний ринок електронних платежів залишається на початковій стадії. Причинами цього $є$ низка проблем, які значно сповільнюють розвиток електронного бізнесу.

1. Безпечність. Незважаючи на те, що законодавча база функціонування електронної торгівлі уже створена, вона потребує значного вдосконалення щодо відповідальності за інтернет-шахрайства та кібератаки. Саме тому існує багато сумнівів щодо цілісності процесу оплати платежів 3 боку виробників, а також велика кількість підроблених (нереальних) сайтів, де може бути продемонстрований неіснуючий товар. Тобто, розвиток електронної комерції не можливий без ризиків хакерських атак та блокування цілого сайту.

2. Значні терміни доставки товарів. У зв'язку з швидким темпами розвитку технологій та електронних платежів, більшість підприємців ще не відпрацювали швидкого механізму доставки через погану логістичну систему. 


\section{SOCIO-ECONOMIC AND MANAGEMENT CONCEPTS}

I хоча однією 3 найбільш конкурентних переваг будь-якого онлайн-бізнесу, особливо з питань роздрібної торгівлі, є швидкість доставки товарів до споживачів і українська онлайн-комерція намагається вдосконалювати логістичну інфраструктуру. Тому дуже часто термін доставки складають від кількох днів до декількох тижнів.

3. Недостатня нормативно-правова база. Проблема полягає у частому порушенні прав інтелектуальної власності та відсутність контролю щодо цього. Також це не контрольованість державних органів щодо прав споживачів, які в електронній комерції часто можуть бути порушені. У зв'язку з відсутністю грунтовної юридичної бази з питань функціонування електронної комерції, не врегульовані чітко тарифи щодо оплати певних платежів. Також це проблема чіткої уніфікації положень актів та угод щодо купівлі/продажу товарів чи послуг.

4. Недостатня компетентність та кваліфікація працівників щодо застосування електронної комерції та інформаційних технологій. Дуже часто, як споживачі так i виробники, не володіють достатніми знаннями 3 користування технологіями, а тому не можуть бути застосовані для покращення ефективності продажів електронної комерції.

- Надзвичайно широка варіація товарів та втрати у часі. Обсяги інтернет-ресурсів збільшуються щороку вдвічі, пошукові системи дають багатотисячні запити, що часом може зробити процес вибору товару довготривалим.

5. Високі ризики невідповідності продукції 3 iї якісними та фізичними характеристиками у мережі, а значить низький рівень довіри населення до інтернет-покупок.

6. Відсутність обліку та офіційних статистичних даних держслужби статистики, яка б досліджувала питання розвитку електронної комерції та прогнозувала певні економічні тенденції.

7. Труднощі при укладанні договорів та фінансових угод, особливо на рівні Бізнес-Бізнес. Виникає проблема визначення часу, юридично- 
правового статусу такої угоди, а також методів та особливостей оподаткування електронного бізнесу.

У законодавчому забезпеченні е-бізнесу в різних країнах існують три підходи, які доповнюють один одного: перенесення на угоди норм чинного законодавства; регулювання угод за допомогою «звичаїв ділового обороту»; детальне узгодження сторонами положень для кожної угоди [209]. Розробку нормативної та законодавчої бази з огляду на стратегію інтеграції України в Свропу слід провадити з максимальним врахуванням відповідних Директив Свропейського Союзу (СС), прийнятих для формування загальних правил розвитку Інтернет та електронної комерції. Ці документи разом з відповідними нормативними актами ООН, Міжнародного валютного фонду (МВФ), Світової організації торгівлі (СОТ), Свропейського центрального банку та розвинутих країн доцільно розглядати як стратегічну та методологічну основу розробки національної нормативної бази. Адже сьогодні ми практично входимо у світ, де відсутні кордони для технологій, де господарська діяльність в таких ключових сферах, як телекомунікації, фінансові послуги, інформаційні технології, електронна торгівля займає все більше місця в єдиному, глобальному економічному просторі. Перший крок до формування міжнародного права у галузі електронної торгівлі зробила ООН 30 січня 1997 р., прийнявши Типовий закон «Про електронну торгівлю» (відомий як Типовий закон ЮНСИТРАЛ «Про електронну торгівлю»). Цей документ має рамковий, рекомендаційний характер і призначений, насамперед, для використання державами як основи для розробки національного законодавства.

Типовий закон заклав правові засади діяльності у сфері електронної торгівлі, ввів визначення основних понять (електронний документ, електронний документообіг, електронний підпис, автор електронного документа, інформаційна система), визнав юридичну і доказову силу за документами, вчиненими в електронній формі, визначив вимоги до електронного підпису як засобу підтвердження автентичності й цілісності електронного документа. 3 метою подальшого розвитку Типового закону державами-учасницями ООН 
розроблено проект міжнародної Конвенції «Про електронні операції», основним завданням якої $\epsilon$ вироблення єдиних i обов'язкових правил визначення порядку здійснення електронних операцій.

Важлива подія на шляху формування європейського права електронної комерції сталася 4 травня 2000 р., коли Європейським Парламентом була прийнята і 8 червня набула чинності Директива СС № 2000/31/ЕС «Про деякі правові аспекти послуг інформаційного суспільства та електронної комерції» [210], зокрема, на внутрішньому ринку. Директива зобов'язує державиучасниці забезпечити у своїх правових системах можливість укладання договорів (за деяким винятком) 3 використанням електронних засобів. Особлива увага приділяється необхідності роз'яснення процедури i регламентації чітких умов та юридичних наслідків для сторін, які уклали договори в рамках систем електронної комерції, визначено перелік і характер вимог щодо електронних договорів тощо. Також запропоновано принципи регулювання діяльності провайдерів та інших постачальників інформаційних послуг (у тому числі принцип виключення необхідності отримання попередніх санкцій або дозволів для здійснення діяльності подібних організацій, правила їх відповідальності, умови взаємодії цих організацій з національними органами судової влади щодо контролю і пошуку фактів або обставин незаконної діяльності споживачів послуг тощо). Іншим важливим документом, який формує європейське право електронної торгівлі, стала прийнята 13 грудня 1999 p. Директива СС № 1999/93/ЕС «Про правові основи Співтовариств для використання електронних підписів» [211], у якій визначені основні ознаки та поняття електронного підпису, принципи i сфери його застосування, визначаються принципи створення сертифікаційних центрів, порядок надання послуг сертифікації, обов'язки держав-учасниць щодо надання електронному підпису юридичної та доказової сили. Директива також передбачає, що держави - члени Свросоюзу повинні врегулювати правовий статус електронного підпису до кінця 2002 р.

Нарівні з міжнародними нормативними актами розвивається і національне 
законодавство в цій сфері. Відповідно до ст. 2 Угоди про співробітництво держав - учасниць СНД у створенні, використанні та розвитку міждержавної мережі інформаційно-маркетингових центрів для просування товарів і послуг на національні ринки від 21.05.2010 під електронною торгівлею розуміється торгівля, що здійснюється 3 використанням інформаційних систем, інформаційно-комунікаційної мережі та регламентів електронної взаємодії [212]. відповідно до абз. 15 ст. 1 Закону України «Про ліцензування певних видів господарської діяльності» під торгівлею розуміють будь-які операції, що здійснюються за договорами купівлі-продажу, міни, поставки та іншими цивільно-правовими договорами, які передбачають передачу прав власності на товари.

Відповідно до ст. 263 Господарського кодексу України [210] господарськоторговельною є діяльність, що здійснюється суб'єктами господарювання у сфері товарного обігу, спрямована на реалізацію продукції виробничотехнічного призначення і виробів народного споживання, а також допоміжна діяльність, яка забезпечує їх реалізацію шляхом надання відповідних послуг. Тобто діяльність, яка спрямована на реалізацію продукції, а також допоміжна діяльність, яка забезпечує їх реалізацію шляхом надання відповідних послуг. У запропонованому М. Швецем та В. Брижком проекті структури Кодексу України про інформацію один з підрозділів має назву «Електронна торгівля (комерція)». Проект Закону України «Про електронну комерцію» № 6086 від 18 лютого 2010 р., внесений Ю. В. Полунєвим, паралельно оперує поняттями «електронна комерція» та «електронна торгівля».

Неоднозначність у визначенні термінів пов'язана із рядом обставин. Поперше, поняття, які розглядаються, є предметом дослідження відразу кількох галузей наук - юридичної, економічної та технічної. Це значною мірою впливає на вибір дослідником найбільш суттєвих ознак терміна, а відтак безпосередньо на його зміст. Так, науковці часто наголошують на економічному аспекті електронної комерції, визначаючи ії як «різновид бізнес активності», «форму ділової активності (бізнесу, підприємництва)», «форми ділових угод» 
тощо. При цьому юридичний бік поняття зазвичай залишається нерозкритим. По-друге, неоднозначним залишається тлумачення поняття «комерція». Так, «Юридична енциклопедія» наводить визначення терміну «комерційна діяльність» як у вузькому (як діяльність у сфері торгівлі, торгового обміну), так і в ширшому розумінні (як діяльність, спрямована на отримання прибутку). Така двозначність зумовлена історією розвитку комерційних відносин, що, зародившись саме в торгівлі, поступово охоплюють дедалі більше сфер господарської діяльності. У зв'язку з цим деякі автори визначають електронну комерцію як «придбання чи продаж товару за допомогою електронних носіїв чи через мережу, подібну до Інтернет», цим самим звужуючи іiі розуміння до електронної торгівлі. Необхідно погодитися $з$ думкою О. Ю. Черняк, що для даних правовідносин доцільним $є$ використання саме терміну «електронна комерція», а не «електронна торгівля», оскільки, обмежуючи таку діяльність виключно торгівлею, ми спонукатимемо до обмеження ринку робіт та послуг у цій сфері, що не відповідатиме вимогам норм європейського законодавства в цій сфері, зокрема, Директиві 2000/31/ЄС Європейського парламенту та Ради від 8 червня 2000 року про деякі правові аспекти інформаційних послуг, зокрема, електронної комерції, на внутрішньому ринку («Директива про електронну комерцію») [208].

Щодо визначення поняття електронної комерції, то науковці здебільшого визначають іï через ознаки. Так, Н. Солов'яненко визначає електронну комерцію як укладання на міжнародних та внутрішніх ринках у комп'ютерній формі правочинів [208]. І. Т. Балабанов під електронною комерцією розуміє торгівлю через мережу Інтернет за допомогою комп'ютерів покупця та продавця [206]. А. Оперкент вказує, що електронна комерція - це економічний процес обміну товарами та послугами на базі існуючих партнерських зв'язків за допомогою електронних засобів комунікації [206]. Л. Новомлинський розуміє електронну комерцію як будь-яку трансакцію, яка вчиняється за допомогою мережі пов'язаних між собою комп'ютерів, по завершенні якої відбувається передача прав власності або прав користування речовим товаром чи послугою 
[207]. На думку Б. І. Скородумова, електронна комерція - це будь-яка форма бізнес-процесу, у якому взаємодія між суб'єктами відбувається електронним чином і супроводжується постачанням ресурсами та або фізичною доставкою продукції. А електронна торгівля, як він вважає, є частиною електронної комерції і стосується лише процесу продажів [208].

А. Чучковська визначає електронну комерцію як систему взаємопов'язаних правовідносин у сфері вчинення правочинів шляхом обміну електронними документами, який здійснюється за допомогою використання мереж електрозв'язку, зокрема Інтернет [208]. В. Желіховський під електронною комерцією розуміє систему взаємовідносин у сфері здійснення обміну даними (електронними документами) та інформацією між суб'єктами господарювання з використанням глобальної мережі Internet [208]. 


\section{SOCIO-ECONOMIC AND MANAGEMENT CONCEPTS}

\section{9 Адаптація агротехнологій до змін клімату в умовах південного степу України}

Зміни клімату - реальний факт. Чисельні наукові дослідження свідчать про те, що дискусій на цю тему стає усе менше. Очевидно, що до наслідків змін клімату варто готуватися вже сьогодні [213-217]. В сучасному зрошуваному землеробстві важливим є ретроспективний аналіз і перспективна оцінка впливу змін клімату на спрямованість формування еколого - агромеліоративного стану зрошуваних та прилеглих до них земель 3 метою розробки природоохоронних заходів та нормування меліоративних навантажень.

Одна із головних причина змін клімату - емісія газів із грунту в атмосферу, що досягла величезних масштабів і продовжує зростати. Основні причини емісії дегуміфікація, надмірне освоєння й інтенсифікація використання грунтів, зменьшення площі, зайнятої рослинністю, вирубка лісів, осушення гідроморфнихгрунтів, пожежі, які почастішали в останні роки, урбанізація, викиди «брудних» підприємств та інші (серед останніх домінують викиди транспорту із двигунами внутрішнього згоряння).

Збільшення температури повітря i, як наслідок температури грунту негативно впливає на фізичні, фізико-хімічні та агрономічні властивості грунтів, знижують активність грунтового процесу, рухомість поживних елементів i їх поглинання [214].

У грунтах Південного Степу України, за умов збільшення температури повітря і грунту, спостерігаються процеси ксерофітизація рослинності, міграції карбонатів та інших солей у профілі, посилення лужності i навіть зростання площі содозасолених грунтів. Спустелювання підсилюється внаслідок імпульверизації солей із прибережних морів (Азовське та Чорне море).

Зміни кліматунегативно впливають на властивості й режими грунтів: спостерігається цілком очевидне скорочення потужності верхнього горизонту через зниження вологозабезпеченості й погіршення активності грунтотворного процесу; деградація, через цементацію агрегатів і погіршення грунту як об’єкта 
обробітку (брилистість, структурність та ін.). Зміни клімату погіршують вологообмін, зменшується глибина проникнення коренів і, як наслідок, знижується адаптація сільськогосподарських рослин до нестачі вологи [214, 215].

Грунти Південного Степу України поступово втрачають свої екологічні функції, зменшується біорізноманіття, зниження активності біонаселення грунту, призводить до консервації багатьох міграційних, трансформаційних і обмінних процесів і в цілому до зниження стійкості грунту як центральної ланки біосфери.

При зниженні родючості і продуктивності грунтів, збільшується потреба у додатковому капіталі (збільшені доз мінеральних та органічних добрив, впровадження посухостійких сортів та гібридів, відновлення та розвитку зрошення $[214,215]$.

Методологія оцінки агрокліматичних показників та їх впливу на спрямованість формування еколого - агромеліоративного стану зрошуваних та прилеглих до них земель, продуктивність грунтів та ефективність ведення сільськогосподарського виробництва базується на статистичній обробці даних спостережень за попередній багаторічний період. Для сільськогосподарських меліорацій та зрошуваного землеробства важливим етапом $\epsilon$ визначення просторово-часових закономірностей регіонального прояву кліматичних змін 3 метою оцінки, моделювання та прогнозування його наслідків на різних рівнях досліджень, впливу на зональний перерозподіл вологозабезпечення та сумарне випаровування, зміну агрохімічних властивостей родючості грунтів тощо.

Динаміка і ритміка клімату на регіональних рівнях, значною мірою відображають особливості іiі прояву на глобальному рівні і навпаки. Постійні спостереження за температурою повітря і опадами із року в рік дають можливість виявити статистично обгрунтований зв'язок з річними глобальними і регіональними температурою повітря і опадами. Тому, актуальним є питання інтеграції в регіон Сухого Степу України циклу наукових досліджень, спрямованих на обгрунтування комплексу заходів, щодо забезпечення адаптації аграрного сектору економіки України до змін клімату. 
Зміни кліматичних показників Херсонської області яскраво демонструє графік коливань середньорічних температур повітря та суми атмосферних опадів, що наведені на рис. 1.

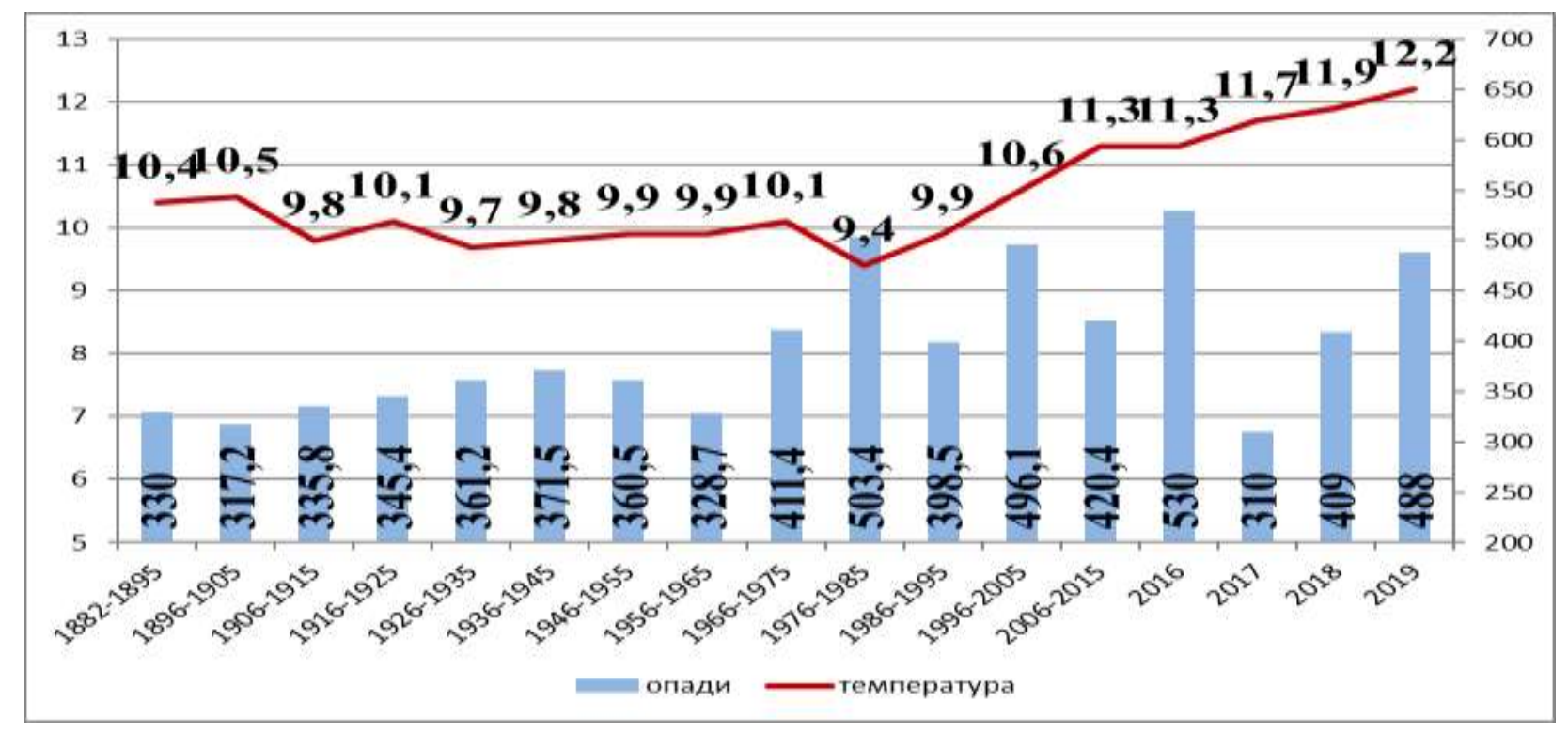

Рисунок 1. Середня кількість опадів та середньорічні температури повітря (за даними агрометеорологічної станції м. Херсон (1882-2019рр.)

За останні 30 років середньорічна температура повітря має сталу тенденцію до збільшення, а у 2019 році досягла максимальних значень $12,9^{\circ} \mathrm{C}$. Опади мають тенденцію до значних коливань, з мінімумом в останні роки 310 мм (2017р.).

Враховуючи результати досліджень змін клімату та коливань кількості опадів, які були проведені спеціалістами Херсонського ЦГМ, і наявність підтверджених даних про зниження річної кількості опадів в посушливі періоди, які настають через 10-15 років після періоду максимальних температур до 192 мм за рік (1891 рік), на нашу думку слід брати до уваги можливість подальшого зменшення кількості опадів в найближчі 15-20 років з досягненням мінімальних значень 230-250 мм за рік.

Існує думка, що недостатність опадів можливо компенсувати за рахунок зрошення, але слід враховувати, що навіть при річній нормі опадів на рівні 441 мм в рік ми уже маємо проблеми з наповненням водних об'єктів, у 2019-2020 роках 
вони заповнені менш ніж на $60 \%$, і як наслідок незадовільною якістю самої води в них. В той же час використання не якісної води при зрошенні може значно збільшити негативний вплив інших чинників змін клімату на якість грунтів.

Також слід брати до уваги, що збільшення температури атмосферного повітря в різних температурних діапазонах відбувається не рівномірно. Так у 2012 році загальне збільшення суми активних температур склало 19\%, а збільшення суми ефективних температур вище $15^{\circ} \mathrm{C}$ склало $63 \%$ (табл. 1). Такий розподіл свідчить про надходження на поверхню грунту в літній період на 63 \% більшої кількості теплової енергії, що призвело до збільшення середньодекадної температури грунту у липні 2012 року на глибині $5 \mathrm{~cm} 326,7^{\circ} \mathrm{C}$ до $31,1^{\circ} \mathrm{C}\left(+4.4^{\circ} \mathrm{C}\right)$, а на глибині $20 \mathrm{~cm} 3$ $25,9^{\circ} \mathrm{C}$ до $29,9^{\circ} \mathrm{C}\left(+4,0^{\circ} \mathrm{C}\right)$.

В умовах змін клімату відбувається зміна температури грунту, тому питання термінів посіву основних сільськогосподарських культур в Південному регіоні України є актуальним (табл. 2).

Таблиця 1.

Річна сума активних та ефективних температур за 2010-2019 роки по агрометеорологічній станції м. Херсон

\begin{tabular}{|c|c|c|c|c|c|c|c|}
\hline \multirow{2}{*}{ Роки } & \multicolumn{4}{|c|}{$\begin{array}{c}\text { Річна сума } \\
\text { активних температур }\end{array}$} & \multicolumn{3}{|c|}{$\begin{array}{c}\text { Річна сума } \\
\text { ефективних температур }\end{array}$} \\
\hline & вище $0^{0}$ & $\begin{array}{l}\text { вище } \\
+5^{0}\end{array}$ & $\begin{array}{l}\text { вище } \\
+10^{0}\end{array}$ & $\begin{array}{l}\text { вище } \\
+15^{0}\end{array}$ & $\begin{array}{l}\text { вище } \\
+5^{0}\end{array}$ & $\begin{array}{l}\text { вище } \\
+10^{0}\end{array}$ & $\begin{array}{l}\text { вище } \\
+15^{0}\end{array}$ \\
\hline 1 & 2 & 3 & 4 & 5 & 6 & 7 & 8 \\
\hline 2010 & $\frac{4443 *}{+13 \% * *}$ & $\begin{array}{l}4338 \\
+17 \%\end{array}$ & $\begin{array}{l}\frac{4066}{+21 \%} \\
\end{array}$ & $\begin{array}{l}\underline{3330} \\
+26 \%\end{array}$ & $\begin{array}{r}3142 \\
+21 \%\end{array}$ & $\begin{array}{l}\frac{1892}{+22 \%} \\
\end{array}$ & $\begin{array}{r}\frac{1042}{+40 \%} \\
+4\end{array}$ \\
\hline 2011 & $\begin{array}{l}\frac{4060}{+3 \%} \\
\end{array}$ & $\begin{array}{l}\frac{3795}{+2 \%} \\
+2 \%\end{array}$ & $\begin{array}{l}3534 \\
+5 \%\end{array}$ & $\begin{array}{r}3169 \\
+18 \%\end{array}$ & $\begin{array}{l}\frac{2720}{+4 \%} \\
\end{array}$ & $\begin{array}{l}\frac{1748}{+13 \%} \\
\end{array}$ & $\begin{array}{r}\frac{934}{25 \%} \\
+25 \%\end{array}$ \\
\hline 2012 & $\begin{array}{l}\frac{4688}{+19 \%} \\
\end{array}$ & $\begin{array}{l}\frac{4654}{+26 \%} \\
\end{array}$ & $\begin{array}{r}\underline{4293} \\
+27 \%\end{array}$ & $\begin{array}{r}3780 \\
+42 \%\end{array}$ & $\begin{array}{l}\underline{3388} \\
+30 \%\end{array}$ & $\begin{array}{r}\frac{2219}{+42 \%} \\
\end{array}$ & $\begin{array}{r}\frac{1246}{+67 \%} \\
\end{array}$ \\
\hline
\end{tabular}


Продовження таблиці 1.

\begin{tabular}{|c|c|c|c|c|c|c|c|}
\hline 1 & 2 & 3 & 4 & 5 & 6 & 7 & 8 \\
\hline \multirow{2}{*}{2013} & $\underline{4385}$ & $\underline{4120}$ & $\underline{3466}$ & $\underline{3211}$ & 2932 & 1788 & 1009 \\
\hline & $+12 \%$ & $+11 \%$ & $+3 \%$ & $+21 \%$ & $+16 \%$ & $+15 \%$ & $+35 \%$ \\
\hline \multirow{2}{*}{2014} & $\underline{4386}$ & $\underline{4228}$ & $\underline{3792}$ & $\underline{3050}$ & $\underline{2970}$ & $\underline{1860}$ & $\underline{1005}$ \\
\hline & $+11 \%$ & $+14 \%$ & $+13 \%$ & $+15 \%$ & $+14 \%$ & $+20 \%$ & $+35 \%$ \\
\hline \multirow{2}{*}{2015} & $\underline{4408}$ & $\underline{4176}$ & $\underline{3458}$ & $\underline{3228}$ & $\underline{2872}$ & $\underline{1788}$ & $\underline{979}$ \\
\hline & $+12 \%$ & $+13 \%$ & $+3 \%$ & $+22 \%$ & $+10 \%$ & $+15 \%$ & $+31 \%$ \\
\hline \multirow{2}{*}{2016} & $\underline{4345}$ & $\underline{4178}$ & $\underline{3710}$ & 2924 & $\underline{2910}$ & $\underline{1822}$ & $\underline{966}$ \\
\hline & $+10 \%$ & $+13 \%$ & $+11 \%$ & $+10 \%$ & $+11 \%$ & $+17 \%$ & $+29 \%$ \\
\hline \multirow{2}{*}{2017} & $\underline{4507}$ & $\underline{4275}$ & $\underline{3625}$ & $\underline{3262}$ & $\underline{2956}$ & $\underline{1826}$ & $\underline{1016}$ \\
\hline & $+15 \%$ & $+15 \%$ & $+8 \%$ & $+23 \%$ & $+13 \%$ & $+18 \%$ & $+36 \%$ \\
\hline \multirow{2}{*}{2018} & $\underline{4419}$ & $\underline{4326}$ & $\underline{4194}$ & $\underline{3420}$ & $\underline{3191}$ & $\underline{2102}$ & $\underline{1127}$ \\
\hline & $+12 \%$ & $+17 \%$ & $+25 \%$ & $+29 \%$ & $+23 \%$ & $+35 \%$ & $+51 \%$ \\
\hline \multirow{2}{*}{2019} & 4549 & $\underline{4299}$ & $\underline{3856}$ & $\underline{2924}$ & $\underline{3017}$ & 1868 & $\underline{1031}$ \\
\hline & $+16 \%$ & $+19 \%$ & $+15 \%$ & $+10 \%$ & $+16 \%$ & $+20 \%$ & $+38 \%$ \\
\hline Середнє & 4419 & 4239 & 3799 & 3231 & 3010 & 1891 & 1035 \\
\hline $\begin{array}{c}\text { Середня } \\
\text { багаторічна } \\
\text { норма }\end{array}$ & 3926 & 3705 & 3357 & 2648 & 2604 & 1553 & 746 \\
\hline $\begin{array}{c}\text { Відхилення, } \\
{ }^{0} \mathrm{C}\end{array}$ & +493 & +534 & +442 & +583 & +406 & +338 & +285 \\
\hline $\begin{array}{c}\text { Відхилення, } \\
\%\end{array}$ & +13 & +14 & +13 & +12 & +16 & +22 & +38 \\
\hline
\end{tabular}

* - показник;

** - відсоток відхилення від середньо багаторічних показників. 
Таблиця 2.

Мінімальна температура для проростання насіння і з'явлення сходів різних культур

\begin{tabular}{|c|c|c|}
\hline $\begin{array}{c}\text { Сільськогосподарська } \\
\text { культура }\end{array}$ & $\begin{array}{c}\text { Проростання насіння } \\
\text { при } \mathrm{t}^{0} \mathrm{C}\end{array}$ & $\begin{array}{c}\text { 3'явлення сходів } \\
\text { при } \mathrm{t}^{0} \mathrm{C}\end{array}$ \\
\hline $\begin{array}{l}\text { Пшениця, жито, ячмінь, } \\
\text { овес, конюшина, люцерна, } \\
\text { віка яра, горох, сочевиця, } \\
\text { гірчиця, коноплі }\end{array}$ & $0-1,0$ & $2,0-3,0$ \\
\hline $\begin{array}{l}\text { Буряки, люпин, льон, } \\
\text { гречка, кормові боби }\end{array}$ & $3,0-4,0$ & $6,0-7,0$ \\
\hline Картопля, соняшник & $5,0-6,0$ & $8,0-9,0$ \\
\hline $\begin{array}{l}\text { Кукурудза, просо, соя, } \\
\text { суданська трава }\end{array}$ & $8,0-10,0$ & $10,0-11,0$ \\
\hline Сорго, квасоля & $10,0-12,0$ & $12,0-13,0$ \\
\hline Рис, арахіс, бавовник & $12,0-14,0$ & $14,0-15,0$ \\
\hline
\end{tabular}

Інтенсивність протікання найважливіших фізіологічних процесів $\mathrm{y}$ рослинах (фотосинтез, дихання, транспірація) безпосередньо залежить від температури грунту і навколишнього середовища. Температура грунту помітно впливає на ріст коренів. Більш розвинута коренева система краще використовує вологу та поживні речовини. Коливання температури грунту негативно впливає на ріст і розвиток рослин, часто призводить до ураження їх хворобами.

Кожна сільськогосподарська культура має індивідуальну реакцію на температуру в різні фази свого розвитку. Зрозуміло, що найкращі умови створюються при оптимальній температурі, адже саме тоді швидкість біохімічних реакцій досягає найбільшої величини. Ці особливості культур та сортів необхідно враховувати на всіх етапах вегетації, починаючи з визначення строків сівби. 
3 підвищенням грунтової температури прискорюються процеси асиміляції та синтезу органічних речовин, але разом з тим підвищується інтенсивність дихання рослин. У зв'язку з чим при надмірному підвищенні температури може скластися ситуація, при якій процеси синтезу речовин та їхньої витрати на дихання врівноважуються. Тобто рослина опиниться в так званому стані компенсаційної точки. А при різкому зниженні температури грунту в рослинах пригальмовуються, а інколи навіть порушуються, процеси обміну речовин, що може призвести, в тому числі, і до загибелі посіву.

Зміною строків сівби можна створити кращі умови для росту й розвитку рослин та уникнути настання несприятливих умов у критичні фази розвитку (табл. 3).

Таблиця 3.

Перехід середньої добової температури грунту на глибині 10 см через $+12^{\circ}$ весною (за даними Херсонського обласного центру з гідрометеорології)

\begin{tabular}{|c|c|}
\hline Роки & ГМС «Херсон» \\
\hline 1 & 2 \\
\hline 1990 & 02 квітня \\
\hline 1991 & 16 квітня \\
\hline 1992 & 16 квітня \\
\hline 1993 & 25 квітня \\
\hline 1994 & 13 квітня \\
\hline 1995 & 21 квітня \\
\hline 1996 & 23 квітня \\
\hline 1997 & 26 квітня \\
\hline 1998 & 5 квітня \\
\hline 1999 & 11 квітня \\
\hline 2000 & 14 квітня \\
\hline
\end{tabular}


Продовження таблиці 3.

\begin{tabular}{|c|c|}
\hline 1 & 2 \\
\hline 2001 & 11 квітня \\
\hline 2002 & 15 квітня \\
\hline 2003 & 23 квітня \\
\hline 2004 & 8 квітня \\
\hline 2005 & 9 квітня \\
\hline 2006 & 18 квітня \\
\hline 2007 & 20 квітня \\
\hline 2008 & 9 квітня \\
\hline 2009 & 5 квітня \\
\hline 2010 & 17 квітня \\
\hline 2011 & 19 квітня \\
\hline 2012 & 13 квітня \\
\hline 2013 & 17 квітня \\
\hline 2014 & 9 квітня \\
\hline 2015 & 12 квітня \\
\hline 2016 & 7 квітня \\
\hline 2017 & 27 квітня \\
\hline 2018 & 6 квітня \\
\hline 2019 & 21 квітня \\
\hline
\end{tabular}

Приклад адаптації строків сівби соняшнику в Південному регіоні Украӥни в умовах регіональних змін клімату. На сьогодні немає сталої наукової думки стосовно оптимальних строків сівби соняшнику. Оскільки різні сорти та гібриди неоднаково реагують на терміни висіву, та враховуючи те, що останніми роками у виробництві з'явилося багато нових гібридів, які відрізняються від попередників скоростиглістю, морфобіологічними ознаками, підвищеною стійкістю до затінення, хвороб, вилягання, вищою врожайністю та якістю продукції, актуальним і важливим для виробництва $є$ визначення оптимальних 
термінів висіву цієї культури за різних грунтово-кліматичних умов для покращання росту і розвитку рослин та підвищення продуктивності з одиниці площі [219].

Вчені і практики наводять дані про терміни посівів, які різняться між собою. Одні автори стверджують, що оптимальною температурою для посівів є 6-9 ${ }^{0} \mathrm{C}$, інші рекомендують проводити сівбу при температурі грунту $16{ }^{0} \mathrm{C}$, а треті називають 10-12 ${ }^{0} \mathrm{C}$ [220]. В південних областях України середня температура грунту $10-12{ }^{0} \mathrm{C}$ за календарем припадає на середину квітня, при оптимальної температури проростання $20^{\circ} \mathrm{C}$.

Оптимальний строк посіву гібридів соняшника 3 урахуванням їхніх біологічних особливостей настає у період, коли температура на глибині загортання насіння становить $10-12{ }^{\circ} \mathrm{C}$. За умов ранньої сівби період отримання сходів розтягується до 3-4 тижнів, сходи не дружні, зрідженні. При пізній сівбі часто відчувається дефіцит вологи у верхньому шарі грунту.

Оптимальною температурою грунту для посіву соняшнику є $10-12{ }^{0} \mathrm{C}$. В південному регіоні України середня температура грунту $10-12{ }^{0} \mathrm{C}$ за календарем припадає на квітень місяць. За період охоплений дослідженнями (1990-2019 рр.) перехід середньодобової температури грунту на глибині $10 \mathrm{~cm}$ через $+12^{\circ} \mathrm{C}$ весною коливався від початку до кінця квітня. У більшості років перехід температури середньодобової грунту на глибині $10 \mathrm{~cm}$ через $+12^{\circ} \mathrm{C}$ відбувався 3 6 по 20 квітня (табл. 4, рис. 2).

Таблиця 4

Перехід середньої добової температури грунту на глибині 10 см через $+12^{\circ} \mathrm{C}$ весною (метеостанція м. Херсон)

\begin{tabular}{|c|c|}
\hline $1-5$ квітня & $1990,1998,2009$ \\
\hline $6-10$ квітня & $2004,2005,2008,2014,2016,2018$ \\
\hline $11-15$ квітня & $1994,1999,2001,2012,2015$ \\
\hline $16-20$ квітня & $1991,1992,2006,2007,2010,2011,2013$ \\
\hline $21-25$ квітня & $1993,1995,1996,2003,2019$ \\
\hline $26-30$ квітня & 1997,2017 \\
\hline
\end{tabular}




\section{SOCIO-ECONOMIC AND MANAGEMENT CONCEPTS}

У роки із швидким нарощуванням температур оптимальні строки сівби соняшнику при середньодобової температури грунту на глибині 10 см через $+12^{\circ} \mathrm{C}$ були 31 по 5 квітня (1990, 1998, 2009 рр.). У ці роки вже в середині квітня добові температури повітря були більш $15^{\circ} \mathrm{C}$ - починається метеорологічне літо.

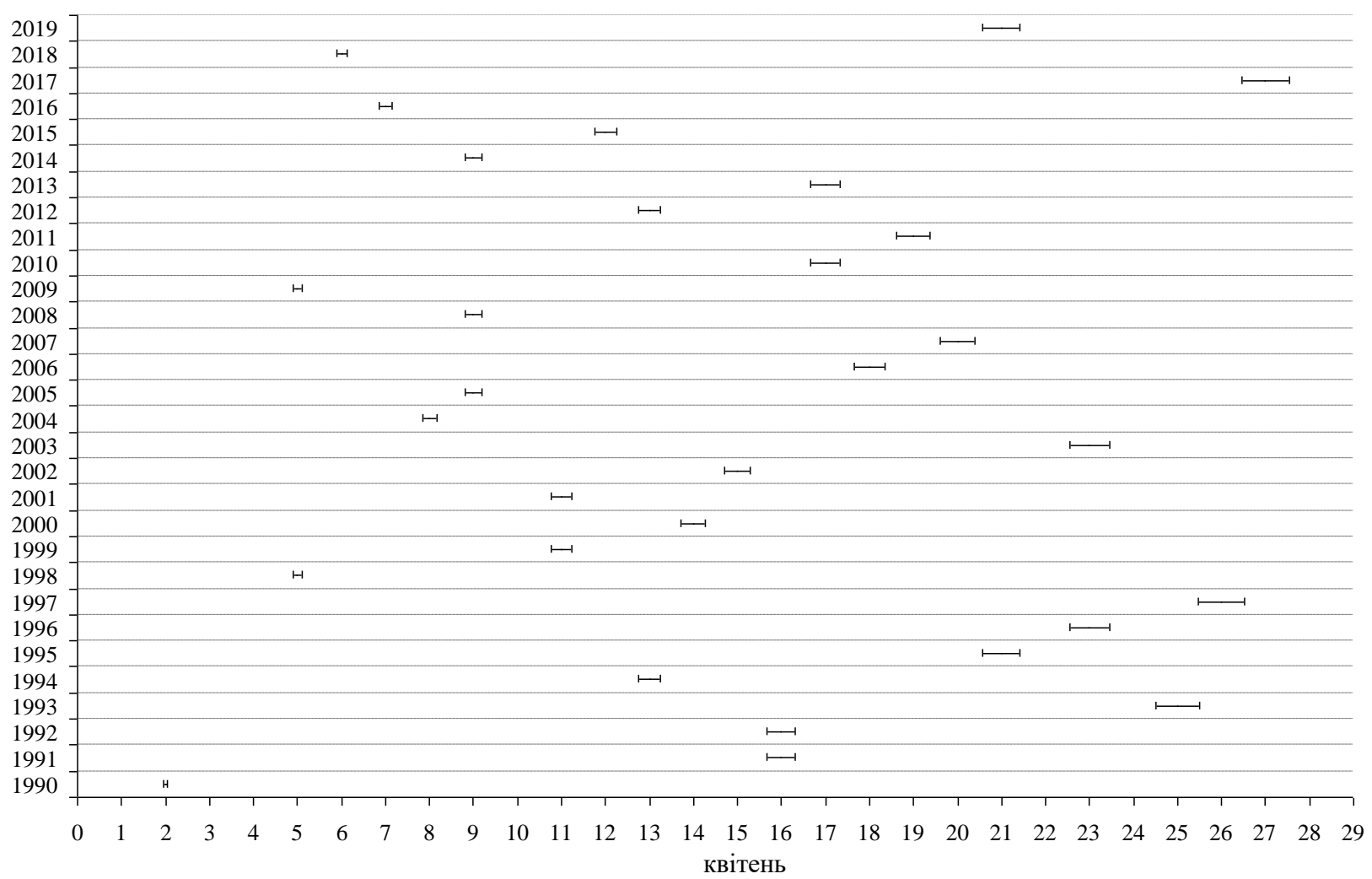

Рисунок 2. Оптимальні строки сівби соняшнику за температурою грунту (10-12 $\left.{ }^{\circ} \mathrm{C}\right)$ в Херсонській області (1990-2019 рр.)

За холодної весни оптимальні строки сівби соняшнику при середньодобової температури грунту на глибині 10 см через $+12^{\circ} \mathrm{C}$ були з 21 по 30 квітня (1993, 1996, 2003, 2017, 2019 рр.) (табл. 4).

Не менш важливим фактором для забезпечення росту та розвитку рослин соняшнику, є наявність вологи. Так, за багаторічними даними на першу та другу декаду квітня припадає максимальна кількість опадів весняного періоду (рис. 3).

Також слід враховувати таке метеорологічне явище, як заморозки. За багаторічними спостереженнями Херсонського обласного центру 3 
гідрометеорології у квітні місяці в Херсонській області в середньому спостерігається від 5 до 8 днів з заморозками. В окремі роки кількість днів 3 заморозками може становити від 10 до 20 днів.

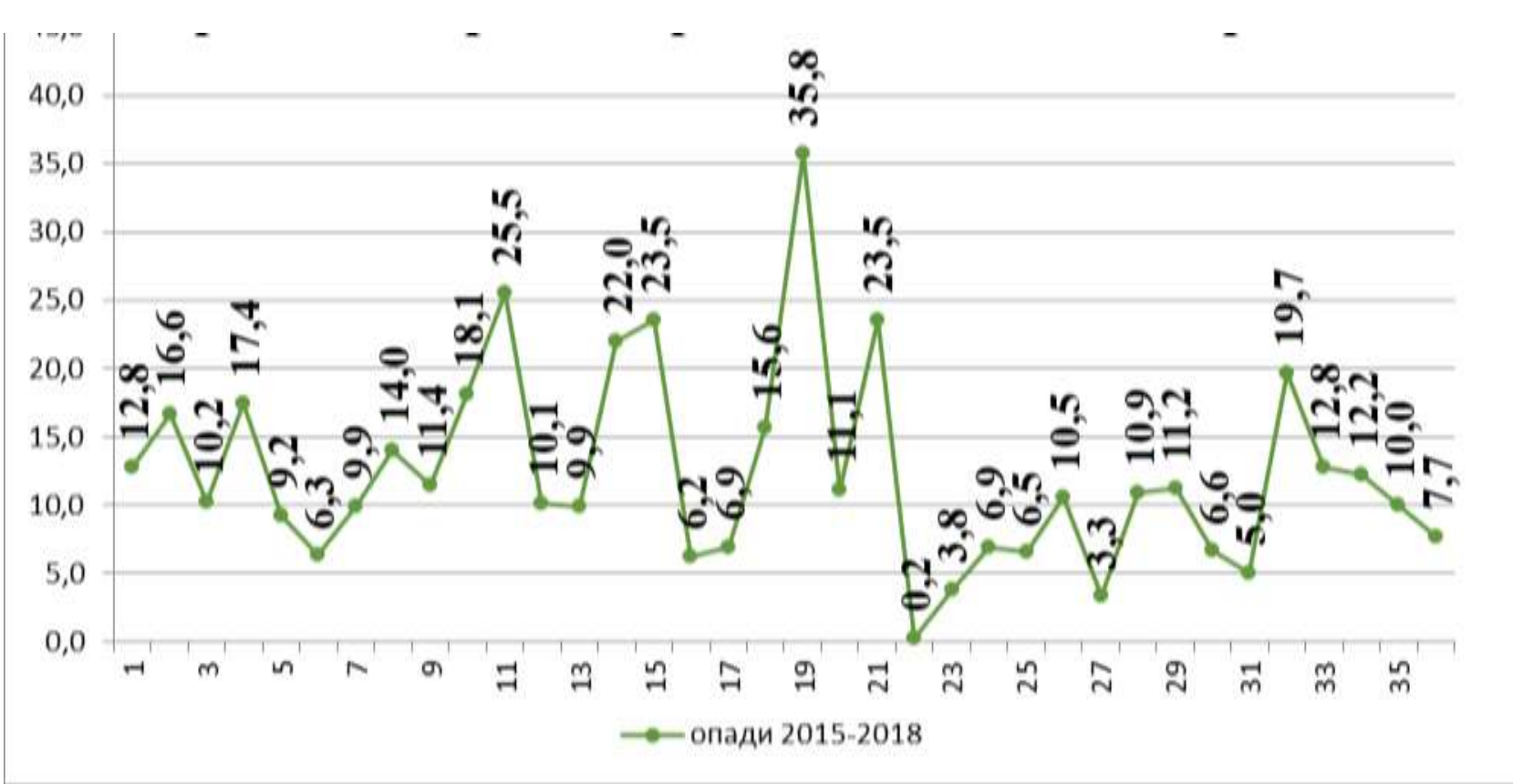

Рисунок 3. Середньо декадна кількість опадів у квітні (1990-2019рр.) за даними агрометеорологічної станції Херсон.

В умовах південного Степу діапазон оптимальних строків посівів соняшнику досить тривалий. За багаторічними спостереженнями по Херсонської області оптимальні строки сівби соняшнику за температурою прогрівання грунту та наявністю продуктивної вологи 36 по 20 квітня.

В результаті аналізу кліматичних показників (температура повітря, суми опадів) за даними ГМС "Херсон» Білозерського району Херсонської області в зоні Південного Степу Україні спостерігається самий тривалий за сторіччя період потепління.

За період охоплений дослідженнями (1990-2019 рр.) норма середньорічної температури повітря за рік по ГМС "Херсон» складає $10,2^{\circ} \mathrm{C}$. Найбільш високі середньорічні температури повітря відмічені у роки: $2015\left(12,8^{\circ} \mathrm{C}\right), 2017\left(12,4^{\circ} \mathrm{C}\right)$, 2007, $2018\left(12,2^{\circ} \mathrm{C}\right)$ та $2013\left(12,1^{\circ} \mathrm{C}\right)$ pр. Найбільш низькі середньорічні температури повітря відмічені у роки: 1990 (8,0 C), 1997 (9,0), 1996, 2003 
$\left(9,7^{\circ} \mathrm{C}\right)$ та $1992\left(9,8^{\circ} \mathrm{C}\right)$ (рис. 4). Максимальне значення було в $2017\left(12,4^{0} \mathrm{C}\right)$, мінімальне-в 1990 p. $\left(8,0^{\circ} \mathrm{C}\right)$.

За період досліджень (1990-2019рр.) спостерігається тенденція до збільшення середньорічної температури повітря по ГМС "Херсон». Швидкість зростання середньорічної температури повітря: у період з 1990 по 1999 рр. складає $0,1812^{\circ} \mathrm{C}$ за рік, у період з 1990 по 2009 pp. $+0,1143{ }^{\circ} \mathrm{C}$ за рік, а з 1990 по 2019 pp. $+0,1134^{\circ} \mathrm{C}$ за рік.

За вегетаційний період (IX-IX місяці) норма температури повітря по ГМС "Херсон» складає $18,2^{\circ} \mathrm{C}$. Найбільш високі середньорічні температури відмічені у роки: $2012\left(21,1^{\circ} \mathrm{C}\right), 2018\left(20,8^{\circ} \mathrm{C}\right), 2013\left(20,6^{\circ} \mathrm{C}\right)$ та $2007\left(20,2^{\circ} \mathrm{C}\right) \mathrm{pp}$. Найбільш низькі середньорічні температури відмічені у роки: $1997\left(16,6^{\circ} \mathrm{C}\right), 1990\left(17,2^{\circ} \mathrm{C}\right)$, $2004\left(17,3^{\circ} \mathrm{C}\right)$ та $1992\left(17,4^{\circ} \mathrm{C}\right)$ рр.. (рис. 5).

За період досліджень (1990-2018рр.) спостерігається тенденція до збільшення середньорічної температури повітря по ГМС "Херсон» за вегетаційний період, що підтверджується рівнянням регресії (рис. 5). Швидкість зростання середньорічної температури повітря: у період з 1990 по 1999 рр. складає $0,117^{\circ} \mathrm{C}$ за рік, у період з 1990 по 2009 pp. $-0,0839^{\circ} \mathrm{C}$ за рік, а з 1990 по $2019 \mathrm{pp}-0,0961^{\circ} \mathrm{C}$ за рік. 


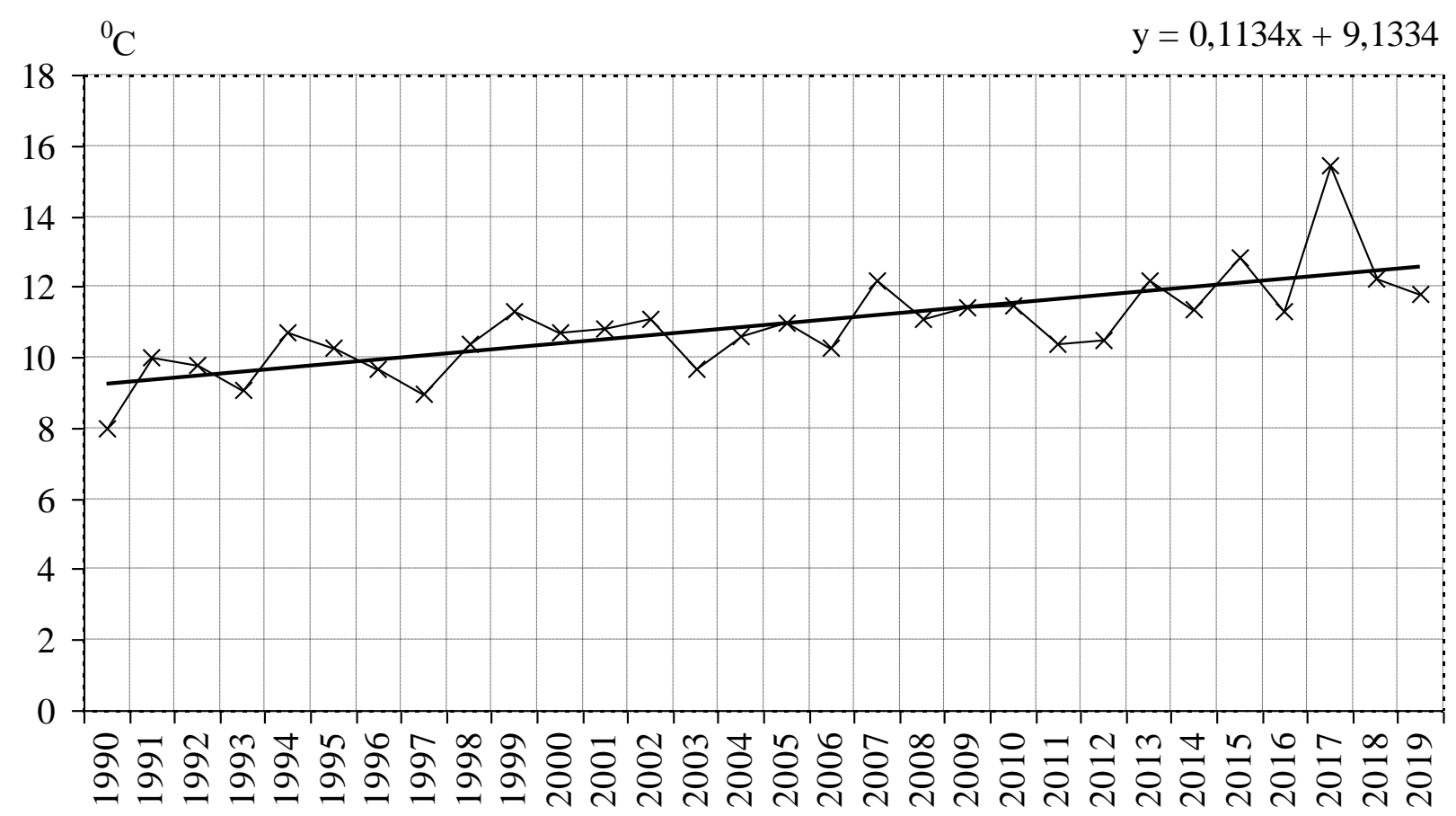

Рисунок 4. Середньорічна температура повітря по ГМС "Херсон"

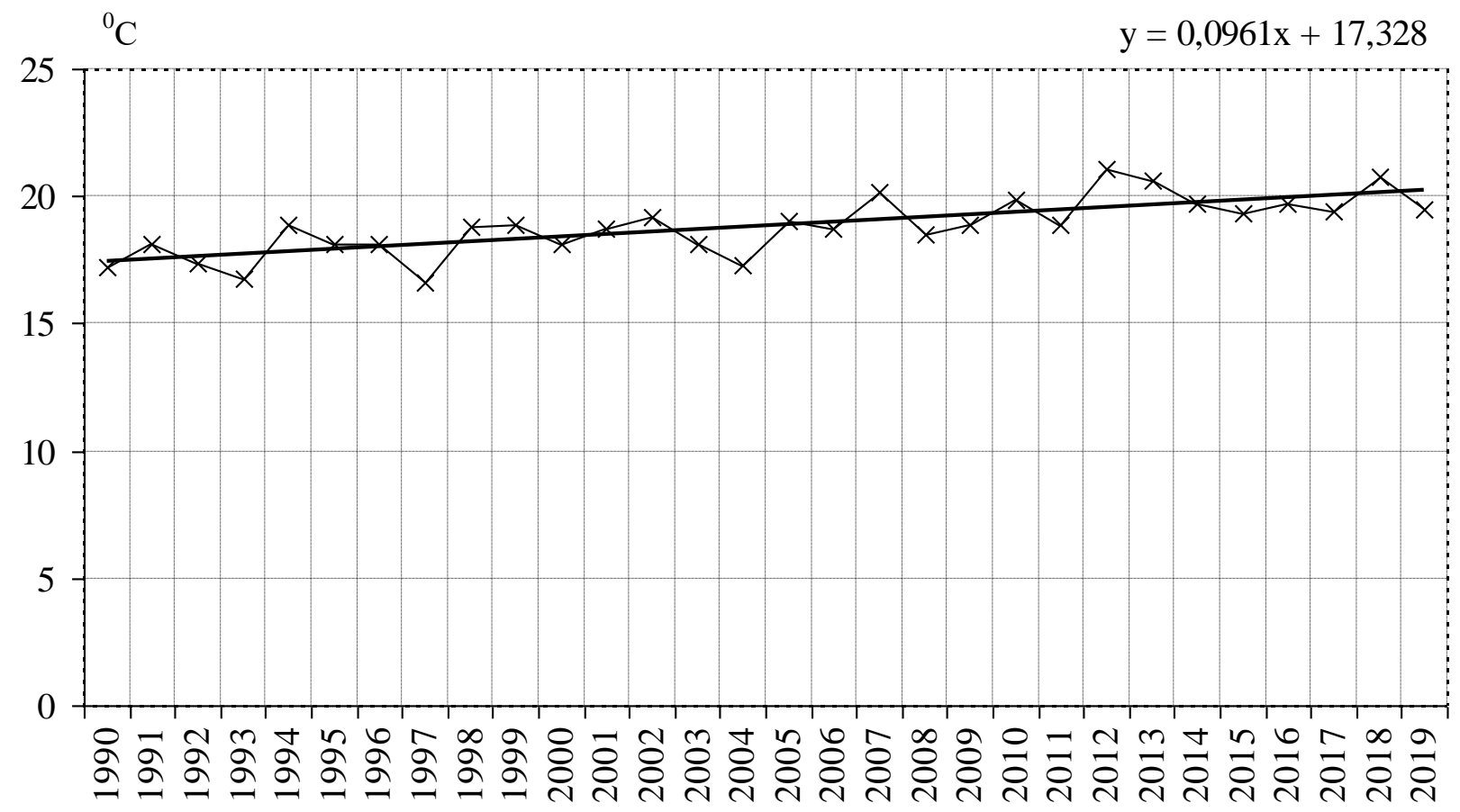

Рисунок 5. Середня температура повітря за вегетаційний період (IX-IX місяці) по ГМС "Херсон" 
Максимальна кількість атмосферних опадів за рік по ГМС "Херсон» становила від 701,1 до 703,5 мм (1997, 2004 рр.), що значно перевищувало середньомісячну норму 380,4 мм. Найменша кількість атмосферних опадів 310,9363,5 мм, що нижча від кліматичної норми на 69,5-16,9 мм, спостерігалась у 1991, 1992, 2004, 2006, 2013, 2014 та 2017 рр. (рис. 6).

За період досліджень (1990-2019рр.) спостерігається тенденція до збільшення суми атмосферних опадів по ГМС "Херсон» (рис. 6) Швидкість зростання кількості опадів (наростаючим підсумком): у період з 1990 по 1999 pp. складає 20,71 мм за рік, у період з 1990 по 2009 рp. - 3,63 мм за рік, а з 1990 по 2019 pp. - 49,12 мм за рік, але опади мають зливовий характер.

Максимальна кількість атмосферних опадів за вегетаційний період (IX-IX місяці) по ГМС "Херсон» становила від 315,3 до 426,6 мм (1997, 2000, 2004, 2008, 2014 рр.), що значно перевищувало середньомісячну норму 218,0 мм. Найменша кількість опадів 149,1-177,4 мм, що нижча від кліматичної норми на 68,9-40,6 мм, спостерігалась у 1992, 2002, 2011 та 2017 рр. (рис. 7).

За період досліджень (1990-2019рр.) спостерігається тенденція до незначного зменшення кількості атмосферних опадів за вегетаційний період по ГМС "Херсон» (рис. 8) За період з 1990 по 1999 рр. спостерігається тенденція до збільшення кількості опадів (швидкість зростання - 8,56 мм за рік.

За період з 1990 по 2009 рр. (наростаючим підсумком) спостерігається тенденція до збільшення кількості опадів (швидкість зростання - 0,23 мм за рік. За період з 1990 по 2019 рр. спостерігається тенденція до зменшення кількості опадів - 0,56 мм за рік.

Зміна температури повітря та кількості опадів у місячному розрізі по ГМС «Херсон» представлена в табл. 5. 


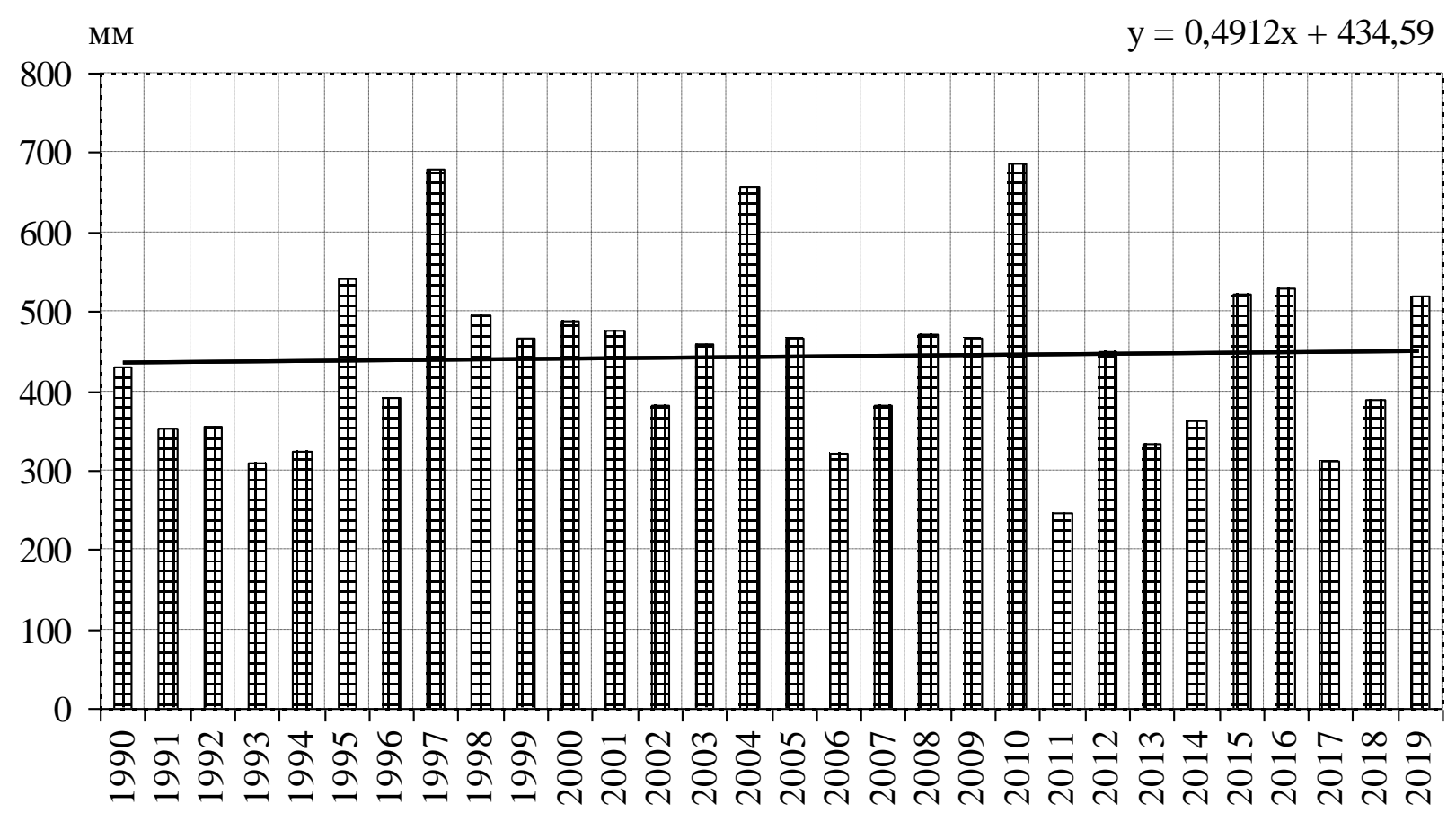

Рисунок 6. Сума опадів за рік по ГМС "Херсон"

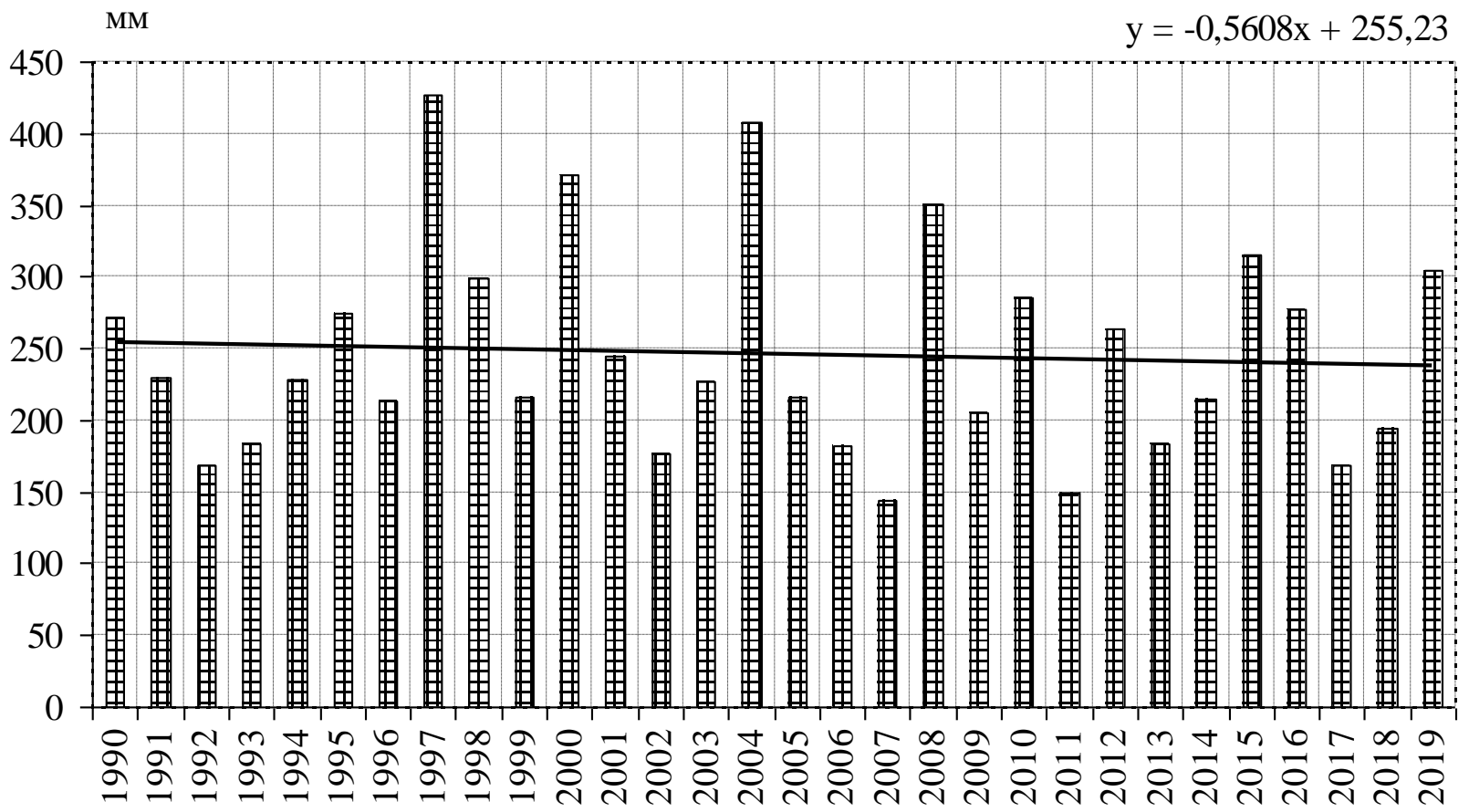

Рисунок 7. Сума опадів за вегетаційний період (IX-IX місяці) по ГМС "Херсон" 
Таблиця 5.

Зміна температури повітря та кількості опадів по місяцях (ГМС «Херсон»)

\begin{tabular}{|c|c|c|}
\hline Показники & Збільшення & Зменшення \\
\hline $\begin{array}{c}\text { Температура } \\
\text { повітря }\end{array}$ & $\begin{array}{l}\text { лютий, березень, квітень, } \\
\text { травень, червень, липень, } \\
\text { серпень, } \\
\text { жовтень, } \\
\text { груденень, }\end{array}$ & січень \\
\hline Сума опадів & $\begin{array}{l}\text { січень, лютий, березень, } \\
\text { квітень, липень, листопад }\end{array}$ & $\begin{array}{l}\text { травень, червень, серпень, } \\
\text { вересень, жовтень, } \\
\text { грудень }\end{array}$ \\
\hline
\end{tabular}

Висновки. За результатом ретроспективного аналізу змін клімату південного регіону України (на прикладі Херсонської області) визначено багаторічні особливості формування основних регіональних кліматичних показників (середньорічної температури повітря, суми річних опадів).

За останні 30 років середньорічна температура повітря має сталу тенденцію до збільшення, а у 2019 році досягла максимальних значень $12,9^{\circ} \mathrm{C}$. Опади мають тенденцію до значних коливань, з мінімумом в останні роки 310 мм (2017 р.).Визначено тенденцію до збільшення суми атмосферних опадів за рік та незначного їх зменшення за вегетаційний період по ГМС "Херсон». 


\section{SECTION 6. ECONOMY OF MANAGEMENT AND ADMINISTRATION OF RADIO TECHNOLOGY}

\subsection{The dynamics of development of the main types of food and beverage services in the hotel and restaurant entrepreneurship}

Restaurants and hotels were founded in every country around the world many years ago. In modern times, the economy of hotels and restaurants is closely related to the tourism industry, business travel, etc. In turn, the tourism industry is an important part of the economies of many countries in the world.

For example: «The U.S. travel and tourism industry generated over \$1.6 trillion in economic output in 2017, supporting 7.8 million U.S. jobs» [221]. Almost a fifth of this amount was travellers spent (more than $\$ 300$ billion) on traveller accommodations, they also spent more than $\$ 254$ billion on food services in 2017 [221].

According to various market forecasts, the annual growth of the global market for food services before the covid pandemic was estimated at about $4.3 \%$ in the world and $3.1 \%$ in Europe. But the covid pandemic has made its own tough adjustments. According to preliminary estimates, the annual growth of the global food services market in 2020-2027 will be about 2.2\% [222].

Due to the coronavirus pandemic, many restaurants and hotels in the world are suffering significant losses and are closing. For example, in Ukraine, restaurateur Savely Libkin closed eight out of ten of his restaurants this year. "And only two restaurants - «Kompot» on Deribasovskaya in Odessa and «Steak House» in Kyiv will operate in the take away mode through a special window» [223].

Therefore, the topic of providing hotels and restaurants with food remains especially acute and relevant in modern economic conditions.

The works of such scientists as Pam Tau Lee, Manish Gupta, O. Borisova, O. Vorobyov, O. Butenko, K. Gavrish, O. Golovko, N. Danko, M. Dolishniy, G. Krul, L. Kuzmenko, M. Malska, I. Minich, L. Nechayuk, J. Ostapenko, O. Shapovalova, O. Yurchenko and others are devoted to the research of problems of development of hotel and restaurant business. The works of these scientists explore various issues of hotel 
and restaurant business development. At the same time, there is no single classification of the main types of food and beverage services in the hotel and restaurant entrepreneurship. Also, the issues of the dynamics of development of the main types of food and beverage services on the context of the current coronavirus pandemic remain open. This article is devoted to the study of the above two aspects.

Generally, «The primary function of a restaurant is to provide food and drink to people outside the home» [224]. From the very beginning, in hotels, the function of feeding guests is a concomitant one.

However, since the 50s, the twentieth century, the role of the catering service in hotels as a source of income began to increase, and now it also brings significant profit almost equal to the role of rooms.

«Hence the increased attention to this service - hotel restaurants are becoming more and more luxurious, the number of them in one hotel is increasing, there are specialized restaurants with national cuisines, coffee houses, bars, etc.» [225].

Very close to the term hotel and restaurant business is the term HoReCa, - «is a sphere of hospitality and catering services... HoReCa (Horeca) is a segment of the service sector and a distribution channel for goods with direct consumption of goods at the point of sale». The term itself is an abbreviation from the words Hotel, Restaurant, Catering (Cafe) [226].

Similarly to $\mathrm{HoReCa}$, the marketing of providing food for hotels and restaurants can be divided into 2 groups:

1) Marketing of goods, which are sold directly inside the point of sale.

2) «Marketing of points of sale (hotels, restaurants, etc.). Marketing is carried out not only inside, but also outside the point of sale (company branding, loyalty programs, etc.)»[226].

Accordingly, the management of food provision for hotels and restaurants can be classified in several main areas:

- management of procurement, logistics and food delivery channels;

- management of conservation processes, processing and cooking; 


\section{SOCIO-ECONOMIC AND MANAGEMENT CONCEPTS}

- management of food and beverage services etc.

F\&B services can be a part of hotel business and it can also be an independent business. «Food and Beverage cost is the biggest cost for any restaurant which range between $30-40 \%$ of revenue depending on the style of restaurant» [227].

The star-ranked hotels often offer different F\&B services:

1. Restaurants serving lunch and breakfast of different cuisines of the world.

2. Lounge.

3. Coffee shops, often located on the ground floors.

4. Room service.

5. Poolside BBC outdoors.

6. Banquet service.

7. The hotel bar, like a nice place to sit down for a drink.

8. Outside catering service [228].

In the restaurants of hotel complexes usually offer the following food conditions: «1) full board, i.e. three meals a day (breakfast, lunch and dinner) - full board (FB);

2) half board, i.e. two meals a day (breakfast plus lunch or dinner) - half board (HB);

3) only breakfast, i.e. one-time meal - bed and breakfast (BB)» [9, c 140].

The scientific and professional literature distinguishes different views to the classification of types of service in restaurants. For example, in accordance with one classification, the following types of $\mathrm{F} \& \mathrm{~B}$ services in hotels and restaurants are distinguished: «1) Plate service, 2) Cart service, 3) Platter service, 4) Buffet service, 5) Family style service» [230].

Further, in accordance with this classification, the above-selected types are divided into 18 subcategories: 1. Table service, 2. English service, 3. French Service, 4. Silver Service, 5. American Service, 6. Russian Service, 7. Cart Service, 8. Snack Bar Service, 9. Self Service, 10. Buffet Service, 11.Cafeteria Service, 12.Sngle Point 
Service, 13.Room Service, 14. Take Away Service, 15. Mobile Pantries, 16. Blue Plate Service, 17. Automatic or Conveyer Belt Service, 18. Robotic Service [230].

According to another classification, the following types of food and beverage services are distinguished:

1. Table Service in seven variants:

1.1. English or Family Service

1.2. American or Plate Service

1.3. Plate Service

1.4. French Service, which $i$ two variants: Cart French Service and Banquet French Service

1.5. Gueridon Service

1.6. Silver Service

1.7. Russian Service

2. Assisted Service

3. Buffet Service

4. Self Service

5. Cafeteria Service

6. Single Point Service, which consists of:

6.1. Food Court

6.2. Kiosks

6.3. Take Away

6.4. Vending

7. Special Service which includes:

7.1. Grill Room Service 
SOCIO-ECONOMIC AND MANAGEMENT CONCEPTS

7.2. Tray Service

7.3. Trolley/Gueridon Service

7.4. Home Delivery

7.5. Lounge Service

7.6. Room Service [231].

In general, food delivery systems for hotels have not undergone much change in connection with the coronavirus pandemic. In contrast, many innovations have been introduced in the catering sector of hotels and restaurants [232]:

1. QR codes for menus, which were previously also used, but are now getting more and more widespread.

2. Contactless delivery and self-delivery of food.

3. Disposable product packaging.

4. Knock and leave service - «the staff knocks on the door, stands six feet away from the customer and lets you pick up a meal that's in a disposable package».

5. Redevelopment of premises for catering to visitors taking into account the quarantine requirements.

6. Drone food delivery [233].

7. Social distance dummies that prevent visitors from taking seats near other groups of people without social distance.

8. TV tasting of food and drinks, virtual tours of hotels and restaurants.

9. Picnic on request and al fresco dining etc. [232]

Consequently, in the hotel and restaurant entrepreneurship, we can observe a gradual (accelerated by the coronavirus pandemic) transition from classical forms of F\&B services to modern and further to innovative ones. 
Table 1. Classification of F\&B services in the hotel and restaurant entrepreneurship.

\begin{tabular}{|l|l|l|l|}
\hline & Classical & Modern & Innovative \\
\hline 1 & Table Service & Single Point Service & Contactless delivery \\
\hline 2 & Assisted Service & Special Service & Knock and leave service \\
\hline 3 & Buffet Service & $\begin{array}{l}\text { Picnic on request and al fresco } \\
\text { dining }\end{array}$ & TV tasting of food and drinks \\
\hline 4 & Self Service & QR codes for menus & Drone food delivery \\
\hline 5 & Cafeteria Service & Disposable product packaging. & etc. \\
\hline
\end{tabular}

Conclusions: Today, the hotel and restaurant business must operate in force majeure, in a pandemic, with constant restrictions on activities due to quarantine imposed by the states. This situation is observed all over the world. An innovative breakthrough, a way out of this difficult situation was the active introduction of computerization, Internet technologies, online services that help the existence of the restaurant business today, and open up new opportunities to promote their product on the market. 


\subsection{Ways to improve the career management system through staff motivation in the context of trends in the it field}

Personnel management is the formation of a personnel management system; planning personnel work, developing an operational plan for working with personnel; marketing personnel; determination of human resources, and the needs of the organization in personnel.

HR management in the IT field is divided into several stages:

- Search and selection of staff units. You need to know where IT specialists post their resume, where it is worth publishing vacancy announcements, what other ways of finding the right specialists exist (contacts in the professional community, recommendations of business partners). Potential employees should be interviewed, tested, and offered trial assignments.

- Employee adaptation. An experienced HR manager knows what tasks to set for a newcomer for the first time, how to include him in the work process, how to acquaint him with the specifics of the firm's activities, what training materials to offer, and which of his colleagues to first of all introduce.

- Assessment of competence. Subsequently, it becomes clear what professional skills and personal characteristics of the employee, how best to apply them. The assessment is carried out not only about newcomers, but also on an ongoing basis about all employees. This can be both formal regular attestation and informal conversations and observations.

- Development. Having assessed the competence, the HR manager may conclude that some of the specialists should be offered to improve their qualifications, while someone, on the contrary, should be transferred to a higher position. Sometimes retraining courses are carried out en masse - for example, when fundamentally new technologies are introduced.

- Salary. The specialist responsible for personnel management should take part in the choice of the remuneration system, in determining the level of salaries, and in 
awarding bonuses. He must clearly understand how much the company can spend on wages and how these funds are distributed.

Motivation and stimulation. A business develops successfully if the majority of employees are interested in their work and treat colleagues well. However, motivation issues, especially in the IT-sphere, cannot be approached formally and intrusively. People who are accustomed to working with computers and programs are often wary of the idea of participating in standard corporate entertainment. But you can find an approach to them if you understand their professional culture and traditions.

- Administration. The HR manager must understand labor legislation, be able to conclude labor contracts, draw up instructions and reports. Many nuances of work with personnel are spelled out in the laws, and incompetence in this area can lead to negative consequences in the event of a visit by regulatory authorities [234].

To ensure successful management of the career process in general and the individual career of each employee in the organization, detailed development of the concept of career management is required, which has absorbed all previous positive experience, and other constructive approaches and principles are listed. An organization's offering of career development opportunities to employees can be shaped from simple training programs and more detailed consulting services to improve future career plans.

The career opportunity program that is being created should include the following services:

- give a wide range of information about vacancies and qualifications that are needed to take them;

- indicate the system according to which qualified workers can apply for these places;

- help employees set career goals;

- to encourage meaningful dialogue between employees and their managers about career goals.

As you know, no company can achieve success without a good leader. Nowadays, the following trend is observed: the manager is trying to create a system of motivation 
that does not require his constant intervention. Therefore, monetary incentives remain the main incentive. However, the methods of motivation through the material resources of any enterprise are limited, sooner or later the manager will face the question of other methods of personnel motivation.

In this case, the following methods of employee motivation are used:

- remuneration for the required quality and quantity of labor and sanctions in case of insufficient quality or quantity;

- organizational and administrative methods of motivation based on subordination to a senior in position with possible compulsion to comply with instructions. Such methods provide effective organizational performance at any level;

- methods that involve the involvement of personnel in the management of the enterprise are mainly used in small enterprises;

- methods of removing negative incentives such as injustice;

- methods of personnel motivation by expanding and enriching work;

- the target method, the so-called motivation by work.

Employees should perceive their work as a source of self-improvement, as the basis for their professional growth. Today there are many methods of increasing motivation. A manager can: provide more freedom and authority to employees, improve working conditions, carry out activities to build a team, tie wages to work results, create opportunities for professional and career growth, replace individual employees, award certificates to the most productive employees, and so on.

Currently, goal setting is one of the main methods of employee motivation. The reason for this is increased competition. Both managers and employees want to learn how to set goals correctly, not only the goals of the company but also their own. This helps to see the contribution of each employee to the activities of the enterprise. Therefore, goal setting is becoming more common among leading firms.

Today, the goal of any company is to identify and retain talented employees, competent specialists. The correct system of employee motivation will help to achieve full dedication from employees, and, as a result, increase labor productivity and efficiency. 
EPAM Systems is one of the largest IT enterprises in the country and the world, successfully developing, has a high scientific and technical potential. The analysis of the EPAM Systems labor motivation system showed that the personnel management of the enterprise is carried out using a combination of administrative, economic, and socio-psychological methods of management. The basis of the personnel incentive system is laid by the use of organizational and technical methods that optimize the construction of a labor efficiency management system. The socio-psychological methods used effectively carry out moral stimulation, creating a favorable psychological climate in the team and a sense of belonging to the organization. The stable size of staff remuneration established at the enterprise prevents an increase in staff turnover and reduces the cost of finding new labor resources.

In general, well-focused efforts to develop a career management system in the firm can help employees identify their own advancement needs, provide information on career opportunities within the firm, and align the employee's needs and goals with the organizational goals. The establishment of such a system can reduce the aging of human resources, which are so expensive for the enterprise. In addition, the career counseling system is able to provide considerable assistance to the management of the enterprise in terms of understanding the system of motivating its employees and making adjustments to the methods and systems of motivation used.

It is proposed in EPAM Systems' salary policy to use a merit system. The system of "merit assessment" is designed to establish wages for employees of the same qualifications, with different indicators of the quality of work. The factors by which workers are assessed can be production and personal. Methods for assessing the merits of employees are different - scoring, questioning, expert assessment, grouping of employees based on the results of evaluating their work. To ensure successful management of the career process in the organization as a whole and the individual career of each employee, a detailed development of the concept of career management is required. An organisation's proposal for career development opportunities for employees can be formed from simple training programs and more detailed consulting services to improve further career plans. 


\subsection{Modern innovative concept of anti-crisis enterprise management}

В науковій літературі описується еволюція контентного терміну «антикризове управління» [235,236,237,238,239,240,241,242]. Перші спроби здійснювати антикризове управління підприємством відносяться до початку попереднього століття. Перед ним позиція природного перебігу без необхідності постійного нагляду відображала бачення економічної системи. Не було ніякої потреби в антикризовому управлінні. Загострення кризи взагалі й реальне іiі проявлення в 1929-1933pp. збільшило чисельність безробітних, призвело до різкого інвестиційного спаду, підвищило рівень інфляції й уповільнило темпи економічного розвитку. Така ситуація була характерною для промислових підприємств розвинених країн. В той період антикризове управління асоціювалося 3 « антикризовим менеджментом», який розглядався як цілеспрямоване на ліквідацію негативних економічних, соціальних, екологічних і політичних ситуацій управління.

У 90-і роки XX століття появився інститут банкрутства. Бурхливий розвиток приватизаційних процесів того періоду обумовив необхідність актуалізації дефініції “антикризове управління”. Річ в тому, що дієвим інструментом розв'язання державних проблем через пошук ефективного власника та підвищення ефективності функціонування і розвитку національних підприємств у розвинених країнах саме і $є$ приватизація. На жаль, з плином часу функціонування інституту банкрутства в національній економіці трансформувалося в інструмент тінізації й знищення конкурентоспроможних підприємств, звівши нанівець перспективи розвитку українських суб'єктів господарювання. Цим і пояснюється нерозвиненість теоретичного й практичного антикризового управління в національній економіці, яка зумовлена, в першу чергу, інституційними деформаціями, внаслідок чого на базі недосконалої нормативно-правової бази здійснювалося нецільове використання державного інституційного інструментарію задля потреб приватизації. 


\section{SOCIO-ECONOMIC AND MANAGEMENT CONCEPTS}

Численні дослідження свідчать [ 243, 244, 245, 246, 247, 248...], що основними чинниками гальмування розвитку теорії й практики антикризового управління $є$ елементи мікрорівня, а саме: відсутність ефективного методичного інструментарію діагностування кризового стану підприємств, який би приймав до уваги насамперед галузеві особливості кожного суб'єкта господарювання та унікальність його потенціалу; низьку ефективність антикризового управління на національних підприємствах, зокрема щодо несвоєчасності розробки антикризових заходів, низьку їх ефективність унаслідок некомпетентності управлінського персоналу, необгрунтованості та браку інформації для прийняття дієвих та виважених антикризових управлінських рішень.

В нинішніх умовах теоретичні та прикладні засади антикризового управління все частіше постають в якості об'єкта наукових досліджень як за кордоном, так і в нашій країні. В багатьох наукових працях антикризове управління розглядається як тимчасовий вид управління, потреба в якому зникає за відсутності кризи. Не дивлячись на досягнуті значні наукові наробки, актуальність цієї проблематики підсилюється також сучасною управлінською практикою підприємств, де інструментарій антикризового управління застосовується епізодично як засіб реагування на окремі кризові явища. Особливістю сучасного етапу економічного розвитку суспільства є те, що він супроводжується нерівномірним розвитком його складових, які потрібно збалансовувати.

Вагомий внесок у формування теоретико-методологічних засад антикризового управління підприємств зробили такі українські та іноземні дослідники, як: І. Ансофф, Е. Альтман, О. Апарова, Д. Баюра, Л. Беркман, I. Балабанов, О. Білорус, У. Бівер, І. Бланк, С. Боняр, В. Василенко, О. Ващенко, О. Василенко, А. П. Градов, А. Г. Грязнова, Е. М. Короткова, Л. О. Лігоненко, Е. С. Мінаєв, Л. С. Ситник, О. Виноградова, Г. Грязнова, О. Гусєва, В. Геєць, О. Гудзь, О. Гук, П. Друкер, І. Зеліско, С. Кваша, Р. Келлер, О. Князєва, М. Крупка, О. Кузьмін, Л. Лазоренко, К. Ларіонова, Т. Лепейко, С. Мінаєва, А. Мазаракі, О. Маковська, О. Мельник, І. Охрименко, П. Перерва, В. Плескач, Н. Прокопенко, 
Т. Пуліна, О. Пушкар, Л. Ситник, С. Смерека, П. Стецюк, А. Томпсон, Р. Таффлер, О. Терещенко, С. Філіпова, А. Шегда, 3. Шершньова, М. Шкільняк, А. Штангрет, О. Ястремська. Високо оцінюючи їх науковий доробок у створення теоретичних i методологічних засад розбудови системи антикризового управління насамперед на промислових підприємствах, слід акцентувати увагу, на наш погляд, на превентивне й динамічне антикризове управління, вартісноорієнтоване управління й антикризовий контролінговий менеджмент.

Слід відзначити, що сьогодні поняття антикризового управління досить багатозначне й різноконтентне. Одні науковці під ним розуміють управління компанією тільки в умовах загальної (в межах країни або міжнародної) кризи економіки, для інших це управління підприємством, що потрапило в кризову ситуацію внаслідок незадовільного менеджменту. Також є думки, що це є управління на порозі або в період банкрутства. Це не дивно тому, що аналізуються думки різних періодів. Річ в тому що в економічних явищах немає стійких термінів. 3 часом вони змінюються під впливом різних наукових, технічних, економічних, соціальних, організаційних та управлінських факторів. В останні роки появилися нові форми управління, організаційні методи, міждисциплінарні курси. В більшості наукових публікацій, особливо дисертаційного напрямку розглядаються авторські підходи щодо інтерпретації багатьох економічних термінів. В найбільшій мірі необхідність актуалізації змісту економічних термінів обумовлюється турбулентністю зовнішнього середовища та функціонуванням економічних систем в умовах невизначеності та ризиків. Відносно астрономічного часу акцент повсюди в управлінській діяльності змістився на прогнозування розвитку тієї чи іншої підвладної системи [ 249, с. 46 ]. Сьогоднішні події в світі призвели до необхідності перегляду всіх наукових постулатів і трактовки економічних термінів.

Так, Коротков С.М. розуміє антикризове управління як “передбачення небезпеки кризи, аналіз її симптомів, заходів по зниженню негативних наслідків кризи і використання ії̈ чинників для подальшого розвитку” [250, с.128]. Шварц I.B. трактує поняття “антикризовий менеджмент” у більш ширшому розумінні, 
яке ..полягає у плануванні та проведенні заходів по збереженню та покращенню базисних показників сталості та розвитку на підприємстві, а також створенні моніторингової системи аналізу відповідних показників [251].

“Антикризове управління - це управління, в якому певним чином поставлено попередження небезпеки щодо приближення кризи, аналіз його симптомів, заходів щодо зниження негативних наслідків кризи та використання його факторів для подальшого розвитку. Метою антикризового управління $\epsilon$ попередження кризових режимів роботи та розробка заходів по організації діяльності в цих режимах. Тобто, антикризове управління - це формування такої системи управління підприємства, яка забезпечує його ефективну роботу при певному рівні ризику” [252]. Таке визначення дають Беліков О. і Василенко В. О. у роботі «Антикризове управління підприємством» [252].

Л. С. Ситник трактує антикризове управління як ...систему управління, що спрямована на вирішення задач інтенсивного розвитку підприємства завдяки мобілізації та інтенсифікації всіх ресурсів на противагу екстенсивному розвитку [253]. Е. С. Мінаєва та В. П. Панагушина розглядають антикризове управління дуже широко. В своїй роботі, вони зазначають, що “антикризове управління попередити неплатоспроможність підприємства, а в стратегічному плані забезпечити йому протягом тривалого часу конкурентні переваги" [ 260].

Ткаченко А.М. та Мельничук А.К. трактують антикризове управління як “ цілеспрямована система управління, що передбачає постійну реалізацію превентивних заходів, механізму аналізу, оцінки та подолання негативних явищ, що впливають на підприємство та несуть загрозу для його подальшого безперебійного функціонування 3 метою покращення конкурентних переваг...... під антикризовим управлінням слід розуміти сукупність дієвих прийомів, способів, засобів, які дозволяють завчасно спрогнозувати усі негативні явища, що виникають у процесі діяльності суб'єктів господарювання та недопущення його банкрутства у найближчий час" [ 255].

3. Айвазян та В. Кириченко стверджують, що: “..визначення «антикризове управління» дуже розпливчате на сьогоднішній день, щоб дати чітке визначення 
та сформулювати основу антикризового управління потрібно більш чітко розглянути визначення «криза підприємства" [235].

Коваленко О.В. та Дробишева О.О. в контенті відокремлюють так зване стабілізаційне та превентивне антикризове управління. Перше реалізується у тих випадках, коли показники функціонування системи суттєво нижчі від нормативного рівня, не задовольняють запитам об'єкта управління, значно нижчі показників стану аналогічних об'єктів. Головне завдання стабілізаційного антикризового управління полягає у стабілізації фінансово-економічного становища та створенні передумов підйому. Натомість превентивне антикризове управління реалізується з метою запобігання кризовим явищам і включає оцінку ймовірності виникнення кризової ситуації; розробку та вжиття заходів, які спрямовані на підвищення опірності підприємства впливу критичних факторів за рахунок більш ефективного використання потенціалу підприємства; управління процесом переходу підприємства в якісно новий стан [ 256 ].

Островська О.А. зазначає, що “система антикризового управління корпоративними фінансами має передбачати упровадження превентивних заходів протягом усього періоду функціонування підприємства. Зволікання із застосуванням адекватних заходів із попередження, локалізації та нейтралізації кризи на макро- та на мікро рівні може стати передумовою розгортання кризових явищ як на рівні підприємства, так і на рівні економічної системи держави загалом" [ 257].

Старинець О.Г. трактує цей термін у розширеному вигляді наступним чином: “Отже, антикризове управління підприємства - це комплекс постійно діючих, взаємозумовлених i взаємопов'язаних складових управлінського процесу щодо запобігання, попередження та подолання кризових явищ або усунення їх негативних наслідків на основі використання всього потенціалу відповідного підприємства" [258, с.51].

Пілецька С.Т. виділяє декілька наукових підходів щодо визначення контенту антикризовго управління для сьогоденних умов [25, с.67 -76)]: 
- Перший науковий підхід. Антикризове управління розглядається як управління, спрямоване на попередження, запобігання або усунення кризових ситуацій. Підтримують цей напрям такі дослідники, як Уткін Е., Мінаєва Е. С., Сметанюк О. А., Гершанок А. А., Короткова С. М. [ 259, с.67-69 ].

- Другий науковий підхід. Він стосується тих визначень, де є положення про ризик, тому підприємство має адаптуватися до цього ризику з урахуванням свого потенціалу. Прибічниками цього підходу є Іванова Є. А., Терлецька Ю. О., Король В. С., Друкер П. [259, с.69-70 ].

- Третій науковий підхід. Антикризове управління розглядається як організоване на постійній основі спеціальне управління, спрямоване в найбільшій мірі на оперативний рівень виявлення кризового стану та створення своєчасних та ефективних передумов для його подолання, щоб забезпечити відновлення життєдіяльності підприємства й недопущення появи ситуації його банкрутства. Представниками цього підходу є Лігоненко Л., Гайворонська Ю. Є., Ситник Л. С., Нікітіна Н. В., Партина Г. О., Градова А. П. [259, с.70-72 ].

- Четвертий науковий підхід. Антикризове управління розглядається як система заходів, спрямованих на попередження, нейтралізацію і подолання кризових процесів та їх причин виникнення в економічних системах на всіх рівнях економіки. Представниками цього напряму є: Смельчанова Д. В., Нечай М. Г., Шапурова О. О., Іванюта С. М., Холод 3. М., Шпачук В. В. [259,с.72-74 ].

- Пятий науковий підхід. Антикризове управління підприємством $\epsilon$ невід’ємною частиною загальної системи управління, необхідне на усіх фазах життєвого циклу підприємства. Представниками цього напряму є Соколова Г. Ю., Шевченко В. В. [ 259, с.74-75 ].

- Шостий науковий підхід. Антикризове управління розглядається як розроблення та реалізація заходів, які спрямовані на недопущення ліквідації підприємства. Представниками такого підходу є: Терещенко О. О., Топій I. I., Пилипчук В. В. [259, с.75-76 ].

Узагальнюючи наукові підходи до сутності антикризового управління, можна констатувати наступне: 1) не звертається значна увага на вплив зовнішніх 


\section{SOCIO-ECONOMIC AND MANAGEMENT CONCEPTS}

факторів; 2) в дефініціях не віддзеркалюються стадії життєвого циклу підприємства і його продукції; 3) не враховуються нормативно-правові документи; 4) відсутній акцент на превентивне управління; 5) немає інформації щодо визначення й прогнозування банкрутства; 6) значна частина визначень обмежується внутрішніми аспектами антикризового управління; 7) не приймається до уваги оцінка ефективності менеджменту компанії; 8) практично за межами визначень знаходяться інноваційні управлінські технології вартісноорієнтованого управління й контролінгу; 9) у визначеннях домінує фінансовий аспект [ 260, с.176- 177 ].

Зовсім іншої думки придержуються англійські науковці, які розглядають питання антикризового управління та його завдання щодо запобігання або прискорення банкрутства. Їхній підхід базується на концепції щодо виживання сильніших. Якщо ж є дійсно така необхідність, зокрема, для компаній 3 негативними суспільними наслідками, то антикризове управління таким підприємством повинно бути зовнішнім і здійснюватися кваліфікованими запрошеними на підприємство фахівцями" [261].

Еволюційний аналіз наукових джерел по антикризовому управлінню дозволяє зробити наступні висновки [260, с.176 ]. .

1. Виділення 2 умовних етапів в судженнях про термін антикризового управління. Приблизно до 2012 року визначення цієї дефініції в основному стосувалися періоду кризи і виходу з неї і лише в деяких публікаціях з'являлися фрагменти визначень про необхідність врахування аспектів передкризового стану та вдосконалення моделей аналізу фінансової стійкості підприємства та небезпеки банкрутства. Після 2012 року акцент почав переміщуватися в бік розширеного бачення антикризового управління з наповненням цього терміну такими аспектами як превентивне антикризове управління, вартісно-орієнтоване управління, контролінгове антикризове управління.

2. Наповнення контентів антикризового управління стратегічною орієнтацією та необхідністю вдосконалення інформаційно-методичної бази такого управління. 
3. Приділення значної уваги контролінгу як управлінськоі функції й інструментарію антикризового управління.

4. Прийняття до уваги екзогенних факторів, які відображають процес гармонізації інтересів і поведінки всіх учасників створення, виготовлення й реалізації продукції компанії.

5. Пошук нових інноваційних методів для оцінки фінансового стану підприємства з урахуванням національних, галузевих й статусних особливостей [260, c 176$]$.

Таким чином, дослідження сутності поняття «антикризове управління» в наукових працях дозволяє констатувати, що воно в нинішніх умовах потребує актуалізації, конкретизації, фокусування, розмежування та установлення взаємозв'язку. 3 урахуванням проаналізованих наукових джерел та авторських суджень можна представити сьогоднішнє бачення антикризового управління підприємством, як: “перманентне стеження за ознаками можливої появи тенденції наближення до кризової ситуації, формування й реалізація відповідних оперативних та стратегічних управлінських рішень в умовах ризику й невизначеності, ресурсних та часових обмежень в окремі періоди, фінансових та інтелектуальних витрат на відновлення та підтримку життєздатності підприємства й недопущення ліквідації його як суб'скта господарювання" [260, с. 176-177 ].

Запропоноване визначення має наступні особливості: 1) враховує не тільки внутрішні складові, але й зовнішні чинники впливу на діяльність підприємства, які можуть бути враховані за допомогою зовнішнього моніторингу; 2) включає фінансові і не фінансові показники діяльності підприємства; 3) уможливлює в значній мірі адаптацію та гнучкість підприємства й здатність його до перманентного реагування на слабкі сигнали мінливого зовнішнього середовища; 4) дозволяє оцінювати ефективність менеджменту; 5) включає інтелектуальний капітал в процес антикризового управління [260, с. 177].

Узагальнюючи різні погляди науковців на сутність та завдання антикризового управління можна констатувати, що нинішня всеохоплююча не 
визначена ситуація в світі дозволяє переконатися лишній раз, що термін антикризового управління має повністю замінити поняття простого або класичного управління. Від епізодичного або періодичного антикризового управління необхідно перейти до постійного й превентивного антикризового управління [260, с 177]. Складовими його концепції являються вартісноорієнтований підхід, антикризовий контролінг і превентивний менеджмент. В цьому аспекті ми розділяємо думку науковців $[256,262]$ стосовно сучасних вимог до структури та задач управління підприємством або установою, які вважають конче необхідним надання управлінню будь-яким підприємством ознак перманентної антикризовості. 


\subsection{Theoretical and methodological principles of assessment of the level of financial security of the enterprise}

Сучасні умови господарювання підприємств, зумовлені наслідками фінансово-економічної кризи спричиненої масштабами пандемії COVID-19 та політичною нестабільністю, породжують проблеми, які носять гострий та непередбачуваний характер, a, відповідно, й загрози фінансовій безпеці підприємства стають реальнішими і небезпечними. Відсутність досвіду роботи у конкурентному середовищі за новітніми викликами призвела до виникнення та поглиблення кризових явищ на підприємствах. У зв'язку з цим гостро постала проблема досягнення та підтримки необхідного рівня фінансової безпеки кожного підприємства.

Слід зазначити, що на сьогоднішній день відсутній єдиний науковообгрунтований підхід чи методика оцінки рівня фінансової безпеки. У зв'язку 3 цим, потреба в узагальнені та систематизації існуючих методів і моделей й розроблення єдиної методики оцінки рівня фінансової безпеки підприємства $є$ актуальним завданням.

Методи оцінки фінансової безпеки підприємства досліджували такі вченіекономісти, зокрема, О. Ареф'єва, Т. Кузенко [263], Ю. Кракос, Н. Сєрик [264], Л. Донець, Н. Ващенко [265], І. Бланк [266], О. Пластун [267], К. Горячева [268], О. Кириченко, I. Кудря [269] та інші. Однак, незважаючи на значну кількість наукових праць, питання методології оцінки фінансової безпеки підприємства надалі залишається дискусійним, оскільки донині відсутня єдина методика оцінки стану фінансової безпеки підприємств як на макро-, так і на мікрорівнях.

Опрацювання й аналіз наукової фахової літератури [263-276] дали змогу усі існуючі та запропоновані моделі та методи оцінки фінансової безпеки підприємства розділити на три групи (табл. 1). 


\section{SOCIO-ECONOMIC AND MANAGEMENT CONCEPTS}

Таблиця 1

\section{Основні методи оцінки рівня фінансової безпеки підприємства}

\begin{tabular}{|c|c|c|}
\hline \multicolumn{2}{|r|}{ Найменування методу } & Трактування суті методу \\
\hline \multirow{3}{*}{ 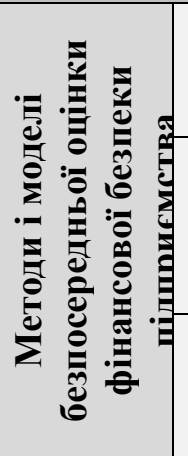 } & $\begin{array}{c}\text { Оцінка фінансової безпеки } \\
\text { підприємства, як складова } \\
\text { економічної безпеки }\end{array}$ & $\begin{array}{l}\text { передбачає оцінку рівня фінансової безпеки } \\
\text { підприємства на підставі аналізу індикаторів } \\
\text { фінансової безпеки підприємства. }\end{array}$ \\
\hline & $\begin{array}{c}\text { Оцінка фінансової безпеки, на } \\
\text { основі визначення інтегрального } \\
\text { показника }\end{array}$ & $\begin{array}{l}\text { грунтується на визначені інтегрального показника } \\
\text { на основі розрахунку фінансових коефіцієнтів або } \\
\text { на основі рівня безпеки за кожною із } \\
\text { функціональних складових }\end{array}$ \\
\hline & $\begin{array}{c}\text { Оцінка фінансової безпеки, на } \\
\text { основі визначення загального стану } \\
\text { фінансової діяльності підприємства }\end{array}$ & $\begin{array}{l}\text { передбачає горизонтальний аналіз, вертикальний } \\
\text { аналіз, порівняльний аналіз, інтегральний аналіз } \\
\text { та аналіз коефіцієнтів }\end{array}$ \\
\hline \multirow{6}{*}{ 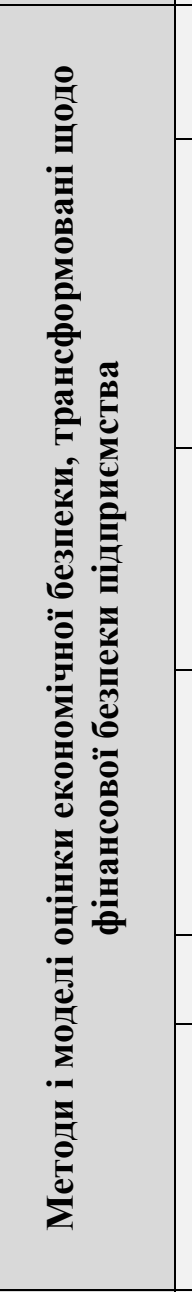 } & Індикаторний & $\begin{array}{l}\text { передбачає порівняння фактичних значень } \\
\text { показників фінансової безпеки } 3 \text { пороговими } \\
\text { (граничними) значеннями індикаторів їі рівня }\end{array}$ \\
\hline & Ресурсно-функціональний & $\begin{array}{l}\text { передбачає оцінку ступеня використання } \\
\text { фінансових ресурсів підприємства за кожним } \\
\text { функціональним складником, після чого на основі } \\
\text { розрахованих у ході такого аналізу показників } \\
\text { шляхом експертної оцінки визначається } \\
\text { інтегральний показник, який і є показником рівня } \\
\text { ФБП }\end{array}$ \\
\hline & Програмно-цільовий & $\begin{array}{l}\text { грунтується на інтегруванні } \\
\text { покупнності } \\
\text { вокаків, що визначають ФБП, при цьому } \\
\text { використовується кілька рівнів інтеграції } \\
\text { показників і такі методи їх аналізу, як кластерний } \\
\text { та багатовимірний аналіз }\end{array}$ \\
\hline & Ранжування & $\begin{array}{l}\text { полягає в тому, що рівень фінансової безпеки } \\
\text { розраховується в балах як сума добутків рейтингу } \\
\text { кожного показника на клас, який визначається в } \\
\text { залежності від значення нормативного показника, } \\
\text { тобто оцінка рівня фінансової безпеки базується } \\
\text { на використанні рангових ознак }\end{array}$ \\
\hline & Вартісний & $\begin{array}{l}\text { передбачає нарощення капіталізації підприємства } \\
\text { та збільшення його ринкової вартості }\end{array}$ \\
\hline & Стратегічно-цільовий & 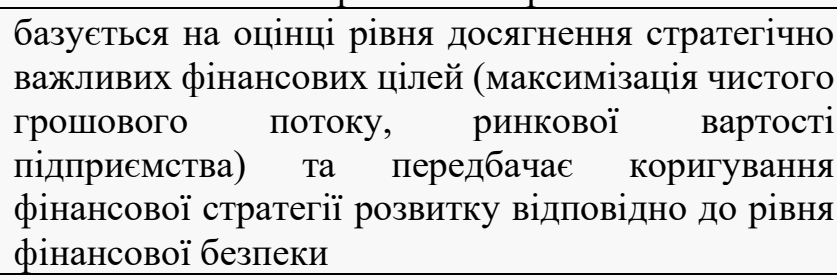 \\
\hline 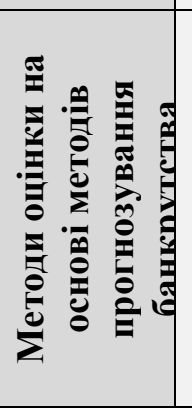 & $\begin{array}{c}\text { Зарубіжні моделі: } \\
\text { Z-моделі Е. Альтмана } \\
\text { Модель У. Бівера } \\
\text { Модель Ж. Депаляна } \\
\text { Модель Р. Таффлера Г. Тішоу } \\
\text { Модель Г. Спрінгейта } \\
\text { Модель Дж. Фулмера }\end{array}$ & $\begin{array}{l}\text { грунтується на оцінці рівня фінансової безпеки } \\
\text { через аналіз значної сукупності фінансових } \\
\text { коефіцієнтів, у результаті чого отриманий } \\
\text { показник порівнюється з критичним значенням та } \\
\text { визначається ймовірність банкрутства } \\
\text { підприємства в майбутніх періодах. Ці методи } \\
\text { дають можливість своєчасно виявляти факти } \\
\text { фінансової неспроможності підприємства, що є } \\
\text { одним із індикаторів фінансової безпеки }\end{array}$ \\
\hline
\end{tabular}

Перш за все пропонуємо розглянути методи та моделі безпосередньої

оцінки фінансової безпеки підприємства. Прихильниками оцінки фінансової 
безпеки як складової економічної безпеки підприємства є такі науковці як О. Ареф'єва, Т. Кузенко, Ю. Кракос, Н. Сєрик, Л. Донець, Н. Ващенко. Дослідники пропонують оцінювати рівень фінансової безпеки підприємства на підставі аналізу індикаторів фінансової безпеки підприємства. У якості індикаторів автори наводять граничні значення фінансових показників (коефіцієнта покриття, коефіцієнта автономії, рівня фінансового левериджу, рентабельності активів, рентабельності власного капіталу, середньозваженої вартості капіталу, співвідношення оборотності дебіторської і кредиторської заборгованості тощо) [263]. Запропонована методика, на нашу думку, не повнію мірою $є$ універсальною та комплексною, адже порогові значення показників значно різняться для підприємств різних галузей господарства. Також, дана методика не дає змоги провести діагностику загроз, що виникають у фінансовій сфері діяльності підприємства.

Аналізуючи економічну літературу нами було зауважено, що чіткішою та обгрунтованішою є оцінка рівня фінансової безпеки підприємства на основі іiі інтегрального показника. Проте, існують розбіжності стосовно алгоритму його розрахунку. Зокрема, ряд дослідників визначають інтегральний показник на основі розрахунку фінансових коефіцієнтів, або на основі рівня безпеки за кожною із функціональних складових [268, с. 7].

Так, О. Кириченко, І. Кудря запропонували систему відносних показників оцінки фінансової безпеки, яка складається 3 п'яти груп коефіцієнтів: коефіцієнти структури капіталу, ділової активності підприємства, рентабельності, платоспроможності та коефіцієнти, які показують ефективність використання власних оборотних коштів [269, с. 25].

Здійснювати оцінку рівня фінансової безпеки підприємства на основі розрахунку фінансових показників також пропонує О. Пластун за допомогою наступних семи показників, а саме: коефіцієнту зносу основних засобів, рентабельності активів, фондовіддачі основних засобів, коефіцієнту оборотності активів, коефіцієнту фінансування, втрати платоспроможності та загального коефіцієнту покриття [267]. 
В процесі даного дослідження було виявлено, що ряд науковців, зокрема, I. Бланк, І. Алєксандров, О. Орлова, А. Половян [266, с. 9] пропонують оцінювати фінансову безпеку підприємства на основі визначення загального стану фінансової діяльності підприємства. Так, І. Бланк виділяє системи аналізу фінансової безпеки підприємства (горизонтальний аналіз, вертикальний аналіз, порівняльний аналіз, інтегральний аналіз тощо) та групи аналітичних фінансових коефіцієнтів (коефіцієнти оцінки фінансової стійкості підприємства, платоспроможності (ліквідності), оборотності активів, оборотності капіталу, рентабельності (прибутковості)) [266, с. 121]. На нашу думку, оцінка фінансової безпеки підприємства не може зводитись до простого аналізу фінансового стану підприємств, адже, виходячи із особливостей даної економічної категорії, оцінка iii рівня потребує особливих підходів та методів.

На сьогоднішній день в науково-фаховій літературі також є методи оцінки рівня економічної безпеки підприємства, які трансформовані стосовно фінансової безпеки підприємства: індикаторний; ресурсно-функціональний; програмно-цільовий; ранговий; вартісний; стратегічно-цільовий.

Дані методи переважно є загальновідомими й вважаються підходами до оцінки економічної безпеки, що переводяться в площину фінансової безпеки як іiї основної складової з відповідними інтерпретаціями.

Найбільш поширеним методом оцінки рівня фінансової безпеки $\epsilon$ індикаторний. Він передбачає порівняння фактичних значень показників фінансової безпеки 3 пороговими значеннями індикаторів iï рівня. Порогові значення індикаторів фінансової безпеки - це граничні величини, недотримання яких, призводить до формування негативних тенденцій (виникнення загроз) у сфері фінансової безпеки. За такого підходу найвищий рівень фінансової безпеки підприємства досягається при умові, що уся сукупність індикаторів знаходиться в межах порогових значень, а порогове значення кожного 3 індикаторів досягається не за рахунок інших.

Даний підхід є найбільш застосований на макрорівні (на рівні держави), що розкрито у Концепції економічної безпеки України [272], у роботах О. 
Барановського [273, с. 14] (для оцінки фінансової безпеки держави) та В. Тамбовцева (в загальних теоретичних рисах). Прихильниками цього підходу $є$ також Т. Гладченко [274] й М. Дмитрієва [275]. На нашу думку інтерпретація даного підходу на рівні підприємства $є$ абсолютно не розробленою і відображає лише поверхневий характер, оскільки для підприємства дуже важко визначити ці граничні рівні, до того ж вони будуть різними для кожного окремого підприємства залежно від галузевих особливостей діяльності, форми господарювання та стану зовнішнього середовища. Крім того, серед науковців та практиків не існує єдиної думки відносно сукупності показників, що характеризують діяльність підприємств і відповідають певному рівню його фінансової безпеки. Правда, практично всі вказують на те, що існує зв'язок фінансової безпеки підприємства з фінансовою забезпеченістю його діяльності, тобто з його забезпеченістю фінансовими ресурсами.

Основою ресурсно-функціонального підходу для оцінки рівня фінансової безпеки підприємства $є$ характеристика ефективності використання корпоративних ресурсів за спеціальними критеріями 3 метою попередження ризиків та забезпечення стабільного функціонування підприємства [276]. При цьому в якості корпоративних ресурсів розглядаються фактори бізнесу, що використовуються керівниками підприємства 3 метою досягнення кінцевих цілей.

Ресурсно-функціональний підхід до визначення рівня фінансової безпеки включає такі методи:

- вимір стану фінансової безпеки на основі оцінювання рівня використання фінансових ресурсів за спеціальними критеріями - власні фінансові ресурси та позикові фінансові ресурси.

- оцінювання рівня виконання функцій - забезпечення високої фінансової ефективності діяльності підприємства, його фінансової стабільності і незалежності.

Варто зазначити, що такий підхід є дуже широким, оскільки, по-перше, процес забезпечення фінансової безпеки ототожнюється фактично з усією 
діяльністю підприємства, і по-друге, зводиться до оцінювання використання ресурсів підприємством.

Також пропонуємо розглянути використання програмно-цільового методу, авторами якого є В. Забродський та Н. Капустін [276] Так, оцінка фінансової безпеки грунтується на інтегруванні сукупності показників, що визначають економічну безпеку. При цьому використовується декілька рівнів інтеграції показників і такі методи їх аналізу, як кластерний і багатовимірний аналіз. Даний підхід, на нашу думку, є доволі складним для використання в практичній діяльності підприємства, оскільки вимагає застосування методів математичного моделювання. До того ж він дає змогу оцінити рівень фінансової безпеки 3 позиції математики, а не менеджера.

Ще один підхід до оцінки рівня економічної безпеки підприємства, який трансформований щодо фінансової безпеки підприємства - метод ранжування. Його сутність полягає в тому, що рівень фінансової безпеки підприємства розраховується в балах як сума добутків рейтингу кожного показника на клас, який визначається в залежності від значення нормативного показника, тобто оцінка рівня фінансової безпеки підприємства базується на використанні рангових ознак [277]. Ускладнює процес оцінки фінансової безпеки підприємства за даним методом суб'єктивізм при здійсненні відбору індикаторів фінансової безпеки та невизначеність процесу формування діапазону нормативних значень показників. Також цей метод не дає змоги отримати інформацію про загальний рівень фінансової безпеки підприємства.

Остатнім часом серед дослідників проблем методології фінансової безпеки набув поширення так званий вартісний підхід, який дає можливість здійснити оцінку принципово 3 іншого боку, а саме 3 позицій можливості нарощувати капіталізацію підприємства, збільшувати його ринкову вартість. Ключовою метою управління фінансовою безпекою підприємства в межах цього підходу $є$ максимізація вартості підприємства, а особливістю застосування - бачення перспектив розвитку підприємства як ознаки управління його майбутнім. 
Прихильником стратегічно-цільового підходу щодо оцінки фінансової безпеки $є$ Н. Пойда-Носик [277]. Цей підхід базується на оцінці рівня досягнення стратегічно важливих фінансових цілей (максимізація чистого грошового потоку, ринкової вартості підприємства) та передбачає коригування фінансової стратегії розвитку відповідно до рівня фінансової безпеки.

Прикро визнавати, проте, одним з серйозніших недоліків у здійснені оцінки та діагностики фінансової безпеки підприємства за допомогою прогнозування ймовірності настання банкрутства підприємства $є$ те, що дані методики не адаптовані до сучасних реалій вітчизняної економіки.

В результаті грунтовного аналізу наукових праць виявлено, що на даний час не існує універсальної методики оцінки рівня фінансової безпеки підприємства, тому для вирішення цієї проблеми авторами запропоновано власний теоретикометодологічний підхід.

На нашу думку, процес формування інформаційної бази для оцінки рівня фінансової безпеки підприємства повинен бути багатоаспектним, спиратись не лише на визначення певної кількості якісних та кількісних показників стосовно фінансової діяльності підприємства, а бути ширшим, тобто брати до уваги зміни як внутрішнього, так і зовнішнього середовища підприємства. У свою чергу, оцінка фінансової безпеки підприємства має бути комплексною, тобто містити характеристику основних параметрів розвитку вітчизняних підприємств, ключових показників діяльності певного підприємства, і не лише тих, які безпосередньо пов’язані із фінансовою діяльністю; уможливлювати визначення інтегрального показника, який би давав чітке уявлення про поточний стан та динаміку рівня фінансової безпеки підприємства [270, с. 16-17]. Процес оцінки фінансової безпеки підприємства можна схематично представити у вигляді певного алгоритму (рис. 1). 


\section{SOCIO-ECONOMIC AND MANAGEMENT CONCEPTS}

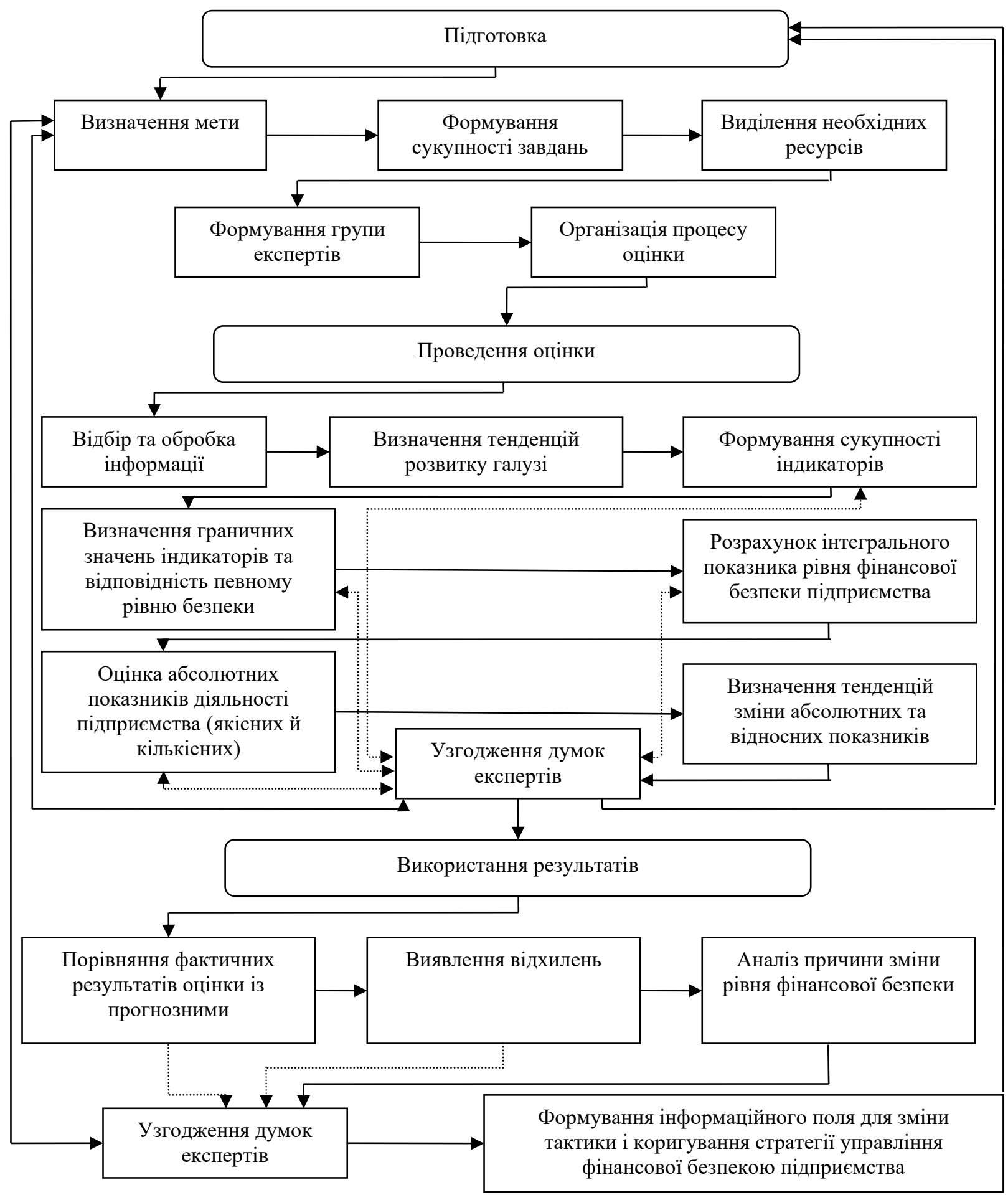

Рис. 1. Алгоритм здійснення оцінки фінансової безпеки підприємства (авторська розробка)

Важливо звернути увагу на те, що центральне місце в процесі оцінки займає процедура формування групи експертів та узгодження їх думок стосовно кожного етапу оцінювання. Стосовно ж формування методики оцінки рівня фінансової безпеки, то саме узгодження точок зору експертів дасть змогу визначити сукупність індикаторів, ïx граничних значень та відповідність певному рівню безпеки, що стало основою для розроблення моделі (рис. 2). 


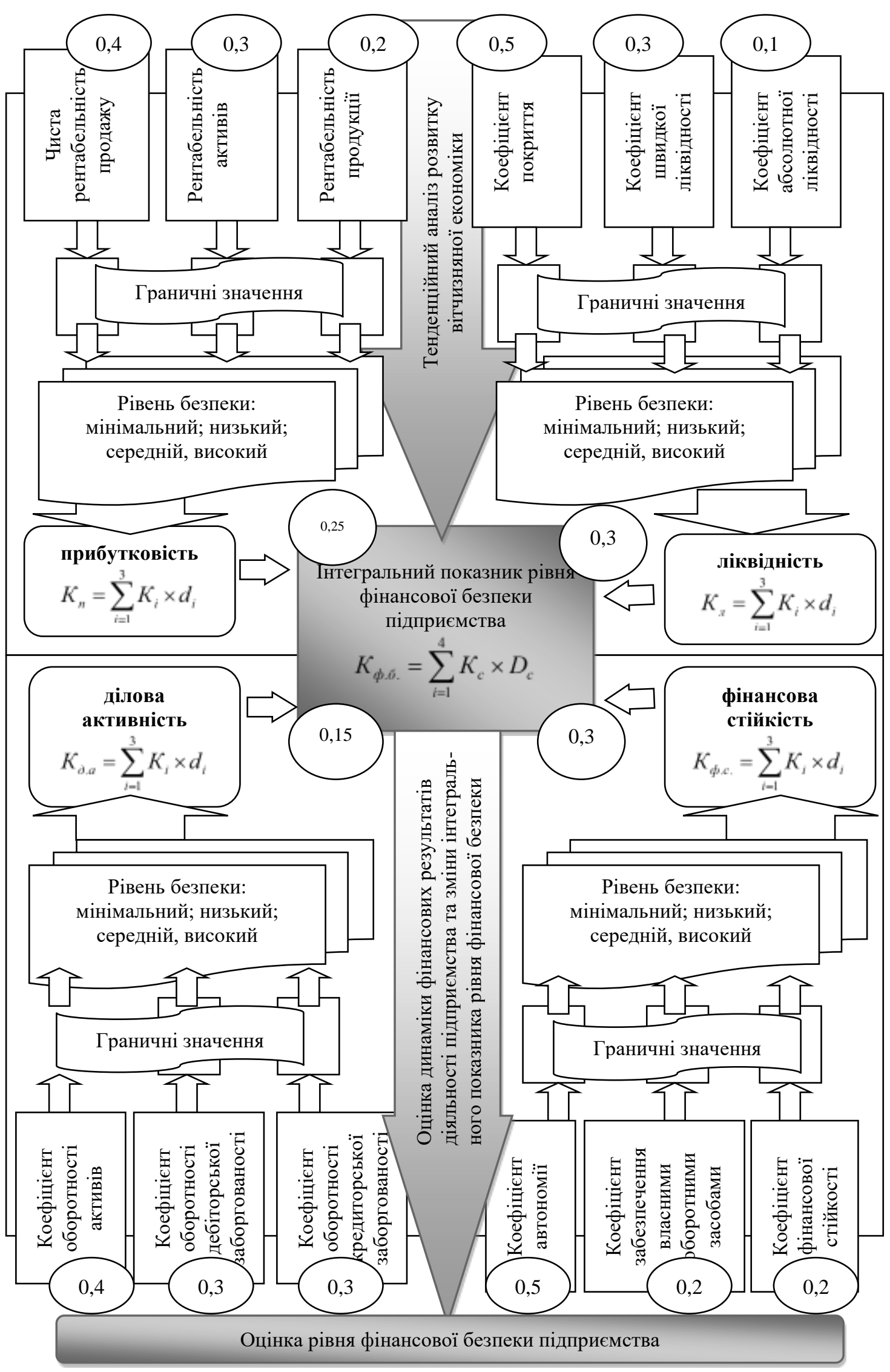

Рис. 2. Модель оцінювання рівня фінансової безпеки підприємства (авторська розробка) 


\section{SOCIO-ECONOMIC AND MANAGEMENT CONCEPTS}

Розроблена модель оцінювання рівня фінансової безпеки підприємства відрізняється від інших кількома важливими моментами:

- для характеристики рівня фінансової безпеки враховуються тенденції розвитку вітчизняної економіки та будь-який параметр розробленої моделі може бути скоригований із врахуванням специфіки діяльності конкретного підприємства;

- інтегральний показник, складові методик розрахунку якого представлені у таблиці 2, уможливлює отримання чіткої характеристики рівня фінансової безпеки за чотирма рівнями: «мінімальний», «низький», «середній», «високий» на будь-який актуальний момент часу;

- граничні значення кожного індикатора будуть визначені на основі опитування та узгодження думок експертів, відтак, будуть актуальними саме для поточного періоду розвитку вітчизняної економіки;

- процес розрахунку інтегрального показника може бути автоматизований та використовуватися як аналітичний інструмент при прийнятті кожного рішення в системі фінансової безпеки підприємства.

Таблиця 2

Методика розрахунку та градація рівнів індикаторів (авторська розробка)

\begin{tabular}{|c|c|c|c|c|c|}
\hline \multirow[t]{2}{*}{ Показник } & Мінімальний & Низький & Середній & Високий & \multirow{2}{*}{$\begin{array}{l}\text { Питома } \\
\text { вага } \\
\text { показни } \\
\text { ка, d }\end{array}$} \\
\hline & $0-0,25$ & $0,25-0,5$ & $0,5-0,75$ & $0,75-1,0$ & \\
\hline 1 & 3 & 4 & 5 & 6 & 7 \\
\hline \multicolumn{5}{|c|}{ Прибутковість } & 0,25 \\
\hline Чиста рентабельність продажу & $1-3 \%$ & $3-5 \%$ & $5-10 \%$ & $10-15 \%$ & 0,4 \\
\hline Рентабельність активів & $2-5 \%$ & $5-10 \%$ & $10-15 \%$ & $15-12 \%$ & 0,35 \\
\hline Рентабельність продукції & $10-30 \%$ & $30-50 \%$ & $50-70 \%$ & $70-90 \%$ & 0,25 \\
\hline \multicolumn{5}{|c|}{ Ліквідність } & $\mathbf{0 , 3}$ \\
\hline Коефіцієнт покриття & $\prec 1$ & $1,0-1,5$ & $1,5-2,0$ & $\succ 2$ & 0,5 \\
\hline Коефіцієнт швидкої ліквідності & $\prec 0,2$ & $0,2-0,5$ & $0,5-1,0$ & $\succ 1$ & 0,35 \\
\hline Коефіцієнт абсолютної ліквідності & $\prec 0,05$ & $0,05-0,1$ & $0,1-0,2$ & $\succ 0,2$ & 0,15 \\
\hline \multicolumn{5}{|c|}{ Ділова активність } & 0,15 \\
\hline Коефіцієнт оборотності активів & $\prec 1,0$ & $1-1,5$ & $1,5-2$ & $\succ 2$ & 0,4 \\
\hline Коефіцієнт оборотності ДЗ & $\prec 1,5$ & $1,5-2$ & $2-3$ & $\succ 3$ & 0,3 \\
\hline Коефіцієнт оборотності КЗ & $\prec 2,0$ & $2-3$ & $3-4$ & $\succ 4$ & 0,3 \\
\hline \multicolumn{5}{|c|}{ Фінансова стійкість } & $\mathbf{0 , 3}$ \\
\hline Коефіцієнт автономії & $0-0,25$ & $0,25-0,5$ & $0,5-0,7$ & $0,7-1,0$ & 0,5 \\
\hline
\end{tabular}


Продовження таблиці 2

\begin{tabular}{|c|c|c|c|c|c|}
\hline 1 & 2 & 3 & 4 & 5 & 6 \\
\hline $\begin{array}{c}\text { Коефіцієнт забезпечення власними } \\
\text { оборотними засобами }\end{array}$ & $\prec 0,05$ & $0,05-0,1$ & $0,1-0,3$ & $\succ 0,3$ & 0,25 \\
\hline Коефіцієнт фінансової стійкості & $\prec 0,5$ & $0,5-1$ & $1-2$ & $\succ 2$ & 0,25 \\
\hline
\end{tabular}

На основі результатів проведеного теоретико-аналітичного дослідження, встановлено, що ефективність формування та забезпечення фінансової безпеки в умовах кожного підприємства значною мірою залежить від початкової інформації про стан фінансової сфери суб'єкта господарювання. Запропонований авторами науково-методологічний підхід містить розроблений алгоритм, побудовану модель та методику визначення основних індикаторів. Застосування такого підходу дає можливість отримувати всю необхідну первинну фінансову інформацію та здійснювати оцінювання рівня фінансової безпеки підприємства в повному обсязі враховуючи специфіку господарської діяльності вітчизняних підприємств. Запропонована методологія $є$ грунтовною та ефективною для управління фінансовою безпекою суб' єкта господарювання. 


\section{5 Концептуальные основы управления HR-потенциалом предприятия}

В современных условиях основное внимание руководителей предприятий сфокусировано на достижении долгосрочного успеха как на рынке основной деятельности, так и на рынке труда. Это обусловливает необходимость поиска таких конкурентных преимуществ, которые обеспечат решение вышеуказанных задач с минимальными затратами. Именно этому будет способствовать эффективное управление HR-потенциалом предприятия.

Исследование теоретических аспектов управления HR-потенциалом должно базироваться на анализе категорий „,трудовой потенциал”, „кадровый потенциал”. Так, термин „трудовой потенциал” вошел в научный оборот в 60-70е гг. ХХ в. По мнению современных исследователей, его широкое использование обусловлено необходимостью трансформации традиционных взглядов на место и роль человека в процессе производства при постоянном развитии научнотехнического прогресса; характером демографического процесса, которому присуще постепенное снижение доли населения в трудоспособном возрасте; исчерпанием емкости категории ,трудовые ресурсы”. При этом понятие „трудовой потенциал” может применяться на трех уровнях: государство (регион), предприятие, работник.

Отсутствие единого однозначного подхода к семантическому наполнению понятий „трудовой потенциал предприятия” и „,трудовой потенциал работника” требует четкой и обоснованной формализации данных дефиниций.

Как показали исследования, трудовой потенциал работника целесообразно трактовать как совокупность реальных и потенциальных способностей, физических и духовных качеств человека, возможностей и компетенций относительно выполнения определенного вида трудовой деятельности, которые могут быть использованы для достижения личных и профессиональных целей работника. В свою очередь, трудовой потенциал предприятия - это объединение трудовых потенциалов всех его работников с реальными и потенциальными 
возможностями предприятия к созданию условий для их использования и развития в процессе достижения поставленных целей.

Термин „кадровый потенциал” вошел в научное обращение в период перехода от экстенсивного к интенсивному способу развития производства. Это была своеобразная реакция науки на потребность практики обеспечить качественное совершенствование формирования и использования соответствующих возможностей работника как совокупного объекта производства и управления [280, с.16-17]. Само повышение роли человеческого фактора в деятельности предприятия привело к возникновению понятия „кадровый потенциал”, которое сегодня используется для характеристики термина „человеческий фактор” в объемном выражении, как в масштабах всего общества, так и в рамках отдельных производственных коллективов [281, с.48]. Беляцкий Н.П., Велесько С.Е., Ройш П. отмечают, что кадровый потенциал синтезирует то, что в литературе советского периода называли человеческим фактором, а в западной - персоналом организации, ее структурой управления, а также характерные для данной организации формы управленческих отношений, или стили управления [282, с.35].

Неоднозначность существующих подходов в восприятии дефиниций „кадровый потенциал” и ,трудовой потенциал предприятия” обусловливают необходимость уточнения степени правомерности отождествления или расхождения этих категорий. Так, отдельные авторы рассматривают эти понятия как синонимичные [283, с.127; 284, с.181]. Согласно иной точки зрения, понятие „кадровый потенциал” является подчиненным понятию „трудовой потенциал”. В частности, Кузьмина Н.M. рассматривает кадровый потенциал как ограниченный определенными условиями совокупный трудовой потенциал [285, с.33]. По мнению других ученых, разница между этими понятиями заключается в том, что трудовой потенциал - это более абстрактное понятие, которое отражает фактические и потенциальные способности людей к труду, а кадровый потенциал - это конкретное понятие, которое характеризуется с помощью количественных и качественных показателей людей, осуществляющих трудовую 
деятельность [286, с.17]. Последний подход является более обоснованным, хотя и в кадровом потенциале с определенной долей субъективности можно выделить абстрактные элементы (в частности, совокупность способностей и возможностей работников).

Анализ многочисленных дефиниций и научных дискуссий по поводу определения категории „кадровый потенциал” позволил выделить основные подходы к ее трактовке. Так, кадровый потенциал рассматривается как:

- совокупность работников, которые могут работать в предприятии при определенных условиях [283, с.127], или могут обеспечить качественное выполнение заданий [287, с.173];

- совокупность способностей и возможностей, способных обеспечить эффективное функционирование предприятия, эффективное выполнение обязанностей, эффективное достижение целей и т.п. [288, с.143; 289, с.141];

- совокупность качественных и количественных характеристик персонала [281, c.48; 290, c.11];

- кадры и их общие возможности для достижения поставленных целей, выполнения трудовой деятельности [282, с.35]: объединение первого и второго подходов;

- совокупность качественных и количественных характеристик персонала и возможностей обеспечивать достижение задач предприятия [291, с.302]: соединение второго и третьего подходов.

Однако, следует отметить, что в существующих дефинициях кадрового потенциала в недостаточной мере учитывается его компетентностная сторона, при этом особое внимание акцентируется на способностях и возможностях персонала.

Таким образом, можно считать целесообразным использование термина «HR-потенциал», который следует рассматривать как совокупность работников предприятия, их трудовых потенциалов, потенциала межличностного и межгруппового взаимодействия, а также возможностей предприятия к созданию условий для их использования и развития, которые могут быть использованы для 
более эффективного достижения целей и получения конкурентных преимуществ предприятия.

Такая трактовка HR-потенциала предприятия объединяет в себе как материальную сторону (ресурсы, в качестве которых рассматривается персонал предприятия) так и нематериальную (совокупность способностей, возможностей, компетенций, которые могут быть использованы для достижения поставленных целей, - человеческий капитал предприятия). При этом в HRпотенциал предприятия не входит та часть человеческого капитала, которая не влияет на получение доходов предприятием, а может быть использована работниками для получения личных доходов за его пределами, в других сферах деятельности. К тому же, HR-потенциал предприятия охватывает не только потенциалы отдельных работников, но и потенциал HR-взаимодействия (т.е. совокупность способностей, возможностей, компетенций работников в сфере межличностного и межгруппового взаимодействия для наиболее действенного достижения целей предприятия).

HR-потенциал предприятия (в отличие от трудового потенциала, который является абстрактной категорией, отражающей реальные и потенциальные способности к труду и условия их реализации) включает также количественные характеристики персонала (численность, структура), но не рассматривает условия реализации труда (техническую оснащенность труда, уровень механизации, организацию производства), выступающие элементом трудового потенциала предприятия, поскольку в этом контексте они будут рассматриваться как часть материально-технического потенциала предприятия.

Между трудовым потенциалом работников и HR-потенциалом предприятия целесообразно выделить еще один уровень потенциала - потенциал группы (состоит из трудовых потенциалов ее членов и потенциала HR-взаимодействия). B свою очередь, HR-потенциал предприятия состоит из совокупности HRпотенциалов групп (формальных и неформальных), а также потенциалов межгруппового взаимодействия. 
Таким образом, HR-потенциал предприятия охватывает совокупность трудовых потенциалов его работников и потенциалов межличностного и межгруппового взаимодействия. При этом, каждый из рассмотренных уровней кадрового потенциала (работник, группа, предприятие) можно представить как совокупность вышеуказанных элементов потенциала: работники, способности и возможности, компетенции. 


\section{SOCIO-ECONOMIC AND MANAGEMENT CONCEPTS}

\section{6 Концептуальні засади забезпечення стійкого економічного розвитку підприсмств}

Ресурсні обмеження, існування яких визначило увагу до проблем стійкості, носять комплексний характер і пов’язані не тільки 3 обмеженістю власне сировини, але і з взаємодією між антропосистемою і біосферою. Тому поняття стійкого розвитку містить у собі стабільний соціально-економічний збалансований розвиток, що не руйнує навколишнє природне середовище i забезпечує безперервний прогрес суспільства.

Виходячи з теорії максимального потоку сукупного доходу Хікса-Ліндаль в концепції сталого (стійкого) розвитку передбачається оптимальне використання обмежених ресурсів і використання ресурсозберігаючих технологій [292].

Стійкий розвиток окремих підприємств, які $є$ фактично елементами суспільного розподілу праці, формує об’єктивні передумови сталого розвитку економіки, що доводить важливість його вивчення.

Одностайність вчених у визнанні важливості і неминучості процесу розвитку супроводжується розбіжністю у визначені його мети, що значно ускладнює категоріально-понятійний апарат. Наукові поняття «сталий», «стійкий», «збалансований», «усталений», «підтримуваний» розвиток - лише частково відбивають його мету.

Проблемі визначення методологічних засад щодо побудови ефективної системи управління стійким розвитком підприємств присвячені дослідження таких учених як К. Друрі, С. Бондаренко, Р. Коуз, В. Сопко, О. Головченко, Б. Буркинський, О. Нікішина та ін.

Метою дослідження $є$ поглиблення концептуальних положень щодо забезпечення стійкого економічного розвитку підприємств.

Структура виробничих систем може розглядатися як певний набір економічних ресурсів, a їх стійкість залежить від співвідношення різних елементів. Як показує аналіз господарської практики, у процесі управління підприємством не повинна досягатися єдина мета отримання і максимізації 


\section{SOCIO-ECONOMIC AND MANAGEMENT CONCEPTS}

прибутку. Стійкий розвиток підприємства визначається можливостями підприємства адаптуватися до впливу зовнішнього середовища на основі вибору найбільш ефективних науково обгрунтованих управлінських рішень в інтересах самого підприємства і суспільства в цілому.

До традиційних для ринкової економіки механізмів адаптації до стійкого розвитку відносять технічні i технологічні інновації, реструктуризацію, диверсифікацію, удосконалення організаційної структури і загальної структури управління.

На нашу думку, стійким розвитком слід вважати напрямок, який мінімізує негативний вплив зовнішніх і внутрішніх факторів, що впливають на економічну систему підприємства, на підставі передбачення різних ринкових перетворень $\mathrm{i}$ прийняття своєчасних управлінських рішень.

Для оцінки рівня стійкого розвитку підприємства приймаються наступні групи показників відповідно до їх ролі в процесі виробництва: ринкові, виробничі, соціальні, фінансово-економічні (табл. 1).

Інформаційною базою слугує фінансова звітність підприємств, форми державної статистичної звітності, дані підприємств, які не включені до неї.

Процес створення інформаційно-аналітичної бази аналізу та побудови похідних показників оцінки стійкого розвитку підприємства відбувається наступним чином:

а) введення початкової інформації по підприємству;

б) розрахунок фінансових і економічних показників, що характеризують стан підприємства;

в) аналітичне порівняння показників;

г) побудова зваженого індексу інтегральної оцінки стійкого розвитку підприємства. 


\section{SOCIO-ECONOMIC AND MANAGEMENT CONCEPTS}

Таблиця 1.

Основні економічні показники стійкого розвитку підприємства та форми вираження їх оцінки

\begin{tabular}{|c|c|c|}
\hline Показники & Критерії & Одиниці виміру \\
\hline \multirow{3}{*}{ Ринкові } & Частка ринку продажів продукції & $\%$ \\
\hline & Оборот на конкретному ринку & тис. грн. / год \\
\hline & Частка грошових коштів в обороті & $\%$ \\
\hline \multirow{8}{*}{ Виробничі } & Товарна продукція в фактичних і порівнянних цінах & тис. грн \\
\hline & Індекс зростання об’ємів виробленої продукції & індекс \\
\hline & Реалізована продукція & тис.грн \\
\hline & Витрати на виготовлення продукції & тис.грн \\
\hline & Індекс росту витрат & індекс \\
\hline & Частка змінних витрат в собівартості продукції & $\%$ \\
\hline & Виробіток на одного робітника & тис.грн./ос./год \\
\hline & Відсоток виконаних замовлень в термін & $\%$ \\
\hline \multirow{3}{*}{ Соціальні } & Чисельність працівників по категоріям & oc. \\
\hline & $\begin{array}{l}\text { Відношення заробітної платні до прожиткового } \\
\text { мінімуму }\end{array}$ & коефіцієнт \\
\hline & $\begin{array}{l}\text { Відношення середньомісячної заробітної плати до } \\
\text { середньомісячної по країні }\end{array}$ & коефіцієнт \\
\hline \multirow{6}{*}{$\begin{array}{l}\text { Фінансово- } \\
\text { економічні }\end{array}$} & Оборотні кошти & тис.грн. \\
\hline & Власні оборотні кошти & тис.грн. \\
\hline & Чистий прибуток & тис.грн./год. \\
\hline & Чиста рентабельність & $\%$ \\
\hline & Поточна ліквідність & коефіцієнт \\
\hline & Фондовіддача & p./p. \\
\hline
\end{tabular}

Забезпечення стійкого економічного розвитку підприємства - одна 3 основних задач, що стоять перед власниками i керівниками всіх рівнів управління. Реалізація принципу фінансової стабілізації в довгостроковій перспективі передбачає розробку, вибір і оцінку фінансової стратегії, заснованої на забезпеченні фінансової стійкості і фінансового рівноваги підприємства.

Протягом останніх років в оцінках фінансової стійкості склалася традиційна методика, яка грунтується на розрахунках показників, що обчислюються за даними бухгалтерського балансу. Однак використання цієї методики, досить простої в застосуванні, можлива лише для попереднього ознайомлення 3 фінансовим станом підприємства. 


\section{SOCIO-ECONOMIC AND MANAGEMENT CONCEPTS}

Процес управління діяльністю підприємства починається з розробки візії, місії та кінцевої мети, яка ставиться на найближчу і віддалену перспективу, i сприйняття призначеного підприємства на конкурентному ринку. В першу чергу це пов'язано з розумінням сутності економічної системи, яка має на увазі в мікроекономічної теорії конкретний господарюючий суб'єкт, тобто саме підприємство, яке виробляє конкретний продукт або послугу для задоволення потреб ринку.

Досягнення стійкого розвитку підприємства можливо на підставі виконання наступних вимог:

a) необхідність максимально можливого збільшення потенціалу підприємства;

б) оптимальність темпів розвитку з урахуванням впливу безлічі факторів, у тому числі і ринкової кон’юнктури;

в) інтенсифікація виробництва за умови зниження матеріальних витрат 3 метою вивільнення невикористовуваних ресурсів;

г) можливість стимулювання виробництва за рахунок фондів підтримки, таких, як фонди матеріального заохочення персоналу, фонди під майбутні витрати, страхові фонди і т.ін.;

д) обгрунтованість запасів невикористаних потужностей з метою зниження витрат на утримання і експлуатацію зайвої кількості складів;

е) визначення якісних характеристик, таких, як надійність продукції, обгрунтованість ціни виробу або послуги, позитивна ділова репутація підприємства і здатність в майбутньому задовольняти потреби споживача.

Дослідження поняття стійкого розвитку підприємства та система оцінки його стійкості дозволяють перейти до побудови концепції стійкого економічного розвитку підприємства. Для реалізації цієї мети використовувалися методи аналізу економічного стану, оцінки фінансових результатів, факторного детермінованого аналізу, математичного моделювання та прогнозування економічних систем. 


\section{SOCIO-ECONOMIC AND MANAGEMENT CONCEPTS}

На підставі вищевикладеного в рамках динамічної теорії сталого розвитку розроблено концепцію стійкого економічного розвитку підприємства, яка грунтується на трьох стратегіях (рис. 1 (авторська розробка)):

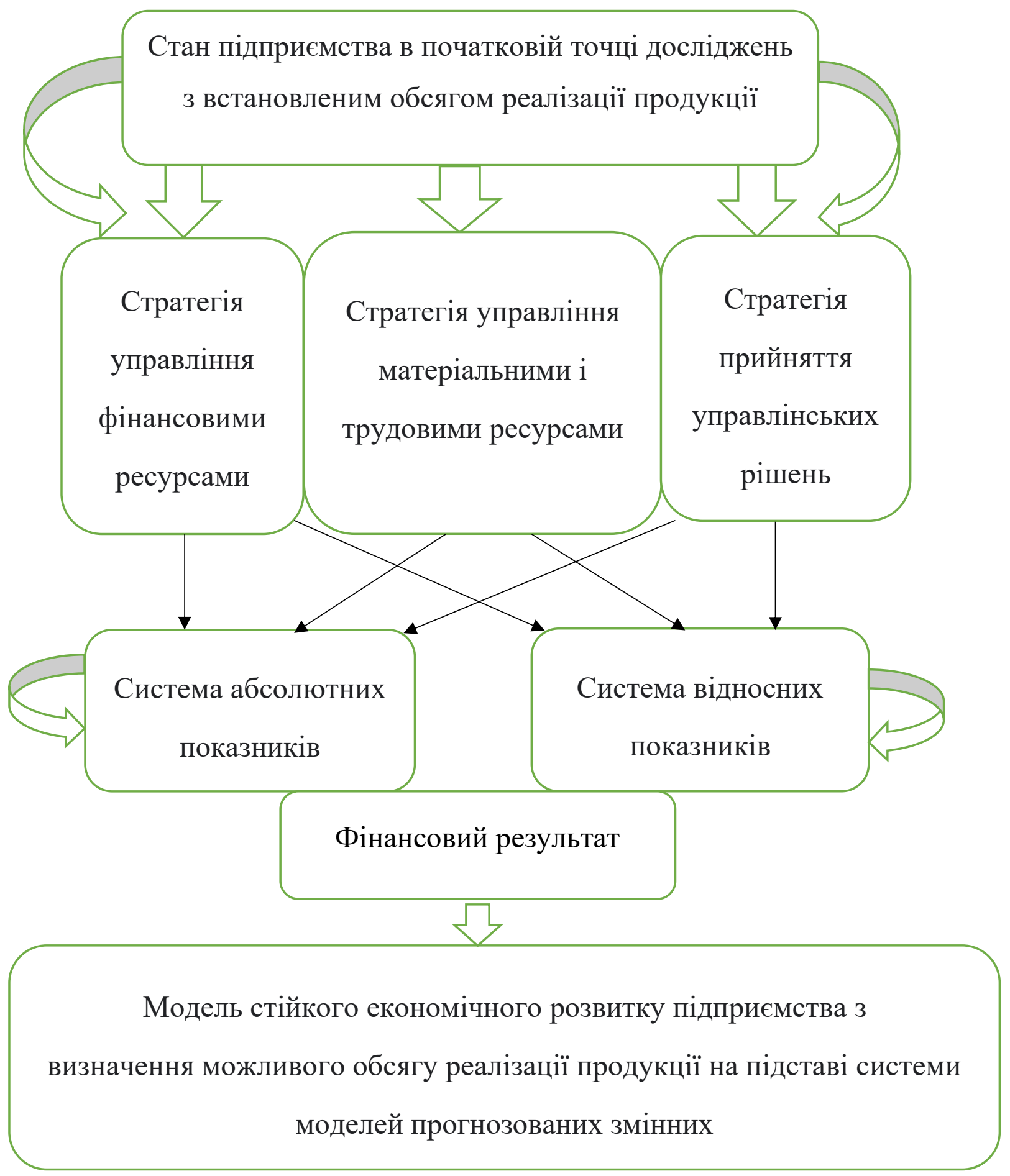

Рисунок 1. Концепція стійкого економічного розвитку підприємства

1. Стратегія управління фінансовими ресурсами для забезпечення стійкого економічного розвитку. 


\section{SOCIO-ECONOMIC AND MANAGEMENT CONCEPTS}

2. Стратегія управління виробничим потенціалом на принципі оптимізації ресурсів підприємства.

3. Стратегія прийняття оптимальних управлінських рішень.

Концепція стійкого економічного зростання представлена як сукупний вплив фінансових, матеріальних і трудових ресурсів, а також обраних стратегій управління ними, на кінцевий результат - обсяг реалізації продукції.

При оцінці кінцевого фінансового результату слід враховувати вплив зовнішніх факторів і внутрішнього середовища, управління яким пов'язано 3 використанням власного потенціалу. Визначено, що до факторів зовнішнього i внутрішнього середовища потрібно не тільки пристосовуватися, а також по можливості, масштабуватися й управляти ними.

Схематично концепція може бути представлена як сукупний вплив фінансових, матеріальних і трудових ресурсів, а також обраних стратегій управління ними на кінцевий результат - можливий обсяг реалізації продукції, обсяг операційної діяльності підприємства, величина прибутку.

При оцінці кінцевого фінансового результату враховують також вплив зовнішніх некерованих факторів (зростання інфляції, цін, нестабільність податкової системи, що регулює законодавства, зниження доходів населення i т.п.), а також внутрішніх (перевищення допустимих рівнів фінансових ризиків, неефективна фінансова стратегія, маркетинг тощо).

У загальному розумінні ідея концепції управління стійким розвитком полягає у використанні таких методів управління, які найкращим чином будуть впливати на економічний стан підприємства, на кінцеві результати його діяльності та можливості їх досягнення. У концепції управління стійким розвитком підприємства необхідно враховувати сукупність принципів і правил управління стійким розвитком підприємства, які випливають 3 відповідності можливостей підприємства і його кінцевої мети.

Головним завданням в загальній концепції управління стійким розвитком є прийняття управлінських рішень, які діляться на оперативні та довгострокові. Ці рішення взаємопов’язані, i, отже, їх обгрунтування потребує всебічної оцінки 
вихідної бази даних, яка, в свою чергу, виходить в результаті комплексної переробки інформації внутрішніх і зовнішніх досліджень.

Така переробка входить в систему управління і їі можна назвати одним із завдань механізму управління стійким розвитком. Необхідна інформація міститься в системі бухгалтерського обліку та відомостях відділу маркетингу. Від прийнятих рішень, як оперативних, так і довгострокових, залежить, чи досягне підприємство кінцевої мети чи ні. Звідси видно, що ще одним завданням механізму управління стійким розвитком $є$ контроль відповідності роботи підприємства з його метою і при необхідності жорстке регулювання стійким розвитком підприємства.

Стійкий розвиток підприємств має відповідати певним принципам [293]:

- цілеспрямованості;

- системності;

- збалансованості;

- інтегрованості;

- керованості;

- раціональності.

Перший з принципів означає встановлення довго- та короткострокових цілей підприємства у відповідності до ідей стійкого розвитку.

Другий принцип означає врахування внутрішніх багатосторонніх зв'язків між елементами підприємства та їх взаємодоповнення.

Третій з принципів передбачає збалансованість економічних та соціальних цілей розвитку підприємства, а також відносин у відповідності до інтересів стейкхолдерів, корпоративних і суспільних інтересів, соціо-економікоекологічного (сталого) розвитку, інтересів сьогоднішніх та майбутніх поколінь.

Четвертий принцип відображає ідею стійкого розвитку - філософію бізнесу, яка має інтегруватися у стратегічні цілі підприємства. 


\section{SOCIO-ECONOMIC AND MANAGEMENT CONCEPTS}

П'ятий - формування механізму стійкого розвитку має охоплювати всі сфери діяльності керованого об'єкта; багаторівневу організаційну структуру; роботу з релевантною інформацією.

Шостий - раціональне використання наявних ресурсів підприємства, застосування у виробництві ресурсозберігаючих технологій й стабільне підвищення ефективності використання фінансових, матеріальних, інтелектуальних ресурсів у відповідності до цілей даного підприємства.

Отож, реалізація вище вказаних принципів може розглядатися як головний критерій забезпечення стійкого розвитку підприємства [293, с. 78].

У цій зв’язці доцільно представити методологію управління стійким розвитком підприємства, яка відрізняється комплексним, скоординованим підходом до оцінки, управління і прогнозування стійкого розвитку підприємства в сучасних умовах ринку під впливом зовнішніх і внутрішніх факторів.

Методологія управління стійким розвитком підприємства структурно включає в себе наступні етапи:

- збір, аналіз і обробку фактичних даних, що складають основу експерименту і дозволяють сформувати банк вихідної інформації;

- застосування комплексу взаємопов'язаних методик для аналізу використання як виробничого потенціалу, так i фінансових ресурсів підприємства; визначення залежних параметрів зовнішніх впливів, що враховуються при аналізі економічних систем;

- розробка методики і алгоритму структурної ідентифікації економічних систем;

- отримання моделі стійкого розвитку підприємства в умовах впливу зовнішніх і внутрішніх факторів;

- визначення системи моделей для прогнозування поведінки підприємства на конкурентному ринку, що дозволяє врахувати різноманіття збуджуючих факторів;

- отримання довгострокового прогнозу поведінки економічної системи за моделями і вибір оптимальної на основі «сценарного критерію»; 


\section{SOCIO-ECONOMIC AND MANAGEMENT CONCEPTS}

- уточнення моделі методами структурної ідентифікації.

При розробці методології управління стійким розвитком підприємств слід враховувати основні вимоги до такого розвитку; брати до уваги, що показники зовнішнього і внутрішнього середовища здатні вплинути на зміни параметрів економічного розвитку підприємств; необхідність використання методологічного підходу в процесі управлінської діяльності.

Результати моделювання залежних і незалежних змінних економічної системи підприємств дозволяють визначити системний науково обгрунтований алгоритмічний підхід до процесу управління стійким розвитком підприємств в сучасному ринковому середовищі.

Стійкий розвиток підприємства передбачає узгодження короткострокових цілей і інтересів різних груп і окремих індивідів в складі підприємства 3 довгостроковими стратегічними цілями, обумовленими вимогами його внутрішнього розвитку.

Необхідними умовами досягнення стійкого розвитку підприємства $є$ випуск якісної продукції, що відповідає потребам цільової групи споживачів; збереження і модернізація матеріально-технічної бази підприємства; створення позитивного образу підприємства в сприйнятті споживачів і ділової репутації в очах партнерів; формування трудового колективу підприємства в рамках сучасної професійно-кваліфікаційної структури і підтримання сприятливого соціально-психологічної атмосфери в колективі; забезпечення екологічної безпеки виробничого процесу.

Отже, у даному дослідженні поглиблено концептуальні положення щодо забезпечення стійкого економічного розвитку підприємств.

Стійкий розвиток пропонується розглядати як результат прийнятих рішень, сукупну характеристику потенціалу управління, спрямовану на забезпечення саме довгострокових умов стабільності його функціонування. Однак варто зазначити, що на кожному етапі повинні вирішуватися і поточні завдання задоволення насущних матеріальних потреб, що утворює основу для досягнення цілей більш високого порядку. Управління стійким розвитком підприємств 


\section{SOCIO-ECONOMIC AND MANAGEMENT CONCEPTS}

відрізняється комплексним, скоординованим підходом до оцінки, управління i прогнозування в сучасних умовах ринку під впливом зовнішніх і внутрішніх факторів.

\section{7 Обгрунтування системи показників ефективності функціонування бурякоцукрового підкомплексу}

Проблема підвищення ефективності функціонування бурякоцукрового підкомплексу АПК в нашій країні стала об’єктом уваги багатьох вченихекономістів. Вивчення низки проблем, пов'язаних із пошуком шляхів підвищення ефективності функціонування бурякоцукрового підкомплексу $\epsilon$ одним 3 найактуальніших завдань, які стоять перед вітчизняною аграрною наукою. [296]

Через відсутність науково обгрунтованого механізму дії економічного взаємозв'язку окремих галузей промисловості і сільського господарства як на загальнонаціональному, так і регіональному рівнях стає неможливим в усіх випадках скористатися прийнятим підходом вибору критерію ефективності, за яким зіставляються досягнення найвищих народногосподарських результатів за найменших затрат живої та уречевленої праці. Саме тому на кожному рівні необхідно визначити властивий йому критерій і відповідно до нього - систему економічних показників. Так, для національного рівня критерієм ефективності може бути зіставлення частки АПК комплексу у використанні народногосподарського виробничого потенціалу i макроекономічних показників. На регіональному рівні критерієм ефективності слід вважати ступінь використання виробничого потенціалу регіону i вплив на рівень самозабезпечення товарами. Для локального рівня критерій ефективності має відображати рівень використання виробничого потенціалу через його окупність продукцією (прибутком).

Таку класифікацію системи показників наведено на рис. 1. 


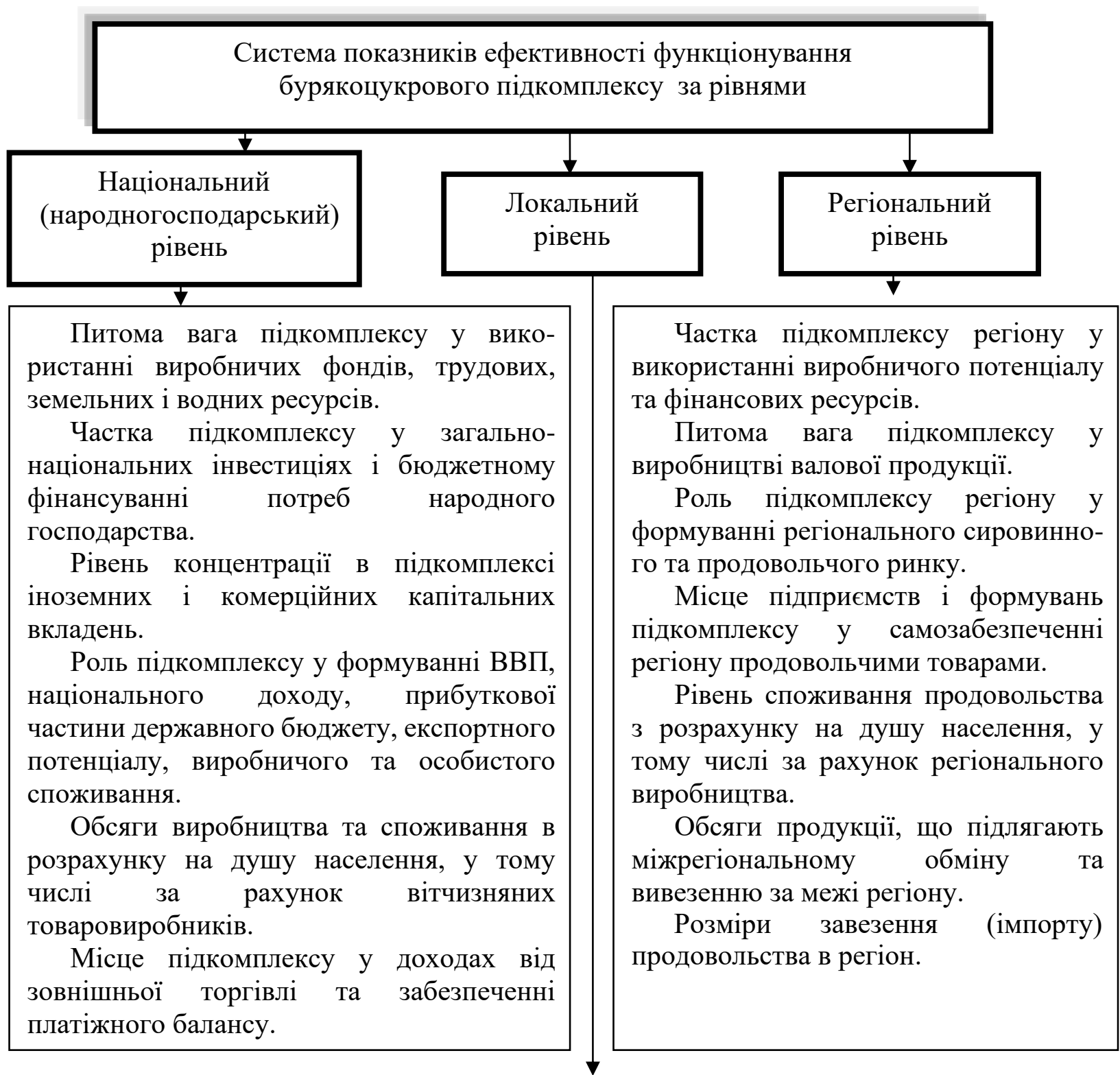

Валова, товарна продукція, валовий і чистий дохід, прибуток $з$ розрахунку на одиницю виробничого потенціалу підприємства (групи підприємств).

Ступінь розвитку підприємства та міжгосподарського кооперування.

Ефективність переробки сільськогосподарської продукції і сировини.

Рівень функціонування прямих зв'язків і виконання договірних зобов'язань між сільськогосподарськими, переробними і сервісними підприємствами.

Динаміка кінцевої продукції з розрахунку на одиницю витрат

Фондомісткість, матеріаломісткість, трудомісткість продукції в сільськогосподарських і переробних підприємствах.

Частка сільського господарства, переробної промисловості та торгівлі в сукупних витратах і прибутку окремо взятих продуктових вертикалей.

Ефективність виробництва як відношення одержаного прибутку до сукупних витрат у кожній галузі.

Рис. 1. Класифікація показників на різних рівнях*

*Джерело: розробка автора.

Для здійснення глибокого аналізу ступеня розвитку бурякоцукрового

підкомплексу на різних рівнях національної економіки існує система економічних 


\section{SOCIO-ECONOMIC AND MANAGEMENT CONCEPTS}

показників. Ці показники дають змогу не лише оцінити стан розвитку, а й прогнозувати зрушення, які необхідні для підвищення ефективності виробництва.

Узагальнення робіт вчених-економістів 3 питань розвитку бурякоцукрового підкомплексу, форм статистичної та бухгалтерської звітності дозволили обгрунтувати систему основних показників його розвитку та ефективності. Сюди ми зарахували:

- посівні площі, урожайність і валове виробництво цукрових буряків у господарствах різних форм власності, що формують сировинну зону;

- товарну продукцію, яка становить собою частину виробленої ВПФ і призначена для реалізації за межі і всередині агропромислового формування;

- затрати праці (в людино-годинах), затрати виробництва (у грошовому вираженні) й відповідно трудомісткість і собівартість 1 ц цукрових буряків;

- обсяги реалізації сировини виробниками та показники їі якості (цукристість, забрудненість);

- сукупну кінцеву продукцію - вартісне вираження усіх видів кінцевих продуктів;

- чисту продукцію, створену у сфері обігу під час реалізації сільськогосподарської і переробленої продукції;

- чисту продукцію, створену під час виробничо-технічного обслуговування;

- амортизаційні відрахування i вартість предметів праці фондозабезпечувальних галузей;

- різниці між вартістю спожитих засобів сільськогосподарського походження та їх запасами на початок наступного року;

- ціну реалізації 1 ц цукрових буряків у середньому, а також за окремими каналами продажів; чисельність цукрових заводів, їх розміщення й потужності, завантаженість, обсяги випуску цукру-піску;

- території сировинних зон, заводів, їх фактичні та потенціальні потужності щодо поставок цукрових буряків для переробки;

- грошові надходження від реалізації (окремо для виробників за сировину, переробників - за цукор-пісок); 
- прибуток (збиток), рівень рентабельності (з диференціацією за технологічним циклом виробник - переробник);

- балансову рентабельність, що характеризує ефективність виробничофінансової (комерційної) діяльності і визначається відношенням балансового прибутку до вартості капіталу виробничого призначення;

- рентабельність продукції, яка характеризує ефективність використання поточних затрат живої та уречевленої праці і визначається діленням прибутку від реалізації продукції (робіт, послуг) на витрати виробництва (повну собівартість);

- рентабельність продажів, що характеризує окупність прибутком витрат 3 виробництва і реалізації продукції та визначається діленням прибутку від реалізації продукції на виручку (обсяг продажів) і т д.

Усю цю сукупність можна систематизувати за низкою ознак (рис. 2).

Вирішальним чинником виступає людський фактор, як сукупність знань, здібностей, професійних навичок і умінь. Враховуючи значення цього фактора, відповідною повинна бути й пріоритетна інноваційна діяльність щодо нього. [297]

Визначають економічну ефективність виробництва за допомогою системи економічних показників. Окремі автори небезпідставно вказують на те, що ці показники характеризують вихід валової продукції, чистої продукції та чистого доходу на одиницю витрат виробничих ресурсів і на одиницю повного обсягу ресурсів, які беруть участь у виробництві. [298] 


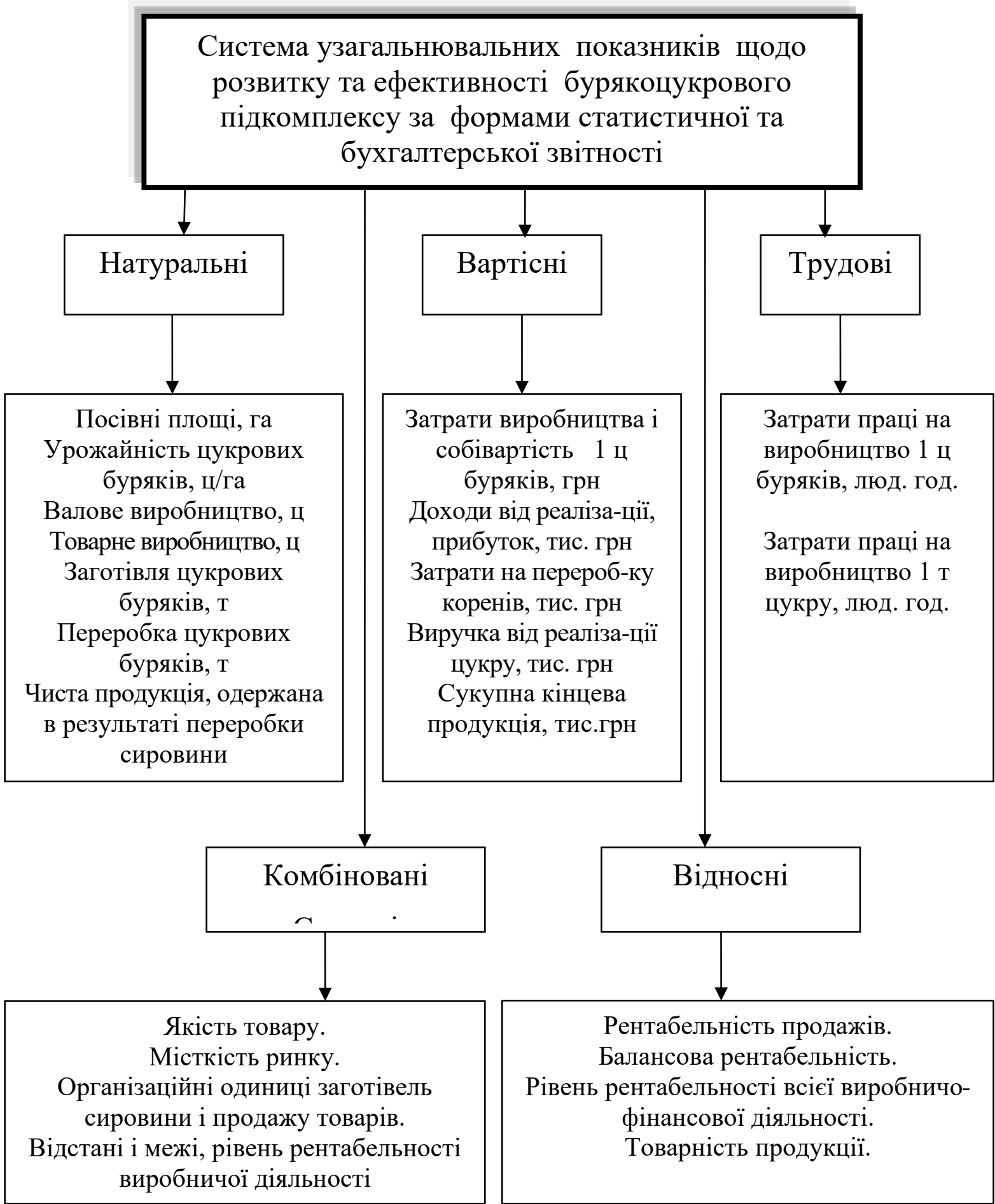

Рис.2. Класифікація узагальнювальних показників щодо розвитку

та ефективності бурякоцукрового підкомплексу за формами статистичної та бухгалтерської звітності*.

*Джерело: розробка автора.

Економічна ефективність виробництва визначається за окремими видами продукції, за групами однорідних культур, наприклад, за цукровими буряками чи 
зерновими культурами, за окремими галузями тваринництва i загалом у сільському господарстві. У цілому щодо галузі вона визначається ефективністю виробництва кожного продукту і часткою витрат на певний продукт у загальних витратах.

Разом 3 тим, усі застосовувані сучасні показники ефективності бурякоцукрового підкомплексу грунтовно були розроблені ще радянською економічною наукою і не завжди пристосовані до реального відображення існуючих економічних процесів. Зокрема вони не враховують ринковий підхід щодо оцінки господарювання, мало пристосовані, як і вся система статистичної звітності в Україні, до відображення сільськогосподарських процесів у господарствах населення. 


\section{8 Аналіз виробничого ризику з допомогою експертної оцінки}

Анотація. У цій монографії розглядаються можливості застосування методів експертної оцінки в аналізу виробничого ризику.

Ключові слова: охорона праці, надзвичайна ситуація, техногенна подія, виробничий ризик, якісний та кількісний метод, наслідки.

На сьогоднішній день вивчення питань виробничих ризиків дуже актуально у ряді країн світу, у тому числі і у Україні, і щоденно це питання різко зростає. Чому?

Перше, необхідність активізувати профілактичні заходи, які спрямовані на збереження життя і здоров'я працівників.

Друге, збільшення правових наслідків, пов'язаних з урахуванням рівня виробничого ризику при оцінці якості управління охороною праці в даній виробничій системі.

У цьому плані особливої уваги заслуговує процедура аналізу виробничих ризиків, що включає ідентифікацію і оцінку ризиків. Вона може здійснюватися за допомогою різних методів і схем.

Існує багато різних методів оцінки виробничого ризику. Серед них навряд чи можна виділити деякий універсальний метод, який підійшов би усім організаціям. Тому, вибір способу оцінки ризику фахівці, як правило, роблять самостійно.

Виробничий ризик можна оцінити якісно або кількісно. Як що виробничий ризик оцінений якісно, то він характеризує походження потенційної небезпеки і вид небезпеки. I при цій оцінці в процедуру оцінки ризику може вводиться система балів, яка більш менш суб'єктивно (чисельне) оцінює можливість події і наслідку його небезпеки, то тоді можна говорити і про напівкількісний метод оцінки.

Напівкількісний метод доповнює якісний аналіз. Як правіло, його використовують в початковій стадії кількісного аналізу. 
Кількісна (чисельна) оцінка ризику по відношенню до якісної має ряд переваг: вона дає основу об'єктивно судити про міру загрози; вона дає можливість розробити ту, що відповідає мірі ризику систему управління; вона показує, що тільки чисельне можливо бути оцінені ризики порівняти 3 нормативними вимогами, а також між собою, незважаючи на відмінну природу їх походження.

В житті найчастіше застосовуються якісні методи. Особливо коли відсутні необхідні дані або їх дуже мало, яскравим прикладом якісного аналізу виробничого ризику, являється метод, грунтований на застосуванні діаграм в системі координат вірогідність події - наслідку події. Такі діаграми, як правило, представляються у вигляді матриць, які показують залежність рівня (категорії) ризику від співвідношення вірогідності події і тяжкості його наслідків. Якщо якісна оцінка ризику показує вірогідність і небезпеку наслідків, то необхідні параметри визначаються за системою балів або пунктів. Цей метод оцінки ризиків широко використовується в Україні в системі управління охороною праці [299-303]. По цьому методу оцінку виробничого ризику на виробничому об'єкті проводить, як правило, сам керівник цього об'єкту, і він часто залучає незалежних експертів, від кваліфікації і досвіду яких залежить якість і повнота виконаної роботи. Головним недоліком цього методу $є$ його абсолютна суб'єктивність: по-перше, експерти, грунтуючись тільки на своїх знаннях, своєму досвіді, відчуттях, по-друге, вони вирішують, до якої категорії віднести вірогідність і тяжкість небажаних наслідків. Величина ризику $(\mathrm{R})$ визначається як твір вірогідності (Р) події на його наслідки (S): $\mathrm{R}=\mathrm{P} \times \mathrm{S}$ [299].

По-третє, різні експерти можуть оцінюватимуть одну і ту ж ситуацію порізному, і не виключено, що один і той же експерт через деякий час оцінить той же ризик на тому ж робочому місці по-іншому.

I тоді, можна задати питання про коректність вживаних експертних методів оцінки виробничого ризику, а відповідь наступна:

1. Експерти спеціально не підбираються, і можливо бути зацікавленими особами, що найсуворіше заборонене при проведенні експертної оцінки; 
2. Оцінка виробничого ризику проводиться, як правило, у рамках одного туру, що не дає можливості обговорення і узгодження оцінок;

3. Може бути так, що не завжди на підприємстві $є$ математичка обробка результатів.

Щоб розібратися в цьому питанні, зупинимося детальніше на методах експертної оцінки i, зокрема, можливості застосування їх для оцінки виробничого ризику.

«Експерт» в дослівному перекладі 3 латинської мови означає «досвідчений». Тому метод експертних оцінок полягає в обробці інформації, отриманої шляхом опитування експертів. Використання експертів як джерел інформації про майбутній розвиток досліджуваного процесу (явища, об'єкта), грунтується на гіпотезі наявності бодай у частини провідних спеціалістів конкретної області глибоких $\mathrm{i}$ достатніх знань про шляхи розв'язання досліджуваних проблем. Доречно зазначити, що широке використання методів експертних оцінок в сучасній методології прогнозування «Форсайт» обумовлено тим, що управлінці мають справу з «живим життям», а не з стабільною системою [312]. Таке твердження пояснюється тим, що статистичний апарат прогнозування, який використовується в дослідженнях, виник із методології експериментальної фізики - зокрема, теорії експерименту. У сучасному світі внаслідок науково-технічного прогресу особливу увагу у прогнозуванні i стратегічному аналізі звертають на якісні аспекти змін. Тенденції зростання цих змін обумовили, як свідчить огляд літературних джерел, збільшення питомої ваги експертних методів прогнозування приблизно до 40...50 \% [319]. Отже, зростання якісних змін сприяє розвитку і вдосконаленню експертних методів прогнозування і водночас звужує можливість використання точних розрахунків, які грунтуються на формалізованих моделях, що відображають різноманітність причинно-наслідкових зв'язків еволюції явищ (процесів, об’єктів).

Підсумовуючи сказане, можна зі всією визначеністю стверджувати, що методи експертних оцінок в прогнозуванні використовуються в таких випадках: 3/4 в умовах відсутності достатньої за обсягом та достовірної інформації про 
прогнозовані явища (процеси, об'єкти); 3/4 в умовах значної невизначеності середовища, де функціонує об’ єкт; 3/4 в умовах дефіциту часу або екстремальних ситуаціях; 3/4 при розробці середньо - та довгострокових прогнозів об'єктів, які підпадають під вплив корінних змін, наприклад, наукові відкриття.

3 цією метою не протязі останніх десятирічь були розроблені ряд прийомів і методики, що сприяли значному поглибленню дослідження проблем, які не піддавались кількісній формалізації.

Діапазон таких методик досить широкий - від відбору експертів, до розробки і вдосконалення методів оброблення даних анкетного опитування.

Методи експертної оцінки нині стали невід'ємною частиною науковопрактичної діяльності. Це пов'язано з тим, що для вирішення поставлених завдань, по стратегії введення представлених для ухвалення обгрунтованих і зважених рішень завжди необхідно спиратися на професійний досвід, на знання і інтуїцію фахівців (експертів), що часто є єдиним і незамінним засобом для досягнення поставленої мети. Методи, що грунтуються на використанні експертних оцінок, діляться на дві групи: індивідуальні (персональні) експертні оцінки та групові (колективні) експертні оцінки. Виділяється два методи індивідуальних експертних оцінок: інтерв'ю і аналітичні записки.

Метод інтерв'ю передбачає бесіду організатора експертизи (прогнозиста) 3 спеціалістом-експертом у певній галузі знань, що проводиться у відповідності за заздалегідь розробленою програмою?

Прогнозист ставить перед експертом питання відносно перспектив розвитку об'єкта прогнозування. В процесі проведення індивідуального опитування програма дослідження може неодноразово корегуватися в наслідок отримання нової інформації на проміжних етапах дослідження.

Теоретично, при індивідуальному опитуванні може бути задіяний лише один експерт за умови, що рівень його знань дозволить інформаційно забезпечити потреби організаторів експертизи по досліджуваній проблематиці. Однак, як правіло, до опитування з метою підвищення надійності експертизи залучають групу експертів. 
Ступінь формалізації інтерв’ю по певній проблематиці може бути різною. Низький рівень формалізації опитування - неформальна бесіда, в результаті якої визначається тільки тема проблеми.

Експерт у такому випадку самостійно вирішує як ії̈ висвітлювати і що по ней доповідати. При необхідності, організатор експертизи може задати експерту уточнюючі або навідні питання.

Високий рівень формалізації передбачає чітко відповідати на [299] листа 3 питаннями відкритого типу. Цей метод у порівнянні з попереднім складніший як на етапі проведення опитування, тому що вимагає високої кваліфікації інтерв’ю, так і на етапі інтерпретації отриманої інформації - вимагає високої кваліфікації дослідника (експерта).

Успіх експертизи за методом інтерв’ю в значній мірі визначається здібністю експерта експромтом давати відповіді на найрізноманітніші складні, фундаментальні питання про перспективи розвитку досліджуваного об'єкта (процесу, явища). Суттєвий недолік зазначеного методу - недостатність часу для експерта на підготовку відповідей.

Метод аналітичних записок проводиться у письмовій формі (анкета) шляхом надсилання експерту питань з зацікавленої проблематики, на які повинні бути отримані однозначні відповіді.

Питання можуть бути як відкритого, так і закритого типу. В останньому випадку повинні бути запропоновані варіанти відповідей. Анкета може бути відправлена по звичайній або електронній пошті, однак заздалегідь повинна бути попередня домовленість 3 експертом. Цей метод передбачає високий рівень кваліфікації організаторів експертизи на етапі постановки питань і організації проведення опитування, а також в частині обробки одержаної інформації.

На відміну від методу інтерв’ю метод аналітичних записок надає можливість експерту на проведення тривалої і ретельної роботи над аналізом тенденцій, оцінкою стану і шляхів розвитку прогнозованого об'єкта. Цей метод дозволяє експерту використати всю необхідну йому інформацію про об'єкт 


\section{SOCIO-ECONOMIC AND MANAGEMENT CONCEPTS}

прогнозування. Свої міркування i висновки експерт оформляє у вигляді аналітичної записки.

Основними перевагами розглянутих методів є можливість максимального використання потенційних можливостей експертів та незначний психологічний тиск, який чиниться на спеціалістів [320].

Суттєвим недоліком методу індивідуальних експертних оцінок $є$ те, що не кожний експерт бере на себе відповідальність самостійно дати оцінку складним явищам (процесам, об’єктам) без урахування думок інших експертів. Власне відсутність наукових зв'язків між експертами, обмеженість знань окремих спеціалістів робить розглянуті методи мало придатними для прогнозування найбільш складних загальних стратегій. Індивідуальні методи експертної оцінки в основному застосовують для оцінки добре відомого об'єкту за відпрацьованими і перевіреними на практиці критеріями. Поняття індивідуальної оцінки тут використовується в тому сенсі, що кожен учасник експертної комісії робить оцінку незалежно від інших членів комісії. Аудит такого типу більшою чи меншою мірою є рутинною роботою, яка не вимагає глибоких знань про суть аналізованого ризику. У зв'язку з цим індивідуальна оцінка експертів допустима у випадках, коли необхідно зробити малозначні висновки або прийняти маловажні рішення. У області охорони праці така оцінка може бути застосовна у випадках, коли проводять перевірку безпеки праці, дотримання норм пожежної безпеки і тому подібне. Оцінка експертів в таких перевірках обмежується виведеними "є" - "ні" або "відповідає" - "не відповідає", які вказують в заздалегідь розробленому опитному листі. Найбільш об'єктивним є колективні методи експертної оцінки, які характеризується відкритим обговоренням проблем і оцінок і колективним ухваленням рішення. До колективних методів експертних оцінок відносяться, насамперед, метод комісій і метод Дельфі. Сьогодні широке розповсюдження отримали експертні методи, які грунтуються на роботі створених спеціальних комісій. Суть методу комісії полягає в тому, що спеціалісти, які входять до однієї групи, погоджують свою думку про стан будь - якого об’ єкту в майбутньому або шляхах і методах досягнення цілей у відкритій 


\section{SOCIO-ECONOMIC AND MANAGEMENT CONCEPTS}

дискусії, найчастіше за круглим столом. В ході проведення дискусії узгоджуються думки всіх експертів і розробляється загальний експертний висновок на основі консенсусу.

Колективна думка експертів в результаті дискусії визначається шляхом відкритого або таємного голосування. В деяких випадках до голосування не удаються, коли загальна думка виявляється в процесі дискусії [321].

Метод комісії має як свої переваги, так і недоліки. До переваг методу комісії можна віднести наступне [305]:

Перше, сукупність інформації, якою володіють всі члени групи принаймні не менша обсягу інформації чим володіє досвідчений експерт.

I якщо навіть і $є$ спеціаліст, який в більшій мірі знайомий 3 об'єктом дослідження ніж решта частина групи, то все ж останні здатні зробити корисний внесок у прогнозну оцінку досліджуваної проблеми.

Як правило, до складу групи входять спеціалісти, які добре обізнані на певній проблематиці, тому їх сукупний обсяг знань перевищує кількість інформації, якою володіє будь-який із спеціалістів групи, інакше кажучи, група спеціалістів виробляє більше «розумової» енергії ніж один спеціаліст.

До того ж, в процесі дискусії, коли експерти обговорюють проблеми i аргументують свою точку зору, зазвичай, можливе зростання інформованості спеціалістів по досліджуваній проблематиці.

Друге, відомо, що кількість факторів (напрямків), що визначає розвиток об’єкта (процесу, явища), і які розглядаються всіма членами групи, по меншій мірі не менше тієї, яку може визначити будь-який член групи.

Третє, група експертів, принаймні, з більшою готовністю бере на себе відповідальність за прийняття важливих, ризикованих рішень, ніж окремий спеціаліст.

Незважаючи на простоту процедури опитування і широке розповсюдження, метод комісії має і принципові недоліки [305, с. 23, с. 24]:

1. Частина групи може мати певний вплив на решту членів групи. Нерідко «криклива меншість», керуючись власними інтересами, може подавити 
більшість, і ті вимушені будуть погодитись під тиском наполегливості меншості, розуміючи при цьому, що аргументи останніх помилкові.

2. Суттєвим фактором, який впливає на загальні висновки, стає різна активність експертів групи. Дискусія в групі зводиться, зазвичай, до полеміки найбільш авторитетних експертів (знані спеціалісти, вчені-корифеї, крупні керівники). I якщо названі експерти мають талант переконання, то вони в змозі рішуче впроваджувати свої ідеї шляхом наполегливої постійної аргументації, навіть при наявності у інших членів групи своїх протилежних переконань.

Крім того, публічність висловлювання може призвести до небажання окремих експертів відмовитися від раніше висловлених думок, навіть в умовах, коли вони зазнали змін в процесі дискусії.

3. Група експертів, як і будь-яка група, $є$ самостійним організмом i функціонує завдяки цьому за певними законами. В групах існує думка, що досягти згоди більш важливо, а ніж розробка найобгрунтованішого і практично корисного прогнозу, або іншими словами, група у своїх судженнях керується в основному логікою компромісу, а не однією лише внутрішньою логікою досліджуваної проблеми. Все це пояснюється психологією групи експертів, а саме: схильністю окремих експертів періодично міняти свою точку зору; небажанням відкрито дебатувати; схильністю окремих експертів відстоювати один раз висловленим судженням, якщо вони навіть виявились помилковими, що стало очевидним самому експерту та інше. При цьому не фіксуються думки i аргументи тих експертів, які не співпадають з думками більшості.

Метод комісії можливо поліпшити, якщо забезпечити безперешкодний обмін інформацією, діджиталізацію, цифрову трансформацію усередині групи і створити умови для вільного, незалежного висловлення суджень кожним експертом.

4. Інерційність мислення, «честь мундира» переконує певну частину групи схиляти решту членів до прийняття рішень, особливо якщо вони були орієнтовані на ці рішення з самого початку. 
У цьому сенсі найбільш прийнятним є метод Дельфі, відповідно до якого процедура оцінки розбивається на декілька турів, а також проводиться узгодження оцінок. Цей метод є більше трудомістким, оскільки процедура його проведення включає декілька етапів: формулювання мети експертизи і розробка процедури опитування; відбір і формування групи експертів; проведення опитування; аналіз і обробка інформації, отриманої від експертів; ухвалення рішення відповідно до результатів [304, 307-313, 318].

При використанні цього методу експерти спеціально підбираються згідно 3 рівнем їх кваліфікації (професійна освіта), стажу роботи, спеціальності і досвіду практичної роботи. Але вони, експерти, заздалегідь надають інформацію про себе у формі "анкети" за наступними характеристиками: компетентність; діловитість; об'єктивність; зацікавленість в участі в роботі експертної комісії.

Компетентність повинна включати: - професійна освіта, у тому числі в області охорони праці; - досвід розробки нормативної, технічної і методичної документації в області охорони праці; - підготовку і перепідготовку в області охорони праці; - досвід практичної роботи в області охорони праці та ін.

Від індивідуальних особливостей, завантаженості основною роботою, цілей оцінки і можливостей використання результатів у своїй практичній діяльності залежить зацікавленість експерта в роботі експертної комісії. Вона повинна включати: участь у функціонуванні системи управління охороною праці в організації (об’єкта); участь в наукових семінарах і конференціях 3 охорони праці; наявність наукових робіт, публікацій в області охорони праці. Стратегічним напрямком $є$ : зібраність, оперативність в роботі, здатність швидко перемикатися з однієї проблеми на іншу, уміння працювати з людьми при рішенні завдань в конфліктній ситуації, здатність протистояти думці більшості при упевненості у своїй правоті, уміння чітко формулювати свої думки - це все включає - діловитість експерта. Для цілей оцінки професійних ризиків може бути важливий досвід участі в проведенні наглядове-контрольних заходів, експертиз в області охорони праці. 
Об'єктивність (неупередженість) експерта полягає у винесенні ним суджень, що характеризують дійсний стан даної проблеми, зокрема, оцінки професійних ризиків. Упередженості і упередженості бути не повинно. Слід враховувати чинник можливої суб'єктивної зацікавленості експертів зрештою.

При використанні цього методу оцінки виробничого ризику, експерт (як і у других методів) не має бути пов'язаний з оцінюваним об'єктом за ознаками участі в трудовому процесі. Він має бути неупереджений (відсутня матеріальна зацікавленість в діяльності на аналізованому робітнику місці). Може формуватися робоча група, (крім експертної групи) яка організовує і проводить засідання експертних груп, аналізує отримані результати і проводить розрахунок експертних оцінок. Проведення оцінювання здійснюється в декілька турів. У першому турі експертам пропонуються питання, на які вони дають відповіді без аргументації. Результати опитування обробляються і повідомляються експертам. У другому турі експерти аргументують або змінюють свою первинну оцінку 3 поясненням причин коригування. Подальші тури здійснюються при дотриманні аналогічної процедури. Зазвичай після третього або четвертого туру значення оцінки стабілізуються, що служить критерієм припинення подальшого опитування. Об'єктивність (неупередженість) експерта полягає у винесенні ним суджень, що характеризують дійсний стан даної проблеми, зокрема, оцінки професійних ризиків. Упередженості і упередженості бути не повинно. Слід враховувати чинник можливої суб'єктивної зацікавленості експертів зрештою. При використанні цього методу оцінки виробничого ризику, експерт (як і у других методів) не має бути пов'язаний з оцінюваним об'єктом за ознаками участі в трудовому процесі. Він має бути неупереджений (відсутня матеріальна зацікавленість в діяльності на аналізованому робітнику місці).

Спосіб опитування експертів визначається робочою групою до формування експертної групи, щоб ії структура, професійний склад і кількість експертів відповідали способу опитування. При цьому вибирається один з варіантів організації спілкування експертів: відсутність спілкування, заочне анонімне спілкування, заочне спілкування без анонімності, очне спілкування. За 
відсутності спілкування експерт висловлює свою думку, нічого не знаючи про інших експертів і про їх думки. Заочне анонімне спілкування означає, що експерт знайомиться з думками і аргументами інших експертів, але не знає, хто саме висловив те або інше положення. Заочне спілкування без анонімності робиться, наприклад, шляхом розсилок листів, опитувань по телефону або по Інтернету. Усі варіанти заочної експертизи хороші тим, що немає необхідності збирати експертів разом, отже, знаходити для цього зручне час і місце. Проте для досягнення погоджених відповідей необхідно більше часу.

При очному спілкуванні експерти говорять, а не пишуть, як при заочних спілкуваннях, і тому устигають за той же час зробити істотно більше. Очне спілкування - ці збори, що йдуть за фіксованим регламентом. Воно має недоліки, пов'язані 3 можливостями негативного впливу на їх проведення соціальнопсихологічних властивостей і пристрастей учасників, а також нерівності їх професійної, посадової i наукової статусів. Залежно від характеру досліджуваного об'єкту, від міри його формалізації, відповідності характеристик експертів вимогам, що пред'являються, порядок роботи з ними може бути різним, але в основному передбачає проходження наступних послідовних стадій: 1уточнення виду об'єкту, його параметрів і показників, що підлягають експертній оцінці; 2 - уточнення формулювання питань і вживаної термінології; 3 узгодження форми представлення результатів експертних оцінок; 4 пред'явлення експертам анкет, опитних листів і інших роздавальних матеріалів. Потім передаються відповідні пояснення, в яких описується мета роботи, структура i порядок побудови роздавального матеріалу; 5 - самостійне заповнення експертами анкет.

Робоча група обробляє результати експертної оцінки виробничого ризику. Враховуючи, що колективні методи експертної оцінки є більше трудомісткими, ніж індивідуальні, вони рідше застосовуються у рамках окремих організацій при оцінці виробничих ризиків. Але ці методи незамінні у випадках, коли необхідно отримати кількісну оцінку ризиків. Повертаючись до методології оцінки виробничого ризику в організаціях за допомогою діаграм у вигляді матриць, 
грунтованих на вірогідності і наслідках подій, можна з упевненістю сказати, що в даному випадку використовуються індивідуальні методи експертної оцінки, які характеризуються, як вже було сказано вище, високою мірою суб'єктивності. Щоб посилити об'єктивність індивідуального методу експертної оцінки виробничого ризику, можна додатково використати метод опитних анкет для працівників різних професій[300]. Цей метод застосовують у випадках, коли вимагається оцінити небезпеку виробництва або окремих робочих місць, грунтуючись на типових робітничих операціях, оцінити об'єкт на відповідність вимогам нормативів або стандартів, а також, щоб об'єктивно оцінити і взяти до уваги думки і побажання самих працівників. Перевагою цього методу є те, що фахівець з охорони праці без спеціальної підготовки, аналізуючи інформацію, отриману з опитних анкет, може прийти до задовільного результату і отримати необхідні дані для проведення подальшої повнішої оцінки ризиків. Ефективність використання анкет залежить від компетенції і досвіду їх укладачів, тому їх необхідно постійно переглядати і доповнювати. Самі «Опитні анкети» необхідно розробляти індивідуально для кожного виду діяльності (професії). У анкеті мають бути присутніми такі позиції, як оцінка робочого місця, робоче навантаження, характеристика приміщення, організація праці, а також показники, що дозволяють визначити професію працівника, професійний стаж, вік, чол./жінка і отримати іншу необхідну інформацію. У анкету бажано включати питання, що зачіпають відношення працівників до ризику, присутніх в ïx робочому середовищі: чи відповідає мікроклімат необхідним вимогам; чи існують фізичні (шум, вібрація та ін.), хімічні і біологічні чинники, психічні проблеми і тому подібне. Якщо є присутнім фізичне навантаження, то в анкеті мають бути питання про тяжкість предмета, що піднімається або переміщуваного, або вантажу, кількість операцій за зміну, дискомфорт або больові відчуття в окремих частинах тіла до кінця зміни і інші відомості. I на останок, варто звернути увагу на наступне. Досить простий апарат обробки даних анкетного опитування справляє враження, що методом Дельфи без всяких проблем можна досягти необхідних результатів. Однак це оманливе враження. 
Анкетне опитування - це досить складна і витончена наукова робота [322]. Особливо складні проблеми виникають про формуванні експертної групи. Високий професіоналізм і творча активність експерта - це далеко не всі риси, які необхідні для проведення якісного дослідження. В сучасних умовах переходу до нових напрямків сталого розвитку, заснованої на знаннях, коли основним джерелом переваг у конкурентній боротьбі є інноваційна діяльність $[314,316]$, без якої неможливо підвищити ефективність будь-якого сектору у виробничої діяльності, не менш важливо, щоб експерти грунтовно знали зміст досліджуваних процесів (явищ, об'єктів), розуміли всі різноманітні зв'язки взаємозалежності між окремими елементами, цих процесів. І лише за органічного сполучення таких рис дослідників експертні методи стають ефективним інноваційним інструментом для успішного розв'язання поставлених завдань. Головним фактором, в цьому, що обумовлює інноваційну активність, впродовж останніх 10 років залишається людський капітал [320]. Підсумовуючи сказане, що зараз коли компанії змушені переходити на методи, в тому числі діджиталізації, цифрової трансформації, які вони не планували впроваджувати до певного часу, і переглядати свої стратегічні пріоритети, можна зі всією визначеністю стверджувати, що єдиним критерієм для визначення якості прогнозу - це його корисність для особи, що приймає рішення, тобто, на скільки прогноз сприяє прийняттю вірних і своєчасних рішень [305]. Неоцінену послугу тут можуть надати науково-обгрунтовані прогнози, моніторинг, які грунтуються на сучасній теорії і методології прогнозування з урахуванням безперервних змін у зовнішньому середовищі і надання пріоритету тим методам, які у найбільшій мірі відповідають сучасним вимогам і реаліям [306]. Експертні методи у теперішній час $\epsilon$ найбільш розповсюдженим способом отримання i аналізу якісної інформації. Все це обумовило подальший розвиток і удосконалення зазначеного методу, підвищення рівня його надійності. 3 цією метою протягом останніх десятирічь були розроблені ряд прийомів і методик, які значно поглибили можливості досліджування проблем, які не піддавались раніш 


\section{SOCIO-ECONOMIC AND MANAGEMENT CONCEPTS}

кількісній формалізації. Діапазон таких методик досить широкий: від відбору експертів, до розробки методів оброблення даних анкетного опитування.

Підводячи підсумок вищевикладеному, слід зазначити, що існуючі різноманітні формальні методи оцінки ризиків у багатьох випадках (реально в усіх нетривіальних ситуаціях) не можуть дати однозначних рекомендацій. Зрештою рішення приймає людина, яка несе за це відповідальність (керівник підприємства, об'єкту, то що). Тому процедури експертного оцінювання бажано включати в аналіз виробничих ризиків у рамках новостворюваних, а також функціонуючих систем управління охороною праці. Тому, щоб знизити ризик прийняття невдалих управлінських рішень, необхідно постійно підвищувати ступінь інформованості керівників підприємства 3 метою посилення передбачуваної складової системи управління. 


\section{9 Економічний механізм розрахунку вартості та просування туру в контексті туроператорської діяльності підприємства}

Туризм - це сучасна світова економічна індустрія, що акумулює в собі величезну долю фінансових, соціально-культурних, інтелектуально-трудових та інших складових ресурсного потенціалу, дослідження яких $є$ необхідною умовою їх раціонального та ефективного використання. Тому питання організації туроператорської діяльності в практичній сфері туріндустрії, зокрема формування цікавих та якісних туристичних продуктів, які б задовольняли потреби сучасних і одночасно вибагливих туристів $є$ важливими, своєчасними та актуальними для дослідження. Це в повній мірі можна віднести до вивчення механізму створення і просування туристичного продукту.

Авторами розглянуто механізм формування та просування туристичного продукту на основі використання маржинального доходу турфірми, починаючи с формування тур-проекту, розрахунку його собівартості та напрямів його подальшої популяризації. [323, 325, 326]

В якості об’єкта для формування туристичного продукту обрано гірськолижний курорт «Оберйох» в Німеччині, по якому сформовано елементарний тур та наведено приклад розрахунку його вартості. Цей курорт характеризується багатьма конкурентними перевагами, тому тур-проект по цій туристичній дестинації - це ідеальне рішення для туроператорів, що працюють на ринку спортивно-відпочивального туризму. [326]

Тур-проект має назву «Гостинний Оберйох». Його спроектовано на 9 днів, включаючи переіт Київ - Мюнхен і Мюнхен - Київ. Передбачає розміщення і основне харчування в 4-х зірковому готелі «Panoramahotel Oberjoch»; включає 12 головних та інших програм: привітальна вечірня програма в готелі; відвідування лижної та сноубордшкіл; піші прогулянки по лісовим маршрутам; катання на червоних, синіх, чорних трасах з інструктором; катання на санках, собачих упряжках, ковзанах, в кареті, запряженій лошадьми; паб-екскурсія 3 дегустацією найкращих сортів німецького пива та національних страв; купання 
в басейні; літання на повітряному шарі; відвідування найкрасивішого озера країни - озера Бодензее; екскурсія по старовинним баварським монастирям та замкам королів; відвідування сувенірної лавки.

Економічна ефективність туристичного продукту «Гостинний Оберйох» буде обчислена на основі вартісних показників основних та додаткових послуг.

1. Визначення вартості проживання в 4-х зірковому готелі «Panoramahotel Oberjoch»: кількість проживаючих в номері -3 особи, вартість номеру в готелі за тур - 3675 євро. Вартість мешкання одного туриста по маршруту: 3675/3 = 1225 (євро).

2. Визначення вартості харчування: харчування включає сніданок, обід і вечерю; вартість харчування одного туриста на добу - 175 євро, кількість днів туру -9 . Розрахунок вартості харчування по маршруту: 175*9=1575 (євро).

3. Розрахунок витрат на проїзд: переїзд в обидва боки: $120 * 2=240$ (євро), трансфер (зустріч, проводи) - 30 євро, інше - 12 євро. Всього сума 31 особи по туру на витрати на проїзд: $240+30+12=282$ (євро).

4. Визначення витрат на додаткове обслуговування по маршруту: екскурсійне обслуговування включає 12 програм. Загальна їх вартість на одну особу по всьому туру 1700 євро.

5. Видатки на страхування становлять 31 євро, а витрати на керівника по туру складають 155 євро.

6. Розрахунок видатків на оплатукомісійних турагентам: 9\% від 4968 або 0,09*4968, тобто 447,12 євро.

7. Розрахунок собівартості туру на одного туриста проводиться за підсумком всіх понесених витрат і становить 5415,12 (євро).

8. Встановлення ринкової ціни туру для одного туриста здійснюється по формулі:

$$
\text { Цод. = Сод. + Пдод.од., }
$$

де Цод. - установлена підприємством ціна на послугу (без ПДВ 20\%);

Сод. - собівартість одиниці продукції, послуги (турпродукту); 


\section{SOCIO-ECONOMIC AND MANAGEMENT CONCEPTS}

Пдод.од. - припустимий для даної галузі прибуток, що доводиться на одиницю продукції.

Отже, а) припустимий для даної галузі прибуток: Пдод.од. $=5415,12 * 19 \%$ $=1028,87$ (євро); б) установлена підприємством ціна на тур для одного туриста Цод (без ПДВ $)=5415,12+1028,87=6443,99$ (євро); в) вартість турпродукту для кінцевих споживачів (Цк) з урахуванням ставки ПДВ 20\% складатиме: 6443,99 $+20 \%=7732,79$ (євро).

9. Планування реалізації турів на основі маркетингових досліджень: кількість реалізованих групових турів - 52 тура, кількість людей в групі - 14; тобто за рік планується здійснити 52 групових турів по 14 осіб, у цілому за рік таким чином буде продано 728 тури одноосібні (Nтур).

10. Розрахунок маржинального доходу (Мp) від кількості проданих турів:

$$
\text { Мр = Пдод.од. * Nтур }
$$

Отже, $\mathrm{Mp}=1028,87 * 728$ тура $=749017,36(\epsilon в р о)$.

11. Визначення річного валового прибутку (Пвал), одержуваного фірмою по даному турпродукту:

Крім врахованих у собівартості тура прямих витрат, фірма несе й постійні витрати по організації й реалізації даного й інших турів. Сума постійних витрат на даний тур складатиме 120 євро. Знаючи величину річного маржинального доходу (Mp) і суму постійних витрат за рік (Впост), визначають річний валовий прибуток (Пвал), одержуваний фірмою по даному турпродукту:

$$
\text { Пвал }=\mathrm{Mp}-\text { Впост * } 12 \text { місяців }
$$

Отже, Пвал $=749017,36-120 * 12$ місяців $=747577,36$ ( євро).

12. Визначення чистого прибутку (Пч) фірми по даному турпродукту:

Для визначення чистого прибутку необхідно відняти із валового прибутку податок на прибуток (приймемо базову ставку, що діє в Україні і становить 18\%):

$$
\text { Пч = Пвал - Податок на прибуток }
$$

Отже, Пч $=747577,36-18 \%=613013,44$ ( євро).

13. Оцінка економічної ефективності нового продукту за допомогою показників рентабельності й прибутковості продукції: 
Показник прибутковості розраховується по формулі:

$$
\text { Ппр = Пвал / Sпр * } 100 \text { \%, }
$$

де Ппр - прибутковість нового продукту, послуги,\%;

Пвал - валовий прибуток компанії, одержуваний від продажів нового турпродукту, послуги, гр.од.;

Sпр - сума продажів нового турпродукту, послуги, гр.од.

$$
\text { Sпр = Цк * Nтур }
$$

Отже, Спр $=7732,79 * 728$ турів $=5629471,12($ євро $)$;

Ппр $=747577,36 / 5629471,12 * 100 \%=13,3 \%$.

Коефіцієнт рентабельності розраховується по формулі:

$$
\text { Рпр }=\text { Пч / Sпр* } 100 \%,
$$

де Рпр - коефіцієнт рентабельності нового продукту, послуги по методиці компаній США, \%;

Пч - чистий прибуток компанії, одержуваний від продажу нового продукту, послуги, гр. од.

Отже, Рпр = 613013,44/5629471,12*100\% = 10,9\%.

Виробнику турів слід враховувати той факт, що якщо очікування споживачів щодо туристських вражень не виправдовуються, вони можуть переключитися на купівлю турів інших туроператорів, а це в підсумку позначиться на прибутках турфірми-виробника. Тому після формування туру, наступною головною задачею туроператора $є$ його популяризація, просування $\mathrm{i}$ реалізація кінцевому споживачу. Іншими словами - застосування системи маркетингу турпродукту. [324]

В першу чергу необхідно використати описову рекламу турпродукту - в засобах масової інформації. Та каталожну 3 яскравим візуальним супроводженням, в якій надати головні характеристики курорту та його конкурентні переваги. Застосування безлічі рекламних механізмів не дасть користі без використання розгалуженої системи агентської мережі, оскільки сама туроператорська фірма є оптовиком послуг, не має прямого контакту з дрібними споживачами і потребує послуг посередників. Для цього існують туристичні 
агенції та постійно діючі активні агенти. В контексті реалізації туру, що пропонується, бажаним є його подальше удосконалення. Для реалізації цієї складової туроператору чи агенціям слід розробити анкету для вивчення потенційних споживачів, їх мотивів і цілей відпочинку з метою удосконалення та формування якісного і комплексного туристичного продукту.

Таким чином, розглянутий механізм формування i просування туристичного продукту на прикладі засвідчує, що він $є$ ефективним, економічно вигідним для туроператора та цікавим для туристів, які полюбляють чисте повітря і зимовий спорт, особливо в контексті сімейного відпочинку. Реклама курорту, що може бути застосована агентською мережею, добре демонструє його конкурентні переваги. Анкета споживача допоможе виявити побажання потенційних туристів, які можна врахувати при удосконаленні турпродукту. 


\subsection{0 Економічна сутність та особливості аутсорсингу}

Процеси глобалізації та кооперації, необхідність підвищення ефективності у змінному середовищі, розвиток теорії стейкхолдерів призводять до необхідності пошуку все нових способів взаємодії між різними суб'єктами ринку. Однією із найбільш поширюваних форм взаємодії та кооперації протягом останнього десятиліття стало використання аутсорсингу. Поняття “аутсорсинг” (“outsourcing”) є англомовного походження, а точніше скороченням англійського терміну “outside source using" або "outsideresourcing”, що означає застосування (використання) зовнішніх джерел або ресурсів [328]. З'явився цей термін у практичній діяльності на початку 60 років минулого століття, а саме - у 1962 р., коли було засновано Electronic Data System Corporation (EDS) [329].

Аутсорсинг найчастіше поділяють на внутрішній (угоди укладаються в середині країни) або інколи його називають інсорсинг (insourcing) та іноземний (iз іноземними контрагентами) [330]. Серед іноземного аутсорсингу виокремлюють офшоринг (offshoring) - перенесення окремих бізнес-процесів в іншу країну. Основна причина офшорингу, як зазначають практики та науковці, уникнення оподаткування або низька вартість робочої сили [331].

Розвиток інформаційних технологій та перших IT підприємств став фактично акселератором поширення аутсорсингу. Використання у своїй практиці компанією Eastman Kodak інструментарію передавання зовнішнім партнерам процесів збирання, обробки та забезпечення інформаційними потоками прийняття управлінських рішень утвердив доцільність застосування аутсорсингу в діяльності компаній-лідерів. Фірми почали вишукувати та формувати бізнес-моделі як конгломерат оптимального поєднання внутрішніх та зовнішніх процесів, необхідних менеджерських компетентностей, підходів реагування на зміни зовнішнього середовища, яке представлено сукупністю різноспрямованих цілей та завдань стейкхолдерів 3 метою досягнення максимально можливого рівня конкурентоспроможності за ціною, якістю, обсягом виробленої продукції, охопленням ринку тощо. 
Хоча в тій чи іншій формі аутсорсинг використовувався ще від початку економічної кооперації між людьми, які намагались взаємодіяти у виробництві товарів чи послуги, враховуючи ключові переваги кожного із членів такої взаємодії та забезпечуючи їм бажані результати. Аутсорсинг в результаті кооперації та перенесення виконання окремих функцій чи завдань із базового підприємства до контрагентів дає змогу отримати конкурентну перевагу. При запровадженні перших аутсорсингових проектів компанії, які наважилися ними скористатись, розраховували на скорочення витрат на рівні 15-20\%, однак реалізація показала, що в середньому витрати компаній знижувались на рівні $40 \%$ (в розрахунку враховувались, насамперед, передача фінансових та інформаційних функцій) [332]. Хоча багато перших аутсорсингових угод були катастрофічними для однієї або іншої сторони через відсутність достатньо розроблених нормативно-правових актів, які б регулювати цей вид угод. Як свідчать результати дослідження ринку Американської асоціації менеджменту, більше аніж 50\% усіх підприємств на ринку США застосовують аутсорсинг для одного і більше етапів виробництва чи бізнес-процесу.

Особливого поширення аутсорсинг набуває у сферах діяльності чи виконанні окремих функцій, які потребують вузькоспеціалізованих знань чи навиків, водночас, які реалізуються рідко або фрагментарно. Тому аутсорсинг, насамперед, розвинувся у маркетинговій, рекрутинговій, правовій, логістичній, фінансовій, обліковій, безпековій та IT діяльностях.

Основними центрами аутсорсингу вважається Європа, США та Японія. Однак в останні десятиліття активно почали долучатись до формування та розподілу аутсорсингових потоків країни Південної Америки, Східної Свропи та Азії. Завдяки поширення та розвитку IT, Україна стала одним із світових лідерів аутсорсингових послуг, саме в цій сфері і набуває поширення на інші види економічної діяльності. Тому, слід теоретично досліджувати та практично намагатись впроваджувати найкращі із моделей аутсорсингу у діяльність підприємств різних видів економічної діяльності. 
Як і будь-який новий термін аутсорсинг немає чіткого визначення із окремо окресленими границями та чіткими ознаками. Фактично поняття аутсорсинг використовується як об'єднавче для багатьох видів активності підприємства із винесенням певних операцій, дій та функцій за межі підрозділу або організації загалом, фокусуванні на основному майданчику чи виробництві основного продукту тощо.

У одній із найцитованіших вітчизняних наукових праць, присвяченій проблемам аутсорсингу, визначення цього явища полягає в тому, що у “реалізації окремих функцій або бізнес-процесів зовнішньою організацією, яка володіє необхідними для цього ресурсами, на основі довгострокової угоди” [333].

Схожим до попереднього є визначення українських науковців Загороднього А.Г. та Партин Г.О., що аутсорсинг - це передача окремих дій та функцій провайдерам або постачальникам, у випадку коли останні здатні гарантувати необхідні параметри якості та результативності виконання із можливістю передавання також і частини працівників підприємства замовника. [334].

На передачі функцій наголошують і Тищенко О.М. та Хаустова В.С., а саме на їхню думку аутсорсинг - це залучення підприємством зовнішніх виконавців, що спеціалізуються у відповідній області, для виконання деяких функцій або обслуговування окремих бізнес-процесів [335]. Дж. Кросс доходить висновку, що встановивши конкретні цілі та визначившись із формою аутсорсингу, підприємство фактично таким чином формує індивідуальну стратегію управління із елементами аутсорсингу. Відповідно аутсорсинг є нічим іншим як діловою або корпоративною стратегією діяльності підприємства, оскільки вимагає від керівництва реструктуризацію більшості внутрішньокорпоративних процесів і встановлення тісних коопераційних відносин із аутсорсерами [336]. Вітчизняні науковці підтримують стратегічну спрямованість аутсорсингу як інструменту підвищення рівня конкурентоспроможності організації через фокусування iї діяльності на ключових, компетенціях, завданнях, функціях та/або бізнес-процесах [329]. При цьому бізнес-процес нічим іншим як 
взаємоузгодженням операцій та функцій, спрямованих на реалізацію певного завдання чи досягнення цілі.

Схожим до попереднього запропоноване наступне визначення - аутсорсинг $€$ управлінською стратегію підприємства, яка передбачає оптимізування діяльності шляхом фокусування на основних стратегічних бізнес перевагах обраної моделі та передавання вторинних функцій професійним, спеціалізованим у конкретних сферах компаніям [337].

Також зазначають, що аутсорсинг спрямований на підвищення виробничої ефективності фірми шляхом скорочення витрат, формування гнучкості для адаптування до динамічного середовища, забезпечення належної якості продуктам, уникнення або зниження рівня ризиків [338]. Дослідження промислових підприємств показало, що аутсорсинг є способом розвитку та вдосконалення коопераційних виробничих відносин між суб'єктами в ринкових умовах [339].

Крім того, аутсорсинг є інструментом підвищення конкурентоспроможності фірми шляхом можливості концентрації підприємницьких зусиль на «ядрі» бізнесу, використанні доступності високоякісних послуг і робіт, які необхідні для розвитку бізнесу та оптимізації співвідношення сукупних витрат на ядрові (основні) й не ядрові (допоміжні) бізнес-процеси, бізнес-операції, підприємницькі функції загалом [340, с.84].

Хейвуд Дж. зазначає, що аутсорсинг $\epsilon$ «перенесенням окремих організаційних підрозділів чи відділів організації із пов'язаними активами до провайдера послуг, із зазначенням в аутсорсинговій угоді термінів та ціни виконання угоди» [341, с.40].

До цікавого висновку доходить С. Календжян, який зазначає, що аутсорсинг $€$ інструментом надання на довготерміновий період організаційно-управлінських завдань та функцій із комплексом потрібних ресурсів зовнішнім виконавцям, які здатні реалізувати такі завдання результативніше, тобто аутсорсинг передбачає надання провайдеру не лише повноважень, але й відповідальності за 


\section{SOCIO-ECONOMIC AND MANAGEMENT CONCEPTS}

виробництво певних товарів і надання певних видів послуг компаніям партнерам по бізнесу [342].

При використанні аутсорсингу як маркетингового інструменту передбачається “можливість передачі всіх або ж частини маркетингових функцій іншій фірмі, яка спеціалізується на виконанні певного виду робіт у цій cфepi”'[343].

Слід зазначити, що насамперед в аутсорсингу є достатньо особливостей застосування, які формують його у окремий вид підприємницької діяльності поруч із лізингом, франчайзингом, краудфандингом, інженірінгом тощо. Однак чомусь вітчизняні та іноземні науковці на поспішають визнавати аутсорсинг як окремий вид підприємницької діяльності.

Усі сформовані на сьогоднішній день визначення можна чітко поділити за такими домінуючими аспектами:

Цільовий - описує спектр основних цілей та завдань, які досягаються через використанням аутсорсингу у діяльності підприємств. Серед найбільш поширених цілей $\epsilon$ пошук відповідних ресурсів, зниження собівартості, досягнення вищого рівня гнучкості.

Процесний - передавання певних (як правило, вторинних) функцій, окремих завдань або етапів виробничо-господарської діяльності, які не цікаві для підприємства, враховуючи його основні цілі, постачальникам товарів та послуг.

Стратегічний - полягає в удосконаленні існуючої корпоративної або ділової стратегії, окремих функціональних або операційних стратегій, або вироблення на основі аутсорсингу абсолютно нової стратегії з метою отримання конкурентних переваг та досягнення вищого рівня конкурентоспроможності на ринку.

Стейкхолдерський - знаходження за допомогою аутсорсингу нового балансу інтересів між зацікавленими групами (стейкхолдерами) у діяльності підприємства через залучення постачальників, конкурентів, споживачів або інших стейкхолдерів до побудови спільних бізнес-процесів. 
Усі визначення поняття аутсорсинг систематизовано в розрізі чотирьох домінуючих аспектів та зведено в таблицю 1.

Таблиця 1. Систематизація визначень аутсорсингу в розрізі домінуючих аспектів

\begin{tabular}{|c|c|c|}
\hline $\begin{array}{c}\text { Домінуючий аспект } \\
\text { аутсорсингу }\end{array}$ & Засаднича ідея & $\begin{array}{c}\text { Науковці, що виокремлюють } \\
\text { у визначеннях домінуючий } \\
\text { аспект }\end{array}$ \\
\hline Цільовий & $\begin{array}{c}\text { Спектр основних цілей та завдань, } \\
\text { які можуть досягатись або стають } \\
\text { більш досяжними за допомогою } \\
\text { аутсорсингу }\end{array}$ & $\begin{array}{l}\text { Кесарчук Г.С. [338], } \\
\text { Денисов С.Б.[340], }\end{array}$ \\
\hline Процесний & $\begin{array}{c}\text { Передавання вторинних функцій чи } \\
\text { бізнес-процесів та фокусування на } \\
\text { виконанні основних }\end{array}$ & $\begin{array}{c}\text { Анікін Б.А.[333], Бойчук } \\
\text { І.В.[343], Хейвуд Дж. [341], } \\
\text { Загородній А.Г., Партин } \\
\text { Г.О. [334],Тищенко О.М., } \\
\text { Хаустова В.С. [335]. }\end{array}$ \\
\hline Стратегічний & $\begin{array}{c}\text { Вироблення нової стратегії або } \\
\text { удосконалення існуючої шляхом } \\
\text { застосування аутсорсингу }\end{array}$ & $\begin{array}{c}\text { Дж. Кросс [336], Микало } \\
\text { О.І. [329], Срмошина О. } \\
\text { [337] }\end{array}$ \\
\hline Стейкхолдерський & $\begin{array}{c}\text { Пошук нового балансу інтересів } \\
\text { між зацікавленими групами }\end{array}$ & Матвій I.С. [339] \\
\hline
\end{tabular}

Отже проаналізовані поняття аутсорсингу дають змогу виокремити його ознаки, які є засадничими і відповідно дозволять удосконалити це поняття із максимальним змістовим наповненням. Основними ознаками аутсорсингу є:

- участь у його організуванні та виконанні зацікавлених груп (стейкхолдерів) підприємства чи проекту;

- реорганізація бізнесу та побудова нових бізнес-процесів із інтеграцією у них стейкхолдерів із визначеними стратегічними та операційними цілями;

- фокусування замовника на ключових бізнес-процесах та передачі вторинних - провайдерам; 
- забезпечення належної якості та параметрів з боку провайдера для збереження існуючого становища на ринку та розвитку замовника, при цьому провайдер не тільки фактично фокусується та адаптується до клієнта, а в більшості випадків їхні бізнес-процеси стають вертикально або горизонтально інтегрованими;

- а найголовніше, що це вид підприємницької діяльності, який дає змогу отримувати провайдеру прибуток та інші фінансово-економічні результати, а замовнику покращити результати своєї діяльності.

Використовуючи основні виділені ознаки аутсорсингу, маємо змогу запропонувати таке удосконалене його визначення - аутсорсинг це вид підприємницької діяльності, який полягає у реорганізації бізнес-процесів підприємства шляхом залучення стейкхолдерів до виконання вторинних i неефективних функцій та концентрації на ключових продуктах, сервісах, господарських процесах. 


\subsection{1 Маркетингові інструменти в діяльності підприсмств легкої промисловості}

Основною комунікацією із споживачем в маркетинговій діяльності $є$ реклама, яка відіграє важливу роль у просуванні товарів чи брендів. Статистика показує, що більшість користувачів звертають увагу на рекламу саме на просторах Інтернет-мережі та соціальних мереж. Існує велика кількість рекламних інструментів, серед яких одними із найефективніших є: контекстна реклама, таргетована реклама, банерна реклама, просування товарів за допомогою соціальних мереж, а також Інтернет-маркетинг в цілому.

Найефективнішим способом просування продукції є таргетована реклама, яка дає можливість досягти збільшенню продаж та отриманню прибутків. Прблеми розробки таргетованої реклами досліджувалися в роботах Н. Холліса, Г. Шмітта, Л. Вундерман, М. Супе, О. Петрик, Т. Данько, Б. Лерча, Дж. Бергофа, Т. Дейнекіна, А. Хартмана, С. Мура, Т. Гнатюка, Ф. Котлера, В. Пилипчука.

3 розвитком інновацій в Інтернет-мережі підходи до управління маркетинговою діяльність підприємств змінюються. 3 огляду на це, комплекс маркетингових інструментів можна розглядати з позиції його застосування в мережі, а Інтернет-маркетинг можна вважати інноваційним процесом, спрямованим на задоволення потреб користувачів із застосування рекламних інструментів.

У більшості країн витрати на комунікацію засобами телебачення нижчі, ніж в Україні, проте витрати на комунікацію в Інтернеті більші. В цілому рекламний ринок залишається в таких же об'ємах; при цьому деякі медіа скоротилися в своїх об'ємах. 3 огляду на це Digital (Internet) Media реклама $\epsilon$ однією 3 найкращих способів просування продукції (рисунок 1). 


\section{SOCIO-ECONOMIC AND MANAGEMENT CONCEPTS}

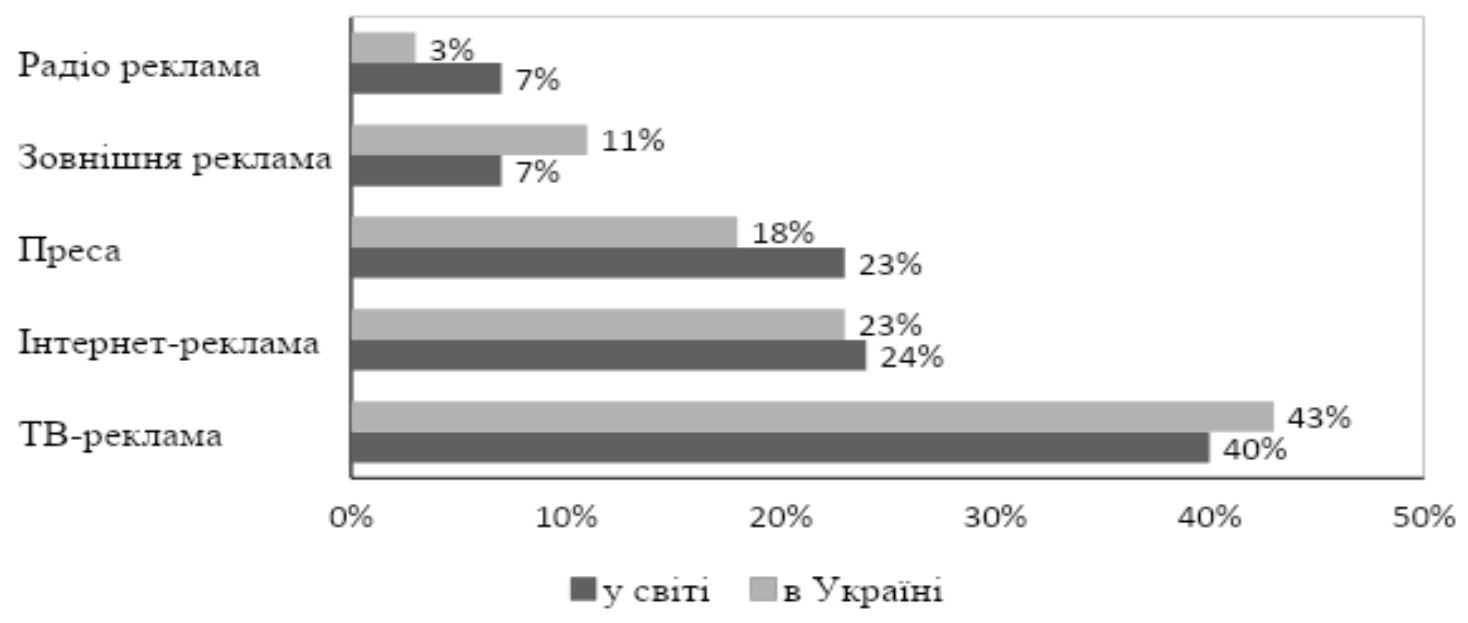

Рисунок 1. Витрати на медіа-рекламу в Україні та світі Джерело: побудовано на основі [344]

В дослідженні здійснено оцінку маркетингового макросередовища одного 3 підприємств легкої промисловості - TM «Luxik», яке пропонує споживачам дитячий та молодіжний одяг.

Ринок дитячого одягу активно розвивається. Виробники намагаються виробляти якісний одяг для дитячого сегменту та слідувати модним тенденціям. Ринок дитячого одягу є частиною ринку дитячих товарів і послуг, обсяг якого експерти оцінюють в 14-15 млрд доларів США, при цьому його потенціал складає 20-25 млрд доларів США. Значна частина цього обороту припадає на виробництво і реалізацію дитячого одягу. Розвиток ринку дитячого та молодіжного одягу супроводжується активним зростанням конкурентної боротьби між виробниками та зарубіжними постачальниками. Проте, ринок дитячих товарів, а саме: одяг, іграшки, взуття та інші дитячі товари, припинив ефективно розвиватися та функціонувати. У 2017 р. продаж дитячих товарів впали на 32\%, у 2018 р. також відбулося падіння ринку, але на відсоток більше, тобто на 20\%. Проте, у 2019 р. ринок дитячих товарів почав стрімко розвиватися [345].

Для аналізу такого середовища застосовано метод PEST-аналізу: Politicallegal - політико-правові, Economic - економічні, Sociocultural соціокультурні, Technological forces - технологічні фактори (рисунок 2). 


\begin{tabular}{|c|c|}
\hline $\begin{array}{l}\text { Політико-правові фактори: } \\
-\quad \text { позиція законодавчих органів щодо } \\
\text { ведення бізнесу (вимоги щодо найму працівників, } \\
\text { умов праці, захисту споживачів); } \\
-\quad \text { політична та економічна нестабільність; } \\
-\quad \\
\end{array}$ & $\begin{array}{l}\text { Економічні фактори: } \\
-\quad \text { економічна криза внаслідок } \\
\text { карантинних заходів під час пандемії; } \\
-\quad \text { постійна зміна курсу валюти; } \\
-\end{array}$ \\
\hline $\begin{array}{l}\text { Соціокультурні фактори: } \\
-\quad \text { рівень народжуваності; } \\
-\quad \text { чисельність населення по Хмельницькій } \\
\text { області; } \\
-\quad \text { поява нових модних тенденцій; } \\
-\quad \text { поведінка споживачів щодо покупки } \\
\text { дитячого та молодіжного одягу }\end{array}$ & $\begin{array}{l}\text { Технологічні фактори: } \\
\quad-\quad \text { інновації в процесах виробництва } \\
\text { дитячого одягу; } \\
\quad-\quad \text { зміни у тенденціях торгівлі товарами }\end{array}$ \\
\hline
\end{tabular}

Рисунок 2. PEST-аналіз TOB «Хмельничанка»

Виходячи 3 аналізу, для TM «Luxik» досить вагомими факторами $\epsilon$ економічні і технологічні фактори. 3 кожний днем з'являються інновації у виробництві одягу. Для виробництва дитячого одягу це має велике значення, оскільки дитячий сегмент потребує досить якісного одягу із якісних тканин. Ще одним показником при виборі одягу є мода. На ринку дитячого одягу спостерігається зростання конкуруючих між собою виробників дитячого та молодіжного одягу, тому кожна компанія намагається слідкувати за модними тенденціями.

Наступним етапом $є$ дослідження маркетингового мікросередовища за допомогою SWOT-аналізу (рисунок 3).

\begin{tabular}{|c|c|}
\hline 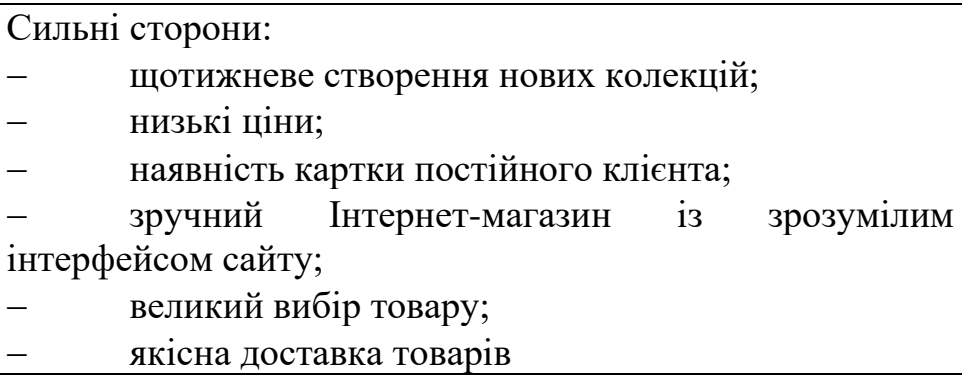 & 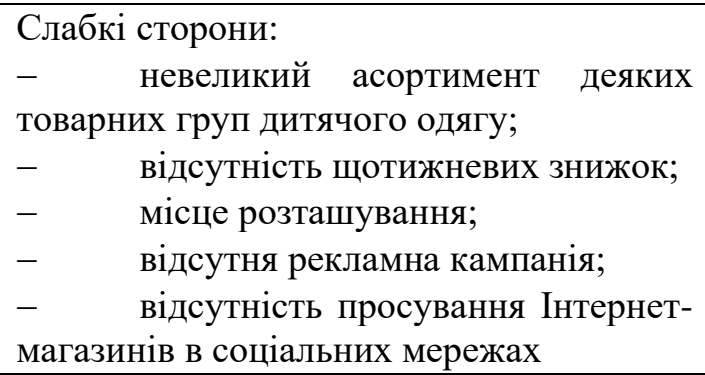 \\
\hline $\begin{array}{l}\text { Можливості: } \\
-\quad \text { розширення товарного асортименту; } \\
-\quad \text { колаборація з іншими брендами; } \\
-\quad \text { просування Інтернет-магазину в соціальних } \\
\text { мережах; } \\
-\quad \text { збільшення витрат на рекламну діяльність; } \\
-\quad \text { налаштування та запуск таргетингу в соціальних } \\
\text { мережах; } \\
-\quad \text { використання контекстної реклами }\end{array}$ & $\begin{array}{l}\text { Загрози: } \\
\quad-\quad \text { посилення конкуренції; } \\
\text { - } \text { зниження народжуваності; } \\
\text { - скорочення прибутків внаслідок } \\
\text { економічної кризи; } \\
\text { - збільшення цін рекламодавців на } \\
\text { рекламну діяльність }\end{array}$ \\
\hline
\end{tabular}

Рисунок 3. SWOT-аналіз TOB «Хмельничанка» 
Отже, TM «Luxik» є досить перспективним виробником дитячого та молодіжного одягу. Сильною стороною виробника є щотижневе оновлення колекцій дитячого одягу дизайнерами 3 урахуванням модних тенденцій. Сильними сторонами виробника $є$ використання гнучкої цінової політики, наявність Інтернет-магазину на сайті та в соціальних мережах [346]. Разом з тим недостатньо використовуються рекламні інструменти для просування своїх виробів. Для подальшого розвитку бренду є колаборація з більш відомим брендом дитячого одягу. При запуску рекламної кампанії необхідно застосовувати найменш затратні способи рекламної діяльності.

Основною причиною відмови покупців від онлайн-покупок є неякісна доставка та недовіра до Інтернет-магазину. При створені Інтернет-магазину необхідно розміщувати інформацію про товар, тканини, з яких виготовлений дитячий одяг, вказувати на цінову політику для порівняння із магазинамиконкурентами.

Можна використати деякі способи, завдяки яким зможна зменшити бюджет на таргетовну рекламу та підвищити іiі ефективність. Якщо закладений ліміт на рекламний бюджет, то ефективніше буде розподілити кошти таким способом: кожного дня витрачати мінімальну суму бюджету на протязі 10 днів, а ніж повністю весь рекламний бюджет витратити на велику кількість охоплення. Цільову аудиторію можна розподілити по групам та витрачати мінімальну суму бюджету на кожну з груп. Прикладом цього проведемо розрахунок витрат на рекламу в соціальних мережах, а також ціну за пост, ціну за перехід на сайт. Перш за все розрахуємо ціну переходу за формулою 1:

$$
Ц_{\Pi}=\frac{\mathrm{B}_{\mathrm{p}}}{\mathrm{K}_{\Pi}} \text {, }
$$

де $Ц_{п}$ - ціна переходу;

$\mathrm{B}_{\mathrm{p}}$ - вартість розміщення;

$\mathrm{K}_{\text {п }}$ - кількість переходів. 


\section{SOCIO-ECONOMIC AND MANAGEMENT CONCEPTS}

Так, якщо витратити 5000 грн на вартість розміщення та кількість переходів на сайт становить 100 кліків, то ціна переходу становить 50 грн. За допомогою цього можна визначити інтенсивність зацікавленості цільової аудиторії. Далі розрахуємо ціну лідів, за допомогою яких можна від слідкувати, як реагують клієнти на сайт за формулою 2:

$$
\bigsqcup_{л}=\frac{\mathrm{B}_{\mathrm{p}}}{\mathrm{K}_{л}} * 100,
$$

де $Ц_{л}$ - ціна ліда;

$K_{л}-$ кількість лідів.

Тобто, якщо витратити на розміщення реклами 5000 грн, а потенційних клієнтів, які відреагували на рекламу, матимемо 200, то ціна за лід становить 25 грн. Звідси виходить, що чим дешевша ціна переходу та ціна за лід, тим ефективніше буде рекламний пост.

Наступним буде розрахунок конверсії, яка визначить реальний відсоток зацікавлений в товарі потенційних споживачів та ефективність рекламного поста [347]. Визначається конверсія за формулою 3 :

$$
\mathrm{K}_{\mathrm{OH}}=\frac{\mathrm{K}_{\mathrm{I}}}{\mathrm{K}_{\mathrm{II}}} * 100,
$$

Якщо є 50 лідів, а 3 них кількість переходів на сайт 100, то відсоткова частка потенційних клієнтів, які зацікавились продукцією становить $25 \%$.

За допомогою таких розрахунків можна аналізувати, чи користується популярністю у споживачів продукція, за яким принципом та за якими цілями вони відвідуються сайт, чи купують товари в Інтернет-магазині.

При удосконаленні таргетованої реклами можна використовувати ретаргетинг. Але слід пам'ятати, що бюджет клікабельності ретаргетингу дещо вищий, аніж в звичайному таргетингу, а бюджет клієнта, який відреагує на таргетовну рекламу - нижчий. 
Проаналізувавши сторінку TM «Luxik» можна побачити, що бренд не бере рекламу у блогерів, а це один із самих ефективних способів просування Інтернетмагазинів. Популярний блогер має велику цільову аудиторію, в якій можуть знаходитися наші потенційні клієнти. Тому необхідно створити шаблон готової рекламної кампанії, яка буде з'являтися в історіях, використовувати якісний контент та зображення продукції. Профіль Інтернет-магазину має бути гармонійно поєднаний та містити певну ідею. Для того, щоб покупець залишив свій відгук про товар можна запропонувати деяку знижку на придбання наступної товарної одиниці.

При налаштуванні такого рекламного інструменту, як контекстна реклама, $€$ можливість у користувачів знайти TM «Luxik». Для цього потрібно обрати якісний контент товарного асортименту для привернення уваги до бренду та використати креативний чи інтригуючий слоган.

Ще одним етапом залучення споживачів до покупки продукції $\epsilon$ використання Social Monitoring, тобто опитування. Детальне вивчення потреб потенційних споживачів дозволить внести певні корективи у розробку одягу та його виробництво. Також слід щоденно вивчати трафік та конверсію сайту Інтернет-магазину, оскільки за допомогою цього $є$ можливість покращити маркетингову діяльність та збільшувати прибутки за допомогою залучення потенційних покупців. 


\subsection{2 Облікова політика як фактор управління доходами і фінансовими результатами діяльності підприсмства}

Сучасні умови господарювання спонукають керівників підприємств до якісного управління доходами i фінансовими результатами діяльності підприємств. Для прийняття управлінських рішень необхідно мати потужну інформаційну базу, що слугуватиме фундаментом для таких цілей. Основою інформаційного забезпечення керівництва $\epsilon$ облікова інформація, тому важливим моментом в управлінні підприємством є формування оптимальної облікової політики, для забезпечення можливості повного та достовірного формування даних обліку.

Об’єктивна оцінка показників прибутку, наведених у фінансовій звітності, необхідна не тільки для його оподаткування, а й для визначення ступеня надійності фінансового становища підприємства зовнішніми користувачами бухгалтерської звітності та для ефективного управління доходами і фінансовими результатами діяльності підприємства. Зазначені причини обумовлюють актуальність дослідження впливу облікової політики на величину прибутку підприємства 3 метою скорочення різниці між зафіксованою у фінансовій звітності номінальною величиною та його реальною величиною, яка виникає внаслідок впливу застосування різних методів облікової політики.

Від прийнятої облікової політики залежить не тільки фінансовий результат, а й фінансовий стан підприємства. Повне та правдиве подання інформації про фінансові результати і фінансовий стан підприємства у фінансовій звітності в значній мірі залежить від рівня формування та застосування облікової політики, яка б враховувала умови діяльності підприємства, організаційно-технічні особливості тощо [348, с. 178].

Облікова політика сформована підприємством, відкриває можливості для обрання методичних прийомів, які можуть радикально змінити показники фінансових результатів підприємства.

Головною метою діяльності будь-яких підприємства в сучасному етапі $є$ 
досягнення високих фінансових результатів у вигляді прибутків при максимально можливих рентабельності виробничих затрат і прибутковості вкладеного капіталу.

Облікова політика, залежно від вибору методів оцінки, зобов'язань, може вплинути на фінансовий результат діяльності підприємства. Прикладом такого впливу може бути застосування різних методів амортизації основних засобів, оцінки виробничих запасів, застосування різних баз розподілу загальновиробничих витрат, методів калькулювання виробничої собівартості продукції. Від уміло сформованої облікової політики багато в чому залежать управління господарською діяльністю підприємства та стратегія його розвитку на тривалу перспективу. Вдало обрана облікова політика позитивно впливає на діяльність підприємства, його рентабельність.

Проте в економічних дослідженнях науковців зазначається, що керівники підприємств не надають належної уваги процесу формування облікової політики, що має негативний вплив на фінансові показники діяльності цих підприємств.

Відповідно до Закону України «Про бухгалтерський облік та фінансову звітність в Україні», облікова політика - це сукупність принципів, методів і процедур, що використовуються підприємством для ведення бухгалтерського обліку, складання та подання фінансової звітності [349].

В міжнародній практиці використовують термін «облікові політики», що означає конкретні принципи, основи, домовленості, правила та практика, застосовані суб'єктом господарювання при складанні та поданні фінансової звітності [350].

Порівнявши вітчизняне та зарубіжне законодавство слід відмітити, що у нас облікова політика розглядається в загальному до усіх об'єктів обліку. В той час як за кордоном облікова політика стосується конкретного об’єкта обліку, а їх сукупність окреслює облікові політики підприємства.

Трактування терміну «облікова політика» як у міжнародному, так і в вітчизняному законодавствах передбачає, що підприємство до початку звітного періоду вибирає в межах, встановлених стандартами або іншими нормативними 
документами, певні методи, методики, способи оцінки, форми організації обліку, які використовуються ним для ведення поточного обліку і складання фінансової звітності. 3 одного боку, це забезпечує однозначність тлумачення показників фінансової звітності, а з іншого - створює умови для здійснення фінансового менеджменту [348].

Головне призначення облікової політики - встановити найвигідніші для конкретного підприємства методи обліку та на їх підставі скласти фінансову звітність, що відповідає встановленим якісним характеристикам. Отже, формуючи облікову політику, підприємство має обирати принципи, методи i процедури обліку так, щоб достовірно відобразити фінансовий стан і результати своєї діяльності та забезпечити зіставність фінансових звітів [351].

Доцільно зауважити, що необхідності в розробці облікової політики підприємств до початку ринкових реформ не виникало, так як законодавство, що регулює організацію бухгалтерського обліку, не передбачало можливості декількох варіантів відображення в обліку та звітності одних i тих господарських операцій. В зв'язку з розширенням видів господарських зв'язків та організаційно-правових форм підприємств з'явилась необхідність та можливість використання декількох підходів до визначення фінансових результатів різних операцій, а, відповідно, і варіантів їх відображення в обліку.

На вибір і обгрунтування облікової політики підприємства впливають такі основні фактори: форма власності та організаційно-правова форма підприємства; галузева приналежність або вид діяльності; обсяги діяльності, чисельність працівників; система оподаткування; ступінь свободи діяльності в ринкових умовах (самостійність рішень щодо ціноутворення, вибору партнера); стратегія фінансово-господарського розвитку (мета і завдання економічного розвитку, очікувані напрямки інвестицій); наявність матеріальної бази (забезпечення комп'ютерною технікою й програмними продуктами тощо); система інформаційного забезпечення підприємства (по всіх необхідних для ефективної діяльності підприємства напрямках); рівень кваліфікації бухгалтерських кадрів, ініціативи підприємництва керівника підприємства; система матеріального 
стимулювання і ефективності роботи підприємства.

Потрібно зазначити, що розроблення облікової політики на підприємстві дуже трудомісткий і відповідальний процес, адже підприємству не один рік доведеться працювати і враховувати всі зобов'язання згідно з розробленою ним обліковою політикою. Облікова політика має довгостроковий характер і не підлягає змінам протягом усього звітного року.

Облікова політика підприємства повинна відповідати принципам бухгалтерського обліку України, з одного боку, і цілям діяльності підприємства по досягненню фінансових результатів - з іншого.

Вважаємо, що розроблення і прийняття облікової політики підприємства має грунтуватися не тільки на глибокому і всебічному вивченні ринкового середовища, потенційних перспектив розвитку підприємства, нормативної бази діяльності, а й на інформації, одержаній бухгалтером-аналітиком після грунтовного проведення розрахунків та оцінки фінансових наслідків вибору того чи іншого варіанту облікової політики.

При здійсненні операцій 3 обліку доходів і фінансових результатів діяльності у складі інформації про облікову політику підлягає розкриттю наступна інформація: порядок обліку позареалізаційних доходів; умови визнання доходів за видами діяльності; використання чистого прибутку підприємства [351].

Як бачимо, питанню операцій з обліку доходів і результатів діяльності увага приділяється, але самі елементи облікової політики таких операцій визначені досить узагальнено. Необхідно щоб наказ про облікову політику містив детальні питання процесу ведення обліку доходів і фінансових результатів діяльності окремо щодо різних видів діяльності підприємства. В наказі про облікову політику в обов'язковому порядку мають бути розкриті питання щодо організації обліку доходів і фінансових результатів діяльності, які відносяться до методології обліку.

Аналіз економічної літератури показав, що, в основному, авторами приділяється увага методам визначення виручки від реалізації продукції та 
порядку розподілу і використання прибутку підприємства. Проте, на нашу думку, нераціонально передбачати в наказі про облікову політику питання щодо обліку використання прибутку підприємства, які передбачені статутом підприємства та не потребують альтернативних варіантів вибору підприємства.

Окремо слід зупинитись на обліковій політиці операцій з визнання доходів від надання послуг та виконання робіт, адже альтернативними варіантами щодо обліку доходів від надання послуг має бути метод рівномірного нарахування або метод поетапного закінчення на підставі: огляду виконаних робіт, співвідношення виконаних робіт на дату балансу робіт до загального їх обсягу за договором, співвідношення фактично понесених витрат на дату балансу до їх оціненої загальної суми.

Варто відмітити, що одними з найсуттєвіших елементів облікової політики підприємства, які впливають на визначення фінансових результатів є моменти визнання доходів і витрат, амортизаційна політика, підходи до оцінки виробничих запасів тощо.

Так, доходи підприємства повинні визнаватися лише в тих випадках, коли на це $\epsilon$ обгрунтована впевненість. При цьому в світовій практиці найпоширенішими $\epsilon$ два методи визнання доходів: касовий та метод нарахування.

На нашу думку, наказ про облікову політику повинен містити такі елементи з обліку доходів і фінансових результатів:

- розмежування доходів за кожною класифікаційною групою: дохід (виручка) від реалізації продукції (товарів, робіт, послуг); інші операційні доходи; фінансові доходи; інші доходи; надзвичайні доходи;

- перелік та склад доходів від реалізації: дохід від реалізації готової продукції; дохід від реалізації товарів; дохід від реалізації робіт, послуг;

- умови визнання та критерії оцінки доходу від надання і виконання робіт та послуг на дату складання балансу: метод оцінки ступеня завершеності операцій; метод рівномірного нарахування;

- перелік та склад інших операційних доходів: дохід від реалізації іноземної 


\section{SOCIO-ECONOMIC AND MANAGEMENT CONCEPTS}

валюти; дохід від реалізації інших оборотних активів; дохід від операційної оренди активів; дохід від операційної курсової різниці; одержані штрафи, пені, неустойки; відшкодування раніше списаних активів; дохід від списання кредиторської заборгованості; одержані гранти та субсидії; інші доходи від операційної діяльності;

- перелік та склад інших фінансових доходів: дивіденди одержані; відсотки одержані; інші доходи від фінансових операцій;

- перелік та склад доходів від участі в капіталі: дохід від інвестицій в асоційовані підприємства; дохід від спільної діяльності; дохід від інвестицій в дочірні підприємства

- перелік та склад інших доходів: дохід від реалізації фінансових інвестицій; дохід від реалізації необоротних активів; дохід від реалізації майнових комплексів; дохід від неопераційної курсової різниці; дохід від безоплатно одержаних активів; інші доходи від звичайної діяльності;

- перелік та склад надзвичайних доходів: відшкодування збитків від надзвичайних подій; інші надзвичайні доходи.

Доцільно відмітити, що вибір способів облікової політики визначається цілями і завданнями підприємства, його взаємовідносинами з податковими органами та інвесторами.

Більшість зовнішніх користувачів облікової інформації не приймають безпосередньої участі в управлінні, однак вони можуть вплинути на результати подальшої діяльності підприємства. Взаємозв'язок інтересів користувачів інформації звітності та складових облікової політики наведено на малюнку 1. 


\section{SOCIO-ECONOMIC AND MANAGEMENT CONCEPTS}

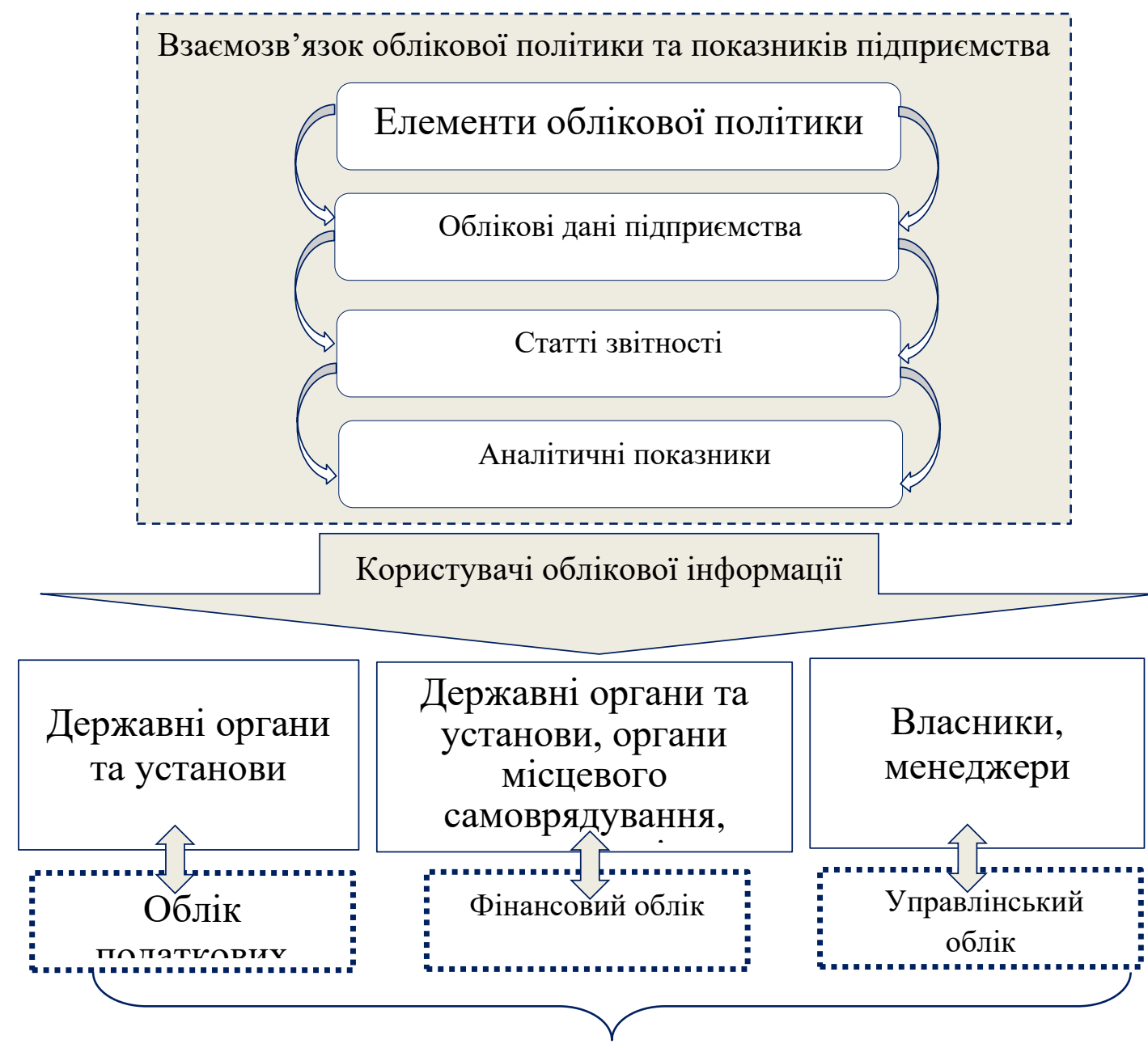

Вплив копистувачів облікової інфопмапії на фопмування

Малюнок 1. Взаємозв’язок інтересів користувачів інформації звітності та складових облікової політики

Як можна бачити 3 малюнку 1, елементи облікової політики впливають на облікові дані підприємства, статті звітності та аналітичні показники. Документ "Наказ про облікову політику" дуже вагомий, проте на багатьох підприємствах такий внутрішній документ відсутній або він не знаходить застосування, також не приділяється належна увага його формуванню, що негативно впливає на процес ведення бухгалтерського обліку та функціонування підприємства в умовах ринку. Надання підприємствам більшої самостійності і свободи при виборі способів і методів облікового процесу сприяє більш швидкому вирішенню проблеми відносин між господарюючим суб’єктом і зовнішніми користувачами інформації.

Підсумовуючи вищевикладене потрібно відмітити, що облікова політика - 


\section{SOCIO-ECONOMIC AND MANAGEMENT CONCEPTS}

це інструмент організації обліку на конкретному підприємстві, який включає сукупність способів та процедур його ведення, що використовуються з метою підготовки, складання та подання фінансової звітності.

Водночас умовності, які виникають при визначенні фінансових результатів діяльності підприємств $є$ наслідком прийнятої підприємством облікової політики, зокрема в таких питаннях, як визнання доходів, методів оцінки виробничих запасів, готової продукції і незавершеного виробництва та інше. Прийняття підприємством конкретної облікової політики на поточний фінансовий рік забезпечує організацію бухгалтерського (особливо аналітичного) обліку відповідно до показників форм річної фінансової звітності, зменшує трудомісткість і тривалість формування фінансової звітності, забезпечує використання оптимальних методів облікових робіт із метою отримання очікуваних результатів фінансово-економічної діяльності підприємства.

Таким чином, основним критерієм при виборі того або іншого методу обліку по елементах облікової політики для кожного підприємства $є$ виключно економічна ефективність, оскільки від установлених методів обліку залежить не тільки об'єктивність і точність розкриття інформації у фінансовій звітності, а й величина чистого прибутку. 


\section{SECTION 7. FINANCE, PENNILESS AND CREDIT}

\subsection{Providing sustainable finance: the role of financial institutions}

Sustainable economic development and, accordingly, all socio-economic development has gained global understanding in the world, and hence the perception as the need to bring into line with its requirements all areas of life of each country. Such an understanding should permeate the minds of officials of all power structures: from the legislature to the executive branch, including at the level of united territorial communities, when it comes to Ukraine. However, one awareness of the tasks of ensuring sustainable development of the country, region, individual territory is not enough. Resource provision is a necessary and obligatory condition. In response to the public demand for environmental protection, concrete measures need to be proposed. Most often, the content of such measures is to attract high-tech equipment, to construct waste processing plants, enterprises for the disposal of waste from hazardous industries, etc. It is well known that the cost of these objects is extremely high. To some extent, the solution of this problem is facilitated by public-private partnership, ie cooperation of enterprises operating in a certain area, with government agencies, local governments.

The successful implementation of environmental measures and through them the implementation of the concept of sustainable development requires: targeted activities of industrial enterprises, banking and parabanking institutions, insurance companies. Business leaders must implement environmentally friendly technologies, heads of financial institutions have to use their means to promote this. In other words, at all stages of the production life cycle to ensure sustainable development, environmentally responsible manufacturing and financial and credit businesses need to cooperate.

In the context of Ukraine's participation in international agreements on climate change and ratification of the Paris Agreement of the parties to the UN Framework Convention on Climate Change [352], the Sustainable Development Strategy "Ukraine - 2020" was approved [355]. In particular, the action plan for the implementation of the provisions of the National Strategy developed vectors of the implementation of 
reforms and development programs of the state, including the Program for Small and Medium Business Development, Financial Sector Reform, Environmental Protection Program and others.

The publication [359] considers the issue of scaling the finances to achieve the Sustainable Development Goals (SDGs) and the corresponding model of this process. In particular, we are talking about the implementation of the sustainable development program until 2030, which was adopted by the UN General Assembly in September 2015 , and new challenges in funding various initiatives and programs to support the new goals of sustainable development. Emphasis is placed on the outcome of a conference known as the Addis Ababa Program of Action for Sustainable Development, which identified a plan to attract various sources of funding and mechanisms to support the Sustainable Development Goals. However, it is noted that even the new sources of funding and mobilization potential of the proposed mechanisms do not meet the necessary resources to adequately support the 17 development targets and their 169 goals set out in the 2030 Agenda for Sustainable Development. The idea of using Multilateral development banks (MDBs), which can serve as effective institutional mechanisms for financing the goals of sustainable development, is put forward. It is noted that their ability in this direction is due to the appropriate mandate to support development-oriented programs, internal experience and experience in identifying, developing, risk assessing and managing complex projects and the balance sheet structure, which corresponds to long-term liabilities with long-term assets. The limiting factor, however, was the conservative lending approach of MDBs and the narrow capital base, which limited their ability to significantly increase borrowing. As the prospect of significant capital expansion is not on the agenda of developed governments in the near future, multilateral development banks are exploring alternative ways to increase their creditworthiness. This paper discusses some of the new modalities that central banks (CBs) are adopting or considering for adoption to reduce their lending restrictions. The model of the Asian Infrastructure Investment Bank (AIIB) is considered, in particular, to expand as a new experiment that can provide significant amounts of development funding, as well as introduce new ideas 
for operational improvements in other banks. However, the AIIB model is not the only way to increase funding for sustainable development. Other multilateral financial institutions may identify alternative ways to scale up in line with their rules, culture and practices.

The purpose of the research is to typologize the requirements for financial institutions, which could be considered as prerequisites for the implementation of measures to influence these institutions by the regulator - the National Bank of Ukraine (NBU). It is also important to establish certain requirements for financial institutions to their activities and to borrowing companies in order to ensure sustainable development in their localization, in the national region, in the state, in the subcontinental region.

Environmental responsibility of banks as an aspect of research has appeared not so long ago, at least in our country. However, sustainable development and ecological safety depend on the directions and conditions of investment and lending, as well as on the ecological perfection of technological processes.

In our country, not enough research has been conducted and no reasoned recommendations have been developed on the activities of financial institutions to ensure conditions for sustainable development. In particular, it is necessary to improve the system of measures to influence financial and credit institutions, which should help settle the relationship between investors and creditors on the one hand and borrowersenterprises on the other. Businesses are directly involved in the use of technological schemes that can be harmful to the environment. However, investors and creditors are involved in these processes, albeit indirectly, but without their participation many projects will not be able to be implemented. It is financial and credit institutions that have the opportunity to influence the nature of industrial projects and create the preconditions for the implementation of measures that will meet the requirements of sustainable development.

The requirements that can be imposed on financial institutions in terms of their participation in ensuring sustainable economic development should be divided into two groups. The first group of requirements is the requirements of the internal order, 
namely those that ensure energy and resource conservation, in the work of financial institutions, as well as their non-pollution of the environment. The second group of requirements is the nature of cooperation of financial institutions with external counterparties. In this group, two subgroups should be considered: one is the whole set of public administration and self-government; the other is borrowing companies. If financial and credit institutions mainly cooperate with the authorities and management in the legislative and regulatory sphere, then cooperation with enterprises takes place in the financial and credit sphere. With regard to cooperation with the first internal group of requirements, financial institutions independently undertake to comply with the relevant standards, which are generally called "green office", and in some institutions - "green bank". Such standards are already well established and known from the activities of leading banks in America and Europe.

Regarding the first subgroup of requirements of the second group, it is necessary to rely on the regulator of the financial and credit system and consider that it is his duty to develop appropriate standards that should regulate financial and credit activities, without interfering with the direct tasks and responsibilities of relevant institutions, in particular investing and lending to their clients.

It is worth considering the problems and tasks of each of the financial institutions separately, as credit institutions (banks and parabanking structures) have their own specifics, and insurance companies - respectively, their own.

One of the most important requirements for commercial banks in terms of sustainable development of the state is, of course, lending to relevant programs and projects, ie giving priority to such enterprises that care about natural resources. As a creditor of industrial enterprises, a bank may impose certain requirements on borrowers in terms of compliance with environmental legislation, the assumption of such obligations by enterprises, which provide for the prevention of environmental damage through harmful emissions, through the production of products for which technological recycling schemes have not yet been developed. It is the creditor who is responsible for providing funds for projects that can be considered environmentally unsafe in advance. 


\section{SOCIO-ECONOMIC AND MANAGEMENT CONCEPTS}

From the standpoint of founders and shareholders, the purpose of the bank is to make a profit from lending, which is possible only with the effective development of borrowing companies. That is, in a way the interests of the state and the bank's shareholders coincide in the field of progressive economic development. Some differences between them may arise due to the need to impose restrictions on sustainable development, in other words, the introduction of environmental requirements for borrowers.

Parabank structures, in particular credit unions, have a slightly different nature of activity. Their founders are guided primarily by the interests of their businesses and, as evidenced by many years of international experience, do not put in the first place the requirement to obtain excessive profits from credit unions. Thus, credit unions are different from commercial banks. It is for this difference that they are created, which allows depositors to create a sufficient credit fund for the implementation of joint projects with a minimum interest rate on loans. However, lending by credit unions agricultural enterprises, processing industry, construction industry must also take place in compliance with the requirements of sustainable development. In other words, credit unions should not be a "workaround" for lending that avoids compliance with environmental legislation.

Thus, it should be recognized, that only centrally established (by the regulator of the credit sector of the economy) rules for all (without exception) banking and parabanking institutions and control of their strict implementation guarantee fair competition in the credit market. After all, the requirements for compliance with environmental requirements by some credit institutions may be the reason for borrowers to turn to other credit institutions - less focused on compliance with these requirements. Ensuring such conditions for the operation of credit institutions requires the creation of an appropriate regulatory framework for the management of lending to production projects in compliance with environmental requirements. Such a regulatory framework should be created and updated by the regulator - the National Bank of Ukraine together with the Association of Commercial Banks, the National Association of Credit Unions of Ukraine (NACUU), the Ukrainian Association of Credit Unions 
(UACU) on the one hand, and the Union of Industrialists and Entrepreneurs of Ukraine - on the other. The cooperation of these institutions will serve as a guarantee of ensuring the balance of interests in the system "society - credit institutions entrepreneurs".

Understanding the role of credit institutions in the process of providing manufacturing enterprises with modern innovative technologies, and most importantly technologies that provide environmental elements, is extremely important in the vector of sustainable development. Such activities of banks and parabanks, which are aimed not just at lending to enterprises, but at lending to business projects taking into account the environmental component, should be considered as environmental responsibility of credit institutions, which in a broader sense can be seen as the participation of banking and parabanking systems.

Usually, credit institutions are interested in the prospects of their project, the borrower's solvency, its integrity and credit history. In the context of the sustainable development program, credit institutions should also have an obligation to take an interest in the environmental safety of the project for which the company is requesting a loan. There are already published enough works in which the authors call for social responsibility of banks [356], including talking about the environmental component of social responsibility [360].

The social responsibility of a credit institution in the environmental aspect is now coming to the fore, as environmental risks are of great concern not only to individual regions, countries, but also to the world community. It should be emphasized that environmental risks should be considered not only from an economic point of view, which is usually done most often. Economic risks in this case are already a monetary expression of other risks, including social, which are manifested in the dissatisfaction of society, individual community, person or group of people. After all, on behalf of enterprises acts usually a small group of people - owners, whose economic interests often differ from the interests of people living in the areas adjacent to the company. Instead, banks are significantly dependent on each individual depositor, and the mood of depositors can contribute to both the inflow and outflow of funds. That is why every 
bank, every credit union is interested in the smooth running of economic processes that guarantee the efficient use of credit resources, timely repayment of loans and payment of interest. Only measured hard work can bring positive results to all participants in economic cooperation. Ecological stability, lack of concern of people about negative technogenic influences should create the corresponding favorable situation in each region.

It is clear that such interest should take place on the part of the entire financial and credit system. When each lender will ask about the environmental component of the project, and does not lend to projects that do not guarantee environmental cleanliness, compliance with the requirements of sustainable development. Fair competition among credit institutions should be based on relevant legislation and regulations of the regulator of the credit sector of the economy.

Scientists have already written about the need to audit bank loans [358]. However, practical actions are needed to implement scientific ideas, as well as the implementation of foreign experience in the practice of domestic banks. The problem of creating an appropriate legal and regulatory framework certainly requires for its solution certain scientific developments. It is necessary to tell, first of all, about development of theoretical bases of formulation of structure and sequence of procedures for process of consideration of inquiries of borrowers and definition of conditions of granting of the credit on ecological criteria. The lender must adhere to such rules, according to which its environmental responsibility will be maximally realized and will be a guarantee of receiving a positive assessment by the community, society, which will strengthen the credibility, improve the image of the credit institution and, most importantly, increase trust from both individuals and legal entities.

When it comes to these procedures, it is definitely necessary to follow the already established practice of interaction between the lender and the borrower. A new element of such interaction should be the verification of the project, which requires lending, for environmental friendliness. Such an inspection requires an appeal to a specialized institution that has the appropriate personnel, experience, license to conduct an environmental examination. Of course, the lender should rely not only on the experts to 


\section{SOCIO-ECONOMIC AND MANAGEMENT CONCEPTS}

whom he commissions expert research. In particular, the bank must have its own specialist, trained accordingly for the correct perception of the results of the examination. The analogy of this practice is involving by banking and business structures the lawyers who protect the interests of legal entities through direct involvement in their activities and appropriate employment relationships.

Environmental control in the process of issuing loans is an important measure. Firstly, such control can serve to implement state and regional programs aimed at protecting the environment. In this way, credit institutions join the bodies of public administration and local self-government and become subjects of ensuring sustainable economic development. Secondly, credit institutions become partners of civil society, which actively requires businesses to take such measures, implement such technological schemes, produce such products that are environmentally friendly. Thirdly, credit institutions adhere de facto to the implementation of international agreements, those conventions that have been adopted by the world community. This participation of credit institutions and the financial and credit system of the state as a whole will be positively assessed in the world, which will improve the image of the state.

Thus, the focus of credit institutions on environmental interaction with enterprises is an important aspect of their activities. Enterprises, for their part, must not only take into account their own economic interests, but also take into account the environmental requirements of society, on whose side credit institutions will act in matters of lending. In other words, subject to the development of relevant laws and regulations, credit institutions become complicit in environmental control.

Summing up, we should emphasize the following. National Bank of Ukraine, as a regulator of financial and credit activities in Ukraine, should develop a number of normative materials to regulate the work of commercial banks, credit unions and other participants in financial markets. Such standards should regulate their participation in programs and projects related to the implementation of innovative measures by industrial enterprises. Their purpose is, on the one hand, to promote lending to innovative economic development; on the other - to establish limits that would not 
allow credit institutions to abuse the environmentally oriented status of individual projects to cover up the abuse of credit resources.

Credit institutions, in turn, should develop a set of measures within their competences in order to establish clear rules for interaction with borrowers, motivating borrowing companies to implement environmentally friendly technologies, produce environmental products, as well as to dispose of their own waste. 


\subsection{Ukraine's position on the world financial market}

The degree of integration into world global processes determines the level of development of the national economy and the well-being of its subjects. This is facilitated by the unification of rules, procedures, instruments and methods of conducting both trade and financial transactions. Numerous risks also become common to all market participants. Nevertheless, the current vector of development of the world financial space is determined by the processes of globalization. The dependence of financial systems among themselves determines the development trends of the world currency market, debt instruments, shares, as well as the financial services market.

The main trends and factors that have determined the current state of the global financial market include the following points:

- consolidation of regional communities and structures;

- strengthening the influence of supranational structures on the debt and capital markets;

- active development of regional markets in the system of international finance;

- appearance and implementation of financial innovations as a tool for smoothing financial risks;

- improving the technical capabilities of conducting transactions on global financial markets;

- financial liberalization, which led to increased access to the global financial markets.

The general trend of our time remains the intensification of activity in the world financial markets, which ensures the circulation of liquid funds and the redistribution of capital to the most potentially profitable projects and industries (pic. 1). 


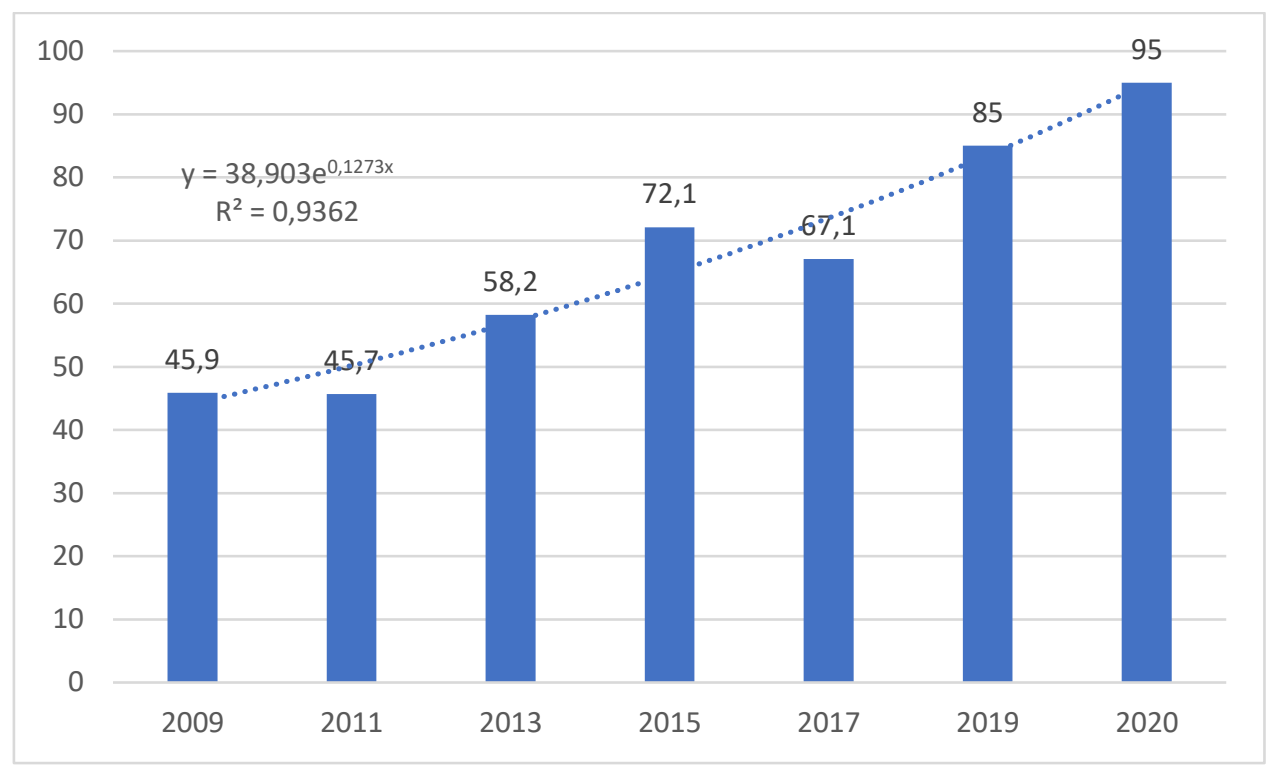

Pic. 1. Capitalization of the world stock market, trillion US dollars*

* - source: built by the authors on the basis of [367].

The capitalization of the global financial market is increasing and, as of early 2021, has already exceeded global GDP. Even the global pandemic and the slowdown in economies in the first half of 2020 did not become an obstacle to the acceleration of growth, which has not yet fully realized its potential. The reasons for this phenomenon were the stable trust of market entities in the leading issuers of securities, which, after a short-term recession, resume their activities. On the other hand, excess liquidity has appeared in the global financial environment due to the large-scale emission of foreign exchange funds by central banks. Having no alternative, funds are invested in the financial market, and the subjects of the financial services market are ready to provide funds to borrowers.

Global trends in the world financial market have an impact on the financial system of Ukraine, the assets of which for the most part have low investment attractiveness. The downtrend of international portfolio investment in stocks [pic. 2] speaks of distrust and low potential for profit of the overwhelming number of issuers from Ukraine. Note that the outflow of equity investments has a long-term downtrend. 


\section{SOCIO-ECONOMIC AND MANAGEMENT CONCEPTS}

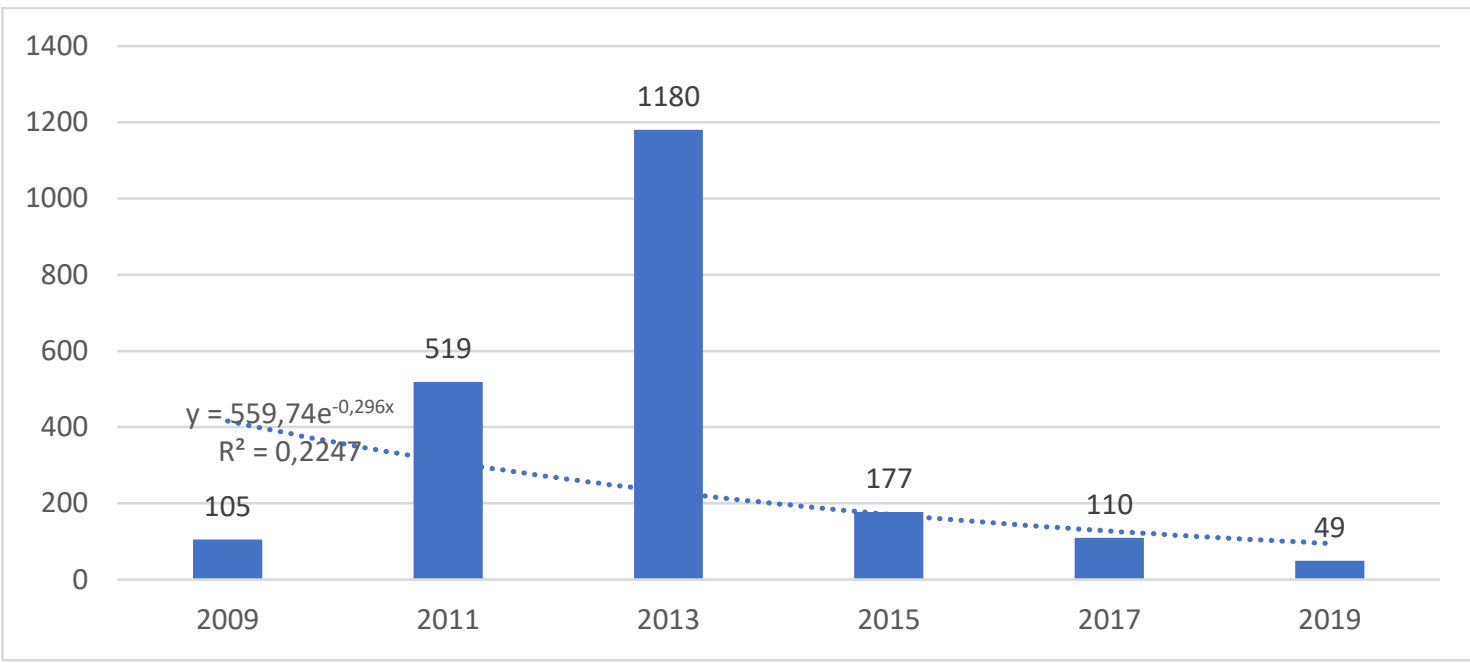

Pic. 2. Net inflow of portfolio investments in shares, USD million* * - source: built by the authors on the basis of [367].

Foreign direct investment in the country's economy is an important indicator, speaking of stability, high business activity and a favorable financial and investment climate. The current stage of development of the financial system of Ukraine indicates the opposite trend (pic. 3).

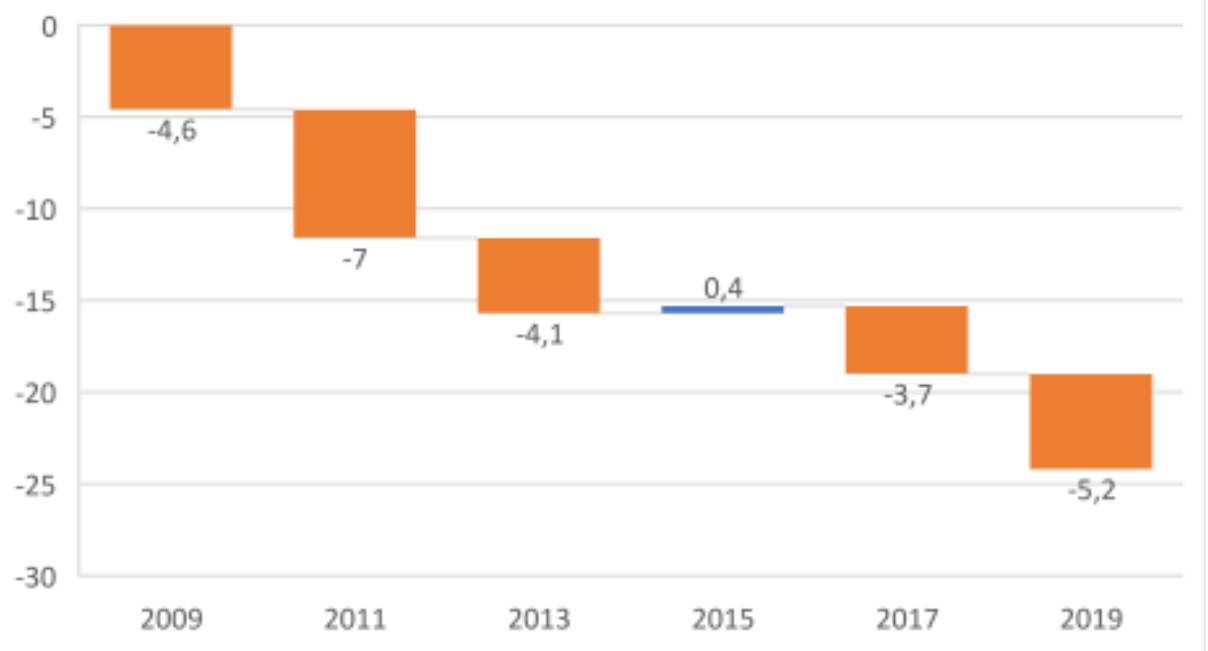

Pic. 3. Direct foreign investments in Ukraine, USD billion* * - source: built by the authors on the basis of [367].

The low activity of financial transactions is also reflected in the state of the financial account (pic. 4). Financial account transactions reflect the receipt and 


\section{SOCIO-ECONOMIC AND MANAGEMENT CONCEPTS}

payment of loans and borrowings, the acquisition and use of foreign currency, the issue, redemption, sale or purchase of securities and others.

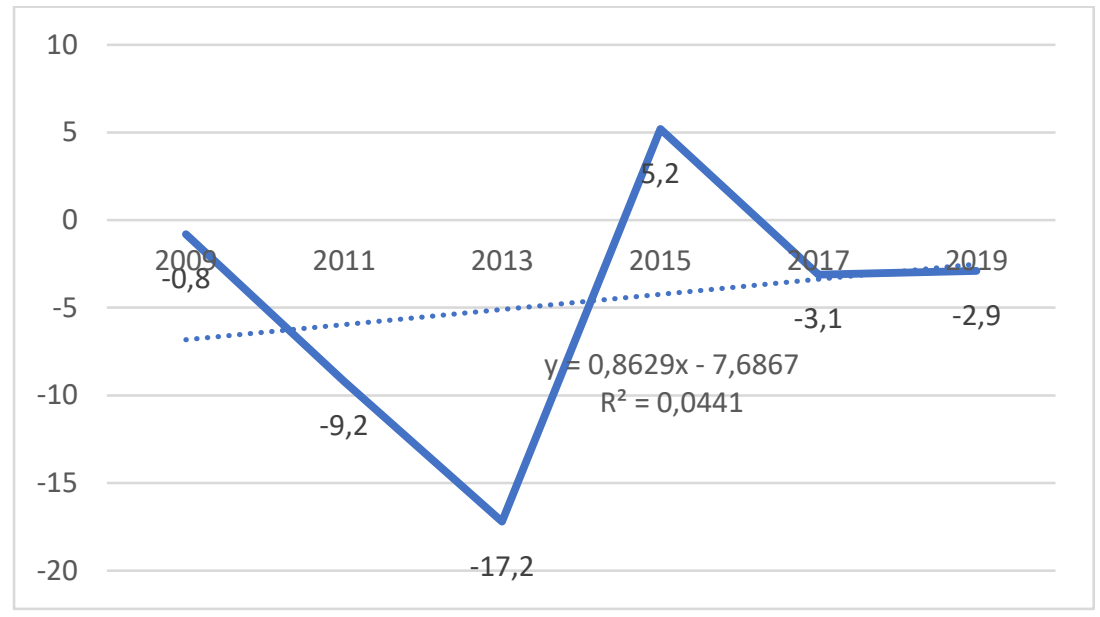

Pic. 4 The value of the financial account of Ukraine in current prices, billion USD* * - source: built by the authors on the basis of [367].

A negative value of the financial account means a chronic outflow of capital and currency values from the Ukrainian economy. Nevertheless, in 2017-2019, there was a tendency to narrow the gap between the outflow and inflow of foreign exchange for conducting transactions in the financial market.

A low level of investment attractiveness is also demonstrated by an insignificant part of the GDP of foreign direct investment in the Ukrainian economy (pic. 5).

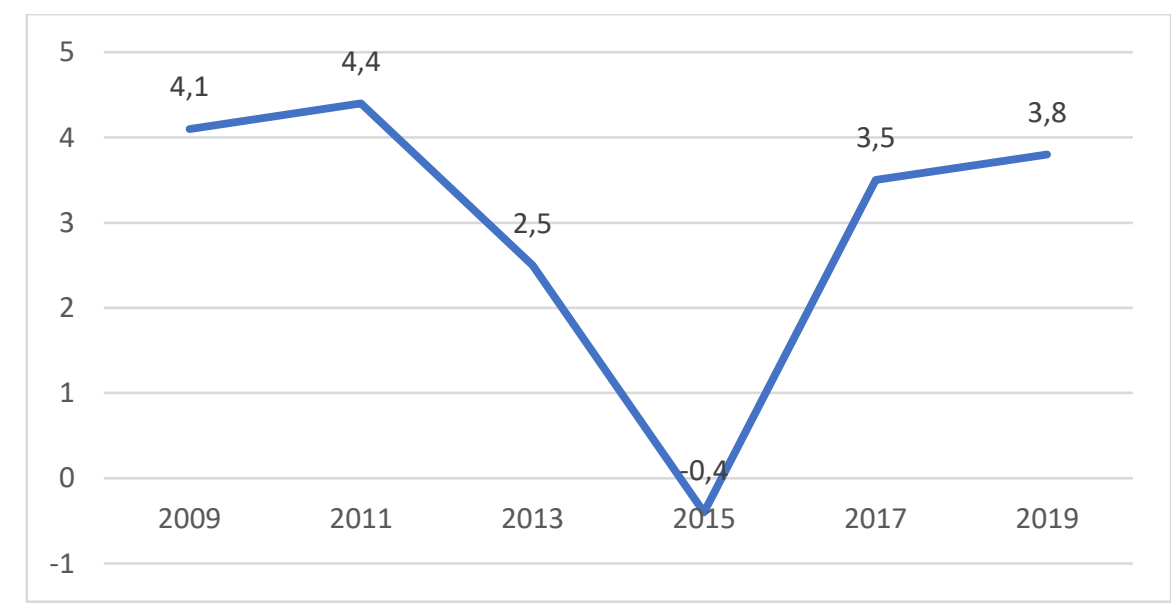

Pic. 5. Direct foreign investments from Ukraine, \% to GDP* * - source: built by the authors on the basis of [367].

Despite the positive trend that has emerged since 2016, the share of foreign investment in GDP remains insignificant. Ukraine remains an inactive participant in 
the international financial market. At the same time, the national economy's need for liquid financial resources remains significant. 


\subsection{Modeling of minimizing credit risks in agriculture}

Забезпечення ефективного функціонування кредитної системи в сільському господарстві неможливе без врахування тих особливостей, які відрізняють сільськогосподарську галузь від інших сфер господарювання. Закономірно, що усвідомлюючи загрозу, яку несе у собі невчасне виконання умов кредитного договору, позичальники, як і кредитори, прагнуть убезпечити себе від негативної дії ризиків, що виникають при банківському кредитуванні. У певній мірі дане твердження стосується сільськогосподарських підприємств, особливості діяльності яких з одного боку обумовлюють потребу у залученні кредитних коштів, а з іншого боку - несуть у собі потенційну загрозу при неповерненні кредитного боргу.

Усвідомлення позичальником наявності ризиків банківського кредитування, є передумовою для ефективних засобів його мінімізації.. Це дасть змогу забезпечити можливості для повернення аграріями кредиту та відсотків за ним згідно умов, визначених кредитним договором, а також отримати економічну вигоду від ведення господарської діяльності з використанням кредитних коштів. У даному випадку мова йде про можливість отримання максимально можливого прибутку.

Прибуток є формою вираження ефективності діяльності підприємства. Якщо підприємство не максимізуватиме прибуток, то воно під впливом ринкової конкуренції рано чи пізно буде ліквідоване [368, с.27].

У даному випадку доцільно застосувати методику економікоматематичного моделювання. Загалом, моделювання дає змогу вивчити властивості об'єкта, прогнозувати його поведінку без постановки натурного експерименту. Модель має бути здатна відображати, відтворювати або замінювати оригінал у його головних рисах так, щоб ії вивчення давало нову інформацію про об'єкт, а точніше, - про цілий клас об'єктів, для яких актуальне завдання, що розглядається. 
Дослідник Грабовецький Б.Є. наголошує, що економіко - математична модель має відповідати певним вимогам:

- формується на основі положень економічної теорії;

- адекватно відображає реальну економічну дійсність;

- враховувати найбільш важливі фактори, які визначають рівень досліджуваних показників;

- відповідати встановленим критеріям;

- дозволяти отримати такі знання, які до їі реалізації були невідомими;

- бути достатньо абстрактною, щоб допустити варіювання великим числом змінних, але не настільки, щоб виникли сумніви в пї надійності і практичній корисності отриманих результатів;

- задовольняти умови, які обмежують строк розв’язування задачі;

- дозволяти реалізувати ії існуючими засобами [369].

Загалом, моделювання - це відтворення або імітація поведінки будь -якої реально існуючої системи на спеціально побудованому за певними правилами іiі аналога моделі [370, с.9].

В економічному термінологічному словнику - довіднику [371,с.222] модель - це відтворення, зображення, опис, імітація якого- небудь явища, процесу або об'єкта.

Враховуючи те, що галузь рослинництва $є$ більш рентабельною, ніж тваринництва, а більшість сільськогосподарських господарств займаються вирощуванням сільськогосподарських культур, вважаємо за доцільне розробити модель оптимального розподілу посівних площ. Дана модель, дозволить підприємствам, що планують отримати кредитні кошти, запрограмувати таким чином виробничу діяльність, щоб отримати від неї максимальний економічний ефект, тобто найбільший прибуток.

Для розробки моделі ми приймаємо до уваги те, що сільськогосподарські підприємства займається вирощуванням декількох видів сільськогосподарських культур. При цьому варто враховувати, що вирощування окремих 3 них 
диктується агрономічною необхідністю, оскільки деякі низькорентабельні культури є складовими сівозміни.

Нехай господарство планує вирощувати такі сільськогосподарські культури: $a_{1}, a_{2}, \ldots, a_{n}$.

Закупівельні ціни прогнозуються такими: $c_{1}, c_{2}, \ldots, c_{\mathrm{n}}$, урожайність - $y_{1}, y_{2}$, $\ldots, y_{n}$, а собівартість вирощуваної продукції - $m_{1}, m_{2}, \ldots, m_{n}$.

Нехай господарство має $\mathrm{y}$ своєму розпорядженні $\mathrm{S}$ сільськогосподарських угідь.

Позначимо через $x_{1}, x_{2}, \quad \ldots, x_{n}-$ площі, які виділяться під сільськогосподарські культури.

Будемо вимагати виконання таких нерівностей:

$$
x_{i} \geq b>0, \quad(i=\overline{1, n}),
$$

що диктується продовольчою і кормовою необхідністю.

Тоді, якщо урожайність відповідних культур складає $y_{1}, y_{2}, \ldots, y_{n}$, то прогнозний дохід складатиме:

$$
D=c_{1} y_{1} x_{1}+c_{2} y_{2} x_{2}+\cdots+c_{n} y_{n} x_{n},
$$

а собівартість становитиме:

$$
M=m_{1}+m_{2}+\cdots+m_{n}
$$

Прибуток знайдемо із рівності:

$$
P=D-M>0 \text {. }
$$

Отримуємо наступну модель:

$$
\begin{aligned}
P=c_{1} y_{1} x_{1}+c_{2} y_{2} x_{2}+\cdots+c_{n} y_{n} x_{n}-\left(m_{1}+m_{2}+\cdots+m_{n}\right) \rightarrow \max \\
\qquad\left\{\begin{array}{l}
b_{1} \leq x_{1}<S, \\
b_{2} \leq x_{2}<S, \\
\cdots \\
b_{n} \leq x_{n}<S, \\
x_{1}+x_{2}+\cdots+x_{n}=S
\end{array}\right.
\end{aligned}
$$


Таким чином, підставивши необхідні дані у систему нерівності можна визначити який максимальний прибуток зможе отримати сільськогосподарське підприємство за вказаних умов.

Для запропонованої моделі необхідно сформувати і згрупувати вихідні данні для моделі, а саме: площа, урожайність, собівартість, ціна і рентабельність.

Очевидно, що використання усієї площі під вирощування однієї найбільш рентабельної культури, недоцільно. В першу чергу, це пов’язано 3 агрономічними особливостями як землі, так і самих сільськогосподарських культур. Окрім того, підприємства потребують насіннєвого матеріалу, а також деякі культури використовуються як корми при веденні змішаного господарювання [372, с.127].

Проаналізуємо вихідні дані 3 метою найбільш оптимального розподілу площ, який дозволить як отримати максимально можливий прибуток, так i забезпечити продовольчу і кормову безпеку для аграрного підприємства.

Отже, визначивши найбільш прибуткову культуру у господарстві, варто звернути увагу на коливання даного показника протягом досліджуваного періоду. При цьому, за досліджуваний період необхідно брати не менше п'яти останніх років. Суттєве коливання прибутковості може спричинити коливання урожайності відповідної культури, що обернено пропорційно впливає на ціну реалізації на ринку. Крім того, суттєві коливання рентабельності свідчать про недоцільність вирощування цієї культури на значній площі сільськогосподарських угідь.

Для остаточного вибору культури, під яку варто використати найбільшу площу сільськогосподарських угідь, варто провести прогнозування ймовірної урожайності даної культури на період, у якому планується отримання кредиту Для цього використовуємо програму Microsoft Office Excel.

На основі даних щодо урожайності аналізованих культур будуємо діаграму i визначаємо лінію тренду на основі визначення величини достовірності апроксимації, яка має бути максимально наближеною до 1. 
Отримавши рівняння лінії тренду, яке для наочності доречно відобразити на діаграмі, можна, підставити відповідні дані і отримати прогнозний розрахунок аналізованого показника на будь-який проміжок часу. Безсумнівно, що чим більша вибірка даних, тим точнішим буде результат. Отож, для побудови діаграм слід використати дані щодо урожайності усіх культур господарства.

Таким чином, на основі визначених формул ліній трендів можемо спрогнозувати урожайність сільськогосподарських культур на майбутній період.

Виявивши, по яким культурам прогнозується суттєве зростання урожайності, доречно дещо збільшувати площу посіву даних культур.

Тому, приймаючи до уваги вищезазначене і знаючи загальну площу ріллі господарства, слід запропонувати новий розподіл посівних площ під основні сільськогосподарські культури, враховуючи їх рентабельність за попередні періоди. Окрім того, слід припустити, що ціни та собівартість продукції будуть не меншими , ніж середньостатистичні по даній територіальній одиниці. Таким чином, підставивши відповідні данні у модель, отримуємо прогнозований прибуток від вирощування зазначеного переліку сільськогосподарських культур.

Відмітимо, що використання даної моделі особливо доцільно за умов отримання сільськогосподарським підприємством кредитних коштів, оскільки дозволяє розрахувати потребу в оборотному капіталі на період виробництва продукції, а відтак і обгрунтувати розмір необхідної позики і тим самим знизити рівень ризиків банківського кредитування для сільськогосподарських підприємств.

Одначе, окрім сільськогосподарських підприємств, подібну модель можуть використовувати банківські установи, які бажають співпрацювати із сектором сільського господарства. Відтак, виникає необхідність в оцінці кредитного ризику, яка б враховувала особливості діяльності даної категорії позичальників. Запропонована модель дозволяє зважати на індивідуальні особливості господарства щодо вирощування ним сільськогосподарських культур і отримувати прогнозний результат прибутку. 


\subsection{Management and formation of cash flows in agricultural enterprises}

Cash flow can be represented as a system of "financial circulation" of the economic organism of the enterprise. Effectively organized cash flows are the most important symptoms of its economic performance as a whole.

In the long run, free cash flow, equity and debt financing are the best sources of working capital. However, these options may not be available to all businesses. In such cases, there are alternative cash flow management strategies that the agricultural business can use to ease the strain on its working capital. Here are some of them:

1. Request to make an advance or full payment.

2. Customer request to pay faster.

3 . Reduce or delay costs.

4. Requests from suppliers for more favorable payment terms.

5. Purchase order.

6. Increasing margins.

7. Sale or lease of equipment that is idle.

8. Sale of future income.

9. Sale of invoices [373].

Understanding the available options, agricultural enterprises will be much better equipped to manage their working capital and, in turn, to support and increase their activities.

Agricultural enterprises that lack positive cash flow, those that pay more money than they bring in, will almost certainly be forced to close down sooner or later. Without a positive cash flow, all businesses (including agricultural ones) are unlikely to have the agility needed to respond to today's rapidly evolving business landscape [374].

Although many decision-makers understand the need for skillful cash flow management, two-thirds of all agricultural enterprises experience cash flow problems from time to time. In addition, each of the five agricultural business owners points out that cash flow problems are in fact the norm - no exception. 
If the agricultural business has problems maintaining a positive cash flow, it does not necessarily mean that bankruptcy is imminent. In fact, with due diligence and redesigning the way a business operates, it is possible to understand its cash flow by giving the business access to the capital it needs to grow.

Therefore, for better cash flow management manager need:

1. Know when to rent and know when to buy. Almost all companies need equipment, facilities and property to work; whether to buy or rent them is another question. If your business is tied to cash, you may want to consider renting equipment and renting retail or office space instead of buying them directly. Apart from gaining access to the materials and space for which an agricultural enterprise must be successful when management decides to lease these elements, the enterprise does not have to link significant parts of its capital. In other words, the agricultural business will be more profitable to respond to new opportunities and address unforeseen challenges.

2. Manager needs to make it a habit to buy at the best prices. How confident is the company that you are getting the best deals on supplies, systems and utilities? Although, it is counterproductive to buy from new suppliers every other day, you should regularly re-evaluate your operations - whether it will be monthly, quarterly or even annually depending on the business. In today's competitive and connected market, there is a lack of efficient suppliers. But it is important not to choose new suppliers only on the basis of price. After all, if the shipment does not arrive on time, or cloud computing assets are not always available, the business can be very successful. So, when buying from new suppliers, it is necessary to analyze the price - this is how to solve cash flow problems. But manager should also consider the track record of new potential suppliers.

3. Reasoning of raising prices for goods and services of an agricultural enterprise. Many customers will be a little annoyed, when the company raises prices. In fact, most people are already accustomed to rising prices: health insurance costs are rising every year, rents are rising, and consumer goods are becoming more expensive. So if an agricultural enterprise has not raised prices for a long time and is trying to solve cash flow problems, then it is time to approach them optimally. But don't just increase them throughout the year; so as not to risk distracting loyal customers. Instead, by carefully 
planning price increases and selling them effectively, it is possible to generate more income and more sales, while enhancing the financial and economic performance of the agricultural enterprise.

4. There are a variety of tactics that can be used to reduce the likelihood that customers will get angry when a business raises prices. To begin with, do not increase prices if you are not sure that customers are completely satisfied. You can have time to raise prices to improve your products.

5. Account is on a more direct basis. It is not uncommon for companies to wait until the end of the month to bill their customers immediately. But the longer the company waits to send invoices, the longer it will need to collect them. If the agricultural enterprise has problems with cash flow, it is necessary to consider the possibility of speeding up the invoicing process by sending invoices at the time of completion and sending orders. In this way, the company guarantees that customers will receive invoices faster - which mean faster payment.

6. Incentives for customers to pay money faster. To solve cash flow problems, you can offer customers favorable payment terms if they pay their bills early. Customers receive a two percent discount if they pay their bills within 10 days; otherwise full payments must be made within 30 days.

7. Development of new campaigns to increase sales. If sales are stagnant (or even non-existent), you need to re-equip your campaigns. If your business is struggling with cash flow, it's time to think about new ways to increase your own sales.

8. Use the invoice cleaning service. This is an opportunity to access money that needs growth immediately, even if their customers are slowly paying their bills.

9. Keeping cash flow reports. Although they may seem cumbersome from the start, regular cash flow reporting can reduce the likelihood of cash flow problems - at least unexpectedly. In general, cash flow statements track the cash inflows and outflows of an enterprise related to its operations, investments and financial activities. Although a large enterprise may not care too much about its cash flow, many small businesses choose to report on a regular basis on a quarterly or even monthly basis. By doing so, 


\section{SOCIO-ECONOMIC AND MANAGEMENT CONCEPTS}

they will be able to predict with much greater accuracy how healthy their cash flow will be in the future [378].

By drawing up cash flow reports, the company will be able to make the right adjustments to its business if necessary - whether raising prices, reducing costs or conducting new campaigns - so that the farm always has the money needed for its development.

The first step in cash management is to increase the importance of cash. The basic cash management process is straightforward. Try to maintain an adequate level of cash to meet current obligations and invest non-performing cash in profits. Profitable assets must have high liquidity; that is, businesses should be able to quickly convert investments into cash. In addition, the company wants to protect its cash balance by paying liabilities only as they arise. Cash management also involves the aggressive conversion of current assets into cash.

It is determined that at the agricultural enterprise the incoming cash flow begins at the stage of signing the contract on performance of contractual obligations (fig. 1).

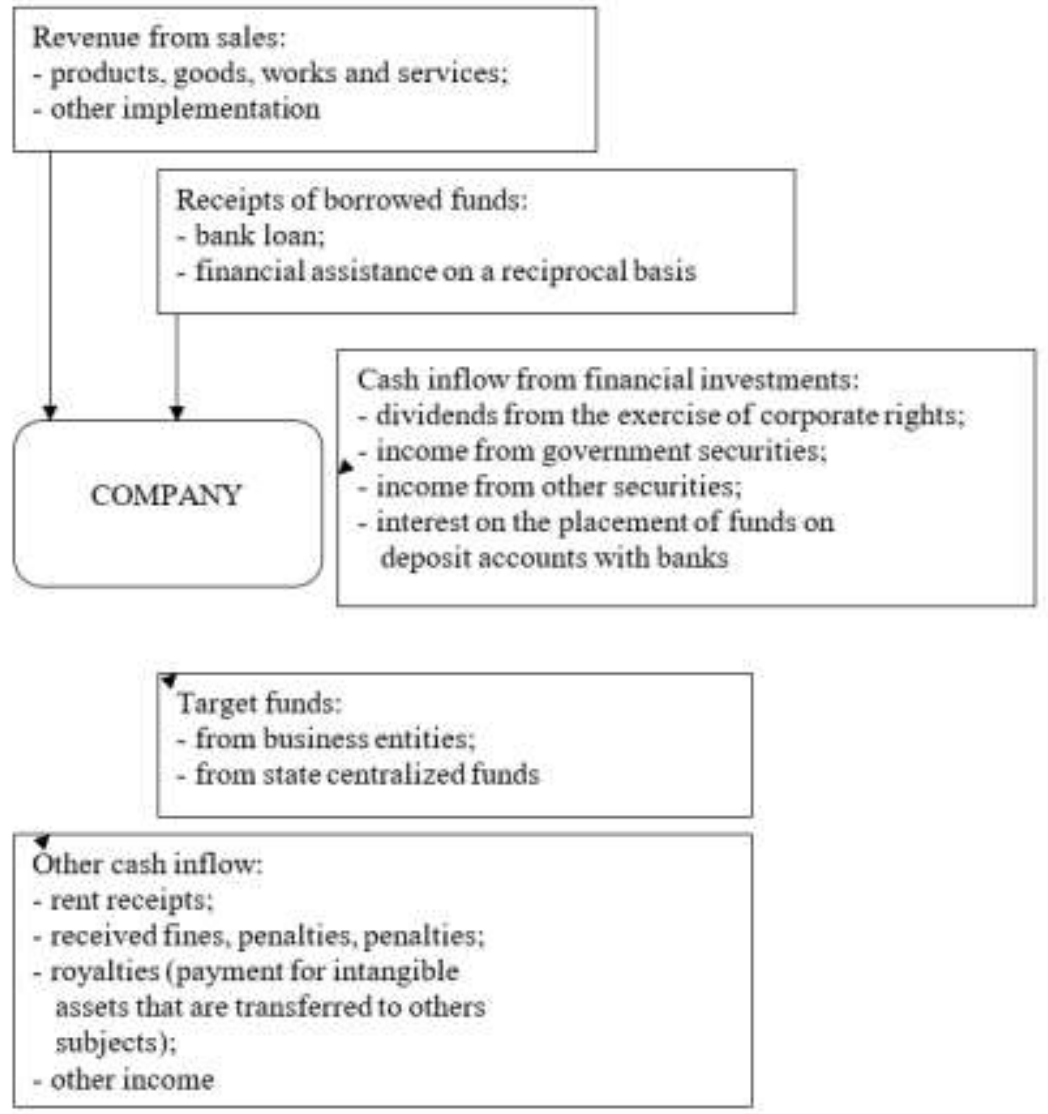

Fig. 1 Formation of cash inflows in an agricultural enterprise 
Agricultural business can bring a significant amount of profit. But much of this profit can be related to receivables, which does not bring anything good if you need cash to cover operating expenses. But if the company focuses more on constantly maintaining a positive cash flow, profits will follow.

The cash outflow occurs when cash is spent from an agro-industrial enterprise or cash register (Fig. 2).

Payment of bills of economic entities

Payment of taxes and contributions to trust funds

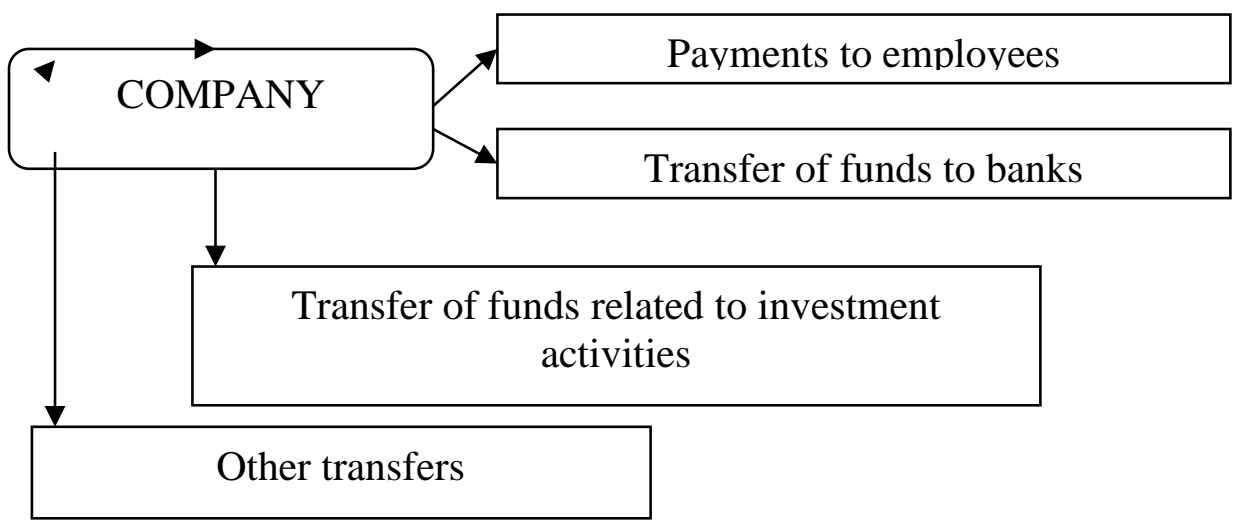

Fig. 2 Formation of cash outflows in an agricultural enterprise

Improving cash flow. The first step to improving cash flow is to understand the history of the company's cash flows. To do this, you need to plan the inflows and outflows of funds. Once the story is clear, it is possible to take steps to reduce cash outflows and increase penalties. One of the largest cash outflows is wages. Wages should be managed flexibly. Other cash traps include insurance.

As sales grow, cash needs will increase. Planning for future sales should include planning for additional cash requirements. The basic formula for the amount of 


\section{SOCIO-ECONOMIC AND MANAGEMENT CONCEPTS}

additional cash required for new sales can be used to determine. The formula is calculated as follows:

Additional cash $=(($ new sales - gross profit $)+$ additional overhead costs $) /($ sales duration of growth in days $\mathrm{x}$ Average number of days to collect receivables + security factor).

The basis of receivables is the policy and procedures of sales. In particular, does the company have a credit policy? When and how does the company assess the customer's creditworthiness? If you look at your past payment history, you should be able to find out who should get a loan and who should not. Additionally, you need to set the terms of sale. Is it profitable to offer discounts to speed up cash fees? What the industry standard is for terms of sale? There are several questions that need to be answered when building the foundation for receivables management [375].

A system for tracking receivables should be established. It will include a balance sheet, a list of all open invoices and the generation of monthly statements to customers. The old receivables will be used to collect overdue receivables. The company must act quickly to collect overdue bills.

Measurement - another component in the management of receivables. Traditional ratios, such as turnover, measure how many times you have been able to convert receivables into cash. The measurement will need to be modified to take into account large fluctuations within the sales cycle. The use of scales can help ensure comparable measurements.

Accounts receivable management also involves the use of a specialist. After all, you need to spend most of your time trying to reduce your losses and not trying to collect overdue bills. A wide range of professionals can help:

- credit bureau services for review and approval of new customers;

- deduction and recovery agencies;

- full account management.

Cash management in agricultural enterprises is to optimize their total average current balance from the standpoint of ensuring the continued solvency of the entity, and therefore involves the performance of certain tasks. Determining the minimum 
required cash for current business activities is based on the calculation of cash flows from current business transactions that occur at the enterprise.

The activity of the enterprise is characterized by a whole system of indicators, among which the indicators of cash flow assessment become important. In practice, the following cash flow estimates are used:

- debt repayment duration indicator;

- debt reversal ratio;

- net operating margin;

- indicator of the ratio of cash flow to equity, the ratio of total capital to cash flow.

To use a better form of cash management, an agricultural enterprise must be able to accurately estimate the current cash position and make fairly reliable forecasts at key intervals about how much it takes to cover the company's costs. If the company's cash flow becomes so predictable that you can leave the amounts for several months or more, you need to purchase certificates of deposit [380].

The biggest cash management mistake a business owner can make is to take risks when investing free money. This is because losing a business's cushion is too easy and may jeopardize the survival of your business by making inappropriate investments (such as risky futures gambling). Sometimes investing is not the best option. Then, when the company's financial position stabilizes and cash flow becomes more predictable, it is optimal to start exploring investment options. In particular, if the company expects to attract a large amount from investors or venture capitalists - it is useful to do some research in advance, so as not to waste time when cash comes.

When the economy is strong, agricultural enterprises may turn to inefficient cash management practices. The following options are being studied:

- bank accounts are the easiest way to get some income from the reserve funds of an agricultural enterprise; however, they only make sense if the money is more than the fee the bank will charge.

- bills at the end of the day. A safer rate for most farm business owners, these bills are awaiting late approval to determine how much to invest over the course of the day. 
Typically, their return on investment is $10-20$ basis points (from $0.1 \%$ to $0.2 \%$ of investment) lower than those offered for controlled investments.

- local accounts, usually created with the help of a large money center or regional bank, provide the agricultural enterprise with a special postal code and, as a rule, faster deliveries from regional post offices. They are especially important if the company has clusters of customers in freelance places and it does not want to waste days waiting for checks to arrive at a distant post office.

Net income accounting measures economic efficiency, which is necessarily consistent with the timing of cash flows. Many profitable businesses have been wiped out by cash flow problems, often in the start-up phase. Business has three types of cash flows: operating, investment and financial. A key indicator of the effectiveness of cash flow management is free cash flow, the amount of operating cash flow generated in excess of the cash required for important expenses, such as capital expenditures. Managers should pay particular attention to the difference in the timing between when cash is collected from customers from the sale of inventory and when cash must be paid to suppliers for the purchase of inventory. The significant discrepancy between these figures indicates potential cash flow problems.

Managers and business owners who are inefficient because of cash spend most of their time surviving cash flows and are therefore distracted from making tactical and strategic decisions important to the long-term success of their business.

Similarly, many agricultural enterprises went bankrupt because they did not manage their cash flow properly. An agricultural enterprise cannot operate efficiently when it does not manage its cash flow properly to be able to repay loans, pay employees, pay suppliers and pay taxes [377].

Even profitable businesses may experience cash flow problems. Net income, or profit, is a measure of economic value added. The timing of operating cash flow does not necessarily coincide with the timing of economic performance. Cash flow problems can destroy businesses, even when those businesses have a profitable business model.

The statement of cash flows is the most recent of the primary financial statements. The balance sheet and income statement have been in place for over 500 years. In 
contrast, the cash flow statement first appeared in 1988, so accountants think it's completely new. For this reason, many managers still focus on the balance sheet and income statement and simply skip past cash flow data. Operating activities are what an enterprise does on a daily basis; his operations. The company receives cash from its customers, pays salaries, pays utilities, pays taxes, pays interest. This is all that is done every day. Operating activities are ordinary things that are done hundreds of times a day.

Thus, the need to create an effective management system and the formation of cash flows of the enterprise is undeniable, as well as the importance of understanding the need to develop theoretical aspects of its operation for the financial management of enterprises. The main stages of management and formation of cash flows, in our opinion, include: ensuring complete and accurate accounting of cash flows at the enterprise and the formation of appropriate reporting; analysis of cash flows for the previous period; cash flow optimization; cash flow control. 


\section{5 Сучасні тенденції та проблеми формування фінансових ресурсів комерційних банків}

Динамічний розвиток вітчизняної економіки підкріплений процесами євроінтеграції істотно підсилює вимоги до розвитку комерційних банків та банківської системи України загалом. Першочергово це пов'язано із провідною роллю банківських установ, які виконують роль фінансових посередників, забезпечуючи переміщення фінансових ресурсів між місцевими, регіональними, національними та міжнародними господарюючими суб'єктами, задля повного та своєчасного задоволення їх потреб.

Для забезпечення зазначеного діяльність банківських установ повинна характеризуватися високим рівнем ліквідності, надійності та прибутковості, що залежить від забезпеченості останніх достатнім обсягом фінансових ресурсів. Чим вищий рівень забезпеченості банку фінансовими ресурсами тим більші можливості у задоволені потреб їх клієнтів. Однак, як показують численні статистичні та наукові дослідження з кожним роком рівень забезпеченості банків фінансовими ресурсами зменшується, що пов'язано із низкою чинників макроекономічного та мікроекономічного характеру. Відповідно зазначеному проблема формування ресурсної бази вітчизняних банків $є$ надзвичайно актуально.

Проблема формування, використання та управління банківськими ресурсами не $€$ новою та давно досліджується як вітчизняними, так і зарубіжними науковцями та економістами. Так, дослідженню проблем формування ресурсної бази банків присвячені праці таких науковців, як: Александренко М.П., Тихонов А.І., Омар Т.П., Лисенко В.І., Вовчак О.О., Алєксєєв І.В., Бондарчук М.К. тощо. Проблемам управління фінансовими ресурсами банків присвячені праці Смовженка П.Р., Ятченка В.Ф., Мірошника В.Р. та інших. Праці більшості науковців банківської галузі переважно присвячені сутності, значенню, принципам та класифікації ресурсів банку. 
На наш погляд, найбільш гострою є проблема формування банківських ресурсів, а тому вимагає більш глибоких досліджень.

Дослідження наукових праць найбільш провідних вітчизняних та зарубіжних науковців, присвячених проблемам банківської сфери дозволили сформувати власний підхід до визначення поняття ресурсів банку. Отже, під ресурсами банку варто вважати сукупність власних, позичених та залучених коштів, які банк використовує для здійснення основних операцій з метою забезпечення високого рівня прибутковості, а також утримання чи розширення набутих ринкових позицій.

Умовою успішної та ефективної роботи банків $\epsilon$ достатній обсяг сформованої ресурсної бази. Проаналізуємо структуру та динаміку обсягу фінансових ресурсів вітчизняних банків на основі статистичних даних Національного банку України.

Як уже зазначалося вище структуру банківських ресурсів складають власні, залучені та запозичені кошти, складові яких відображені на рисунку 1.

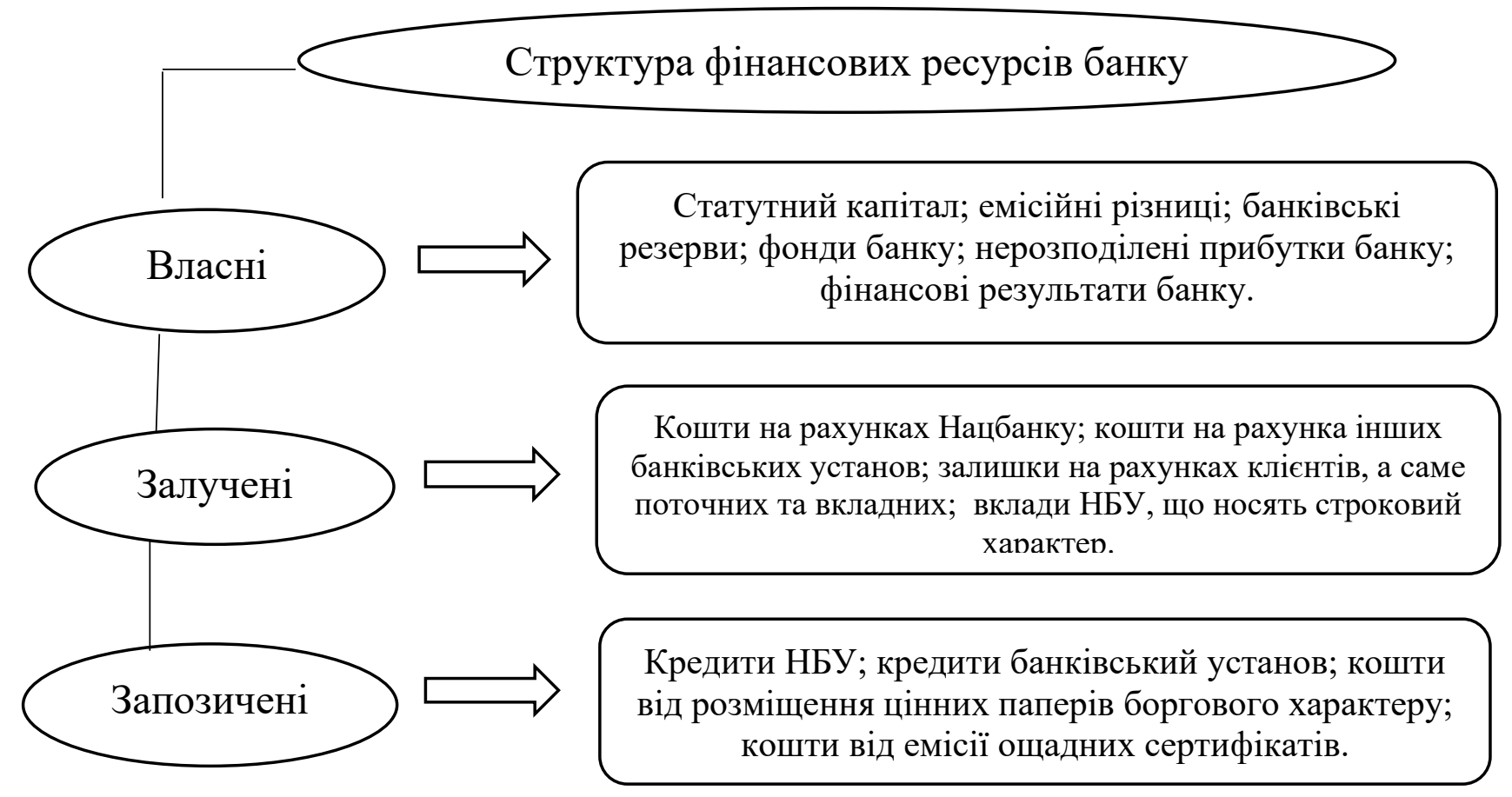

Рисунок 1. Графічна інтерпретація складу та структури фінансових ресурсів комерційного банку [381, с. $85 ; 382$, с. 166] 


\section{SOCIO-ECONOMIC AND MANAGEMENT CONCEPTS}

3 рисунку видно, що в основі власних фінансових ресурсів лежать[381, с. 85]: статутний капітал; емісійні різниці; сформовані резерви та фонди банківської установи; прибуток та нерозподілені прибутки.

Основу залучених фінансових ресурсів складають: кошти на рахунках НБУ та інших банківських установ; залишки на поточних та вкладних рахунках клієнтів; вклади НБУ строкового характеру.

До запозичених фінансових ресурсів належать: кредити НБУ та інших банківських установ; кошти від розміщення боргових цінних паперів, а також емітованих ощадних сертифікатів.

Перш ніж перейти до аналізування обсягів фінансових ресурсів банків, проаналізуємо зміну їх кількості протягом 2017-2020 років за даними Національного банку України. Отримані результати зведемо у таблицю 1.

Таблиця 1. Аналіз динаміки кількості вітчизняних комерційних банків за період 2017-2020 роки [383-385]

\begin{tabular}{|c|c|c|c|c|}
\hline Показники & 2017 рік & 2018 рік & 2019 рік & 2020 рік \\
\hline Кількість діючих банків & 98 & 84 & 75 & 75 \\
\hline з них: з іноземним капіталом & 40 & 38 & 37 & 36 \\
\hline 3 100\% іноземним капіталом & 17 & 19 & 24 & 22 \\
\hline
\end{tabular}

Графічно, тенденція зміни кількості банків України наведена на рисунку 2.

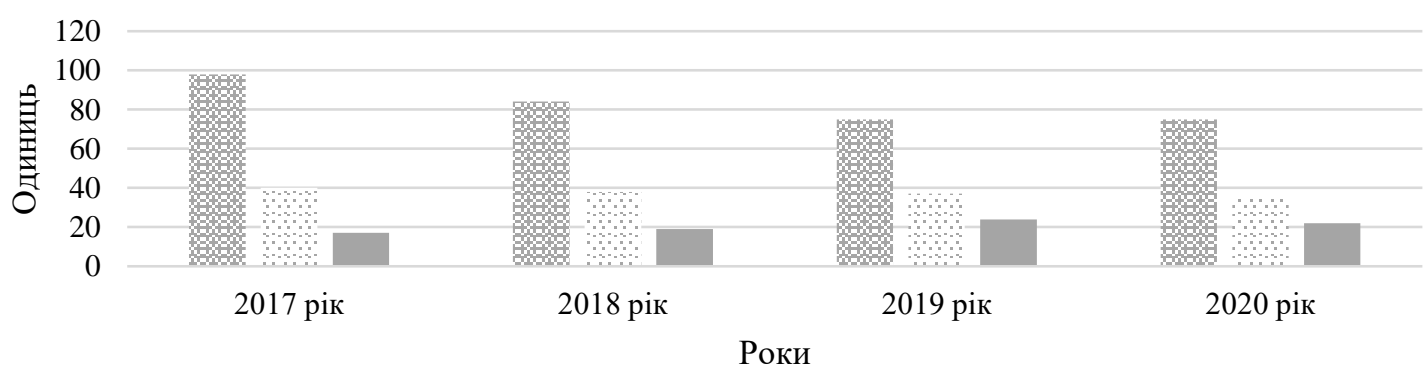

Кількість діючих банків 3 них: з іноземним капіталом 3 100\% іноземним капіталом

Рисунок 2. Графічна інтерпретація зміни кількості банків в Україні за період 2017-2020 рр.[383-385]

Дані таблиці 1 дозволяють зробити такі висновки: кількість банків протягом аналізованих років зменшувалася, а саме у 2018 році у порівнянні із 2017 роком 
на 14 банків, у 2019 році у порівнянні із 2018 роком на 9 банків, у 2020 році у порівнянні із 2019 роком їх кількість була незмінною і складала 75 од.; спадаюча тенденція була характерною і для банків з іноземним капіталом, а саме у 2020 році у порівнянні із 2017 роком їх кількість скоротилася на 4 банки, а у порівнянні із 2019 роком на 1 банк; дещо інша тенденція склалася стосовно банків із $100 \%$ іноземним капіталом, а саме на кінець 2019 року у порівнянні із базовим їх кількість зросла на 7 банківських установ, а до кінця звітного періоду скоротилася на 2 установи.

Проаналізуємо склад та структуру пасивів вітчизняних банків, а отримані результати зведемо у таблицю 2.

Таблиця 2. Результати аналізування складу та обсягів пасивів вітчизняних банків за період 2017-2020 роки [383-385]

\begin{tabular}{|c|c|c|c|c|}
\hline Показники & 2017 рік & 2018 рік & 2019 рік & 2020 рік \\
\hline Капітал (усього) & 123784 & 161108 & 154960 & 200854 \\
\hline Статутний капітал & 414668 & 495377 & 465532 & 470712 \\
\hline Зобов’язання банків (усього) & 1132515 & 1172723 & 1204743 & 1293606 \\
\hline Зобов'язання в іноземній валюті & 644223 & 613681 & 587940 & 568561 \\
\hline Депозити та кредити, отримані від & 73938 & 50240 & 42178 & 23912 \\
\hline інших банків & & & & \\
\hline Кошти юридичних осів & 369913 & 403955 & 406367 & 498156 \\
\hline Кошти фізичних осіб & 437152 & 478100 & 508457 & 552592 \\
\hline Кошти небанківських установ & 42813 & 22907 & 23794 & 26885 \\
\hline Усього пасивів & 1256299 & 1333831 & 1359703 & 1494460 \\
\hline
\end{tabular}

Динаміка обсягу пасивів вітчизняних банків наведена у таблиці 3.

Таблиця 3. Динаміка пасивів вітчизняних банків за період 2017-2020 роки

\begin{tabular}{|c|c|c|c|c|c|c|}
\hline \multirow{2}{*}{ Показники } & \multicolumn{2}{|c|}{ Абсолютна зміна, тис. грн. } & \multicolumn{3}{c|}{ Відносна зміна, \% } \\
\cline { 2 - 7 } & $\begin{array}{c}2018 \mathrm{p} . / \\
2017 \mathrm{p} .\end{array}$ & $\begin{array}{c}2019 \mathrm{p} . / \\
2018 \mathrm{p} .\end{array}$ & $\begin{array}{c}2020 \text { p./ } \\
2019 \text { p. }\end{array}$ & $\begin{array}{c}2018 \mathrm{p} . / \\
2017 \mathrm{p} .\end{array}$ & $\begin{array}{c}2019 \mathrm{p} . / \\
2018 \mathrm{p} .\end{array}$ & $\begin{array}{c}2020 \mathrm{p} . / \\
2019 \text { p. }\end{array}$ \\
\hline Капітал (усього) & 37324 & -6148 & 45894 & 30,2 & $-3,8$ & 29,6 \\
\hline Статутний капітал & 80709 & -29845 & 5180 & 19,5 & $-6,1$ & 1,1 \\
\hline Зобов'язання банків (усього) & 40208 & 32020 & 88863 & 3,5 & 2,7 & 7,4 \\
\hline
\end{tabular}




\section{SOCIO-ECONOMIC AND MANAGEMENT CONCEPTS}

Продовження таблиці 3.

\begin{tabular}{|c|c|c|c|c|c|c|}
\hline Зобов’язання в іноземній валюті & -30542 & -25741 & -19379 & $-4,7$ & $-4,2$ & $-3,3$ \\
\hline Депозити та кредити, отримані & & & & & & \\
від інших банків & -23698 & -8062 & -18266 & $-32,1$ & $-16,1$ & $-43,3$ \\
\hline Кошти юридичних осів & 34042 & 2412 & 91789 & 9,2 & 0,6 & 22,6 \\
\hline Кошти фізичних осіб & 40948 & 30357 & 44135 & 9,4 & 6,3 & 8,7 \\
\hline Кошти небанківських установ & -19906 & 887 & 3091 & $-46,4$ & 3,8 & 12,9 \\
\hline Усього пасивів & 77532 & 25872 & 134757 & 6,2 & 1,9 & 9,9 \\
\hline
\end{tabular}

*Сформовано авторами на основі [383-385]

За даними таблиці 3 склалася наступна ситуація: загальний обсяг капіталу банків на кінець звітного року зріс на 29,6\%; статутний капітал банків у 2019 році зменшився на 6,1\%, тоді як у 2019 році зріс на 1,1\%; зобов’язання банків на кінець звітного року зросли на 7,4\%, що є негативним моментом; зменшувалися у динаміці зобов'язання банків в іноземній валюті, а саме на 4,7\%, 4,2\% та 3,3\% відповідно; обсяг депозитів та кредитів, отриманих від інших банківських установ також зменшувалися у динаміці, а саме на 32\%, 16\% та 43\% відповідно; зростаючою тенденцією характеризувалися обсяги коштів фізичних та юридичних осіб, а також небанківських установ; загальний обсяг пасивів у 2019 році у порівнянні із 2018 роком зріс на 1,9\%, тоді як у 2020 році у порівнянні із 2019 роком зріс на 9,9\%.

Проаналізуємо динаміку рентабельності активів та капіталу банків(табл. 4).

Таблиця 4. Динаміка рентабельності активів і капіталу вітчизняних банків за 2017-2020 роки [383-385]

\begin{tabular}{|c|c|c|c|c|c|c|c|}
\hline & 2017 & 2018 & 2019 & 2020 & \multicolumn{3}{|c|}{ 3міна, \% } \\
\cline { 6 - 8 } & Показники & рік & рік & рік & $2018 \mathrm{p}$. & $2019 \mathrm{p}$. & $2020 \mathrm{p}$. \\
\hline $\begin{array}{c}\text { Рентабельність } \\
\text { активів,\% }\end{array}$ & $-12,6$ & $-1,9$ & 1,6 & 4,3 & & & \\
\hline $\begin{array}{c}\text { Рентабельність } \\
\text { капіталу, \% }\end{array}$ & $-116,7$ & $-15,8$ & 14,6 & 34,1 & 10,6 & 3,6 & 2,6 \\
\hline
\end{tabular}

Графічна інтерпретація зміни рентабельності активів та капіталу вітчизняних банків наведена на рисунку 3. 


\section{SOCIO-ECONOMIC AND MANAGEMENT CONCEPTS}

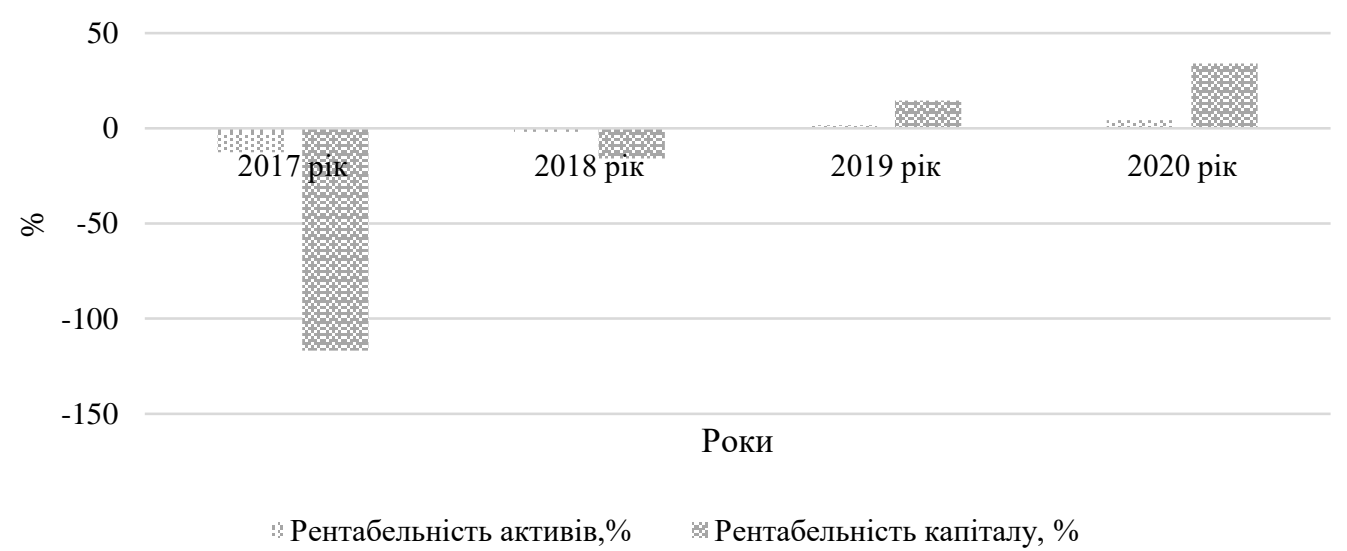

Рисунок 3. Графічна інтерпретація зміни рівня рентабельності активів та капіталу вітчизняних банків за 2017-2020 роки

Рентабельність активів банків зростала протягом аналізованого періоду, а саме на 10,6\%, 3,6\% та 2,6\% відповідно. Показник рентабельності капіталу банків має надзвичайно важливе значення адже характеризує ефективність формування та використання власних фінансових ресурсів. Так, протягом аналізованого періоду рівень рентабельності капіталу банків зростав на 100,9\%, 30,5\% та 19,5\% відповідно. Зазначена ситуація склалася стосовно покращення фінансового результату банків протягом аналізованих років, який лежить в основі розрахунку зазначених вище показників.

Проаналізувавши склад та структуру банківських ресурсів можна стверджувати про їх незадовільний стан, що у першу чергу пов'язано із переважаючим обсягом та динамічним зростання зобов'язань банків.

Основними ендогенними та екзогенними чинниками незадовільного стану ресурсної бази комерційних банків є: недовіра до банківської системи з боку фізичних та юридичних осіб; низький рівень платоспроможності населення та суб'єктів господарювання; висока конкуренція на ринку банківських послуг; одноманітність продуктів та послуг, які пропонуються на ринку; скорочення обсягу інвестування у вітчизняну економіку; висока вартість банківських ресурсів тощо. 
Ресурсне забезпечення банківських установ відіграє першочергову роль у забезпеченні їх успішного та ефективного розвитку. Проаналізовані склад та структура ресурсної бази вітчизняних банків показали їх незадовільний стан, що $\epsilon$ причиною збільшення кількості збанкрутілих та ліквідованих установ. Основним заходом покращення ресурсної бази банків та відповідно покращення їх діяльності є підвищення довіри до банківської системи серед населення та іноземних інвесторів. Окрім зазначеного повинні бути проведені ряд маркетингових заходів, удосконалення кредитної та депозитної політики, а також розвиток та запровадження інноваційних банківських послуг. Перспективним напрямом подальших досліджень є розроблення комплексу заходів на рівні банків, а також органів державної влади, спрямованих на зміцнення ресурсного потенціалу останніх та розвиток банківського сектору загалом. 


\section{6 Банківська система України: тенденції розвитку та наслідки кризи COVID-19}

Економічна криза 2014-2015 pр. вивела назовні цілу низку проблем банківського сектору України. Нове керівництво НБУ розпочало серйозні зміни у напрямку трансформації основних вимог щодо регулювання банків. Введено жорсткіші вимоги, які були покликані, в першу чергу, очистити банківську систему і суттєво зміцнити іiі. На початку весни 2020 р. НБУ сміливо заявив, що банківський сектор України повністю готовий до роботи в умовах економічної нестабільності, яка була спричинена пандемією COVID-19. За підсумками 2020 року варто проаналізувати чи дійсно банківська система змогла без значних втрат пережити цю кризу та які напрями банківської діяльності постраждали найбільше.

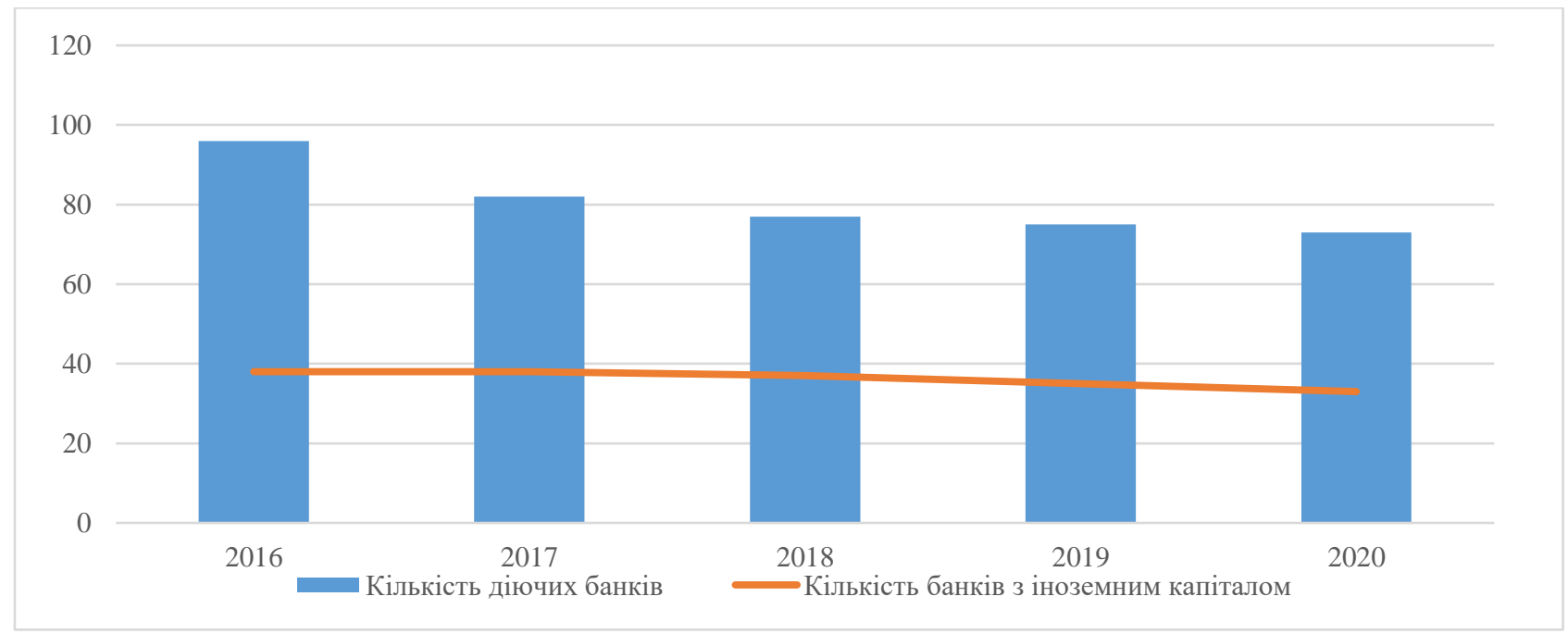

Рисунок 1. Динаміка кількості українських банків протягом 2016-2020 pp. * * складено авторами на основі даних [386]

Якщо подивитися на динаміку кількості банків (рис. 1), то бачимо, що пандемія COVID-19 не вплинула на основні тенденції ринку. До кінця 2020 року ринок покинуло два банки, проте НБУ стверджує, що це не було наслідком світової кризи, а лише нездатністю самих банків справитися 3 фінансовими проблемами, які гостро стояли ще до того. Якщо порівнювати з попередніми роками, то до прикладу, у 2019 році ринок покинуло також два банки, у 2018 році 
- п’ять, а у 2017 році - аж чотирнадцять банківських установ припинили свою діяльність. Варто також зазначити, що в останні два роки саме банки з іноземним капіталом покидають ринок.

Дані також ілюструють (рис. 2), що протягом 2020 р. банківському сектору вдалося наростити сукупні активи на 20\% порівняно з 2019 р. I це найвищий показник приросту за останні 5 років. 3 чого можемо зробити висновок, що незважаючи на те, що темпи кредитування у 2020 р. сповільнилися, приріст активів відбувався за рахунок інших статей, наприклад високоліквідних активів, а також за рахунок зростання інвестицій у ОВДП.

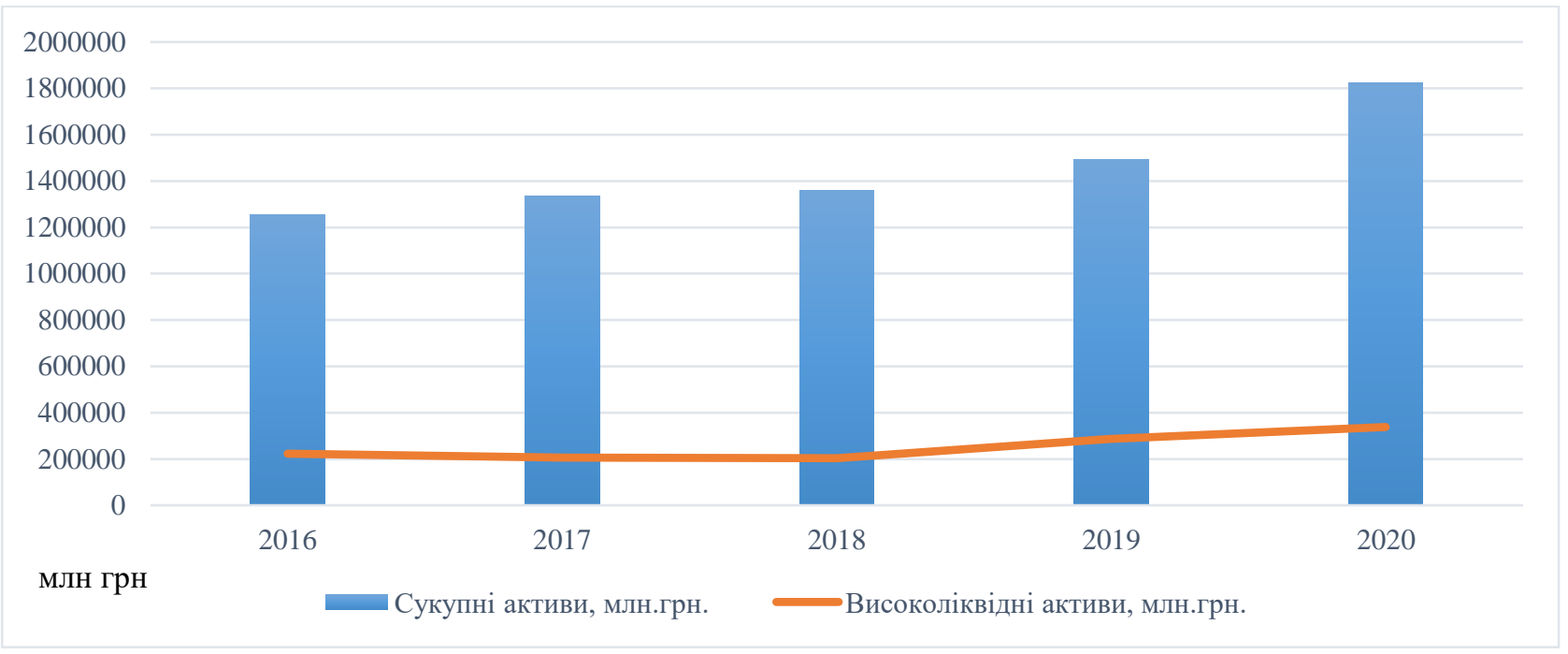

Рисунок 2. Динаміка величини сукупних активів та високоліквідних активів українських банків протягом 2016-2020 pp. *

* складено авторами на основі даних [386]

У 2020 р. приріст високоліквідних активів вітчизняних банків становив 18\%, що є цілком виправданим кроком у час економічної нестабільності, коли банки не впевнені у глибині та тривалості кризи, тож намагаються наростити високоліквідні активи задля згладження можливих шоків ліквідності. Проте, найвищий приріст високоліквідних активів відбувся у 2019 р., коли банки змушені були відкоригувати свою структуру активів під нові вимоги коефіцієнта покриття ліквідності LSR. Саме тому завдяки завчасній зміні вимог до 
ліквідності, українські банки увійшли в коронакризу 3 високим запасом ліквідності.

У 2018-2020 рр. спостерігається зменшення величини високоліквідних активів, оскільки все ж ці активи суттєво обмежують потенційну дохідність банків, які після кризи 2014-2015 рр. намагалися відновити свою прибутковість та покращити фінансові показники.

У табл. 1 представлені основні фінансові показники банківського сектору за останні п’ять років.

Таблиця 1. Основні фінансові показники банківського сектору, 2016-2020 pр.*

\begin{tabular}{|c|l|c|c|c|c|c|}
\hline № & \multicolumn{1}{|c|}{ Назва показника } & 2016 p. & 2017 p. & 2018 p. & 2019 p. & 2020 p. \\
\hline 1. & $\begin{array}{l}\text { Величина доходу, млн } \\
\text { грн }\end{array}$ & 190691 & 178054 & 204554 & 243102 & 249745 \\
\hline 2. & $\begin{array}{l}\text { Процентний дохід, млн } \\
\text { грн }\end{array}$ & 135807 & 124009 & 140803 & 152954 & 147312 \\
\hline 3. & $\begin{array}{l}\text { Комісійний дохід, млн } \\
\text { грн }\end{array}$ & 31362 & 37138 & 50969 & 62057 & 70640 \\
\hline 4. & $\begin{array}{l}\text { Чистий прибуток, млн } \\
\text { грн }\end{array}$ & -159388 & -26491 & 22339 & 58356 & 41296 \\
\hline 5. & Витрати, млн грн. & 350078 & 204545 & 182215 & 184746 & 208449 \\
\hline 6. & $\begin{array}{l}\text { Рентабельність } \\
\text { активів, \% }\end{array}$ & $-12,60$ & $-1,93$ & 1,69 & 4,26 & 2,54 \\
\hline 7. & $\begin{array}{l}\text { Рентабельність } \\
\text { капіталу, \% }\end{array}$ & $-116,74$ & $-15,84$ & 14,68 & 33,45 & 19,97 \\
\hline
\end{tabular}

* складено авторами на основі даних [386]

Хоча, за підсумками 2020 р., дохід банківського сектору загалом зріс на 2,7\% порівняно з попереднім роком, процентні доходи і чистий фінансовий результат зменшилися. Проте, якщо порівняти 3 даними 2019 р., де зростання доходу склало 18,8\%, то негативні наслідки пандемії COVID-19 все ж відчутні.

Погіршення банківської прибутковості, в першу чергу, пов’язано зі значним підвищенням відрахувань на формування резервів під кредитні операції, що $\epsilon$ очікуваним кроком для банків в період кризи, коли неплатоспроможність позичальників різко зростає. Процентні доходи, у свою чергу, зменшилися (на 3,7\%) через очевидне падіння ділової активності у період жорстких карантинних обмежень. Чистий комісійний дохід зазнав значного падіння у першій половині 
2020 р, але вже у другому півріччі почав зростати завдяки відновленню безготівкових операцій, і за підсумками року зріс на 13,8\%.

Загалом збитковими у 2020 р. стали 8 банків, вони отримали збитків на суму 6,4 млрд грн. Проте, незважаючи на доволі песимістичні очікування, які озвучив НБУ ще на початку весни, банківський сектор показав набагато кращі фінансові результати у 2020 р., залишився прибутковим і заробив сукупно 41296 млн грн.

Незважаючи на повсюдне закриття банківських відділень (у II півріччі 2020 року закрилося 304 відділення), вітчизняні банки так і не змогли досягнути загального скорочення витрат у 2020 р. За підсумками 2020 р. сукупні витрати банківського сектору зросли на 12,8\%. Це найбільше зростання за досліджуваний п’ятирічний період. Так, у 2017-2018 рр. банки досягли значного скорочення своїх витрат, а у 2019 р. банківські витрати зросли лише на 1\%. Таке зростання витрат у 2020 р. знову ж таки пов'язане зі збільшенням відрахувань у резерви, а також значним зростанням комісійних витрат.

У табл. 2 представлені дані чистого фінансового результату 15 найбільших українських банків за останні три роки.

Т а б ли ця 2. 3 н а ч е н н я ч и с т о Г о п р и бу тк у

( з б и т к у ) 15 н а й більш и х б а н к і в 2018-2020 p p.*

\begin{tabular}{|c|c|c|c|c|}
\hline No. & Н а 3 в а б б а н & $\begin{array}{c}\text { Ч и с т и й } \\
\text { П р и б у т о к , } \\
2018 \text { р. , м л н } \\
\text { Г р }\end{array}$ & $\begin{array}{c}\text { Ч и с т и й } \\
\text { П р и б у т о к }, \\
2019 \text { р. , м л н } \\
\text { Г р н }\end{array}$ & $\begin{array}{l}\text { Ч и с т и й } \\
\text { П р и б у т о к, } \\
2020 \text { р. , м Л н } \\
\text { Г р н }\end{array}$ \\
\hline 1 & $\begin{array}{l}\text { А Т } \\
\text { 《П р и в а Т Б а н к } 》\end{array}$ & 111668 & 32600 & 25305,9 \\
\hline 2 & А Т 《Oщ а д б а н к & 131,8 & 277 & 2831,7 \\
\hline 3 & 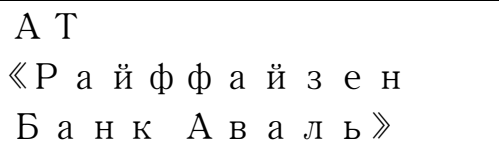 & 5087,9 & 4750 & 4074,8 \\
\hline 4 & 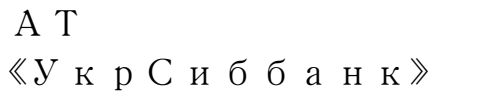 & 2657,9 & 2580 & 1310 \\
\hline 5 & А Т 《O Т П Б а н к & 1974,3 & 2540 & 1733,7 \\
\hline 6 & $\begin{array}{l}\text { А Т 《Прок р ед и т } \\
\text { Б а н к }\end{array}$ & 662,5 & 696 & 542 \\
\hline 7 & $\mathrm{~A} \mathrm{~T} \ll \mathrm{K} \mathrm{p}$ е д о б а н к & 520,3 & 538 & 531 \\
\hline
\end{tabular}


SOCIO-ECONOMIC AND MANAGEMENT CONCEPTS

\begin{tabular}{|c|c|c|c|c|}
\hline 8 & 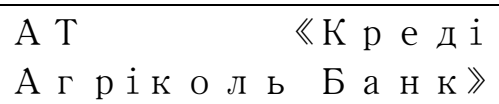 & 1462,7 & 1730 & 927 \\
\hline 9 & 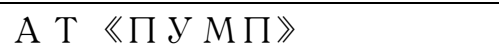 & 2037,5 & 2620 & 2633,8 \\
\hline 10 & 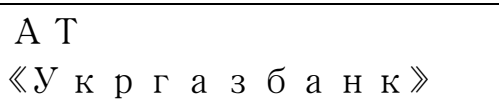 & 766,1 & 1300 & 542,8 \\
\hline 11 & 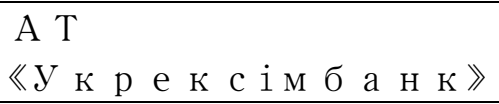 & 958,5 & 1000 & $-5593,9$ \\
\hline 12 & 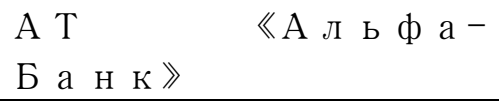 & 1258,3 & 1590 & 1209,7 \\
\hline 13 & $\mathrm{~A} \mathrm{~T} 《 \mathrm{CiTi}$ Б а $\mathrm{H} \mathrm{K} 》$ & 1414,6 & 2210 & 1332,5 \\
\hline 14 & 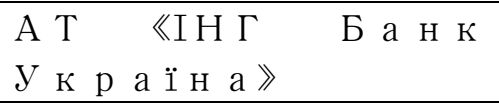 & 510,9 & 710 & 333 \\
\hline 15 & АТ «Сбербанк & -7614 & 441,8 & 932,5 \\
\hline
\end{tabular}

Лідером банківського ринку за величиною чистого прибутку у 2020 р. став АТ «Приватбанк». Він отримав 61\% усього прибутку банківського сектору. А на А Т 《Пр и в а т Б а н к А в а ль 《П У М П》 припадало приблизно 89\% усього чистого прибутку ринку ( р и с . 3). Також високі показники прибутковості у 2020 р. показав АТ «Універсал Банк» - 637 млн грн.

При цьому, державний А Т 《У к p е к с і м б а н к 》, я к и й 2019 р. 3 а й н я в д е с я т е мі с ц е 3 а в е ли ч и н о ю ч и с т о г о п ри б у т к у, $2020 \quad$ p. 3 а к ін ч и в 3 i з би т к о. Т а к о ж 3 н а ч н ч и с ти й фін а н с о в и й 《У к р С б б а н к $(-49 \%), \quad$ А Т $\ll$ р е ді А г рік о л ь Б а н Б а н к $\gg(-39 \%) . \quad 3$ а г а л о м в $\mathrm{i}$ т и и н я н и п о гірше н н я п р и б у т к о в о с 


\section{SOCIO-ECONOMIC AND MANAGEMENT CONCEPTS}

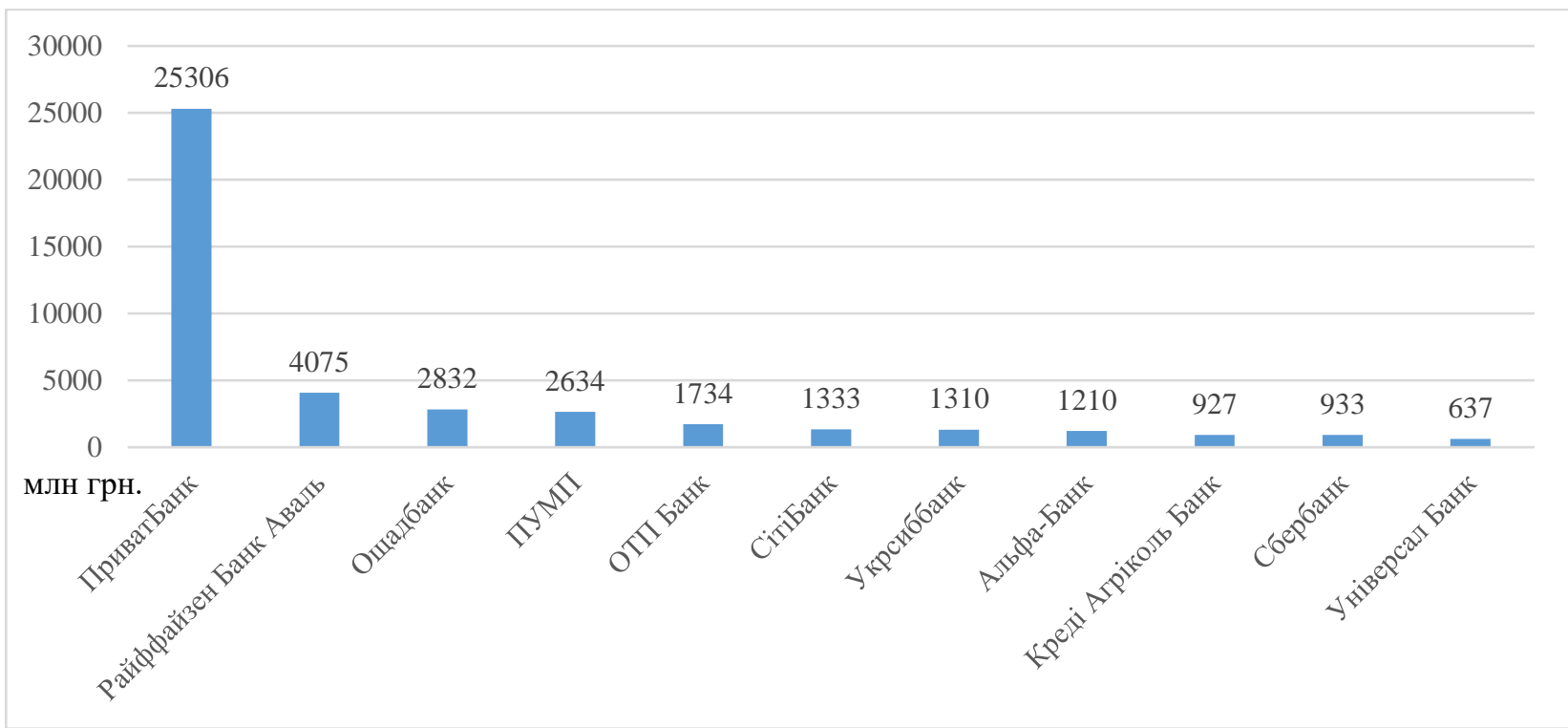

Рисунок 3. Рейтинг десяти найбільших банків України за величиною чистого прибутку у 2020 p.*

* складено авторами на основі даних [386]

Рейтинг українських банків у 2020 р. за величиною активів дещо відрізняється (рис. 4). Першу четвірку найбільш капіталізованих банків займають державні банки, а п’яте місце посідає $\mathrm{A} \mathrm{T} \ll \mathrm{P}$ а й ф ф а й 3 е н Б а нк А в а ль 》, п р и ц ь о м у п е ршіс ть с е р ед

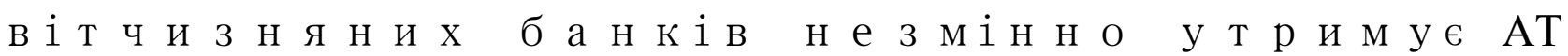
«Приватбанк».

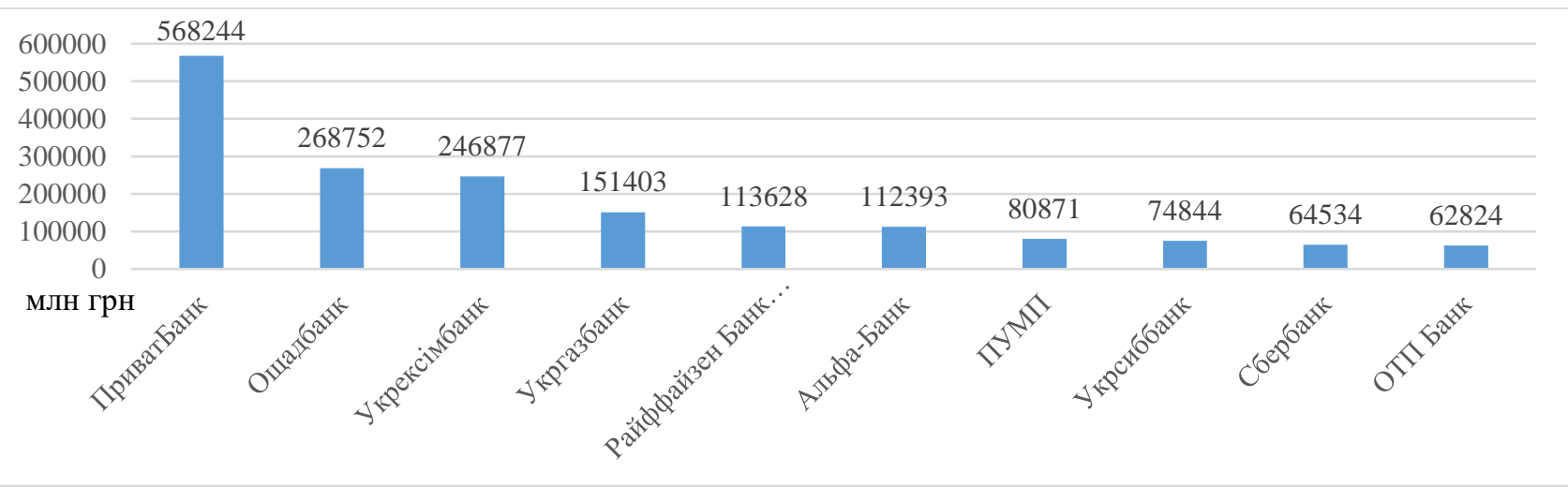

Рисунок 4. Рейтинг десяти найбільших банків України за величиною активів у

$$
2020 \text { p.* }
$$

* складено авторами на основі даних [386] 
Ще на початку коронавірусної кризи НБУ оголосив, що банківський сектор України достатньо капіталізований. Банки нарощували свій капітал у попередні періоди, оскільки готувалися до запровадження обов'язкових буферів капіталу, імплементація яких була першочергово запланована на перший квартал 2020 p.

Якщо детальніше розглянути основні фінансові показники українських банків за групами у 2020 р. (рис. 5), то можна побачити наступні тенденції. Державні банки очевидно домінують на ринку і за величиною активів, і за величиною зобов'язань, основу яких безпосередньо складають кошти клієнтів, а також переважають і за величиною чистого прибутку. Проте, за рівнем дохідності банки 3 іноземним капіталом знаходяться майже на рівні 3 державними банками. Банки з приватним капіталом найменш чисельні, а тому в загальному займають за основними фінансовими показниками найменшу частку.

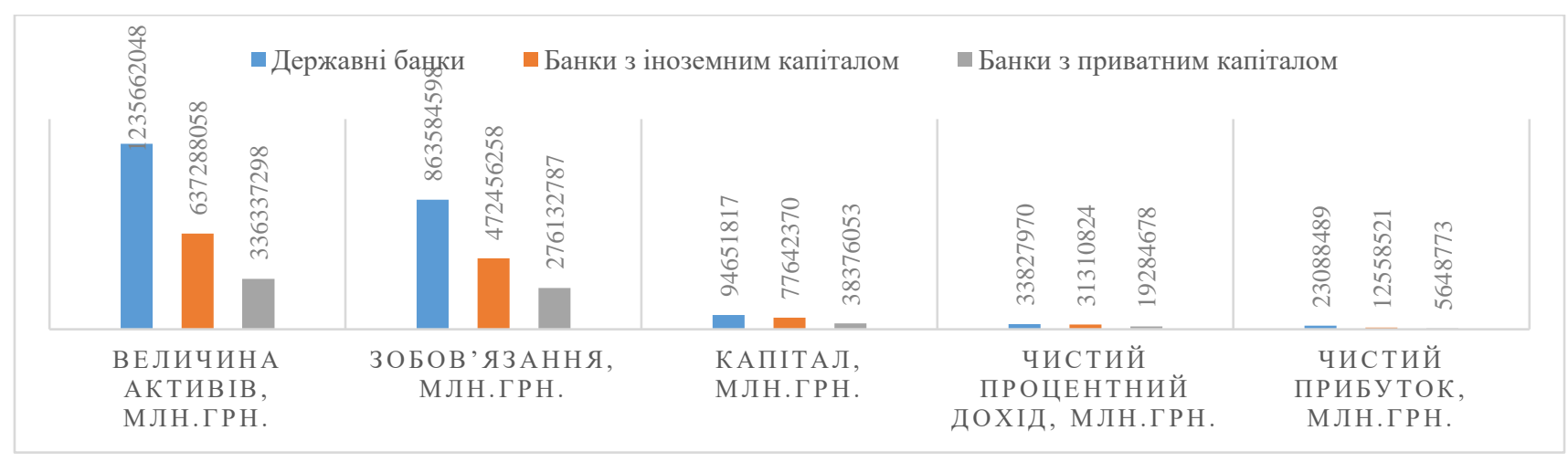

Рисунок 5. Основні показники банківського сектору за групами банків, 2020 р.*

* складено авторами на основі даних [386]

В результаті пандемії COVID-19 вітчизняний банківський сектор суттєво не погіршив ні показники ліквідності, ні показники достатності капіталу (табл. 3). Капітал банку, який покликаний першим поглинати можливі збитки, зріс на 21\% у 2020 р. I хоча це зумовлено, в першу чергу, тим, що НБУ не рекомендував банкам виплачувати дивіденди та бонуси, а увесь наявний прибуток капіталізувати, все ж зростання регулятивного капіталу свідчить про те, що банкам не довелося його задіювати для боротьби з наслідками кризи. Загалом забезпеченість капіталом банківського сектору у 2020 р. навіть покращилася, це говорить про достатній рівень капіталізації вітчизняної банківської системи. 


\section{SOCIO-ECONOMIC AND MANAGEMENT CONCEPTS}

Таблиця 3. Основні економічні нормативи ліквідності та достатності капіталу банківського сектору загалом протягом 2016-2020 pp.*

\begin{tabular}{|c|l|c|c|c|c|c|}
\hline № & \multicolumn{1}{|c|}{ Назва показника } & $2016 \mathrm{p}$. & $2017 \mathrm{p}$. & $2018 \mathrm{p}$. & $2019 \mathrm{p}$. & $2020 \mathrm{p.}$ \\
\hline 1. & $\begin{array}{l}\text { Регулятивний капітал } \mathrm{H}_{1}, \\
\text { млн.грн. }\end{array}$ & 109654 & 115818 & 126117 & 150314 & 182284 \\
\hline 2. & $\begin{array}{l}\text { Норматив достатності } \\
\text { регулятивного капіталу } \mathrm{H}_{2}, \%\end{array}$ & 12,68 & 16,10 & 16,18 & 19,66 & 21,98 \\
\hline 3. & $\begin{array}{l}\text { Норматив досатності } \\
\text { основного капіталу, } \mathrm{H}_{3}, \%\end{array}$ & - & - & 10,43 & 13,50 & 15,67 \\
\hline 4. & $\begin{array}{l}\text { Коефіцієнт покриття ліквідності } \\
\text { LSR,\% }\end{array}$ & - & - & 292,42 & 481,07 & 449,54 \\
\hline 5. & $\begin{array}{l}\text { Норматив короткострокової } \\
\text { ліквідності } \mathrm{H}_{6}, \%\end{array}$ & 92,09 & 98,37 & 93,52 & 94,35 & 86,62 \\
\hline
\end{tabular}

* складено авторами на основі даних [386]

Дані свідчать, що основні показники ліквідності ринку дещо погіршилися у 2020 р., але критичних змін не відбулося. Банківська система України на початку 2020 р. була надліквідною, а отже готовою до несприятливих економічних потрясінь. Погіршення ліквідності стало очевидною реакцію на фінансові труднощі клієнтів банків. НБУ прогнозує, що у 2021 р. через фінансову нестабільність багатьох секторів економіки, кредитний ризик для банків буде залишатися достатньо високим.

Фінансовий портал «Мінфін» починаючи з 2012 р. складає власний рейтинг стійкості українських банків базуючись на даних щодо ліквідності, якості активів, приросту вкладів та іншій фінансовій інформації (табл. 4). Обов’язковою умовою включення до рейтингу $є$ наявність у банку портфеля роздрібних депозитів на суму не менше 1 млрд.грн. Рейтинг має шкалу від 1 до 5 i узагальнює чотири різні рейтинги: стресостійкість, лояльність вкладників, оцінка аналітиків та рейтинг за вкладами фізичних осіб.

Таблиця 4. Рейтинг стійкості банків протягом 2018-2020 pp.*

\begin{tabular}{|c|c|c|c|c|}
\hline No. & Н а 3 в а б а н & 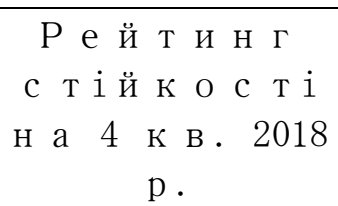 & 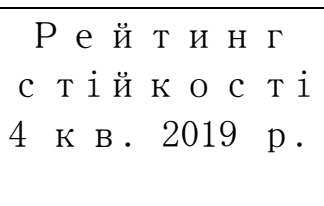 & 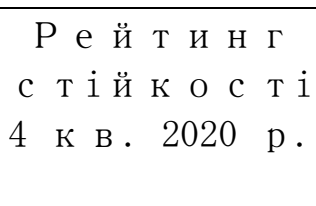 \\
\hline 1 & 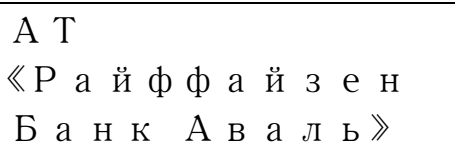 & 4,58 & 4,84 & 4,66 \\
\hline
\end{tabular}


SOCIO-ECONOMIC AND MANAGEMENT CONCEPTS

\begin{tabular}{|c|c|c|c|c|}
\hline 2 & 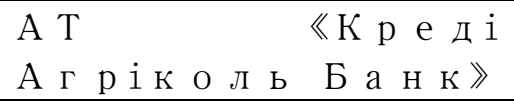 & 4,06 & 4,59 & 4,31 \\
\hline 3 & А Т 《O Т П Б а н к $》$ & 4,15 & 4,45 & 4,27 \\
\hline 4 & $\begin{array}{l}\mathrm{A} \mathrm{T} \\
\ll У \text { р С ибббанк } џ\end{array}$ & 4,49 & 4,62 & 4,16 \\
\hline 5 & $\mathrm{~A} \mathrm{~T} \ll \mathrm{K}$ р е д о б а н & 3,85 & 4,06 & 3,96 \\
\hline 6 & $\begin{array}{l}\text { A Т } \\
\ll П р \text { и в а т Б а н к } 》\end{array}$ & 3,59 & 4,11 & 3,91 \\
\hline 7 & $\begin{array}{l}\text { А Т 《Прокр еди т } \\
\text { Б а н к》 }\end{array}$ & 4,03 & 4,18 & 3,85 \\
\hline 8 & 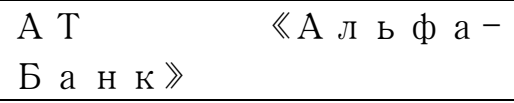 & 3,53 & 3,85 & 3,74 \\
\hline 9 & А Т 《ПУ & 3,67 & 3,90 & 3,70 \\
\hline 10 & $\mathrm{~A} \mathrm{~T} 《 \mathrm{O} щ \mathrm{a} д$ б $а$ н н & 3,65 & 3,94 & 3,49 \\
\hline 11 & 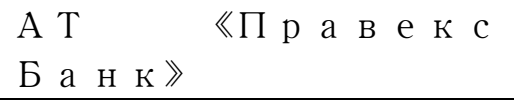 & 3,60 & 3,70 & 3,49 \\
\hline 12 & 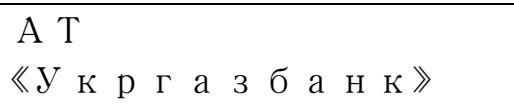 & 3,83 & 4,12 & 3,48 \\
\hline 13 & 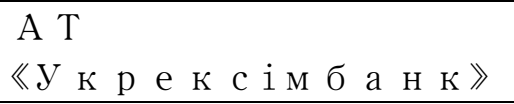 & 3,69 & 3,81 & 3,45 \\
\hline 14 & АТ «Універсал Банк» & 3,05 & 3,41 & 3,23 \\
\hline 15 & А Т 《Ід е я Б а н к》 & 3,27 & 3,52 & 3,22 \\
\hline
\end{tabular}

* складено авторами на основі даних [387]

Очевидно, що у 2020 р. рейтинг стійкості банків погіршився у порівнянні з 2019 р., проте суттєвих змін у окремих рейтингових позиціях банків-лідерів не відбулося. АТ «Райффайзен Банк Аваль» очолює рейтинг уже три роки поспіль, а перша четвірка лідерів загалом також не змінилася. У 2020 р. А Т 《K р ед о б ан н П’ я т у п О

Національний банк України здійснює пом'якшення монетарної політики, поступово знижуючи облікову ставку, оскільки висока відсоткова ставка стримує кредитування. Регулятор проводить прогнозування облікової ставки та публікацію прогнозу в Інфляційному звіті з метою підвищення прозорості та передбачуваності монетарної політики, а також формування очікувань стейкхолдерів. Прогнозований рівень ставки не є зобов'язанням НБУ та може переглядатися у разі виникнення відхилень. Відкритість та передбачуваність 


\section{SOCIO-ECONOMIC AND MANAGEMENT CONCEPTS}

монетарної політики збільшує довіру до НБУ та спрощує досягнення головним банком своїх інфляційних цілей [388].

Облікова ставка 6\% була найнижчою за весь час (рис. 6), проте Правління НБУ прийняло рішення з 05.03.2021 р. підвищити іiі до 6,5\%. Це пов’язано із прискоренням інфляції у зв’язку із зростанням споживчих цін, а також ризиками посилення карантинних обмежень у боротьбі із поширенням пандемії.

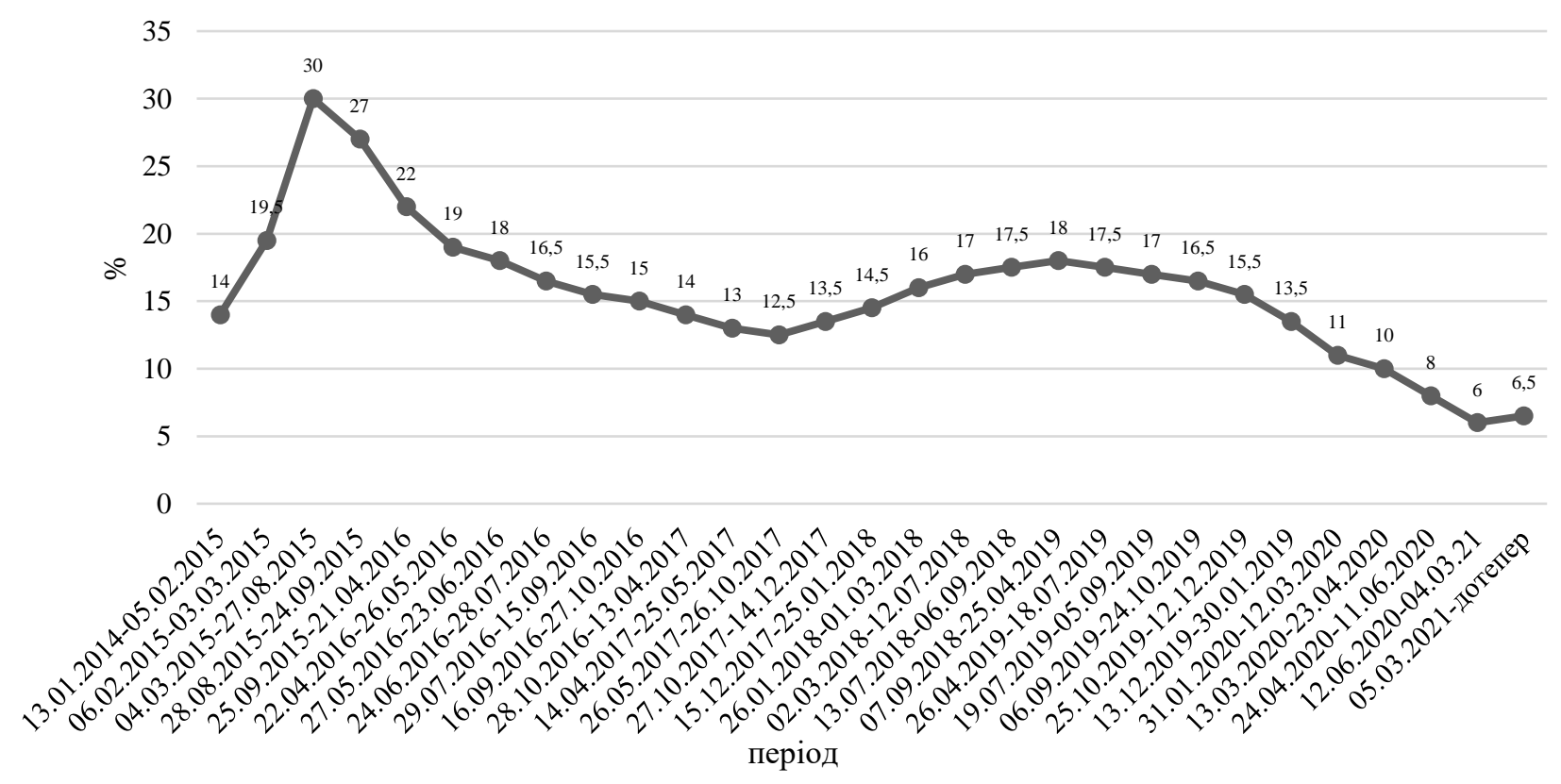

Рисунок 6. Динаміка облікової ставки НБУ у 2014-2021 pp., \%*

* складено авторами на основі даних [386]

Обсяг активів банківської системи зростав упродовж 2016-2020 pp., найбільші темпи зростання 22,1 \% були у 2020 році у порівнянні з попереднім роком. Ця зміна спричинена зростанням статутного капіталу в даному періоді на 24,6\% (табл. 5).

Таблиця 5. Динаміка показників банківської системи України 2016-2020 pр., млн грн

\begin{tabular}{|l|c|c|c|c|c|c|}
\hline Показники & 01.01 .2016 & 01.01 .2017 & 01.01 .2018 & 01.01 .2019 & 01.01 .2020 & 01.01 .2021 \\
\hline Активи & 1254385 & 1256299 & 1333831 & 1359703 & 1493298 & 1822814 \\
\hline Капітал & 103713 & 123784 & 161108 & 154960 & 199921 & 210640 \\
\hline $\begin{array}{l}\text { з нього: статутний } \\
\text { капітал }\end{array}$ & 222170 & 414668 & 495377 & 465532 & 470712 & 479932 \\
\hline Зобов'язання банків & 1150672 & 1132515 & 1172723 & 1204743 & 1293377 & 1612174 \\
\hline
\end{tabular}

* складено авторами на основі даних [386] 


\section{SOCIO-ECONOMIC AND MANAGEMENT CONCEPTS}

Частка капіталу в пасивах банків України зростала від 17,71 \% (станом на 01.01.2016 р.) до 37,14 \% (станом на 01.01.2018 р.) і у подальшому зменшувалася до 26,33 \% (станом на 01.01.2021 р.). Частка статутного капіталу найменшою була на початку 2016 р. - 8,27 \% та найбільшою на початку 2020 року - 13,39 \%, станом на 01.01.2021 р. становила 11,56 \% (рис. 7).

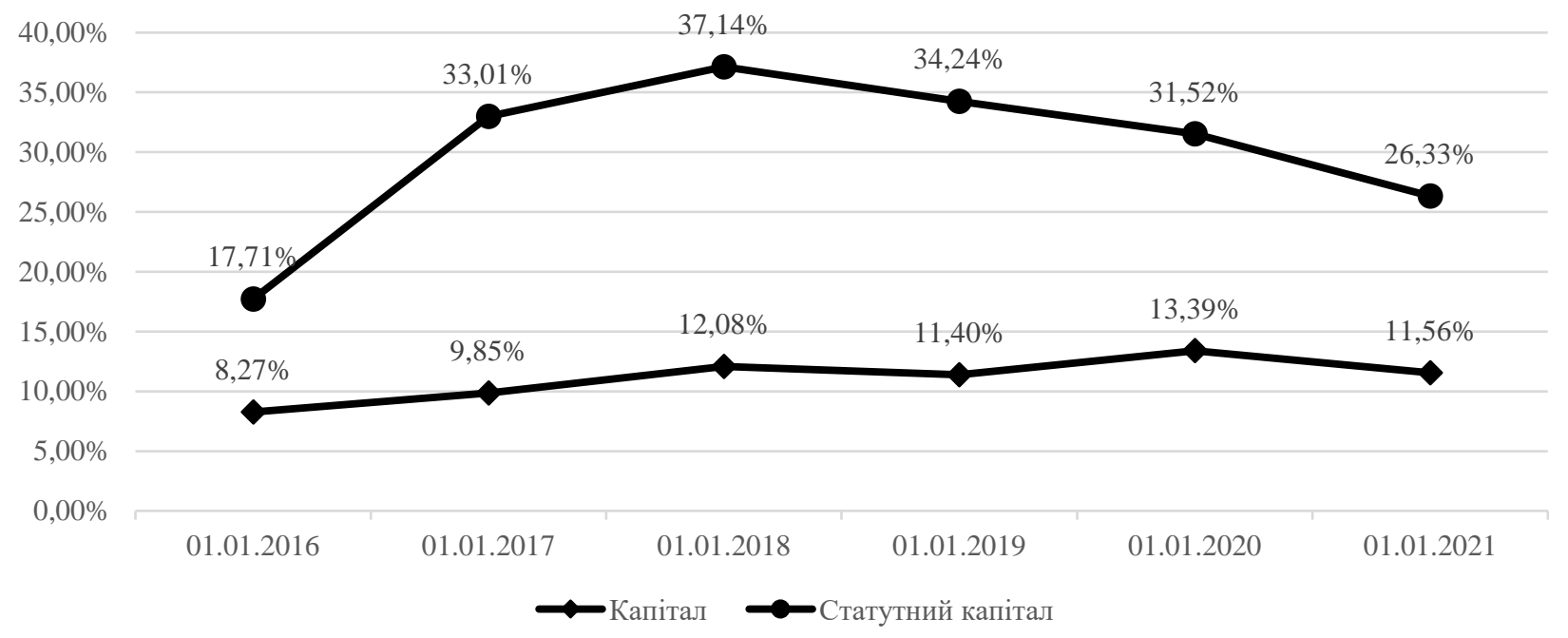

Рисунок 7. Динаміка частки капіталу в пасивах банків у 2016-2020 pp., \%*

* складено авторами на основі даних [386]

Кошти суб'єктів господарювання зростали упродовж 2016-2020 рр. (табл. 6), найвищі темпи зростання 29,8 \% були за 2020 рік, у якому юридичні особи збільшили обсяг своїх строкових коштів у банках на 43,3 \%. За проаналізований період 60-65 \% цих коштів зберігалося у національній валюті.

Таблиця 6. Динаміка залучених коштів банківської системи України упродовж 2016-2020 рр., млн грн*

\begin{tabular}{|l|c|c|c|c|c|c|}
\hline Показники & 01.01 .2016 & 01.01 .2017 & 01.01 .2018 & 01.01 .2019 & 01.01 .2020 & 01.01 .2021 \\
\hline $\begin{array}{l}\text { Строкові вклади інших } \\
\text { банків та кредити, що } \\
\text { отримані від інших } \\
\text { банків }\end{array}$ & 122592 & 73938 & 50240 & 42178 & 23912 & 24235 \\
\hline $\begin{array}{l}\text { Кошти суб'єктів } \\
\text { господарювання }\end{array}$ & 318568 & 369913 & 403955 & 406367 & 498157 & 646491 \\
\hline з них: строкові кошти & 96679 & 102469 & 108214 & 110359 & 103191 & 147871 \\
\hline $\begin{array}{l}\text { Кошти фізичних осіб } \\
\text { (зщадними } \\
\text { (депозитними) } \\
\text { сертифікатами) }\end{array}$ & 402137 & 437152 & 478100 & 508457 & 552115 & 682029 \\
\hline
\end{tabular}


SOCIO-ECONOMIC AND MANAGEMENT CONCEPTS

\begin{tabular}{|l|c|c|c|c|c|c|}
\hline з них: строкові кошти & 294155 & 319551 & 325411 & 327615 & 336663 & 344353 \\
\hline $\begin{array}{l}\text { Кошти небанківських } \\
\text { фінансових установ }\end{array}$ & 30474 & 42813 & 22907 & 23794 & 26885 & 34704 \\
\hline
\end{tabular}

* складено авторами на основі даних [386]

Голова НБУ на початку 2019 року оголосив, що головним завданням банків України на цей рік $є$ відновлення кредитування юридичних осіб, проте досягнути цього не вдалося. Натомість корпоративний кредитний портфель банків зменшився на $12 \%$ упродовж 2019 року та ще на $6 \%$ уподовж 2020 року. Під час пандемії COVID-19 багато великих компаній - позичальників зазнали зниження попиту на свою продукцію, зросла невизначеність, що зосередило зусилля юридичних осіб на погашенні наявних позик, а не отриманні нових.

Найбільш фундаментальною зміною у сфері кредитування $є$ зміни в оцінюванні платоспроможності позичальників. Адекватність проведення цього оцінювання перевіряє НБУ, що спричиняє підвищення якості позичальників. Кредитування корпоративних клієнтів відбувається із прозорою та якісною фінансовою звітністю. Для великих позичальників обов'язковим $\epsilon$ фінансова звітність, яка підтверджена аудитом. Саме ці позитивні зміни, запроваджені регулятором, що спрямовані на підвищення якості кредитування, стримують його обсяги через неготовність корпоративних позичальників відповідати визначеним вимогам. Проте висока частка непрацюючих кредитів юридичних осіб (табл. 7) стала причиною прийняття відповідних рішень [388].

Упродовж 2017-2018 рр. зростали обсяги кредитування юридичних осіб від 657 млрд грн станом на 01.02.2017 р. до 959 млрд грн станом на 01.01.2019 р. та разом з тим зростали обсяги непрацюючих кредитів. Проте із запровадженням пруденційних заходів впливу, спрямованих на підвищення якості кредитування корпоративного сектору, упродовж 2019 року спостерігається зменшення як обсягів кредитування (847 млрд грн станом на 01.01.2020р.), так і обсягів непрацюючих кредитів (456 млрд грн станом на 01.01.2020р.).

Упродовж 2020 року сума корпоративних кредитів зменшилася на 51,85 млрд.грн (795,41 млрд.грн станом на 01.01.2021 р.), сума непрацюючих кредитів зменшилася більшими темпами на 84,9 млрд грн до 371,16 млрд грн. Частка 


\section{SOCIO-ECONOMIC AND MANAGEMENT CONCEPTS}

непрацюючих кредитів юридичних осіб хоча і зменшувалася із 2018 року, проте станом на 01.01.2021 р. залишається ще досить високою 46,66 \%.

Таблиця 7. Динаміка показників кредитування банківської системи України за

2017-2020 рр., млн грн*

\begin{tabular}{|l|c|c|c|c|c|}
\hline Кредитні операції & 01.02 .2017 & 01.01 .2018 & 01.01 .2019 & 01.01 .2020 & 01.01 .2021 \\
\hline $\begin{array}{l}\text { Кредити корпоративним } \\
\text { кліснтам }\end{array}$ & 657098 & 892900 & 959601 & 847259 & 795405 \\
\hline $\begin{array}{l}\text { непрацюючі кредити } \\
\text { частка непрацюючих } \\
\text { кредитів, \% }\end{array}$ & 345661 & 500263 & 535770 & 456074 & 371157 \\
\hline Кредити фізичним особам & 52,60 & 56,03 & 55,83 & 53,83 & 46,66 \\
\hline непрацюючі кредити & 985514 & 174448 & 202202 & 214252 & 208383 \\
\hline $\begin{array}{l}\text { частка непрацюючих } \\
\text { кредитів, \% }\end{array}$ & 62,96 & 53,51 & 46,04 & 34,11 & 27,94 \\
\hline $\begin{array}{l}\text { Міжбанківські кредити, } \\
\text { депозити }\end{array}$ & 9884 & 22046 & 28888 & 31368 & 34057 \\
\hline $\begin{array}{c}\text { непрацюючі кредити } \\
\text { частка непрацюючих } \\
\text { кредитів, \% }\end{array}$ & 454 & 1372 & 1073 & 946 & 984 \\
\hline $\begin{array}{l}\text { Кредити органам державної } \\
\text { влади та місцевого } \\
\text { самоврядування }\end{array}$ & 118 & 1519 & 2867 & 4717 & 11734 \\
\hline непрацюючі кредити & 14 & 10 & 838 & 6393 & 2,89 \\
\hline $\begin{array}{l}\text { частка непрацюючих } \\
\text { кредитів, \% }\end{array}$ & 11,97 & 0,69 & 29,22 & 14,48 & 0,00 \\
\hline Всі кредити & 823614 & 1090914 & 1193558 & 1097595 & 1049579 \\
\hline
\end{tabular}

* складено авторами на основі даних [386]

Обсяги кредитування фізичних осіб зростали, за винятком 2020 року, станом на 01.02.2017 р. сума його становила 156,51 млрд грн, а станом на 01.01.2020 p. - 214,25 млрд грн. Проте упродовж 2020 року відбулося падіння обсягів кредитування фізичних осіб на 2,7 \%, що вочевидь є наслідком коронакризи. Якість наданих кредитів покращується щороку, частка непрацюючих кредитів фізичних осіб станом на 01.01.2021 р. становить 27,94 \%.

Якість міжбанківського кредитування та кредитів, наданих органам державної влади та місцевого самоврядування є досить високою.

Величина кредитів банківської системи зростала від 823 млрд грн станом на 01.02.2017 р. до 1193 млрд грн станом на 01.01.2019 р., зменшилася до 1097 
млрд грн станом на 01.01.2020 р. та до значення 1049 млрд грн станом на 01.01.2021 p.

Частка усіх непрацюючих кредитів банківської системи України станом на 01.01.2017 р. становила 53,7 \% та зросла на кінець 2017 року до значення 54,5 \%, у подальшому відбувалося поступове падіння даного показника та станом на 01.01.2021 р. значення його становило $41 \%$ (рис. 8, табл. 8).

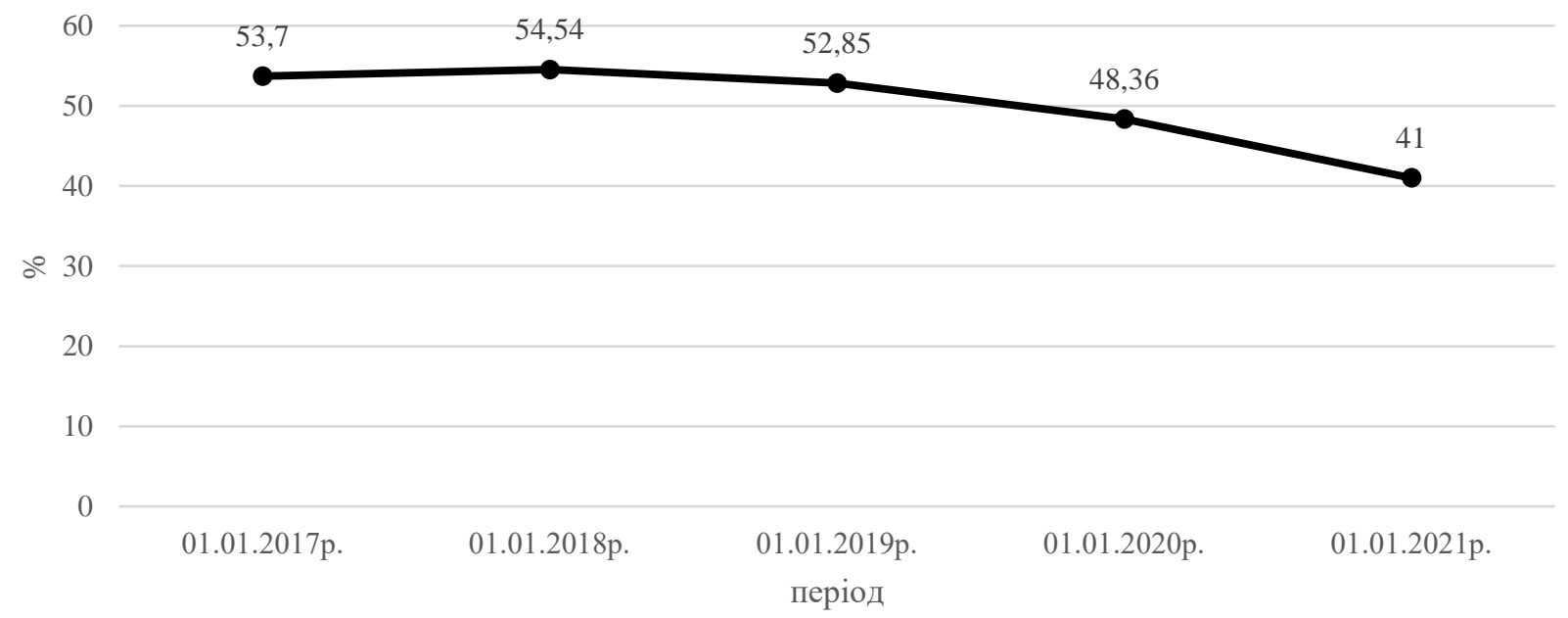

Рисунок 8. Динаміка частки непрацюючих кредитів банківської системи України 2017-2020 pp.*

* складено авторами на основі даних [386]

Таблиця 8. Динаміка непрацюючих кредитів банківської системи України 2017$2020 \mathrm{pp}$.

\begin{tabular}{|c|c|c|c|c|c|c|c|c|c|c|}
\hline \multirow[b]{2}{*}{ Кредитні операції } & \multicolumn{2}{|c|}{$01.02 .2017 \mathrm{p}$. } & \multicolumn{2}{|c|}{ 01.01.2018p. } & \multicolumn{2}{|c|}{ 01.01.2019p. } & \multicolumn{2}{|c|}{ 01.01.2020p. } & \multicolumn{2}{|c|}{ 01.01.2021p. } \\
\hline & $\begin{array}{c}\text { млрд } \\
\text { грн }\end{array}$ & $\%$ & $\begin{array}{c}\text { млрд } \\
\text { грн }\end{array}$ & $\%$ & $\begin{array}{l}\text { млрд } \\
\text { грн }\end{array}$ & $\%$ & $\begin{array}{c}\text { млрд } \\
\text { грн }\end{array}$ & $\%$ & $\begin{array}{c}\text { млрд } \\
\text { грн }\end{array}$ & $\%$ \\
\hline Непрацюючі кредити & 444,6 & 54 & 594,9 & 55 & 630,7 & 53 & 530,7 & 48 & 430,4 & 41 \\
\hline у т.ч. банки: & & & & & & & & & & \\
\hline $\begin{array}{l}\text { - } 3 \text { державною } \\
\text { часткою, } 3 \text { них }\end{array}$ & 198,0 & 77 & 397,5 & 71 & 437,1 & 68 & 396,9 & 64 & 310,2 & 57 \\
\hline $\begin{array}{c}\text { ПАТ КБ } \\
\text { "Приватбанк" }\end{array}$ & 189,9 & 83 & 236,2 & 88 & 244,8 & 83 & 239,1 & 78 & 181,2 & 74 \\
\hline $\begin{array}{l}\text { з державною } \\
\text { часткою крім ПАТ КБ } \\
\text { "Приватбанк" }\end{array}$ & 8,0 & 29 & 161,3 & 56 & 192,2 & 55 & 157,7 & 49 & 129,0 & 44 \\
\hline $\begin{array}{c}\text { - іноземних } \\
\text { банківських груп }\end{array}$ & 205,3 & 50 & 156,8 & 41 & 151,1 & 39 & 107,4 & 33 & 95,9 & 28 \\
\hline
\end{tabular}


SOCIO-ECONOMIC AND MANAGEMENT CONCEPTS

\begin{tabular}{|l|c|c|c|c|c|c|c|c|c|c|}
\hline $\begin{array}{l}\text { - з приватним } \\
\text { капіталом }\end{array}$ & 27,8 & 24 & 30,1 & 24 & 31,2 & 23 & 26,4 & 19 & 24,0 & 15 \\
\hline - неплатоспроможні & 13,4 & 37 & 10,4 & 43 & 11,2 & 52 & 0,00 & 0 & 280 & 75 \\
\hline
\end{tabular}

Найгірша якість кредитного портфелю у банків із державним капіталом, частка непрацюючих кредитів станом на 01.02.2017 р. становила 77,23 \%, поступово зменшувалася до 57,41 \% станом на 01.01.2021 р. Зокрема станом на 01.01.2021 р. непрацюючі кредити ПАТ КБ "Приватбанк" становили 73,95 \% його кредитного портфелю та 42,1 \% усіх непрацюючих кредитів банківської системи.

Банки із приватним капіталом мають найменшу частку непрацюючих кредитів 14,56 \% станом на 01.01.2021 р. Банкам іноземних банківських груп вдалося покращити якість свого кредитного портфелю, знизивши частку NPL від 49,66 \% станом на 01.02.2017 р. до 27,86 \% станом на 01.01.2021 p.

На основі даних Національного банку України сформовано групу десяти банків із найбільшою часткою непрацюючих кредитів (табл. 9).

Таблиця 9. Банки з найбільшою часткою непрацюючих кредитів станом на 01.01.2021 p.*

\begin{tabular}{|c|c|c|c|}
\hline $\begin{array}{c}\text { № } \\
\text { ח/п }\end{array}$ & Назва Банку & $\begin{array}{c}\text { Обсяг непрацюючих } \\
\text { кредитів, млн грн }\end{array}$ & $\begin{array}{c}\text { Частка непрацюючих } \\
\text { кредитів }\end{array}$ \\
\hline 1 & ПАТ "Промінвестбанк" & 24987 & $99,4 \%$ \\
\hline 2 & АТ "СБЕРБАНК" & 37137 & $83,3 \%$ \\
\hline 3 & АТ "АЛЬПАРІ БАНК" & 71 & $82,3 \%$ \\
\hline 4 & АТ "Місто Банк" & 280 & $74,8 \%$ \\
\hline 5 & АТ КБ "ПриватБанк" & 181196 & $74 \%$ \\
\hline 6 & АТ "БТА БАНК" & 3 & $61,5 \%$ \\
\hline 7 & АТ "БАНК КРЕДИТ ДНІПРО" & 3836 & $58,6 \%$ \\
\hline 8 & АТ "Укрексімбанк" & 64227 & $53,9 \%$ \\
\hline 9 & АТ "МІБ" & 1068 & $51 \%$ \\
\hline 10 & АТ "КОМІНВЕСТБАНК" & 291 & $50,8 \%$ \\
\hline \multicolumn{2}{|c|}{$*$ складено авторами на основі даних [386] } \\
\hline
\end{tabular}

Більшість із наведених у таблиці банків хоча i мають велику частку непрацюючих кредитів, проте обсяг їх невеликий та вплив на банківську систему $\epsilon$ незначним. Найбільшу величину непрацюючих кредитів має АТ КБ "ПриватБанк" 181196 млн грн, АТ "Укрексімбанк" 64227 млн грн, АТ 
"Ощадбанк" 56900 млн грн, АТ "СБЕРБАНК" 37137 млн грн, ПАТ "Промінвестбанк" 24987 млн грн, АТ "АЛЬФА-БАНК" 19240 млн грн (рис. 9).

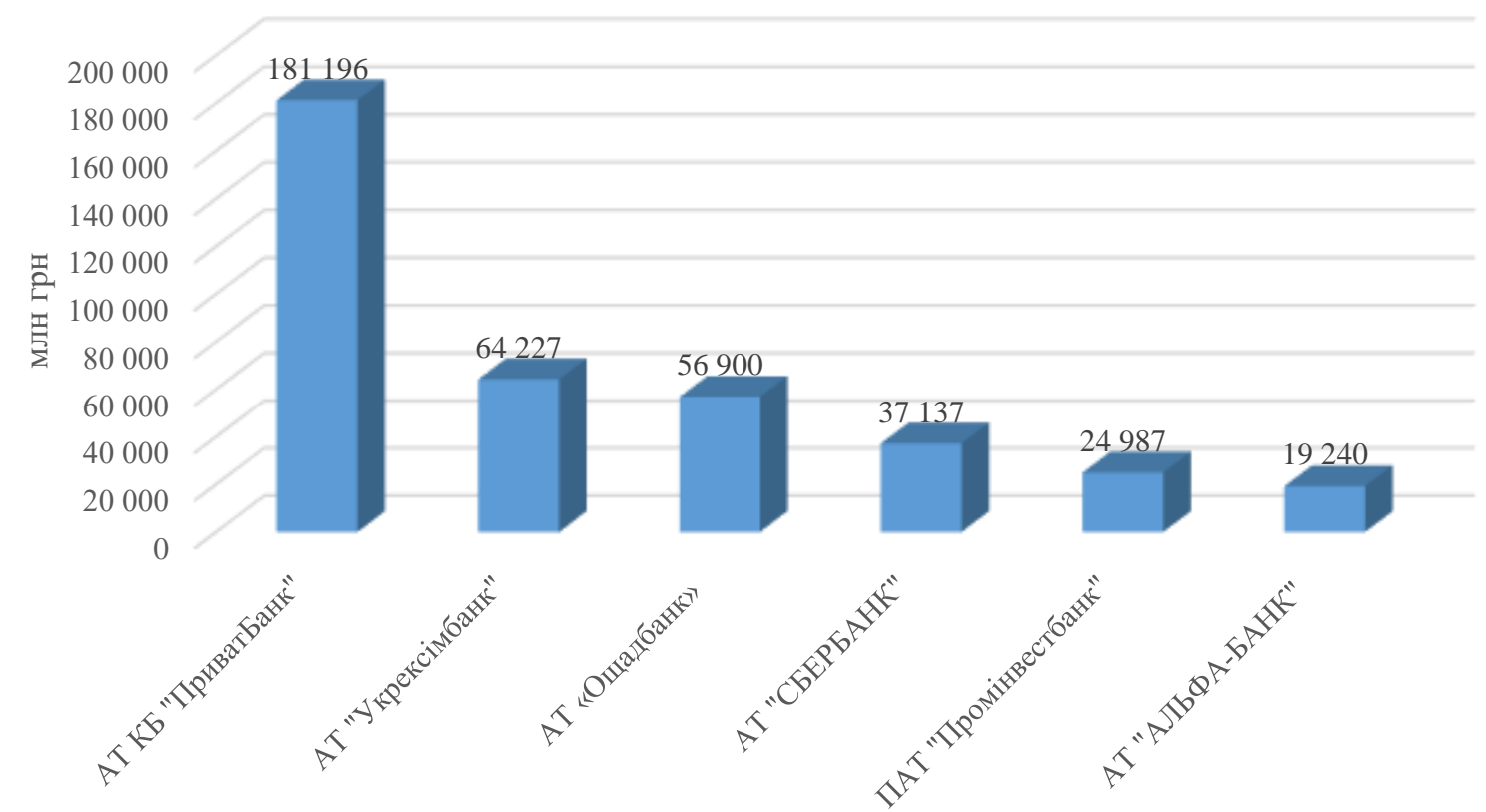

Рисунок 9. Банки з найбільшою величиною непрацюючих кредитів станом на 01.01.2021 p.*

* складено авторами на основі даних [386]

АТ "СБЕРБАНК" і ПАТ "Промінвестбанк" - це банки, що є під контролем Російської Федерації. АТ КБ "ПриватБанк", АТ "Укрексімбанк", АТ «Ощадбанк», АТ "АЛЬФА-БАНК" є системно важливими банками і станом на 01.01.2021 p. 75 \% усіх непрацюючих кредитів банківської системи належать саме цим чотирьом банкам.

Системно важливий банк - це банк, не відповідне функціонування або ж банкрутство якого може призвести до зростання системних ризиків банківської системи [389]. Тому наявність такої великої частки проблемних кредитів у системно важливих банках може містити загрози фінансовій системі країни. Національному банку варто взяти під контроль дану ситуацію та посилити вимоги до якості кредитного портфелю системно важливих банків.

Доходи банків різко сповільнилися під час кризи, тому банкам варто активніше списувати зі своїх балансів непрацюючі кредити, продавати та 


\section{SOCIO-ECONOMIC AND MANAGEMENT CONCEPTS}

реструктурувати їх. НБУ та уряд прийняли відповідні рішення, що спонукають до списання банками своїх проблемних активів.

Оскільки найслабші банки виведено 3 ринку банківських послуг та банківська система показала свою високу прибутковість, можна стверджувати, що обсяги кредитування стримують саме недобросовісність корпоративних позичальників, а не можливості банків. А саме непрозорість структур власності та фінансової звітності представників бізнесу не відповідає новим стандартам якості. Низька якість кредитного портфелю окремих банків потребує активізації заходів, спрямованих на інтенсивне зменшення обсягів непрацюючих кредитів. На сьогодні банкам з іноземним капіталом вдалося очистити свій кредитний портфель, тому іншим банкам, а особливо державним, слід активно переймати цей успішний досвід. 3 метою стимулювання подолання банками цієї проблеми 18.07.2019 р. прийнято Положення про організацію процесу управління проблемними активами в банках України, проте темпи зниження рівня проблемних активів є досить повільними. Варто було б активізувати даний процес як на рівні НБУ, так і на рівні кожного окремого банку.

Під с у м о у ю и т р е б а від міти ти, що ц ь о Г о в е к о н о міч н у к р и з у ді ̈й капіталіз о в а ним, лік в

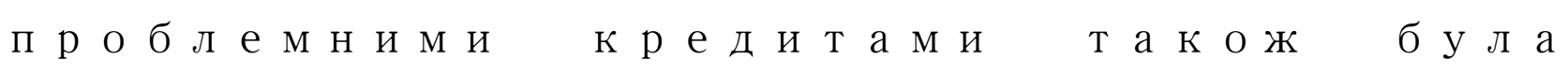
п р о р о бл е н а щ е д о $\quad$ п о ч З в и ч а й н О у П О в

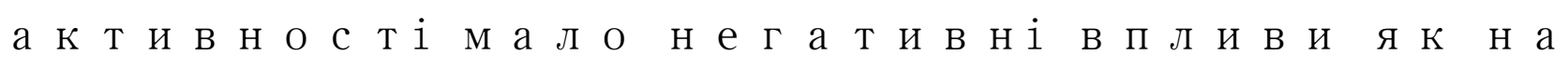
рів е н ь лік в ід н о с т і, т а к

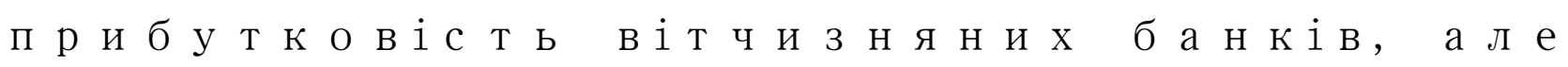
с е р й о 3 н и х по т ря с ін ь н е від б ул о с я. Вж е у д р у г і й п о л о в и ні 2020 р. с п о с т е ріг а л о с я 


\section{SOCIO-ECONOMIC AND MANAGEMENT CONCEPTS}
3 H а ч
П О Ж в а в л е $\mathrm{H} \mathrm{H}$ Я
П О П И Т
$\mathrm{H}$ a

б ан ків ськ о п е р а цї̈

с в ід ч а ть фін ан с о в $\mathrm{i}$ д а ні, б ан
c e $\mathrm{K}$ T $\mathrm{O}$ p
3 а в е р ш и в
$\begin{array}{llllllllllll}3 & \text { а } & \Gamma & \text { a } & \pi & \mathrm{O} & \mathrm{M}\end{array}$
$\mathrm{H}$ a

з а д о в іл ь

Отже, пандемія COVID-19 стала першим суттєвим випробуванням оновленої та зміцненої української банківської системи. А імплементовані зміни та жорсткі нові вимоги щодо регулювання банківських установ показали свою ефективність та дієвість в умовах економічної нестабільності. 


\section{7 Сучасні цифрові технології в банківській сфері України}

Сьогодні банківські установи всього світу сконцентрували свої зусилля на впровадження та розвиток інноваційних проектів. Науково-технічний прогрес відкрив можливості для скорочення вартості застосування цифрових технологій, що сприяло розвитку цифрової економіки. Банки широко використовують цифрові технології в процесі обслуговування клієнтів, що дозволяє швидко і точно ідентифікувати клієнтів, скоротити час відкриття банківського рахунку, поліпшити якість електронного документообігу, оптимізувати внутрішні процеси.

Таким чином, цифрові технології дозволили перейти від продуктового до клієнтоорієнтованого підходу. Лідерами в плані банківських інновацій в цифрову економіку є такі країни як: Німеччина, Японія, США, Південна Корея та Великобританія.

В Україні формальним підтвердженням старту формування політики у цифровій сфері стало прийняття на початку 2018p. Концепції розвитку цифрової економіки і суспільства України на 2018-2020pp. Документ містить основні цілі та принципи цифрового розвитку країни, а також індикативний план їх реалізації. Концепція розвитку цифрової економіки і суспільства України на 2018-2020pp. передбачала здійснення заходів із впровадження відповідних стимулів для цифровізації економіки, суспільної та соціальної сфер, усвідомлення наявних викликів та інструментів розвитку цифрових інфраструктур, набуття громадянами цифрових компетенцій, а також визначила критичні сфери для проектів цифровізації, стимулювання внутрішнього ринку виробництва, використання та споживання цифрових технологій [390].

«Цифрова адженда України - 2020» стала короткостроковим та початковим інструментом розвитку та стимулювання внутрішніх ринків споживання, впровадження та виробництва «цифрових» технологій. Вона містить бачення трансформації економіки від «аналогової» до «цифрової», заходи щодо 


\section{SOCIO-ECONOMIC AND MANAGEMENT CONCEPTS}

імплементації відповідних стимулів для «цифровізації» суспільно-економічного життя, освіти, медицини і т. д.[391].

Понад 25 млн. українців вже можуть користуватись послугами банків 3 допомогою цифрових документів. Передача (шеринг) електронних паспортів у застосунку Дія - це послуга, що, зокрема, дозволяє громадянам ідентифікувати свою особистість у банку та надати свої документи у цифровому форматі, щоб відкрити банківський рахунок, не виходячи 3 дому. Послугу можна використовувати як на онлайн-ресурсах банку (мобільному застосунку чи сайті), так і у звичайному відділенні банку. На смартфоні клієнта автоматично генерується коди доступу (QR-код та штрихкод), які зчитуються у банку. Далі клієнт підтверджує дозвіл на передачу власних даних з Дії, і банк може надавати необхідну клієнту послугу. Наразі послуга шерінгу цифрових документів доступна у ПриватБанку, Монобанку та А-Банку (наприклад, на сьогодні у Приватбанку зареєстровано 25 млн. клієнтів-фізичних осіб, який має 1974 відділення, шеренг працює у всіх відділеннях України; у Монобанку зареєстровано - 2,8 млн. клієнтів, отримано 3796 заявок на реєстрацію через документи в Дії, з них активних клієнтів - 491 (віртуальний рахунок або картка в точці видачі); в А-Банку зареєстровано - 3 млн. клієнтів, 455 точок входу: 230 відділень по всій країні, 225 точок РІП (в магазинах), запустив шеренг по всіх відділеннях банку) [392].

Найбільш поширеною банківської інновацією в цифрову економіку сьогодні $€$ впровадження дистанційного обслуговування за допомогою застосування інтернет-технологій. Це дозволяє виконувати онлайнове інформаційне консультування, виконувати інвестиційні та валютні операції, електронні розрахунки і платежі, операції 3 інвестиціями, депозитами та валютою. Ознайомитися з умовами та видами банківських послуг можна в онлайн-режимі завітавши на сайт банку. У Таблиці 1 подано рейтинг 10 найпопулярніших сайтів банків України [392]. 
ТОП-10 найпопулярніших сайтів банків України

\begin{tabular}{|l|c|c|c|c|c|}
\hline № & Банк & $\begin{array}{c}\text { Similar Web } \\
\text { Traffic (3a 6 міс.) }\end{array}$ & $\begin{array}{c}\text { Similar Web } \\
\text { Country Rank }\end{array}$ & $\begin{array}{c}\text { Alexa } \\
\text { Country Rank }\end{array}$ & $\begin{array}{c}\text { Semrush } \\
\text { Traffic (3a 6 } \\
\text { мic.) }\end{array}$ \\
\hline 1 & $\begin{array}{c}\text { Райффайзен Банк } \\
\text { Аваль }\end{array}$ & 10300000 & 353 & 510 & 3777000 \\
\hline 2 & ПУМБ & 8150000 & 350 & 705 & 3711600 \\
\hline 3 & Альфа-Банк & 3760000 & 1518 & 1331 & 3643800 \\
\hline 4 & топовапк & 2110000 & 1937 & 550 & 1372200 \\
\hline 5 & Укрсіббанк & 1940000 & Не має даних & 243 & 2892000 \\
\hline 6 & Креді Агріколь & 1640000 & 2184 & 2716 & 1015800 \\
\hline 7 & ОТП Банк & 2033000 & Не має даних & 2018 & 1680000 \\
\hline 8 & Кредобанк & 1190000 & 2992 & 3310 & 946200 \\
\hline 9 & Південний & 1167000 & 3119 & 3893 & 596400 \\
\hline 10 & Форвард банк & 981000 & 3864 & 2700 & 140400 \\
\hline
\end{tabular}

Сьогодні банки успішно адаптуються до викликів, спричинених пандемією короновірусу, прискорюючи впровадження інтенсивної програми діджиталізації та роширюючи платформу онлайн-банкінгу. Сьогодні клієнти банків мають можливість отримати швидкий і надійний доступ до банківських послуг і за нижчою ціною, прикладом цього $є$ швидке зростання кількості онлайнтранзакцій.

Перехід до онлайн-банкінгу стає все більш популярним, особливо 3 початком пандемії. I все ж, за винятком молоді, для людей це ще не усталена практика. Проведення цифрових реформ у минулому було викликом, але ситуація з пандемією допомагає нам вже зараз стати більш інноваційними, ефективними та економічно раціональними. Сьогодні люди вже більш адаптовані до цифрових технологій. Клієнти можуть легко та надійно виконувати більшість банківських операцій, користуючись електронними інструментами на кшталт е-банкінгу на веб-сайті чи через мобільні додатки. Сьогодні банки здатні здійснювати більшість транзакцій та запитів клієнтів онлайн. Клієнти банків мають доступ до приватного банкінгу на веб-сайті, а також встановлюють мобільні додатки на телефони, відтак отримуючи доступ майже до всіх доступних в Україні банківських послуг: перекази 3 картки на 
картку, комунальні платежі, відкриття депозитних рахунків, валютні операції, міжнародні платежі тощо. У стрімкому просуванні до онлайн-банкінгу безперечною вигодою для клієнтів є структура плати за послуги. У ній закладені операційні витрати банку на підтримку мережі фізичних відділень, але чим більше цифровим стає банк, тим більше знижуються витрати, і ця економія передається споживачу. Наслідком цієї моделі $є$ якісне обслуговування за низькою ціною. Ефективність витрат - не єдина перевага використання цифрових технологій.

Свій вклад внесло й прийняття закону про віддалену ідентифікацію клієнтів, який діє в Україні з травня 2020 року. Він дозволив банкам ідентифікувати і верифікувати клієнтів онлайн: тепер відкрити рахунок або оформити картку можна без паперової тяганини і відвідування банківського відділення.

Дистанційне обслуговування вигідно обом сторонам: банкам діджіталізація послуг дозволяє знизити витрати на зарплату персоналу, оренду та утримання приміщень, а клієнтам - отримати практично повний асортимент сервісів без відвідування банку. Клієнти можуть вирішувати свої фінансові питання цілодобово, у комфортній обстановці і з високим рівнем безпеки.

Сьогодні можна виділити найпопулярніші канали дистанційного банківського обслуговування, а саме:

- Чат-боти - останнє слово в сфері банківського обслуговування, яке отримає подальший розвиток і поширення найближчими роками. Chat-bot комп'ютерна програма, яка використовує алгоритми машинного навчання i нейромережі. Це «наймолодший» канал дистанційного банківського обслуговування, який вже встигли оцінити багато клієнтів. На відміну від дзвінків до колл-центрів, відповіді на необхідні питання можна отримати дуже швидко і в будь-який час доби. До того ж, вся історія листування і звернень зберігається в чатах. Банки використовують чат-боти для комунікації з клієнтами в інтернет- i мобільному-банкінгу, а також у популярних месенджерах. Чат-боти дозволяють вирішувати безліч рутинних завдань, адже в більшості випадків користувачі звертаються до підтримки банку з простими, 


\section{SOCIO-ECONOMIC AND MANAGEMENT CONCEPTS}

часто вживаними питаннями: перевірка балансу рахунку, отримання інформації про послуги або переказ грошей. Але це далеко не все, що вміють чат-боти банків. Наприклад, Citizens Bank в США запустив свій перший чат-бот, орієнтований на клієнта в період пандемії. Він займається рутинними запитами, такими як скидання пароля від особистого кабінету, запити балансу по рахунку i грошові перекази. Також бот може передавати клієнта оператору або співробітнику філії, коли питання більш складне.

Популярним каналом взаємодії залишається онлайн-банкінг, для якого потрібен лише інтернет, а також комп'ютер або смартфон. У розвиток інтернет та мобільного банкінгу українські банки сьогодні інвестують значні грошові та інтелектуальні ресурси. Сьогодні виділяють інтернет-банкінг для приватних осіб i корпоративних клієнтів. Інтернет-банкінг провідних фінансових установ України сьогодні практично повністю дублює ті послуги, які надає клієнтам персонал банку у відділеннях. Найбільш затребувані у клієнтів-фізичних осіб такі операції:

- відкриття та управління рахунками, контроль залишку коштів, блокування рахунку;

- перекази між рахунками;

- практично будь-які види платежів, в т. ч. комунальних, поповнення мобільного телефону;

- отримання виписки за рухом коштів;

- обмін валюти, створення віртуальної картки;

- відкриття та управління депозитними рахунками.

Абонентна плата за користування інтернет-банкінгом зазвичай не стягується, а транзакції проводяться швидко i захищені двофакторною аутентифікацією: особистим паролем і одноразовим кодом, який надходить на фінансовий номер клієнта.

SMS - ще один вже звичний клієнтам інструмент дистанційного спілкування банків з клієнтами через мобільний телефон. Банк можуть за допомогою смс-повідомлень оперативно інформувати користувачів про такі 
операції: поповнення рахунку і зняття грошей; проведення оплат; рух коштів по картці; інформація про доступний залишок на рахунку. Ця технологія допомагає клієнту тримати свій бюджет і транзакції під контролем, а також швидко реагувати в разі підозрілої активності за рахунком.

Отже, українські банки мають високий інноваційний потенціал. Для його успішної реалізації з урахуванням поточних реалій необхідно вивчати та впроваджувати міжнародний досвід банків-лідерів, що успішно впроваджують сучасні цифрові технології у банківську сферу.

Важливою проблемою банківського сектора сьогодні є необхідність розробки регуляторних механізмів у сфері цифрової економіки, а також створення механізмів запобігання та протидії кібершахрайству. Від конкурентоспроможності банківських структур безпосередньо залежить ефективність і розвиток фінансово-кредитної системи, фінансових ринків і розвиток національної економіки загалом. 


\section{8 Ризик-менеджмент в системі управління заборгованістю підприсмства}

Сучасні умови функціонування ринкової економіки, які зумовлюють активізацію конкуренції, розширення глобальних ринкових кордонів, а також непередбачуваність, викликана пандемією на Covid-19, в загальному, призводять до невизначеності прогнозів щодо можливого попиту, собівартості продукції, рівня рентабельності та результатів господарської діяльності підприємства. Дані умови актуалізують потребу в механізмі управління, який дозволить врахувати ризики, зменшити потенційні втрати та відповідним чином реагувати на зміни у ринковому середовищі. 3 цієї точки зору, ризик-менеджмент має займати ключову позицію в структурі сучасного підприємства, як один 3 найбільш перспективних механізмів забезпечення його стійкого та прибуткового функціонування.

Одним із ризиків діяльності підприємства $є$ неефективне управління заборгованістю. Можна стверджувати, що неефективне управління заборгованістю призводить до зниження фінансової стійкості, далі - до втрати платоспроможності, як результат - збільшується ризик банкрутства підприємства. Виникнення заборгованості уникнути неможливо, але воно супроводжується ризиком неповернення, породжує втрату коштів у вигляді інфляції, на залучення банківського кредиту для забезпечення безперервної діяльності, на повернення заборгованості тощо. Відповідно, заборгованість підприємства супроводжується певними ризиками для його діяльності.

Зважаючи на економічну сутність заборгованості, іiі функціональну роль, види та вплив на фінансово-економічний стан підприємства, можна стверджувати, що вона зумовлює такі фінансові та операційні ризики в його діяльності [395-402]:

- ризик неплатоспроможності - пов'язаний з відволіканням коштів у дебіторську заборгованість. Суть цього ризику полягає в тому, що рівень ліквідності дебіторської заборгованості нижчий рівня ліквідності грошей. Вкладаючи активи в дебіторську заборгованість, підприємство може опинитись 
в ситуації коли нема чим погасити власні борги, що може призвести навіть до його банкрутства;

- ризик несплати дебіторської заборгованості - цей ризик зумовлений неплатоспроможністю чи недобросовісністю дебіторів підприємства i може призвести до втрати ресурсів при неможливості дебіторами погасити свої борги перед підприємством. Іншими словами цей ризик можна охарактеризувати як ризик виникнення безнадійних боргів;

- ризик зниження фінансової стійкості. Цей ризик характеризують як «ймовірність виникнення фінансових втрат через неефективну структуру капіталу, що спричинює розбалансованість грошових потоків підприємства» [400]. Зростання обсягу залученого капіталу, зокрема кредиторської заборгованості, зумовлює погіршення фінансової незалежності підприємства, хоча з іншого боку, відмова від них понижує ефективність використання власних коштів;

- інфляційний ризик - пов’язаний із знеціненням коштів, вкладених в дебіторську заборгованість підприємства. Проте, інфляція здійснює і позитивний вплив на фінансово-майновий стан підприємства, зменшуючи реальну вартість кредиторської заборгованості;

- ризик репутації - полягає в погіршенні взаємовідносин з контрагентами у зв’язку з протермінуванням чи неможливістю погашення заборгованості;

- ризик втрати персоналу - зумовлений звільненням працівників підприємства у зв’язку з несвоєчасною виплатою заробітної плати;

- ризик додаткових втрат (збитків) внаслідок нарахування штрафних санкцій. Цей ризик виникає при протермінуванні погашення кредиторської заборгованості, зокрема 3 податків, соціального страхування, а також комерційної заборгованості при наявності відповідних умов стягнення санкцій у договорі тощо;

- інвестиційно-фінансові ризики - пов’язані зі зниженням курсу цінних паперів підприємства у зв’язку з протермінуванням виплати чи невиплатою 
оголошених дивідендів, а також погашенням інших заборгованостей, пов’язаних з інвестиційно-фінансової діяльністю підприємства.

В теорії ризик-менеджменту економічні ризики класифікують за багатьма ознаками [395,397,399,401,403]. За основними з них ризики заборгованості, на нашу думку, можна охарактеризувати таким чином:

- за середовищем виникнення ризики заборгованості можуть походити як із внутрішнього (ризики репутації, втрати персоналу тощо), так і з зовнішнього (інфляційний, несплати дебіторської заборгованості та інші) середовища;

- за правовими умовами виникнення вони належать до ризиків, що виникають із зобов'язань;

- за часом виникнення ризики заборгованості можуть бути як фактичними, так і плановими чи проектними;

- по відношенню до джерела виникнення ці ризики можуть бути економічними, юридичними, соціальними, комбінованими та іншими;

- за рівнем допустимості вони можуть бути несуттєвими, допустимими, критичними та катастрофічними;

- за масштабами наслідків ризики заборгованості можуть бути як фірмовими, так і мати регіональний чи глобальний;

- за характером прояву ризики заборгованості, як правило, є систематичними.

Зважаючи на те, що заборгованість є об’єктивним явищем в діяльності підприємства і їі уникнути неможливо й недоцільно, то неможливо уникнути i ризиків, які вона зумовлює. Тому менеджерам підприємства необхідно враховувати ці ризики та вживати заходів щодо їхньої мінімізації чи зведення до допустимого рівня, тобто здійснювати управління ризиками заборгованості.

3 точки зору процесно-структурованого менеджменту заборгованості, управління ㄲi ризиками повинно мати системний характер. Базуючись на загальнотеоретичних та спеціалізованих працях 3 ризик-менеджменту [396,398,401,402- 405], склад системи управління ризиками заборгованості підприємства можна визначити таким чином: суб’єкти управління ризиками 
заборгованості; об’єкти управління ризиками заборгованості; методи і засоби впливу суб’єктів на об’єкти (рис. 1).

\section{Система управління ризиками заборгованості підприємства}

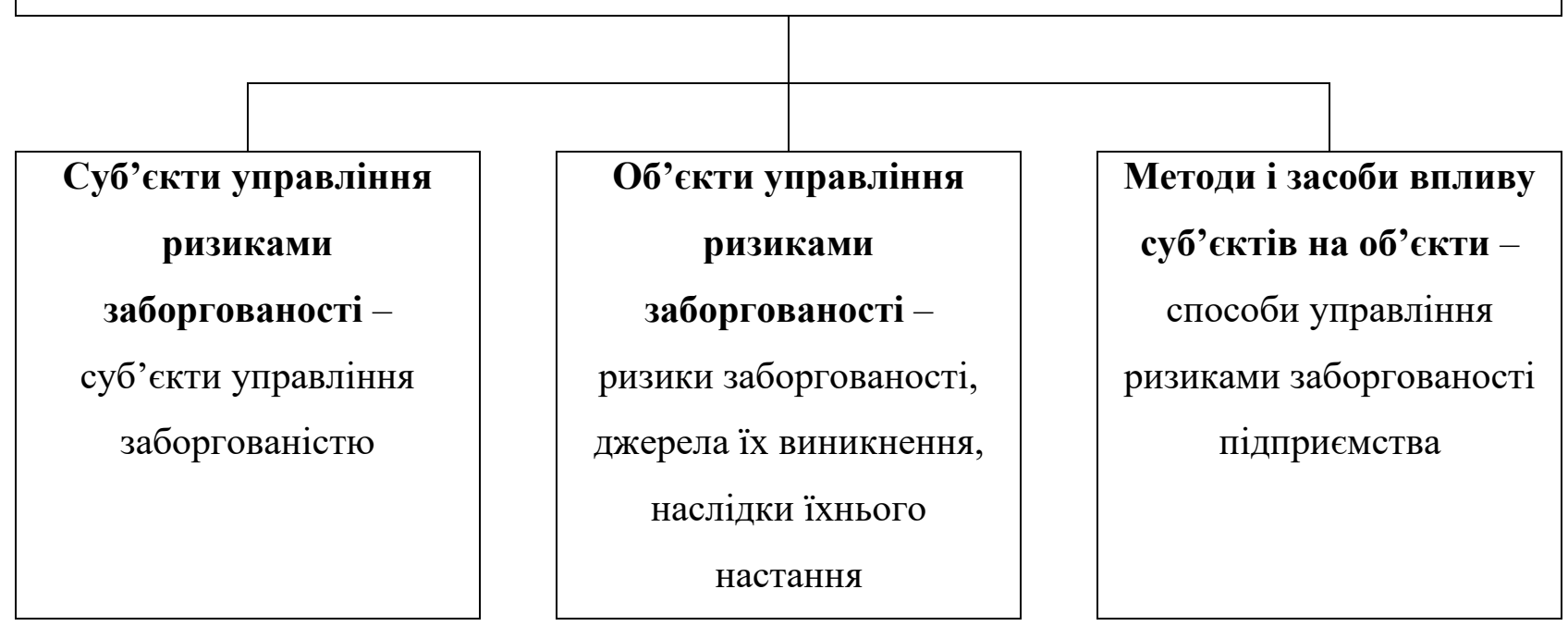

Рис. 1. Склад системи управління ризиками заборгованості підприємства Джерело: визначено автором

На підставі досліджень праць вітчизняних вчених з ризик-менеджменту [399] можна виокремити чотири етапи процесу управління ризиками:

1) виявлення та розпізнавання (ідентифікація) ризиків;

2) оцінювання ризиків;

3) вибір і реалізація методів управління ризиками;

4) аналіз результатів управління та покриття можливих збитків [399].

Виявлення, розпізнавання й оцінювання ризиків заборгованості підприємства переважно здійснюють з використанням методів економічного аналізу. При цьому здебільшого аналізують платоспроможність і репутацію контрагента, вплив заборгованості на фінансово-майновий стан підприємства, положення законодавчо-нормативних актів i договірних документів підприємства тощо.

Загалом за призначенням методи управління ризиками науковці поділяють на такі групи:

- методи уникнення ризиків;

- методи попередження ризиків; 
- методи розподілу ризиків;

- методи передання ризиків;

- методи самофінансування (самострахування) ризиків;

- методи здобуття додаткової інформації [395,397,399].

\section{Конкретні методи управління ризиками заборгованості доцільно} досліджувати в розрізі ризиків та призначення методу (табл. 1).

\section{Таблиця 1. Методи управління ризиками заборгованості підприємства}

\begin{tabular}{|c|c|c|c|c|c|c|}
\hline \multirow{2}{*}{$\begin{array}{c}\text { Вид } \\
\text { ризику } \\
\text { заборго- } \\
\text { ваності }\end{array}$} & \multicolumn{6}{|c|}{ Методи управління заборгованістю підприємства за групами призначення: } \\
\hline & $\begin{array}{c}\text { уникнення } \\
\text { ризиків }\end{array}$ & $\begin{array}{c}\text { попереджен- } \\
\text { ня ризиків }\end{array}$ & $\begin{array}{c}\text { розподілу } \\
\text { ризиків }\end{array}$ & $\begin{array}{c}\text { передання } \\
\text { ризиків }\end{array}$ & $\begin{array}{c}\text { самофінан- } \\
\text { сування } \\
\text { ризиків }\end{array}$ & $\begin{array}{c}\text { здобуття } \\
\text { додаткової } \\
\text { інформації }\end{array}$ \\
\hline $\begin{array}{l}\text { Ризик } \\
\text { неплато- } \\
\text { спромож- } \\
\text { ності }\end{array}$ & $\begin{array}{lr}\text { Відмова від } \\
\text { реалізації } \\
\text { відтерміну- } \\
\text { ванням } \\
\text { платежу } \\
\end{array}$ & $\begin{array}{l}\text { Лімітування } \\
\text { обсягу } \\
\text { дебіторської } \\
\text { заборгова- } \\
\text { ності }\end{array}$ & $\mathrm{X}$ & $\mathrm{X}$ & $\begin{array}{l}\text { Формування } \\
\text { резервного } \\
\text { фонду }\end{array}$ & $\begin{array}{l}\text { Попередній } \\
\text { аналіз } \\
\text { платоспро- } \\
\text { можності } \\
\text { підприємства }\end{array}$ \\
\hline $\begin{array}{l}\text { Ризик } \\
\text { несплати } \\
\text { дебі- } \\
\text { торської } \\
\text { заборгова- } \\
\text { ності }\end{array}$ & $\begin{array}{l}\text { Відмова від } \\
\text { здійснення } \\
\text { госпо- } \\
\text { дарських } \\
\text { операцій } 3 \\
\text { неплатоспро- } \\
\text { можними } \\
\text { покупцями }\end{array}$ & $\begin{array}{l}\text { Встановлення } \\
\text { знижок за } \\
\text { дострокову } \\
\text { оплату і } \\
\text { штрафів за іiі } \\
\text { протерміну- } \\
\text { вання, ре } \\
\text { структури- } \\
\text { зація }\end{array}$ & $\begin{array}{l}\text { Диверси- } \\
\text { фікація } \\
\text { портфеля } \\
\text { дебітор- } \\
\text { ської за } \\
\text { боргова- } \\
\text { ності за } \\
\text { контр- } \\
\text { агентами, } \\
\text { факторинг, } \\
\text { форфей- } \\
\text { тинг }\end{array}$ & $\begin{array}{l}\text { Забезпечення } \\
\text { забор- } \\
\text { гованості } \\
\text { (застави, } \\
\text { гарантії, } \\
\text { поручитель- } \\
\text { ство) та } \\
\text { страхування, } \\
\text { передавання } \\
\text { колекторам }\end{array}$ & $\begin{array}{l}\text { Формування } \\
\text { резерву } \\
\text { сумнівних } \\
\text { боргів }\end{array}$ & $\begin{array}{l}\text { Попередній } \\
\text { аналіз } \\
\text { платоспромож } \\
\text { ності } \\
\text { потенційних } \\
\text { дебіторів }\end{array}$ \\
\hline $\begin{array}{l}\text { Ризик } \\
\text { зниження } \\
\text { фінансової } \\
\text { стійкості }\end{array}$ & $\begin{array}{l}\text { Здійснення } \\
\text { операцій } 3 \\
\text { придбання } 3 \\
\text { передопла- } \\
\text { тою }\end{array}$ & $\begin{array}{l}\text { Лімітування } \\
\text { обсягу } \\
\text { заборгова- } \\
\text { ності }\end{array}$ & $\begin{array}{l}\text { Диверси- } \\
\text { фікація } \\
\text { портфеля } \\
\text { кредитор- } \\
\text { ської } \\
\text { заборго- } \\
\text { ваності за } \\
\text { контр- } \\
\text { агентами } \\
\end{array}$ & $\mathrm{X}$ & $\mathrm{X}$ & $\begin{array}{l}\text { Попередній } \\
\text { аналіз } \\
\text { фінансово- } \\
\text { майнового } \\
\text { стану та } \\
\text { моделювання } \\
\text { його зміни від } \\
\text { змін заборгова- } \\
\text { ності }\end{array}$ \\
\hline $\begin{array}{l}\text { Інфляцій- } \\
\text { ний ризик }\end{array}$ & $\begin{array}{lr}\text { Відмова } & \text { від } \\
\text { реалізації } & 3 \\
\text { відтерміну- } & \\
\text { ванням } & \\
\text { платежу } & \end{array}$ & $\mathrm{X}$ & $\mathrm{X}$ & $\begin{array}{l}\text { Встановлен- } \\
\text { ня } \\
\text { індексації } \\
\text { заборгова- } \\
\text { ності у у } \\
\text { договорах } \\
\end{array}$ & $\begin{array}{l}\text { Формування } \\
\text { цільового } \\
\text { резервного } \\
\text { фонду }\end{array}$ & $\begin{array}{l}\text { Вивчення } \\
\text { інфляційних } \\
\text { прогнозів } \\
\text { експертів }\end{array}$ \\
\hline $\begin{array}{l}\text { Ризик } \\
\text { репутації }\end{array}$ & $\begin{array}{l}\text { Своєчасне } \\
\text { погашення } \\
\text { заборгова- } \\
\text { ності }\end{array}$ & $\begin{array}{l}\text { Попереджен- } \\
\text { ня партнерів } \\
\text { про певні } \\
\text { фінансові } \\
\text { труднощі }\end{array}$ & $\mathrm{X}$ & $\mathrm{X}$ & $\begin{array}{l}\text { Формування } \\
\text { цільового } \\
\text { резервного } \\
\text { фонду }\end{array}$ & $\begin{array}{l}\text { Попередній } \\
\text { аналіз репутації } \\
\text { і поведінки } \\
\text { контрагента }\end{array}$ \\
\hline
\end{tabular}


Продовження таблиці 1.

\begin{tabular}{|c|c|c|c|c|c|c|}
\hline \multirow{2}{*}{$\begin{array}{c}\text { Вид } \\
\text { ризику } \\
\text { заборго- } \\
\text { ваності }\end{array}$} & \multicolumn{6}{|c|}{ Методи управління заборгованістю підприємства за групами призначення: } \\
\hline & $\begin{array}{c}\text { уникнення } \\
\text { ризиків }\end{array}$ & $\begin{array}{c}\text { попереджен- } \\
\text { ня ризиків }\end{array}$ & $\begin{array}{c}\text { розподілу } \\
\text { ризиків }\end{array}$ & $\begin{array}{c}\text { передання } \\
\text { ризиків }\end{array}$ & $\begin{array}{c}\text { самофінан- } \\
\text { сування } \\
\text { ризиків }\end{array}$ & $\begin{array}{c}\text { здобуття } \\
\text { додаткової } \\
\text { інформації }\end{array}$ \\
\hline $\begin{array}{l}\text { Ризик } \\
\text { втрати } \\
\text { персоналу }\end{array}$ & $\begin{array}{l}\text { Своєчасне } \\
\text { погашення } \\
\text { заборгова- } \\
\text { ності }\end{array}$ & $\begin{array}{l}\text { Індексація } \\
\text { заборгова- } \\
\text { ності }\end{array}$ & $\mathrm{X}$ & $\mathrm{X}$ & $\begin{array}{l}\text { Формування } \\
\text { цільового } \\
\text { резервного } \\
\text { фонду, } \\
\text { формування } \\
\text { кадрового } \\
\text { резерву }\end{array}$ & $\mathrm{X}$ \\
\hline $\begin{array}{l}\text { Ризик } \\
\text { додатко- } \\
\text { вих втрат } \\
\text { внаслідок } \\
\text { нарахуван- } \\
\text { ня } \\
\text { штрафних } \\
\text { санкцій }\end{array}$ & $\begin{array}{l}\text { Своєчасне } \\
\text { погашення } \\
\text { заборгова- } \\
\text { ності }\end{array}$ & $\mathrm{X}$ & $\begin{array}{l}\text { Відшкоду- } \\
\text { вання } \\
\text { частини } \\
\text { втрат } \\
\text { винними } \\
\text { працівник- } \\
\text { ками } \\
\text { підприєм- } \\
\text { ства }\end{array}$ & $\begin{array}{l}\text { Страхуван- } \\
\text { ня ризиків } \\
\text { виконання } \\
\text { комерцій- } \\
\text { них } \\
\text { зобов'язань }\end{array}$ & $\begin{array}{l}\text { Формування } \\
\text { цільового } \\
\text { резервного } \\
\text { фонду }\end{array}$ & $\mathrm{X}$ \\
\hline $\begin{array}{l}\text { Інвести- } \\
\text { ційно- } \\
\text { фінансові } \\
\text { ризики }\end{array}$ & $\begin{array}{l}\text { Своєчасне } \\
\text { погашення } \\
\text { заборгова- } \\
\text { ності }\end{array}$ & $\mathrm{X}$ & $\begin{array}{l}\text { Хеджуван- } \\
\text { ня }\end{array}$ & $\begin{array}{l}\text { Страхуван- } \\
\text { ня }\end{array}$ & $\begin{array}{l}\text { Формування } \\
\text { цільового } \\
\text { резервного } \\
\text { фонду }\end{array}$ & $\mathrm{X}$ \\
\hline
\end{tabular}

Джерело: визначено автором

Методи уникнення ризиків заборгованості, як правило, пов'язані з відмовою від здійснення господарських операцій, які призводять до виникнення заборгованості. Заборгованість уникати повністю недоцільно і навряд чи можливо, проте, якщо наперед відомо про високий ризик заборгованості при операціях з певним контрагентом, то в таких випадках необхідно відмовлятися від співпраці з ним.

Методи попередження ризиків заборгованості спрямовані на проведення певної попереджувальної діяльності, яка призведе до зменшення їхнього рівня. По відношенню до ризиків фінансового стану (неплатоспроможності та погіршення стійкості) такими методами є лімітування обсягів заборгованості, що дасть змогу утримувати ії вплив на фінансовий стан у допустимих межах.

Щодо ризику несплати заборгованості, то ефективними методами його попередження, на нашу думку, мали б бути способи мотивування в управлінні заборгованістю - встановлення знижок за дострокове погашення заборгованості та фінансових санкцій за іiі протермінування. Якщо заборгованість протермінована, а платоспроможність дебітора низька, то доцільно розглянути 
можливість реструктуризації такої заборгованості. Плинність кадрів, яка $є$ наслідком заборгованості з оплати праці, повинна б стримуватись індексацією такої заборгованості за весь період іiі протермінування.

Розподіл ризиків заборгованості, як правило, здійснюють за допомогою диверсифікації портфеля заборгованості за контрагентами для мінімізації впливу діяльності конкретного партнера на фінансовий стан підприємства. При нарахуванні підприємству штрафних санкцій з вини його працівників, частину суми таких санкцій можна відшкодувати за рахунок заробітку винних осіб.

Щодо дебіторської заборгованості існують і спеціальні методи розподілу ризику - факторинг, форфейтинг і облік векселів, які належать до способів рефінансування дебіторської заборгованості. Ці способи, за рахунок уступки банку чи іншій фінансовій установі права вимоги платежу до дебітора, дають змогу кредитору з одного боку поповнити свої обігові кошти внаслідок погашення заборгованості банком чи фінансовою установою, а 3 іншого мінімізувати ризики несплати заборгованості. [406].

Передання ризиків заборгованості здебільшого здійснюють через їхнє страхування. Іншою формою передання ризику є його передача під гарантію іншого суб'єкта чи забезпечення дебіторської заборгованості заставою. Ще однією формою передання ризиків дебіторської заборгованості є іiі аутсорсинг через колекторські компанії. Щодо інфляційного ризику, то його передання може здійснюватись через індексацію заборгованості.

Самофінансування (самострахування) ризиків заборгованості відбувається шляхом створення загальних чи цільових резервних фондів. Для покриття ризиків виникнення безнадійної дебіторської заборгованості покупців і замовників національними та міжнародними стандартами бухгалтерського обліку і фінансової звітності передбачено створення резерву сумнівних боргів. Проте, цей резерв не $є$ фондом і не передбачає акумулювання грошових коштів. Він має лише обліковий характер і є регулятивом в системі бухгалтерського обліку, призначеним для вирівнювання впливу втрат від списання безнадійної 
заборгованості на фінансовий результат діяльності підприємства впродовж певного періоду часу.

Здобуття додаткової інформації як метод управління ризиками заборгованості полягає, насамперед, в попередньому аналізі впливу заборгованості на фінансово-майновий стан, внаслідок чого визначається доцільність їі формування і прийняття ризику. Крім того, цей метод пов'язаний з аналізом діяльності контрагентів підприємства, їх фінансових станів, репутації тощо для прогнозування майбутньої поведінки.

Отже, здійснюючи управління заборгованістю підприємства необхідно враховувати ризики, якими вона супроводжується. Для побудови ефективної системи ризик-менеджменту заборгованості доцільно застосувати процесноструктурований підхід, який зокрема передбачає створення інтегрованої в систему управління заборгованістю системи управління ризиками з визначенням ії конкретних суб’єктів, об’єктів та методів управління. 


\section{SECTION 8. INNOVATIVE ECONOMY}

\subsection{Disruptive technologies for green economy formation in conditions of the fourth industrial revolution: the EU experience}

Disruptive technologies create the prerequisites for the decrease in demand of a resource or substituting one resource by another, which is more effective from an economic or ecological point of view. In this context economy can increase along with several pathways: 1). Increase in the efficiency of production or consumption without the substitution of critical resources (in this case, the production process's efficiency increases, the use of raw materials, and the demand for energy decreases). 2). Substitution of less effective resources by more effective ones. 3). Less effective resources are substituted by more effective social demand.

By green economy we understand a phase transition to new energy; new communications; new settlements, new economic relations; a new lifestyle; new needs; and a new man. The green economy includes sectors and types of activities, which help reduce a load of production and consumption processes (goods and services) on the environment and man's biological nature and create conditions for personal difference human development.

The essential characteristics of the green economy are continuous selfoptimization (self-adjustment) of technical systems, continuous improvement, environmental limits, conservation of biodiversity and ecosystems; the priority of the reproduction of human personality basis.

The Fourth Industrial Revolution (known as "Industry 4.0") introduces cyber physical systems in production processes. It is foreseen that cyber-physical systems will combine into a single network with the formation of particular local "ecosystems" serving for the maintenance of a specific house, company, or city.

The Third and Fourth Industrial Revolutions facilitate achieving sustainable development. We can expect two critical transformations in socio-economic activity:

1. Changes in consumption: transition from creation and production of different products and services to systemic complexes for creating comfortable 
conditions for human biological needs, development of social needs, and the realization of human creativity.

2. Changes in production: transition from "torn" production cycles to the formation of nature-friendly labor, production, and consumption organized according to closed processes.

Based on the analysis of publications (Schwab, 2017; Melnyk et al. 2019a; Melnyk et al. 2019b; Melnyk et al. 2020), the authors formulated the most important functions of cyber-physical systems carried out without any human participation: information exchange (a kind of a "dialogue") in real-time; control of external and internal parameters; self-activation and stop under specific information signals; selftuning for optimal operating conditions; forecasted (anticipatory, preventive) systems self-service; interaction with produced goods (production systems case); adaptation to the new needs of consumers; definition of the needed equipment to make the required products or meet new demands; self-learning of new work methods.

The EU experience of a green economy is based on a fundamentally new type of technology and economic relations. On the one hand, this is due to the need to transition to sustainable development, which allows overcoming the threat of a global environmental catastrophe and ensuring the transition to social (personal) development priorities. On the other hand, the achieved scientific and technical level of society at the present stage creates prerequisites for solving various corresponding problems.

The green economy is the mainstream worldwide nowadays, a new economic model without harmful pressure on the environment. Industry 4.0 is the bridge for transforming the economy to green energy systems based on renewable energy sources (RES), green technology based on additive methods and 3D printers; new materials based on progressive characteristics (10 times lighter than aluminum and ten times more potent than steel) and are environmentally friendly. As a result of innovation activities in conditions of the Third and Fourth Industrial Revolutions, the variety of technological principles for implementing energy, working on renewable sources, has dramatically increased. Whole clusters are successfully developing today in each of their components (solar, wind, biogas, geothermal, etc.). 
The main areas of energy systems' development are development of new principles for RES implementation; improvement of technological solutions (efficiency increase) within the framework of the research; efficiency increase of energy storage processes; optimization of spatial solutions for RES placement; formation of information systems optimizing RES operation and related infrastructure; the formation of communication systems that integrate the operation of certain RES into integrated energy systems.

Successful implementation of renewable energy projects depends mainly on the efficiency of the appropriate methods of obtaining energy. In this case, the efficiency should be understood as the ratio between the assimilated amount of energy and maximally reaching the source. This indicator is an analog of the efficiency coefficient used in the energy industry and other technical spheres.

RES installations' efficiency entirely depends on other indicators - economic characteristics, showing the profitability of using these generators compared with other obtaining energy methods. The fact is that for forty years, the cost of getting a unit of solar energy has dropped by 150 times. In terms of cheapness, it goes ahead of traditional power. It means that the efficiency of solar energy installations is hugely increasing.

The report of the International Council on the Agenda for the Future of Software and Society, organized in the framework of the World Economic Forum, states that many disruptive technologies will reach a crucial point in their development by 2025 (Deep Shift, 2015). Society comes closer and faster near surprising technological innovations, as, e.g., quantum computer, the universal introduction of the blockchain, virtual reality, and developments based on artificial intelligence. Every year experts and scientists discuss the issues related to disruptive technologies, focusing on the positive sides for economic growth promotion. The other researchers are more skeptical of these positive effects and refer to the negative direct impacts and potential threats (Sotnyk et al., 2013).

The main direction of Industry 4.0 is the formation of cyber-physical systems and the Internet of Things (IoT). The Internet of Things is a concept of an information- 
driven network of physical objects ("things") equipped with built-in technologies to interact with others or with the external environment. The formation of IoT can rebuild economic and social systems, contribute to personality development, and achieve sustainable development goals. IoT is closely related to sustainable development issues. First, it may significantly increase social systems' efficiency, dematerialize industrial metabolism, and reduce the ecological impact on nature (Karintseva, 2017). Second, it establishes conditions for the implementation of a circular economy. Third, disruptive technologies providing IoT (alternative energy, additive technologies, artificial intelligence, cloud technologies, etc.) are inherently sustainable phenomena. They provide a solution to economic, environmental, and social problems. As a rule, disruptive technologies are not realized as separate innovations but within a broad front (cluster) with other disruptive technologies. In one case, they serve as an auxiliary, providing the implementation of other disruptive technologies. In another example, they are the leading (essential) application of which other disruptive technologies work.

In particular, for the realization of every disruptive technology, three dates are provided. The first characterizes the critical event's implementation when an industrial sample is produced, and disruptive technology moves from the scientific sphere to an industrial application. The main event of the technology development period refers to the second date, which characterizes the technological maturity and its readiness for implementation within the Internet of Things. The last date shows the most specific event(s) related to the given technology's current state.

Without completing all disruptive technologies (Personal computer - PC, mobile phone, Internet, Wi-Fi, Renewable energy, 3D printing, digital technology, artificial intelligence, RFID tags, GPS, robot, cloud), the implementation of the Internet of Things would be impossible. Only the essential components of the necessary disruptive technologies are shown in the table. There are many more, as the production of new materials for the operation of 3D printers, the formation of energy storage systems necessary for the full service of renewable energy sources, and new disruptive technology, creating the conditions for implementing GPS. 
PC, mobile phone, Internet, Wi-Fi, Renewable energy, 3D printing, digital technology, artificial intelligence, RFID tags, GPS, robot, cloud are the original "components" for assembling the IoT. Each of these phenomena is a landmark in the history of human civilization. The results of these innovations are called phenomena because of their scale and versatility. In particular, "mobile phones" or "3D printers" necessitate various objects and technologies that constantly change in space and time.

The Internet of Things could not appear before the production and use of each of the mentioned phenomena (from a personal computer to "cloud" technologies) reached industrial maturity. The latter involves at least two aspects: firstly, achieving cheapness, which ensures the profitability of mass production and uses; secondly, the success of the massive scales of the application.

Cisco analysts consider 2009 as the start of the era of the Internet of Things (IoT). By this time, the number of devices connected to the Internet has exceeded Earth's population. Thus, the global network began to serve people and the things themselves (Evans, 2011).

The formation of a green economy, especially the EU experience at this stage of civilizational development, becomes possible because the Third and Fourth Industrial Revolution form prerequisites for the transition to much more efficient technological solutions to produce and consume goods and services.

It is essential to see the logic of the events taking place when analyzing economic systems' behavior. It helps make reasonable decisions and avoid mistakes that could lead to negative consequences in the future. 


\section{SOCIO-ECONOMIC AND MANAGEMENT CONCEPTS}

\subsection{Intellectual assets of human potential in a digital economy}

The peculiarities of the modern global world development are due to the processes that manifested at the turn of the millennium and gained widespread progress at the beginning of the XXI century, the transition to a knowledge economy and information society and strengthening of digitalization (digital transformation), which determine the economic and social type of development of international and national economies, regions and individual cities. The globalization of the world economy, the rapid development of research and information technology, the creation of transnational companies create objective conditions for the emergence of a new direction of economics, the digital economy. Informatization, the emergence of new technologies and mobile automated high-tech industries, all has led to radical changes that continue to shape the economy of developed countries and have a significant impact on the formation and implementation of human capital.

Ukraine is in the process of forming an institutional mechanism for the development of digitalization. The Government began working on the development of the digital economy and society in January 2018 with the approval of the Concept of the same name for 2018-2020 and the approval of the Action Plan for its implementation.

According to the report of the experts of the World Economic Forum in Davos "Readiness for the Future of Production" [415], for countries like Ukraine, focusing on digitalization is the right and only way to reduce such a significant gap in international performance compared to other countries. According to domestic experts, investment in business innovation, development of technological base and infrastructure, financing of large engineering projects will allow to make a stunning breakthrough.

Nowadays the development of the digital environment and the global network covers almost all spheres of life. The guideline in hiring is the possession of digital skills that allow you to quickly and efficiently perform tasks, be successful and use potential opportunities. Modern dynamic development of society and global economic trends have contributed to increasing the attention of scientists and practitioners to human and the development of their potential. It is possible to note that educational, 
intellectual, creative potentials of the person are not only a powerful factor of economic growth, but also a source of incomes at all levels: the person, the enterprise, the state. Interest in human and their knowledge has become especially acute in the context of the digital economy and the acceleration of the transition to the 4th industrial revolution, which, according to Klaus Schwab, will be fully manifested in 2025, when there will be numerous large-scale changes in all spheres of human life due to unprecedented horizons in the processing and storage of information and access to knowledge [416, p. 7]. The pace of change will be much faster than in previous periods, as digital, physical and biological systems are becoming increasingly interconnected in today's world. The reaction of the world community demonstrates the rapid perception of forecasts and current trends and the introduction of appropriate steps to promote and develop the infrastructure of the digital economy, involving the population in the process of digitalization. The spread of the digital economy confirms the growing share of intellectual activity in the value of social product and dependence on this level of national economy and forces the population to develop digital and other related skills, which are one of its main elements along with digital infrastructure and digital transformation projects.

The formation, accumulation and development of intellectual capital are among the main drivers of scientific, technological and socio-economic progress. In the formation of a digital society, the possession of unique information and knowledge, which acquiring new properties in the reproduction process are realized in the form of intellectual capital, provides their owners with a high level of competitiveness and technological development.

According to the European Innovation Scoreboard Ukraine belongs to the countries of the last fourth group - "emerging innovator" for 10 years in a row.

In the works of the classics of political economy W. Petty, A. Smith, D. Ricardo, A. Marshall laid the first foundations of analysis and scientific knowledge about the productive abilities of human as a kind of capital. The term "human capital" first appears in the work of M. Friedman. The greatest contribution to the development of the theory of human capital was made by T. Schultz [417] and Becker [418], as well 
as their followers, American and British economists, who introduced the human factor into the system of economic concepts. The researches of K. Griffin, T. McKinley, M. ul Haq, R. Jolly, A. Cornia, A. Sen were of key importance for the formation of the theory of human potential.

The concept of "human potential" includes the concept of "human capital", is much broader, because it contains opportunities that under certain circumstances (motivation, time, work, socio-economic conditions, quality of government and society) are realized as human capital, and opportunities that remain unrealized [419, p. 76].

The methodological basis for the assessment of intellectual capital was formed by foreign specialists-consultants in the business practice as E. Brooking, D. Galbraith, L. Edvinsson, M. Malone, P. Sullivan, K. Sveiby, J. Tobin.

The search for solutions to the problems of intellectual capital development in Ukraine is covered in the scientific works of such Ukrainian scientists as: V. Bazylevych, V. Vrublevsky, N. Gavkalova, V. Geitz, A. Hrytsenko, B. Dergalyuk, Y. Zaitseva, A. Kolot, L Kurilo, L. Lazebnyk, V. Lych, G. Lyashenko, E. Libanova, V. Mandibura, A. Oleshko, S. Onyshko, Y. Pakhomov, V. Savchuk, V. Svichkar, L. Fedulova, A. Chukhno, O. Shkurupiy, V. Yakubenko and others.

However, nowadays in the conditions of active intellectualization and digitalization of national economies, it is necessary to develop an effective strategy for the development of intellectual capital of Ukraine. It is time to solve the problems of ensuring the advanced development of science and education, the creation and use of intellectual property assets, the intensification of inventive, scientific-research and development engineering work.

The theory of human potential is based on the special role of a human in modern society, the need to provide each person with the conditions and opportunities necessary to earn a decent income, creative potential, mastery of necessary knowledge, skills, continuing education, development of abilities and skills, long and healthy life, entrepreneurial and social activity that can be implemented in society.

The information economy permeates all spheres of life and is characterized by scale and wide distribution. In the process of economic globalization, the main factors 


\section{SOCIO-ECONOMIC AND MANAGEMENT CONCEPTS}

in the development of the national economy are the creative abilities of the individual, scientific knowledge and intellectual resources.

Intellectual activity becomes the main condition for economic growth, and intellectual capital - the most important resource to achieve this goal.

In the modern economic literature the following approaches to the analysis of the essence of intellectual capital can be distinguished:

- definition of intellectual capital by unveiling its structure (intellectual capital as a unity of human and structural capital, the amount of intangible assets of the enterprise);

- definition of intellectual capital by analyzing its purpose, the specific role it plays in the process of social reproduction (intellectual capital as a formalized and fixed intellectual material intended for the production of more valuable property; knowledge used for competitive advantage);

- definition of intellectual capital through an established understanding of the essence of certain investments (values, resources), which allows to receive income (intellectual capital as knowledge, able to make a profit, business intelligence, able to create new values, generate income, etc).

Intellectual capital is the intellectual potential that is actively used by economic entities in the process of economic development in order to generate income. Intellectual potential is interpreted as opportunities created by intellectual resources of different levels to achieve a certain goal. Intellectual resources generate human capital (a set of mental functions that convert information into knowledge), artificial intelligence (mechanical reproduction of some intellectual human actions related to the perception of information and some elements of reasoning, intellectual products (information provided on tangible media containing new knowledge that is the result of intellectual work).

Views on the nature and role of intellectual capital in the economic life of society have changed over the centuries with the evolution of the economic worldview. The concept of "intellectual capital" was finally formed in the late 90's of the twentieth century. in Western countries due to the informatization of production and 
intellectualization of products. The main function of intellectual capital is to obtain technological and organizational advantages over competitors. Today, the most widely used definition of intellectual capital as those intangible assets of the company, which, without being reflected in its financial statements, can be codified, valued and used by the company [420].

The following approaches in the formation of its definition can be identified by summarizing the theoretical material on the nature of intellectual capital (Table 1): structural, human capital, intangible assets, knowledge and value of existing intellectual assets.

Table 1

\section{The main directions for interpretation of the essence of intellectual capital}

\begin{tabular}{|c|c|c|}
\hline Directions & Authors & Characteristics \\
\hline 1 & 2 & 3 \\
\hline Structural & $\begin{array}{l}\text { L. Edvinsson and } \\
\text { M. Malone [421] }\end{array}$ & $\begin{array}{l}\text { special combination of human capital (real and potential } \\
\text { intellectual abilities) and structural capital, determined by such } \\
\text { specific factors as consumer relations, business processes, } \\
\text { databases, brands and IT systems }\end{array}$ \\
\hline \multirow{3}{*}{ Human capital } & T. Stuart [422] & $\begin{array}{l}\text { is the sum of knowledge of all employees of the company, } \\
\text { which ensures its competitiveness (invisible assets, } \\
\text { knowledge, basic competence, strategic assets, basic } \\
\text { opportunities, elusive resources, organizational memory) }\end{array}$ \\
\hline & D. Bell [423] & $\begin{array}{l}\text { a set of knowledge, skills, abilities of a person, their mobility } \\
\text { and creativity, providing the opportunity to create an additional } \\
\text { product in the process of movement of intellectual capital }\end{array}$ \\
\hline & $\begin{array}{l}\text { V. Inozemtsev } \\
\text { [424] }\end{array}$ & $\begin{array}{l}\text { collective brain that accumulates workers' knowledge, } \\
\text { experience, intellectual property and organizational structure }\end{array}$ \\
\hline \multirow{3}{*}{$\begin{array}{l}\text { Intangible } \\
\text { assets }\end{array}$} & $\begin{array}{l}\text { E. Brooking } \\
{[425]}\end{array}$ & $\begin{array}{l}\text { a set of intangible assets (market assets, intellectual property } \\
\text { and infrastructure assets, humanitarian assets), without which } \\
\text { the company cannot exist }\end{array}$ \\
\hline & K. Sveiby [426] & $\begin{array}{l}\text { includes the following components: individual competence, } \\
\text { internal and external structure of the company }\end{array}$ \\
\hline & $\begin{array}{c}\text { O. Butnik- } \\
\text { Siverskiy [427] }\end{array}$ & $\begin{array}{l}\text { created or purchased intellectual product, which has a value, } \\
\text { objectified and identified (separated from the enterprise), is } \\
\text { maintained by the enterprise (business entity) for the purpose } \\
\text { of probability of profit (additional value) }\end{array}$ \\
\hline \multirow{3}{*}{ Knowledge } & $\begin{array}{l}\text { H. Macdonald } \\
{[428]}\end{array}$ & $\begin{array}{l}\text { attributed knowledge that can be used to obtain various } \\
\text { advantages over competitors }\end{array}$ \\
\hline & $\begin{array}{l}\text { V. Bazylevych, } \\
\text { V. Zinov [429] }\end{array}$ & $\begin{array}{l}\text { define intellectual capital as knowledge that can be turned into } \\
\text { profit }\end{array}$ \\
\hline & $\begin{array}{c}\text { O. Stryzhak } \\
{[430]}\end{array}$ & $\begin{array}{l}\text { a set of abilities and knowledge that have economic value and } \\
\text { are used in the production system, focused on meeting the } \\
\text { needs of society in order to create innovative potential and } \\
\text { generate income }\end{array}$ \\
\hline
\end{tabular}


Continuation of table 1

\begin{tabular}{|c|c|c|}
\hline 1 & 2 & 3 \\
\hline Human ability & $\begin{array}{l}\text { M. Eskindarov } \\
{[431]}\end{array}$ & $\begin{array}{l}\text { system of characteristics that determine the ability of man, i.e. } \\
\text { the quality of labor of the individual, the total employee of the } \\
\text { enterprise, agency, corporation, country that creates the goods, } \\
\text { services, additional product for their reproduction based on } \\
\text { personalized economic interest of each entity and totally }\end{array}$ \\
\hline \multirow{2}{*}{$\begin{array}{l}\text { Value of } \\
\text { available } \\
\text { intellectual } \\
\quad \text { assets }\end{array}$} & B. Leontiev [432] & $\begin{array}{l}\text { including intellectual property, its natural and acquired } \\
\text { intellectual abilities and skills, as well as accumulated } \\
\text { knowledge bases and useful relationships with other entities } \\
\text { (i.e. brands, customers, sales channels, licensing and other } \\
\text { agreements, etc.) }\end{array}$ \\
\hline & $\begin{array}{l}\text { O. Kendyukhov } \\
{[433]}\end{array}$ & $\begin{array}{l}\text { intellectual resources which are able to create value: } \\
\text { intellectual resources of the enterprise, represented by human } \\
\text { and machine intelligence, as well as intellectual products created } \\
\text { independently or involved as a means of creating new value }\end{array}$ \\
\hline
\end{tabular}

The study of economic literature, which addresses issues related to the nature, structure and development of intellectual capital, made it possible to identify such approaches to the analysis of the essence of intellectual capital as the set of values, process and result.

1. The set of values (knowledge, skills, experience that are integral to their carrier - a living human person). In particular, intellectual capital, according to V. Inozemtsev is the information and knowledge that play the role of the "collective brain", which accumulates knowledge of employees, intellectual property, experience, organizational structure, information networks, enterprise image [424].

2. The process. Within this approach, scholars interpret the essence of "intellectual capital" as the process of transforming knowledge and intangible assets into resources that bring added value. Thus, A. Vasylyk argues that intellectual capital is an intellectual value that brings additional value in the process of its circulation [434].

3. The result. The emphasis is on the fact that intellectual capital is knowledge, information that is formed, used and multiplied and bring a positive economic and social effect. Thus, the essence of intellectual capital as a result lies in its ability to grow and ensure the competitive advantages of the economy.

Thus, the analysis of the evolution of views on the development of intellectual capital, demonstrated the definition of it as a certain competitive advantage for the national economy. Having analyzed the definitions of "intellectual capital" proposed 
by Western and domestic scholars, the lack of unification should be noted. The variety of approaches to intellectual capital confirms how obvious the differences of researchers still are on views on its essence. This is due to the fact that each author puts in this term a different meaning. The main conclusion is that the basic component of intellectual capital in most interpretations of this concept is "knowledge".

According to the above approaches, the term "intellectual capital" can be defined as following: intellectual capital is a strategic business asset of any person, organization, country, consisting of explicit and implicit knowledge, which can be used to obtain competitive advantage and added value in the process of its development and transformation.

The most important elements of intellectual capital, distinguished by L. Edvinsson and M. Malone, are the following:

1) human capital: the total amount of investment in training, skills and experience of employees. The competence of the employee, his sociability and personal contribution to the company's activities are also assessed;

2) structural capital: databases, customer lists, trademarks, corporate culture, organizational structure, etc.;

3) organizational capital: a set of organizational competencies of the company that allow to realize its ability to invest and innovate;

4) innovative capital: intellectual property of a legally protected company, trade secrets, etc.

5) process capital: the total cost of the business process system.

Thus, there are three main components: human, organizational (structural) and consumer (client) capital.

Human capital is the accumulated knowledge, practical skills, creativity, experience, general culture, moral values and attitude to business. In the post-industrial era, human capital becomes a system-forming factor in the structure of intellectual capital. Unlike physical capital, human capital is inseparable from the individual, inalienable.

Organizational (structural) capital - software, organizational structure, patents, 
trademarks and service marks, etc. Unlike human capital, structural capital as a whole or its individual parts can be copied, reproduced. This capital is most closely related to the concept of intangible assets. In addition, organizational capital grows through the effective transformation of information and resources, the emergence of new knowledge and opportunities, and the improvement and development of human capital.

Consumer (client) capital is a relationship with customers and buyers that contribute to the successful sale of goods and services. This type of capital includes marketing and technology cooperation agreements, communications, image, brand, reputation, etc.

Some scholars also attribute an important element to the structure of intellectual capital - social capital. Social capital is the "youngest" and "most elusive" category. This is a special form of capital that exists in these elements of social organization, such as: social networks, social norms and trust, creating conditions for coordination and cooperation for mutual benefit. The source of social capital in developing countries is globalization. Although it partially threatens ancient traditions, it also generates new images, customs and lessons learned, from the organization of economic activities to the activities of non-governmental organizations. Under these conditions, it should be noted that globalization is an important element in the process of self-organization of complex systems that allow the exchange of matter (export-import of goods), energy (labor migration) and information and ensures the borrowing of order from outside.

As we can see, intellectual capital is a complex system of education. It is a multifaceted concept that combines intellectual property, knowledge, skills and abilities of employees, various systems, networks, procedures, which when included in the business cycle bring income. At the same time, the components of intellectual capital are heterogeneous. Some of them are the product of human intelligence, others create specific conditions for its use in order to increase the competitiveness of the national economy as a whole. Not surprisingly, this category is based on the concepts of intelligence (cognition, understanding, reason) and capital (factor of production in the form of value added, capable of bringing profit or loss). 
Currently, the technological revolution with information technology at the center is re-forming the material basis of society. In the new information economy, the economy based on knowledge, the source of productivity is the technology of knowledge generation. The concept of "information economy" was introduced into scientific circulation in the early 60's of last century. Knowledge and information are critical elements in all economic systems, as the production process always takes place on the acquired knowledge and on the processing of relevant specialized information.

The integration of knowledge allows to solve new problems, based on experience, avoiding repetition of mistakes. Knowledge management in today's economy is an important task. Nowadays, the efficiency of production largely depends on the speed and quality of processing the knowledge accumulated by the company's specialists. After all, knowledge that is not used and does not grow - become obsolete and useless, in turn, knowledge that is disseminated and exchanged, on the contrary, generate new knowledge. Many modern companies that have succeeded and won a significant percentage of the market have already recognized the fact that knowledge, the ability to use them properly and produce new knowledge are the secret of their success. Based on this, knowledge can be defined as information organized to solve a problem. In the process of their development, knowledge acquires new qualities through the addition of extra skills and experience.

Knowledge involves the use of the benefits of data and information, enriched with individual experience, talents, skills in order to be able to make the right decisions.

Digital development involves the implementation of tasks that will positively affect the economy, business, society and life of the country as a whole.

The main goals of digital development are:

- acceleration of economic growth and attraction of investment;

- transformation of economic sectors into competitive ones;

- technological and digital modernization of industry and creation of high-tech industries;

- accessibility of the benefits and opportunities of the digital world for citizens;

- realization of human resources, development of digital industries and digital 


\section{SOCIO-ECONOMIC AND MANAGEMENT CONCEPTS}

entrepreneurship.

Sectors of the economy that use digital technologies are growing faster, cheaper and better. Areas of life, including education, medicine, transport, which are being modernized through digital technologies, are becoming much more efficient and creating new value and quality.

The main goal of the Concept of Digital Development is to implement the accelerated scenario of digital development, as the most relevant for Ukraine in terms of challenges, needs and opportunities.

The policy of human intellectual capital development today becomes one of the main components of the strategy of competitiveness of a country in the formation of a knowledge-based economy.

The basis of the process of formation and reproduction of intellectual capital is intellectual potential. The intellectual potential of society means a set of human, material and financial resources that are involved in two closely related key areas of spiritual life, science and education, and the measured value of which shows the created and accumulated in society the ability to creatively create new knowledge. technologies, products. As far as the intellectual potential of the individual is concerned, the category characterizes the potential (perhaps not yet used at present) the ability of the individual to solve complex mental problems, and quickly and accurately. Hence, intellectual potential provides an individual with the opportunity to learn new knowledge, skills and intellectual skills at a high rate. But a high level of intellectual potential does not guarantee high productivity of the employee, who has no acquired specialized skills.

Thus, the intellectual potential with the help of intellectual activity is transformed into possible intellectual resources, which, in turn, are reflected in intellectual assets, the results of creative, scientific activities. All these processes form intellectual capital in their development and interconnection.

It is possible to identify qualitative levels of intellectual activity, which are represented by intellectual potential, intellectual activities, intellectual capital, intellectual resources and intellectual assets. 
In accordance with this approach, the process of reproduction of intellectual capital over time is characterized by the following levels:

- the first: passive, or stimulated-productive, is characterized by the fact that the individual in the most energetic and conscientious work does not go beyond a given or initially found mode of action, and cognitive activity is carried out through external stimuli;

- the second: heuristic, when the individual shows a certain intellectual activity (intellectual activity is not stimulated by external factors and dissatisfaction with the results of activities), analyzes their activities and discovers new, original, more advanced ways to solve problems;

- the third (higher level of intellectual activity): informational, there is an accumulation of a set of knowledge, information that can bring value during the use;

- the fourth: innovative, new products are created, we see the results of intellectual activity that can bring economic benefits, higher added value;

- the fifth: creativity, when there is a penetration into the essence of phenomena, processes, new tasks are set, existing and new problems are solved through the use of created intellectual assets.

Intellectual resources are formed by the mental work of workers and highly qualified personnel who create products of intellectual activity and innovative technologies, i.e. intellectual assets, the totality of which forms intellectual capital. Intellectual resources become assets after fulfilling the conditions of recognition: the ability to identify, evaluate, the ability to bring economic benefits.

Speaking of intellectual assets, it is necessary to identify a number of specific properties that cause their active use in production:

1) first of all, intellectual assets have an intangible nature, i.e. they are ideal, which is their main property and determines all the following;

2) unlike natural resources, they have no physical wear and tear, are inexhaustible and capable of self-reproduction. That is, they develop faster and better in the process of their productive consumption; 
3) the property of intellectual resources, which ensures their active use in production - is the ability to replicate, i.e. they can be used at any scale [435, p. 35].

Accordingly, in the digital economy, human potential at all levels of government should be given priority, especially its intellectual component, which is able to capitalize and ensure high added value, which will determine the future level of competitiveness at both micro and macro levels [436, p. 46]. That is, such a part of human potential can be recognized as an asset. It is known that an asset takes the form of certain resources or property rights that belong to a natural or legal person and are able to provide economic benefits in the future. Intellectual assets are basically presented as assets created by intellectual labor, typical of a person who has a certain intelligence and has the ability to increase and commercialize it. Human potential is characterized mainly as the potential of man or the population as a whole. Therefore, it is necessary to identify these opportunities, evaluate them and ensure the further development and sale of such assets [436, p. 55]. M. Martynenko made a rather detailed grouping of the main approaches of scientists to the definition of the category "intellectual assets" according to the following key groups of concepts [23, pp. 522523]: ideas, knowledge and abilities of employees; part of intellectual capital; source of value creation, economic benefits; intellectual resources and valuable information; component of intangible assets, intangible origin; unique resources. The analysis of this grouping reflects the features of human potential already in the first group of concepts, which allow us to state that intellectual assets are their basis. And then there are all the characteristics of intellectual assets that do not contradict the first, but only complement them. The growing role of intellectual assets and attention to their study during the development of the information age is caused by a shift in emphasis in theory and practice to the "intangible" resources of organizations. The priorities of tangible asset management are changing to the use of appropriate investments in the development of intangible and intellectual assets and the creation of innovations. In our opinion, intellectual assets can be defined as an economic category that reflects the process of transformation of the part of human potential capable of development and change into other capital [2, pp. 47-48]. 


\section{SOCIO-ECONOMIC AND MANAGEMENT CONCEPTS}

Intellectual assets of human potential are individual elements of human potential that gradually accumulate and transform from birth in the process of education, cultural development and involvement in a healthy lifestyle, education and training, as well as intellectual results of capitalization of this potential in the process. man. They are considered as competencies (cognitive, emotional, creative), as they have an intangible nature, as well as the results of intellectual activity (intangible and tangible form). The value of intellectual assets is determined by the knowledge, skills and experience of man (staff of the organization, the entire population). They are formed as a result of investing in a person alone or by the company / state of money, material resources and knowledge, are characterized by deterministic value, productivity and ability to generate income, the constant circulation of which is influenced by time, risk and liquidity. That is, intellectual assets are a kind of reflection of the properties (competencies) of human potential and are characterized by the following features: formed and developed by investing money, material resources and knowledge; require maintenance and development costs; bring income to the owner; have an intangible nature; aimed at the future; are resources that are stored and renewed; the carrier and owner is a person (staff of the organization, the population) [22, pp. 55-56]. The basis for the formation of intellectual assets is the developmentable share of human potential, which under the influence of investment in the external and internal environment is transformed into intellectual capital. In view of this, intellectual assets can rightly be recognized as an active factor of production in a digital economy.

Figure 1 shows the scheme of formation and use of intellectual assets of human potential. 


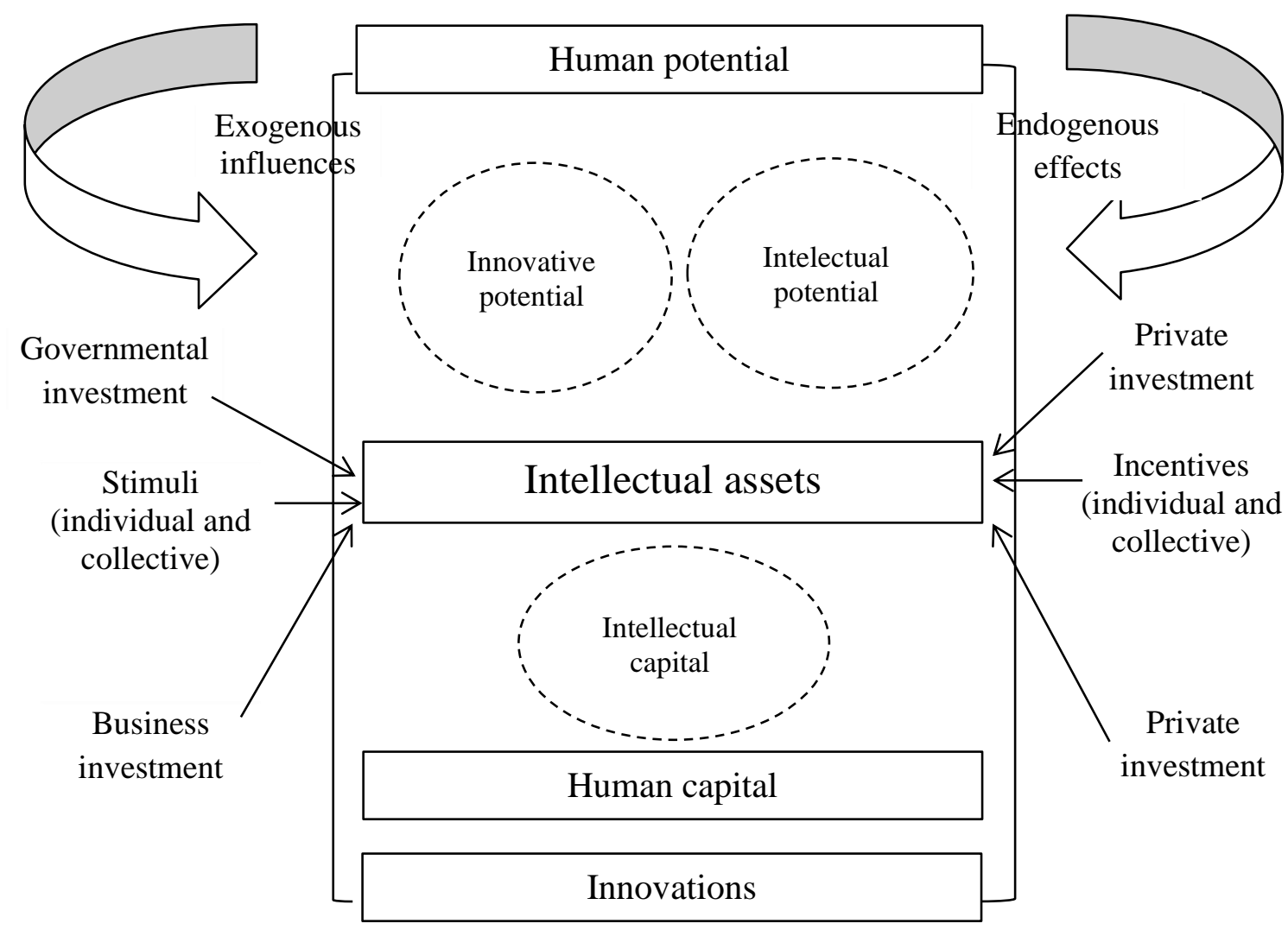

Fig. 1. Structural and logical scheme of formation and use of intellectual assets of human potential

The final stage of the process of reproduction of intellectual capital is directly intellectual capital. The main link that connects intellectual potential, intellectual activity, intellectual resources, intellectual assets and intellectual capital is science, which in a narrower sense is represented by scientific discoveries, research, projects. In general, for the stable functioning and development of intellectual capital it is necessary to effectively manage it. Intellectual capital management is a multifaceted process that involves the strategic planning, organization and motivation of management entities, as well as the administration, control and comprehensive evaluation of the results of investments in intellectual capital. A characteristic feature of this category is the systematic management of knowledge.

Management of intellectual capital at the national level is a rather complex process and involves effective strategic planning and administration of public policy to improve its overall level, preventing "intellectual gap" between the development and 
implementation of research programs, in particular through the implementation of these programs and projects.

The systematic knowledge management for the purposes of formation, approval and development of socially oriented economy is most fully provided at this level (Fig. 2).

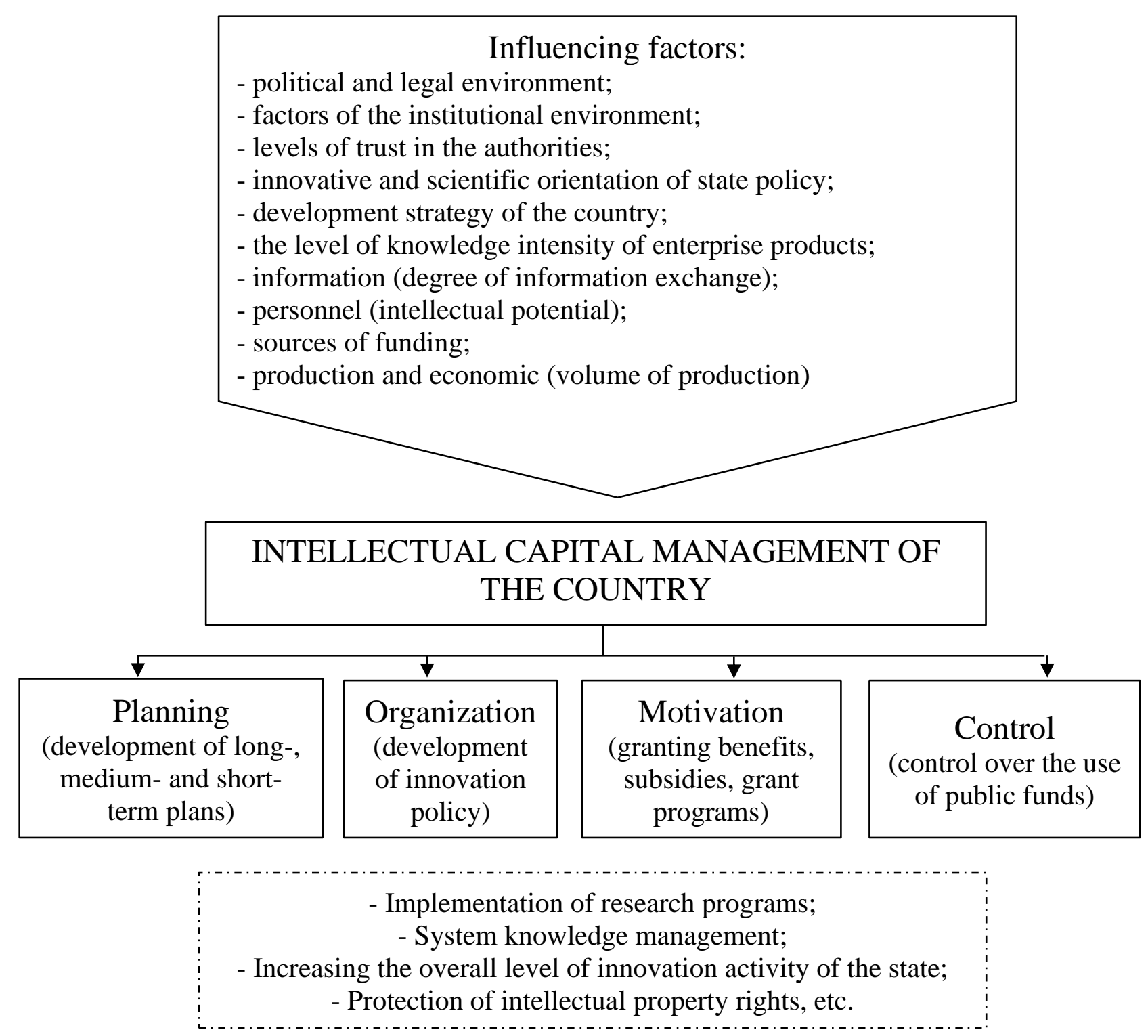

Fig. 2. The process of intellectual capital management at the national level

The main task of intellectual capital management involves the support of scientific activities and knowledge-intensive, innovative industries, protection of intellectual property rights, state creation of a favorable investment climate and more. Based on this process of intellectual capital management at the national level, attention should 
be paid to the need to develop priority areas for improving the country's economy, it is necessary to form the main tasks for intellectual capital management and make them proposals to the overall development strategy. At the national level, it is necessary to form a new national economic doctrine, the purpose of which will be to create the preconditions for the formation of an intellectual economy in Ukraine. The long-term strategy of economic development should include large investments in education, training and informatization, which will expand access to knowledge and create a human resource base for the formation of an intellectual economy. The formation of a creative personality with innovative thinking should be fixed as the main goal of the national education system, and according to this goal, curricula should be adjusted. Ukraine should make every effort to participate in European high-tech programs.

Intellectual potential is a share of economic and innovation potential, which describes and determines the possible growth of "elusive" assets; is not separated from the organization; is the result of the market's perception of the intellectual efforts of the regional system as a whole.

Intellectual capital characterizes the human resource as a social component and as individual capabilities; it shows knowledge, abilities and activity of use; has signs of ownership, is included in the economic process in the first place in the knowledge economy; has close ties with other capital and resources (structural, innovative, process).

In our opinion, one of the priority tasks in the field of reproduction of intellectual potential is the task of transforming the part of human capital in the form of knowledge, experience, skills, which is a value for the production, management or other process of the enterprise. This transformation is a process of autonomy of knowledge into a material form, in which it is separated from the carrier and is transitioned to an independent form of existence under certain conditions.

It is necessary to consider intellectual capital as a special resource to provide economic systems with market advantages due to innovation potential, including knowledge, experience, abilities. Intellectual capital is a multifaceted phenomenon that is formed as a result of the interaction of human, organizational, emotional capital and 
relationship capital, which leads to the acquisition of new knowledge and the intensification of innovation at all levels of the economy. The main task of economic policy of the state at the present stage is the implementation of an innovative model of economic growth as a necessary prerequisite for Ukraine's transition to the information economy.

At the present stage of development of society, it is intellectual capital that determines the competitiveness of economic systems, is a key resource for development. With this resource, the country's economy becomes more technological and innovation-oriented. The process of formation and reproduction of intellectual capital is multifaceted and goes through periods from the formation of intellectual potential, activity, creation of resources, assets and ultimately - the receipt of intellectual capital. For the purpose of regulation and stable functioning of intellectual capital, a process of category management at the state level was proposed. The ability of the economy to create and effectively use intellectual capital is increasingly determining the economic strength of a nation and its well-being.

Thus, there are the reasons to propose defining intellectual assets of human potential as a unique type of resources, an integral component of human potential, which is transformed (integrated) into the structure of intellectual capital and based on special (rare and exceptional) economic resources, which is the result of intellectual creative, scientific-research and inventive activities and is able to provide future socioeconomic benefits. At the enterprise level, intellectual assets not only increase its balance sheet value, but also provide its capitalization and the ability to attract additional investment resources. Therefore, the identification and effective management of intellectual assets of human potential is a key condition for competitiveness in the digital economy. 


\subsection{The conceptual basis of innovation management in socially-oriented marketing includes}

The modern terms of development of market relations in the market of consumer goods are characterized by the increase of standards of social obligations, high role of specific labours assets. An enterprise presently goes near the use of innovative types of development of corporate social responsibility.

In present socio-economic term business-organizations run into serious problems, for the decision of which the search of new approaches, allowing to remain competitive and to grow the productivity is required. Continuous innovations always were a deciding factor for achievement of competitive edges. Today, innovations are acknowledged and by the key mechanism of decision of problems of steady development [438].

In order to adhere to the concept of sustainable development, enterprises create innovations that simultaneously pursue economic, environmental and social goals. However, attaining this triune purpose is ensemble. In area of steady innovations systematization of present both theoretical and practical results absents.

Innovations of the socially-oriented marketing are purposeful steady changes of commodities, processes, relations, resulting in appearance of innovations, satisfying consumer needs both and enterprises, and societies, assist the development of the welfare of society, diminishing of the negative affecting environment.

The conceptual base of management innovations in the socially-oriented marketing includes (fig. 1): "conception of diamond"; conception is creation of general values (CSV); the conception of steady development; the conception of marketing of innovations is conception of social responsibility of marketing.

The "Diamond Concept", authored by Michael Porter, is characterized by the fact that with the increasing degree of competitiveness of the markets in which the company operates, the main factor in its competitiveness, maintaining and improving its financial condition becomes innovation. 


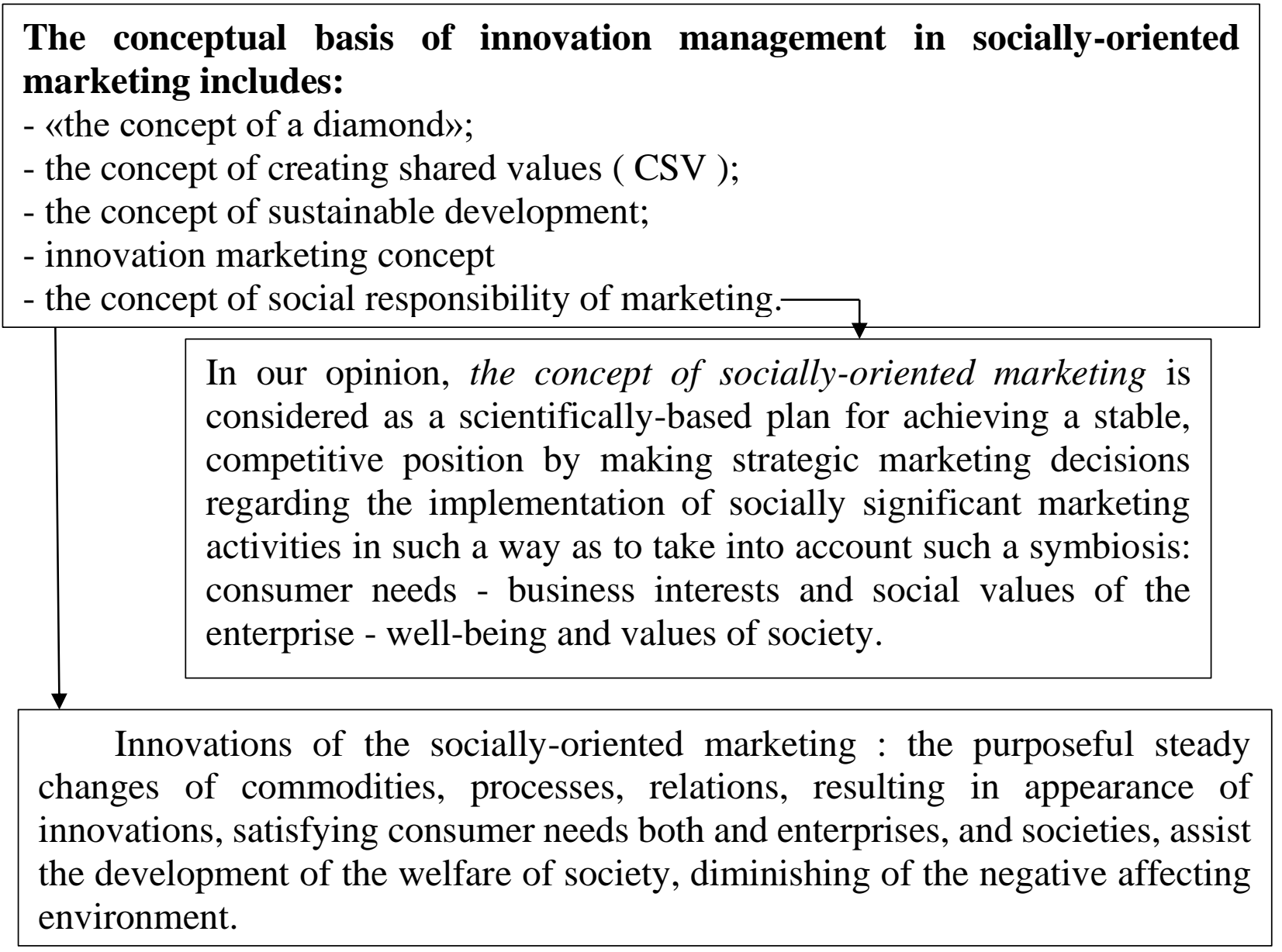

Figure 1. The conceptual basis of innovation management in socially-oriented marketing includes

It is understood as the ability, on the basis of existing proprietary technologies (or access to technologies acquired under licenses created to order) and commercial knowhow in the areas of sales and supply, to constantly master the production and sale of new products that meet demand, as well as to master new technological processes (if necessary, simultaneously with new technological equipment), which rely on the supply of affordable and cheap purchased resources. The first allows to win a food competition, the second makes possible without losses in profitability successfully to participate in a prize competition. The innovativeness of the enterprise, being like the "core" of a diamond, must be strengthened, " cut " by the observance of certain additional conditions - the reproducibility of the competitive advantages of the company, the competitiveness of related parties and suppliers of complementary goods and services, a sufficient level of consumer requirements in the target segments of the 
innovative enterprise, constant institutional innovations in the economic behavior of the enterprise.

Creation of general values (CSV) is a business-conception, first presented in the article of Harvard Business Review "Strategy and society : connection between a competitive edge and corporate social responsibility". In 2012 the Cramer and malt Liquor by means of global noncommercial consulting company FSG was founded project Shared Values Initiative for expansion of exchange and practice of creation of general values knowledge in the whole world. The basic premise of creating shared values is that the competitiveness of a company and the health of its surrounding communities are interdependent.

Companies can create general values three methods:

- New understanding of products and markets-companies can meet social needs by improving service to existing markets, access to new ones, or reducing costs through innovation.

- A new definition of productivity in the value chain-companies can improve the quality, quantity, value, and reliability of resources and distribution, while acting as stewards of key natural resources and driving economic and social development.

- Promote local cluster development-companies do not operate in isolation from their environment to compete and thrive, they need reliable local suppliers, functioning road and telecommunications infrastructure, access to talent, and an effective and predictable legal system. CSV recognizes the trade-off between short-term profitability and social or environmental goals, but focuses more on opportunities to gain a competitive advantage by incorporating a social value proposition.

Under steady development it is accepted to understand development, satisfying the necessities of the real generation and not putting under the threat of the possibility of future generations to satisfy the necessities [439]. Also steady development can be presented as a process of co-operation of three components: "social sphere - ecology economy". The economic going near steady development is implied by the optimal use of the limited resources. A social constituent is sent to the maintenance of social stability and cultural variety in global scales. Under the ecological system it is 
necessary to understand the association of life and environment, which is characterized by certain stability and possesses the clearly functioning internal rotation of matters [440].

"Steady development" of the company is not only accounting, but also new administrative philosophy, when any administrative decision is accepted recognition and economic, and ecological, and social effect (fig. 2).

\begin{tabular}{|c|c|c|}
\hline \multicolumn{3}{|c|}{ Conception of steady development of enterprise } \\
\hline \multicolumn{3}{|c|}{$\begin{array}{l}\text { Idea - any administrative decision is accepted recognition and economic, and ecological, and } \\
\text { social effect. }\end{array}$} \\
\hline Strategy & Purpose & Instruments \\
\hline $\begin{array}{l}\text { long-term decline of } \\
\text { negative ecological } \\
\text { influence of the } \\
\text { simultaneous height of } \\
\text { producing goods and } \\
\text { services }\end{array}$ & $\begin{array}{l}\text { - growth of image and business } \\
\text { reputation; } \\
\text { - capitalization growth; } \\
\text { - strengthening the cohesion of } \\
\text { the workforce; } \\
\text { - development of the } \\
\text { company's transparency to the } \\
\text { public; } \\
\text { - increase of investment } \\
\text { attractiveness; } \\
\text { - social contribution to } \\
\text { sustainable } \\
\text { development }\end{array}$ & $\begin{array}{l}\text {-development of corporate plans } \\
\text { for "sustainable development", } \\
\text { corporate reports on social } \\
\text { responsibility, } \\
\text { - special PR events: negotiations } \\
\text { and exchange of experience at } \\
\text { the global, European and } \\
\text { national levels, presentations of } \\
\text { companies abroad. }\end{array}$ \\
\hline
\end{tabular}

Figure 2 The concept of sustainable development of the enterprise (author's development)

Interlacing of marketing and innovative activity is supposed by a conception of marketing of innovations, the purpose of which consists of exposure of the poorly satisfied or latent queries of consumers, development and advancement at the market of new products, satisfying these queries complete and more effective, than the products of competitors.

F. Kotler identified five main approaches to marketing activities: the concept of production improvement, the concept of product improvements, the concept of intensifying commercial efforts, the concept of marketing, and the concept of social and ethical marketing. These concepts represent the evolution of business concepts. All existing concepts use certain innovations.

Conception of improvement of production foresees the improvement of technology of producing goods, which can result in appearance of technology- 
innovation; the conception of improvement of commodity is an improvement of

Table 1.

Innovations in marketing concepts

\begin{tabular}{|c|c|}
\hline Marketing conceptions & Innovations \\
\hline $\begin{array}{l}\text { conception of improvement } \\
\text { of production }\end{array}$ & $\begin{array}{c}\text { improvement of technology of producing goods, which can result } \\
\text { in appearance of technology-innovation }\end{array}$ \\
\hline $\begin{array}{l}\text { conception of improvement } \\
\text { of commodity }\end{array}$ & $\begin{array}{l}\text { improvement of quality of commodity, that by a certain measure, } \\
\text { appearance of commodity innovation provides for }\end{array}$ \\
\hline $\begin{array}{l}\text { conception of intensification } \\
\text { of commercial efforts }\end{array}$ & $\begin{array}{c}\text { improvement of complex of measures on advancement of } \\
\text { commodity to the market, by a result what of communication } \\
\text { innovations can be }\end{array}$ \\
\hline marketing conception & $\begin{array}{l}\text { appearance of new necessities (necessities of consumers) which } \\
\text { can be innovative }\end{array}$ \\
\hline $\begin{array}{l}\text { conception of the socially- } \\
\text { ethics marketing }\end{array}$ & $\begin{array}{l}\text { satisfaction of another group of necessities - necessities of all } \\
\text { society }\end{array}$ \\
\hline
\end{tabular}

quality of commodity, that by a certain measure, appearance of commodity innovation provides for; conception of intensification of commercial efforts is an improvement of complex of measures on the advancement of commodity in the market, by a result what of communication innovations can be; marketing conception is the appearance of new necessities (necessities of consumers) which can be innovative; conception of the socially-ethics marketing foresees satisfaction of another group of necessities necessities of all society, i.e., possibly, innovative necessities. And all these conceptions do not foresee the permanent creation of innovations and the use of innovative methods and marketing instruments. Exactly conception of the innovative marketing is that conception, which unites the interests of producers, consumers and all society.

In our opinion, the concept of socially-oriented marketing is considered as a scientifically-based plan for achieving a stable competitive position by making strategic marketing decisions regarding the implementation of socially significant marketing activities in such a way as to take into account such a symbiosis: consumer needs - business interests and social values of the enterprise - well-being and values of society.

The social responsibility of marketing responsibility is the basis of those, who accepts marketing decisions and also the influence of marketing activity in the field of innovations on society. So, socially the responsible marketing of innovations differs 
in the variety of aims which are not closed only by an income, and must be related to the decision and social problems, taking into account social values and traditions [441]. 


\section{4 Сучасні підходи обробки великих інформаційних потоків на підприсмствах}

В умовах сучасного розвитку економіки України цифрові технології стали ключовим фактором економічного зростання, національної безпеки та міжнародної конкурентоспроможності. Цифрова економіка має глибокий вплив на світову глабализацію та поведінку споживачів. Це впливає на усі етапи роботи підприємства від розподілу ресурсів до розподілу і зростання доходів. Цифрова економіка охоплює оборот товарів та послуг, які були виготовлені 3 використанням цифрових технологій або включають ці технології. Інформаційно-комунікаційні технології 3 кожним роком все більше стають головними у роботі підприємств усіх сфер економічної діяльності.

Використання сучасних інформаційних технологій на підприємствах сприяє стійкому зростанню економіки України вцілому. Завдяки цифровізації усіх виробничих процесів та зменшення кількості посередників між виробниками та споживачами збільшується потік запитів та інформації на підприємстві. Компанії стикаються з питаннями як виявити інновації з високим потенціалом доходів, та як ефективніше обробляти великі масиви даних, щоб отримати глибоке розуміння мотивів та бажань клієнтів. Для рішеня цих питань необхідно розробити та впроваджувати гнучку архітектуру продукту, яка забезпечує швидке реагування на зміни і може у короткі строки адаптуватися під смаки споживачів.

Інновації утворюють ключові напрями зростання підприємства XXI-го століття. 3 поширенням електроної комерції робота по обробці великих масивів даних стає основним активом в економіці, сприяючи появі нових галузей, процесів та продуктів створення значних конкурентних переваг. Таким чином ефективна обробка даних сприяє створенню цінність у різних операціях, від оптимізації ланцюгів виробництва та послуг до ефективного використання праці та відносин з клієнтами. 
Слід зазначити, що за останні три роки людство зробило інформації більше, ніж за всю історію свого існування до 2008 року. І зростання триває 3 кожним роком [442]. Такий швидкий ріст можна пояснити зростанням обчислювальних засобів, додатків і користувачів - від мільйонів в епоху мейнфреймів до сотень мільйонів в епоху ПК і мільярдів користувачів в епоху мобільних пристроїв, мобільного Інтернету, соціальних мереж, «хмарних» технологій і побудови всіляких рішень «розумної» економіки.

Потік даних у кожній сфері економіки зростає з неймовірною швидкістю. На підприємствах дані надходять з різного роду пристроїв безпеки, проводиться моніторинг зносостійкості і міцності викотовлкних продуктів. Для оптимізації будь-яких робочих процесів потрібна інформація. У розвинених країнах навіть у сільському господарстві інформатизація досягла небачених масштабів. На фермі в США одна корова генерує 200 мбайт інформації на рік. Моніторинг та оптимізація утримання тварини дозволяють збільшити надої молока тим самим покращити роботу підприємства [442].

Іеснує багато програмних продуктів для обробки та оптимізації потоків інформації на підприємствах. Розглянемо один 3 таких програмних продуктів систему Арата. Придбана компанією Software AG система Арата розробки Progress Software призначена для аналізу потоків даних і пошуку в них кореляцій i повторюваних шаблонів. Подібні системи обробки складних подій (Complex Event Processing, CEP) широко використовуються в торгівлі, для виявлення шахрайства та в інших фінансових задачах [443] .

Сучасна система Арата, лідирує на ринку платформ для обробки складних подій і створення СЕР-додатків. Ця платформа забезпечує зіставлення і аналіз бізнес-операцій в реальному часі на підприємстві 3 використанням безлічі потоків даних, допомагаючи керівнитству компанії своєчасно приймати грамотні бізнес-рішення по вдосконаленню та оптимізації бізнес-процесів. Високопродуктивна платформа Арата, використовує технології обміну повідомленнями з низьким рівнем затримки і обробки даних in-memory, що допомогає клієнтам отримати максимум користі зі своїх бізнес-даних. Це 
особливо актуально для компаній, яким необхідно миттєво реагувати на різні події, щоб запобігати шахрайським діям, ефективно працювати 3 клієнтами або займатися трейдингом. Крім того, платформа Арата дозволить клієнтам розробляти, тестувати, відстежувати i контролювати роботу середовища електронної комерції з найвищим рівнем точності .

Впровадження системи Арата у діяльність підприємства дає можливість здійснювати моніторинг потоків подій, виявляти і аналізувати їх поєднання i реагувати на них - в лічені мілісекунди або швидше. Платформа Progress Apama сфокусована на реалізації моделі виявлення певного поєднання подій в реальному часі, яка обробляє дані про вхідний потік подій в процесі їх виникнення. Її подієво-орієнтована архітектура забезпечує оперативний відгук в реальному часі на швидко мінливі дані про будь-які події. Реагування на події бізнесу як тільки вони відбуваються, дає підприємствам перевагу перед конкурентами. Незалежно від галузі, в якій працює фірма, платформа Арата проводить моніторинг, аналіз та швидко реагує на події у реальному часі.

Важливими перевагами платформи Арата $є$ те, що підприємство може виявити важливі події або поєднання подій, які сигналізують про нові можливості, критичні загрози, зміну умов або інших матеріальних факторів, що впливають на прийняття управлінських рішень. Платформа Арата працює 3 вхідними подіями, в момент їх надходження, тим самим, надаючи можливість моментального відгуку на них

Використання ціє платформи можливо у різних галузях економіки. Ось лише деякі галузі, що використовують цю платформу:

Ринки капіталу: трейдери можуть швидко розробляти складні алгоритми торгівлі, а менеджери, що відповідають за відповідність нормам, ризикменеджери можуть швидше реагувати на мінливий ринок і умови бізнесу.

Транспортування і логістика: операційні менеджери використовують обробку складних подій для стеження i виявлення товарів, автомобілів i інтелектуального моніторингу об'єктів, що переміщаються по ланцюжку поставок, для забезпечення своєчасності доставки вантажів. 
Телекомунікації: провайдери комунікаційних сервісів (CSP) можуть отримати нові рівні якості роботи мереж, зменшити кількість необроблених замовлень, забезпечити більш високу якість обслуговування клієнтів i збільшення доходів за рахунок моніторингу використання мережі в реальному часі і запитів на надання сервісів.

Енергетика: операції видобутку і транспортування можуть бути значно поліпшені і оптимізовані за рахунок поліпшеного оглядовості і проактивного контролю за процесами пошуку, видобутку i виробництві. Може бути застосована технологія з використанням мереж інтелектуальних датчиків.

Військове застосування: картина поля бою в режимі реального часу може бути отримана шляхом швидкої обробки потоків даних з різних джерел.

Компанії-продавці можуть використовувати гнучкість Арата для переходу на якісно новий рівень власних трейдингових операцій , використовуючи нові власні сценарії трейдингу. Підприємці які займаються торгівлею можуть також використовувати Арата для підтримки клієнтів під час покупки, гарантуючи, що усі операції компанії по продажу володіють конкурентними перевагами перед іншими пропозиціями на ринку.

Компанії-покупці, зі свого боку, можуть безпосередньо використовувати Aрата для своїх операцій. Інструменти Арата для швидкої "розробки і впровадження" дозволяють клієнтам отримати безпосередній контроль над трейдинговими стратегіями, отримати більш гнучкий вибір у виконанні угоди, включаючи прямий доступ до ринку [443].

Програмний продукт Арата включає в себе сучасне середовище розробки, що охоплює як аналітиків, що займаються розробкою стратегій продажу, так i розробників. Засіб моделювання подій Аpama Event Modeler дозволяє трейдерам створювати і впроваджувати унікальні алгоритмічні стратегії. Також ефективним $є$ графічне середовище яке представляє сценарії трейдингу.

Інструменти Apama Research Studio i Apama EventStore ще більш полегшують розробку за рахунок використання гнучкого середовища тестування на основі минулих даних. Research Studio працює з реальними ринковими 


\section{SOCIO-ECONOMIC AND MANAGEMENT CONCEPTS}

даними, зібраними в Apama EventStore, що $є$ сховищем даних у вигляді упорядкованих у часі послідовності даних, i, дозволяє здійснювати операції повторного відтворення даних в режимі TiVo для оцінки нових трейдингових стратегій. Research Studio може проводити «цифрове розслідування», яке забезпечує аудит продуктивності сценаріїв в умовах їх реального впровадження.

Економіка XXI ст. потребує вдосконалення усіх галузей економіки. Наближення виробників до споживачів без посередників, скорочення часу отпримання заказів, збільшення на виробництві кількості запитів для обробки та вдосконалення якості виробнитцва, усе це не можливо без впровадження сучасних систем обробки великих масивів інформаціії таких наприклад як розглянута нами Арата.

Нажаль велика кількість підприємств України, як правило, багато уваги надають поточним операціям та бізнес-моделями, та не мають часу передбачити інший спосіб функціонування. Щоб уникнути витіснення з ринку компанії повинні змінити свій напрямок дій. Потрібно надавати можливість інноваціям втручатися у жорстку корпоративну культуру та організаційну структуру. Дєякі підприємства вважать, що впровадження інновацій полягає в тому, щоб залучити досвідченого партнера з можливістю швидко створювати та впроваджувати нові цифрові продукти на ринку. Такий підхід не забеспечує ефективної роботи підприємства в епоху цифровізації та обробки великої кількості даних. 


\section{5 Сучасні технології у банківському бізнесі}

У сучасних умовах розвитку та функціонування ринку банківських послуг, відділення банку змінює свою роль 3 традиційного каналу обслуговування клієнта на місце, яке повинно створити приємне враження на клієнта, оскільки відділення залишається першою «точкою дотику» клієнта до банку. Натомість українці активно користуються онлайн-послугами, особливо сьогодні, коли вони більшість часу проводять вдома, перебуваючи на ізоляції та дотримуючись карантину, адже це швидко та безпечно. 3 огляду на це, усі традиційні банки швидко адаптуються та діджиталізуються. Користувачі банківських послуг дедалі частіше надають перевагу «банкам у смартфоні» (яскравим представником необанків в Україні $є$ «Monobank», який є спільним проектом Fintech Band i Universal Bank), адже вони отримали змогу керувати особистими рахунками, аналізувати доходи та витрати, сплачувати комунальні платежі дистанційно та без комісії, а також планувати свій бюджет на майбутнє. Таким чином, банкам вдалось одночасно вирішити два питання, які суперечать одне одному: збільшити час перебування клієнта в мобільному додатку за рахунок збільшення кількості проведених операцій і зменшенні часу на їх проведення.

Протягом останніх років ПАТ КБ «Приватбанк» вважається найбільш інноваційним банком України, найбільш прогресивним, зважаючи на впровадження в його роботу цифрових технологій. Для фізичних осіб ПАТ КБ «Приватбанк» пропонує наступні дистанційні банківські послуги: Інтернет-Банк «Приват24», платежі за безкоштовним телефоном 3700, мобільні додатки, регулярні платежі, СМС-банкінг, банкомати, термінали самообслуговування [444-445]. Орім цього, ПриватБанком та Міністерством цифрової трансформації було підписано Меморандум про співпрацю й упровадження інноваційних державних сервісів у нашій країні. В межах співпраці передбачено повноцінний запуск технології SmartID, що дасть змогу прискорити процес й розширити зону дії цифрових послуг для українців. 
До ключових подій та тенденцій українського ринку фінансових технологій, що відбулися за останнє десятиліття у банківській сфері, належать:

1. Україна посіла 4 місце в світі за кількістю платежів за допомогою смартфону та смарт-годинника. А за рівнем зростання платежів NFC ми випереджаємо Канаду та Польщу. Окрім глобальних платіжних сервісів - Apple, Google та Garmin Pay, на сьогодні в Україні є десяток мобільних банківських гаманців. I ви можете їх оплатити навіть в Інтернеті. Крім того, в Україні продовжує зростати кількість безконтактних карток: наприкінці 2019 року було зафіксовано 5,3 мільйона карт, що означає, що майже кожна сьома активна платіжна картка оснащена чіпом.

2. POS-термінал необхідний для оплати карткою. I взагалі в Україні все йде добре: три чверті терміналів підтримують безконтактні платежі. Однак проблема полягає в тому, що 60\% торгових точок ними не користуються, оскільки термінали дорого обслуговувати.

3. В Україні активно розвиваються альтернативні засоби отримання оплати. I однією $з$ них є технологія Tap to Phone, яку пропонує Visa та MasterCard в Україні. Справа в тому, що продавцю, який вже має смартфон 3 модулем NFC, не потрібно встановлювати POS-термінал. Досить встановити додаток отримання безконтактних платежів на смартфон. У цьому випадку покупцеві потрібно прикласти до гаджету безконтактну карту або цифровий гаманець, а гроші будуть списані з рахунку. У червні Visa та Ощадбанк оголосили про запуск тестування технології Тар to Phone. Подібні рішення розпочато лише у кількох країнах, окрім України [445-446].

Розвиток банківському бізнесі у сьогоднішніх умовах має базуватися на найсучасніших технологіях, щоб забезпечити клієнтоорієнтовану перспективу, а не традиційну спрямованість на продукти; інтелектуальну інтеграцію даних у режимі реального часу, та повільний аналіз, що проводиться після факту та відкриту платформу.

Розглянемо десять технологій, які кардинально змінюють банківські та фінансові послуги (рисунок 1): 
1. Розширена реальність

2. Блокчейн

3. Роботизована автоматизація процесів

4. Квантові обчислення

5. Штучний інтелект

6. Платформи API

7. Безпека 'на випередження'

8. Гібридна хмара

9. Миттєві платежі

10. Розумні машини

Рисунок 1. Сучасні технології у банківському бізнесі

Складено на основі [447]

Технології, такі як доповнена, віртуальна та змішана реальність, покращують взаємодію 3 клієнтами. Можливості впровадження технології доповненої реальності в банківському секторі обмежені лише уявою, хоча вони все ще перебувають на дуже ранній стадії розвитку. Кінцева мета полягає у наданні користувачам повної автономії у діях та операціях, які вони можуть здійснювати вдома. Гібридні філії були передбачені технологічними експертами, які вважають, що філії банків, якими ми їх знаємо сьогодні, пішли в минуле.

Одне 3 впроваджень технологій доповненої реальності в банківському секторі, яке вже працює, було здійснено Австралійським банком. У банку створили розширений додаток із доповненою реальністю для своїх клієнтів, які прагнули придбати або продати будинок. Він надає їм таку інформацію, як поточні списки, останні продажі та цінові тенденції, щоб допомогти клієнту прийняти кращі рішення.

Активно сьогодні розвивається таке явище, як блокчейн (Blockchain) - це загальна фраза, яка використовується для опису технологій «розподіленої книги». Клієнти можуть сприймати це як розподілену базу даних без участі 
регулятора. Це дозволяє кільком сторонам одночасно отримувати доступ до одних і тих самих даних, і одночасно забезпечує цілісність і незмінність записів, що вводяться в базу даних. Проста аналогія для розуміння технології блокчейн це Google Doc. Коли ми створюємо документ і ділимось ним з групою людей, документ поширюється замість того, щоб скопіюватися або передатися. Це створює децентралізований ланцюжок розповсюдження, який надає кожному доступ до документа одночасно. В даний час провідні банки світу вивчають можливості використання цього проекту у різних аспектах банківських та фінансових послуг. Перше велике впровадження сучасних технологій, яке ми, зможемо спостерігати - це у сфері клірингу та розрахунках. За оцінками «Accenture», інвестиційні банки зможуть заощадити 10 мільярдів доларів, використовуючи технологію блокчейн для підвищення ефективності клірингових та розрахункових систем.

Ще однією важливою областю, в якій банки можуть отримати вигоду за допомогою технології блокчейн, є операції «КYС» (Знай свого клієнта). Бізнесмоделі, що розробляються на даний момент, перетворять КYС з центру витрат на центр прибутку для банків - оскільки вони будуть базуватия на спільному блокчейні для цієї діяльності. Синдиковані позики, торгове фінансування та платежі - це також інші сфери, де розумні контракти на блокчейні можуть бути високоефективними.

Обсяг неструктурованих даних, які банк повинен обробляти, зростає в геометричній прогресії із зростанням цифрової економіки. Це не просто дані банківських операцій, а й інші дані про поведінку потенційних споживачів банківських послуг, які дають можливість банкам вдосконалити та інноваційно покращити роботу з клієнтами. Це, відповідо, змушує банкірів усвідомити, що їм потрібно знайти технології, які можуть імітувати людські дії та судження, але 3 більшою швидкістю, масштабами та якістю. Таким чином, необхідне таке поєднання різноманітних технологій, що дозволить автоматизувати когнітивні та роботизовані процеси в банківській діяльності. 


\section{SOCIO-ECONOMIC AND MANAGEMENT CONCEPTS}

Ці технології можуть застосовуватися у автоматизованому навчанні, обробці мови, роботизованій автоматизації процесів та інтелектуальній аналітиці в банківській справі, що дозволяє чат-ботам навчатися та вдосконалюватися.

Не дивно, що опитування Deloitte про стан пізнавальної діяльності показало, що 88\% фахівців 3 фінансових послуг вважають, що такі технології $\epsilon$ стратегічним пріоритетом. Тим не менш, сучасний рівень техніки роботизованої автоматизації все ще є досить слабким у когнітивному та аналітичному процесах. Проте, сподіватимемося, що у наступні роки ми побачимо, як сучасні когнітивні можливості поєднуються з автоматизованою робототехнікою для досягнення ще кращих результатів. Це вже впроваджено в рішення торгових точок, які автоматично пропонують маркетингові акції, які будуть найбільш ефективними для окремого клієнта.

Ще одним, неменш цікавим досягненням є квантові обчислення. Це спосіб використання квантової механіки для відпрацювання складних операцій 3 великим обсягом даних. Як загальновідомо, сьогодні, комп'ютери використовують біти, які можуть мати два значення - 1 або 0. Квантові обчислення використовують «квантові біти», які замість цього можуть мати три стани - 1 або 0, або обидва. Це розблоковує експоненціальні обчислювальні потужності, що переважає над традиційними обчисленнями - коли використовується правильний алгоритм. Це являє собою величезний стрибок у обчислювальних потужностях, але до будь-яких комерційних реалізацій ще десятки років. Тим не менше, такі фірми, як JPMorgan Chase та Barclays, інвестують у дослідження квантових обчислень у партнерстві з IBM.

Стрімке зростання, яке спостерігалося за останнє десятиліття в кількості структурованих та неструктурованих даних, доступних у банках, у поєднанні 3 ростом хмарних обчислень та технологій створило ідеальні умови для використання штучного інтелекту в усьому спектрі банківських та фінансових послуг. Потреби бізнесу та можливості впровадження штуного інтлекту зросли і банки розглядають впровадення штучного інтелекту як конкурентну перевагу. Штучний інтелект дозволяє банкам використовувати велику історію даних про 
клінтів для прийняття набагато вигідіших фінансвих рішень, включаючи бекофісні операції, маркетинг, управління ризиками, надання послуг та виконання вимог. У звіті «Нова фізика фінансових послуг» визначено наступні можливості, які будуть відкриті завдяки впровадженню штуного інтлекту у банківські та фінансові послуги. Ці можливості поширюються на депозити, позики, платежі, управління інвестиціями, формування капіталу та інше.

Штучний інтелект зробить революцію в банках, перенісши фокус із масштабу активів на масштаб даних. Зараз банки прагнуть задовільнити індивідуальні потреби своїм клієнтам, а не створювати масові продукти для великих ринків. Замість того, щоб утримувати клієнтів за рахунок високих витрат на комунікацію, банки тепер зможуть стати більш орієнтованими на клієнтів. Найголовніше, що банки не залежатимуть від людської винахідливості для покращення своїх послуг. Натомість продуктивність буде результатом взаємодії технологій та навиків. Час, коли банки могли контролювати усю базу клієнтів за допомогою монолітної системи, яка контролювала все, від ведення обліку до кожної взаємодії з клієнтами, давно минув. I вимоги часу, i швидкозмінні потреби споживачів перетворили цю величезну систему на історію. Сьогодні банки повинні замість цього створити "банківські стеки", які дозволять їм бути платформою, до якої клієнти та сторонні постачальники послуг можуть підключатися, щоб забезпечити гнучкий та персоналізований доступ. Для цього вони можуть використовувати платформи API для банківської діяльності. [447]

Це дозволяє банкам застосовувати абсолютно нові бізнес-моделі та використовувати кейси та експериментувати з новими технологіями, такими як блокчейн, за низькою вартістю. AРI також допоможуть банкам забезпечити надійність своїх систем у майбутньому, оскільки інтерфейс більше не буде пов'язаний із серверною базою.

Характер кібер-ризику змінюється 3 великою швидкістю. Це робить традиційні підходи до управління ризиками застарілими. Зараз стає ясно, що організаціям неможливо усунути всі можливі джерела кіберзагроз, і як 
найшвидше обмежити ознаки атаки - найкращий спосіб боротьби з ними. Банки повинні шукати нові підході до кібербезпеки.

Банки дедалі частіше застосовують вдосконалений аналітичний моніторинг у реальному часі та штучний інтелект для виявлення загроз і зупинки їх від збою в роботі систем. Використання методів аналізу великих даних для отримання більш ранньої видимості загроз та припинення їх дії до того, як вони трапляються, називається безпекою на випередження. Хоча зміни, спричинені впровадженням сучасних технологій, можуть призвести до збільшення вразливості на самому початку їх застосування, це шлях вперед, щоб зупинити постійно зростаючі кібер-ризики.

Один з найбільших викликів, яку цифрова ера поставила перед банківською справою, є необхідність швидкого реагування. Постійний розвиток ринку, на якому працюють банки, вимагає від них бути якомога гнучкими та динамічними. Вони повинні мати можливість своєчасно надавати позики підприємствам для швидшого вирішення їх ділових проблем.

Великі банки виявили, що найефективніший спосіб досягти цього - гібридна хмара для підприємства. Це дозволяє їм одночасно вирішуючи такі питання, як безпека даних, управління та дотримання, а також можливість мобілізації великих ресурсів за лічені хвилини. Гібридна хмара також дозволяє банкам пропонувати інноваційно нові пропозиції своїм клієнтам. Наприклад, ICICI Bank співпрацює з Zoho, щоб дозволити компанії автоматизувати основний процес звірки за допомогою Zoho Books, програмного забезпечення для хмарного обліку. Партнерство полегшує процес пропонування клієнтам безлічі варіантів оплати за товари та послуги [448].

Оскільки, світ рухається до менш готівкової економіки, бажання споживачів щодо форм оплати різко змінюються. Як клієнти, так і бізнес очікують, що платежі відбуватимуться миттєво, і саме тут вступають у дію системи миттєвих платежів. Миттєвий платіж є обов'язковим, якщо онлайн-платежі потребують заміни готівкових операцій. Тому банки по всьому світу знаходять способи надати своїм клієнтам можливості миттєвої оплати, навіть коли умови, необхідні 
для надання послуги, відсутні. Наприклад, банки в Кенії співпрацюють, щоб надати своїм клієнтам можливість оплати Р2Р. Незабаром ми побачимо, як банки поєднують свої можливості миттєвих платежів для формування нового портфеля послуг.

Ti хто мав можливість спостерігати за роботою таких помічників, як Aleха від Amazon i Google Home, уявляє, який вплив вони можуть мати на банківське програмне забезпечення. Насправді один з банків Америки вже розробив «Еріку», як віртуального помічника спеціально для банківських операцій. Ці інтелектуальні машини починають діяти, як цифрові помічники для клієнта у взаємодії з банками.

Банкам доведеться інвестувати в цифрові технології, щоб забезпечити довготривалі стосунки 3 клієнтом. Клієнти будуть тяжіти до банків, з якими найпростіше працювати, коли вони використовують технології, до яких вони звикли.

Згідно 3 опитуванням банкірів, проведеним PwC можливості їх установ відстають у цілому ряді надзвичайно важливих областей, включаючи кібербезпеку та конфіденційність, розвиток нових технологій, досвід користувачів та дизайн, орієнтований на людину. Окрім того, рівень технологічних можливостей знижувався, навіть коли вимоги до цифрових технологій продовжували прогресувати.

Оскільки банки усвідомлюють цей розрив у діджиталізації, який заважає їм трансформуватися, щоб реалізувати потенціал, представлений технологіями, вони починають вкладати значні суми в банківські технології, які, на їх думку, $є$ найбільш актуальними для їх бізнес-моделей.

Наприклад, сьогодні блокчейн може не бути пріоритетом для більшості галузей, але банки та фінансові інститути передбачають велику перевагу в їх реалізації. Отже, галузь фінансових послуг в цілому розглядає їх як пріоритетну інвестицію.

Крім того, еволюція банківської галузі потребує, щоб технологія стала “основною компетенцією” із залученням усіх клієнтів як фізичних так i 


\section{SOCIO-ECONOMIC AND MANAGEMENT CONCEPTS}

юридичних осіб. Фокус на технології не може бути обмежений лише для лідерів ринку чи скинутий на плечі IT-відділу певної компанії і існувати окремо від решти їх операцій. В центрі уваги впровадження сучасних технологій повинен бути досвід клієнтів - а не доходи або контроль витрат. Сучасні технології $€$ важливими, і дадуть можливість банкам утримати клієнтів у майбутньому. 


\section{6 Особливості управління організаціями ринкової інфраструктури в умовах цифрової економіки}

Сучасний етап розвитку суспільства характеризується всеохоплюючим проникненням інформаційних технологій, цифрових інструментів у всі сфери людського життя. Увиразнюються контури принципово нової економіки, яка спирається на широке використання інформаційних ресурсів. Ї̈̈ ефективність, економічне зростання значною мірою залежать не від прогресу матеріального виробництва, а від швидкого розвитку інформатизації.

Як відомо, менеджмент - це безперервний пошук нових способів зробити свою компанію більш конкурентоспроможною. Сучасний менеджмент істотно більш складний і відрізняється від традиційного менеджменту, який протягом багатьох десятиліть застосовувався у всіх галузях і сферах життя суспільства.

Донедавна інфраструктура товарного ринку здебільшого забезпечувала організацію й технологію просування товару до споживача, а іiі послуги: торгівельні, виробничо-технологічні, транспортно-логістичні, інформаційні відігравали допоміжну роль. На сучасному етапі вирішальний вплив на економічні процеси справлятиме саме інформаційна складова, яка створює новий простір для бізнесу. За рахунок використання новітніх інформаційних технологій скорочується потреба в оборотному капіталі, оскільки узгоджуються системи оперативного управління виробництвом та забезпечення його необхідними матеріальними ресурсами. Завдяки цьому не лише зменшуються матеріальні запаси та вивільняються складські приміщення, а й взагалі зникає потреба у складуванні

Світова економіка поступово починає функціонувати за умов об'єднаного ринку, коли наявні товари віртуально зосереджені в одному місці. Поява глобальних комунікаційних мереж уможливлює забезпечення швидкої циркуляції товарів, інформації і грошей, подолання численних перешкод у глобальному обміні інформацією. 
Існує значний потенціал використання сучасних цифрових технологій в діяльності фірм. Важливо приділяти увагу таким аспектам, як використання сучасної обчислювальної техніки, програмного забезпечення, наявності кваліфікованих фахівців. Необхідно враховувати, що цифрові технології мають істотний потенціал для прискорення інноваційних процесів, тому показники інвестицій в розвиток цифрового потенціалу фірми $є$ важливим фактором іiі конкурентоспроможності в сучасних умовах.

3'являються нові моделі ведення бізнесу, мережеві структури, нові формати комкнікацій зі споживачами, які трансформують традиційні ринкові відносини i вимагають вироблення нових рішень в галузі управління сучасною фірмою. Подальший розвиток цифрових технологій має значення для всієї економіки в цілому. Використання інформаційних технологій в менеджменті якісно змінюють характер праці, прискорюють обмін інформацією та комунікації, знижують ризик і невизначеність, що викликаються дефіцитом інформації в прийнятті управлінських рішень.

Сучасний етап розвитку економіки України характеризується низкою тенденцій та проблем, що робить надзвичайно складним процес виживання та розвитку підприємств в усіх галузях. Зростання кількості конкурентів у всіх сферах, перенасиченість ринку товарами і послугами, зміна потреб споживачів змушує бізнес-структури шукати шляхи розширення цільових сегментів, диверсифікації своєї діяльності. Одним з найбільш перспективних сучасних способів диверсифікації $є$ вихід на електронні ринки. Адже 3 підвищенням доступності Інтернету, розвитком систем автоматизації управління підприємством, споживач отримав доступ до величезної кількості інформації про товари і послуги, можливість вибору кращих 3 них, а бізнес-одиниці можливість розширити цільові сегменти, одержати оперативну інформацію про потреби споживачів, знайти оптимальні шляхи постачання.

Взаємодія споживачів і постачальників в Інтернет-середовищі визначає функціонування інтерактивного електронного ринку. Такий ринок надає нові 


\section{SOCIO-ECONOMIC AND MANAGEMENT CONCEPTS}

можливості комунікацій з постачальниками і споживачами, більш ефективні технології продажів.

Електронний ринок являє собою середовище 3 більш досконалою конкуренцією, ніж традиційний ринок. На електронному ринку значно більша кількість продавців і покупців, практично відсутні бар'єри для виходу на ринок нових учасників, $є$ вільний доступ до інформації. Переваги ведення господарської діяльності на електронному ринку (малюнок 1).

Що стосується недоліків, то зазвичай продавці їх пов'язують з необхідністю реагування на високу швидкість зміни технологій електронного бізнесу; постійною потребою в нарощуванні потужностей телекомунікаційного обладнання свого підприємства; складністю інтеграції застосовуваних інформаційних систем 3 обладнанням для електронного бізнесу; постійно виникають проблемами в забезпеченні безпеки і надійності інформаційних систем; складністю підготовки та перепідготовки персоналу, особливо в зв'язку з глобальними проблемами ринку (мовний бар'єр, політичне середовище, мінливі валютні курси, правові проблеми та ін.).

Інфраструктура електронного ринку - це скупність об’єктів, що обслуговують ринок, забезпечують реалізацію ринкових процесів, створюють сприятливі умови для його ефективного функціонування. Вона представлена різними типами веб-сайтів, які мають різноманітне цільове призначення та роль на інтернет-ринку, а також володіють різними формами, методами, засобами, інструментами реалізації ринкових процесів. До учасників електронного ринку відносяться продавці, покупці та посередники, а також організації, що забезпечують інфраструктуру та правила ринку. 
Переваги ведення господарської діяльності на електронному ринку

\begin{tabular}{|c|}
\hline $\begin{array}{c}\text { наявність якісної і доступної інформації для проведення ринкових } \\
\text { досліджень }\end{array}$ \\
\hline інтерактивність і сумісність дій в реальному масштабі часу \\
\hline $\begin{array}{c}\text { можливість впроваджувати в практику комерційної діяльності системи } \\
\text { автоматизації господарської діяльності }\end{array}$ \\
\hline $\begin{array}{c}\text { інтерактивна участь споживача у визначенні конкурентоспроможних } \\
\text { властивостей і дизайну кінцевого продукту }\end{array}$ \\
\hline поява нових технологій продажів та обслуговування клієнтів \\
\hline $\begin{array}{c}\text { чіткий таргетинг і контроль рекламних і PR - інструментів для } \\
\text { просування товарів і послуг підприємств }\end{array}$ \\
\hline $\begin{array}{l}\text { можливість використання гнучких цінових моделей, висока швидкість } \\
\text { зміни ринкової кон'юнктури }\end{array}$ \\
\hline можливість роботи одночасно з великою кількістю клієнтів \\
\hline $\begin{array}{c}\text { висока оперативність взаємодії з клієнтами, постачальниками, } \\
\text { партнерами }\end{array}$ \\
\hline $\begin{array}{c}\text { зручність здійснення покупки та відстеження доставки товару для } \\
\text { клієнта }\end{array}$ \\
\hline $\begin{array}{c}\text { зниження витрат за рахунок виконання деяких функцій комерційної } \\
\text { операції самими користувачами та окремих накладних витрат }\end{array}$ \\
\hline $\begin{array}{l}\text { персоналізація обслуговування, цілодобова робота, збільшення } \\
\text { швидкості реакції на запити клієнта }\end{array}$ \\
\hline \multirow{2}{*}{$\begin{array}{c}\text { менші обсяги вкладень для виходу на ринок з боку суб'єктів } \\
\text { електронної комерції }\end{array}$} \\
\hline \\
\hline широкі можливості вибору каналів просування \\
\hline
\end{tabular}

Малюнок 1. Переваги ведення бізнес-діяльності на електронному ринку 
В загальному вигляді можна виділити три сектори Internet-ринку (малюнок 2):

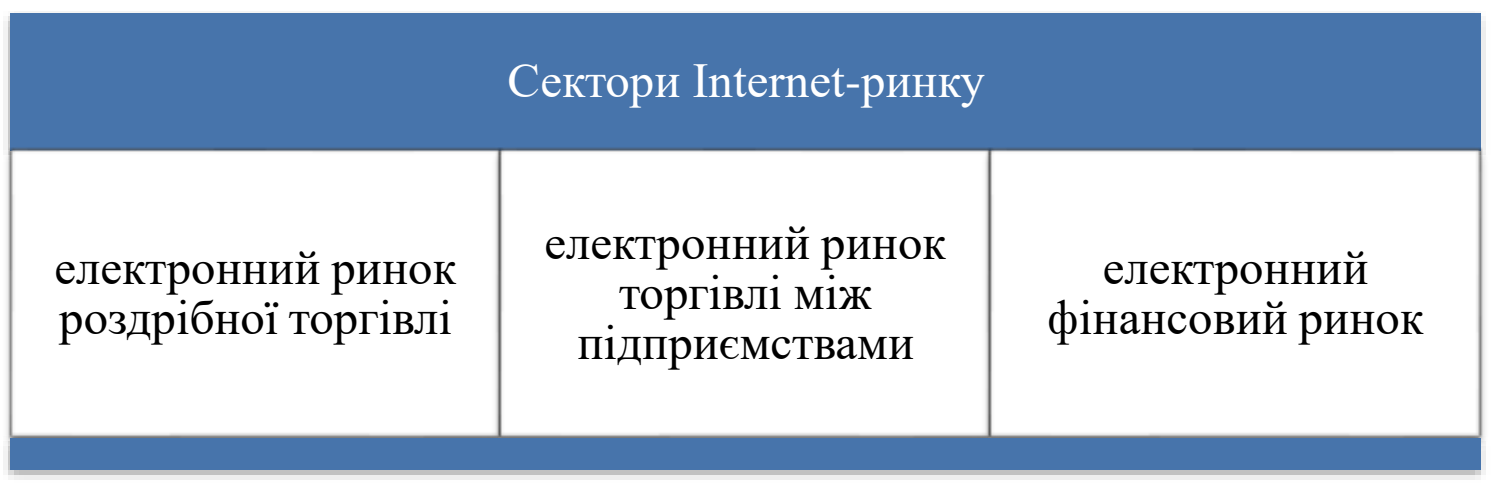

Малюнок 2. Сектори електронного ринку

Основною структурною одиницею електронного ринку є веб-сайт. Сьогодні немає єдиної класифікації сайтів, проте аналіз існуючих підходів дозволив структурувати типи сайтів за критеріями їх призначення (малюнок 3).
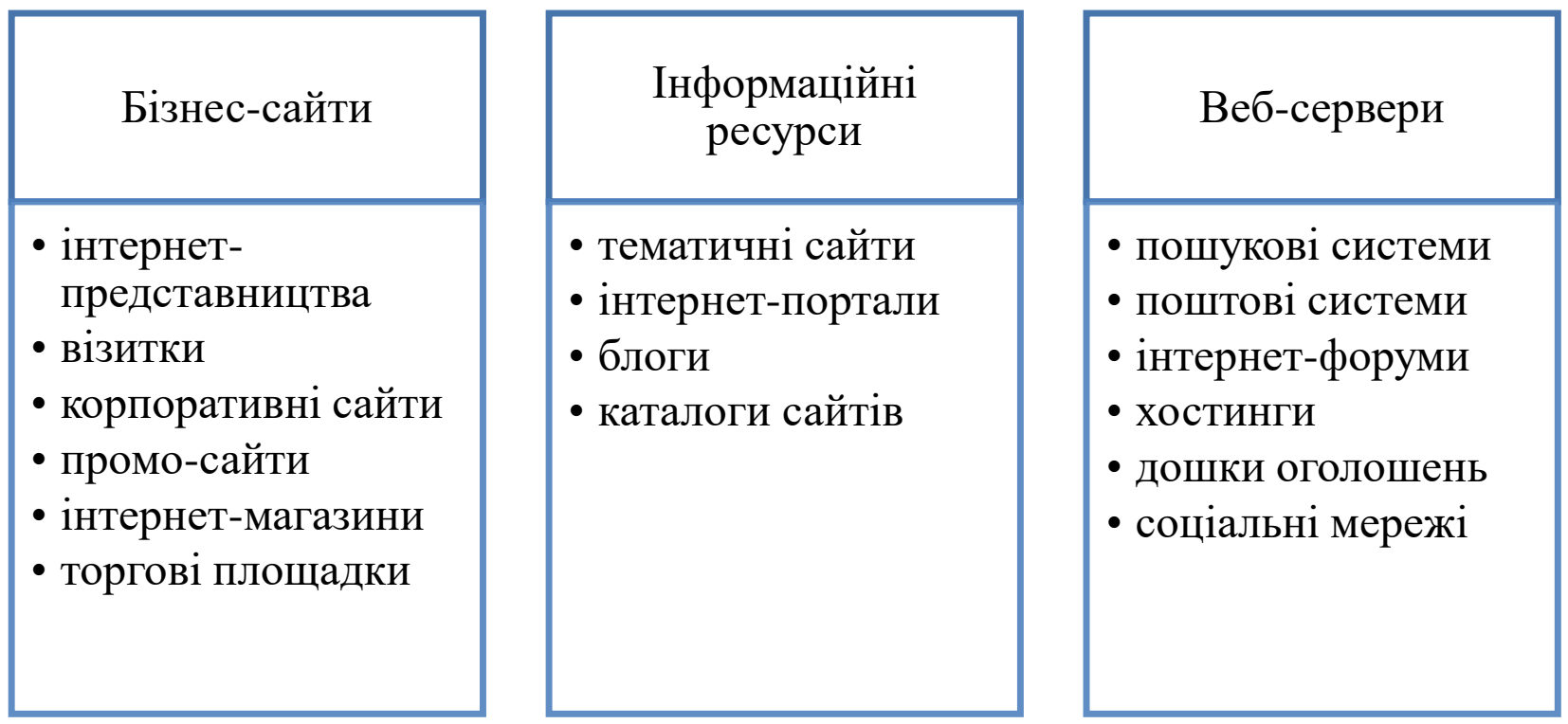

Малюнок 3. Класифікація сайтів

Кожен тип сайту володіє своїми перевагами і недоліками, особливостями у призначенні, структурі, адмініструванні, що визначає необхідність їх оцінювання з точки зору придатності для того чи іншого бізнесу. 3 точки зору бізнес-діяльності веб-сайт може виконувати такі основні завдання:

- реклама продукції, послуг, ідей;

- продаж товарів, послуг, інформації, ідей; 


\section{SOCIO-ECONOMIC AND MANAGEMENT CONCEPTS}

- безкоштовне надання інформації або послуг;

- підтримка клієнтів.

Електронна комериія є складовою частиною електронного бізнесу і означає широкий набір інтерактивних методів ведення діяльності з надання споживачам товарів та послуг. Це використання електронних комунікацій та технологій обробки цифрової інформації для встановлення та зміни відносин створення вартості між підприємствами (B2B) та між організаціями і споживачами (B2C). Електронна комерція в більшості випадків означає технологію використання інтернет як каналу збуту, тобто для здійснення розрахунків з покупцями за допомогою веб-ресурсів. До електронної комерції відносять електронний обмін інформацією, електронний рух капіталу, електронну торгівлю, електронний банкінг, електронні страхові послуги.

3 іншого боку, поняття «електронний бізнес», окрім електронної комерції включає багато інших способів використання Інтернет для ведення бізнесу, наприклад, логістику, управління постачанням та збутом продукції, встановлення та підтримка відносин 3 постійними клієнтами, керування інформаційними потоками всередині підприємства.

Отже, існування успішного бізнесу зараз, в епоху інформаційного суспільства, є неможливим без присутності компанії на цифровому ринку. Використання інтернет-технологій дозволить бізнесу функціонувати цілодобово і цілорічно, сприяє створенню бізнес-іміджу, підвищенню довіри клієнтів, забезпеченню кращої віддачі від інвестицій, ніж будь-яка інша форма реклами. Особливої актуальності цей процес набуває сьогодні, коли режим карантину та самоізоляції поставив бізнес в скрутне становище. Саме тому поступовий перехід в інтернет-середовище $з$ урахуванням його особливостей та форматів функціонування дозволить сучасним компаніям залишатись стабільними та рентабельними. 


\section{SECTION 9. INSURANCE}

\subsection{Prospects for the development of the reinsurance market of Ukraine}

One of the most important areas of development of the modern market of insurance services is reinsurance. According to Article 12 of the Law of Ukraine "On Insurance" reinsurance is insurance by one insurer (assignor, reinsurer) on the terms of the risk of fulfilling part of its obligations to the insured with another insurer (reinsurer) resident or nonresident who has the status of insurer or reinsurer, according to the legislation of the country in which it is registered [450].

In the practice of different countries, reinsurance is used as a tool to increase the solvency and economically correct distribution and redistribution of insurance funds of various insurance companies. Reinsurance activities in Ukraine are regulated, in addition to the above law, by several bylaws and directives of the European Union.

Currently, Ukraine is actively developing such a sector of the economy as insurance, which is an integral part of market relations. In all developed countries, insurance is a strategically important sector of the economy, providing the bulk of investment in its development and freeing state budgets from the cost of compensation for unforeseen events. Reinsurance is an independent type of insurance. With the help of reinsurance, the insurer can increase the capacity of its insurance portfolio by concluding direct insurance contracts for risks that exceed its full financial resources.

There are no reinsurance companies on the Ukrainian insurance market that would purposefully engage in reinsurance operations on the territory of Ukraine. Reinsurance is carried out by insurance companies that are authorized to carry out such operations.

Consider the total number of insurance companies engaged in insurance and reinsurance in the Ukrainian insurance market. 
SOCIO-ECONOMIC AND MANAGEMENT CONCEPTS

Table 1.

Number of insurance companies in 2015-2019

\begin{tabular}{|l|l|l|l|}
\hline Year & Number of companies & Non-life & Life \\
\hline 2015 & 361 & 312 & 49 \\
\hline 2016 & 310 & 271 & 39 \\
\hline 2017 & 294 & 271 & 33 \\
\hline 2018 & 281 & 251 & 30 \\
\hline 2019 & 233 & 210 & 23 \\
\hline
\end{tabular}

Source: Compiled by the author based on [451]

Table 1 shows that since 2015 the number of insurance companies has been declining every year, as there is an unstable economic situation in the country and insurance companies can not carry out insurance and reinsurance operations. Certain insurance companies failed to maintain market leadership and closed down. The same trend is observed in the number of life and non-life insurance companies. At present, the insurance and reinsurance market is represented by only $50-80$ insurance companies, which almost completely cover the insurance market in Ukraine.

Reinsurance is derived from insurance, so the peculiarities of the insurance market are mainly reflected in the reinsurance market. Consider the volume of the domestic reinsurance market (table 2).

Table 2.

Volumes of internal reinsurance in 2015-2019

\begin{tabular}{|l|c|c|c|}
\hline Year & $\begin{array}{c}\text { Gross premium, UAH } \\
\text { million }\end{array}$ & $\begin{array}{c}\text { Insurance premium } \\
\text { transferred to reinsurers, } \\
\text { UAH million }\end{array}$ & Reinsurance share, \% \\
\hline 2015 & 29736,0 & 9911,3 & 33,3 \\
\hline 2016 & 35170,3 & 12668,7 & 36,0 \\
\hline 2017 & 43431,8 & 18333,6 & 42,2 \\
\hline 2018 & 49367,5 & 17940,7 & 36,3 \\
\hline 2019 & 53001,2 & 16713,4 & 31,5 \\
\hline
\end{tabular}

Source: Compiled by the author based on [451]

Based on the data in Table 2, it can be seen that reinsurance companies maintain stable reinsurance volumes after the economic crisis. In 2017, the share of insurance 


\section{SOCIO-ECONOMIC AND MANAGEMENT CONCEPTS}

premiums transferred to reinsurance was $42.2 \%$, which is a pretty good result compared to other years.

The main indicator that characterizes the reinsurance market is the indicator of insurance indemnity payments by reinsurers (residents and non-residents) and its dynamics.

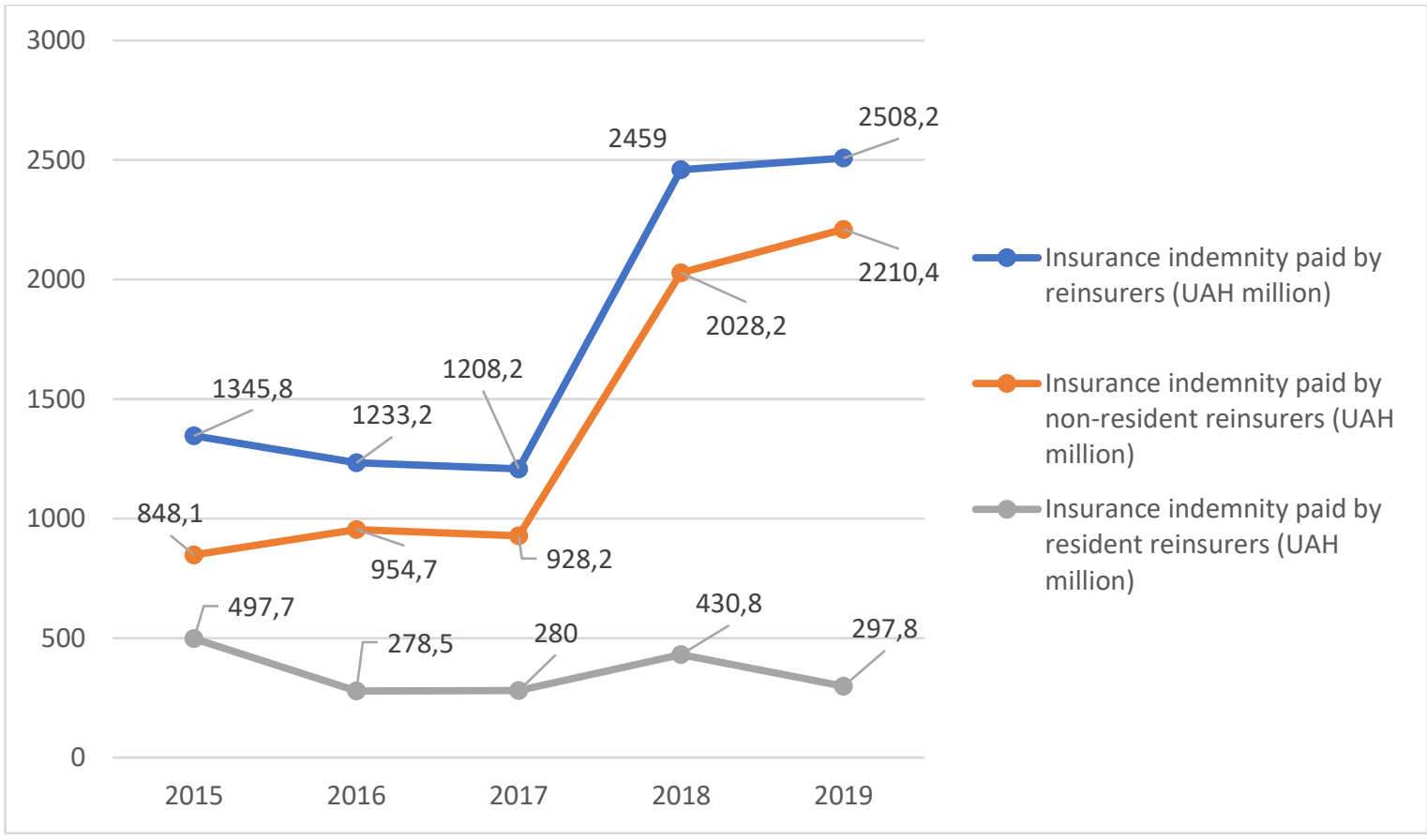

Figure 1. Payment of insurance indemnity by reinsurers, including residents and non-residents in 2015-2019 [451].

Reinsurers' payments increase every year due to an increase in the level of reinsurance premiums. During the period under review, companies again began to increase their capacity and increase the share of insurance indemnity.

Let's analyze the structure of initial reinsurance by types of insurance. During the study period, the largest share of insurance premiums was paid for such types of insurance as property insurance; insurance against fire risks and natural disasters; financial risk insurance; cargo and luggage insurance (cargo luggage); land transport insurance (CASCO); third party liability insurance; civil liability insurance of vehicle owners ("Green Card"). 


\section{SOCIO-ECONOMIC AND MANAGEMENT CONCEPTS}

The riskiest type of insurance that is transferred to reinsurance is property insurance. The riskiest types of insurance are also fired risk insurance and financial risk insurance. Other types of insurance are quite important, which include civil liability insurance of vehicle owners (under ordinary and additional contracts), health insurance (continuous health insurance), credit insurance, insurance of issued guarantees (guarantees), and accepted guarantees.

The size of incoming reinsurance is significantly different from the volume of outgoing reinsurance. The dynamics of the development of incoming reinsurance are presented in the table 3 .

Table 3.

Dynamics of development of incoming reinsurance in Ukraine in 2015-2019

(UAH million)

\begin{tabular}{|l|l|l|l|l|l|}
\hline \multicolumn{1}{|c|}{ Indicator } & 2015 & 2016 & 2017 & 2018 & 2019 \\
\hline $\begin{array}{l}\text { Premiums received from } \\
\text { non-resident reinsurers }\end{array}$ & 38,1 & 40,1 & 46,1 & 48,4 & 56,8 \\
\hline $\begin{array}{l}\text { Payments to reinsurers - } \\
\text { non-residents }\end{array}$ & 12,9 & 14,2 & 13,8 & 44,4 & 8,9 \\
\hline
\end{tabular}

Source: Compiled by the author based on [451]

From this table we can conclude that it is not profitable for non-residents to reinsure their risks in Ukraine, is because Ukrainian insurance and reinsurance companies do not have sufficient financial stability, and the Ukrainian economy cannot provide guarantees to non-residents. All these factors lead to the fact that Ukrainian insurers and reinsurers do not receive sufficient financial resources from abroad.

Thus, the Ukrainian reinsurance market on the one hand is subject to the influence of global trends, on the other - has its specifics. For example, the volumes of the Ukrainian reinsurance market, as well as the reinsurance market of other countries, tend to decrease due to the consolidation of companies and increase their maintenance.

The development of the Ukrainian reinsurance market requires the integration and intensification of actions aimed at attracting to the global reinsurance space. 


\section{SOCIO-ECONOMIC AND MANAGEMENT CONCEPTS}

\subsection{Problems of life insurance development in Ukraine}

Майбутнє України насамперед залежить від ії̈ громадян, здорових громадян. У прагненні стати європейською державою нам потрібно забезпечити гідний рівень життя людини, що сьогодні не вдається. За кількістю смертей від раку Україна посідає друге місце (після Росії) в Європі. Онкологія в нашій державі охоплює 22\% населення працездатного віку. Головною проблемою цього є проблема невчасної діагностики захворювання через відсутність можливості якісного огляду, адже за роки незалежності медична система стала настільки корумпованою, не здатною забезпечити належний медичний догляд, що рівень смертності в Україні значно вищий за рівень народжуваності. Також, дуже великих втрат життєвих втрат приніс вірус 2020-го року COVID-19. За офіційними даними під час пандемії померло понад 2,5 мільйони людей у всьому світі, зокрема в Україні близько 430 тисяч людей. Тому страхування життя є дуже актуальним на сьогоднішній день.

Традиційно в лайфовому страхуванні виділяються два напрямки: ризикове страхування (класичний захист від можливих ризиків) i довгострокове накопичувальне страхування, яке дозволяє не тільки застрахуватися від певного переліку ризиків, а й накопичити і навіть примножити вкладення[453]. До початку 2017 року трохи менше 1,5 млн українців були клієнтами компаній зі страхування життя.

3 одного боку, для більшості власників полісів страхування життя накопичення коштів - останнє, про що вони думають, укладаючи договір. Першочергове завдання - застрахувати своє життя: якщо зі страхувальником щонебудь трапиться, він сам і його близькі будуть фінансово захищені. Для цього страховики включають в накопичувальні поліси додаткові опції (ризик критичних захворювань, травми, отримані в результаті занять екстремальними видами спорту, авіакатастрофи, ДТП тощо).

У той же час накопичувальне страхування $є$ одним 3 небагатьох інструментів в Україні для довгострокового вкладення і накопичення коштів. 
Серед плюсів такого інструменту - гарантований дохід у розмірі 4\% річних. За європейськими стандартами 4\% річних - цілком пристойний дохід, але в Україні такий прибуток сильно програє інфляції. У 2016 році інфляція склала 12,4\%, в 2015-му - 43,3\%, в 2014-му - 24,9\% [454].

Найціннішим для клієнта є додатковий інвестиційний дохід, який може отримати компанія від управління коштами. За законодавством 85\% такого прибутку буде розподілено між власниками полісів. Страхові компанії дуже неохоче розкривають результати своєї інвестиційної діяльності, та вони й не зобов'язані це робити. За неофіційними відомостями, за останні п’ять років додатковий інвестиційний дохід в ряді компаній з іноземним капіталом був на рівні $18-20 \%$.

Додатковий дохід компанії зі страхування життя отримують від інвестування коштів. Компанії зі страхування життя вкладають кошти в низькоризикові фінансові інструменти - депозити (40,1\% всіх коштів СК за станом на 1 січня 2017 року), державні облігації внутрішньої держпозики (ОВДП), дорогоцінні метали (46, 4\%). Ще 7,4\% - кошти на поточних рахунках. Раніше страховики частина коштів вкладали в інструменти фондового ринку, але останні п'ять років цей ринок в Україні скоріше мертвий, ніж живий.

У світовій практиці досить поширеним є інвестиційне страхування (Unitlinked): частину страхової премії направляється на покриття страхових ризиків, а основна (накопичувальна) частина, за вибором клієнта, інвестується в різні фінансові інструменти або інвестиційні фонди [455]. Такий продукт дозволяє застосовувати різні інвестиційні стратегії.

Наприклад, якщо клієнт готовий до ризику, тоді він може вкладати кошти у високоприбуткові ризикові інструменти: він може як втратити частину своїх заощаджень, так і заробити більше. А якщо ж застрахований дотримується консервативної інвестиційної політики, тоді інвесткеруючому запропонує йому найменш ризиковий варіант вкладень, який принесе йому менший прибуток. В Україні таких продуктів від локальних компаній поки немає, і вони можуть з'явитися тільки після внесення змін до закону «Про страхування». Учасники 
ринку домагаються цього вже не один рік, але у депутатів часу на розгляд страхових законів немає.

Щоб урізноманітнити свою продуктову лінійку, страхові компанії розробляють продукти для різних категорій населення. Наприклад, батьки можуть укласти договір довгострокового страхування для своєї неповнолітньої дитини, щоб накопичити йому на навчання або на квартиру (по досягненню певного віку), окремі програми є для тих, хто хоче отримати додаткову надбавку до пенсії (договір укладається на термін до досягнення страхувальником пенсійного віку). Для активного працездатного населення $є$ накопичувальні програми на фіксований термін (на 5, 10, 15, 20 років). Окремі програми є для жінок: вони захищають, наприклад, від специфічних жіночих онкологічних захворювань. Для клієнтів передпенсійного віку враховуються специфічні «вікові» захворювання, травми, загострення хронічних захворювань. При цьому кожна програма фактично є «конструктором»: за бажанням клієнта страхова компанія може включити або, навпаки, виключити певні ризики або опції.

Для прикладу, зробимо розрахунок страхування життя для клієнта: Микола, 33 роки, власник і одночасно директор середнього бізнесу. Мета страхування захистити себе і сім’ю, де він є основним годувальником, від можливих втрат. Термін страхування - 10 років. Страхова сума - 100 тис. грн. Зі здоров’ям у нашого героя все в порядку, спадкових захворювань немає, травм і оперативних втручань останнім часом не було.

Згідно розрахунків, щорічний платіж становить 11893 грн, з яких 10126 грн - це накопичувальна програма, 571 грн - страхування на випадок критичних захворювань, 266 грн - страхування на випадок звільнення в результаті інвалідності, а ще 930 грн - страхування від таких ризиків як смерть, інвалідність I-III груп, травма в результаті нещасного випадку. Важливо відзначити, що платіж за договором довгострокового страхування потрапляє під податкову пільгу - на суму платежу зменшується дохід, на який нараховується податок на доходи фізичних осіб. 
Страхові компанії дозволяють платити внески щоквартально, раз на півроку або щорічно. При цьому при розбивці платежу сума за підсумками року буде трохи вище, ніж якби клієнт платив одноразово. Якби Микола платив поквартально, розмір платежу склав би 3063 грн (або 12252 грн в рік), поквартально - 6066 грн (12132 грн).

Якщо у застрахованого є якісь хронічні захворювання або травми, а також якщо його робота пов'язана з ризиками і допускає виробничі травми, тоді розмір страхових платежів буде більше. Крім того, чим більше вік застрахованого, тим вище платіж. У кожному конкретному випадку страхової менеджер визначає розмір страхової суми виходячи з конкретних параметрів клієнта (здоров'я, спосіб життя, робота, хобі) і його побажань.

У разі настання будь-якого з включених в страховий договір ризиків, Микола або члени його сім’ї отримають 100 тис. грн. Якщо він благополучно дочекається закінчення терміну дії договору через 10 років, він отримає всю страхову суму (в нашому випадку це 100 тис. грн) разом 3 накопиченим інвестиційним доходом.

За бажанням, застрахований може включити опцію «індексація» - щорічно розмір страхової суми i, відповідно, розмір платежу буде переглядатися 3 залежності від рівня інфляції.

Варіанти отримання виплати є два: одноразова виплата і 3 розбивкою платежів. Наприклад, за 10 років Микола накопичив 150 тис. грн. А отримувати відшкодування хоче щомісяця протягом 5 років. Тобто в місяць страхова буде виплачувати йому 2500 грн. 3 одного боку, отримувати щомісяця надбавку до основного доходу дуже зручно. Але є одне «але»: після закінчення терміну дії страхового договору гроші перестають «працювати», тобто страхова компанія вже не займається їх інвестуванням, на них не нараховується інвестиційний дохід. В результаті за п’ять років, протягом яких кошти буду зберігатися на рахунках страхової компанії, інвестиції можуть знецінитися. Набагато логічніше отримати разову виплату і вибрати інший варіант вкладення цих коштів. Наприклад, розмістити на банківському депозиті. 


\section{SOCIO-ECONOMIC AND MANAGEMENT CONCEPTS}

Договір страхування життя передбачає можливість дострокового розірвання: клієнт отримує так звану «викупну суму». Як правило, протягом перших двох років сенсу розривати договір немає: всю суму внесених i зароблених коштів поглинуть адміністративні витрати і штрафні санкції з боку страхової компанії. Повернути достроково суму, порівнянну 3 сплаченими платежами, можна починаючи з шостого року дії договору. Якщо страхувальник 3 якихось причин не може вносити платежі, то тоді краще «заморозити» страховий договір або редукувати (зменшити) страхову суму і платити посильну суму платежу.

В Україні лайфові страхові компанії пропонують укладати договори як в гривні, так і у валюті (долар, євро). Більш того, до фінансової кризи 2008 року більше половини накопичувальних договорів було номіновано як раз в валюті. Але після девальвації гривні більш ніж в півтора рази регулярний страховий платіж в гривневому еквіваленті істотно виріс. Для більшості застрахованих це стало непосильним фінансовим навантаженням, тому в 2008-2009 роках спостерігався масовий переклад валютних полісів в гривневі[456]. Такий крок виправданий, якщо дохід клієнт отримує дохід саме в гривні без прив'язки до валютного курсу. До того ж інвестиційний дохід за гривневими договорами, як показує практика, істотно перевищує прибутковість полісів, номінованих в доларах або євро (іноді більш ніж в два рази).

Але, в гривневих договорах є свої ризики. Наприклад, вони більш схильні до впливу інфляційних процесів. Як зазначалося вище, для мінімізації цього ризику в договір можна включити опцію індексації.

Також віддавши перевагу гривні, клієнти позбавляються додаткового заробітку: валютні договори дозволяють отримувати не тільки інвестиційний дохід, а й заробляти на різниці валютних курсів.

Є в страхуванні життя в Україні і свої особливості. У період «кредитного буму» 2006-2008 років і 2010-2013 році головними «популяризаторами» страхування життя були банки, які зобов’язували позичальників страхувати життя. Досить часто в рамках соціального пакета страхували своїх 


\section{SOCIO-ECONOMIC AND MANAGEMENT CONCEPTS}

співробітників і роботодавці. Іноді роботодавець укладав договір на невелику суму, але сам страхувальник міг укласти додаткову угоду і збільшити розмір страхової суми і самостійно доплачувати різницю.

Добровільно ж українці страхуються вкрай неохоче. Одна з причин низький рівень довіри до страхових компаній. 3 одного боку, приводів для особливого занепокоєння немає. Під час попередніх криз компанії зі страхування життя ставилися в приклад іншим учасникам фінансового ринку. Ні в 2008-2009 роках, ні в 2013-2014-х, коли банкрутували банки, фіксували неймовірні збитки компанії з управління активами та пенсійні фонди, жоден лайфовий страховик не пішов з ринку. Проблеми виникли хіба що у страхової компанії «Зеніт»: восени 2013 року виявилося, що на рахунках компанії всього 30 тис. грн, ще 370 тис. грн залишились на рахунках Укрпромбанку, який на той час вже знаходився на стадії ліквідації. При цьому загальна сума зобов'язань страхової компанії перевищувала 4 млн грн. Ситуацію вдалося вирішити: деякі клієнти перейшли в інші страхові компанії, які в гонитві за страхувальниками запропонували вигідні умови і погодилися за свій рахунок частково компенсувати втрати. Частина застрахованих, в першу чергу ті, чиї страхові суми були скорочені, морально попрощалися зі своїми заощадженнями.

Але минулий рік показав, що ситуація в сегменті страхування життя в Україні набагато складніше: разом з грошима клієнтів зникли ще дві страхові компанії - «Еко» та «Гарант-Лайф». Від цієї афери постраждало понад 10 тис. Чоловік. Зараз розслідуванням справ займаються правоохоронні органи.

Страхування життя в Україні - ринок дуже концентрований. П'ять компаній - «МетЛайф», «ТАС», «Уніка Життя», «Граве Україна Страхування життя», «PZU Україна Страхування життя» - збирають 80\% страхових премій. Ці компанії вже багато років працюють а ринку, у чотирьох з них (крім СК «ТАС») іноземні власники з багаторічною історією на світовому ринку. СК «ТАС», хоч $\mathrm{i}$ 3 українським капіталом, але встигла добре зарекомендувати себе: в минулому році компанія закрила операцію 3 купівлі страхової компанії «Aegon Life 
Україна» у міжнародній страхової групи Aegon. Тому при покупці страхового поліса клієнти як правило розглядає як правило саме 5 лідерів ринку [457].

Перейдемо до розгляду діяльності страхових компаній за видами виплат премій та страхових виплат у 2020 році за допомогою таблиці 1.

Таблиця 1

Рейтинг страхових компаній по страхуванню життя за 2020 рік

\begin{tabular}{|c|c|c|c|c|}
\hline № & Страхова компанія & Премії, тис. грн. & Виплати, тис. грн. & $\begin{array}{c}\text { Рівень виплат, } \\
\%\end{array}$ \\
\hline 1 & $\begin{array}{c}\text { АЛЬФА } \\
\text { СТРАХУВАННЯ }\end{array}$ & 191313 & 1845 & 1,0 \\
\hline 2 & КРЕДО & 72347 & 553 & 0,8 \\
\hline 3 & ВУСО & 57513 & 16196 & 28,2 \\
\hline 4 & УНІКА & 50550 & 21671 & 42,9 \\
\hline 5 & КРАЇНА & 34814 & 13521 & 38,8 \\
\hline 6 & ТАС СГ & 16259 & 1437 & 8,8 \\
\hline 7 & РZU УКРАЇНА & 12580 & 400 & 3,2 \\
\hline 8 & МЕГА-ГАРАНТ & 11029 & 4 & 45,6 \\
\hline 9 & АСКО-ДОНБАСС & 4388 & 2001 & 28,3 \\
\hline 10 & ПІВНІЧНИЙ & & & 988 \\
\hline
\end{tabular}

3 вищенаведеної таблиці видно, що компанія «Альфа Страхування» займає перше місце по рівню виплати премій у розрізі страхування життя, що свідчить про велику довіру зі сторони клієнтів, регулярність внесків та якісний менеджмент вкладення коштів. Дивлячись на суму виплат, наприклад. Компанії «Мега-Гарант», яка виплатила усього 4000 грн, що є дуже вагомим показником для діяльності будь-якої страхової компанії, а саме відображає професійний підхід у прогнозуванні смертності в індивідуальних випадках. Стосовно співвідношення виплат премій до страхових виплат: найбільший показник має компанія «Аско-Донбас Північний» - 45,6\%, а найменший «Мега-Гарант» 0,0\%. Отже, можна зробити висновок, що у 2020 році найбільш активну діяльність у сфері страхування життя, вже вдруге поспіль, вела компанія «Альфа страхування». Така компанія як «ВУСО» змогла змістити 3 третього місця компанію «Довіра та гарантія». «ТАС СГ» змістилась 3 5-го на 6-те місце в рейтингу у 2020 році[457]. 
Важливим та прибутковим показником діяльності страхових компаній $є$ довіра зі сторони клієнтів, тому проаналізуємо рейтинг компаній по кількості застрахованих осіб( дані таблиці 2.)

Таблиця 2

ТОП-10 найбільших компаній по кількості осіб, які застрахували життя станом на 2020 рік

\begin{tabular}{|c|c|c|}
\hline № & Назва компанії & $\begin{array}{c}\text { Кількість застрахованих громадян станом } \\
\text { на } 31.12 .2020 \text { р. }\end{array}$ \\
\hline 1 & МЕТЛАЙФ & 759604 \\
\hline 2 & АСКА-ЖИТТЯ & 455321 \\
\hline 3 & АRХ LІІЕ & 430951 \\
\hline 4 & УНІКА ЖИТТЯ & 367019 \\
\hline 5 & ТАС & 295948 \\
\hline 6 & РZU УКРАЇНА СТРАХУВАННЯ & 134452 \\
\hline 7 & ЖИТТЯ & 15241 \\
\hline 8 & КД-ЖИТТЯ & 15105 \\
\hline 9 & ІНГО УКРАЇНА ЖИТТЯ & 12758 \\
\hline 10 & КНЯЖА ЛАЙФ УІG & 6249 \\
\hline
\end{tabular}

У 2020 році перше місце в рейтингу займає все ж та «Метлайф», кількість клієнтів якої у порівнянні з 2019 роком зросла на 34604 осіб, що свідчить про постійну та інтенсивну роботу всіх ланок компанії. На останньому місці аналізованого рейтингу розташувалась компанія «Грінвуд Лайф Іншуранс» 6249 осіб. Остання компанія діє на території України з 2007 року та має такі переваги: привабливу цінову політику; широку територіальну присутність; фінансову стійкість та надійність; широкий спектр послуг.

Довгострокове лайфове страхування - це комбінація страхового поліса та інвестиційної програми. Клієнт вносить щороку страховий платіж, а компанія його інвестує в різні (дозволені законодавством) інструменти. В кінці терміну договору застрахований отримує накопичену суму плюс відсотки. Весь час дії поліса він знаходиться під страховим захистом.

Договір можна укласти в гривні, доларах або євро. Клієнт вносить платіж завжди в гривні, а потім страховик купує валюту і розміщує $\dddot{11}$ на відповідний 
депозит. Виплачує компанія по валютним договорами також в гривні. Але сума розраховується за курсом НБУ на момент виплати.

До кризи страхувальники, в основному, вважали за краще збирати в валюті. Але після різкої девальвації гривні ситуація змінилася. Зараз більше половини договорів номіновані в національній валюті, і це цілком зрозуміло. Якщо раніше люди віддавали страховику 1000 доларів в рік, і це було 8000 гривень, то тепер сума такого внеску перевищує 27000 гривень. Багатьом такі виплати не по кишені.

Якщо клієнт не може платити внески, у нього є кілька варіантів. По-перше, можна взяти так звані «канікули» $\mathrm{i}$ його договір буде на час заморожений. А коли фінансова ситуація вирівняється, він знову повернеться до колишньої схеми. Подруге, може бути зменшений розмір річного платежу. Але тоді і страхова сума, відповідно, стане менше. По-третє, клієнт може взагалі перестати вносити платежі. Тоді після закінчення договору він отримає ту суму, яку встиг накопичити. Останній варіант - розірвати договір і забрати викупну суму. Але цей варіант самий невигідний. Викупна сума, особливо в перші три роки, набагато менша від тієї, яку клієнт де-факто сплатив за договором.

Прибутковість договорів порівнянна із прибутковістю по депозитах. У минулому році, наприклад, в гривні це було в середньому 17\%, в доларах - 89\%. Цього року інвестиційний дохід буде точно менше, оскільки ставки в банках істотно впали, особливо по валютних внесках. У банках з іноземним капіталом вони взагалі прагнуть до $0 \%$.

Сьогодні, страхування в Україні все ще залишається нерозвинутим та слабким економічним складником. Більшість компаній сьогодні - це дочірні компанії іноземних інвесторів. В таких умовах державі не вистачає дієвої національної страхової компанії із різноманітним спектром страхових послуг, яка буде керуватись та забезпечуватись органами державної влади.

За роки діяльності страхових компаній на території України існувало багато чого цікавого: розширення клієнтської бази, підтримка громадян при попаданні в скрутні становища та інші. 


\section{SOCIO-ECONOMIC AND MANAGEMENT CONCEPTS}

Отже, сучасний страховий ринок у своєму розвитку має певні досягнення й численні недоліки, властиві функціонуванню, як окремий страхових компаній, так і системи страхування в цілому. Ринок страхових послуг в Україні показавши, що в сьогоднішніх умовах дуже важливими є розробка та ефективне впровадження антикризового плану, який повинен передбачати: доступ страхових компаній до засобів резервів, розміщених на депозитах банків; консультаційну допомогу по можливості рекапіталізації небанківських фінансових установ, зняття жорстоких обмежень в частині вимог стосовно рівня кредитного рейтингу для інвестування активів страхових компаній, створення фонду гарантій страхових виплат за рахунок коштів страхових резервів страхових компаній на рахунки Національного банку України и та інше. Оскільки страховий ринок $є$ невід'ємною складового фінансової системи України, то, формування досконалий, фінансово стійкого страхового ринку є важливим аспектом ії подальшого розвитку. 


\section{SECTION 10. INTERNATIONAL ECONOMIC NEWS}

\subsection{Non-equity modes (NEMs) of production in asean countries in conditions of GVCs reorganization}

According to UNCTAD experts estimation [458], the current crisis caused by the impact of COVID-19 has global nature and affects all spheres of life on the planet. It can accelerate the processes of structural transformation of international manufacturing in the next decade. However, significant factors that can affect the course and success of this transformation are the priorities of the new industrial revolution and the activation of the economic nationalism forces in the system of international economic relations [459].

The general trend towards international production is to reduce value-creating chains, increase the concentration of value added and reduce foreign direct investment (FDI) into physical production assets. This will create enormous challenges for those countries that have been integrated into global value-creating chains for decades and thus provide support for national employment and production.

Global value chains (GVCs) play an extremely important role in the development of world trade and production in the $21^{\text {st }}$ century, although they are perceived as a controversial phenomenon. After all, there are not only significant benefits that arise from the formation of global value chains (GVCs). The positive consequences include acceleration of economic growth in both customer and contractor countries, which are integrated into global production networks due to more efficient allocation of manufacture processes and reduction of transaction costs. The negative results of the GVCs development manifest significant asymmetry regarding distribution of positive effects, including income between countries, the preservation of technological backwardness of the manufacture implementing countries, high level of import dependence of national development. GVCs are developed through both joint-stock and non-equity models (NEMs) of international interaction between chain participants. The use of hybrid formats of international business [460] is especially common for ASEAN 
countries (Association of SouthEast Asian Nations). Among them, a special role belongs to the Philippines, which has been the driver of these processes on the continent of Asia for decades.

As of 2019, approximately one third of the world trade is proceeded through GVCs, in which the production process crosses at least one border and, as a rule, many borders more [458]. Over the past two decades, the phenomenal growth of trade related to GVCs has led to significant economic growth in many countries around the world, which has contributed to reduced transport and communication costs, lower trade barriers. But, at the same time, it contributed to the distributive effect, which means that the benefits of trade have not been accumulated equally for every country or entity, as well as not to the same extent. Partially, this has become the driving force reaction for the response to globalization and the rise of protectionism, as well as to the threats of global and regional trade agreements. In addition, new technological development, such as robotics, large-scale data, and the Internet of Things (IoT), are mobilized to transform GVCs even more.

GVCs are being sequential chains or complex networks formed by the fragmentation of production processes and the distribution between different countries of production operations (and/or business functions) both on the basis of direct ownership and in the form of non-equity models. GVCs are managed through a complex network of relationships with counterparties and various forms of administration. These may include multiple operations and tasks; numerous branches, partners in non-equity models and provide trade in its pure form or combination of these forms and models. This course of events corresponds to companies with highly fragmented organizational structure or configuration of global production networks [461-462]: from of direct ownership of foreign assets to non-equity models (NEMs) and to ordinary way of trading. These managerial regimes and hierarchical structures in GVCs through which they manifest significantly influence upon distribution of economic benefits and longterm incentives for their development [463-464].

After the global financial crisis of 2008, the slowdown as for the growth of trade in goods and services regarding world GDP was only the first, and the most noticeable 
manifestation of much more significant changes. The latest practice of cross-border capital movements shows slowdown within dynamics of international production and sales of global companies through branches as investment forms of external expansion: in 2011-2018 the average annual growth rate of goods turnover (7.3\%), value added (4.9\%) and employment ( $4.9 \%$ ) of foreign branches were lower than during the same period before $2010(9.7 \%, 10.7 \%$ and $7.6 \%$, respectively). Moreover, the scale of global FDIs, the lion's share of which consists of investment of TNCs in the last decade, just once reached the level of pre-crisis 2008 (that is in 2016), furthermore this tendency was not fixed, showing a decline in 2017 by 16\%, in 2018 by 23\%. It is also projected that the reduction in global FDI inflows is going to increase up to $40 \%$ in 2020 compared to 2019 stopping on the level of US 1.54 trillion dollars. As a result, for the first time since 2005 , FDI are to be less than $\$ 1$ trillion. It is projected that in 2021 FDIs are to decline by another 5-10\% and will start to recover in 2022 [458]. The relative growth rates of royalties and license fees over the past five years (almost 5 percent per year) compared to trade in foreign direct investment (less than 1 percent per year) have shown the way of international manufacture shift from cross-border production networks to non-equity models of value initiation.

New opportunities have opened up for ASEAN countries through international innovation networks of transnational corporations (TNCs). Although attracting foreign direct investment (FDI) and encouraging foreign TNCs to establish branches remain important areas of development for ASEAN countries, however, in recent years the member countries have begun to reap significant benefits from engaging chains of nonequity forms into global supply through international production and trade.

In the ranking of countries involved into GVCs, the leading positions are occupied by ASEAN countries, which have become the location of major global plants, namely in Singapore, Malaysia, the Philippines, Thailand, Vietnam, Indonesia [465]. An important indicator that gives an understanding of the degree of integration of the country's economy in GVCs are indicators of downward and upward integration. The relationship between the country's downward and upward integration into GVCs is an important element regarding analysis of global value chains. The GVCs participation 
index most reliably takes into account both the downgoing (part of national value added integrated into third country exports) and ascending (part of foreign value added integrated into national exports) component. Most often, the index is expressed as a percentage of the country's exports. For Singapore, respectively, it reaches 65\% ascending and $10 \%$ descending, Malaysia (35\% and 30\% respectively), the Philippines (28\% and $32 \%$ ), Thailand (32\% and 20\%) [466].

The GVCs participation coefficient demonstrates both upward and downward integration of countries, smoothes out noticable differences in foreign value added on different regional models. Regions with lower foreign value added tend to have relatively greater downward component. A vivid example of the developed countries may be the United States of America and Japan.

As for developing countries and countries with transitional economies, the inclusion of downward component helps to mitigate regional disparities. The most noticeable effect is observed in regions and groups dominated by exporters of goods, especially in Africa, as well as in countries with economies in transition and, to some extent, in the least developed countries. Africa and countries with transitional economies have moved from a very low level of foreign value added in GVCs to a global average index. Participation in GVCs, driven by commodity exports, has specific development implications: on one hand, almost all exports transends into national value added; on the other hand, the share of value added obtained from the ascending component is usually rather small in comparison to the cost of the final product.

Let us take into consideration the local inclusion dimension of one of the ASEAN countries in GVCs, and identify the risks for it mentioning the reduction of GVCs due to the current global crisis caused by the global pandemic of COVID-19. In the Philippines, non-equity models are distributed in the form of international subcontracts within the industries like automotive, electronics and clothing manufacturing; contracting soil cultivation in agriculture, both on banana plantations and in the food industry; international franchising of fast food shops and retail stores (including fast service ones); variations like "build-operate-give" agreements and other contracts in infrastructure projects; and management contracts (for example, in international hotel 
chains). Recently, outsourcing of information technology and business processes (ITBPO) has become a leading industry of non-equity models, which are usually carried out on the basis of contractual agreements with foreign companies.

In the Philippines, the world's $36^{\text {th }}$ largest economy and ASEAN's third largest one (after Indonesia and Thailand), non-equity models in all three sectors of economy, i. e. primary, manufacturing and services, have made a significant contribution into the country's economic development. For example, the electronics industry, which accounts for 47 percent of exports, plays a key role in the manufacturing industry, with each of the 258 companies exporting more than US \$ 1 billion annually through 2014-2019. This industry includes semiconductor manufacturing services (73\% of exports) and electronics manufacturing services (27\% of exports). Major global semiconductor manufacturers, such as Samsung (Republic of Korea), Texas Instruments (USA), Toshiba (Japan), NXP (Netherlands) and STMicroelectronics (Switzerland), have manufacturing facilities in the Philippines, and their overseas branches are engaged into operations not only with their parent companies, but also with partners in non-equity models within the country and abroad. Integrated Microelectronics Inc. (IMI), located in the Philippines, is the world's $6^{\text {th }}$ largest provider of automotive electronic services and major supplier for Bosch (Germany), the world's largest automotive component supplier. IMI provides Bosch with automotive, industrial and consumer electronics.

Outsourcing of information technology and business processes has become the strongest and fastest growing sector of the Philippine economy; this area is one of the most efficient industries in the country, generating revenues of $\$ 25$ billion annually. The Philippines attracts not only foreign direct investment (FDI) from large trans-national companies (TNCs) in the field of IT-BPO, but also non-equity forms of international production and trade. Another example is that with the changing lifestyle of consumers, with the growing number of stores and restaurant chains located close to citizens' habitat; foreign companies are entering the Philippine market through franchising: for example, 7-Eleven, the world's largest net of stores, planning to open in the Philippines 1000 stores by the year of 2023. These examples show that NFs are integrated into the economic development and daily life of the Philippines. Table 1 describes the non-equity models 
of production and trade in the Philippines with examples of typical industries representatives.

Table 1

Characteristics of non-equity models (NEMs) of manufacture and trade in the Philippines

\begin{tabular}{|c|c|c|c|}
\hline Form & Content of International Agreement & $\begin{array}{l}\text { Industries of } \\
\text { application }\end{array}$ & $\begin{array}{c}\text { Companies } \\
\text { (as example) }\end{array}$ \\
\hline \multirow[t]{4}{*}{ Subcontracting } & \multirow{4}{*}{$\begin{array}{l}\text { An agreement under which a TNC enters into } \\
\text { agreement with a firm of the host country on } \\
\text { one or more aspects of projecting, processing } \\
\text { or manufacture of products; including } \\
\text { contract manufacturing and design, and } \\
\text { outsourcing of services or business } \\
\text { processes. }\end{array}$} & Electronics & $\begin{array}{c}\text { Integrated } \\
\text { Microelectronics Inc. }\end{array}$ \\
\hline & & $\begin{array}{l}\text { Manufacture of } \\
\text { wearing apparel }\end{array}$ & LHK Creation \\
\hline & & $\begin{array}{l}\text { Automotive } \\
\text { components }\end{array}$ & Yazaki Torres \\
\hline & & $\begin{array}{l}\text { Business process } \\
\text { management }\end{array}$ & $\begin{array}{l}\text { Accenture, } \\
\text { JPMorgan } \\
\text { Chase }\end{array}$ \\
\hline $\begin{array}{l}\text { Contracting } \\
\text { agriculture/ } \\
\text { mining }\end{array}$ & $\begin{array}{l}\text { An agreement between the TNC-purchaser } \\
\text { and the farmers or miners of the host country } \\
\text { (including government representatives) that } \\
\text { sets out conditions for production and } \\
\text { marketing of agricultural and mining } \\
\text { products. }\end{array}$ & Agriculture & $\begin{array}{l}\text { Dole, Del Monte, } \\
\text { Chiquita, Sumifru }\end{array}$ \\
\hline \multirow[t]{3}{*}{ Licensing } & \multirow{3}{*}{$\begin{array}{l}\text { Contractual relations under which TNC } \\
\text { (licensor) grants the firm of the host country } \\
\text { (licensee) the right to use intellectual } \\
\text { property (for example, copyrights, } \\
\text { trademarks, patents, industrial design rights, } \\
\text { trade secrets) in exchange for a fee } \\
\text { (royalties); includes trademark licensing, } \\
\text { product licensing and process licensing } \\
\text { (cross-licensing, in-house licensing). }\end{array}$} & Pharmaceutics & Cathay Drug \\
\hline & & Consumer goods & Licensing Asia \\
\hline & & Electronics & $\begin{array}{l}\text { Dae Kyung } \\
\text { Philippines }\end{array}$ \\
\hline \multirow[t]{2}{*}{ Franchising } & \multirow{2}{*}{$\begin{array}{l}\text { Contractual relations in which TNC } \\
\text { (franchisor) allows the firm of the host } \\
\text { country (franchisee) to run certain business } \\
\text { according to the models developed by the } \\
\text { franchisor in exchange for a certain fee. }\end{array}$} & Retail Trade & 7-11, McDonalds \\
\hline & & Education & $\begin{array}{c}\text { Canadian Tourism \& } \\
\text { Hospitality Institute }\end{array}$ \\
\hline $\begin{array}{l}\text { Contract } \\
\text { management }\end{array}$ & $\begin{array}{l}\text { An agreement under which the operational } \\
\text { control of an asset in the host country is } \\
\text { entrusted to TNC contractor and is carried } \\
\text { out for a certain fee. }\end{array}$ & $\begin{array}{c}\text { Tourism and } \\
\text { hospitality }\end{array}$ & S\&P, SM Hotels \\
\hline Others & $\begin{array}{l}\text { Concessions, leases, transfer agreements, } \\
\text { etc., in the context of public-private } \\
\text { partnerships }\end{array}$ & Infrastructure & GMR Infrastructure \\
\hline
\end{tabular}

Source: developed by the authors based on [467] 
In 2016 peak manufacture and export revenew in the Philippines were reached due to non-equity models ( $\$ 40$ billion and $\$ 32$ billion, respectively). Over the next three years, the figures were slightly lower. In total, $43 \%$ of the country's exports were generated through non-equity models.

Information technology and business processes outsourcing (IT-BPO) is a good example of outsourcing (subcontracting) being one of the most efficient and best ways of activity in the Philippines. It is also the fastest growing industry in the Philippines, generating \$ 25 billion in sales in 2016 and accounting for 8\% of GDP.

The Philippines' furniture industry, which may boast world-renowned designers and more than 5.4 million people in the supply network, is another successful example of subcontracting that demonstrates steady export growth. In 2016, furniture exports increased to 354 million US dollars, which is US 136 million dollars more than in 2012. Although various support programs make Philippines' products even more competitive on the international market; local furniture companies are building part of their competitiveness at the expense of customers and consumers outside the country.

About 30 percent of the Philippines' retail sales come from the retail sales of franchises of foreign yrans-national corporations (TNCs). Among others, the franchise of hardware stores is expanding, so in 2016 the leading operator of branded hardware stores "Philippine Seven Corp." received gross revenue of \$ 652 million and generated assets of \$ 248 million.

International hotel nets operate in the Philippines through management contracts or franchise agreements, or on long-term land leases on which hotels are built through investment project. The country's domestic foreign direct investment policy does not allow foreigners to own private land.

Non-equity models can play a role in reducing the potential jeopardy associated with economic characteristics of the Philippines' external dependence and express critical value to further economic development.

Emphasizing on the prospects for the development of non-equity models of international businesses of both Philippine and other Asian manufacturers through global production and sales networks, it should be noted that they are to correspond to 
the logic of transformation of global production and sales networks [468]. UNCTAD experts attribute their further development to the reduction of GVCs, increasing the concentration of value added in some particular countries that demonstrate the most attractive conditions, and reducing the capital intensity of industries that develop both through the format of investment-equity relations and non-equity models of international cooperation [458].

Taking into account that the largest share of production processes concentrated in the Philippines, being the part of GVCs, are focused mainly on low-tech industries, the negative effects in the short and medium term are going to be manifested in the form of job cuts, reduced share of local national global income. In the long run, the country will have to consider the possibility of import substitution on a larger list of manufacture operations cycle in order to develop national manufacture of finished products and establishment of national brands. 


\subsection{Economic researches of the financial statements of the enterprise to identify the signs of financial insolvency}

Modern economic conditions are characterized by negative trends due to the increase in the number of economic crimes. It is quite difficult to reveal them without carrying out economic expertise, which is considered a necessary instrument for the economy of any country. Without economic expertise, it is impossible not only for the judicial system to function properly, but also for the application of the relevant articles of the Criminal Code, the legislation that regulates the activities of economic entities.

The study of information sources suggests that most research is aimed at identifying violations that occur during transactions of economic and financial nature, and issues of economic examination of financial statements of economic entities are insufficiently investigated. It should be noted that a significant part of violations of economic legislation is committed by accounting staff during the preparation of financial statements. Because of this, financial statements are not only a source of information that comprehensively characterizes the conditions and results of enterprises, but also an important object of economic expertise. This applies to cases where the supervisory authorities have identified violations, various illegal actions in economic activities or trends that have caused or could cause damage to activities; when economic crimes are investigated and economic conflicts between economic entities are considered.

It should be noted that the financial statements together with the primary accounting documents are the subject of economic expertise, if the court or investigation sets the task of the expert to assess the legality of receiving and using budget and credit funds.

During the documents expertise on economic activity of enterprises and organizations, the expert faces tasks related to determining the documentary validity and analysis of indicators of financial condition, structure of assets and sources of their financing; condition and intensity of use of working capital and sources of their acquisition; sources of own funds and results of financial and economic activities; the 


\section{SOCIO-ECONOMIC AND MANAGEMENT CONCEPTS}

reality of settlements with debtors and creditors; economic feasibility of obtaining and using loans and borrowings; costs and prices as factors of financial stability, breakeven. In addition, the auditor-expert must determine the documentary validity of the calculations of the share of property when the participant leaves the founders; targeted spending of budget funds, etc. Such tasks are provided in [483].

The tasks set out the list of issues to be considered by the auditor-expert. They are the definition of the main economic indicators of economic and financial activities and the formation of conclusions on its implementation. The analysis of indicators allows establishing the presence of signs of bankruptcy, fictitious bankruptcy, and hidden bankruptcy. In addition, the expert auditor must find documentary evidence:

- the amount of the contribution of the founders of the enterprise in the formation of the authorized capital and the size of the property to be returned upon withdrawal from their membership;

- the amount of damage suffered from unjustified understatement or nonpayment of rent;

- facts of misuse of public funds received by the enterprise under the budget program;

- the facts that the company has arrears of wages as of a certain date;

- the amount of dividend payments made by the enterprise to the issuer of corporate rights for a certain period, etc.

Examining the forms of financial statement and the indicators presented in them, experts with the help of appropriate methodological instruments of financial analysis study the financial condition, characterize the stability of the enterprise. According to the results of such analysis, the company's financial resources, expediency and efficiency of their use, the level of solvency and profitability of the enterprise, the establishment of economic relations with counterparties are assessed.

Clarification of these aspects is very important in judicial and economic researches on financial insolvency, assessment of the value of the property of the 
economic entity, determining the share of the owner (owners) in it. With the help of this analysis, they study the real financial situations in which the company finds itself and assess the impact of various factors that led to their occurrence. Such factors may be errors or unprofessionalism of the management staff, as well as intentional illegal acts related to the illegal increase or decrease of profits, misappropriation of values, violation of financial, payment disciplines, and legalization of funds obtained by criminal means. Therefore, when conducting an economic examination of the information provided in the financial statements, it is in these cases, the object of study, first of all, are those forms of reporting of the enterprise, which reflect the financial results of its activities and cash dynamics for certain periods.

Domestic enterprises operate in difficult economic conditions, characterized by instability of the macroeconomic situation, fierce competition, lack of sufficient investment, which in many cases can lead the economic entity to a crisis, loss of financial capacity, and subsequent bankruptcy.

The category of "bankruptcy" and some of its types emerged in the XX century. Bankruptcy is understood as the inability of the debtor, recognized by the commercial court, to restore its solvency through the reorganization and restructuring procedure and to repay the monetary claims through the reorganization and restructuring procedure and repay the monetary claims of creditors other than through the application of the liquidation procedure [474]. Depending on the reasons that cause the financial crisis of the enterprise, there are real, fictitious or intentional bankruptcies.

Real bankruptcy arises due to inefficient, unprofitable work and risky operations that lead to catastrophic loss of resources that do not allow the company to carry out successful economic activities.

Fictitious bankruptcy arises as a result of a deliberate declaration by an enterprise of its inability to obtain a deferral of its credit obligations or a discount on the amount of accounts payable.

Intentional bankruptcy of an entity arises as a result of its intentional creation by the manager or the owner of a state of financial insolvency of the enterprise in the 
personal interests or the interests of others through intentional incompetent financial management.

According to the Criminal Code of Ukraine, fictitious bankruptcy, leading to bankruptcy, concealment of persistent financial insolvency and illegal actions in the event of bankruptcy are considered a crime. Fictitious bankruptcy is associated with the concealment, destruction, falsification of accounting documents and other data that reflect its economic activity; concealment of information on the size of the property, its location, transfer of property to another possession, alienation or even its destruction, etc. [475].

The Article 215 of the Commercial Code of Ukraine interprets intentional bankruptcy as a permanent insolvency of a business entity caused by deliberate actions of owners (the owner) of property or officials of the entity, if it caused significant material damage to the interests of the state, society, creditors protected by the law [469].

It should be noted that the Criminal Code of Ukraine (Article 219) details and clarifies the concept of "leading to bankruptcy" and defines the responsibility for bringing an economic entity to such a state. According to this article, "leading to bankruptcy" is a deliberate, for selfish reasons, other personal interest or in the interests of the third parties, the actions of the owner or official of the economic entity actions that led to its stable financial insolvency, if it caused significant material losses to the state or the creditor [475].

Thus, fictitious bankruptcy, intentional leading of an economic entity to bankruptcy, concealment of bankruptcy are considered to be specific offenses prosecuted by law. After all, such illegal types of bankruptcies arise as a result of evil intentions, intentional actions of certain persons with the purpose of non-payment of debts or obtaining a deferral of their repayment, seizing of the property of the entity and changing its management. There are companies that, hiding behind bankruptcy, are trying not to fulfill their obligations to their creditors and, especially, the state.

Bankruptcy can be also used as an instrument of competition. An aggressive investor, having bought up the debts of a certain company, can initiate bankruptcy 


\section{SOCIO-ECONOMIC AND MANAGEMENT CONCEPTS}

proceedings and appoint his own arbitration trustee, through whom he will continue to control the activities and all financial flows of the debtor.

It is worth noting that bankruptcy is associated with both external legal transactions and direct violations of the law - forgery of documents, bribery of officials, concealment of property, etc. Experts often state that the very fact of initiating a bankruptcy case or declaring a company bankrupt is a consequence of incorrect or intentional actions of the management of the debtor company. Therefore, illegal bankruptcy can be called both economically and socially dangerous phenomenon that destroys the market principles of economic activity and is accompanied by certain actions and specific initiators (Figure 1).

To identify the cases of unfair actions in bankruptcy, it is necessary to improve the entire mechanism of bankruptcy, i.e. the methodical, methodological basis used in the study of bankruptcy cases of enterprises. The use of such a mechanism should prevent the intentional creation of a state of insolvency of the enterprise and help to increase the relevant parameters of its economic security.

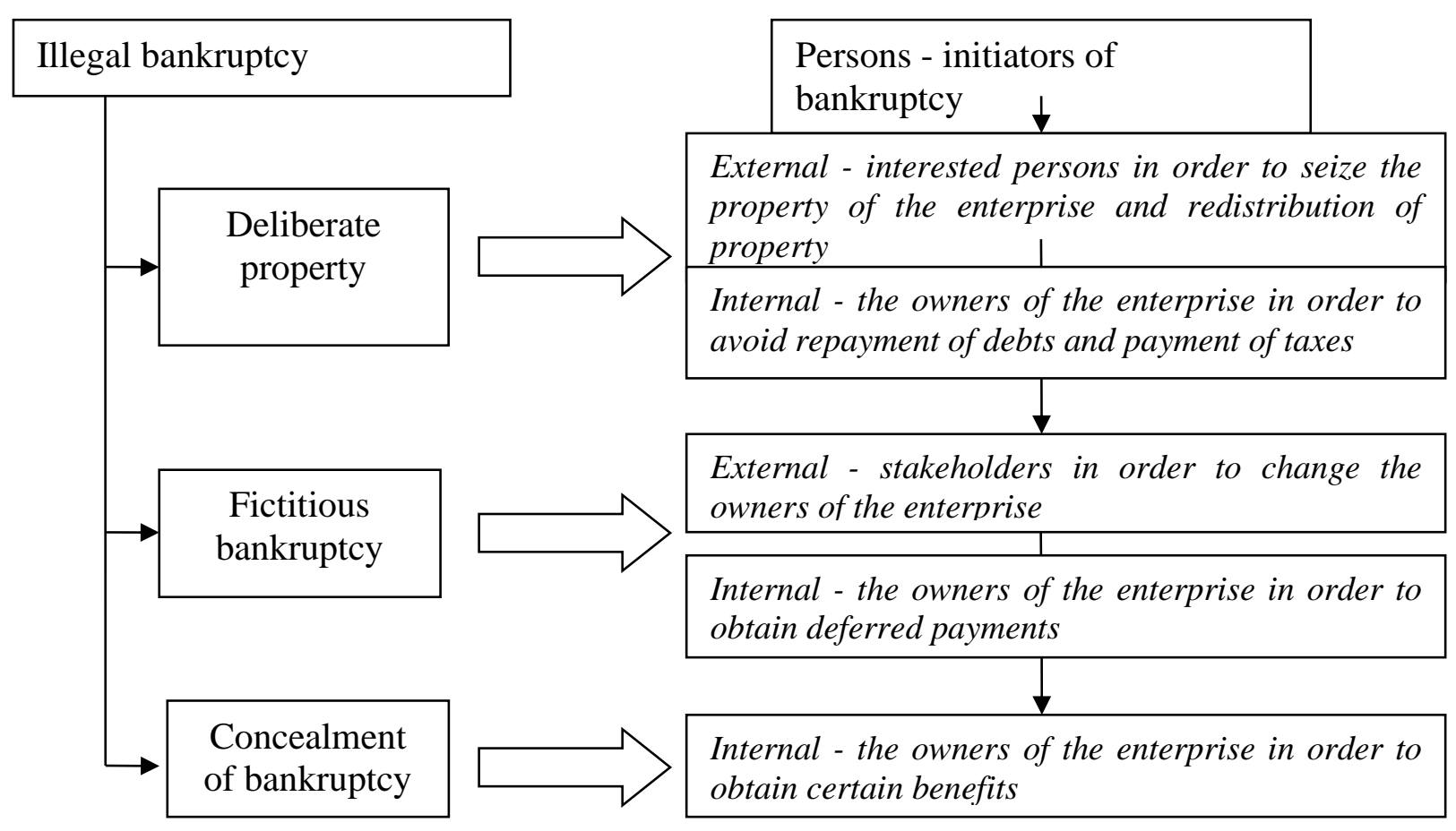

Figure1. Illegal actions in bankruptcy and its initiators

Source: generated by the author 
A necessary component, without which the bankruptcy examination is not conducted, is the analysis of the information provided in the financial statements of the enterprise. This analysis is used to assess the financial condition of the enterprise, identify the changes in terms of space and time that occur in it, identify the factors that caused them, give recommendations for strengthening the financial position of the economic entity. Analysis is not only a method of evaluation, but also a method of predicting the possible direction of development of financial stability of the enterprise. It should be mentioned separately about the role of financial statements in order to assess the financial and economic activities of enterprises for signs of hidden, fictitious bankruptcy or bankruptcy; timely identification of signs of unsatisfactory balance sheet structure to substantiate recommendations and implement preventive measures to prevent bankruptcy. Therefore, the analysis of the financial condition of the enterprise, a careful assessment of the information provided in the forms of financial statements are extremely important for the company itself and necessary for the arbitral trustee, tax authorities, public administration bodies in the study of its activities for the presence of signs of illegal actions that led to bankruptcy.

The study of current methodical approaches according to assessment of the financial condition of enterprises shows that government institutions of Ukraine have some experience in solution of this issue. In particular, the Agency for Prevention of Bankruptcy of Enterprises and Organizations has introduced a Methodology for indepth analysis of the financial and economic condition of enterprises and organizations [485], as well as a Methodology for integrated assessment of investment attractiveness of enterprises and organizations [484].

The Ministry of Finance and the State Property Fund of Ukraine in 2001 approved the Regulations on the procedure for analyzing the financial condition of enterprises that are subjected to privatization [488], and the Ministry of Economy in 2006 - Guidelines for identifying signs of insolvency and signs of concealment of bankruptcy, fictitious bankruptcy or bankruptcy [486].

In 2013, the Ministry of Justice of Ukraine approved the Procedure for analyzing the financial and economic condition of economic entities of state-owned enterprises 
and enterprises in the authorized capital of which the share of state ownership exceeds fifty percent, and preparing conclusions on requests from the court, prosecutor's office or other authorized body about the signs of fictitious bankruptcy, leading to bankruptcy, concealment of persistent financial insolvency, illegal actions in case of bankruptcy [489]. The same ministry in 2014 approved Changes to the Procedure for analyzing the financial and economic condition of economic entities of state enterprises [481].

The study of the above regulations proves that the analysis of the financial and economic condition of economic entities in order to identify signs of fictitious bankruptcy, bankruptcy, concealment of persistent financial insolvency, illegal actions in case of bankruptcy, which is provided by the Procedure [489], is carried out according to the Guidelines [486]. The method of diagnostics of bankruptcy of the enterprises of national economy offered in the specified regulatory legal act together with definition of signs of illegal bankruptcies (fictitious, intentional and hidden) provides carrying out of the analysis of a financial condition of the economic subject in a certain sequence. Let's consider its main directions.

First of all, the main indicators that characterize the activity of the enterprise $\neg$ the object of study for previous periods are studied in order to form a general idea of the prospective trends of its development. These include: general performance indicators; liquidity indicators; indicators of financial stability and profitability (Table $1)$.

Table 1

Indicators of financial condition and algorithm for their determination

\begin{tabular}{|l|l|l|}
\hline \multicolumn{1}{|c|}{$\begin{array}{c}\text { Name of the } \\
\text { indicator }\end{array}$} & \multicolumn{1}{|c|}{ Calculation } & \multicolumn{1}{c|}{ Economic interpretation } \\
\hline \multicolumn{1}{|c|}{ A } & \multicolumn{1}{|c|}{1} & \multicolumn{1}{c|}{2} \\
\hline $\begin{array}{l}\text { Productivity of } \\
\text { the } \\
\text { employees }\end{array}$ & $\begin{array}{l}\text { Net income (revenue) from sales } \\
\text { of products (goods, works) } \\
\text { average number of employees }\end{array}$ & $\begin{array}{l}\text { Shows how much income on average per } \\
\text { employee of the enterprise }\end{array}$ \\
\hline $\begin{array}{l}\text { Own } \\
\text { current assets }\end{array}$ & $\begin{array}{l}\text { Current assets minus current } \\
\text { liabilities }\end{array}$ & $\begin{array}{l}\text { Characterizes the amount of equity aimed } \\
\text { at financing the current assets of the } \\
\text { enterprise (current activities) }\end{array}$ \\
\hline
\end{tabular}


Continuation of table 1

\begin{tabular}{|c|c|c|}
\hline A & 1 & 2 \\
\hline $\begin{array}{l}\text { Current } \\
\text { liquidity ratio }\end{array}$ & Current assets / borrowed capital & $\begin{array}{l}\text { Characterizes the ability of the company } \\
\text { to cover the full amount of its debts } \\
\text { (liabilities) }\end{array}$ \\
\hline Coverage ratio & Current assets / current liabilities & $\begin{array}{l}\text { Characterizes the adequacy of working } \\
\text { capital to cover current liabilities }\end{array}$ \\
\hline $\begin{array}{l}\text { Rapid liquidity } \\
\text { ratio }\end{array}$ & $\begin{array}{l}\text { The amount of cash assets of the } \\
\text { enterprise and receivables / } \\
\text { current liabilities }\end{array}$ & $\begin{array}{l}\text { Shows how much the company can repay } \\
\text { its current liabilities without selling } \\
\text { tangible current assets }\end{array}$ \\
\hline ute liquidity & $\begin{array}{l}\text { Cash assets of the enterprise / } \\
\text { current liabilities }\end{array}$ & $\begin{array}{l}\text { Shows the part of the current liabilities } \\
\text { that the company can repay immediately }\end{array}$ \\
\hline $\begin{array}{l}\text { Maneuverability } \\
\text { of own working } \\
\text { capital }\end{array}$ & $\begin{array}{l}\text { Own current assets / current } \\
\text { assets }\end{array}$ & $\begin{array}{l}\text { Characterizes the degree of coverage of } \\
\text { current assets of the enterprise with its } \\
\text { own financial resources }\end{array}$ \\
\hline $\begin{array}{l}\text { ventory } \\
\text { verage ratio }\end{array}$ & Own current assets / stocks & $\begin{array}{l}\text { Characterizes the degree of coverage of } \\
\text { tangible current assets (sstocks) of the } \\
\text { enterprise by its own sources }\end{array}$ \\
\hline $\begin{array}{l}\text { Coefficient of } \\
\text { financial } \\
\text { autonomy }\end{array}$ & Equity / assets (capital) & $\begin{array}{l}\text { Shows the autonomy of the enterprise } \\
\text { (independence from borrowed funding } \\
\text { sources), the limit value - } 0.5 \text {. }\end{array}$ \\
\hline $\begin{array}{l}\text { Coefficient of } \\
\text { financial } \\
\text { dependence }\end{array}$ & $\begin{array}{l}\text { Capital (balance sheet total) / } \\
\text { equity }\end{array}$ & $\begin{array}{l}\text { Characterizes the level of dependence of } \\
\text { the enterprise on borrowed sources of } \\
\text { funding, the limit value - } 2\end{array}$ \\
\hline $\begin{array}{l}\text { Equity } \\
\text { maneuvering ratio }\end{array}$ & Own current assets / equity & $\begin{array}{l}\text { Shows the mobility of own financial } \\
\text { resources (the share of equity invested in } \\
\text { working capital), the limit value - } 0.1 \text {. }\end{array}$ \\
\hline $\begin{array}{l}\text { Concentration } \\
\text { ratio of the } \\
\text { borrowed } \\
\text { capital }\end{array}$ & Borrowed capital / capital & $\begin{array}{l}\text { Shows the share of borrowed sources in } \\
\text { total funding sources }\end{array}$ \\
\hline $\begin{array}{l}\text { Coefficient of } \\
\text { long-term } \\
\text { investment } \\
\text { structure }\end{array}$ & $\begin{array}{l}\text { Long-term liabilities / non- } \\
\text { current assets }\end{array}$ & $\begin{array}{l}\text { Characterizes the part of fixed assets and } \\
\text { other non-current assets financed by } \\
\text { external investors }\end{array}$ \\
\hline $\begin{array}{l}\text { Long-term } \\
\text { borrowing ratio }\end{array}$ & $\begin{array}{l}\text { Long-term liabilities / amount of } \\
\text { equity and long-term liabilities }\end{array}$ & $\begin{array}{l}\text { Characterizes the share of long-term } \\
\text { liabilities that is used to finance assets } \\
\text { alongside its own financial resources }\end{array}$ \\
\hline $\begin{array}{l}\text { Coefficient of the } \\
\text { structure of } \\
\text { borrowed capital }\end{array}$ & $\begin{array}{l}\text { Long-term liabilities / borrowed } \\
\text { capital }\end{array}$ & $\begin{array}{l}\text { Characterizes the share of long-term } \\
\text { liabilities of the enterprise in borrowed } \\
\text { funding sources }\end{array}$ \\
\hline $\begin{array}{l}\text { Ratio of borrowed } \\
\text { and own funds }\end{array}$ & Borrowed capital / equity & $\begin{array}{l}\text { Shows which amount of borrowed capital } \\
\text { of the company raises for } 1 \text { UAH of own } \\
\text { financial resources }\end{array}$ \\
\hline $\begin{array}{l}\text { Financial leverage } \\
\text { ratio }\end{array}$ & $\begin{array}{l}\text { Equity minus own equity / own } \\
\text { equity }\end{array}$ & $\begin{array}{l}\text { Characterizes the relationship between } \\
\text { borrowed and own sources of financing of } \\
\text { the enterprise }\end{array}$ \\
\hline $\begin{array}{l}\text { The duration of } \\
\text { the financial cycle }\end{array}$ & $\begin{array}{l}\text { The duration of the operating } \\
\text { cycle minus the duration of the } \\
\text { turnover of accounts payable }\end{array}$ & $\begin{array}{l}\text { Characterizes the duration of the cash flow } \\
\text { cycle }\end{array}$ \\
\hline
\end{tabular}


Continuation of table 1

\begin{tabular}{|c|c|c|}
\hline $\mathrm{A}$ & 1 & 2 \\
\hline $\begin{array}{l}\text { The duration of } \\
\text { the operating } \\
\text { cycle }\end{array}$ & $\begin{array}{l}\text { The sum of the duration of } \\
\text { turnover of funds in the } \\
\text { calculations aand tangible } \\
\text { current assets (inventories) }\end{array}$ & $\begin{array}{l}\text { Shows how many days the company needs } \\
\text { to produce and pay for products }\end{array}$ \\
\hline Current solvency & $\begin{array}{l}\text { The amount of long-term } \\
\text { financial investments accounted } \\
\text { for using the equity method, } \\
\text { other long-term financial } \\
\text { investments and monetary assets } \\
\text { borrowed capital }\end{array}$ & $\begin{array}{l}\text { Obtaining a negative result characterizes } \\
\text { the current insolvency of the enterprise }\end{array}$ \\
\hline $\begin{array}{l}\text { Beaver's } \\
\text { Coefficient }\end{array}$ & $\begin{array}{l}\text { Net income in the amount of } \\
\text { depreciation / borrowed capital }\end{array}$ & $\begin{array}{l}\text { Characterizes the emergence of trends in } \\
\text { the formation of an unsatisfactory balance } \\
\text { sheet structure }\end{array}$ \\
\hline $\begin{array}{l}\text { Product } \\
\text { profitability }(\%)\end{array}$ & Gross profit (loss) / cost of sales & $\begin{array}{l}\text { Characterizes the effectiveness of the } \\
\text { main activity of the enterprise }\end{array}$ \\
\hline $\begin{array}{l}\text { Profitability of } \\
\text { activity }(\%)\end{array}$ & Net profit / net income & $\begin{array}{l}\text { Characterizes the effectiveness of sold } \\
\text { products, goods, services provided }\end{array}$ \\
\hline $\begin{array}{l}\text { Return on total } \\
\text { assets }(\%)\end{array}$ & Net income / average assets & $\begin{array}{l}\text { Characterizes the overall efficiency of all } \\
\text { economic resources of the enterprise }\end{array}$ \\
\hline $\begin{array}{l}\text { Return on equity } \\
(\%)\end{array}$ & Net income / average equity & $\begin{array}{l}\text { Characterizes the effectiveness of own } \\
\text { sources of funding }\end{array}$ \\
\hline
\end{tabular}

Then, based on the data reflected in the financial statements of the enterprise (balance sheet, statement of financial performance, statement of equity, statement of cash flows, notes to the financial statements, notes to the annual financial statements (segment information)) the actual values of the above indicators (Table 2) are calculated and their dynamics is studied and compared with normative (theoretically substantiated) values. Based on the results of such a comparison, characteristics of the presence or absence of bankruptcy are identified and a conclusion is formulated (the information is summarized) on the direction of changes and their impact on the solvency of the enterprise. 


\section{SOCIO-ECONOMIC AND MANAGEMENT CONCEPTS}

Table 2

The main indicators of the activity of the enterprise

\begin{tabular}{|c|c|c|c|c|c|c|c|}
\hline \multirow[t]{2}{*}{ № } & \multirow[t]{2}{*}{ Indicator } & \multirow{2}{*}{$\begin{array}{l}\text { Unit of } \\
\text { measure } \\
\text { ment }\end{array}$} & \multirow{2}{*}{$\begin{array}{l}\text { Previous } \\
\text { year }\end{array}$} & \multirow{2}{*}{$\begin{array}{l}\text { Reporting } \\
\text { year }\end{array}$} & \multicolumn{2}{|c|}{ Dynamics } & \multirow{2}{*}{$\begin{array}{l}\text { Normati } \\
\text { ve value }\end{array}$} \\
\hline & & & & & $\begin{array}{c}\text { absolu } \\
\text { te }\end{array}$ & $\begin{array}{c}\text { relativ } \\
\mathrm{e}\end{array}$ & \\
\hline \multicolumn{8}{|c|}{ General indicators of the activity } \\
\hline 1 & $\begin{array}{l}\text { Net income (revenue) from sales } \\
\text { of products (goods, works, } \\
\text { services) }\end{array}$ & $\begin{array}{l}\text { Thousan } \\
\text { d } \\
\text { hryvnias }\end{array}$ & 45484 & 73145 & 27661 & 60,82 & - \\
\hline 2 & Net profit (loss) & $\begin{array}{l}\text { thous. } \\
\text { hrn. }\end{array}$ & 86 & 2271 & 2185 & 2541 & - \\
\hline 3 & Average number of employees & persons & 610 & 627 & 17 & 2,79 & - \\
\hline 4 & Remuneration fund & $\begin{array}{l}\text { thous. } \\
\text { hrn. }\end{array}$ & 12201 & 23222 & 11021 & 90,33 & - \\
\hline 5 & Equity capital & $\begin{array}{l}\text { thous. } \\
\text { hrn. }\end{array}$ & 39144 & 40280 & 1136 & 2,90 & - \\
\hline 6 & Non-current assets & $\begin{array}{l}\text { thous. } \\
\text { hrn. }\end{array}$ & 27515 & 27681,5 & 166,5 & 0,61 & - \\
\hline 7 & Long-term liabilities & $\begin{array}{l}\text { thous. } \\
\text { hrn. }\end{array}$ & - & 1210 & 1210 & - & - \\
\hline 8 & $\begin{array}{l}\text { Short-term loans and } \\
\text { borrowings }\end{array}$ & $\begin{array}{l}\text { thous. } \\
\text { hrn. }\end{array}$ & 2967 & 3538 & 571 & 19,25 & - \\
\hline 9 & Accounts receivable & $\begin{array}{l}\text { thous. } \\
\text { hrn. }\end{array}$ & 4498,5 & 5070 & 571,5 & 12,70 & - \\
\hline 10 & Stocks & $\begin{array}{l}\text { thous. } \\
\text { hrn. }\end{array}$ & 18098,5 & 19578 & 1479,5 & 8,18 & - \\
\hline 11 & Own current assets & $\begin{array}{l}\text { thous. } \\
\text { hrn. }\end{array}$ & 11628,5 & 13808,5 & 2180 & 18,75 & - \\
\hline 12 & Labor productivity & $\begin{array}{l}\text { thous. } \\
\text { hrn.//pers } \\
\text { on }\end{array}$ & 74,6 & 116,7 & 42,1 & 56,43 & - \\
\hline \multicolumn{8}{|c|}{ Liquidity ratios } \\
\hline 1 & Current ratio & & 1,91 & 1,87 & $-0,04$ & $-2,09$ & $>1,5$ \\
\hline 2 & Coverage ratio & & 1,91 & 2,04 & 0,13 & 6,81 & $>1,0$ \\
\hline 3 & Rapid liquidity ratio & & 0,47 & 0,52 & 0,05 & 10,64 & $0,6-0,8$ \\
\hline 4 & $\begin{array}{l}\text { Absolute liquidity ratio } \\
\text { (solvency) }\end{array}$ & & 0,11 & 0,14 & 0,03 & 27,27 & $0,2-0,35$ \\
\hline 5 & Current solvency & & $-11332,5$ & -12723 & -1391 & 12,27 & \\
\hline \multicolumn{8}{|c|}{ Indicators of financial stability } \\
\hline 1 & $\begin{array}{l}\text { Equity concentration ratio } \\
\text { (autonomy) }\end{array}$ & - & 0,76 & 0,74 & $-0,02$ & $-2,63$ & $>0,5$ \\
\hline 2 & $\begin{array}{l}\text { Coefficient of financial } \\
\text { dependence }\end{array}$ & - & 1,33 & 1,36 & 0,03 & 2,26 & $=2$ \\
\hline 3 & $\begin{array}{l}\text { Concentration ratio of borrowed } \\
\text { capital }\end{array}$ & - & 0,25 & 0,26 & 0,01 & 4,0 & $<0,5$ \\
\hline 4 & $\begin{array}{l}\text { Ratio of borrowed and own } \\
\text { funds }\end{array}$ & - & 0,33 & 0,36 & 0,03 & 9,09 & \\
\hline 5 & $\begin{array}{l}\text { Coefficient of long-term } \\
\text { investment structure }\end{array}$ & - & - & 0,04 & 0,04 & - & \\
\hline 6 & Long-term borrowed funds ratio & _ & - & 0,03 & 0.03 & - & \\
\hline 7 & $\begin{array}{l}\text { Coefficient of the structure of } \\
\text { borrowed capital }\end{array}$ & - & - & 0,08 & 0,08 & - & \\
\hline
\end{tabular}


Continuation of table 2

\begin{tabular}{|c|c|c|c|c|c|c|c|}
\hline 8 & $\begin{array}{l}\text { Maneuverability of own } \\
\text { working capital }\end{array}$ & - & 0,48 & 0.51 & 0,03 & 6,25 & $0-1$ \\
\hline 9 & Inventory coverage ratio & _ & 0,64 & 0,71 & 0,07 & 10,94 & $>0,5$ \\
\hline 10 & Equity maneuverability ratio & - & 0,30 & 0,34 & 0,04 & 13,33 & $>0,1$ \\
\hline 11 & Financial leverage ratio & - & 0,33 & 0,36 & 0,03 & 9,09 & $<0,25$ \\
\hline 12 & $\begin{array}{l}\text { The duration of the financial } \\
\text { cycle }\end{array}$ & days & 141 & 97 & -44 & $-31,21$ & \\
\hline 13 & Beaver's ratio & _- & 0,13 & 0,28 & 0,15 & 115,39 & $>0,2$ \\
\hline \multicolumn{8}{|c|}{ Profitability indicators } \\
\hline 1 & Product profitability & $\%$ & 59,8 & 48,0 & $-11,8$ & $-19,73$ & - \\
\hline 2 & Profitability of activity & $\%$ & 0,19 & 3,1 & 2,91 & 1531,58 & - \\
\hline 3 & Return on total capital & $\%$ & 0,17 & 4,14 & 3,97 & 2335,29 & - \\
\hline 4 & Return on equity & $\%$ & 0,22 & 5,64 & 5,42 & 2463,64 & - \\
\hline
\end{tabular}

According to Table 2, it can be stated that all general performance indicators of the analyzed enterprise tend to increase, which should be assessed positively. Thus, revenue (net income) from sales increased by 27661 thousand UAH, or $60.82 \%$. The company received a net profit both in the reporting and in previous years. The volume of positive financial result of the reporting year is 2271 thousand UAH, which is 2185 thousand UAH, or 26.4 times higher than the same period in the previous period.

The average number of employees of the enterprise for two years has increased by 17 people, and the wage fund - by 11021 thousand UAH, or $90.33 \%$. Staff efficiency has also increased. If in the previous year the net income per employee was 74.6 thousand UAH, then in the reporting it was 116.7 thousand UAH, which is 42.1 thousand UAH, or $56.43 \%$ more than the previous period.

It should be noted that the changes in the activity of an economic entity are considered progressive when the growth rate of labor productivity exceeds the growth rate of the average wage. For the researched enterprise, the subordination of these indicators is somewhat different, namely the growth rate of labor productivity is $156.43 \%$, and the average wage is $185.17 \%$.

The amount of own working capital of the enterprise has also increased in dynamics by 2180 thousand UAH, or by $18.75 \%$ and has reached in the reporting period 13808, 5 thousand UAH. This growth is assessed positively, as the amount of 
own financial resources, which the company used to finance its current assets (current activities), has increased.

Regarding liquidity ratios, the current liquidity ratio for both previous and reporting periods is higher than the limit value. It shows how the current assets of the enterprise exceed the total amount of its long-term and current debts (borrowed capital). Within two years, the value of the coefficient decreased by 0.04 points, or $2.1 \%$.

The quantitative value of the coverage ratio for two periods indicates that the company fully mobilizes its current liabilities by mobilizing working capital. The growth of the coefficient in the dynamics and the excess of the actual value over the normative allow us to say that the company is liquid.

Due to cash and repayment of receivables, the company covered $47 \%$ of its current liabilities last year, and in the reporting - 52\%, while the theoretically justified value is in the range from $60 \%$ to $80 \%$.

The dynamics of the absolute liquidity ratio confirms that $11 \%$ of the liabilities of the previous year and $14 \%$ of the reporting company are able to cover immediately. Thus, neither in the past nor in the reporting periods the company has not reached a theoretically reasonable value of the coefficient (20\%-35\%). A negative indicator of current solvency for two years also indicates its current insolvency.

As for the indicators of financial stability of the enterprise, during the analyzed period they have not undergone significant changes.

The coefficient of autonomy characterizes the financial independence, the independence of the enterprise. Thus, from the assessment of its values it follows that $76 \%$ of assets the enterprise formed at the expense of its own financial sources in the previous year, and in the reporting - $74 \%$. Therefore, it can be stated that $24 \%$ of last year's assets and $26 \%$ of the reported were financed by borrowed sources, which is confirmed by the coefficient of concentration of borrowed capital.

The coefficient of autonomy characterizes the financial independence, the independence of the enterprise. Thus, from the assessment of its values it follows that $76 \%$ of the company's assets in the previous year were formed at the expense of its 
own financial sources, and in the reporting - $74 \%$. Therefore, it can be stated that $24 \%$ of last year's assets and $26 \%$ of the reported were financed by borrowed sources, which is confirmed by the coefficient of concentration of borrowed capital.

Opposite in content to the coefficient of autonomy are the coefficients: financial dependence; the ratio of borrowed equity and own equity; financial leverage. The economic essence of all three indicators is the same as they characterize the dependence of the enterprise on borrowed financial sources. Estimation of their quantitative values allows stating that in one hryvnia which was invested in the assets of the enterprise last year borrowed funds amounted to 33 kopecks, and in the reporting year - 36 kopecks. A slight increase in these ratios still characterizes the growing dependence of the company on borrowed capital. A positive aspect should be considered in the context of two periods of actual financial leverage to its regulatory value.

The borrowed capital of the enterprise mainly consists of current liabilities and only in the reporting period it has long-term collateral, which confirms the ratio of the structure of borrowed capital.

Regarding the maneuverability of own current assets, it is at the expense of working capital of the company in the past period formed $48 \%$ of its current assets, and in the reporting this share increased to $51 \%$, respectively, $49 \%$ of current assets in the reporting year the company formed from borrowed funds. Judging by the values of the ratios of inventories with working capital, it is possible to state their growth. In the reporting year the company covers $71 \%$ of its tangible current assets (inventories) at the expense of own financial resources.

The maneuverability coefficient increased during the analyzed period. Thus, last year $30 \%$ of equity was used to finance current activities, and in the reporting period this share increased to $34 \%$, i.e. $64 \%$ of the enterprise's own financial resources were capitalized, namely invested in non-current assets.

The duration of the financial cycle of the reporting year (97 days) is lower than the previous year by 44 days. The period of money diversion from circulation has decreased, which should be assessed positively. 


\section{SOCIO-ECONOMIC AND MANAGEMENT CONCEPTS}

Beaver's ratio is marked by positive changes, so in the reporting period its value (0.28) is slightly higher than the normative (0.2). This trend indicates the formation of a rational structure of the balance sheet and further development of the enterprise.

The data in Table 2 also show that the efficiency of the research enterprise is increasing, because profitability is growing. The only exception is the profitability of products $(48 \%)$, which decreased by $11.8 \%$ compared to the previous year. With the help of methodological instruments of factor analysis it is possible to quantify the possibilities of increasing this indicator and identify the ways of their implementation.

The next stage of the analysis is the research of the dynamics of the property of the enterprise, its structure, as well as the sources of formation by determining the specific weigh of individual items in the balance sheet and assessing the identified changes (Table 3).

Table 3.

Assets of the enterprise and sources of their formation

\begin{tabular}{|c|c|c|c|c|}
\hline Indicators & Previous year & $\begin{array}{l}\text { Reporting } \\
\text { year }\end{array}$ & $\begin{array}{l}\text { Absolute } \\
\text { dynamics }\end{array}$ & $\begin{array}{c}\text { The rate } \\
\text { of change } \\
(\%)\end{array}$ \\
\hline A & 1 & 2 & 3 & 4 \\
\hline $\begin{array}{l}\text { Total assets (thousand UAH), } \\
\text { including: }\end{array}$ & 51915,5 & 54805 & 2889,5 & 105,6 \\
\hline $\begin{array}{l}\text { 1. Non-current assets, (thousand } \\
\text { UAH) in } \% \text { to the value of assets }\end{array}$ & $\begin{array}{r}27515 \\
53,0 \\
\end{array}$ & $\begin{array}{r}27681,5 \\
50,5 \\
\end{array}$ & $\begin{array}{r}166,5 \\
-2,5 \\
\end{array}$ & $\begin{array}{r}100.6 \\
95.3\end{array}$ \\
\hline $\begin{array}{l}\text { 2. Current assets (thousand UAH) } \\
\text { in } \% \text { to the value of assets, }\end{array}$ & $\begin{array}{r}24400,5 \\
47,0 \\
\end{array}$ & $\begin{array}{r}27123,5 \\
49,5 \\
\end{array}$ & $\begin{array}{r}2723 \\
2,5 \\
\end{array}$ & $\begin{array}{l}111,2 \\
105,3\end{array}$ \\
\hline $\begin{array}{l}\text { Total liabilities, thousand UAH, } \\
\text { including: }\end{array}$ & 51915,5 & 54805 & 2889,5 & 105,6 \\
\hline $\begin{array}{l}\text { 1. Own Equity } \\
\text { in } \% \text { to liabilities }\end{array}$ & $\begin{array}{r}39143,5 \\
75,4\end{array}$ & $\begin{array}{r}40280 \\
73,5\end{array}$ & $\begin{array}{r}1136,5 \\
-1,9\end{array}$ & $\begin{array}{r}102,9 \\
97,4\end{array}$ \\
\hline $\begin{array}{l}\text { 2. Borrowed capital in } \% \text { to } \\
\text { liabilities, including }\end{array}$ & $\begin{array}{r}12772 \\
24,6 \\
\end{array}$ & $\begin{array}{r}14525 \\
26,5 \\
\end{array}$ & $\begin{array}{r}1753 \\
1,9\end{array}$ & $\begin{array}{l}113.7 \\
107.7\end{array}$ \\
\hline $\begin{array}{l}2.1 \text { Long-term liabilities in } \% \text { to } \\
\text { borrowed capital }\end{array}$ & - & $\begin{array}{r}1210 \\
8,3\end{array}$ & 1210 & - \\
\hline $\begin{array}{l}\text { 2.2. Current liabilities in\% to } \\
\text { borrowed capital }\end{array}$ & $\begin{array}{r}12772 \\
100 \\
\end{array}$ & $\begin{array}{r}13315 \\
91,7 \\
\end{array}$ & $\begin{array}{r}543 \\
-8,3 \\
\end{array}$ & $\begin{array}{r}104,3 \\
91,7 \\
\end{array}$ \\
\hline
\end{tabular}


The data in Table 3 show that the enterprise's assets and sources of financing increased by UAH 2,889.5 thousand or by $5.6 \%$ during the analyzed period. Both the volume of non-current and current assets is growing, which is a sign of expanding the scale of the enterprise. The growth rate of non-current (111.2\%) exceeds the growth rate of non-current $(100.6 \%)$. This ratio indicates the expansion of the production potential of the enterprise and the acceleration of the turnover of its current assets.

Non-current assets occupy a fairly high share $-50.5 \%$ of total assets of the enterprise, due to the industry characteristics of its operation. The small but still increasing mobility of the economic entity's assets is evidenced by the increase in their composition the share of current assets. Thus, last year the company invested $47.0 \%$ of its capital in current assets, and in the reporting year this share reached $49.5 \%$.

Own equity increased by 1,136.5 thousand UAH. In the sources of asset formation the largest share are the company's own funds - 73, 5\%. During the analyzed period, we observe a decrease of specific weigh of own funding sources by $1.9 \%$.

Borrowed capital is also characterized by an increase in both the absolute amount (1753 thousand UAH) and the share, which in the capital structure increased by $1.9 \%$ and is $26.5 \%$ of all financial sources of the enterprise. There have been some changes in both the composition and structure of borrowed capital. If last year its entire volume was formed only by current liabilities, then in the reporting it was formed also by longterm, which accounted for $8.3 \%$ of borrowed capital.

Then, in the process of analysis and according to the statement of cash flows of the enterprise assess cash flows by type of activity, the dynamics of indicators is studied and the change in cash balance is analyzed (Table 4).

Table 4

Cash flow of the enterprise (thous. hrn.)

\begin{tabular}{|c|c|c|c|c|c|c|}
\hline \multirow{2}{*}{ Indicators } & \multicolumn{2}{|c|}{$\begin{array}{c}\text { Previous } \\
\text { year }\end{array}$} & \multicolumn{2}{c|}{$\begin{array}{c}\text { Reporting } \\
\text { year }\end{array}$} & \multicolumn{2}{c|}{ Dynamics } \\
\cline { 2 - 7 } & $\begin{array}{c}\text { earnings } \\
\langle+\rangle\end{array}$ & $\begin{array}{c}\text { expenses } \\
\ll-»\end{array}$ & $\begin{array}{c}\text { earnings } \\
\langle+\rangle\end{array}$ & $\begin{array}{c}\text { expenses } \\
\langle-»\end{array}$ & absolute & $\begin{array}{c}\text { relative } \\
\%\end{array}$ \\
\hline A & 1 & 2 & 3 & 4 & 5 & 6 \\
\hline $\begin{array}{l}\text { Cash balance at the beginning of } \\
\text { the year }\end{array}$ & 384 & $\mathrm{x}$ & 2495 & $\mathrm{x}$ & +2111 & $+549,74$ \\
\hline
\end{tabular}


Continuation of table 4

\begin{tabular}{|l|c|c|c|c|c|c|}
\hline $\begin{array}{l}\text { Net cash flow from operating } \\
\text { activities }\end{array}$ & 2966 & & 23735 & & +20769 & 700,24 \\
\hline $\begin{array}{l}\text { Net cash flow from investing } \\
\text { activities }\end{array}$ & 92 & & - & 23708 & -23800 & $-25869,57$ \\
\hline $\begin{array}{l}\text { Net cash flow from financing } \\
\text { activities }\end{array}$ & - & 935 & & 2222 & -1287 & $-137,65$ \\
\hline $\begin{array}{l}\text { Net cash flow for the reporting } \\
\text { period }\end{array}$ & 2123 & - & - & 2195 & -4318 & $-203,39$ \\
\hline $\begin{array}{l}\text { The impact of changes in } \\
\text { exchange rates on the balance of } \\
\text { funds }\end{array}$ & & 12 & 809 & & 821 & 6841,67 \\
\hline $\begin{array}{l}\text { Cash balance at the end of the year } \\
\text { Change in cash balance for the } \\
\text { period }\end{array}$ & 2111 & & -1386 & & -3497 & $-165,67$ \\
\hline
\end{tabular}

According to the results of calculations, the enterprise's cash for the reporting year decreased by 1386 thousand $\mathrm{UAH}$, or $55.56 \%$, while in the previous year in the course of its operation the enterprise increased the balance of cash at the end of the period compared to the beginning by 2111 thousand UAH, or 6.5 times.

The activity of the enterprise of the reporting year is characterized by a negative net cash flow (expenditure exceeded their income) in the amount of 2195 thousand UAH, while in the previous year its value was positive and amounted to 2123 thousand UAH (the amount of cash exceeded their expenditure). In particular, cash inflows from operating activities increased significantly, namely by UAH 20,769 thousand, or 8 times. The company spent 23,708 thousand hryvnias on investment needs in the reporting period, while in the previous type of activity cash inflows exceeded expenditures by 92 thousand hryvnias. This fact is evidence of the development of the enterprise and its investment activity. During two years, spending money on financial activities prevails over revenues from it. The negative cash flow from the financial activities of the company is associated with dividend payments and debt coverage, which accordingly affected the performance of its activities. 
This dynamics of cash flows in general positively characterizes the company, because the main source of income is operating activities.

At the same time, the cash balance for the analyzed period decreased by UAH 3,497 thousand, compared to its last year's growth by UAH 2,111 thousand. Let's identify the factors and quantify their impact on the identified dynamics of changes in the cash balance at the enterprise.

The study of the interdependence of indicators reflected in the Statement of Cash Flows confirms that the balance of cash of the enterprise at the end of the period (CB at the end of the period) can be calculated as the sum of cash balance at the beginning of the period ( $\mathrm{CB}$ at the beginning of the period) of the net cash flow for the reporting period (NCF of the reporting period) and the impact of changes in exchange rates (EXR changes).

$C B$ at the end of period $=C B$ at the beginning of period $\pm N C F$ of reporting period $\pm E X R$ changes

Accordingly, the change in the cash balance of the enterprise should be presented in the form of the following factor model:

$C B$ at the end of period $-C B$ at the beginning of period $= \pm N C F$ of reporting period $\pm E X R$ changes

Thus, the dynamics of changes in the cash balance for the analyzed period depends on the net cash flow and changes in exchange rates. Let's demonstrate the above based on the information shown in Table 4.

Reporting period: $1109-2495=(23735-23708-2222)+809$ or $-1386=-2195+809$

Previous period: $2495-384=(2966+92-935)-12$ or $2111=2123-12$

Dynamics during the period: $-1386-2111=(20769-23800-1287)+821 \quad$ or $3497=-4318+821$

Thus, it can be stated that the identified negative dynamics of changes in the balance of cash of the enterprise in the amount of 3497 thousand UAH., decisively affected by the decrease in net cash flow, namely 4318 thousand UAH (UAH 2,195 thousand), while in the previous year it was surplus (UAH 2,123 thousand). The change in exchange rates led to an increase in the cash balance by UAH 821 thousand, which is significantly (68 times) higher than its negative impact of the previous year. 


\section{SOCIO-ECONOMIC AND MANAGEMENT CONCEPTS}

The results of the analysis of cash flows are the basis for assessing the quality of enterprise management . The quality of management of the analyzed enterprise is characterized by the sign of "good", because during the reporting period, net cash flow from operating activities is positive, and from investment and financial is negative. In terms of the negative cash flow from operating activities and positive from investment and financial activities, the quality of enterprise management is assessed by the level of "crisis".

The analysis of the financial condition of the entity also involves assessing the composition and dynamics of its financial results on the basis of information form №2. The required calculations should be shown in the following table (Table 5).

Table5

Dynamics of financial results of the enterprise

(thous. hrn, )

\begin{tabular}{|c|c|c|c|c|c|}
\hline \multirow[t]{2}{*}{ № } & \multirow[t]{2}{*}{ Indicators } & \multirow{2}{*}{$\begin{array}{l}\text { Previous } \\
\text { period }\end{array}$} & \multirow{2}{*}{$\begin{array}{l}\text { Reporting } \\
\text { period }\end{array}$} & \multicolumn{2}{|c|}{ Dynamics } \\
\hline & & & & absolute & relative \\
\hline 0 & A & 1 & 2 & 3 & 4 \\
\hline 1 & Net income (revenue) from sales & 45484 & 73145 & 6707 & 39,41 \\
\hline 2 & The cost of goods sold & 28465 & 49419 & 20954 & 73,61 \\
\hline 3 & Gross profit (loss) & 17019 & 23726 & 6707 & 39,41 \\
\hline 4 & $\begin{array}{l}\text { Financial result from operating } \\
\text { activities }\end{array}$ & 75 & 2139 & 2064 & 2752 \\
\hline 5 & $\begin{array}{l}\text { Income from investment and } \\
\text { financial activities }\end{array}$ & 629 & 1008 & 379 & 60,25 \\
\hline 6 & investment and financial expenses & 202 & 574 & 372 & 184,16 \\
\hline 7 & financial result before tax & 86 & 2573 & 2487 & 2892 \\
\hline 8 & Net profit (loss) & 86 & 2271 & 2185 & 2541 \\
\hline
\end{tabular}

As shown by the data given in Table 5, the activity of the enterprise during the study period is profitable. The net financial result is positive and amounts to UAH 2,271 thousand in the reporting period, which is UAH 2,185 thousand or 26 times its value in the previous period.

The result of the main activity is gross profit. We observe its positive dynamics, namely the growth compared to last year by 6707 thousand UAH, or $39.41 \%$. The operating activity of the enterprise is also profitable. The financial result for this type of activity has increased by UAH 2,064,000, or 29 times. 


\section{SOCIO-ECONOMIC AND MANAGEMENT CONCEPTS}

A negative trend in the operation of the enterprise can be called lower growth rates of income from investment and financial activities compared to the growth rate of their costs $(160.25 \%$ vs. $284.16 \%)$. This makes it necessary to analyze in detail the components of the costs of both investment and financial activities in order to identify specific reasons for their increase.

In general, the dynamics of financial results is assessed positively.

Next, the analytical study of the financial condition of the enterprise is aimed at estimating its operating costs (Table 6).

Table 6

Dynamics of operating costs of the enterprise

thous. hrn.

\begin{tabular}{|l|l|r|r|r|r|r|r|r|}
\hline \multirow{2}{*}{$\begin{array}{l}\text { № } \\
\Pi\end{array}$} & Cost elements & \multicolumn{2}{|c|}{ Previous year } & \multicolumn{2}{|c|}{ Reporting year } & \multicolumn{3}{|c|}{ Dynamics } \\
\cline { 2 - 9 } & & $\begin{array}{l}\text { absolute } \\
\text { value }\end{array}$ & $\begin{array}{l}\text { Share } \\
(\%)\end{array}$ & $\begin{array}{l}\text { Absolute } \\
\text { value }\end{array}$ & $\begin{array}{l}\text { Share } \\
(\%)\end{array}$ & Absolute & $\begin{array}{c}\text { Relativ } \\
\text { e } \\
(\%)\end{array}$ & $\begin{array}{c}\text { Share } \\
\text { s } \\
(\%)\end{array}$ \\
\hline 0 & \multicolumn{1}{|c|}{$\mathrm{A}$} & 2 & 3 & 4 & 5 & 6 & 7 \\
\hline 1 & Material costs & 21836 & 49,59 & 40268 & 48,36 & 18432 & 84,41 & $-1,23$ \\
\hline 2 & Labor costs & 12638 & 28,70 & 25556 & 30,69 & 12918 & 102,21 & 1,99 \\
\hline 3 & $\begin{array}{l}\text { Expenses on } \\
\text { Social events }\end{array}$ & 4633 & 10,52 & 5649 & 6,78 & 1016 & 21,93 & $-3,74$ \\
\hline 4 & Amortization & 1563 & 3,55 & 1824 & 2.19 & 261 & 16,70 & 1,36 \\
\hline 5 & $\begin{array}{l}\text { Other operating } \\
\text { expenses }\end{array}$ & 3364 & 7,64 & 9963 & 11,98 & 6599 & 196,16 & 4,34 \\
\hline 6 & Total & 44034 & 100 & 83260 & 100 & 39226 & 89,08 & - \\
\hline
\end{tabular}

According to the calculations shown in table 6, the operating costs of the enterprise for the reporting year have been to 83,260 thousand UAH, which is 39,226 thousand UAH, or $89.08 \%$ more than the previous year.

Regarding the components of operating costs, we see growth in all elements of costs. It should be noted that "other operating expenses" (296.16\%) and "labor costs" $(202.21 \%)$ grew at the highest rates.

Analysis of the structure of operating costs of the enterprise gives reasons to state that no significant changes have occurred in two years. Both in the reporting and previous years, the largest share was "material costs" - 48.36\%. This cost element significantly affected the dynamics of operating costs in general $(+41.86 \%)$. 


\section{SOCIO-ECONOMIC AND MANAGEMENT CONCEPTS}

When analyzing the financial condition, in order to identify signs of bankruptcy of the company, information about the volume of its net assets and the level of security for obligations is very important. The results of the calculation of indicators are shown in Table 7.

Table 7

Dynamics of net assets of the enterprise

\begin{tabular}{|c|c|c|c|c|c|}
\hline № & Indicators & $\begin{array}{c}\text { Unit of } \\
\text { measurement }\end{array}$ & $\begin{array}{l}\text { At the beginning } \\
\text { of the reporting } \\
\text { period }\end{array}$ & $\begin{array}{l}\text { At the end of } \\
\text { the reporting } \\
\text { period }\end{array}$ & Deviation \\
\hline 0 & $\mathrm{~A}$ & 1 & 2 & 3 & 4 \\
\hline 1 & Net assets & thous.hrn. & 39175 & 41385 & 2210 \\
\hline 2 & Registered capital & thous.hrn. & 25888 & 25888 & - \\
\hline 3 & $\begin{array}{l}\text { Securing the } \\
\text { company's liabilities } \\
\text { with all its assets }\end{array}$ & coefficient & 3,86 & 4,39 & 0,53 \\
\hline 4 & $\begin{array}{l}\text { Securing the } \\
\text { company's liabilities } \\
\text { with its current assets }\end{array}$ & coefficient & 1,86 & 2,22 & 0,36 \\
\hline
\end{tabular}

Estimation of quantitative values of indicators and their changes shows that the level of securing the total debt of the enterprise with all its assets is quite high both at the beginning and at the end of the reporting year. The assets of the company at the end of the reporting period are 4.4 times higher than all its liabilities, which is an important condition for the ability of the company to return them and to continue its activity.

The ratio of current liabilities of the enterprise to current assets (current liquidity) is characterized by positive dynamics; its value at both the beginning and end of the reporting period exceeds the normative (1.5).

The net assets of the enterprise have also increased, namely by UAH 2,210,000, and their value exceeds the amount of the registered capital of the enterprise, which is considered a positive trend.

Thus, on the basis of our analysis of the information reflected in the financial statements of the enterprise (Tables 1,2,3,4,5,6,7), namely the assessment of quantitative values and dynamics of solvency ratios, changes in key balance sheet indicators, evaluation of performance indicators, its functioning, no signs of insolvency have been detected, no crisis phenomena of doing business have been diagnosed, and 
therefore it can be argued that the financial condition of the investigated enterprise is stable.

It should be emphasized that during the examination of the financial condition of the enterprise, the analysis should be preceded by an audit of its financial statements. The results of the analysis, its depth and the necessity to take into account the factors that affect the object of expert research, are largely determined by the objectivity, adequacy of information sources. The reliability of the financial statements is confirmed by the auditor's report, which is the basis for its further use by the expert during the research.

If the results of the analysis of the financial condition of the enterprise recognized its insolvency, it is necessary to assess the factors that caused this condition, to confirm or refute the signs of fictitious, covert or intentional bankruptcy and determine the feasibility of reorganization. The tasks of the analysis in this case will be aimed at substantiating the answers to the possible restoration of the solvency of the debtor company and the sufficiency of its assets to meet its obligations to creditors.

To confirm the accuracy of data on the volume of property of the enterprise an inventory should be conducted, which will identify missing objects of property, as well as estimate its actual value. If there is a certain probability that the economic entity is intentionally brought to bankruptcy, or the bankruptcy is fictitious, then the actual value of the property may differ significantly from the book value.

The analysis of the debtor company is conducted for the previous three years, which precede the bankruptcy proceedings [474]. There are cases when the activities of the debtor company at the beginning of the analysis are not yet characterized by signs of financial insolvency. In the case of intentional or fictitious bankruptcy, the process of implementing invalid bankruptcy schemes may be in the preparatory stage before initiating bankruptcy proceedings. Then, the task of the analysis will be not only to diagnose the presence or absence of facts of intentional, fictitious bankruptcy, but also in identifying appropriate procedures for preparing the company for it. At the same time, it becomes necessary to conduct a detailed analysis of activities for any period if 
there is a suspicion that the company currently has signs of illegal actions that caused its bankruptcy.

Estimation of coefficients of solvency of the enterprise in dynamics gives the bases to find out the moment of its loss. In the case of instant bankruptcy, the period of sharp decline in economic activity of the enterprise must be analyzed quite carefully. Namely, it is necessary to find out the reasons for bankruptcy and identify them for the presence of intentions by stakeholders.

It is also important to conduct a detailed analysis of the effectiveness of the enterprise which helps to identify irrational actions that could lead to a crisis situation. Thus, the detection of inefficient financial agreements, financial investments in unfavorable conditions, indicates certain signs of illegal actions regarding the bankruptcy of the enterprise.

The signs of illegal actions in bankruptcy can be called:

- reduction of assets required for operating activities. If the share of property required for the specified activity of the enterprise (the main source of cash flow) decreases, it may be a sign that it does not plan to operate in the future;

- excess of the turnover of receivables over accounts payable. The ability of the enterprise to use loans longer than to allow it to do so to its obligors (debtors) is evidenced by the higher turnover rate of receivables compared to the turnover rate of accounts payable;

- artificial increase in accounts payable to "their" creditors by paying fines, reimbursement. An increase in the volume of this component of borrowed capital in significant amounts can cause bankruptcy of the enterprises;

- reduction of net income (revenue) from sales of goods, works, services and increase in other costs (administrative, other operating expenses);

- growth of costs due to the facts of writing off receivables. In a situation of intentional or fictitious bankruptcy, significant amounts of the reserve for doubtful debts may indicate the withdrawal of property;

- transfer of liquid property into illiquid, alienation of property which is important for operating activities; 
- payment of fictitious transactions. Evaluation of such agreements is an important task of the expert, because such operations indicate the withdrawal of enterprise property;

- withdrawal of assets into the registered capital of the newly created economic entity. Any financial investment in the period preceding the bankruptcy proceedings is questionable;

- sale or lease of non-current assets on deliberately unfavorable terms (transfer of such components of assets as collateral for much less credit, loans). Therefore, agreements concluded on deliberately unfavorable terms are subjected to detailed analysis;

- the use of economic resources for purposes not related to the development of the enterprise (fictitious costs of research and development, etc.);

The listed characteristics are found at calculation and studying of dynamics of the coefficients considered by us, estimation of structure of balance of the enterprise, carrying out the factor analysis of the change of its indicators.

It should be noted that the amount of information contained in the financial statements may not be sufficient to draw a conclusion on the presence or absence of signs of illegal bankruptcy. Then, the expert must provide all the necessary information data (registers of analytical, synthetic accounting, financial information, agreements, etc.) regarding the debtor company. After conducting a detailed analysis and its results, a conclusion is formulated on the presence or absence of signs of illegal bankruptcy. If during the previous periods illegal actions which could become the reason of bankruptcy of the enterprise have been revealed, then on the basis of an estimation of character of infringement it is possible to define type of bankruptcy concerning each separate case. 


\section{3 Фінансова глобалізація в контексті сучасного розвитку світової економіки}

Розвиток сучасних економік світу створює відповідні умови для їх спільної характеристики. Глобалізація - це результат розвитку продуктивних сил, інтернаціоналізації всіх сфер суспільного життя, встановлення безпосередніх сталих зв'язків між суб'єктами різних країн, унаслідок чого виробничий процес в одній країні стає складовою частиною процесу, який відбувається в інтернаціональному і світовому масштабах. Світова економіка стає єдиним ринком і виробничою зоною з національними та регіональними секторами, а не просто сукупністю національних економік, що розгортають взаємне економічне співробітництво [495].

Досліджуючи питання сучасного розвитку світової економіки, необхідно також враховувати iï поточний стан та інші глобальні проблеми. Особливу значимість це набуває в контексті проблематики пандемії COVID-19 та відповідних негативних впливів на макроекономічні показники.

Міжнародний валютний фонд порахував, що глобальна економіка у 2020 році зменшилася на 3,5\% через коронакризу та очікує зростання у 5,5\% в 2021 році у зв'язку з початком вакцинації від COVID-19. Про це йдеться в січневому 2021 року огляді світової економіки World Economic Outlook [496].

Економічний спад виявився менш глибоким, ніж очікували експерти фонду. Ще в жовтні 2020 року прогнозувалося падіння в 4,4\% , але економічна динаміка в другій половині року виявилася більш активною. Незважаючи на це, обвал у 2020 році став найбільшим за багато років. Для прикладу, в 2009 році через світову фінансову кризу падіння становило тільки 1,7\%

Падіння відбулося у всіх великих економіках, за винятком Китаю. Іспанія на $11,1 \%$, Великобританія - на 10,0\%, Італія - на 9,2\%, Франція - на 9,0\%, Індія на $8,0 \%$, Канада - на 5,5\%, Німеччина - на 5,4\%, Японія - на 5,1\%, Росія - на 3,6\%, США - на 3,4\% тощо. 


\section{SOCIO-ECONOMIC AND MANAGEMENT CONCEPTS}

Прогноз на 2021 рік також покращений, - тепер зростання глобальної економіки очікується на рівні 5,5\%, а не 5,2\%, як раніше. Більш оптимістичний прогноз базується на тому, що економічна активність буде збільшуватися завдяки вакцинам і додатковим програмам стимулювання в окремих великих країнах. Темпі зростання будуть значно відрізнятися між країнами залежно від доступу до медичної допомоги, дієвості державної підтримки, впливу вторинних ефектів і структурних характеристик економіки на початок кризи. Прогноз на 2022 рік залишився без змін - зростання на 4,2\%.

Основні прогнозні показники щодо динаміки ВВП по країнам світу представлені в Таблиці 1.

Таблиця 1.

Прогнозні показники ВВП в 2020-2022 pр., річні зміни в \%*.

\begin{tabular}{|c|c|c|c|}
\hline & $\mathbf{2 0 2 0}$ & $\mathbf{2 0 2 1}$ & $\mathbf{2 0 2 2}$ \\
\hline Світ в цілому & $-3,5$ & 5,5 & 4,2 \\
\hline Розвинуті країни & $-4,9$ & 4,3 & 3,1 \\
\hline $\begin{array}{c}\text { Країни з ринком, що } \\
\text { формуєтья, та } \\
\text { країни, що розвиваються }\end{array}$ & $-2,4$ & 6,3 & 5,0 \\
\hline
\end{tabular}

* Джерело: складено автором за даними: IMF. World Economic Outlook: Policy Support and Vaccines Expected to Lift Activity. - International Monetary Fund. - Janиагу 2021. - P.4. - [Електронний ресурс]. - Режим доступу: https://www.imf.org/en/Publications/WEO/Issues/2021/01/26/2021-worldeconomic-outlook-update.

Світові економічні і політичні процеси підштовхують розмежування між заможними i бідними країнами. Це призводить до зменшення центрів економічної і політичної могутності в світі та їх певної стабілізації. Зважаючи на процеси загальної глобалізації з їх усіма перевагами та недоліками, треба визначити вагому їх складову - фінансову глобалізацію. При тому, що фінансова глобалізація досить нова 3 точки зору розвитку людства, західні фахівці відносять їі зародження до 60-х рp XX ст, коли почалися процеси активного розвитку торгівлі, міграції та руху капіталу [497]. 
Зараз фінансова глобалізація активно розвивається у світі. Фінансова глобалізація відображає процес руху фінансових ресурсів за межами державних кордонів. А окрім безпосереднього руху фінансових ресурсів, фінансова глобалізація охоплює також сукупність відносин, що пов'язані з формуванням, акумулюванням та використанням фінансових ресурсів, не зважаючи на існування державних кордонів.

Фінансова глобалізація є багатогранним процесом, який має як позитивні, так і негативні впливи на розвиток людства. Причому, як і оцінка процесу загальної глобалізації, фінансова глобалізація має неоднозначний (позитивний або негативний) вплив на різні країни, залежно від міри їх економічної розвиненості та політичного впливу в світі.

У межах фінансової глобалізації інформаційні технології, до мінімуму знижуючи витрати на здійснення конкретних операцій і ціну входу на глобальні фінансові ринки, знищують ці перешкоди, усуваючи тим самим і перешкоди для будь-якого стійкого поділу цих ринків.

Формування єдиних загальносвітових ринків у фінансовій сфері, i поступова інтеграція глобальних ринків різних фінансових інструментів в єдиний світовий фінансовий ринок, ставить на порядок денний питання про виникнення глобальних монополій як наслідок фінансової глобалізації.

Фінансова глобалізація має певні небезпеки як для розвинутих країн, так і для країн, що мають невисокий економічний рівень розвитку. Існують реальні небезпеки фінансової глобалізації: по-перше, небезпека глобальних фінансових криз; по-друге, небезпека підриву суверенітету країн 3 невисоким рівнем розвитку з причин боргової та іншої фінансової залежності; по-третє, розрив рівня фінансового i, в цілому економічного, розвитку окремих країн; почетверте, фінансове підпорядкування країн із невисоким рівнем розвитку з боку розвинутих країн; по-п'яте, фінансиалізація культурних та інших нематеріальних цінностей. Ці небезпеки є досить серйозними небезпеками в глобальному аспекті. 


\section{SOCIO-ECONOMIC AND MANAGEMENT CONCEPTS}

Фінансова глобалізація характеризується низкою напрямків, які дозволяють як поєднати національні особливості окремих країн та стерти бар’єри між ними, так і навпаки, підкреслити саме національні особливості окремих країн та регіонів. Все це характеризується такими напрямками як: використання єдиних фінансових інструментів як засіб уніфікації економічного розвитку; формування фінансових центрів у процесі цивілізаційного розвитку; можливості використання Україною негативів та позитивів фінансової глобалізації.

Вся сукупність економічних відносин, яка пов'язана 3 фінансовою глобалізацією - формуванням, рухом та використанням фінансових ресурсів за межами національних кордонів держав - має досить жорсткі уніфіковані правила розвитку. При цьому, використання інструментів формування фінансових ресурсів, їх руху та використання, відкидає будь-які національні особливості і робить їх однаковими незалежно від регіональних, країнових, релігійних та інших особливостей. При цьому, все, що може залишатися особливого, не $\epsilon$ принциповим для фінансової глобалізації. Національні та інші особливості, що пов’язані інструментами формування, руху та використання фінансових ресурсів можуть зберігатися на напівофіційному або тіньовому рівнях [498].

Розвиток економік різних країн світу свідчить про те, що однією 3 головних проблем є знаходження адекватного місця в глобалізаційних процесах. У свою чергу, вплив визначальних складових частин кризової економіки ставить під сумнів можливості пошуку такого місця за допомогою звичайних «некризових» засобів.

Водночас саме кризовий розвиток економіки виступає як поштовх для пошуку нових нетрадиційних шляхів максимізації позитивних впливів глобалізації та мінімізації негативних.

Характеризуючи сучасну світову економіку в контексті глобальних фінансових дисбалансів, треба зазначити, що актуальність даної проблематики обумовила не лише необхідність їі теоретичного й практичного переосмислення, а й поставила на порядок денний масштабніші завдання. Адже кінець ХХ початок XXI століття характеризується вкрай неоднозначними і динамічними 
процесами, наростаючим хаосом та порушенням стійкості i рівноваги у фінансовій сфері, й в інших сферах економічного життя. Саме на цей період припадає зростання фінансових новацій i створення нових фінансових інститутів, поява віртуального капіталу і перетворення компаній в основний об’єкт ринкових спекуляцій. У результаті цих трансформацій світова економіка втрачає здатність до створення матеріального багатства і реальної вартості, час від часу впадаючи у кризу і депресію. За таких обставин реструктуризація геофінансового простору має визначатися зміщенням вектору від фінансових спекуляцій до збалансованого розвитку реальної економіки [499].

Звичайно, рівень розвитку національних економік та визначення їх розміру характеризуються багатьма іншими факторами, але наш предмет дослідження також має відповідний вплив.

Потрясіння світової економіки не мають однозначного впливу на Україну. Серед позитивів можна визначити те, що так чи інакше західний капітал працюватиме з Україною, хоч умови і принципи такої роботи, зазвичай, зазнають змін. До негативів можна віднести історичні умови такого потрясіння - зараз країни Заходу більш зациклені «самі на собі», а не на пошуку можливостей роботи з ризикованими ринками, до яких відноситься і Україна. В будь-якому випадку, Україна не може і не буде відігравати провідну роль у процесі розподілу економічного впливу в світі. При тому їй вкрай необхідно знайти своє оптимальне місце 3 тим, щоб мінімізувати негативні впливи фінансової глобалізації на своє майбутнє.

Дії фактично єдиної наддержави в межах фінансової глобалізації дозволяють США захопити ініціативу i самостійно вибирати час, сферу i характер конкурентної боротьби, що в результаті надає їм перевагу. 3 точки зору конкуренції з країнами Західної Свропи, США мають певні переваги. При першому розгляді перспектив такої конкуренції, що грунтується на зіставленні наявних запасів ресурсів, безумовно переважними уявляються шанси Європи. Однак зіставлення в динаміці, з урахуванням різного рівня витрат, зростаючої ролі найбільш сучасних технологій і фактично природної монополії США на 
володіння ними та на їх розвиток, примушує в довгостроковій перспективі зробити висновок на користь США.

Конкуренція між США та зоною євро може мати відчутні негативні наслідки не лише в межах фінансової глобалізації, а й у масштабнішому сенсі. При цьому можлива втрата або принаймні консервація найбільш передових технологій: у разі перемоги єврозони - оскільки вона традиційно має проблеми 3 їх створенням, у разі перемоги США - через різке стиснення ринків продажу і реалізацію цих технологій, що послабить стимули їх розробки і зменшить ресурси, що залучаються на ці цілі.

3 точки зору фінансової глобалізації, Україна не є країною, яка може характеризувати прогресивні рухи загальноекономічних та безпосередньо фінансових процесів. Більше того, враховуючи динаміку та основні характеристики сучасного світу, Україна знаходиться на узбіччі світових фінансових процесів.

Якщо врахувати те, що перспектив вступу у зону євро в будь-якій перспективі в України немає, країні залишається знайти місце в процесі конкурентної боротьби між США та зоною євро, чи, принаймні, спробувати пом'якшити впливи такої конкурентної боротьби на власний економічний i політичний розвиток.

Все це повною мірою характеризує фінансову глобалізацію. $Є$ досить відомий перелік проблематики, який охоплює національну фінансову сферу. Тут і проблеми вибору структури валютних резервів країни, і створення необхідної фінансової інфраструктури, і виконання умов для заохочення іноземних інвестицій в Україну. Потоки фінансових ресурсів просто обходять Україну, використовуючи так би мовити добре відомі обхідні шляхи.

Україні важко знайти своє місце в процесі суперечностей «Великої сімки» [500]., враховуючи всю складність зовнішніх чинників і зовнішню залежність. Бажання підтримувати однакові рівні відносини з усіма країнами «Великої сімки», не дозволяє враховувати їх суперечності для досягнення національних інтересів та грати на таких суперечностях. 
Рівень інтегрованості до міжнародних економічних відносин виступає як деякий бар'єр для розповсюдження негативних наслідків кризових явищ та потрясінь у світі. Проблеми інтеграції України і міжнародні економічні відносини мають досить особливу, внутрішню сторону.

Досить торкнутися однієї з складових проблем інтеграції до міжнародних економічних відносин - рівня зрілості фінансового ринку. Розвиненість фінансового ринку на національному рівні $є$ необхідною умовою для розвитку інтеграційних процесів у ринок світовий. Так, зокрема, загальновідомий показник ринкової капіталізації внутрішнього ринку дозволяє не лише давати оцінки конкретним ринковим секторам, а й використовувати динаміку цих показників при стосунках 3 іноземними кредиторами - як міжнародними фінансово-кредитними установами, так і приватними інвесторами. Теж саме можна казати й про формування та динаміку розвитку національного фондового індексу.

Традиційні труднощі з залученням в Україну іноземних інвестицій. Навіть, не зважаючи на наслідки наведених подій, сфера залучення іноземних інвестицій $\epsilon$ вкрай вразливою сферою в Україні. Існуючий стан процесу залучення іноземного капіталу в економіку України не дозволяє стверджувати про ефективність його надходження. Оцінюючи ситуацію в сфері залучення іноземного капіталу, слід відзначити, що загальна маса іноземних інвестицій в Україні, що нагромаджена протягом останніх років, $є$ невеликою.

Враховуючи параметри соціальної статистики, а також рейтинги різних міжнародних організацій, ставлення до держави не може швидко змінитися. Імідж України в світі ще довго зберігатиметься як ризикової держави 3 непередбачуваним розгортанням політичної й економічної ситуації.

На жаль, процес трансформації в Україні затягнувся: якщо порівняти Україну з країнами Центральної й Східної Свропи, то, звичайно, ці країни мають зовсім інші - набагато більш позитивні - економічні показники. Це стосується й того, як розвивається їхній національний капітал, і як вони працюють із 
іноземними інвестиціями. А Україна все ще знаходиться в пошуках того, як стати на рейки ефективного розвитку.

Україна продовжує закріплюватися як об’єкт, а не як суб’єкт міжнародних політичних та економічних відносин. Це також не дозволяє використовувати в національних інтересах суперечності країн «Великої сімки».

Можливості використання досвіду розвитку інших країн є вкрай важливим для України як для визначення її поточного місця в світі, так і для можливостей максимального використання позитивних впливів фінансової глобалізації та мінімізації впливів негативних. 


\section{SECTION 11. MECHANISMS OF REGULATION OF THE ECONOMY}

\subsection{Evolution of scientific understanding of "rural development" in the context of the concept of organizational and economic mechanism of rural development}

In Ukraine, the problems of rural development are quite actively studied, because rural areas in the conditions of rural economy growth, diversification of production and economic activities, improvement of social conditions in the countryside are the main object of national development. Rural areas are complex spatial natural resources, production and economic, social formations, the main function of which is to ensure harmonious development in the system "environment - population - development", first of all, needs to clarify the conceptual apparatus, which has many design features, depending from the context of its use. Rural territory, as a system, has two driving forces - the desire to survive (to ensure the stability of existence) and the desire to develop (self-improvement). Therefore, we consider it necessary, first of all, to explore the essence of the category of "development" as a basis. Despite a respectable history of research, questions about the nature of the development of systems (including economic) remain uncertain and largely debatable in both philosophical and economic aspects.

According to the explanatory dictionary of the Ukrainian language "...development - the process of growth, development, scope, prosperity, prosperity, movement, progress, progress" [1, T4 p. 20]. More broadly, the meaning of the definition of "development" reveals the "Great Economic Dictionary", according to which it is: "... the process of natural change, the transition from one state to another more perfect; transition from the old qualitative state to the new, from simple to complex, from lower to higher "[502, p. 962].

To our mind, the most complete interpretation of the definition of "development" can be found in the philosophical encyclopedic dictionary: "Development - an irreversible, directed, natural change of material and ideal objects; one of the general types of communication "[503, p.555]. 
It should be noted that development is a complex concept, which, first of all, means the directed, irreversible movement of the object (subject), the change of its qualitative state, the connection - the transition between states; secondly, it is a prerequisite for growth. "Development" as a philosophical and general scientific category is the opposite of "unchanging existence." At the same time, "development" affects "being" as a certain process, that is, being is a prerequisite for development, and development is inherent in being.

A significant contribution to the study of the definition of "development" was made by ancient scientists, who understood "development" as cyclical re-changes, the constant emergence of something exceptionally new and irreversible. Heraclitus claimed: "Everything that has always existed, is and will be an eternally living fire, which over time then erupts brighter, stronger, then goes out" [504, p. 31].

In his works, Aristotle highlighted his own general philosophical positions based on the analysis of the development of forms in wildlife. The philosopher asserted: "development - is the realization, the disclosure under the action of the ultimate goal of those trends that were originally laid down in a living being, thus reducing development to a set of quantitative changes, to repeat once and for all [505, p. 54].

"Negative development", a kind of regression was first introduced by Plato [506, p. 620]. In the Middle Ages, the definition of "development" was defined as a temporal orientation from past to future [507].

Scientific research on the essence of the definition of "development" can be traced in the works of the classics of German philosophy. Summarizing the philosophical and general scientific interpretation of the definition of "development", it should be noted that the basis of "development" are quantitative and qualitative changes, which are characterized by multidimensionality, direction and irreversibility. Thus, the general scientific concept of the definition of "development" has a deep philosophical rationale, which is constantly evolving. The very philosophical basis served as a meaningful content of most interpretations of development in the works of foreign and domestic scholars [505, 508, 509].

From the moment when economics became an independent science, various 
approaches to the interpretation of the definition of "development" began to be constantly improved. That is, under the influence of objective factors, the category of "development" begins to be studied in economics. The definition of "development" as an economic category is an extrapolation of the general scientific understanding of the definition of "development" to the objects of economic science.

The issue of long-term economic development was given considerable attention by mercantilists, in particular J. Stewart (representative of late mercantilism), in his study of the principles of political economy (1767) noted that the desire to be first and natural advantages talent - the factors of economic development and growth of countries [510]. Aspects of the development and growth of nations were studied by Adam Smith, who established the classical tradition in economics.

Based on the ideas of Hegel, the definition of "development" in economics was introduced by K. Marx and F. Engels [511, p. 128-129]. K. Marx stated: "In no sphere can there be development that does not deny its former form of existence" [511, p. 128]. Ideas of development are reflected in the works of V. Lenin: [512, p. 55].

It is advisable to pay attention to the study of "development" as a general economic category of J. Clark [513]. The interpretation of economic development by J. Clark was the basis for modeling development at the macro level in the 60-70-s of the twentieth century. In particular, he identified the main factors of economic development (moral, technological) and identified five driving forces of "economic development" - new equipment or production technology (the point of view coincides with the opinion of J. Schumpeter), change of organizational forms, population growth, capital accumulation in monetary or material form, change in the structure of consumption [513, p. 142, 651]. Schumpeter conducted a study of the definition of "development" as a general economic category in the context of innovation. $\mathrm{He}$ considered important not only the factors, but also the way of combining them [514, p. 184]. The universality of this approach is that it is effective at both macro and micro levels.

Thus, the study of "development" in the economy began with the analysis of economic cycles at the macro level. The first developments in economic dynamics, its 
causes, etc. belong to M. Kondratiev, K. Zhuglyar, D. Kitchina, V. Mitchell and A. Spithof, S. Kuznets.

Thus, in the twentieth century, the definition of "development" is actively used in the economy, initially at the macro level. Thus, in the 60's and 70's it was widely used in probabilistic models of economic equilibrium and economic dynamics (models of Gale, Arrow, J. von Neumann). By the way, interesting and useful are Keynesian (J. M. Keynes, R. Harrod, M. Hansen, E. Domar), neo-Keynesian J. Mead, T.V. Swan, R. Solow, E. Denison) and historical-sociological theory of growth (W. Rostow, E. Madison), but the definition of "development" was considered in them in part, because growth is a component of development, not synonymous with it.

The main thing, in our opinion, is that the provisions of these theories led to the implementation of biological theory of evolution in the economy, according to which the basis of development in economics is the existence of dialectically opposite, but complementary processes - variability and selection.

Studies of the definition of "development", including in the form of economic growth, continue today, both foreign and in the works of domestic scientists. The number of publications on development issues is growing exponentially. Usually, they have different interpretations of the definition of "development", which indicates the lack of a single definition. Different interpretations of its essence are due to the historicism of scientific thought and the purpose of research, setting goals and objectives, ideas that each scientist has their own.

Thus, "development" as a general economic category should be understood as a complex long-term process in the economy associated with the qualitative transformation of the whole set of economic and social structures of society, in particular, all elements of its productive forces and economic relations. at the same time meeting social needs. However, it should be remembered that "development" is non-monotonous and includes not only progressive directions, but also degradation (which can later be replaced by progress or lead to the collapse of the system), and destructive.

The process of development is a set of three sub processes: chaos, ordering and 
stabilization. All components of this process play a special role and are therefore important for the development of any system. Despite the long process of scientific and applied research, the interpretation of the concept of "rural development" remains multivariate and debatable.

When studying the "development of rural areas", it is worth remembering that the rural area as an open system is an organized set of components (potential, business processes, rural population, education, culture, health, information and population and business, etc.), which inherent relative integrity, multifunctional, hierarchical organization, as a result of which the rural area is characterized by certain structure and dynamics, which affects its functioning and development. In view of the above, "rural development" will be understood as the transition to a new state due to irreversible, directed, natural changes in equipment, technology, labor organization and management.

Rural territory as a system is both in the process of functioning and in the process of development. These processes are non-linear, interdependent, interconnected and interdependent, which creates an inseparable connection and interpenetration. However, the "functioning of the system" is the implementation in time and space of its function (purpose, role), given by the environment of the system.

That is, the definition of "development" is distinguished by such characteristics as irreversibility, direction, regularity of change. Therefore, the development of rural areas should be considered as a result of the synergistic effect of the manifestation of these properties. Accordingly, the process of "functioning" reflects only the activities to achieve a specific goal, and the process of "development" involves the production of new goals depending on changing conditions, as well as to create conditions for the transition from one goal to another. That is, the process of functioning is part of the process of development, and the latter, in turn, determines the radical transformation of rural areas as a system. Thus, the nature of change in the rural area and its surroundings determines the essence of the processes of growth, functioning and development.

Thus, the development of rural areas as an economic category contains the 


\section{SOCIO-ECONOMIC AND MANAGEMENT CONCEPTS}

following important components: movement, process, change. Characteristic signs of development are also irreversibility, direction (orientation) and regularity. It is irreversibility that provides variability and protects against permanence and repetition. Orientation (orientation), as a characteristic feature of rural development, ensures the emergence and accumulation of changes that subsequently lead to the emergence of a new quality - from descending to ascending; from old to new; from simple to complex; from accidental to necessary (regular) [515, p. 55]. Thus, the development of rural areas is due to the necessary properties - irreversibility (irreversibility), orientation (direction) and regularity becomes systemic.

Analyzing the process of "rural development", it should be noted that this is a continuous process, unlimited in time. Ensuring the "development of rural areas" should be carried out through an organizational and economic mechanism, which is a set of methods and means of action of subjects and objects of rural areas. That is why it is important to clarify the nature and components of the organizational and economic mechanism of rural development, as the mechanism is characterized by a finite set of elements and relationships between them, which occur through the appropriate levers of system-forming regulators.

It should be noted that the number of publications on the formation of "organizational and economic mechanism of development" is growing exponentially. However, note that the most complete definition of "organizational and economic mechanism" by L. Hurwitz, R. Myerson, E. Maskin (Nobel Prize winners in economics for "fundamental contribution to the theory of design of economic mechanisms", 2007). In particular, L. Hurwitz under the "organizational and economic mechanism" considers a set of choices of economic entities, each of which is associated with some result [516].

It should be noted that the organizational and economic mechanism of rural development is much broader than economic laws and forms of their manifestation, as it covers, in addition to basic, and superstructure relations, namely - legal, political, ideological, moral, psychological, ethical and others that are effective and affect the basis. 
As part of the organizational and economic mechanism of rural development, such objects as state-legal, economic-legal, administrative-executive, state, municipal and economic management, self-government, self-government, etc. should be distinguished by independent objects. At the same time, it can be argued that each of these industries (systems or subsystems of economic activity) has its own structure of the mechanism, because the quintessence of the mechanism and the conditions of its operation follow from the economic interests of different social groups in rural areas. space for socio-economic development. For example, the target orientation of the economic mechanism and the set of its levers is formed taking into account the interests, influence on them, management of interests and through interests, the realization of economic interests, the set of which is the driving force of rural development. By means of the organizational and economic mechanism transformation of entrance conditions (reproductive potential) of rural territories into desirable processes - development is carried out, influence on factors is provided. The driving force of environmental factors is aimed at the organizational and economic mechanism of rural development;

However, it should be emphasized that in the implementation of integration choices in the state and efforts to ensure the development of rural areas of Ukraine, the style of any type of organizational and economic mechanism depends on the presence of signs and level of development of the state. The mechanism should take into account the possibility of introducing three system-forming regulators (key components which represent the most effective levers of influence, namely: regulatory, organizational, cognitive-informational), however, formed on the principles of implementing a process approach to rural development management.

Thus, the issue of formation and implementation of an effective organizational and economic mechanism for the development of rural areas as a socio-ecological and economic system and the development of economic entities on them is particularly relevant. In view of the above, it can be argued that: first, the functioning of the organizational and economic mechanism of rural development (as well as any nature of the system-forming regulator), includes a combination of two components: 
organizational, which involves the formation of a system of various institutions that have organizational influence on rural areas; economic - tax system, financial policy, investment activities, etc; secondly, we believe that the organizational and economic mechanism of rural development - is a holistic entity with a clear structure subsystems, which form it into two basic blocks (organizational and economic), between which there is a system of stable interdependencies. That is, destructive transformations of one component can cause the destruction of another and, as a consequence, the whole mechanism, and vice versa.

Thus, the main goal of the formation and implementation of organizational and economic mechanism of rural development in modern conditions is to ensure the quality of services, competitiveness of rural areas, replenishment of rural communities, attract foreign investment, increase effective demand of rural population, increase rural employment, historical and cultural resources and improving the quality of internal infrastructure. 


\subsection{Entrepreneurial adaptation of public utilities: Ukrainian experience}

Water supply and sewerage companies are both consumers and suppliers of renewable natural resources. They form a single system of raw materials and resources transformation into the final product and service they provide to consumers. The «industrial vertical» is formed, which combines different production phases of raw material extraction, processing, supply of finished product and provision of services for its use and release of the consumer from waste products sold by water supply and sewerage enterprises in the following separate technological stages: rise (water intake), purification of source water to drinking quality, transportation by water mains to the city networks, supply and water distribution to the consumer, drainage, wastewater treatment and discharge.

The formed vertical integration of most enterprises of water supply and sewerage (WSS) can be developed in two directions [517, 519]:

- connection of hydraulic structures (canals, reservoirs, dams) as sources of raw materials - back integration;

- diversification of services and consumption - forward integration (additional market proposals and services diversification).

Both areas of vertical integration require additional (significant) investment, however, the balance of potential commercial benefits of the enterprise can be changed. In the first case - by changing the cost of the main product. In the second - by increasing the range of sales and services.

As a rule, one of the main motives for vertical integration is the desire to expand the business in connection with the managerial "drift" of the enterprise or the stabilization of the market situation and the inability to increase market share. In such situations, the company no longer has the opportunity to grow "in width" and decides to use growth "in length". In Fig.1. classical schemes of entrepreneurial adaptation, including integration and diversification for WSS enterprises, are presented [518].

As a rule, one of the main motives for vertical integration is the desire to expand the business in connection with the managerial "drift" of the enterprise or the 


\section{SOCIO-ECONOMIC AND MANAGEMENT CONCEPTS}

stabilization of the market situation and the inability to increase market share. In such situations, the company no longer has the opportunity to grow "in width" and decides to use growth "in length".

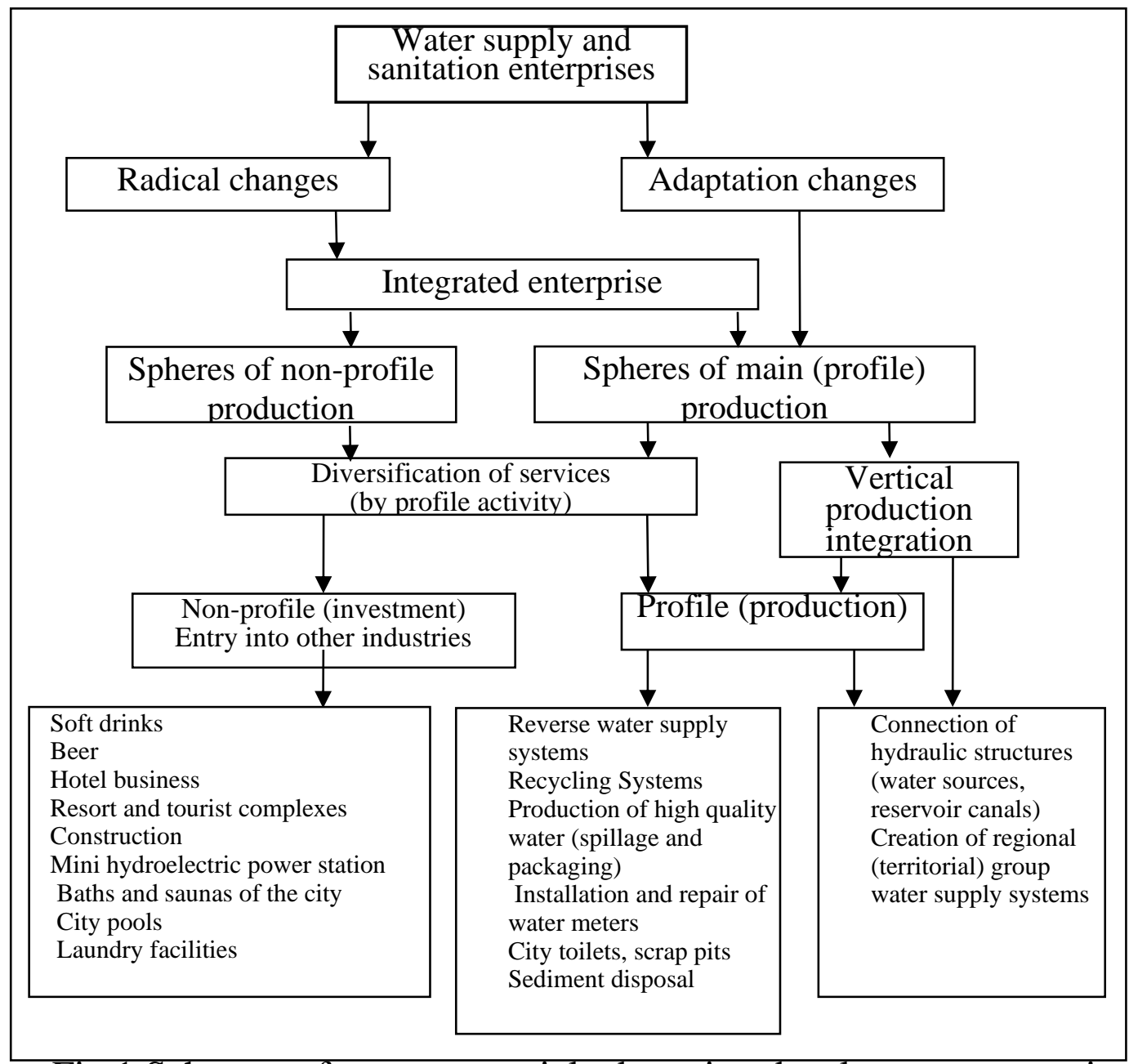

Fig.1.Schemes of entrepreneurial adaptation development strategies for the WSS enterprises

When choosing an organizational and management strategy of entrepreneurial adaptation and elimination of the causes and consequences of economic insolvency should based on analytical data (including marketing research), the provisions of the organizational project or business restructuring plan, choose a targeted, detailed position on the diversification of activities. Undoubtedly, the chosen policy of diversification of products, services, investments (loans) will affect the composition and nature of non-core enterprises created (allocated) in the structure of the integrated enterprise. 


\section{SOCIO-ECONOMIC AND MANAGEMENT CONCEPTS}

As non-core enterprises, the creation of which in the course of integration is expedient from a commercial point of view, we can mention the following examples. In the category of industrial diversification [517-518]:

- Enterprise for electricity generation on the basis of mini hydropower plants;

- Enterprise for installation, repair and verification of meters;

- Enterprise for the design, installation, commissioning and maintenance of water purification systems at consumer facilities, or city pumping stations;

- Enterprise for preparation and sale of water of increased purification (improved quality), including bottling (the form of realization "from wheels" and booths) and bottled (possibly packaged), through a trade network;

- Sludge disposal plant;

- Enterprises of alternative water supply of separate consumer zones (alternative sources, other legal and organizational forms).

In the category of loan diversification [517-518]:

- Investment company for the production of soft drinks;

- Investment company for the arrangement of sanatoriums, tourist areas and cultural facilities, water supply and drainage systems of increased comfort and development of engineering infrastructure;

- Investment company for the creation of revolving water supply systems and regeneration of the consumed product;

- Investment company for the provision of household and repair services. Integration of non-core enterprises on the basis of diversification of the main activity allows to achieve the maximum synergetic effect from use of the basic and auxiliary means (industrial and office areas, land areas, means and communication lines, computer and electric networks, repair, shop, transport and other elements of engineering infrastructure). In addition, using the internal economic mechanism of the corporation, non-core enterprises, as well as enterprises of the main production areas, will be able to use the services of the management of the parent company, gain access to integrated logistics and intellectual resources of the corporation. 


\section{SOCIO-ECONOMIC AND MANAGEMENT CONCEPTS}

There is another powerful prerequisite for the successful operation of non-core enterprises - is their participation in the formation and implementation of corporate policy, as part of and under the protectorate of which they will operate in the regional market, developing new segments, opening new potential [517-518, 520].

Measures to adapt the management system designed to achieve investment attractiveness and attract private investment should have entrepreneurial direction. This means that managerial adaptation measures, in addition to organizational and economic improvements and transformations, should include models of possible forms of public-private interaction that can lead to investment in reforms and strategic development.

The ultimate goal of such an entrepreneurial management adaptation (EMA) is:

- improvement of management accounting;

- organization of management functions and processes;

- introduction of innovative control methods;

- interpreted operational information and analytical support;

- modeling of public-private forms of interaction, ie achieving the conditions of investment attractiveness due to available resources, development and implementation of opportunities dependent on the enterprise.

Most EMA measures are aimed at improving the management of relevant areas of potential, in general, perform, by various means, but one task - to prevent and protect the resource potential of the enterprise from negative influences and loss of resistance to the destructive effects of regular objective challenges $[517,520]$ :

1. The economic condition of the modern market;

2. The natural state of the environment, the subjective conditions of the management crisis.

Creation in the management system of enterprises a set of organizational, methodological, informational conditions for timely detection and assessment of threats, analysis and development of reactive measures and their translation to management for operational decisions on production or commercial maneuver is very 
important. Thus, the meaning of EMA is not only the choice (although it is important) of the nomenclature of appropriate measures to improve the management system of enterprises, but also the necessary setup and implementation in a particular enterprise with all its features.

That is, behind the implementation of these measures is the need to develop them in the format of a comprehensive organizational project. This primarily applies to organizational modeling and reengineering of selected processes, outsourcing and diversification, creating an integrated information and analytical management system, resource monitoring subsystem, controlling implementation, modernization of transactional subsystems, enterprise restructuring, modernization projects.

In fig. 2. The main measures of EMA to overcome the influencing potential factors of the WSS enterprises are presented.

Thus, the most important strategy of the integrated complex of entrepreneurial adaptation is the strategy for reforming the management system, the principle part of which is the strategy of entrepreneurial development and the design of effective forms of public-private partnership. 


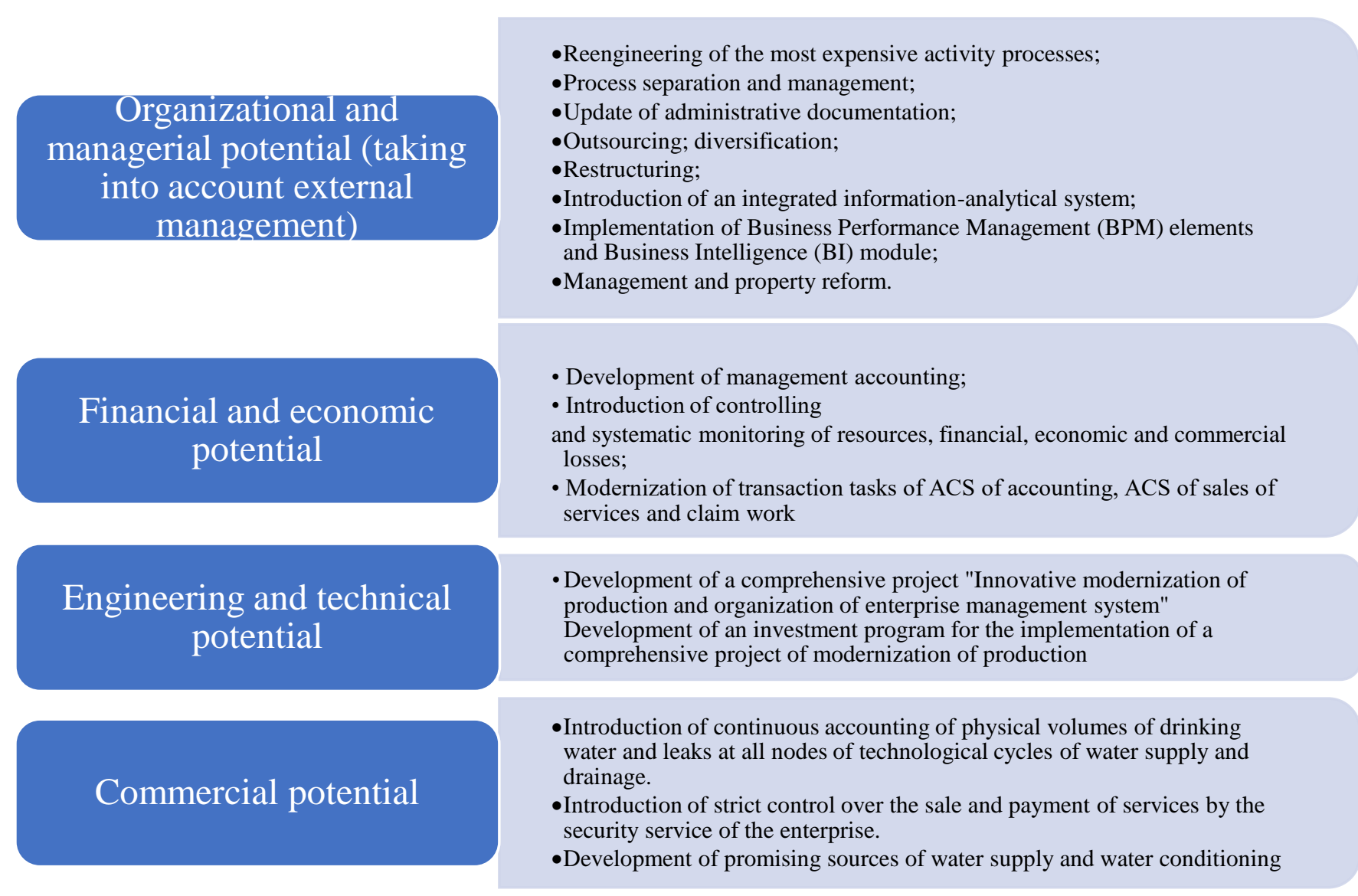

Fig. 2. EMA measures to overcome the potential influencing factors of the WSS enterprises

Sstrategy of adaptation market changes in the provision of services, if pursued for the purpose of not radical but adaptation changes in production activities, consists of a profile strategy and a strategy for vertical integration. The strategy of entrepreneurial adaptation of the management system includes: a strategy for the development of business intelligence of the management system, strategy of reengineering of information and analytical support, strategy of entrepreneurial reform. 


\subsection{Mechanism of state regulation of the environmental taxation effectiveness in the context of national security}

The modern ecological-economic and organizational-technological level of social production, as well as the achievement of scientific and technological progress do not allow to some extent to ensure socio-ecological and economic security of natural resources utilization at all hierarchical levels of spatial development (national, regional and local). Therefore, the costs for preventing environmental pollution and compensating for the negative consequences in the territorial and spatial dimension, as well as in different sectors of the economy are objectively determined and acquire the status of socially necessary costs that must be taken into account and regulated at different hierarchical levels. A constructive tool for solving the problem of rational use of natural resources and reducing the level of environmental pollution is the system of environmental taxation and natural resource payments, which should ensure and achieve the parameters of national social, environmental and economic security.

Strategic guidelines for the state regulation of environmental taxes effectiveness and natural resource payments in the format of their target functions require a certain effective assessment in relation to macroeconomic indicators of environmental spatial development. Strengthening strategic content in the system of national security of spatial development determines the need to assess the impact of the "shadow" economy on threats to environmental security, and this necessitates a hypothetical assessment of shadow "failures" in the system of state environmental regulation of spatial nature management. Ultimately, the mechanism of state regulation should be aimed at increasing the fiscal, regulatory (motivational), stimulating role of environmental taxation and, thus, ensuring implementation of the necessary environmental measures for national security in spatial and time dimensions.

Theoretical and methodological platform for the formation of the taxation and natural resource payments system as a tool for environmental regulation of natural resource utilization and environmental protection in the context of national security is presented, in particular, in [521 - 526]. The substantive basis and methodology for 


\section{SOCIO-ECONOMIC AND MANAGEMENT CONCEPTS}

determining environmental taxes and natural resource payments; features of application of ecological taxation in Ukraine; directions and mechanisms for improving the current system of environmental taxation and natural resource payments, taking into account foreign experience are investigated in these works.

The analysis of scientific publications [521-529] on this issue showed that the formation of strategic guidelines for the state regulation of environmental taxation in the format of implementing the target functions of environmental taxes, as well as in the context of existing socio-environmental and economic challenges to national security. An integrated approach to the regulation of environmental taxation also requires the indicators system formation to assess the environmental taxes effectiveness. The stimulating role of environmental taxes in the motivational systems for the environmental measures implementation is also insufficiently determined.

The mechanism of state regulation of the environmental taxation effectiveness, primarily related to the rethinking of socio - economic development policy on various conceptual bases (in particular, sustainable development, "blue", "green" economy, spatial development) [527]. This is, of course, necessary for the implementation of strategic and tactically balanced measures to "green" production and a more effective environmental taxation system. The primary basis for the environmental taxation regulation can be seen in the synthesis of all components of political processes of national security policy, as well as the use of various mechanisms and economic organizational tools of various kinds (including institutional, economic, environmental and economic, socio - environmental). It, in turn, in particular, will affect the formation of the business environment in all sectors of the economy, which will be more conducive to the effective implementation of the target functions of economic taxes in different sectors of the economy.

It should be noted that the measures to regulate the environmental taxation effectiveness are not the number of administrative and economic methods and the creation of regulatory mechanisms, but it is the presence of an effective strategy for creating a favorable business environment - "sensitive" (flexible) to effective 
environmental taxation from the perspectives of motivational factors for the environmental measures implementation.

The system of environmental taxes implementation requires assessment and regulation of budget, resource and time constraints, taking into account the specifics of national security actors. Mechanisms for achieving economic, energy, social and environmental security through the implementation of appropriate policies should ensure the maximum level of national security.

Strengthening the strategic content also requires proposals for the formation of a budgetary and time constraints system for the further environmental taxes implementation and the assessment of their target functions. It is also necessary to take into account the significant impact of the "shadow" economy on threats to environmental security, and this necessitates a hypothetical assessment of shadow "failures" in the state environmental regulation system of spatial management. Ultimately, environmental regulatory mechanisms should aim to increase the incentive role of environmental taxation and thus ensuring implementation of the necessary environmental measures.

Consider the essential and substantive mechanism of state regulation of environmental taxation implementation as a comprehensive system.

A comprehensive mechanism of state regulation of environmental taxation is a holistic and balanced set of organizational and economic forms, which are implemented in the form of sub - mechanisms, tools and technologies for organizing, regulating and coordinating the environmental taxation implementation in the context of sustainable development and national security.

Taking into account the existing general provisions of the economic mechanism theory [528-531] the target function of the complex mechanism of state regulation for environmental taxes implementation is to coordinate socio - ecological - economic, financial-economic, ecological - economic and social interests of all stakeholders, as well as to resolve emerging contradictions in the national security system in the context of sustainable development. Thus, the appropriate level of greening the production and 
national security, taking into account the environmental component, as well as the public good reproduction.

The main tasks of state regulation mechanism for the implementation of environmental taxation from the standpoint of national security as follows:

1. Ensuring national security (in particular, economic, environmental and energy) on the basis of environmentally sustainable development through the regulation of the system of relations between taxpayers and the state.

2. Ensuring the effective implementation of targeted functions of environmental taxation.

3. Establishment and legal regulation, collection of environmental taxes (rates, structures, entities, objects of taxation and benefits).

4. Formation of the necessary budgetary environmental funds for the greening management on a business basis at different hierarchical levels of spatial development (national, regional and local) in the context of national security.

Taking into consideration the existing general principles of economic management, the formation of the economic mechanism and the state regulation system of environmental and economic development, the principles of the state regulation mechanism for the environmental taxes implementation are as follows [532]:

1. The principle of organizational and institutional regulation of environmental tax regulators. It means normative and legislative regulation of environmental taxation processes.

2. The principle of scientific validity of ecological and economic management of taxation in the national security system. This principle, in particular, provides for the scientific support of a balanced environmental taxation system.

3. A systematic approach to environmental and economic management of taxation in the context of sustainable development principles and ensuring environmentally oriented national security. The systematic approach involves the relationship of economic, environmental and social parameters at different hierarchical levels of sustainable management. 
4. The principle of structure and the need for diversity [529, p. 83-84]. Structuring the mechanism is related to the functional and target orientation of its subsystems (submechanisms), and also determines the analytical basis for the effectiveness assessing, efficiency of environmental tax regulators to ensure national security on an environmental and economic basis. The need for a variety of subsystems of the mechanism is determined by the budgetary, fiscal, environmental, economic and social guidelines for the tax regulators management.

5. The principle of functional integration, specialization, universalization and centralization of the environmental taxes implementation based on the technological approach to the subjects of national security.

6. The principle of environmentally oriented stimulation, motivation of balanced management, nature protection (ecological) activity through the environmental taxation system. This involves, in particular, expanding the production greening on a business basis, improving the environmental quality to ensure environmentally friendly national security. It will also help budget resources savings in terms of centralized financing of environmental measures and reduce funds for management and control measures.

7. The principle of strategicity. This principle presupposes taking into account the sectoral features of sustainable development by the subjects of national security, taking into account the interests and needs of future generations in economic and socioenvironmental measures to ensure national security. Here, too, timeliness in preventing eco-destructive trends in the development of economic entities is important. The principle of strategicity is connected with the further development of entrepreneurial initiatives for the rational use of budgetary resources in the system of state regulation of the environmental taxation implementation.

8.The principle of developed and balanced responsibility, which is realized in the form of economic, legal, social and environmental responsibility for the results of environmental taxation implementation.

Formation of functional and target structure of the regulation mechanism for environmental taxes implementation is carried out on the basis of the analysis of the 
existing concept of matrix (block) functional and target structure of the economic mechanism, the management mechanism of industrial, social and economic processes, and also the nature management (Fig. 1).

The result-target subsystem outlines the goals (sub-goals-tasks), the implementation of which should be ensured by the system of environmental taxes implementation in accordance with the program directions of production greening, implementation of sustainable management in the context of environmentally oriented national security. Within this system, in particular, determine the eco-taxation system effectiveness in accordance with its target functions and the formed environmental funds at different levels of spatial development, as well as directly and the budgetary resources utilization (e.g., environmental measures, functioning the existing ecotaxation system and its development in accordance with the timeframes of the introduction of new tax regulators).

As part of the mechanism for regulating the environmental taxation implementation, the leading system is a functional subsystem, which is divided into general-functional and special-functional. 
SOCIO-ECONOMIC AND MANAGEMENT CONCEPTS

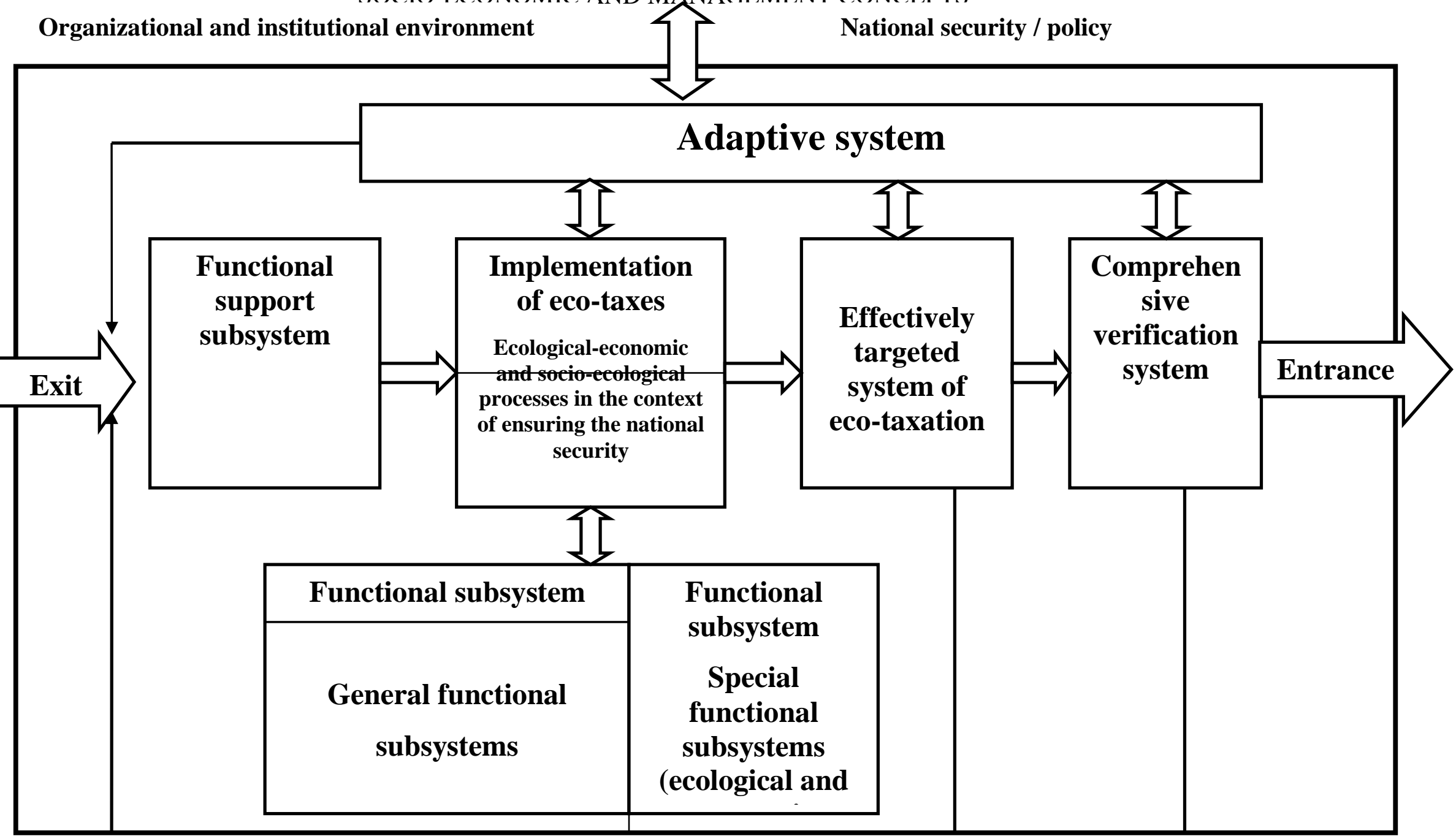

Figure 1 Mechanism of state regulation of the environmental taxes implementation in the context of national security $[10 ; 12]$ 
The general-functional subsystem is connected mainly with realization of the basic traditional functions of environmental management: forecasting, planning and programming; regulation; organization; stimulation; motivation; coordination; analysis, accounting, control and controlling, functional.

The special-functional subsystem is mainly related to the implementation of environmentally oriented management system (ecosystem and ecological), which provides with environmental and economic technologies. Environmental and economic technologies provide an opportunity not only to track environmental, economic, market, business and social characteristics and trends in the use of environmental taxes, but also to take into account their impact on sustainable management in the context of environmentally friendly national security through the feedback. Environmental and economic technologies related to the functioning mechanisms of socio-environmental and economic responsibility, environmental marketing and audit, management of environmental and economic knowledge, they are needed as constructive tools (submechanisms) for the effective environmental taxes implementation.

The proposed functional-target structure of the mechanism for regulating the implementation of environmental taxation provides a supporting subsystem, which consists of regulatory, financial, informational, logistical, and staffing of the mechanism for regulating the environmental taxes implementation. This subsystem should be focused on the rational use of resources and this requires a proper assessment of budgetary resources effectiveness with an emphasis on achieving the maximum parameters of national security.

The purpose of the adaptation subsystem of the state mechanism for regulating the implementation of environmental taxation is to form the "flexibility of the mechanism" in accordance with the requirements and principles of sustainable development in the context of national security and environmental and economic interests of stakeholders. The constituent elements of the adaptation subsystem can be as follows: environmentally oriented monitoring systems (in particular, pollution, state regulation of environmental taxation, waste accumulation); ecological and economic 
analysis (primarily to diagnose relevant problems in environmental taxation and environmental protection).

The formation of the verification subsystem is primarily relevant in connection with the introduction and need for further development of the environmental taxation system. From these perspectives, this system may include the following main components: eco-audit and audit of eco-taxation; social audit. Ultimately, this subsystem should answer the question of whether it is appropriate to spend a certain budgetary resources amount for the implementation of environmental tax regulators.

Thus, all elements of the environmental regulation system should be comprehensive and be both stimulating (motivational) tools for greening production and the basis for the formation of environmental funds at different hierarchical levels of spatial development.

In general, the scope of state regulation of the environmental taxation system should include: determining the list of taxes, their rates and collection procedures; redistribution of mobilized financial resources in the process of determining priority funding objectives; targeted use of mobilized financial resources [533, c. 14].

Taking into account the existing problematic situations and proposals for reforming the environmental taxation system in Ukraine [532-535], emphasis is placed on the main principles on which the mechanism for establishing and collecting environmental taxes should be based:

- use of two types of tax payment standards, firstly, within the permissible (including temporarily agreed with environmental authorities) volumes of emissions and discharges of harmful substances, and, secondly, for exceeding the permissible level of pollution;

- taking into account the qualitative composition of emissions and discharges when setting tax rates as well as the severity of the environmental situation in the competitive region [535];

- granting territorial communities the right to adjust tax revenues for nature management entities taking into account the environmental protection measures implementation; 
- accumulation of funds in nature protection and their target use under the control of territorial communities.

Thus, the current unsatisfactory state of national socio-ecological and economic security of spatial development indicates the environmental taxation system inefficiency. This necessitates the formation of strategic guidelines for the state regulation of environmental taxation in the context of assessing the effective implementation of the main target functions of environmental taxes (in particular, fiscal, regulatory and incentive). A systematic assessment of the environmental taxation effectiveness requires appropriate macroeconomic analysis, as it forms the basis for strategic guidelines for achieving environmentally sustainable spatial development. The proposed system of ecological and economic indicators for assessing the effectiveness of the main functions of eco-taxes implementation is a necessary information and analytical basis for substantiation of strategic management decisions. 


\section{4 Державне регулювання та принципи забезпечення фінансової складової економічної безпеки України}

Фінансово-економічна криза, катаклізми, пандемія постали черговим викликом світовій цивілізації, спричинивши невизначеність перспектив глобальної та національної економік, активізувала пошук шляхів модернізації суспільних систем та вирішення проблем спільними зусиллями держав. Все це пов'язано із тими глобальними змінами на світовій арені, що відбуваються останнім десятиліттям та масштабами розмаху їх впливу на весь світ.

Так, у вересні 2015 року у Нью-Йорку відбувся Саміт Організації Об’єднаних Націй зі сталого розвитку, підсумковим документом якого «Перетворення нашого світу: порядок денний у сфері сталого розвитку до 2030 року» було затверджено 17 Цілей сталого розвитку, таких як: подолання бідності, досягнення продовольчої безпеки, сприяння поступальному, всеохоплюючому та сталому економічному зростанню тощо [536]. Результатом цього Саміту та широкомасштабного процесу адаптації Цілей сталого розвитку з урахуванням специфіки українських реалій, було розроблено Національну систему, що складається iз 86 завдань національного розвитку та 30 вересня 2019 року їі закріплено Указом Президента України «Про Цілі сталого розвитку України на період до 2030 року» [537].

Цей значний для України крок, став поштовхом до активного впровадження на національному рівні відповідних управлінських рішень, законодавчих та нормативно-правових актів, направлених на реалізацію цілей і завдань Цілей сталого розвитку. Не оминуло це і основний об’єкт управління держави - національну безпеку та їі складову - національну економіку та як результат - затвердження Національної економічної стратегії України на період до 2030 року. Безумовно усі ці поступові зміни в державі не $є$ лише зобов’язаннями чи бездумним слідуванням світовим тенденціям. Адже ці тенденції є як ніколи актуальними у час глобальної пандемї, економічної та політичної нестійкості. Не останнє місце у нестабільності країни займає затяжна агресія з боку Російської Федерації та досить активне використання економічних 
методів боротьби. I це не лише економічні санкції, але й застосування енергетичного тиску на українську економіку будівництво «Північного потоку2», блокування потенціалу розвитку двох 3 трьох нафтогазоносних областей України. Загалом загрози економічній та фінансовій безпеці, як іiі невідємної складової, відображаються на рівні життя населення і можуть призвести до критичної дестабілізації політичної ситуації в країні.

Ситуацію ускладнює недостатній рівень ефективності системи управління національною економікою як важливої умови забезпечення економічної безпеки загалом та фінансової безпеки зокрема. У Стратегії національної безпеки, що введена у дію Указом Президента України від 14 вересня 2020 року, зазначається, що «джерелом загроз незалежності України, іiі суверенітету i демократії залишається недостатня ефективність державних органів, що ускладнює вироблення і реалізацію ефективної політики» [538].

Тому важливим наразі є затвердження Національної економічної стратегії на період до 2030 року, що дійсно є великим кроком до розбудови національної економіки з урахуванням Цілей сталого розвитку, та забезпечення відповідного рівня безпеки, без якого неможливий повноцінний вихід України на світову арену. При цьому є необхідність зважати на міжнародний досвід застосування організаційних та правових механізмів забезпечення національної безпеки та розбудови стійкої національної економіки. Тому вдосконалення законодавчої бази шляхом розроблення та впровадження в дію якомога більшої кількості узгоджених між собою нормативно-правових актів у системі національної економіки та сфері забезпечення економічної безпеки держави $є$ одним із пріоритетів у розвитку України як правової держави.

При цьому досить важливою складовою державної політики щодо стабілізації національної економіки є збалансованість між собою іiі функцій (законодавчої, стабілізуючої, розподільчої, соціально-політичної) та повноцінне функціонування іi елементів (державного адміністрування, регулювання та контролю). Усі ці складові $є$ необхідним фундаментом, що забезпечить належне безперебійне функціонування національної економіки та іiі складової - 
фінансової безпеки. Оскільки без всебічного забезпечення фінансової безпеки практично неможливо вирішити жодну з проблем, що постають перед державою. Адже основна мета фінансової безпеки є іiі здатність забезпечити ефективне функціонування економічної системи та стале економічне зростання.

Для більш детального вивчення питання доцільно розглянути на прикладі такого інструменту як державне регулювання. Розглядаючи напрацювання українських вчених слід зазначити, що однозначне визначення державного регулювання відсутнє. Так, Третяк Г. С. та Бліщук К. М. формулюють це поняття як комплекс заходів держави, спрямованих на скерування поведінки суб'єктів господарювання в напрямі, необхідному для досягнення поставлених органами державної влади цілей. [539]. При цьому, класичними цілями державного регулювання національної економіки є: економічний розвиток та ефективнсть, повна зайнятість, стабільний рівень цін, справедливий розподіл доходів, забезпечення конкурентноздатності вітчизняних товарів на світовому ринку тощо, збалансоване досягнення яких і буде передбачати економічну та фінансову безпеку. Мельник В. В. у своій роботі зазначає, що сучасна економічна політика України має бути соціально-орієнтованою. Тобто державне регулювання $\epsilon$ засобом забезпечення рівноваги економіки країни в цілому та сталого розвитку окремих територій зокрема [540].

Слід відзначити, що фундатором теорії державного регулювання економіки $є$ Джон Кейнс. У своій основній науковій праці «Загальна теорія зайнятості, проценту і грошей» Кейнс довів, що держава має відігравати ключову роль та активно втручатися в економічні процеси [541]. Адже без ефективного державного втручання економічний розвиток $є$ неможливим і він неминуче буде супроводжуватися економічними спадами та хаосом. А як відомо, економічний хаос не сприяє стабільності та безпеці, запорукою якої є захищеності фінансових інтересів на усіх рівнях фінансових відносин.

Проведений аналіз показав, що держава для виконання своїх функцій та завдань використовує різні форми державного регулювання національної економіки, до основних 3 яких можна віднести: комплексне (індикативне) 
планування економічного та соціального розвитку (як приклад розроблення Національної стратегії економічної безпеки до 2030 року); прогнозування розвитку народного господарства та кон'юнктури ринку; реалізацію національних та цільових комплексних програм; керування господарською діяльністю державних підприємств; бюджетно-податкову, грошово-кредитну та амортизаційну політику; систему соціального захисту населення. Як зазначалось вище за результатами досягнення позитивних результатів на усіх рівнях фінансових відносин та необхідних фінансових умов для стабільного соціально-економічного розвитку країни, шляхом впливу держави, в особі законодавчих і виконавчих органів, на сферу дії економіки, в свою чергу, забезпечить стійкість їі до фінансових шоків та дисбалансів і створить умови для збереження цілісності та єдності фінансової системи країни у цілому.

3 метою досягнення цього, у ході виконання державою своїх функцій щодо ефективного розвитку національної економіки та забезпечення безпеки на усіх рівнях, необхідним $\epsilon$ всеосяжне використання механізмів державного регулювання. Таких, як: правового (закони Верховної Ради України, постанови Кабінету Міністрів України, укази Президента України, інші нормативні акти), адміністративного (визначення стратегічних цілей розвитку економіки, державна підтримка програм тощо), економічного (бюджетно-податкова, грошово-кредитна, фінансова, митна політики та економічне прогнозування $\mathrm{i}$ планування). Причому оскільки ці механізми є взаємопов'язаними, їх успішна реалізація може бути забезпечена лише у разі належної співпраці суб' єктів, що іiі реалізують на різних етапах їх впровадження. Наріжним каменем чого є саме законодавство, яке при цьому формується за допомогою інструментів адміністративних та економічних механізмів. Тобто ефективність державного регулювання залежить від того, наскільки розумно і виважено використовуються економічні, правові та адміністративні важелі у процесі реалізації економічної політики [542].

При цьому у контексті розгляду такого поняття як державне регулювання, не можна не зазначити, що хоча суб'єктом державного регулювання економіки $є$ 
держава, в особі державних органів управління, для вирішення складних соціально-економічних проблем, всебічного врахування інтересів залучає інститути громадянського суспільства в межах визначених законом повноважень і функціональних обов’язків, що беззаперечно трансформується, як того вимагає час та життя, в публічне управління.

А отже жодне із складових державного, а наразі вже публічноадміністративного управління, не повинно розглядатися нами як стале поняття, оскільки динаміка змін світової економіки ставить будь-яку державу, що зацікавлена у розвитку за таких умов, коли неможливо ігнорувати негативні прояви як то: неефективність системи забезпечення національної безпеки, корупція, зниження рівня фінансової безпеки та виснаження фінансових ресурсів держави, зниження рівня життя населення та іноді неспроможність держави виконувати свої функції, насамперед у сфері захисту прав і свобод людини i громадянина. Усі ці чинники впливають на ступінь довіри до держави з боку суспільства та міжнародних інституцій.

Тому необхідним є проводити відповідну державну політику, яка буде на достатньому рівні забезпечувати гідні умови існування, функціонування та інтеграції різних сфер суспільства з метою захисту національних інтересів від загроз, вирішення завдань забезпечення фінансової безпеки, як невід’ємної складової економічної безпеки. Отже необхідним є ефективне використання усіх наявних у державі інструментів та ресурсів, які будуть побудовані та впроваджені за такими принципами як:

- принцип ефективності (має передбачати кінцевий економічний ефект);

- принцип справедливості (використання регуляторів для коригування ринку перерозподілом з метою встановлення певних засад справедливості);

- принцип стабільності (вплив держави за допомогою заходів державної фінансової, податкової, зовнішньоекономічної та митної політики);

- принцип системності державного впливу (комплексний, системний підхід до вирішення економічних, соціальних, безпекових та інших проблем);

- принцип адекватності (державі передаються лише ті економічні функції, 
які не можуть ефективно виконувати суб’єкти економічних відносин);

- принцип оптимального поєднання адміністративно правових та економічних важелів (гарантування формування відтворювальної структури);

- принцип поступовості та етапності. 


\section{5 Публічне управління та адміністрування в регулюванні сучасними соціально-економічними процесами}

Сучасна наука намагається розглядати підходи до стабілізації процесів у політичному, економічному, соціальному та культурологічному середовищі шляхом пропонування нових засобів використання існуючого інструментарію управління, нових моделей управління як у сфері публічної влади (публічне адміністрування), так і в державному управлінні. Такі механізми, реалізація яких передбачає нове бачення відносин «влада - громадськість» та базується на національній архетипіці.

Динамічні зміни в поведінці суспільства та перетворення у зовнішньому оточенні сприяють змінам в суспільно-політичних та економічних процесах країни, зокрема у сфері публічного управління та адміністрування. Проблема публічного управління та адміністрування привертає увагу багатьох науковців завдяки тому, що майбутнє суспільства залежить від ефективності функціонування системи органів державної влади, які мають за мету реалізацію державної політики в різних сферах суспільного життя. Ключовою умовою для забезпечення надання якісних державних та адміністративних послуг, та проведення подальших реформ в Україні, є адаптація та засвоєння публічного управління та адміністрування, яке переживає зміни внаслідок його прямування до європейської інтеграції.

В контексті суспільних викликів можна виділити три етапи формування сучасної концепції публічного управління та адміністрування:

- $\quad$ етап зародження;

- $\quad$ етап становлення;

- $\quad$ етап впровадження публічного управління та адміністрування як різновиду управління в сучасному суспільстві.

Кожен із етапів розвитку концептуальних засад збагачував методологічними напрацюваннями наступний етап та розкривав перспективи до подальших наукових пошуків. Два перших етапи стали основою для формування 
останнього. Характерно, що під час їх проходження, наука державне управління набула помітного розвитку, тільки на третьому етапі з'являться публічне управління та адміністрування як симбіоз державного управління та місцевого самоврядування [543].

Перший етап бере свій початок ще $з$ досліджень Стародавньої Греції та закінчується наприкінці дев'ятнадцятого століття. У працях Платона, Арістотеля, Н. Макіавеллі, Т. Мора, Т. Гоббса можна відстежити процес зародження науки «державне управління». Другий етап ілюструє наявність соціальної складової у державному управлінні у працях таких класиків управлінської думки як: Л. Г’юмек, Ф. Тейлор, М. Саймон, Л. Ерхард, Г. Мюрдаль. Етап застосування державного управління в сучасному суспільстві та виникнення публічного управління презентовано науковими розробками сучасних теоретиків і практиків державного управління: Дж. Шафрітц, Д. Розенблума, Е. Херрінга, В. Козбаненка, Ф. Шамхалова.

Сутність державного управління та адміністрування можна відстежити за допомогою двох основних підходів. Згідно з американським підходом, державне управління та адміністрування розглядається через призму трьох основних гілок влади: законодавча, виконавча та судова. Другий, європейський підхід розглядає його як підгалузь права. В Україні сутність і спрямованість державного управління та адміністрування визначаються ближче до американського підходу.

В умовах сьогодення співвідношення «державне управління», «публічне адміністрування» та «публічне управління» інколи губиться, а одне поняття замінюється іншим із тієї причини, що «public administration» (публічне адміністрування) та «public management» (публічне управління) перекладаються 3 англійської мови на українську як «державне управління» [544], як показує аналіз змісту понять «публічне адміністрування» та «публічне управління», правильним відповідником терміна «public management» буде «публічне управління», бо в буквальному сенсі це означає «публічний менеджмент». Це свідчить про те, що термін «державне управління» не $є$ точним відповідником терміну «публічне управління» і за своїм значенням наближений до терміну 
«публічне адміністрування». Основним залишається те, що ключовим аспектом державного управління є держава, а ключовим аспектом публічного управління $\epsilon$ народ.

Процес еволюції соціально-економічної системи сприяє поступовій трансформації системи державного управління в сучасні моделі регулювання суспільства, а саме розширенню публічного управління (від лат. «publicus»суспільний, народний, державний).

Водночас необхідно відмітити, що класична теорія менеджменту в державному секторі реалізувалася на практиці через модель публічного адміністрування; неокласична теорія менеджменту - через модель публічного управління, у центрі уваги якої перебуває вже людина, а не організаційна структура; сучасна теорія менеджменту - через модель нового публічного управління (New Public Management), що стосується ефективного функціонування всісї системи політичних інституцій [545].

Наслідком сучасної трансформації державного управління виступає близька замістом до концепції «New Public Management» концепція «Good Governance». Фундаментальними основами виникнення цієї концепції $є$ концепції New Public Managementтa Networked Government («мережевий уряд»). Але жодна 3 них не тільки не стала надбанням управлінської практики в Україні, але й не отримала необхідної теоретичної розробки.

Доцільно розглядати публічне управління та адміністрування як організуючий і регулюючий вплив держави на суспільну життєдіяльність людей 3 метою їі впорядкування, збереження чи перетворення, базуючись на владній силі, яка обмежує дієвий суспільний контроль. Тобто, публічне управління та адміністрування - це, насамперед, управління людьми.

Доктор економічних наук, професор О. Оболенський робить акцент на тому, що публічне управління - це здійснення сукупності раціональних (тобто запрограмованих виокремлених за певними ціннісними ознаками і можливих із урахуванням стану зовнішнього середовища) впливів на функціонування та розвиток колективу людей на основі програми управління та інформації про 
поведінку та стан об’єкта управління, спрямованих на підтримку, поліпшення та розвиток об'єкта управління для досягнення наперед визначеної сукупності цілей. Звідси логічним є висновок, що публічне управління має бути спрямоване на реалізацію цінностей суспільства [546].

Взагалі публічне управління та адміністрування - це різновид суспільно корисної діяльності, яка здійснюється певною сукупністю суб'єктів, зокрема органами державної влади. У цьому випадку наглядним є взаємозв'язок публічного управління та державної влади, яка, відповідно до Конституції України, реалізується згідно з принципом розподілу влади, тобто органами законодавчої, виконавчої та судової влади.

Важливим інструментом адміністративно-правового регулювання публічного управління та адміністрування завжди було і залишається право. Про важливість та зацікавленість держави у вдосконаленні публічного адміністрування свідчить система прийнятих законодавчих актів, норми яких визначають поняття, характеризують суб’єктів публічного адміністрування, принципи тощо.

Проте, проблема правового регулювання публічного управління та адміністрування ще не знайшла належного дослідження у межах вітчизняної теорії адміністративного та публічного права; досі бракує комплексних сучасних розвідок вітчизняних правників у даній площині.

Окрім того, публічне управління завжди здійснюється у контексті подій, що відбуваються в суспільстві і в реальних соціально-економічних, політичних і культурних умовах. Відповідно, публічне управління та адміністрування не може бути ізольованим від суспільства, оскільки воно реалізується частиною цього суспільства і в тісному взаємозв’язку із цим суспільством [547].

Отже, можна констатувати, що публічне управління та адміністрування як об'єкт наукового пізнання є складним та багатоплановим утворенням, основою якого є концепція, що випливає із тісного взаємозв'язку політики і права, управління й влади, політичної системи та суспільства загалом, а також взаємодії суспільства з різними елементами соціальної системи та економічних відносин. 
Взагалі публічне управління та адміністрування в класичному розумінні визначається як вплив суб'єкта управління (що володіє публічною владою) на об'єкт - суспільство (суспільні процеси, відносини) відповідно до покладених на нього суспільно значущих функцій і повноважень. Тобто публічне управління та адміністрування виникає як результат певного суспільного договору між державою i суспільством, коли владними повноваженнями наділяються відповідні органи і посадові особи.

Суб'єктом і одночасно об'єктом публічного управління та адміністрування $\epsilon$ громадянське суспільство, недержавні організації (різні самоврядні структури (громадські організації, об’єднання) та їхні органи), органи державної влади.

Безпосередньо управлінською ланкою суб'єктів управління та адміністрування $є$ органи публічного управління: інституції, обрані шляхом прямих виборів, та їх виконавчі структури; посадові та службові особи, обрані шляхом прямих виборів; посадові та службові особи, призначені інституціями, та їх виконавчі структури.

Визначальними та специфічними серед суб'єктів публічного управління $є$ населення країни (носієм влади залишається народ) та групи інтересів, оскільки в умовах солідаристичної цивілізації та змішаної формації саме вони визначають, стверджують, контролюють та оцінюють прямим або представницьким способами:

- цілі суб’єктів громадянського суспільства, зокрема органів публічного управління та адміністрування, стратегічні програмні рішення з їх досягнення;

- шляхи задоволення потреб колективу та вирішення суспільно значущих поточних проблем;

- результативність і ефективність публічного управління та адміністрування.

Отже, визнання суб’єктності (аж до індивідуалізації) об'єкта публічного управління зумовлює його величезний самоорганізаційний потенціал, чи то суспільства загалом, чи окремого індивіда. Як наслідок, специфічною рисою сучасного публічного управління та адміністрування можна вважати єдність 
управління та самоорганізаційних процесів. Загалом система публічного управління та адміністрування соціально-економічними процесами $\epsilon$ багаторівневою, зображено на малюнку 1.

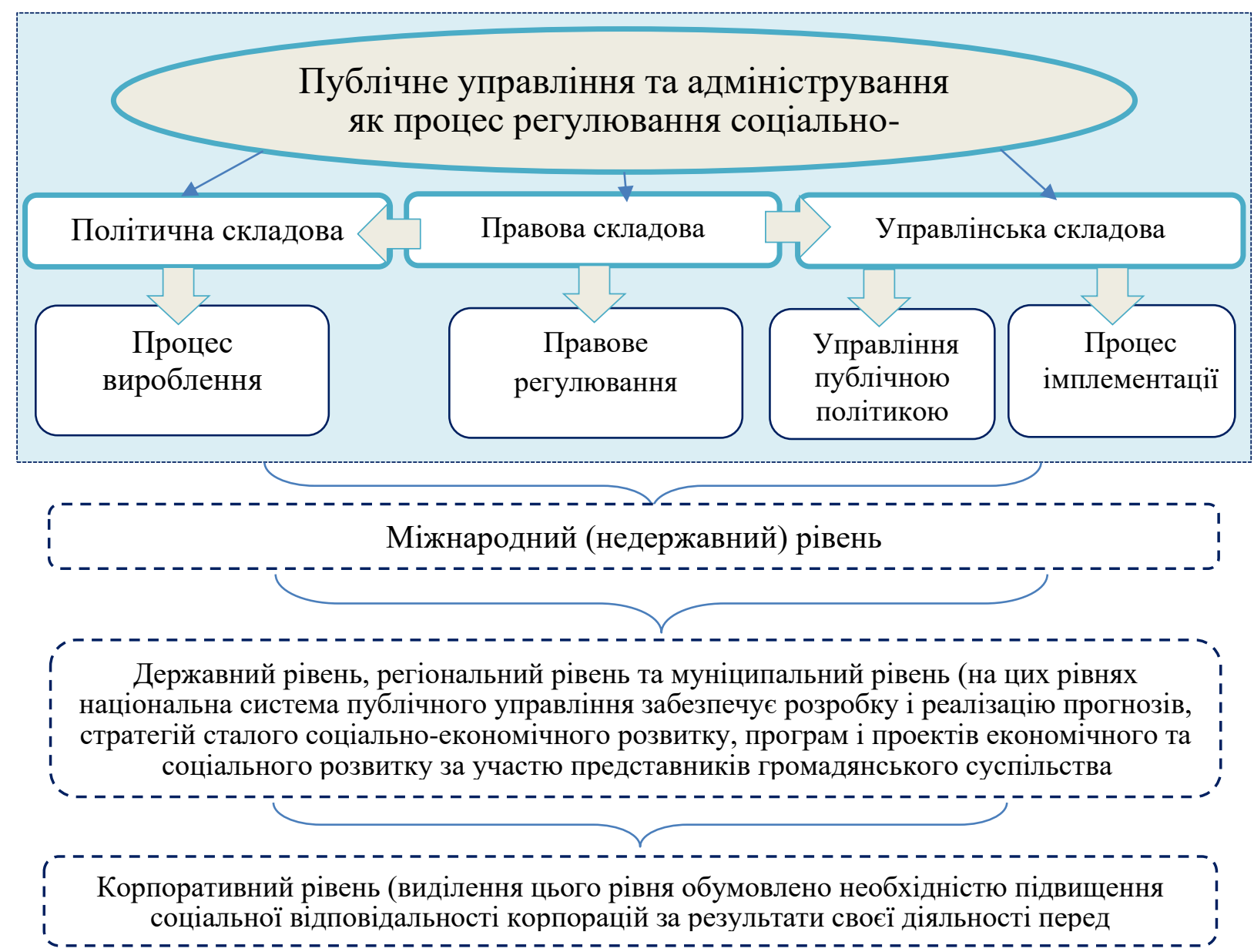

Малюнок 1. Система публічного управління та адміністрування соціальноекономічними процесами

Функціонує система публічного управління та адміністрування на основі нормативних правових актів, що регулюють діяльність суб'єктів і об'єктів публічного управління.

Цілями публічної влади та публічного управління виступають належне функціонування системи публічної влади, іiі відтворення, належні реалізація іiі функцій і надання нею публічних послуг. При цьому цілі публічного управління та адміністрування тісно пов'язані із функціями й спрямовані на гарантування, забезпечення, задоволення, реалізацію, охорону і захист публічних інтересів.

Певною мірою, цілі публічного управління та адміністрування (при широкому тлумаченні цього поняття) можна розглядати як цілі, що співпадають 
із цілями держави, до основних із яких, наприклад, Хосе Р. Кастеласо відносить забезпечення стабільності, мирної обстановки в суспільстві, а також сталого розвитку [547].

Розглядаючи публічне управління та адміністрування в такому контексті, доцільно буде описувати застосування вітчизняного досвіду та Українські реалі для заходу. Цікавий аналіз стану фінансування бюджетних програм з 2014 року і співставлення фінансування цивільного сектору та складових сектору безпеки і оборони. В стратегічних документах вказані недоліки і путі розвитку 2015 - 2021 рік. Таким чином, можливо стверджувати про розвиток економіки (підприємств ОПК та інших), та напрямки розвитку і фінансування соціальних та економічних проектів.

Отже, є очевидним, що набір цілей держави i, відповідно, цілей публічного управління залежить, насамперед, від політичного режиму (демократичний чи недемократичний), від цивілізаційних або формаційних особливостей держави та іï економічного стану.

Водночас публічне управління має свої особливості, які випливають 3 того факту, що суб’єкт публічного управління володіє повноваженнями, похідними від публічної влади (різні способи, засоби і методи застосування якої формують його сутність). Все це уможливлює розгляд публічного управління та адміністрування в трьох взаємопов'язаних аспектах: структурному, функціональному, компетенційному. Своєю чергою, компетенційний аспект (можливість примушувати) не буде мати ніякого значення без структурного аспекту (органів публічного управління), який може отримати реальне втілення тільки у функціональному аспекті (здійснення діяльності органами публічного управління). Прийнявши до уваги вказані аспекти, можна констатувати, що публічне управління та адміністрування - це складна система, функціонування якої пов'язане із великою кількістю суперечностей. 


\section{6 Механізми формування антикризового управління фондовим ринком}

Український фінансовий ринок - в силу своєї природи потенційно великого ринку, що формується (emerging market) буде і надалі (в середньостроковій перспективі) залишатися схильним до високих значень систематичного ризику, демонструвати масштабну волатильність i, потенційно, бути джерелом можливих наступних міжнародних фінансових криз.

Історія попередніх фінансових криз ще раз підтвердила ці припущення. Коливання на ринках, що формуються, викликані потрясіннями на фондовому ринку США, Свропи чи Азії були значно вище, ніж на розвинених ринках. Аналіз показує, що рівень систематичного ризику, притаманний українському ринку акцій, можливості гри на «гарячих грошах» і маніпулювання всім обсягом ринку залишилися тими ж, що і десять чи двадцять років тому.

У зв'язку з цим важливо спробувати здійснити аналіз фактичних дій регулятора українського ринку цінних паперів - Національної комісії з цінних паперів та фондового ринку (НКЦПФР) в момент виникнення кризових явищ та в післякризовий період 3 тим, щоб зрозуміти, наскільки вони були ефективні для подолання кризи і, відповідно, наскільки можна покладатися на них в моменти майбутніх ринкових шоків. Також, важливо, грунтуючись на міжнародній практиці, визначити, які заходи повинні бути прийняті в рамках ринку цінних паперів з тим, щоб послабити або навіть попередити майбутні фондові кризи.

Аналізуючи офіційні реакції НКЦПФР на кризові явища на фондовому ринку варто зауважити, що вона переважно зводилася до публічної дискусії 3 іншими державними відомствами і до видання кількох нормативних актів (вересень 1998 г.), котрі переглядають вимоги до величини капіталів операторів ринку в бік зниження, а також до включення облігацій внутрішньої державної позики до складу активів інвестиційних фондів. У більш складних умовах, в період, коли руйнувалася галузь цінних паперів, основний обсяг діяльності НКЦПФР зводився до внесення не пов'язаних 3 кризою змін в масив нормативних актів, що регулюють ринок цінних паперів, розкриття інформації 
по емітентам, війні з Національним банком - за об'єкт регулювання, ринок цінних паперів, який в цей час практично перестав існувати [548]. Антикризове управління було підмінене повсякденною роботою - ліцензуванням, атестацією фахівців, затвердженням документів щодо емісій і нових нормативних актів.

У післякризові періоди практично не було зроблено кроків для осмислення і набуття досвіду управління фондовим ринком в умовах системної чи секторної кризи. Фактично не було з'ясовано чинники системної кризи; не проаналізовано поведінку різних груп учасників в момент кризи та під час ії розгортання; не розроблено жодних антикризових заходів на майбутнє.

Зважаючи на вищевикладене варто зауважити, що дії регуляторів на фондовому ринку України можна вважати малоефективними та такими, що не виконують покладених на них обов'язків. Водночас, для підвищення ефективності їх роботи доцільно виділити два аспекти: дії регулятора під час кризи та після неї. Розглянемо їх по черзі.

Починаючи з кризи 1987 року (різкий обвал ринку акцій в США) розпочалось обговорення можливості під час появи кризових сигналів на фондовому ринку здійснювати призупинення торгів або взагалі їх закриття до моменту з'ясування причин, їх усунення та стабілізації ситуації. Спочатку такі заходи були введені на Нью-Йоркській фондовій біржі, а потім поширені на решту торгових систем. На сьогодні біржові правила світових фондових бірж містять систему правил, що дозволяють призупинити торги при різких рухах ціни чи фондових індексів. Право на такі дії мають як регулятори, так і самі біржі $[549,550]$.

Варто зауважити, що жоден торговельний майданчик не зацікавлений у руйнуванні ринку чи банкрутстві своїх учасників. А тому, згідно статистичних даних, більшість рішень про призупинення торгів приймається не регулятором ринку, а самою біржою як інструмент самозбереження. Але за умови великих чи стрімких падінь на ринку і масовому виведенні 3 них капіталів самі учасники ринку та їх професійні об'єднання, як правило, не здатні самостійно впоратись 3 
ситуацією. У таких випадках потрібне термінове втручання держави, а конкретніше - фінансових регуляторів.

Оперативні дії регуляторів фондового ринку мають враховувати наступне:

1. Повинна існувати система оперативного спостереження за ринками, яка надає регулятору консолідовану інформацію про базові показники. На підставі цих показників у торговельний майданчик «вбудовуються» обмежувачі системного ризику (автоматичне закриття торгів (circuit breakers, trading holts) при перевищенні відхилення від встановлених показників).

2. Має бути запущена процедура спільних скоординованих дій різних фінансових регуляторів та безперебійному обміну інформацією між ними. За умови втрати об'єкта регулювання державний регулятор має створити разом 3 учасниками ринку та саморегулівними організаціями (СРО) аникризовий центр і щодня моніторити показники капіталізації та обсягів торгів.

3. Крім звичайних процедур регулятор ринку повинен бути готовий застосувати більш радикальні дії - більш тривале припинення торгів для припинення паніки і відтоку капіталу; інтервенція держави на короткостроковому ринку (фондовому, валютному); запровадження обмежень на рух коштів по рахунку капіталів (оперативне введення обмежень на репатріацію коштів від продажу цінних паперів на внутрішньому ринку, заборона внутрішніх кредитів іноземним фінансовим інститутам і ін.); боротьба з маніпулятивними атаками при лібералізованому ринку капіталів.

4. Регулятор ринку у період кризових ситуацій не повинен робити несподівані дії, що зачіпають основи ринку, створювати ними додаткові ринкові шоки. Всі кардинальні зміни і реформи мають бути відтерміновані до стабілізації ситуації на ринку.

Усі чотири аспекти підводять нас до домку, що має бути завчасно розроблений антикризовий план дій в умовах надзвичайної ситуації.

Друга частина дій регулятора стосується післякризового періоду. Тут головним $\epsilon$, щоб офіційна державна політика відновлення фондового ринку передбачала заходи щодо скорочення системного ризику. Зокрема: 
1. Формування та оприлюднення програми антикризового управління як єдиного документа, що описує систему заходів у середньостроковій перспективі, а також при можливому настанні системного ризику.

2. Проведення оцінки динаміки окремих складових фінансового ринку при різних макроекономічних факторах фінансово-кредитної політики (валютна, відсоткова, бюджетна та інші складові).

3. Визначення режиму руху капіталу в частині ступеня лібералізації та наявності обгрунтованих обмежень.

4. Аналіз балансу зобов'язань і активів країни вцілому, особливо в короткостроковому періоді.

5. Розвиток системи індустрії цінних паперів: поповнення капіталів банків та брокерсько-дилерських компаній; поступове введення і розвиток ринків строкових капіталів (відстеження динаміки показників системного ризику).

6. Базуючись сигналах раннього попередження формування системи моніторингу та оцінки системного ризику. Це дозволить впроваджувати попереджуючі заходи до того моменту доки кризові явища не набудуть незворотного характеру.

7. Розвиток ринків корпоративних облігацій, що буде виступати стабілізуючим елементом у порівнянні з ринком акцій та валютним ринком.

Перелічені вище заходи та напрями здійснення державної політики дозволить створити національну інституційну структуру для антикризового управління фінансовими ринками країн та поступово сформувати на цій основі систему ризик-менеджменту для попередження і ослаблення майбутніх криз.

У післякризовий період від регулятора в першу чергу чекають не нових правил та інструкцій, а виведення на ринок емітентів, сприяння створенню нових фінансових інструментів, дій щодо укрупнення, рекапіталізації і відновленню брокерської мережі, припинення війни з банками, заходів по злиттю торгових систем та інфраструктурних організацій, дій по зниженню системного ризику i, врешті-решт, розвитку регулятивної інфраструктури ринку. Якщо ринок по суті зруйнований - не можна і неможливо чекати його самовідновлення, підміняючи 
практичні дії на ринку - розвитком форми, оболонки ринку - регулятивної інфраструктури. Ринок не відновиться в кращій якості, ніж він був до кризи [551].

Таким чином, в післякризовий період ДКЦПФР повинна працювати не тільки за принципом «ми встановлюємо правила гри і контролюємо їх виконання», а й за принципом «ми будуємо ринки».

3 метою недопущення кризових явищ, а у випадку їх прояву для швидкого відновлення фондового ринку необхідно задіяти систему заходів як мікро- так і макроекономічного характеру. Зокрема:

1. Створити систему попереджуючих індикаторів нестабільного функціонування фондового ринку для запровадження превентивних заходів.

2. Розробити систему чіткої взаємодії усіх учасників фондового ринку під час кризових явищ.

3. Впровадити систему автоматичного закриття торгових майданчиків при значних коливаннях цін чи фондових індексів.

4. Розробити національну систему критеріїв, щодо визначення і мінімізації системних ризиків.

5. Позиціонувати Україну не тільки як ринок формується (emerging market), але і як ринок, наближений у відчуттях інвесторів - за ступенем зрілості (по капіталізації, насиченості цінними паперами) - до індустріальних ринків, і на цій основі - знижувати системний ризик, властивий українському ринку цінних паперів. 


\section{SECTION 12. MICRO AND MACRO ECONOMY}

\section{1 ОСОБЛИВОСТІ РЕЛЬЕФУ БАСЕЙНУ РІКИ СТРИЙ ТА ЇХ ВПЛИВ НА ЕКОНОМКУ РЕГІОНУ}

До найважливішого джерела забезпечення водними ресурсами населення, промисловості та сільського господарства у Львівській області України належать природні води басейну р. Стрий - найбільшого правого допливу р. Дністер у верхній течії. Головною площею водозбору в басейні р. Стрий є північно-східний схил Карпатської складчастої області, утворений флішовою формацією палеоген-крейдового віку, зі значною розчленованістю рельєфу і підвищеною кількістю опадів порівняно 3 рівнинними територіями. Такі умови сприяють низькій водозбагаченості порід головної площі водозбору, домінуванні поверхневого стоку над інфільтрацією у водоносні горизонти. Одночасно, акумулюванню підземних вод i постійному поповненню їхніх запасів сприяє потужна товща алювіальних гравійно-галькових відкладів на ділянках заплави та надзаплавних терас р. Стрий у межах Передкарпатської рівнини.

Метою дослідження $є$ визначення етапів формування геохімічних умов басейну р. Стрий та їх впливу на ведення господарської діяльності в цьому регіоні.

Природна складова ландшафту (геологічна будова, рельєф, грунти, гідросфера, атмосферне повітря, біота та інші природні ресурси), їхні природнотехногенні зміни та виявлені наслідки таких змін визначають геоекологічні умови басейну р. Стрий. Геоекологічні умови відображають об'єктивну реальність сучасного стану та часової еволюції напрямку функціонування геосистеми, які є передумовою: (1) стійкості (здатності підтримувати свій нормальний стан у разі природних збурень та антропогенних впливів); (2) стабільності (відсутності або швидкого загасання збурень і впливів);

(3) пружності (відновлювати порушену рівновагу у відповідності до принципу Ле-Шательє - відповідати на зовнішній вплив, що вивів систему з рівноваги, активізацією процесів, які прагнуть послабити результати цього впливу). 
Геоекологічні умови спричинили минулі, обумовлюють сучасні й є основою для прогнозу майбутніх проблем довкілля, природних ресурсів, елементів ландшафту, їхніх характеристик, втрати яких призводять до екологічних збитків. Ранжування геоекологічних умов чи визначення пріоритету є одним 3 ключових моментів, оскільки визначає своєрідну точку відліку при встановленні рівня змін властивостей, що свідчать про виникнення екологічних проблем.

Виходячи $з$ вищезазначеного, геоекологічні умови басейну р. Стрий, як однієї з найсприятливіших територій за станом довкілля у Західній Україні, параметри іiі стабільності та стійкості визначають сейсмічність, поширеність проявів екзогенних геологічних процесів (зсуво- та селенебезпечність, еродованість), заселеність (салітебна освоєність), залісненість, техногенна трасформованість (гірнича, промислова, транспортна), забрудненість, сільськогосподарська освоєність загалом та розораність зокрема. Більшість 3 цих параметрів, що визначають геоекологічні умови мають безпосередній вплив і на об'єкт дисертаційних досліджень - природні води в басейні р. Стрий, закономірності формування їхнього хімічного складу, чинники забруднення та самоочищення.

Сейсмічність басейну р. Стрий зумовлена насамперед особливостями тектонічної позиції та геологічної будови, наявністю тут численних потужних покривів-насувів, спричинених переміщеннями окремих елементів один відносно одного в альпійську епоху, а також розташуванням у відносній віддаленості від найбільш активної у сейсмічному відношені зони Вранча на ділянці стикування Південних (Румунських) та Східних (Українських) Карпат. Найбільша сейсмічна активність притаманна для території басейну у Кросненській, Скибовій та частково Бориславо-Покутській зонах.

Слід зазначити, що така віддаленість від зони Вранча зумовила, насамперед, той факт, що у басейні р. Стрий не задокументовано історичних руйнівних землетрусів. Тим не менше, досліджувана територія характеризується невеликою, але вираженою сейсмічною активністю, обумовленою тектонічною 
позицією й особливостями геологічної будови. Це треба обов’язково враховувати при визначенні геоекологічних умов.

Щодо характеру поширення та інтенсивності розвитку сучасних екзогенних процесів у басейні Стрия, то найбільше, крім особливостей клімату, на це впливають структурно-літологічні, геоморфологічні й інженерно-геологічні чинники. Важливу роль у розвитку таких процесів відіграють гідрографічні особливості території, грунтовий i рослинний покриви, а також характер господарського використання території, грунтово-рослинних і водних ресурсів $[552$, c. 2$]$.

Регіонально-типологічні особливості рельєфу є провідним чинником, який визначає тип процесу й інтенсивність його розвитку. Сучасний рельєф розглядають як структурний елемент досить складної системи, здатної до саморегулювання. Головним регулятором такої системи $є$ поверхневий грунтоворослинний покрив. У масштабах сучасних природних процесів ця система (тектонічні рухи - сучасний грунт - процеси денудації та акумуляції), як зазначив I. Герасимов, динамічно збалансована i тому здається зовні статичною. Природна динамічність (організованість) цієї системи різко порушується під впливом людської діяльності. Внаслідок дезорганізації в ній активізуються ерозія, зсуви, обвали [554].

На інтенсивність сучасних екзогенних рельєфоутворювальних процесів, окрім регіонально-типологічних особливостей рельєфу та морфологічної ярусності, значно впливають повільні тектонічні рухи. До найпоширеніших сучасних екзогенних геологічних процесів у басейні p. Стрий, належать: 1) площинний змив (слабкий, інтенсивний); 2) лінійний ерозійний розмив (донна, бокова ерозія річок та яркова ерозія тимчасових водотоків); 3) зсуви; 4) обвали та осипи; 5) селева небезпека.

Просторове поширення таких процесів показане на рис. 1. 


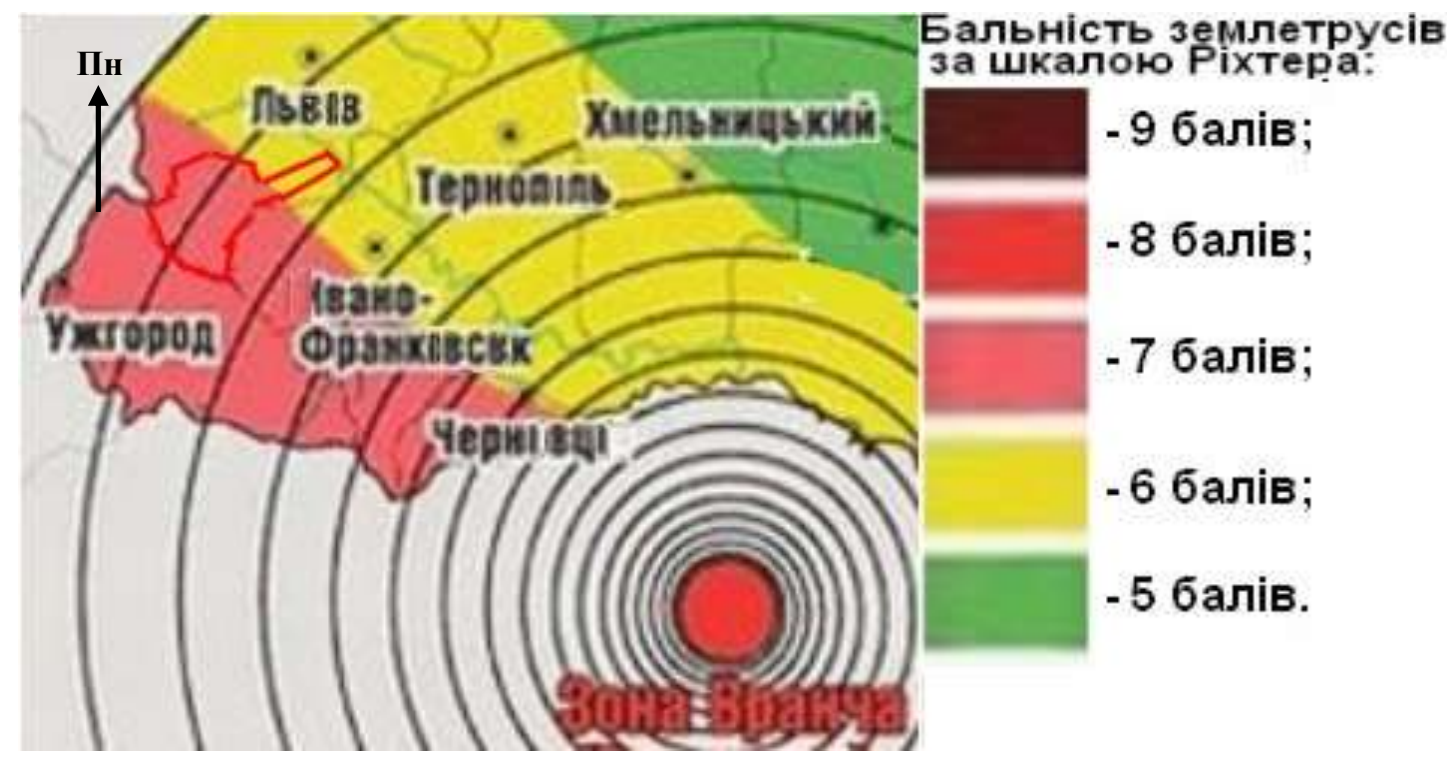

Рис. 1. Сейсмічність басейну р. Стрий та прилеглих територій відносно зони Вранча

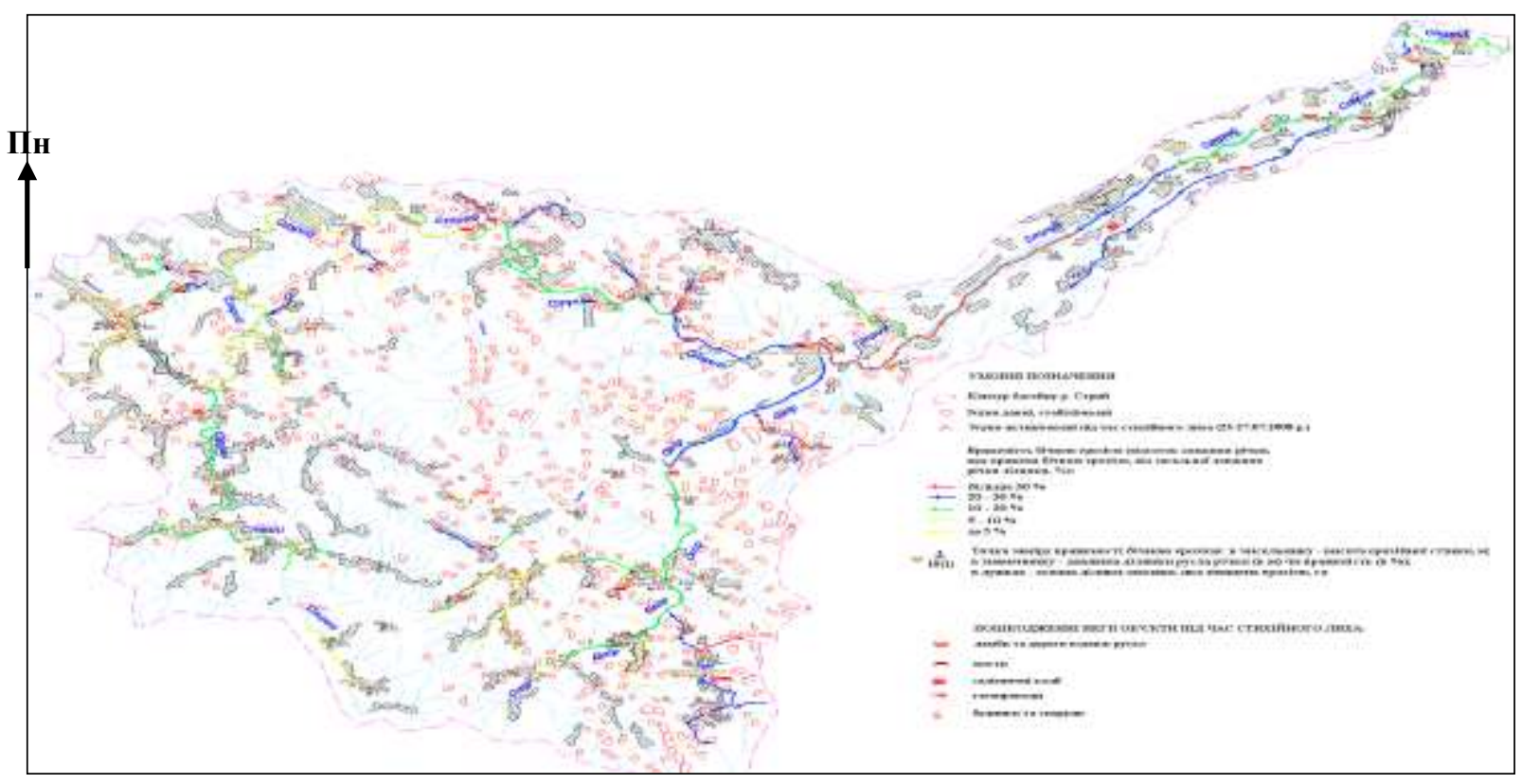

Рис. 2. Просторове поширення сучасних екзогенних геологічних процесів у басейні р. Стрий (складена за матеріалами ДП “Західукргеологія”)

Процеси площинного змиву проявляються доволі нерівномірно на всій площі басейну. На схилах різного профілю, довжини й експозиції вони відбуваються неоднаково: на крутих відрізках - інтенсивніше, на похилих - слабкіше. За однакової кількості атмосферних опадів, які потрапляють на схил, важливе значення має відстань від вододілу. Тобто, у нижній частині схилів, де зосереджена найбільша маса води, змив найінтенсивніший, 3 висотою інтенсивність знижується до середньої та слабкої. 
Ці закономірності порушуються за наявності антропогенного чинника. На ділянках, зайнятих сільськогосподарськими угіддями, на вирубках площинний змив посилюється. Характер змиву залежить, як від стоку талих, дощових або зливових вод, так і від експозиції схилів. Крайньою формою інтенсифікації площинного змиву, за умови зливових дощів, вважають дрібноярковий розмив [552]. Процеси площинного змиву практично не зустрічаються на заліснених ділянках. Натомість, їхня кількість зростає у місцях вирубки лісу, особливо, за умови наземного трелювання деревини, вітровальних ділянках, інтенсивного скупчення сільськогосподарських угідь, селітебних зон. Таким чином, інтенсифікація площинного змиву спричинюється, антропогенним впливом внаслідок господарської діяльності людини, а проявляється внаслідок природних чинників, таких як тривалі зливові дощі, різке танення снігу, буревії.

Лінійна ерозія у басейні Стрия найчастіше характеризується розмиванням i підмиванням берегів річок із проявами бокової та донної ерозії, а також ярковим розмивом тимчасовими водотоками. Це відбувається під час весняних повеней, літніх і осінніх паводків, особливо, на ділянках поширення менілітової та кросненської світ, алювіальних i делювіальних четвертинних відкладів. Завдається шкода господарському комплексу, адже руйнуються підпори мостів, залізничне полотно, грунтові та шосейні дороги.

На території досліджень зафіксовані розмиті ділянки поверхні 2-ої та 3-ої терас Стрия в околицях населених пунктів Підгородці, Корчин, Верхнє Синьовидне, де зосереджена найбільша кількість населених пунктів і важливі магістральні шляхи. Особливо великий ризик підмиву та розмиву берегів, приурочених до допливів головних рік; синклінальні зниження, вздовж яких вони закладені, здебільшого складені відкладами сприятливої для розмивання менілітової серії [552].

Чинниками, котрі зумовлюють ерозійні явища на ділянці досліджень є: гірська місцевість зі значними перепадами висот і великий похил водозбору; відклади потужних товщ пухких порід; хижацьке вирубування лісових 
насаджень на водозборі або його розораність; наявність доріг, канав, улоговин на розораних ділянках тощо.

Обвально-осипні процеси у басейні р. Стрий спостерігаються на г. Явірник і приурочені, головно, до відкладів ямненських і вигодських пісковиків та товщ пісковиків стрийської світи.

Зсувні прочеси у басейні Стрия, головно, пов'язані з ділянками підмивання берегів, обвалів у глинистих сланцях менілітової світи. Техногенними причинами активізації зсувів є: підрізання схилів та укосів, їхнє перевантаження у разі будівельних робіт, обводнення та перезволоження, вибухові роботи, ерозійна робота штучних каналів та дренажів тощо.

Комплексний підхід у вивченні природних вод передбачає детальне вивчення геохімічних умов формування їхнього складу, від встановлення особливостей генези та мінерального складу гірських порід до розподілу мікроелементів у них. Виходячи 3 цього, сучасні геохімічні умови басейну p. Стрий сформувались у чотири головних етапи: первинно-седиментаційний; постседиментаційний; природно-ландшафтний; техногенного впливу.

Перший етап відповідає часу седиментації, яка передувала утворенню порід флішової формації в крейдовий та палеогеновий період і моласової формації у неогеновий період у процесі осадконакопичення.

Другий етап формування геохімічних умов охоплює процеси діагенезу i катагенезу, а також активних тектонічних рухів, завдяки яким сформувались найважливіші риси сучасної геологічної будови, відбувався міграційний перерозподіл хімічних елементів в осадових товщах та акумулювання вуглеводнів у структурних пастках.

Третій етап формування геохімічних умов пов'язаний із ендогенними й екзогенними геологічними процесами, що відбувались у четвертинний період, завдяки яким сформувались головні елементи сучасних природних ландшафтів: рельєф, гідромережа, грунти, рослинний i тваринний світ, природний геохімічний фон басейну р. Стрий.

Четвертий етап формування геохімічних умов пов'язаний із безпосереднім 
та опосередкованим антропогенним впливом, який мав i має визначальне значення у сучасних умовах.

На сучасні геохімічні умови насамперед впливає зростаюче техногенне навантаження на територію басейну р. Стрий та локалізація тут: 1) функціонуючих і недіючих промислів нафтогазових родовищ; 2) кар'єрів бутового каменю, щебеню та гравійно-галькової суміші; 3) ділянок будівництва великих об’єктів, таких як Бескидський двоколійний залізничний тунель 3 відсипкою; 4) магістральних автодоріг, залізничних шляхів, газо- та нафтопроводів; 5) населених пунктів 3 переважаючим недотриманням норм екологічного законодавства щодо обмеження господарської діяльності у визначених санітарно-захисних зонах; 6) лісорозробок, у тому числі, на крутих схилах з активізацією небезпечних екзогенних геологічних процесів; 7) скидів недостатньо-очищених стічних вод та сільськогосподарських угідь; 8) акумулювання твердих побутових відходів на стихійних сміттєзвалищах.

Вищезгадані об’єкти є найважливішими маркерами техногенного впливу на формування геохімічних умов загалом, поверхневі і підземні води в басейні p. Стрий зокрема, які стали потенційними джерелами надходження наступних забруднюючих компонентів: 1) нафти та нафтопродуктів: низько- i високомолекулярних, кисневмісних, азотовмісних та сірковмісних, твердих, рідких та газоподібних, гідрофобних та водорозчинних вуглеводневих сполук. Особливо небезпечна водорозчинна фракція нафтопродуктів (перш за все, феноли) оскільки вона здатна до тривалої міграції у воді, високотоксична; 2) тонкодисперсних, завислих у воді частинок різного речовинного складу. Зростання вмісту завислих частинок спричинене активізацією ерозійного змиву незахищеного чи порушеного грунтового покриву, активної взаємодії “вода порода" з винесенням основних іонів, мікрокомпонентів та глинистих частинок; 3) зв'язаного азоту у вигляді іонів амонію та нітратів. Особливо гострою проблема нітратного забруднення є на територіях надмірного споживання чи неправильного зберігання мінеральних та органічних добрив, через незадовільну роботу очисних споруд та надходження недостатньо очищених стічних вод, 
через недотримання санітарно-гігієнічних норм в облаштуванні домогосподарств у зонах санітарної охорони річок та водозаборів грунтових вод; 4) засобів захисту рослин: пестицидів, гербіцидів, фунгіцидів. Очевидно, що найбільшого “внеску” у погіршення якості води цими компонентами завдає інтенсивне сільське господарство; 5) важких металів: свинцю, ртуті, кадмію, миш'яку, ртуті та ін. “Лепту” у погіршення якості води цими компонентами вносять як техногенні чинники - стихійні сміттєзвалища, так і природні геохімічні процеси вилуговування з корінних порід, активізованих процесами техногенезу [555, с. 5].

Отже, враховуючи вищесказане, чинниками змін хімічного складу вод є специфічні потенційні природні та техногенні джерела надходження полютантів: населені пункти; сільськогосподарські угіддя; ділянки скидів неочищених стоків; звалища твердих відходів; ділянки лісорозробок; пошуковорозвідувального буріння та видобутку вуглеводнів, бутового каменю, гравійногалькових відкладів; транспортного будівництва. Найвагомішими екологічними ризиками погіршення якості природних вод є тривалі меженеві періоди, повені та паводки, зарегульованість стоку і будівництво мініГЕС, аварійні розливи нафти та нафтопродуктів. 


\section{2 Соціальна відповідальність бізнесу як невід'ємна складова розвитку малого підприємництва}

Сьогодні світова економіка одним з ключових елементів ринкових процесів виділяє представників малого та середнього підприємництва, які сприяють поглибленню спеціалізації та децентралізації виробництва, зростанню ролі послуг в економіці, проведенню приватизації та стримуванню регулюючої ролі держави у деяких галузях.

Водночас сьогодні суспільна увага та сподівання багатьох країн спрямовані на соціальну відповідальність, оскільки широко розповсюджені традиційні методи формування конкурентних переваг вже себе майже вичерпали та потребують нового інструментарію, який включає «соціально-орієнтований компонент» та інтенсифікує партнерські відносини між владою, бізнесом i суспільством, і як наслідок, забезпечує довгострокові взаємовідносини зі споживачами, залучає найкращі кадри, сприяє державній підтримці та формуванню конкурентної стійкості.

Статистичні дані свідчать про тенденцію щорічного зростання кількості малих та середніх підприємств, які переважно й визначають рівень добробуту суспільства в цілому, а їх зростання стає пріоритетним напрямом державної політики в сфері економіки та соціального розвитку.

Маючи низький рівень дохідності і короткий життєвий цикл підприємства малого та середнього бізнесу, стикаючись 3 проблемами дефіциту кваліфікованих кадрів, нестачею виробничих потужностей перетворюються на обмежуючий чинник утвердження інституту соціальної відповідальності серед означених представників бізнесі.

Проте, загалом для малого бізнесу соціальна відповідальність являє собою досить складну сферу, яка традиційно зводиться до прямої цільової підтримки товарами власного виробництва тих, хто до них звертається або фінансової підтримки проєктів, що пропонуються представниками місцевої влади.

Сьогодні представники малого підприємництва $є$ ключовими елементами економіки, які переважно й визначають рівень добробуту суспільства в цілому, а 
їх зростання має бути одним з пріоритетних напрямів державної політики в сфері економіки та соціального розвитку. Мале підприємництво відіграє важливу роль в формуванні регіональних та місцевих бюджетів, визначає темпи економічного зростання, структуру та якість валового національного продукту, підтримує конкуренцію в економіці та формує вагомий соціальний прошарок суспільства (табл.1-4).

Необхідно відзначити, що малі підприємства демонструють нехарактерну для великого бізнесу гнучкість, краще пристосовуються до мінливих умов. Крім того представники малого підприємництва здатні працювати в нових секторах виробництва, що стрімко зростають та вирішувати складні соціальні проблеми.

Таблиця 1

Частка суб'єктів великого, середнього, малого та мікропідприємництва у загальній кількості суб'єктів господарювання [557]

\begin{tabular}{|c|c|c|c|c|c|c|c|c|c|c|}
\hline & \multirow{2}{*}{$\begin{array}{c}\text { Ko, sa } \\
\text { KBE I- } \\
2010 \text { ? } \\
\text { Code } \\
\text { NACE. } \\
\text { Rev? }\end{array}$} & \multirow[b]{2}{*}{$\begin{array}{l}\text { Pokn / } \\
\text { Joars }\end{array}$} & \multicolumn{2}{|c|}{$\begin{array}{c}\text { Bелакі } \\
\text { nimpucмctвa/ } \\
\text { Large cuterprises }\end{array}$} & \multicolumn{2}{|c|}{$\begin{array}{c}\text { Середаі } \\
\text { nimpucмcтвa / } \\
\text { Medium enterprises }\end{array}$} & \multicolumn{2}{|c|}{$\begin{array}{c}\text { Mani } \\
\text { nimpucsctea / } \\
\text { Small caicrperses }\end{array}$} & \multicolumn{2}{|c|}{$\begin{array}{l}\text { 3 них } \\
\text { мikponijupuсмствa / } \\
\text { Of thent micromerprises }\end{array}$} \\
\hline & & & $\begin{array}{c}\text { o. waนumb / } \\
\text { units }\end{array}$ & 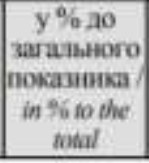 & 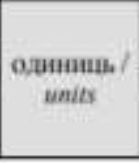 & 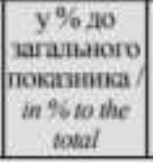 & $\begin{array}{c}\text { o, } \\
\text { units }\end{array}$ & 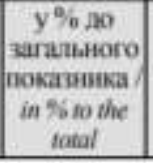 & $\begin{array}{c}\text { oxumumb } \\
\text { units }\end{array}$ & 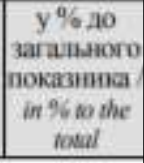 \\
\hline \multirow[t]{7}{*}{ Ycboro } & & 2010 & 586 & 0,2 & 20983 & 5,5 & 357241 & 94,3 & 300445 & 79,3 \\
\hline & & 2014 & 497 & 0,1 & 15906 & 4,7 & 324598 & 95,2 & 278922 & 81,8 \\
\hline & & 2015 & 423 & 0,1 & 15203 & 4,4 & 327814 & 95,5 & 284241 & 82,8 \\
\hline & & 2016 & 383 & 0,1 & 14832 & 4,9 & 291154 & 95,0 & 247695 & 80,8 \\
\hline & & 2017 & 399 & 0,1 & 14937 & 4,4 & 322920 & 95,5 & 278102 & 82.2 \\
\hline & & 2018 & 446 & 0,1 & 16057 & 4,5 & 339374 & 95,4 & 292772 & 82,3 \\
\hline & & 2019 & 518 & 0,1 & 17751 & 4,7 & 362328 & 95,2 & 313380 & 82,3 \\
\hline
\end{tabular}

Таблиця 2

Кількість суб’єктів великого, середнього, малого та мікропідприємництва [557]

\begin{tabular}{|c|c|c|c|c|c|c|c|}
\hline & \multicolumn{7}{|c|}{$\begin{array}{l}\text { Kimbicth cyó' cктів / } \\
\text { Number of entities }\end{array}$} \\
\hline & 2010 & 2014 & 2015 & 2016 & 2017 & 2018 & 2019 \\
\hline $\begin{array}{l}\text { Суб'екти ве.икого піршриємництва, } \\
\text { одиниць / Large entrepreneurship entities, units }\end{array}$ & 586 & 497 & 423 & 383 & 399 & 446 & 518 \\
\hline $\begin{array}{l}\text { Суб'єкти середнього підирисминцтва, } \\
\text { одиниць / Medium entrepreneurship entities, units }\end{array}$ & 21343 & 16618 & 15510 & 15113 & 15254 & 16476 & 18129 \\
\hline 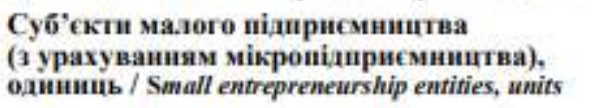 & 2161999 & 1915046 & 1958385 & 1850034 & 1789406 & 1822671 & 1922978 \\
\hline $\begin{array}{l}\text { Суб'єкти мікропідириємництва, } \\
\text { одиниць / Microentrepreneurship entities, units }\end{array}$ & 2093688 & 1859887 & 1910830 & 1800736 & 1737082 & 1764737 & 1864013 \\
\hline
\end{tabular}


Таблиця 3

Частка кількості зайнятих працівників у суб'єктів господарювання за розміром у загальній кількості зайнятих працівників у суб'єктів господарювання [557]

\begin{tabular}{|c|c|c|c|c|c|c|c|}
\hline & \multirow{2}{*}{$\begin{array}{l}\text { Код за } \\
\text { КВЕД- } \\
2010 / \\
\text { Code } \\
\text { NACE. } \\
\text { Rev.2 }\end{array}$} & \multirow{2}{*}{$\begin{array}{c}\text { Pоки / } \\
\text { Years }\end{array}$} & \multirow{2}{*}{\begin{tabular}{|c|} 
Кількість \\
зайнятих \\
працівників у \\
субо'єктів \\
rосподарювання \\
усього, тис. осіб / \\
Number of persons \\
employed of entities \\
total, thsd. persons \\
\end{tabular}} & \multicolumn{4}{|c|}{$\begin{array}{l}\text { Частка кількості зайнятих працівників у суб'єктів господарювання } \\
\text { за їх розмірами у загальній кількості зайнятих працівників у } \\
\text { суб'єктів господарювання, у \% / Share mumber of persons employed of } \\
\text { entities by their size in the total mumber of persons employed of entities, in \% }\end{array}$} \\
\hline & & & & \begin{tabular}{|c|} 
субе'єкти \\
великого \\
підприємництва/ \\
large \\
entrepreneurship \\
entities \\
\end{tabular} & \begin{tabular}{|c} 
суб'єкти \\
середнього \\
підприємництва / \\
medium \\
$\begin{array}{c}\text { entrepreneurship } \\
\text { entities }\end{array}$ \\
\end{tabular} & \begin{tabular}{|c|} 
суб̆'єкти \\
малого \\
підпиємництва / \\
small \\
entrepreneurship \\
entities \\
\end{tabular} & \begin{tabular}{|c|} 
ниих \\
суб' єкти мікро- \\
nimриемництва/ \\
of which micro- \\
entrepreneurship \\
entities
\end{tabular} \\
\hline Усього & & $\begin{array}{l}2010 \\
2014 \\
2015 \\
2016 \\
2017 \\
2018 \\
2019\end{array}$ & $\begin{array}{r}\mathbf{1 0 7 7 2 , 7} \\
\mathbf{8 7 9 6 , 7} \\
\mathbf{8 1 8 0 , 0} \\
\mathbf{8 1 0 8 , 3} \\
\mathbf{8 1 4 1 , 0} \\
\mathbf{8 5 3 2 , 5} \\
\mathbf{9 0 1 7 , 8}\end{array}$ & $\begin{array}{l}22,3 \\
21,8 \\
20,9 \\
19,6 \\
19,2 \\
18,5 \\
17,8\end{array}$ & $\begin{array}{l}31,7 \\
31,4 \\
32,2 \\
32,7 \\
32,2 \\
32,6 \\
34,3\end{array}$ & $\begin{array}{l}46,0 \\
46,8 \\
46,9 \\
47,7 \\
48,6 \\
48,9 \\
47,9\end{array}$ & $\begin{array}{l}32,9 \\
33,8 \\
35,2 \\
34,7 \\
35,3 \\
35,5 \\
35,1\end{array}$ \\
\hline
\end{tabular}

Таблиця 4

Частка обсягу реалізованої продукції (товарів, послуг) суб'єктів господарювання за їх розмірами у загальному обсязі реалізованої продукції (товарів, послуг) суб'єктів господарювання, у \% [557]

\begin{tabular}{|c|c|c|c|c|c|c|c|}
\hline & \multirow{2}{*}{$\begin{array}{l}\text { Koa } 34 \\
\text { KBF } 1- \\
2010 \\
\text { Code } \\
\text { NiCE. } \\
\text { Ren:2 }\end{array}$} & \multirow{2}{*}{$\begin{array}{l}\text { Poku } \\
\text { Years }\end{array}$} & \multirow{2}{*}{ 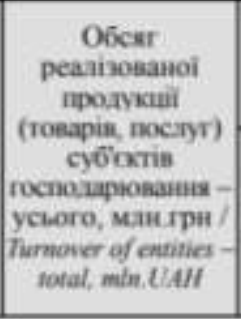 } & \multicolumn{4}{|c|}{ 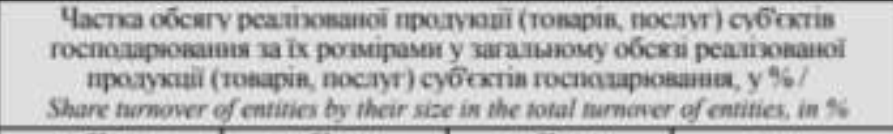 } \\
\hline & & & & 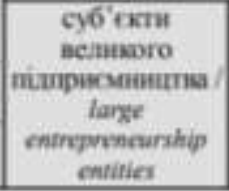 & 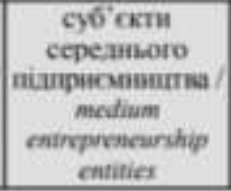 & 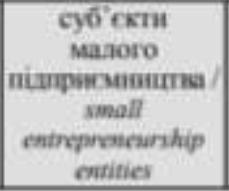 & 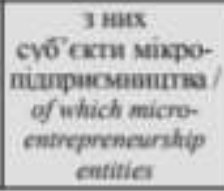 \\
\hline \multirow{7}{*}{ Ychoro } & & 2010 & 3596646,4 & 39,0 & 39,3 & 21,7 & 10,3 \\
\hline & & 2014 & 4459702,2 & 39,1 & 38.9 & 22,0 & 10.9 \\
\hline & & 2015 & 5556540,4 & 37,0 & 39.3 & 23,7 & 12.0 \\
\hline & & 2016 & 6726739.8 & 35,6 & 39.9 & 24,5 & 12,1 \\
\hline & & 2017 & 8312271,9 & 35,2 & 39,9 & 24,9 & 12,7 \\
\hline & & 2018 & 9966804.5 & 35,3 & 39,7 & 25,0 & 13,0 \\
\hline & & 2019 & 10524112,8 & 34,5 & 39.9 & 25,6 & 13,6 \\
\hline
\end{tabular}

Таблиця 5

Додана вартість за витратами виробництва підприємств за їх розмірами за видами економічної діяльності [557]

\begin{tabular}{|c|c|c|c|c|c|c|c|c|c|c|}
\hline & \multirow{2}{*}{$\begin{array}{c}\text { Kon ia } \\
\text { KBIII- } \\
2010 \text { i } \\
\text { Code } \\
\text { NACE } \\
\text { Rev? }\end{array}$} & \multirow[b]{2}{*}{$\begin{array}{c}\text { Poku } / \\
\text { Years }\end{array}$} & \multicolumn{2}{|c|}{$\begin{array}{l}\text { Beiuki } \\
\text { nimpucomerna/ } \\
\text { Large enterprises }\end{array}$} & \multicolumn{2}{|c|}{$\begin{array}{c}\text { Cерсын } \\
\text { miznрuсsictna / } \\
\text { Medium enterprises }\end{array}$} & \multicolumn{2}{|c|}{$\begin{array}{l}\text { Maji } \\
\text { nimpucmerma / } \\
\text { Simall enfergerses }\end{array}$} & \multicolumn{2}{|c|}{ 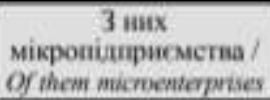 } \\
\hline & & & 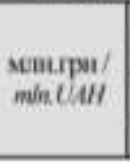 & 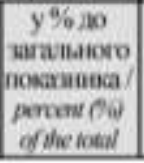 & 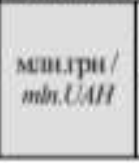 & 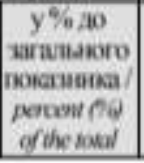 & 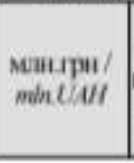 & 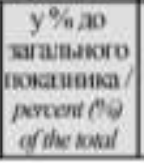 & 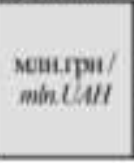 & 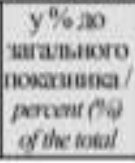 \\
\hline \multirow[t]{6}{*}{ Усьoro } & & 2014 & 530792,4 & 43,0 & 486547,5 & 39,4 & 216750,2 & 17,6 & 81059,8 & 6,6 \\
\hline & & 2015 & 585131,8 & 44,0 & 537956,0 & 40.5 & 206176.7 & 15.5 & 62548,7 & 4.7 \\
\hline & & 2016 & 680193,2 & 39,9 & 738338.3 & 43,4 & 284139,0 & 16,7 & 91867,4 & 5,4 \\
\hline & & 2017 & 844774,1 & 40,2 & 865520,8 & 41,2 & 389209,9 & 18,6 & 140131,4 & 6,7 \\
\hline & & 2018 & 895101,1 & 38,7 & 956970,8 & 41,4 & 458508,7 & 19,9 & 164974,0 & 7,1 \\
\hline & & 2019 & 999622,4 & 36,4 & 1175647,0 & 42,9 & 569026,4 & 20,7 & 221692,6 & 8,1 \\
\hline
\end{tabular}

Саме малі підприємства найбільш мобільно та ефективно реагують на зміни, оскільки їм притаманні такі характеристики: висока організаційно- 
функціональна гнучкість, високий рівень конкуренції, спрощена організаційна структура, а також можливість поєднання в одній особі багатофункціонального працівника. Проте в силу своєї специфіки мале підприємництво характеризується низькою конкурентостійкістю, а тому потребують сприяння 3 боку держави задля забезпечення внутрішньої стабільності та саморозвитку.

До основних проблем малого підприємництва й наразі відносяться проблеми розвитку та підтримки останнього: нерозвиненість інфраструктури підтримки малого підприємництва, організаційні проблеми взаємодії малого бізнесу з державними структурами, адміністративні бар'єри на шляху розвитку малого підприємництва, недосконалість фінансово-кредитної системи підтримки малого підприємництва.

Сьогодні найбільш актуальним державним завданням $є$ створення ефективного механізму підтримки та стимулювання розвитку малого підприємництва в Україні, в якому фінансова підтримка - це лише одна із складових, причому не найбільш пріоритетна. А це, в свою чергу, зумовлює необхідність формування відповідної нової методології, яка повинна враховувати, що на відміну від розвинутих країн, основна роль національних малих підприємств не соціальна, а інноваційна. Тобто, малі підприємства, які створюються, повинні сьогодні орієнтуватись на забезпечення трансформування новацій (новинок) в інновації, на комерціалізацію науково-технічних розробок [558].

Сталий розвиток $\mathrm{i}$ довгострокова конкурентна стійкість соціально відповідальних підприємців забезпечується якістю управління, обізнаністю вищого керівництва і прийняттям управлінських рішень на основі принципів соціальної відповідальності і імплементації цих технологій у стратегічний розвиток. Активна реалізація перспективних соціальних проектів, проведення ефективних соціальних заходів забезпечують розбудову держави, сприяють добробуту і підвищенню якості життя населення України [559].

Соціальна відповідальність - діалектичний взаємозв'язок між особою та суспільством, що характеризується взаємними правами та обов'язками, 
виконання приписів соціальних норм та покладенням різноманітних засобів впливу у разі їі порушення.

Під соизільною відповідальністю розуміють дотриманим суб'єктами суспільних відносин вимог соціальних норм, а у випадках безвідповідальної поведінки, що не відповідає вимогам норм чи порушує суспільний порядок, вони зобов'язані нести додатковий обов'язок особистого чи майнового характеру.

Корпоративна соціальна відповідальність - це добровільна діяльність компаній приватного та державного секторів, спрямована на дотримання високих стандартів операційної та виробничої діяльності, соціальних стандартів та якості роботи з персоналом, мінімізацію шкідливого впливу на навколишнє середовище тощо, з метою вирівнювання існуючих економічних і соціальних диспропорцій, створення довірливих взаємовідносин між бізнесом, суспільством та державою.

Сьогодні наявні різноманітні погляди вчених та керівників компаній стосовно необхідності розвитку соціальної відповідальності в цілому. Аргументами проти даного явища зазвичай стають: порушення принципів максимізації прибутків; великі витрати на участь в соціальних програмах; малодоступність звітностей про соціальну відповідальність в корпораціях для широкого загалу тощо. Проте зазначені проблеми в довгостроковій перспективі в повній мірі або практично в повній покриваються тими вигодами, що отримуються підприємствами, які беруть на себе різноманітні зобов'язання по веденню бізнесу базуючись на принципах соціальної відповідальності. За сучасних умов соціальні очікування різноманітних суспільних груп стосовно організацій, фінансистів та бізнесменів весь час змінюються.

Зараз спостерігається глобальна тенденція зсуву ціннісної орієнтації бізнесу у напрямку від чіткої фінансової орієнтації до більш комплексного підходу реалізації своєї діяльності.

Сучасний суб’ єкт підприємницької діяльності - це цілісний, комплексний, i пов’язаний 3 багатьма соціально-економічними агентами об'єкт, що еволюціонує. Бізнес-середовище акумулює в собі великий обсяг ресурсів - сил, 
знань, вмінь, тобто ресурсів у широкому розумінні. Таким чином, бізнес виступає одним 3 могутніх центрів впливу на соціальне середовище поряд 3 освітою, релігією, наукою тощо.

До трьох основних показників оцінки вигід для бізнесу, пов’язаних з участю компаній в соціальних програмах відносяться: показник окупності інвестицій, що спрямовані на соціальні програми; показник ефективності благодійної допомоги й інших соціальних програм у порівнянні з ефективністю реклами, стимулюванням продажів та ін.; показник процесу реалізації соціальних програм [560].

При цьому об'єктивно постає питання аналізу конкурентних переваг соціально відповідальних компаній. Як свідчить аналіз відомих практик, впровадження соціальної відповідальності у діяльність підприємств створює можливості для: оптимізації стратегії розвитку завдяки запобіганню ризикам (соціальним, економічним, екологічним, юридичним); збільшення обсягів продажу та частки ринку; мотивації співробітників підприємства; оптимізації операційних процесів та зменшення виробничих витрат; покращення інвестиційного клімату; гармонізації відносин з бізнес-середовищем, урядовими структурами та неурядовими організаціями; поліпшення фінансових та економічних показників діяльності.

Зокрема, одним із найбільш важливих чинників впливу на ринок попиту, як показують численні дослідження, в сучасних умовах виступає імідж підприємства як соціально відповідального. Разом 3 тим, названі параметри загалом можуть розглядатися як чинники збалансованого розвитку підприємства.

До питання підвищення соціальної відповідальності потрібно підходити як на загальнодержавному, так і на мікрорівні.

До внутрішньо регіональних аспектів питання можна віднести: економічний потенціал регіону; ступінь концентрації капіталу в регіоні; галузеву структуру економіки регіону; наявність та рівень розвитку асоціацій представників бізнесу; ступінь залучення регіону у міжнародні економічні відносини; рівень соціально- 
економічного та культурного розвитку регіону; рівень забезпеченості населення об'єктами соціальної інфраструктури; рівень розвитку громадянського суспільства; екологічну ситуацію в регіоні; специфічні проблеми конкретного регіону (суспільно-політичні та етнічні конфлікти, криміногенна ситуація, природні і техногенні катастрофи).

Держава в цілому зацікавлена в розвитку соціально відповідального підприємництва, адже це веде за собою покращення умов праці, рівня життя, вирішення певних проблем регіону. Тому загальносвітовою є практика щодо стимуляції подібної діяльності підприємств. Але, оскільки соціально відповідальний бізнес є взаємовигідним явищем (з одного боку, підвищує конкурентоспроможність підприємства, з іншого - покращує економічні та соціальні показники держави), то теоретично можливий i зворотній рух ініціативи: не від владних структур до суб'єктів господарювання, а навпаки. У випадку сучасної України, подібна інверсія стала б в нагоді 3 іншими антикризовими заходами на кшталт інвестицій в провідні сфери економіки.

У сучасному світі представники бізнесу, які планують довгострокову діяльність, постійно шукають різні способи конкуренції на ринку, придумують ідеї і вибудовують стратегії. Сьогодні, компанії націлені не тільки на отримання прибутку, а й на підтримку екологічної стабільності, розвиток суспільства, вирішення соціальних проблем. Вкладення коштів в соціальні програми в перспективі забезпечує компанії стійке економічне становище. В даний момент не існує єдиного визначення корпоративної соціальної відповідальності. Причиною цього може бути те, що даний термін можна розглядати з різних точок зору i концепцій. Тому для одних, це інструмент, за допомогою якого виявляється вплив на суспільство, забезпечуючи його сталий розвиток, для інших відповідальність організації за вплив іiі діяльності на навколишне середовище і суспільство і т.д. [562].

Значним негативним чинником у процесі розвитку соціально відповідального бізнесу виступає відсутність взаємодії суб’єктів господарювання 3 державою. Ланками взаємодії у подібних відносинах 
виступають формальні та неформальні норми, що у свою чергу потребують удосконалення для якісної кооперації сторін.

Новий погляд на проблему в роботі [563] взаємодії держави та підприємців підкреслено наступними логічними ланцюгами:

1. «Соціальні технології - швидке розповсюдження за допомогою соціальних технологій соціальної думки - зміна загального іміджу компанії за рахунок суспільної думки - зміни у прибутках підприємства за рахунок змін у рівні зацікавленості покупців»;

2. «Розвиток соціально відповідального бізнесу (СВБ) як передумова досягнення європейських стандартів - потреба компаній СВБ в інвестиціях звернення до кредитної організації - аналіз кредитного рейтингу та визначення інвестиційної привабливості - розвиток СВБ як результат та невід'ємна характеристика підприємства, інтегрованого в європейський економічний простір».

Саме тому основними напрямами підтримки та розвитку малого підприємництва 3 боку держави мають бути такі вектори сприяння:

- удосконалення нормативно-правової бази розвитку та державної підтримки малого та середнього підприємництва;

- сприяння фінансовій кредитній підтримці малого та середнього підприємництва;

- створення нової та підвищення ефективності діючої інфраструктури підтримки малого та середнього підприємництва;

- науково-методичне та кадрове забезпечення малого та середнього підприємництва.

Якщо брати до уваги місцевий рівень управління, то наразі доцільно виокремити наступні напрями сприяння 3 боку обласних та районних адміністрацій:

- створення сприятливих умов та мінімізація адміністративних бар'єрів на шляху розвитку малого та середнього підприємництва; 
- впровадження прогресивних фінансових технологій підтримки, консолідації ресурсів та інструментів для фінансування пріоритетних напрямків розвитку малого та середнього підприємництва;

- створення умов для економічного зростання, адресної методичної, інформаційної, консультативної, навчально-освітньої та юридичної допомоги 3 боку інфраструктури підтримки;

- практичне сприяння створенню нових та діючих суб’єктів підприємництва, посилення соціального статусу та ін.

Окреслені вище завдання мають бути реалізовані в рамках цільової програми шляхом реалізації наступних заходів:

- надання на конкурсній основі грантової підтримки підприємцямпочатківцям;

- субсидіювання суб’єктів малого та середнього підприємництва в частині витрат, пов’язаних з виплатою відсотків та лізинговими угодами;

- підтримка діючих малих інноваційних компаній, які приймають участь у виставках, конференціях, ярмарках, що пов’язані с просуванням продукції, товарів, послуг на регіональні та міжнародні ринки;

- сприяння підвищенню енергоефективності виробництва малого та середнього підприємництва;

- сприяння розвитку молодіжного підприємництва;

- сприяння інтеграції соціальної відповідальності в діяльність суб'єктів підприємництва та ін.

Влада повинна проводити таку політику, при якій участь бізнесу в соціальній сфері стане у нагоді не тільки для суспільства, а й для самого бізнесу. Від держави чекають комплексних заходів щодо формування єдиної, прозорої політики підтримки благодійності та соціальних інвестицій бізнесу. Для встановлення діалогу між представниками органів влади та бізнесу необхідно обопільне прийняття інтересів і потреб сторін. Якщо органи влади не займуться контролем за діями бізнесу, в той час як бізнес інтегрує в управління 
соціальними програмами елементи соціального інвестування, не буде ні взаєморозуміння, ні вирішення соціальних проблем. 


\section{SECTION 13. QUANTITATIVE METHODS IN ECONOMICS}

\subsection{Optimization approach to determining changes in output and equilibrium prices}

Сучасний етап розвитку ринкової економіки, трансформаційні перетворення, що продовжуються в Україні, мають складний і багатоаспектний характер: з одного боку, задекларовані економічні реформи просуваються досить складно, з іншого - уповільнення світової економіки внаслідок загострення кризових процесів висувають додаткові вимоги щодо протидії поширенню негативних тенденцій в країні та пошуку джерел економічної стабілізації [564].

Деформація і нестабільність регуляторів вітчизняної економіки як результат їхнього становлення в умовах не до кінця сформованої ринкової інфраструктури зумовили накопичення проблем макроструктурного характеру. Структурні зрушення, яких потребувала країна з набуттям незалежності як самостійного економічного утворення у системі міжнародного поділу праці, зазнали складнощів та спротиву в силу інертності перебігу більшої частини трансформаційних змін. Відлік основних еволюційних перетворень обмежувався переважанням розвитку паливно-енергетичного комплексу та продукуванням товарів із низьким ступенем переробки сировини. Як наслідок, єдиним позитивним елементом набуття конкурентних переваг на зовнішньому i внутрішньому ринках збуту стало формування економічної політики, що базується на використанні цінового фактора як тактичного інструмента боротьби за споживача.

Заниженість ціни робочої сили, ऑiі дешевизна робить неефективним використання високотехнологічної техніки замість робочої сили, унеможливлює реформи в соціальній сфері, пов'язані з повнішим відображенням у зарплаті витрат на відтворення робочої сили. Занижені ціни на капітальні ресурси, індексація яких відбувається із запізненням, не дають підстав для визначення економічно обгрунтованої амортизації, що штучно зменшує інвестиційний 
потенціал підприємств, котрий служить для нарощення обсягів виробництва. Завищені відсоткові ставки 3 огляду на високі ризики, невизначеність економічної і політичної ситуацій в рамках середньо- і довгострокового часового горизонту та невисока питома вага пропозиції тимчасово вільних фінансових ресурсів терміном від трьох і більше років не дають змогу широко використовувати кредитні кошти для забезпечення інвестування у розвиток стратегічних об'єктів, спроможних стати базисом економічного зростання в Україні.

Деформація цінової системи через завищення цін на енергетичні ресурси, сировину і матеріали призвела до необгрунтованого здорожчання продукції, що виробляється 3 цих ресурсів, зниження іiі конкурентоспроможності на внутрішньому і зовнішньому ринках збуту, зменшення попиту на неї та, як наслідок, іiі випуску. Зазначені фактори зумовили зростання питомої ваги проміжного споживання у структурі випуску і є одними з головних причин низької рентабельності виробництва, кризи збуту та нарощення заборгованостей між вітчизняними підприємствами. Такий негативний процес постійно поглиблюється через повільне просування впровадження заходів 3 енергозбереження і відповідне фінансове стимулювання змін у структурі виробничих витрат.

Сповільнення промислової динаміки, яке спостерігається починаючи 3 другої половини 2012 р., негативно позначається на темпах економічного зростання України. Падіння обсягів виробництва, криза збуту та початок нарощення неплатежів, збитковість і низька рентабельність, зростання заборгованостей між підприємствами - все це наслідки однієї причини недооцінки ролі балансу між попитом і пропозицією в економіці. Нагальною проблемою сучасного розвитку економіки країни є їі поступова лібералізація, спрямована на врівноваження балансу між попитом i пропозицією. Встановлення такої рівноваги можливе лише за умови реалізації комплексу заходів, центральне місце серед яких посідає пошук внутрішніх джерел покращення макроструктурних індикаторів зростання за рахунок використання 
новітніх технологій 3 метою сприяння енергозбереженню, зниження матеріаломісткості та підвищення якості продукції вітчизняного виробництва. 3 огляду на нестабільність та неоднорідність розвитку як усередині країни, так і за ii межами, для розв’язання поставленого завдання необхідно розробити i скоригувати економічну політику, при оцінці наслідків реалізації якої особливе місце займає прогнозування.

У цьому контексті метою роботи є дослідження можливості застосування макроекономічних показників розвитку економіки до вирішення задачі визначення обсягів випуску у натуральному виразі, а також рівноважних цін в умовах обмеженої інформації щодо прогнозів кінцевого споживання, розробка оптимізаційної моделі міжпродуктового балансу, призначеної для аналізу змін обсягів і цін економічної системи лише за вартісними показниками іï розвитку, зокрема структурою та обсягами валової доданої вартості.

Невизначеність поведінки суб’єктів господарювання, що у підсумку призводить до порушення поточної рівноваги, є характерною ознакою сучасної вітчизняної економіки, розвиток якої відбувається під дією кризових явищ внутрішнього і зовнішнього походження. Враховуючи особливості формування державної політики щодо регулювання розвитку промисловості України у нестабільних умовах господарювання, необхідно створити науково обгрунтований підхід до побудови прогнозу макроекономічних показників, які повною мірою характеризують не тільки попит, але й пропозицію вироблених товарів і послуг. Одним із таких показників за методологією системи національних рахунків є валова додана вартість.

Валова додана вартість, разом 3 кінцевим попитом на продукти галузей економіки, є ключовими показниками моделей міжпродуктового балансу, розробленими на основі класичної моделі В.В. Леонтьєва, побудованої на основі таблиць «витрати - випуск» [565-570]. Запропонований оптимізаційний підхід до вирішення задачі визначення взаємоузгоджених змін обсягів випуску та рівноважних цін базується на балансових співвідношеннях цієї моделі, що подають розподіл випусків продуктів (1), а також витрат у галузях (2): 


$$
\begin{aligned}
& \bar{X}_{i}=\left(\bar{X}_{i 1}+\bar{X}_{i 2}+\cdots+\bar{X}_{i j}+\cdots \bar{X}_{i n}\right)+C_{i}=0, \\
& \bar{Z}_{j}=\left(\bar{X}_{1 j}+\bar{X}_{2 j}+\cdots+\bar{X}_{i j}+\cdots \bar{X}_{n j}\right)+D_{j}=0,
\end{aligned}
$$

за умов рівності випусків і витрат у кожній галузі (3), а також загальної суми кінцевого попиту та загальної доданої вартості (4)

$$
\begin{gathered}
\bar{X}_{k}=\sum_{j=1}^{n} \bar{X}_{k j}+C_{k}=\bar{Z}_{l}=\sum_{i=1}^{n} \bar{X}_{i l}+D_{l}, k, l=\overline{1, n} ; k=l, \\
\sum_{i=1}^{n} C_{i}=\sum_{j=1}^{n} D_{j} .
\end{gathered}
$$

Визначення коефіцієнтів прямих витрат за формулою

$$
a_{i j}=\bar{X}_{i j} / \bar{X}_{j}, i, j=1,2, \ldots, n
$$

та врахування (3.3) подає баланси (3.1) і (3.2) у вигляді

$$
\begin{gathered}
\bar{X}_{i}=\sum_{j=1}^{n} a_{i j} \bar{X}_{j}+C_{i}, i=1,2, \ldots, n, \\
\bar{X}_{j}=\sum_{i=1}^{n} a_{i j} \bar{X}_{i}+D_{j}, j=1,2, \ldots, n .
\end{gathered}
$$

Врахування у (3.6) і (3.7) очевидних співвідношень

$$
\begin{gathered}
\bar{X}_{i} \equiv \sum_{j=1}^{n} \delta_{i j} \bar{X}_{j}, \\
\bar{X}_{j} \equiv \sum_{i=1}^{n} \delta_{i j} \bar{X}_{i}
\end{gathered}
$$

дає класичну форму балансів випусків (3.10) i витрат (3.11) в моделі міжпродуктового балансу

$$
\begin{aligned}
& \sum_{j=1}^{n}\left(\delta_{i j}-a_{i j}\right) \bar{X}_{j}=C_{i}, i=1,2, \ldots, n, \\
& \sum_{i=1}^{n}\left(\delta_{i j}-a_{i j}\right) \bar{X}_{i}=D_{j}, j=1,2, \ldots, n,
\end{aligned}
$$


або

$$
\begin{aligned}
& \sum_{j=1}^{n} g_{i j} \cdot \bar{X}_{j}=C_{i}, i=1,2, \ldots, n, \\
& \sum_{i=1}^{n} g_{i j} \cdot \bar{X}_{i}=D_{j}, j=1,2, \ldots, n,
\end{aligned}
$$

де

$$
g_{i j}=\left(\delta_{i j}-a_{i j}\right), i, j=1,2, \ldots, n
$$

$\epsilon$ технологічними коефіцієнтами матриці міжпродуктового балансу у вартісному виразі, а їх множина у стовпчику $j$ утворює технологічний спосіб $G_{j}$ цієї матриці. Оптимізаційна модель міжпродуктового балансу отримується внаслідок розгляду галузі $j$ як множини $M_{j}$ виробників, що випускають один і той самий продукт $j$ (продукт галузі $j$ ) із сукупним обсягом

$$
\bar{X}_{j} \equiv \sum_{k_{j}=1}^{M_{j}} X_{k_{j}}
$$

i, в загальному випадку, різними питомими витратами $H_{k_{j}}$ на виробництво одиниці його вартості.

Тоді критерієм моделі є сумарні за виробниками галузей (технологічними способами) і галузями витрати на випуск продуктів (15)

$$
\sum_{j=1}^{n} \sum_{k_{j}=1}^{M_{j}} H_{k_{j}} X_{k_{j}} \rightarrow \min
$$

а обсяги випуску виробників мають задовольняти умову створення заданої величини сукупної в галузі $j$ доданої вартості $D_{j}$ :

$$
\sum_{i=1}^{n} \sum_{k_{j}=1}^{M_{j}} g_{i k_{j}} \cdot X_{k_{j}}=D_{j}, j=1,2, \ldots, n,
$$

або із врахуванням (14) 


$$
\sum_{i=1}^{n} \sum_{k_{j}=1}^{M_{j}}\left(\delta_{i k_{j}}-a_{i k_{j}}\right) \cdot X_{k_{j}}=D_{j}, j=1,2, \ldots, n .
$$

Рівняння (18) являє собою систему умов оптимізаційної моделі, яка використовує тільки валову додану вартість галузей економіки для формування обмежень на обсяги випуску виробників у фізичних одиницях виміру їх продуктів, що дозволяє будувати перспективні паливно-енергетичні баланси за відсутності інформації щодо обсягів кінцевого споживання у натуральному чи вартісному вираженні. 


\section{SECTION 14. SOCIOLOGY}

\subsection{Modèle de compétences de la fonction publique Française}

La fonction publique de la France a pour objectif de mener une politique du personnel adaptée à son évolution et d'intégrer davantage les processus ressources humaines existants. Un des moyens pour y parvenir est le modèle de compétences.

Le modèle de compétences permet d'indiquer clairement quelles sont les attentes relatives aux différentes fonctions des collaborateurs au sein de la fonction publique.

Le modèle de compétences est une liste de compétences, mais également un outil qui permet de mesurer et d'évaluer les compétences. L'identification des compétences nécessaires pour réaliser une tache facilite les opérations de recrutement, de sélection, de formation, de l'intégration des nouveaux collaborateurs etc. Ceux-ci soutiennent le développement de l'organisation et des individus, interagissant au sein d'un environnement externe en constante évolution. Un modèle de compétences offre une vue d'ensemble structurée de toutes les compétences auxquelles les collaborateurs d'une organisation font appel (notamment pour réaliser les objectifs fixés).

Une compétence est un ensemble cohérent d'aptitudes, d'attitudes et de connaissances qui s'expriment dans un comportement observable et qui ont une valeur prédictive pour l'accomplissement efficace d'une fonction/d'un rôle précis(e) [571, p. 25].

Le modèle de compétences de la fonction publique française se divise en cinq groupes de compétences génériques et un groupe supplémentaire de compétences qui comprend les compétences techniques.

Les compétences génériques sont organisées en cinq groupes :

1. Gestion de l'information : comprendre l'information, les faits, les perceptions, les connaissances et les idées, tout en s'assurant du développement de nouvelles informations et connaissances. 
2. Gestion des tâches : organiser et structurer le travail, du niveau de l'organisation des tâches jusqu'au niveau de leur réalisation, tout en s'assurant de leur déroulement optimal.

3. Gestion des collaborateurs : gestion des relations avec d'autres collaborateurs dans un contexte fonctionnel et/ou hiérarchique, tout en s'assurant de l'amélioration de leurs prestations et de la stimulation de leur développement.

4. Gestion des relations : gestion des relations avec les autres, sans qu'il y ait nécessairement la présence d'une dimension hiérarchique dans la relation.

5. Gestion de son fonctionnement personnel : gestion de ses propres prestations et de son développement, tout en s'assurant de l'amélioration de son efficacité professionnelle.

Chaque groupe de compétences génériques comprend huit compétences.

Pour la Gestion de l'information, ce sont : - comprendre l'information, - assimiler l'information, - analyser l'information, - intégrer l'information, - innover, conceptualiser, - comprendre l'organisation, - développer une vision.

Pour la Gestion des tâches, ce sont : - exécuter les tâches, - structurer le travail, résoudre des problèmes, - décider, - organiser, - gérer le service, - gérer l'organisation, - piloter l'organisation.

Pour la Gestion des collaborateurs, ce sont : - partager son savoir-faire, - soutenir, - diriger des collaborateurs, - motiver des collaborateurs, - développer des collaborateurs, - souder des équipes, - diriger des équipes, - inspirer.

Pour la Gestion des relations, ce sont : - communiquer, - écouter activement, travailler en équipe, - agir de manière orientée service, - conseiller, - influencer, établir des relations, - construire des réseaux.

Pour la Gestion de son fonctionnement personnel, ce sont : - faire preuve de respect, - s'adapter, - faire preuve de fiabilité, - faire preuve d'engagement, - gérer le stress, - s'auto développer, - atteindre les objectifs, - s'impliquer dans l'organisation.

Dans chaque groupe les compétences sont structurées de manière cohérente. Elles sont reliées entre elles et se complexifient au fur et à mesure qu'elles sont situées en 
haut du modèle. En outre, l'impact des compétences évolue selon que la compétence soit basse ou haute dans le modèle.

Ainsi, l'impact concerne le collaborateur pour ensuite se reporter sur l'équipe, le service et enfin sur l'organisation au fur et à mesure qu'on se rapproche du haut du modèle.

Cette cohérence par groupe est présente dans les quatre premiers groupes.

Dans le dernier groupe "Gestion de son fonctionnement personnel », cette cohérence n'existe pas. Les compétences de ce groupe peuvent être considérées comme totalement indépendantes les unes des autres.

Il faut noter que les cinq compétences sont identifiées comme cruciales et sont attendues de chaque collaborateur de la fonction publique lors de l'exercice de sa fonction et de la réalisation de la mission et de la stratégie de l'organisation.

Les compétences clés figurent dans les deux derniers groupes du modèle, à savoir dans le groupe Gestion des relations et Gestion de son fonctionnement personnel. Ainsi, les compétences clés sont : - travailler en équipes, - agir de manière orientée service, faire preuve de fiabilité, - s'auto développer, - atteindre les objectifs.

Les compétences techniques regroupent les savoirs et les savoir-faire qui sont, d'une part, les connaissances techniques et les expertises, et d'autre part, l'art d'appliquer des connaissances, et des apprentissages à une situation donnée et dans un contexte déterminé [572, p. 73].

En combinaison avec le profil de compétences génériques, elles constituent donc l'ensemble de toutes les compétences.

Les compétences techniques, tout comme les compétences génériques, sont utilisées dans les différents processus ressources humaines : recrutement et sélection, cycles d'évaluation, accompagnement de carrière, formation et développement, etc.

Les compétences techniques sont au cœur des processus de gestion des connaissances tels que

- l'identification des connaissances critiques au sein de l'organisation ;

- la transmission des connaissances entre les seniors et les juniors ; - la création et l'animation de réseaux d'experts ; 
- la construction et la maintenance de bases documentaires par domaines d'expertise etc.

Les compétences techniques attendues dans une fonction sont répertoriées dans une grille d'expertise technique.

Les compétences techniques sont de deux ordres : - Métier ; - Support.

Il n'existe pas de répertoire exhaustif de toutes les compétences techniques. Les domaines d'expertise et les métiers sont très nombreux et souvent aussi très spécifiques. C'est pourquoi le répertoire des compétences techniques, alimenté par les organisations, évolue dans le temps.

Des compétences techniques sont liées aux matières traitées qui sont relatives au(x) métier(s) ou à la discipline ou aux disciplines exercés. Il existe différentes catégories de métiers au sein de la fonction publique. Ces catégories donnent une indication sur l'orientation du/des domaine(s) d'expertise d'une fonction.

A chaque compétence technique est attribué un niveau de maîtrise attendu pour pouvoir exercer sa fonction. Les organisations définissent elles-mêmes le niveau de maîtrise nécessaire et suffisant selon les attentes pour la fonction [573].

Les niveaux de maîtrise prévus sont les 4 suivants: - Niveau « Base »: a besoin du soutien de sa hiérarchie ou de ses collègues, a une compréhension des principes de base, possède une connaissance élémentaire de la matière.

- Niveau « Utilisateur »: est autonome sur des cas simples, peut mettre en pratique ses connaissances et peut résoudre des cas plus complexes avec le soutien de sa hiérarchie ou de ses collègues, possède une connaissance partielle de la matière. - Niveau « Avancé »: est autonome sur des cas complexes, peut rédiger des manuels de procédure sur la matière, est consulté par ses collègues, peut conseiller, joue le rôle de formateur pour un public de débutants ou de non connaisseurs, possède une large connaissance de la matière.

- Niveau « Spécialiste »: est autonome sur des cas spécifiques et exceptionnels, fait des propositions d'amélioration de la matière, est reconnu comme un spécialiste de la 
matière au sein de son organisation et en dehors, joue le rôle de formateur pour un public avisé, possède une connaissance approfondie de la matière.

Ainsi, le modèle de compétences permet de préciser clairement quelles sont les compétences nécessaires pour exercer les différentes fonctions au sein de la fonction publique ainsi que la manière dont ces compétences peuvent être observées et développées par les collaborateurs.

Le modèle de compétences constitue l'outil pour les processus de ressources humaines tels que le recrutement et la sélection, l'intégration des nouveaux collaborateurs, les cycles d'évaluation, l'accompagnement de carrière, formation et développement. Ceux-ci soutiennent le développement de l'organisation et des individus tout au long de leur carrière. 


\subsection{Socio-psychological features of the development of ideas about the world in the children with special educational needs}

Among the wide range of research on learning and development, special attention should be paid to those that consider the formation of ideas about the world in children with special educational needs, as the environment is the basis for organizing various activities of the child that encourage analysis, study subject or phenomenon, promote the active assimilation and use of acquired knowledge. The very idea of the world around us serve as a basis for solving priority practical and cognitive tasks involving the operation of real objects of nature. At the same time, the formation of basic ideas about the world around us, communication and work in children with special educational needs is a necessary condition for their maximum successful inclusion in society in accordance with their potential and increase the degree of independence of daily functioning.

Scientists have considered the problem of development of cognitive activity in the context of social and pedagogical phenomena, a component or variety of which is this activity. Such phenomena include cognition, human activity, learning and teaching.

Thus, considering the process of cognition as a complex social system, scientists identify the interacting main components: 1) cognitive activity of people; 2) means of cognition; 3) objects, objects of knowledge; 4) the results of cognitive activity: knowledge, methods, reflections and actions to obtain new results, constructive decisions, etc.

In addition, analyzing, we can identify certain degrees of cognition in philosophy - living contemplation, abstract thinking and practice - that constitute a subsystem of the process of cognition, each of which is also a specific human activity.

Considering the concept of «activity», scientists, scientists and philosophers also expressed their views, but their interpretation of this definition is almost indistinguishable.

Activity is a form of activity of a living being, which is designed to reproduce the supernatural processes of its existence - social relations, culture, itself as a biosocial, 
not a biological being. The main function of the activity is to ensure the continuity of human society.

Thus, activity is a way of human existence in the world, its ability to make a difference in reality. The main components of the activity are the subject with its needs; the purpose according to which the subject is transformed into the subject to which the activity is directed; means of achieving the aim; result of activity.

As proved by scientists, the methodological basis of the learning process is the scientific theory of cognition, which studies the nature of scientific cognition and its possibilities, the main laws of the cognitive process, forms and methods of human cognition of the surrounding reality, the truth of cognition.

The following are the most important tasks that are solved in the learning process: a) stimulating learning and cognitive activity of students; b) the organization of their cognitive activity with the mastery of scientific knowledge, skills and abilities; c) development of thinking, memory, creative abilities; d) the formation of a scientific worldview and moral and ethical culture; e) improvement of educational skills and abilities.

Thus, the consequences of the learning process are affected:

- in the ability of students to independently use the acquired knowledge and acquire new ones;

- in understanding the ways of their actions, choosing the optimal ones;

- in critical thinking;

- in self-esteem;

- in the orientation of the individual to self-education, self-development;

- in the practical motivation of educational activities;

- in the formation of not only intellectual but also communicative skills, the development of feelings, personality traits.

The real result of learning - objective fixed quantitative and qualitative changes in the student's personality relative to the initial state, which occurred because of his assimilation in the process of cognitive-practical activities, accumulated social experience (educational content). 
Thus, the learning process is a specially organized cognitive activity that is modeled (defined goals, objectives, content, structure, methods and forms) to accelerate the mastery of the basics of social experience gained by humankind. It is in the process of learning that cognition acquires a clear design in a special, unique to man, educational and cognitive activities.

One of the main activities of the individual is his cognitive activity. Despite numerous studies on the development and formation of cognitive activity, in pedagogy, scientists choose different definitions of this concept.

Cognitive activity is the activity of the subject, most often aimed at transforming the object, to understand, to reflect its essence through knowledge. Cognitive activity is a system that combines the main elements that in the process of realization of educational and cognitive goals ensure the implementation of three main functions: orientation, executive, control and corrective.

In the school, the activity is aimed at: 1) to master the techniques of mental activity in order to organize their own mental activity; 2) to master the knowledge, skills, the formation of cognitive interests, a conscious attitude to learning.

In our opinion, cognitive activity is the unity of sensory perception, theoretical thinking and practical activity. It is carried out at every step of life, in all activities and social relations of students, as well as by performing various subject-practical actions in the learning process.

There are different approaches to characterizing the stages of students' cognitive activity. We consider it necessary to present the main stages of development of cognitive activity.

Comparing the different views of the authors on the stages of development of cognitive activity of students, it should be generalized that most of them have a similar meaning.

The carried out theoretical analysis gives grounds to note that the stages of development of cognitive activity of students are dynamic; they can be combined, reduced depending on the conditions. This gives us the opportunity to combine some 
of them into a single whole and to separate our own vision of the stages of formation of cognitive activity in children with special educational needs.

In our opinion, the most substantiated is the selection of the following stages of development of children's cognitive activity: 1) stimulating children to cognitive activity (goal setting, task definition and formation of positive motivation for learning); 2) perception, comprehension, memorization of new material; 3) awareness of new material, application of knowledge in practice; 4) self-control, self-esteem, reflection of cognitive activity.

Analyzing the special literature, we conclude that the development of educational and cognitive activities should be understood as a special order of educational and cognitive activities of students with special educational needs and teachers, which meets the goals, motives and objectives of learning and proceeds in a certain mode.

Thus, the appropriate organization of educational and cognitive activities provides conjugation of external conditions, actions with those internal processes that create a favorable «internal environment» (motivation, activity of mental, emotional, perspective and other processes important for cognition), which contribute to intensive personality development. The general tone of training, discipline of thought, concentration, decency and clarity of pupils in independent educational work, mutual assistance in training depends on the organization of educational and cognitive activity.

In defining the relationship between the content of the concepts of «educational activity», «cognitive activity» and «educational-cognitive activity», many authors believe that cognitive activity is a broader concept than educational activity, as cognition is carried out not only for learning but also to open a new one. Nevertheless, the meaning of the concept of «educational activity» is not a subset of the meaning of the concept of «cognitive activity». On the other hand, although for students cognitive activity usually takes place in an educational and cognitive form, the concept of «educational activity» is broader than the concept of «educational and cognitive activity». Therefore, in the course of training actions of not only cognitive, but also training character connected with working off abilities and skills are applied. 
The content of the concept of «educational and cognitive activity» can be considered as the intersection of the content of the concepts of «educational activity» and «cognitive activity». This approach makes it possible to consider the educational and cognitive activities of primary school students as a dialectical unity of two aspects: educational and cognitive, in which educational activities act as a tool for the implementation of cognition. Educational and cognitive activity is an invariant of the content of education of children with special educational needs.

Analyzing the concepts of «activity», «educational activity» and «educationalcognitive activity», we believe that the educational-cognitive activity of junior students is a substructure of activity as a system. Cognitive activity is a complex system, as a structural unit of which can be distinguished cognitive action.

Cognitive activity is characterized by awareness of the goal, which is aware of the action itself, which leads to the achievement of this goal.

Thus, by cognitive activity we mean a conscious, purposeful, effectively completed cognitive process, which is associated with the solution of the cognitive task. In the educational process, cognitive activity is learning, which is a complex process of transition from ignorance to knowledge. Thanks to learning, there is a transition from systematic knowledge of the subject world to the acquisition of scientific knowledge.

Summarizing the above, we can conclude that the cognitive activity of children with special educational needs - is the activity of children to develop thinking, the formation of the necessary amount of knowledge, skills, abilities, and self-development of children.

Thus, we come to the previously defined essence of the concept: the development of educational and cognitive activities should be understood as a special order of educational and cognitive actions of children and teachers, which corresponds to the purpose, motives and objectives of learning and proceeds in a certain mode.

The development of basic ideas about the world around us, communication and work in children with special educational needs is a necessary condition for their 
maximum successful integration into society in accordance with their potential and increase the degree of independence of daily functioning.

Research has shown that children with special educational needs due to insufficient development of cognitive activity, emotional and volitional sphere and low social activity do not always adequately perceive the world around them and realize the dependence of their lives and health on the environment, which leads to learning problems, communication and perception of the surrounding reality. These factors destroy the child's relationship with the world around him and cause serious secondary disorders of physical, mental and social development.

Scientists and practitioners have proven that insufficient mobility of neuropsychological processes of perception disrupts the analytical and synthetic activity of analyzers in children with special educational needs, which is manifested in the inability to consider objects in a certain sequence, establish connections and relationships between parts of the subject.

Thus, the most pronounced disadvantage of children in this category is insufficient activity, weak focus of this mental process. Also, the perception of children in this category is characterized by chaos, inconsistency; children do not distinguish significant features from secondary ones, do not establish connections between them; there is a slow processing of sensory information, there is no active cognitive interest in objects and phenomena of the surrounding reality, etc. Insufficient comprehension of perception can be manifested in the fact that children with special educational needs have difficulty recognizing even well-known subjects. For example, in a snow-covered hare, they see a squirrel, the oval is confused with a circle and words that sound similar are perceived as the same. Lack of understanding is even more pronounced in the perception of semantic material: cartoons, plot drawings, fairy tales and stories. Children with special educational needs are not able to retell a children's film on their own, because not everyone understands it.

As scientists have proven, the physiological basis of perception of the environment is the nerve connections that arise in response to external stimuli and are combined into a single complex. Imagination is a trace of perceptions and feelings. 
Therefore, the more different connections will be reflected in the process of perception of the subject, the more complete and meaningful the child's ideas about this subject will be.

Important in the development of ideas about the world around is given to speech, which helps to clarify, detail, improve. At the same time, the role of the word should not be overestimated. Speech connections can be full-fledged only when they are followed by a direct sensory perception of reality. In addition, since the category of children with special educational needs has in most cases additional speech disorders, in turn, this complicates the process of development of relevant ideas in them.

The presence of a complex disorder (intellectual development and speech) limits the possibility of direct perception of objects and phenomena of the surrounding reality and affects the development of ideas about the world around us as one of the main mental processes. Therefore, in the education and upbringing of children of this category, importance is attached to the problem of finding ways to develop and concretize ideas about the surrounding objects and phenomena.

Imagining is not just knowing, but also mentally seeing, hearing, visually reflecting. In representations, as well as in perceptions, reality is reflected in visual images, but they differ from each other. Representations of an object can be formed during its description, but with a mandatory reference to the already existing in children ideas acquired through direct sensory perception of objects.

In the psychological and pedagogical literature, many theoretical works and experimental studies are devoted to the development of ideas. They argue that representations cannot be considered as something given forever. So clear and distinct ideas do not arise instantly, in a complete form, but are formed, gradually improving and changing under the influence of new and new purposeful perceptions.

The results of theoretical research allow us to draw the following conclusions:

1. Improving the quality of the educational process of modern special education of children with special educational needs is aimed at maximizing their ability to navigate in the world independently (as far as possible), in turn, properly formed ideas about the world in this category of children contribute to this. 
2. The organization of the educational and developmental process involves strengthening the correctional orientation of the pedagogical process, which will ensure the continuity of the process of development of cognitive activity of children with special educational needs during individual lessons and in educational work.

3. One of the important components of the comprehensive development of children with special educational needs is the development of their ideas about the world around them, as the environment is the basis for organizing various activities of the child, encouraging analysis, study of a subject or phenomenon. Perceptions of the world around us serve as a basis for solving priority practical and cognitive tasks involving the operation of real objects of nature.

4. In general, «representation» is a sensory-visual, generalized image, which reflects the external features, properties, connections of the previously perceived object or group of objects. Representations are created in human memory mainly because of his direct perception of objects and phenomena of the surrounding reality.

5 . The stages of development of ideas in children with special educational needs are specified: 1) the organization of purposeful feeling and perception of signs, properties of natural objects, their external interrelations; 2) the combination of the sensory essence of the perceived with the verbal designation; 3 ) the organization of awareness of the content of the idea; 4) organization of memorization of sensory-visual image of an object or group of objects; 5) the organization of consolidation of the formed representation by reproductive reproduction of its maintenance without existence of object; 6) the organization of application of the formed representation at the decision of problems on a sample, in similar and new situations.

6 . The results of the theoretical analysis showed that the problem of forming ideas about the world around children with special educational needs remains insufficiently solved. Analysis of pedagogical experience shows the lack of a methodological system that ensures the development of ideas about the world around children with special educational needs, which naturally leads to increased state and scientific interest in the development and learning of such children, increases attention to curriculum and the need to develop semantic and methodological support of the educational process. 
At the same time, pedagogical practice requires determining the state of formation of ideas about the world around children with special educational needs to compare them, in order to identify features of the formation of ideas in children with moderate intellectual disabilities, justification and definition of pedagogical tools to ensure the development of ideas, methods and organization of correctional and developmental work with children of this category. 


\subsection{Social responsibility and ethics of marketing}

The social respomsibility of marketing, in modern understanding, is an important element of the social relationship within the business enviponment. The relevance of the socialization of marketing activities is tied to the need for maximum support for the needs of those who are willing to reach a wide range of moral and ethical values. Assurance of the business adaptability to social needs and the formation of a socially advanced model for the national economy development.

Currently, the role and importance of social responsibility, which determines the necessity of interaction between business, the government and society, is widely studied. As the World experience shows, business companies that operate on the basis of social responsibility, are reconciling their economic interests with the socio-environmental interests of society, improve their product positioning in the market, minimize existing risks, including reputational. Consequently, they are able accelerate the process of business capitalization, which has a positive effect on the further activities of the enterprise and improves the image and investment attractiveness of their business [574]. The development of marketing activities within the competative environment implies the need to form and use a socially responsible attitude to the mechanism of development, sale and consumption of goods and services.

Socially responsible marketing is a form of manifestation of needs and interests of participants of target markets based on moral and ethical values for the purpose to fulfil tactical and strategic tasks of functioning of economic entities. Socially responsible marketing closely intersects with corporate social responsibility and is the embodiment of this concept, focused on forming long-term partnerships with its customers by meeting their needs and interests in a way that will have a long-term positive effect on their well-being and society as a whole, and for the financial and marketing position of the enterprise [580]. Therefore, the successful implementation of marketing activities is impossible without a socially responsible approach to doing business. Because only by using morality and humanity towards their partners and 
consumers of products is achieved the desired effectiveness and efficiency of entrepreneurial activities.

The formation of the socially responsible marketing system mplies the need for consistent adherence to certain principles. The basic principles of social responsibility (ensuring transparent activities, responsible attitude to society, sense of humanity, striving for self-improvement, prevention of danger and morality) are the foundation for effective interaction of subjects in the marketing activities of the company. The implementation of the principles of socially responsible marketing is seen in the disclosure of the content and significance of moral and ethical criteria and values.

In modern business conditions, the marketing activities of the company should be based on appropriate moral and ethical criteria and values. Adherence to universal norms of behavior creates the necessary conditions for mutually coordinated activities of all subjects of market relations on the basis of social responsibility. The implementation of the company's marketing policy involves the use of moral and ethical criteria and human values to achieve a positive image and reputation of business entities in the environment of their operation.

Close and significant categories of "morality" and "ethics" should be considered as integral interrelated components that form a responsible attitude of business to the subjects of public relations. In particular, morality, which is a set of systemic norms, establishes the order of relations in society on the basis of cultural and spiritual values, namely goodness, honor, dignity, duty, conscience, justice, etc. [576, p. 100]. The concept of ethics should be considered as an immanent corporate component of the business environment, built on the unity and values of all market participants. In modern business, corporate ethics acts as a system of moral principles and norms of behavior that have a regulatory impact on the organization's relations with internal and external stakeholders [578].

It should be noted that doing business on the basis of corporate ethics is the expression of will and internal consistency of the guidelines of each individual, which together contributes to the harmonious and dynamic development of the company and society as a whole. This requires management to adopt appropriate moral and ethical 
standards of staff behavior that are consistent with the activities and objectives of the company. The particular importance is to unite values and worldview of all participants in public relations in the plane of interaction of the business environment with stakeholders.

Disclosure of the content of marketing ethics necessitates the need to reflect the key criteria needed to ensure universal norms and principles of behavior in society. In the theory and practice of marketing activities of the company the following basic moral and ethical criteria are used: ensuring moral freedom of choice and realization of human capabilities in society; mutual respect between consumers, business, the state and society as a whole; ability to combine moral and ethical and socio-economic needs of individuals in the marketing environment; equality and accessibility of business entities to goods and services; ensuring a combination of needs and incentives of entrepreneurs based on basic moral and ethical values of marketing. The introduction of the above criteria will reproduce the necessary moral and ethical approaches to the organization and conduct of marketing activities of the company.

The observance of fundamental values, that shape universal behavior and provide conditions for the socio-economic development of the business environment, may be suggested as the basic principles of the social relations development. The category "value" refers to everything that is relevant and necessary for society, as well as acts as a guide in the relationship between the subjects of social relations in order to avoid complex moral and ethical situations. At the core of values, there are certain interrelated components, among which marketers distinguish the following: responsibility, honesty, fairness, transparency and respect.

Responsibility. The basis of moral and ethical values in marketing is responsibility, which integrates honesty, fairness, transparency and respect for employees, business partners, the environment and society as a whole. In particular, the implementation of the marketing strategy of the enterprise should be based on a responsible attitude to doing business, fulfilling obligations to the state, society, as well as preserving the environment. The values of responsibility acquire their significance in the process of implementing the main components of the marketing complex, 
focused on openness in relationships, balancing the needs of producers and consumers, openness to stakeholders, as well as in harmonizing relations between market participants.

Honesty. In the marketing environment, one of the most important universal values is honesty. It is the key of business openness to implement successful areas, create a positive image, and is useful in making decisions about attractive prospects. Building relationships based on honesty will promote openness, decency and trust between the subjects of market relations, strengthening consumer welfare and harmonization of society as a whole. However, ignoring this value negatively affects the company's reputation and creates mistrust, which slows down overall social development.

Justice. In the process of meeting the demand of certain groups of consumers, there are various marketing strategies aimed at ensuring the capitalization of profits from the sale of products or services. However, the long-term existence and development of the company depends not only on obtaining maximum profits, but also on fair treatment of others. Therefore, in modern market relations there is a need for a fair balance of needs between producers and consumers of products and services. Justice is based on the observance of certain postulates that determine the moral and ethical norms of the individual behavior in society.

Transparency. Based on the principles of transparency in marketing, there is a need to prevent unfair competition between businesses. The use of transparency as a value guideline will facilitate achievement of marketing goals through open communication, completeness, reliability and availability of information about the manufacturer, which is an important area of interaction with stakeholders. The use of transparency creates opportunities to increase the efficiency and effectiveness of marketing activities, to establish communication links between producers of goods and consumers, to increase the motivation of employees in the team, to improve the image and reputation of the business entity in the market.

Respect. Building respect in the marketing environment is an important condition for ensuring trust and mutual understanding between the subjects of market relations. 
Thanks to the existing respect, the necessary principles are created for the development and adoption of management decisions, based on their own economic interests and the existing needs of business partners. In particular, respect for the team and the human dignity as well as for interests of all market participants in general forms the necessary values to achieve certain socio-economic goals, using a variety of marketing tools.

Therefore, the reflection of moral and ethical criteria and values of marketing gives grounds to state that their observance is a necessary modern attribute and an integral part of corporate management of marketing activities. The formation of fundamental moral and ethical criteria in business is a necessary condition for its development in the medium and long term. The implementation of modern marketing policy should be based on appropriate values, which in their diversity contribute to the establishment of a balanced relationship between all market participants.

The marketing activities of the company are associated with the need to form behavior that must comply with the moral and ethical norms of coexistence within the business environment. Adherence to the basic principles of moral and ethical behavior is a sense of moral responsibility of marketers for the ethical performance of their professional duties, prevention of opportunistic behavior, providing objective professional assessments required of them. Ethical behavior over time creates a good name and reputation for the company, encourages loyalty of consumers and employees, and, last but not least, helps to overcome crises that threaten the existence of the company [575].

For the modern business environment, an important role in the recruitment process is the presence of the marketer's universal qualities, which in combination will contribute to the formation of a moral and ethical values system necessary for the development of the company in a competitive environment. The main factors influencing the behavior of a marketer are values (moral and ethical values), motivation of staff to perform their duties professionally, as well as an objective perception of reality (real assessment of the market situation and making the necessary decisions). Let's reflect the process of influence of these factors on the ethical behavior of the marketer, the combination of which in the activities of the marketer provides him with 
the opportunity to make the necessary decisions in sales, promotion and positioning of goods (services) in specialized markets accordingly satisfying the interests of producers and consumers of products (Figure 1).

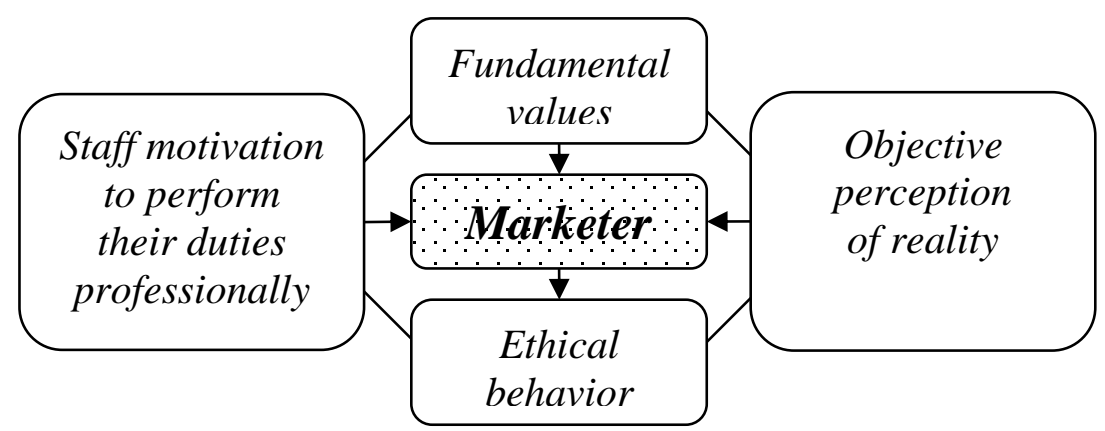

Figure 1. The relationship between factors influencing the ethical behavior of the marketer.

According to F. Kotler, marketers, full of sense of responsibility, interpret the needs of consumers and respond to them by offering appropriate products at prices that would ensure the profitability of purchasing these products for buyers and making a profit for sellers [577]. Ethical behavior of a marketer is a multifaceted phenomenon that determines the need for sufficient motivation, principled adherence to values, objective perception of reality, which will contribute to the formation of a positive image and the necessary reputation of the company among existing competitors and potential consumers. Modern marketer needs to have a variety of moral and ethical competencies, which in their unity are divided into two main groups: professional (those related to the responsibilities and tasks he performs) and personal (those that determine his personal qualities).

The moral and ethical competencies of a marketer must correspond to certain skills and abilities necessary for the organization of activities at a high professional level. Under the optimal combination of professional and personal characteristics of a person, opportunities are created for effective cooperation with consumers in the promotion and sale of goods (services) on the market in order to increase the attractiveness of the company. The use of moral and ethical competencies provides additional arguments to the marketer to form his attitude to others. It can positively affect consumers from the standpoint of stimulating their demand for goods (services) of the producer. 
It is important that the ethical orientation of marketing is a responsible attitude to the consumer, doing business on the basis of openness, honesty and mutual respect. A professional marketer must have the ability to be emotionally attractive, communicative and proactive for self-realization and improvement of quality properties. The formation of personal universal competencies is a necessary prerequisite for the moral and ethical behavior of a marketer in the performance of their professional duties. responsibilities.

Thus, the formation of ethical behavior is a multifaceted concept that is based on values that have a direct impact on the marketer. Compliance with moral and ethical competencies creates the necessary basis for professional growth and implementation of the acquired skills of a marketer, especially given the transient transformation processes currently taking place in the national economy. The integration of ethical behavior in marketing activities determines the implementation of the marketing strategy of the company, improving its image and business reputation.

In the process of marketing there is a need to focus on the socio-ethical aspects of the business entities interaction. This is due to the need to form long-term mutually beneficial relations between market participants in the production, sale and consumption of goods and services. Achieving operational, tactical and strategic goals of the company should be based on the widespread application of the principles of socio-ethical marketing for its further development in conditions of increased competition in target markets.

The essence of the "socio-ethical marketing" must be considered in the form of a certain concept. The socio-ethical marketing is conceptually based on the principles of constant interaction with stakeholders, reducing non-financial risks, long-term improvement of the company's image and business reputation [579]. The role of socioethical marketing concerns to optimally combine the economic needs of business entities with their universal principles and guidelines used in the process of professional activities.

The implementation of the moral and ethical component of marketing in the overall strategy of the company is due to certain reasons. First, doing business should 
be based solely on the responsible awareness of the marketer of their professional responsibilities. Second, adherence to ethical standards of conduct (principled adherence to moral and ethical values, ensuring a sufficient level of motivation, objective perception of reality, etc.) in the business environment creates significant advantages for the competitive positioning of the company in garget markets. Third, the formation of an effective communication environment clearly requires the organization and dissemination of information flows between the subjects of market relations on the basis of universal moral and ethical principles of communication. The formation of socio-ethical marketing in the enterprise involves ensuring a balance between the following interrelated goals: obtaining maximum economic effects from the implementation of marketing activities; satisfaction of the widest needs of consumers and orientation on achievement of priority tasks of the company (Figure 2).

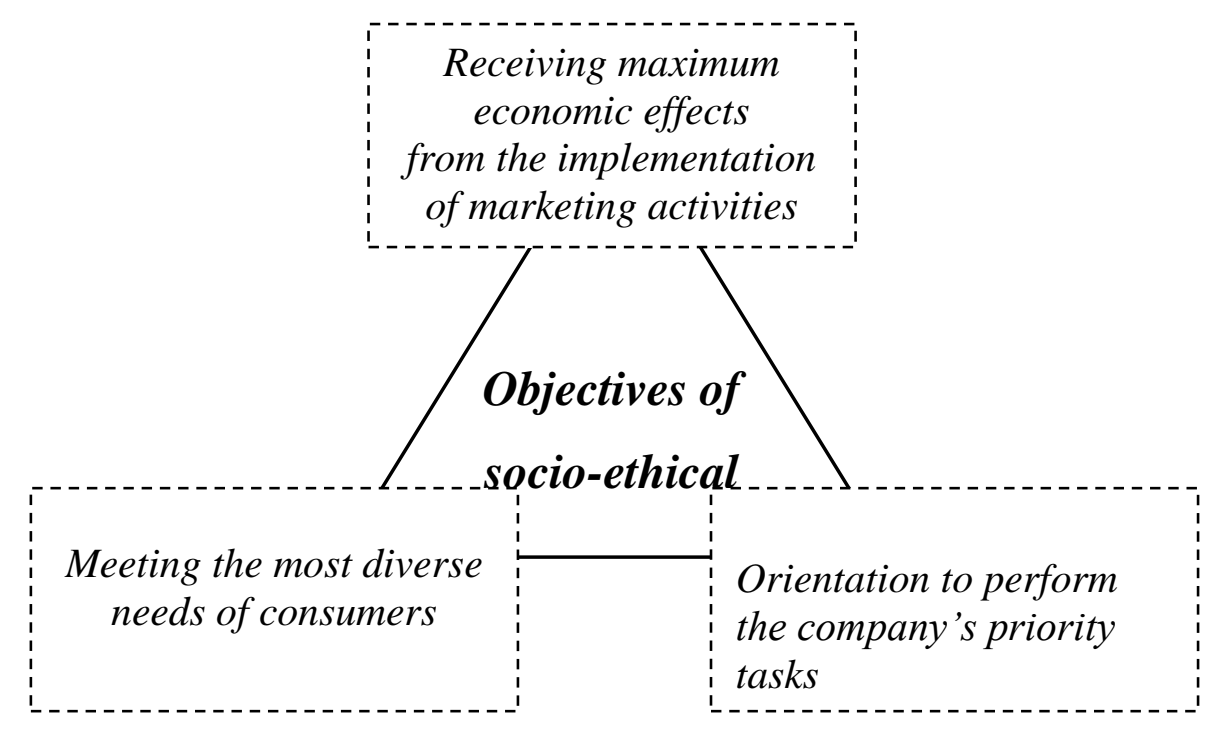

Figure 2. Formation of socio-ethical marketing goals.

Due to the use of existing moral and ethical competencies of marketers, the necessary economic effects are achieved, which are reflected in expanding sales of goods and services, increasing revenue, optimizing cost structure, ensuring profitability, improving the image and reputation of the enterprise. The economic achievements of economic entities should be formed solely on the basis of mutual respect, trust and integrity between all market participants. The combination of moral 
and ethical competencies of a marketer creates the necessary prerequisites for quality interaction with potential consumers (customers) of goods and services.

The strategic task for the marketer is the maximum positioning of the company in the market, and this, in turn, requires compliance with moral and ethical criteria of its behavior. The formation of such a style of professional activities will provide him with respect and understanding with potential consumers, which is a key condition for combining the socio-economic interests of market participants. Adherence to the customer-oriented strategy will contribute to the maximum satisfaction of consumer needs in goods and services, and this will lead to a gradual increase in the company's income from operating, investment and financial activities.

The implementation of operational and current activities of the marketer should be subject to the overall strategic objectives of the company. As part of the operational tasks of the marketer should use the following measures: conducting professional training on the basics of ethics and morality in the modern business environment, promoting the educational process and training of employees. The tactical level includes: strict adherence to ethical behavior between colleagues and in the process of doing business; compliance with the dress code by employees and the formation of an appropriate culture of communication in the team and with potential consumers of goods (services), as well as improving professional competencies in morality and ethics. Reflecting the diversity of moral criteria of marketing behavior requires the development and implementation of strategic directions in the process of balancing the socio-ethical values of all subjects of market relations (Table 1).

Table 1.

Formation of directions for social and ethical marketing strategy

\begin{tabular}{|l|l|l|}
\hline \multicolumn{1}{|c|}{ Strategic direction } & \multicolumn{1}{|c|}{ Goal formation } & \multicolumn{1}{c|}{$\begin{array}{c}\text { Positive effects } \\
\text { of application }\end{array}$} \\
\hline $\begin{array}{l}\text { Reproduction of } \\
\text { moral and ethical } \\
\text { values }\end{array}$ & $\begin{array}{l}\text { Implementation of marketing } \\
\text { activities aimed at using the } \\
\text { professional and personal } \\
\text { competencies of staff }\end{array}$ & $\begin{array}{l}\text { Creating a favorable } \\
\text { microclimate in the team, } \\
\text { necessary to achieve the tactical } \\
\text { and strategic goals of the } \\
\text { company }\end{array}$ \\
\hline $\begin{array}{l}\text { Interaction with } \\
\text { stakeholders on the } \\
\text { principles of social } \\
\text { responsibility }\end{array}$ & $\begin{array}{l}\text { Ensuring the ethical behavior of the } \\
\text { relationship between consumers and } \\
\text { other stakeholders }\end{array}$ & $\begin{array}{l}\text { Formation of socially responsible } \\
\text { attitude to market participants for } \\
\text { mutually beneficial cooperation }\end{array}$ \\
\hline
\end{tabular}


Continuation of table 1 .

\begin{tabular}{|l|l|l|}
\hline $\begin{array}{l}\text { Revival concept } \\
\text { of happiness }\end{array}$ & $\begin{array}{l}\text { Creating favorable conditions for } \\
\text { defending the human-centered } \\
\text { position in target markets }\end{array}$ & $\begin{array}{l}\text { The optimal combination of } \\
\text { material and moral \& ethical } \\
\text { needs from the interaction of } \\
\text { marketers with potential } \\
\text { consumers of goods and services }\end{array}$ \\
\hline
\end{tabular}

Reproduction of moral and ethical values. The need to reproduce moral and ethical values is based on the implementation of educational activities in the team. The formation of this strategic direction is the implementation of marketing activities aimed at maximizing the professional and personal competencies of staff required to conduct business at a sufficiently high professional level. Adherence to moral and ethical values will contribute to the formation of an interpersonal microclimate necessary to achieve the tactical and strategic goals of the company. The presence of relationships based on trust and mutual respect between employees certainly motivate them to cooperate on mutually beneficial terms with potential consumers of goods (services).

Interaction with stakeholders on the principles of social responsibility. The essence of this area is to implement the principles of social responsibility in the process of interaction between the company and various stakeholders. At the same time, there is a need to ensure the ethical behavior of relationships based on mutual respect and understanding between all participants in public relations. In the process of implementation of this strategic direction, a socially responsible attitude of all market participants for further cooperation is formed.

Revival of happiness concept. Revival of happiness concept. The relevance of the application of this strategic direction is to ensure the moral and socio-ethical wellbeing of all subjects of market relations, which has a positive impact on the implementation of the marketing strategy of the enterprise. The presented direction is based on a human-centered position focused on a socially responsible attitude to the development of a set of marketing activities in the interests of all participants in market relations. The expediency of applying this strategy is the optimal combination of material and moral and ethical needs from the interaction of marketers with potential consumers of goods and services in the process of society's desire for happiness. 
Thus, socio-ethical marketing is a multilevel concept of marketing associated with the growth of general social welfare on the basis of moral and ethical criteria of entrepreneurial activities of highly qualified employees to meet existing and future needs of consumers aimed at improving the quality of life with observing the social responsibility principles. The implementation of this concept should be aimed at the optimal combination of moral and ethical, psychological and socio-economic interests of all participants in market relations. The role of socio-ethical behavior of individuals in the target markets is of particular importance given the use of a set of marketing activities for the development, marketing and positioning of goods (services). The formation and implementation of socio-ethical marketing strategy is aimed at defending the multifaceted interests of the company, consumers and other stakeholders, based on the principles of integrity, morality and responsibility. The result of the implementation of socio-ethical strategy should be the achievement of a progressive revival of the concept of happiness to ensure the moral, psychological and material well-being of society in the process of marketing activities of the company. 


\section{SECTION 15. THEORY AND HISTORY}

\subsection{LOCAL ELECTIONS AND CAPITAL INVOLVEMENT IN SOUTH KALIMANTAN}

Historically, the study of the relationship between state and capital in thehistory of political power in IndonesiP, especially under Suharto's government era is a reality of conspiracy between the state capital during past 32 years. The reality of this conspiracy is established through the use of a mutually beneficial institution of power, regulation, and patronage relations to dominate economic resources and political power. Under the Suharto's government era with the political authoritarian power structure the economic resources and political power are in the hands of actor groups who have patronage relationships with those within the bureaucracy of government to accumulation and monopoly of economic resources who have economic and political patronage relationships within the government bureaucracy network.

The rise of Suharto's cronies behavior by Kunio (1991), is described as an erzast capitalism,. Hadiz, (2004), and Winters (2011) called it oligarchy- predatory who were born to obtain facilities and protection from the authorities. Entrepreneurs appear as strategic groups that can influence state policy through conspiracy, which places institutions of power and regulation that are engineered in such a way as to legally control state's economic resources.

The fall of the Suharto's government in May 1998 that led to the transition of democracy has changed the current political order. Although the formal regime had collapsed but the heritage disease grew at the local government, such as the practice of political corruption and nepotism. The political actors who occupy the current stage of power have not undergone much change from the mental oligarch-predatory. The oligarchs are increasingly finding their habitat at the local level with decentralization and local autonomy era to be as an opportunity for these local oligarchs.

In the democratization, local autonomy era has changed the structure of power and new designs on democratic institutions more open and democratic through 
contestation of Regional Head Election (Pemilihan Kepala Daerah/ Pilkada). Democratic capitalization and political pragmatism is increasingly fragmented political behavior of the people, the political choice of the people is increasingly not easy to localize the political choices of the politicians. The politician in various modes display the patterns of money politcs and the make people lose political rationality. The political logic of the people has been caught in the vortex of political pragmatism and has no power to avoid all that. The political market has been colored by political transactional and conspiracy issues between political elites and market (capital) and educating the mentality of the people into political absurdity in the black market of democracy

In the political pragmatism, local Head Election is to be made and fomulation of strategies by local actors to influence political choices of the people. One of the strategies for influencing local actors is use of capital (money politics) and patronage networks played by political elites. The high cost of democracy in local elections making political gambling behavior, that is political mafia by mobilizing economic and political resources, conspiracy, and design by local actors to gain economic and political advantage.

After the fall of Suharto's regime, changing of political institutions are expected to build economic and political life better, does not lead to change significant although the institution of power has changed. The political institution has changed but not changes in the behavior of political actors who still behave in pridatory oligarchy (Hadiz, 2010). Therefore, what is happening about democratization is mostly controlled by political actors. The changing of politics in democratization era is not necessarily accompanied by the fall of the power of the oligarchy.

South Kalimantan Province is known as the region having the second largest mining resource, now shifting to palm plantations that have surrounded 9 districts in South Kalimantan. Citing the news reported by jejakrekam.com on March 8, 2017, from the statement of the Chairman of the Indonesian Palm Oil Association South Kalimantan Totok Dewanto stated that now there are 9 districts that have transformed into a palm plantation center on an area of four hundred thousand $(400,000)$ hectares. 
These oil palm plantations are spread in Barito Kuala, Hulu Sungai Selatan, Hulu Sungai Utara, Tapin, Tanah Bumbu, Kotabaru, Balangan, Tabalong and Tanah Laut.

Well, the big players in the palm business is a national and international network, especially from Malaysia which mostly has mastered the area of productive land and swamp in Barito Kuala District, such as Sinar Mas Group, Astra Graha Lestari Group, Minamas Group and others. In addition, local entrepreneurs joined by Hasnur Group, Jhonlin Group and others also played, including Batola Hasanuddin Murad Regent in the palm business of producing cooking oil (CPO) and soap industrial raw materials and others, amid the mine business melasunya Coal due to price fluctuations from export destination countries such as China, India, Japan and others.Such a position ultimately leaves local actors no longer relying on mine potential but also targeting large-scale plantation enterprises as one of the pundi to generate multiple profits.

Therefore, the mining entrepreneurs who have large capital and have a number of mining companies, as well as retired bureaucrats (regents and governors) who have large capital, competing for a strategic position in a political party or become chairman of one political party. By controlling the institutions of democracy will have value strategic and construct economic and political concessions for ruling candidates, both in terms of funding power and in terms of political value. The mining business network will only revolve around people who have made it into the power network and forming a business client under the protection of the powers of public officials (regions or governor) elected in the electoral process. The actors who play in the arena of the mining industry are the ones who were born as business client, shadow government, and local bossism.

These actors seek to establish power relations with legislative and governmental institutions to gain policy support through the creation of a number of local regulations related to the policy of mining and oil palm plantation management.

The actors involved in the election will eventually appear as rent-seekers. The issuing of mining permits and palm oil plantations will be easier for business clients as a form of political repayment for winning public officials in political or electoral contests. In view of the development of economic and political dynamics, particularly 
in relation to the existing coal mining management policy in South Kalimantan, the meaning of decentralization in the context of natural resource management does not necessarily eliminate the predatory patronage and oligarchy patterns that are inherited from the New Order. The emergence of a number of local actors in the political stage of entrepreneurial background, not just rely on social capacity, political capacity, no less important must have financial capability.

Understanding of local political landscape in Pilkada 2017 in Barito Kuala District is closely related to the succession of Pilkada 2015, especially in the election event of Governor-Vice Governor of South Kalimantan. In general, after the death of Chairman of South Kalimantan Golkar Party, H. Abdussamad Sulaiman HB on June 14, 2015, automatically there are only two power investors that greatly affect the map of politics in South Kalimantan. First, is the person behind the Governor of South Kalimantan H. Sahbirin Noor who is now H. Andi Syamsudin, the owner of the Jhonlin Group, although not appearing in public, but the supply of funds given to H. Sahbirin Noor for campaign funds and money politics is very large.

Jhonlin Group who helped oversee H. Sahbirin Noor who is now familiar with the iconic Uncle Birin in all political activities is now famous. H. Isam's competitors come from Binuang sub-district of H. M. Hatta alias H. Ciut and H. Zaini Mahdi alias H. Izai who are big mining entrepreneurs in Tapin Regency and most influential under the banner of P. T. Batu Gunung Mulia (BGM). They are behind the financial strength as well as the network in the exploitation of former Mayor of Banjarmasin H. Muhidin together with former senator of DPD RI, Gusti Farid Hasan Aman as candidate for Governor-Vice Governor of South Kalimantan period 2016-2021. The rest, small coal entrepreneurs like H. Jahrian Noor, H. Amir, H. Parlin which is the miners and coal cukong with the concession area are in Tanah Laut Regency and part of Tanah Bumbu Regency.

As a result of political parties which have pushed H. Sahbirin Noor who chose Rudy Resnawan who previously served as Vice Governor of South Kalimantan as a companion, automatically made Golkar power to be in the hands of Uncle Birin. Hence, Gusti Iskandar Sukma Alamsyah who want to advance through Golkar, finally 
stuck when enrolled with academics FKIP University Lambung Mangkurat (ULM) Banjarmasin, DR Karyono Ibn Ahmad with support from the DPP Golkar Party version of Agung Laksono. Until finally, the South Kalimantan Election Commission decided not to accommodate the Golkar Party and PPP support letters are stated double.

From here, the beginning of the change of political map in South Kalimantan that affects the next democratic party in 2017, especially in Barito Kuala (Batola) and Hulu Sungai Utara (HSU). It was stipulated by Election Commision of South Kalimantan that H. Sahbirin Noor and Rudy Resnawan as Governor-Vice Governor of South Kalimantan period 2016-2021 with voice reaching 739,588 or 41,09 percent, followed by independent candidate H Muhidin-Gusti Hasan Farid with 725,585 votes or 40,31 percent and Zairullah Azhar-Muhammad Safi who carried PKB, Party Nasdem, and the Democratic Party is only 334,712 votes or 18.6 percent.

According to Arief (Barito Post journalist, interview on February 15, 2017), the reason why $\mathrm{H}$. Muhidin did not file a lawsuit with only 1 percent permitted by the Constitutional Cour in Jakarta was because there is a business political deal that binds between $\mathrm{H}$. Muhidin and $\mathrm{H}$. Isam (owner of Jhonlin Group) for coal transport cooperation through a special port owned by $\mathrm{H}$. Muhidin. Not only business agreements, criminal cases that ensnare H. Muhidin handled Police Headquarters can be dismantled again, if the former mayor of Banjarmasin is still desperate to file a dispute election 2015 to the Constitutional Court in Jakarta.

Not surprising, if finally the Great Coalition which was done by Uncle Birin in the election of Governor-Deputy Governor of South Kalimantan 2015 was imitated Hasan Ismail with the same pattern plans to break the vote of Golkar, by holding Fahrin Nizar (Batola member from Golkar emerges. So, in broad outline, Jhonlin Group did not play very much in Batola with its oligarchic network. It is precisely Binuang Group led by H. Izai and H. Ciut who became opposing H. Isam in the political arena in South Kalimantan, also played behind the scenes H. Bahrian Noor-H. Suwandi. Therefore, the Binuang Group has the interests of the port business of fuel oil (BBM) as well as the existing sand mines on the coast of the Barito River, near the Barito Bridge area. 
Although not too obvious, Binuang Group network is a political enemy Hasnur Group is also targeting palm oil plantation in Batola. The political actualization played by $\mathrm{H}$. Izai and $\mathrm{H}$. Ciut in Batola, can be seen clearly from the movement played by members of the House of Representatives from Golkar Party, Bambang Heri Purnama in every recess or down to the public in absorbing aspirations, promoted $\mathrm{H}$. Bahrian Noor. Meanwhile, Zairullah Azhar also melakoni similar things, with the pattern from the mosque to the mosque, or one pengajian to other pengajian.

Well, the political actors in South Kalimantan have split into two major forces namely H. Sahbirin Noor and H. Muhidin, Mardani H. Maming who became the representative of Jhonlin Group with his 'grand master', H. Isam behind the power of Hasan Ismail-Fahrin Nizar. Then, the political resistance that Zairullah Azhar-Guntur Prawira and Binuang Group-though not too prominent-presented for the victory of $\mathrm{H}$. Bahrian Noor-H. Suwandi in elections 2017. Meanwhile, Hasanuddin Murad (Regent Batola) with bureaucratic and ethnic networks Dayak Bakumpai plus Banjar Pahuluan, also played a role to win the Noormiliyani Aberani Sulaiman-Rahmadian Noor.

The couple of Noormiliyani-Rahmadian Noor excel with 48.11 percent voice managed to surpass her rivals in the elections namely Hasan Ismail-Fahrin Nizar (34.61 percent) and Bahrian Noor-Suwandi (17.28 percent). Regent elected Noormiliyani paired with Rahmadian Noor is the wife of Hasanuddin Murad who has served as Regent Batola two periods. While Ramadian Noor as Vice Regent elected none other than Hasanuddin Murad's nephew. The appearance of Normiliyani-Rahmadian Noor as the winner in the Barito Kuala election has allowed the politics of the dynasty of Hasanuddin Murad's ethnic group on the local political scene in Barito Kuala.

The Normaliyani-Rahmadian Noor pair promoted by the Golkar and Democrat parties, the Bahrianoor-Suwandi couple were supported by the National Awakening Party and Gerindra Party, while the Hasan Ismail-Fahrin Nizar pair was supported by the Prosperous Justice Party, Partai Amanat Nasional (PAN), Partai Unity of Development, Indonesian Democratic Party of Struggle, Hanura Party, and Crescent Star Party 
When observed by the Chairman of the Political Party, the bearers of couples candidate are persons with entrepreneurial background, local officials, or former local officials. Like Golkar Party as a bearer of the couple Normaliyani-Rahmadian Noor, one of the important members of the Golkar Party is Hasanuddin Murad who carried his wife as a candidate for Regent Barito Kuala. PKB and Gerindra Party carrying the couple Bahrianoor-Suwandi as it is known that the Chairman of the PKB South Kalimantan Zahirullah Azhar former Regent Tanah Bumbu two periods that have a network with the mining entrepreneurs, while Chairman of the Gerindra Party of South Kalimantan is H. Abidin who is known as an entrepreneur or owner Port of coal mine.

The couple candidate of Bahrian-Suwandi loses money and not many entrepreneurs provide support to the candidate so that the losses are lost and the community is already patterned with money politics. Why this happened? Therefore, since Thursday (January 26, 2017), hauling (special road) PT Talenta Bumi including mining business owned by H. Jahrian closed the Integrated Team Enforcement of Local Regulation No. 3 of 2012 on Special Road of Coal and Oil Plantation which is a combination of Transportation Department, Communication and Information South Kalimantan together with Directorate of Traffic Polda South Kalimantan, plus assistance from Korem 101/Antasari. Also attended was hauling owned by PT Binuang Mitra Bersama (H. Izai and H. Ciut's business network) and Hasnur Group for 41 days with estimated loss of Rp 41 billion.

This is also explained by the Chairman of the Association of Mining Society (Permata) of the People of Kalimantan, Syamsul Daulah (interview on Thursday, January 26,2017 ) that due to the closing of hauling to three local companies owned by H. Jahrian, H. Izai and Hasnur Group is coal transportation activities ranging from 500 to 1,000 Ton per day by South Kalimantan Governor H. Sahbirin Noor who issued letter number 551/97, dated January 23, 2017 to South Kalimantan Police Chief Brig. Gen. Erwin Triwanto to cover the existing hauling as it was considered violated by law No. 3/2012, and followed up a letter from the Ministry of Public Works And Spatial Planning (PUPR) of the Directorate General of Highways, National Road Implementing Agency XI Number 02.06-Bz / 027, concerning the obligations of the 
mining entrepreneurs to create a flyover in the national road area connecting Marabahan-Margasari to the coal-specific port area in Sungai Puting, Kabupaten Tapin.

H. Syamsuddin or known H. Isam in Barito Kuala election is also barely audible. In the case as always in some elections in South Kalimantan always appear as supporters or supporters of funds or set political calculations for candidates who supported. As is known, H. Isam currently as PAN Council Advisory South Kalimantan and Chairman of DPW PAN South Kalimantan is Muhidin former Mayor of Banjarmasin and former political rival H. Sahbirin Noor in South Kalimantan Governor Election. H Isam is the nephew of H. Sahbirin Noor as the main supporter of political funds in the elections of South Kalimantan Governor since 2015.

CONCLUSION. With that position, H. Isam has also built a strong and influential political network in almost all major political parties. Although Rudy Ariffin, a former governor of South Kalimantan, is able to control the United Development Party (PPP), but essentially debt service or politics to the success of the child, HM Aditya Mufti Ariffin during legislative elections 2014. This further indicates the dominance of the main actors in business and political networks in South Kalimantan is still held by H. Isam. Meanwhile, the concentration of H. Izai and H. Ciut is only in the local level, especially Tapin regency which is ahead of the succession in 2018, after being pressed by Jhonlin Group with power and law networks supported by Police and Military.The phenomenon that occurred in the 2017 Batola Election has shown that financial power, business and political networks including law enforcement officers controlled by $\mathrm{H}$. Isam with a leading figure who appeared to the public, South Kalimantan Governor H. Sahbirin Noor has become the actor of determining the way of political direction in South Kalimantan. Although not appearing publicly, $\mathrm{H}$. Isam hands still gripped strongly in politics and business in South Kalimantan. Whether later in elections in 2018 which will take place in four districts of Tanah Laut Regency, Tabalong Regency, Tapin Regency and Hulu Sungai Selatan Regency (HSS). Even so, out of the four regions that will hold elections of 
Regent's Regents in 2018, Tanah Laut District will be an exciting battle, and the patterns applied in the 2017 Regional Elections can be repeated again. 


\section{2 Аномалії та ефекти в економічній поведінці: історія досліджень та прояви в сучасних економічних відносинах}

Поведінкова економіка, що останнього часу має потужний розвиток та підвищену цікавість з боку як вчених-теоретиків, так і практиків (трейдерів, управлінців), націлена на вивчення впливу соціальних, когнітивних та емоційних факторів на прийняття економічних рішень людьми та організаціями. Поведінкова економіка взяла за основу нераціональність людської поведінки та часто насичена дослідженнями поведінкових аномалій. Поведінкові аномалії прямо суперечать принципам раціональності господарюючих суб'єктів, причому по мірі прогресування цих досліджень, виявлені аномалії стрімко помножувались, а раціональність, відповідно, скорочувалась. Існує концепція поведінкової економіки, яка базується на аксіомі, згідно з якою цінність завжди максимальна. Вона включає так звані аномалії або конфлікти між тимчасовими зразками поведінки та окремими актами, що містять ці зразки. Ця друга концепція поведінкової економіки $є$ як емпіричною, так і внутрішньо узгодженою [586].

У XX ст. були визнані моделі очікуваної і міжчасової корисності, після чого стало можливо безліч гіпотез про прийняття рішень в умовах невизначеності і виборі, розтягнутому в часі. Завдяки ним економічна поведінка вибухнула численними перевірками гіпотез аномалій вибору, що в подальшому були опубліковані. У 1968 р. вийшла праця лауреата Нобелівської премії Гері Беккера (Gary Becker) «Злочин і покарання: економічний підхід», де психологічні фактори були включені в ухвалення економічних рішень. У 1979 р. дослідники в галузі когнітивної психології Даніель Канеман і Амос Тверські (Daniel Kahneman, Amos Tversky) опублікували працю «Теорія перспектив: вивчення процесу прийняття рішень в умовах ризику», який узагальнив емпіричні спостереження вчених. 31980 р активно розвивається поведінкова теорія ігор. У 2002 р Даніелю Канеману вручили Нобелівську премію за включення даних психологічних досліджень в економічну науку. У 2008 р вийшла книга 
професора поведінкової економіки Дена Аріелі (Dan Ariely) «Очікувано ірраціональний». Вважається, що саме $з$ неї почалася популяризація поведінкової економіки серед широкої аудиторії.

В поведінковій економіці можна виділити низку аномалій та ефектів, які не просто ставлять під сумнів раціональність економічної поведінки господарюючих суб’єктів, а формують доказову базу наявності широкого кола психологічних, соціальних, когнітивних чинників, що впливають на процес ухвалення рішень. Систематизація та обгрунтування цих аномалій та ефектів $\epsilon$ метою даного дослідження.

Аномалії - це події, спостереження чи результати, які можуть суперечити сталій науковій теорії. При цьому, згідно з аргументами Томаса Куна (Kuhn T.), аномалії визнаються лише тоді, коли раніше існуюча парадигма спростовується альтернативною, в результаті чого відбувається зміна цієї парадигми [587]. Наявність аномалій в розвитку науки є надзвичайно важливою, оскільки їх виявлення змушує науку модернізуватись відповідно до вимог часу та наблизити теорію до практичного впровадження аж до наукового відкриття.

Парадигми отримують свій статус, коли вони виявляються успішнішими за своїх конкурентів у вирішенні тих проблем, які на даний момент є гострими. При чому парадигма може бути абсолютно успішною для розв'язання однієї проблеми, або припустимо успішною по відношенню до великої кількості проблем. Намагання науковців вирішити ці проблеми змушує їх зосереджуватись на пошуку можливих шляхів розв'язання, що і зумовлює прогрес науки.

Окрім терміну «аномалія» Т. Кун запроваджує поняття «головоломка», яке визначається як проблеми, що «мають рішення за певної прийнятої парадигми» [587, p. 37]. Незважаючи на те, що головоломка, так само як і аномалія, може спричинити модифікацію або розширення парадигми, цей термін у науковому обігу не прижився.

Отже, звернемось до аномалій економічної поведінки. 
Однією з аномалій економічної поведінки є самовпевненість і систематична переоцінка власних знань і здібностей. Так чи інакше, ця характеристика притаманна абсолютно всім господарюючим суб'єктам та $є$ абсолютно очевидною. Людям властиво хронічно переоцінювати достовірність власних знань та можливостей. Будь-який господарюючий суб'єкт, оцінюючи свої здібності, класифікує їх, щонайменше, «вище середнього».

Така надмірна самовпевненість, в свою чергу, формується під впливом ряду психологічних феноменів, які розглянемо далі.

1. Схильність спотворювати у власній свідомості інформацію про минулі події (hindsight bias), або Ефект хіндсайту - це схильність сприймати події, що вже відбулися, або факти, що вже були встановлені, як очевидні та передбачувані, незважаючи на відсутність первинної інформації для їх прогнозу. Це явище також відоме як «я так і знав», «я ж говорив». Упередженість такого сприйняття може спричинити спотворення спогадів, через що може відбуватись викривлення майбутніх прогнозів, і як результат - помилки у прийнятті рішень.

Причинами таких спотворень називають три ключові змінні, які взаємодіють між собою та сприяють такому баченню речей, коли вони здаються більш передбачуваними, ніж вони є насправді [588]:

- пізнавальна, що полягає у використанні людиною такої інформації, що відповідає їі поточним знанням;

- метакогнітивна, що відповідає такій легко зрозумілій події, яка створює переконання, начебто іiї можна було легко передбачити;

- мотиваційна, що стимулює людей сприймати світ як передбачуване місце з неминучими результатами ухвалених рішень.

Ці змінні можуть взаємодіяти, підсилюючи Ефект хіндсайту.

Схильність до спотворення інформації про минулі події створюють різного роду ризики, які можуть бути фінансовими, наприклад, розміщення занадто великої кількості цінних паперів у ризикованому інвестиційному портфелі.

Якщо особа, що ухвалює рішення, намагається протистояти цьому упередженню, вона мусить здійснювати розгляд речей, які могли б статися, але 
не відбувалися. Мисленим аналізом потенційних результатів люди можуть отримати більш збалансоване уявлення про очевидну неминучість результату.

2. Властивий людям систематичний оптимізм (optimistic bias), що змушує недооцінювати ймовірність виникнення негативних подій. Незважаючи на переконання людини про власну раціональність та здатність мислити логічно, людський мозок часом надто оптимістичний для свого блага та недооцінює настання таких подій, як, наприклад, банкрутство, втрата роботи, нещасний випадок тощо. Упередженість оптимізму становить собою хибну думку, що власні шанси настання негативних подій є нижчими, а позитивних - вищими, ніж у інших людей. Це упередження створює ілюзію, що індивід рідше страждаєтиме від нещасть i, має більше шансів на досягнення успіху, ніж це передбачає реальність.

Упередженість оптимізму не просто свідчить про те, що людина має занадто оптимістичні погляди та переоцінює можливість позитивних подій в житті, це також може призвести до невдалого прийняття рішень, що іноді має наслідком катастрофічні результати.

Когнітивний невролог Талі Шарот (Sharot Tali), автор книги «Схильність до оптимізму: подорож ірраціонально позитивного мозку», зазначає, що ця упередженість широко поширена і може спостерігатися в культурах всього світу, починаючи від невиправданої ризикованої поведінки або неправильний вибір щодо здоров'я [589].

Але, в той же час, очікування, що відбуватимуться хороші речі, швидше за все, роблять індивіда щасливішим, оскільки, вірячи у свій успіх, люди насправді мають більше шансів на його досягнення [590].

3. «Ілюзія контролю» (illusion of control), що проявляється в тому, що індивіди мають схильність переоцінювати свою здатність контролювати події. Такий ефект виникає тоді, коли людина вважає, що має контроль над результатами, на які він в реальності не впливає. Свою назву ефект отримав завдяки праці психолога Елен Лангер (Langer, Ellen J), яка дослідила його 
відтворення у багатьох різних контекстах [591]. Поряд з ілюзорною перевагою та упередженістю оптимізму, ілюзія контролю є однією з позитивних ілюзій.

Причиною виникнення цієї ілюзії може бути те, що людям бракує прямого інтроспективного розуміння того, чи контролюють вони події. Це отримало назву ілюзія самоаналізу. Натомість вони можуть судити про ступінь контролю за процесом, який часто $є$ ненадійним, внаслідок чого люди бачать себе відповідальними за події, коли причинний зв'язок є незначним або взагалі відсутнім.

Ілюзія частіше зустрічається у звичних ситуаціях і в ситуаціях, коли людина знає бажаний результат [592]. Якщо індивід вважає, що він має позитивний досвід вирішення аналогічних проблем, ефект бути підсилюватись, тоді як негативний досвід може його нівелювати. При чому мають місце як переоцінка ступеню контролю, так і його недооцінка. Ілюзія контролю $є$ одним 3 когнітивних спотворень та проявляється, коли людина зацікавлена в позитивному результаті події, в якій будь-яким чином залучена.

В той же час може спостерігатися також і зворотний ефект - в деяких випадках люди схильні недооцінювати рівень свого контролю над результатом події.

Наступна аномалія економічної поведінки - когнітивне упередження (Cognitive bias) - виникає як відхилення у судженнях, що супроводжується можливою нелогічністю у прийнятті висновків про інших людей і ситуації. Фактично, індивід створює собі альтернативну реальність, що будується на його суб'єктивному сприйнятті оточуючого світу.

Існує широке коло досліджень, де представлено багато термінів-синонімів для опису цієї аномалії: когнітивне спотворення, когнітивне викривлення, когнітивна помилка, когнітивна девіація, когнітивна ілюзія, ілюзія мислення.

Причини, через які виникають такі упередження, можуть бути різними, наприклад: спрямлення шляхів при обробці інформації (евристика), розумовий шум, обмежена здатність розуму до обробки інформації, емоційні і моральні мотивації, соціальний вплив. 
Нездатність об'єктивно сприймати й інтерпретувати інформацію - ця аномалія пояснюється як не можливість завжди адекватно оцінювати складні ситуації при обмеженій інформації.

Дослідження, які полягали у можливостях зробити вибір між двома альтернативними варіантами дій, Д. Канеман і А. Тверскі виявили, що в умовах невизначеності індивіди частіше використовують спрощені стратегії - евристичний аналіз (heuristics), ігноруючи можливості використання строгих математичних моделей. Однак застосування таких спрощених стратегій при аналізі складних проблем може привести до помилок на ментальному рівні. Цей висновок отримав чимало підтверджень в результаті експериментів, що демонстрували нелогічну і іноді навіть парадоксальну поведінку індивідів, далеку від максимізації корисності.

Крім того, вплив на прийняття рішень чинять і особисті бажання індивідуумів. В разі, коли вони починають впливати на імовірнісні оцінки людей, виникає аномалія «відхилення бажаності» (desirability / wishful / value bias). Цей феномен є наслідком комбінації раніше розглянутих аномалій систематичного оптимізму, надлишкової самовпевненості і ілюзії контролю. Фактично, одного разу застосувавши певний спосіб вирішення ситуації, люди не схильні змінювати їх навіть тоді, коли отримана нова інформація. При цьому, саме цим знайомим явищам присвоюється велика ймовірність та увага економічного суб'єкта концентрується на окремому добре відомому факті, а не на загальній картині.

Пошук компромісу між вже наявним в минулому досвіді індивідуума в якості точки відліку при прийнятті рішень і зрушенням цих точок на основі нової інформації, отримав назву евристики закріплення і пристосованості (anchoring and adjustment heuristics). Евристика пристосованості означає, що при проведенні кількісних оцінок сильний вплив на результат можуть надати початкові, можливо довільні, або недавні значення досліджуваного показника. Евристичні упередженості в кінцевому результаті призводять до хибного трактування інформації, що і спонукає людей повторювати помилки в судженнях. 
Здатність оперувати тільки спрощеними і наочними поняттями є аномалією, що зумовлює таку особливість ухвалення рішень індивідуумом, коли воно ухвалюється на підставі вибору між спрощеними варіантами. Так, люди схильні ігнорувати подібні компоненти альтернатив i зосереджуватися на їх відмінностях - ефект ізоляції (isolation effect). Як наслідок, люди можуть перебільшувати важливість специфічних особливостей різних варіантів i відкидати всю іншу інформацію без розгляду.

Орієнтація свідомості на яскраві враження обумовлює той факт, що індивіди схильні перебільшувати ймовірність знакових подій, які добре запам'ятовуються, або тим, що відбулися недавно (евристика доступності, availability). Так, інвестори на ринку вважають відомі їм великі компанії менш ризикованими, ніж дрібні компанії. Аналогічну ситуацію можна простежити і на фондовому ринку, коли після певного періоду підвищеної прибутковості трейдери починають сприймати його як нормальний, не враховуючи динаміку попередніх періодів. Крім того, надмірне висвітлення в засобах масової інформації якоїсь події, може призвести до неправильного припущення, що така подія виникає набагато частіше, ніж є насправді [593].

При прийнятті рішення за інших рівних умов індивід не бажає робити помилки, що тягнуть за собою втрати, а тому прагне уникнути не стільки некоректно зробленого вибору, скільки жалю за зроблену помилку. Виникаючий ефект жалю (regret aversion) можна охарактеризувати як докори сумління за неправильне рішення, що призвело до негативного результату, або за правильне рішення, що з якихось причин призвело також до негативного результату. Ефективним способом уникнення ефекту жалю буде перекладання відповідальності на іншого, наприклад, агента, в результаті чого з'являються додаткові витрати на оплату послуг цього агента та нейтралізація самого ефекту жалю. До того ж, намагання уникнути почуття жалю змушує людину використовувати розповсюджені схеми поведінки.

Використання таких схем створює нові ефекти - ефект моди (mode effect) i ефект поведінки натовпу (herd behaviour). Натовп можна визначити як явище, 
коли люди вирішують наслідувати інших та повторюють групову поведінку, а не ухвалюють самостійні рішення на основі власної інформації. Теорія натовпу має свої витоки з концепції Дж. М. Кейнса (Keynes J. М.), який досліджував, що у світі невизначеності людину спонукають наслідувати поведінку натовпу уявлення про власне незнання, підтримання власної репутації або конкуренція [594]. В подальшому теорія поведінки натовпу розвивалась в контексті психологічного аналізу, що дозволяє пояснити вплив якостей особистості, настрою та емоцій на відповідну поведінку [595].

Ефект натовпу яскраво проявляє себе на ринках. Усі зміни цін, які відбуваються на товарному ринку, можуть провокувати панічну економічну поведінку, що також може набувати ефекту натовпу [596]. На фінансових ринках інвестор може ухвалювати рішення, спостерігаючи за діями інших учасників ринку й імітуючи їх. Якщо ж у інвестора є переконання, що він може впливати на результат здійснюваної операції, то виникає інший ефект, описаний вище ілюзія контролю.

Важливим прикладом нераціональної поведінки суб’єктів є порушення принципів теорії очікуваної корисності, відомий як парадокс Алле [596]. Теорія очікуваної корисності стверджує, що за необхідності вибору однієї з альтернатив індивід завжди обирає ту, де більша очікувана корисність.

На ухвалення економічних рішень надзвичайний вплив має ефект, що отримав назву ефект оформленості. Його сутність полягає в тому, що різне формулювання певної економічної ситуації дозволяє маніпулювати таким рішенням. «Кожен десятий споживач йде без покупки» та «Дев’яносто відсотків споживачів знаходять бажаний товар» з формальної точки зору відображають абсолютно ідентичні ситуації, але позитивніше сприймається друга фраза.

Організацію контексту, в якому людина ухвалює рішення, Річард Талер і Касс Санстейн (Richard H. Thaler, Cass R. Sunstein) назвали архітектурою вибору, а людину, що формує такий контекст, - архітектором вибору [698]. Можна виділити цілу низку цікавих факторів, що впливають на архітектуру вибору, серед яких можна виділити такі: взаємне розташування варіантів може впливати 
на вибір; презумпція згоди є ефективним способом впливати на рішення; обсяг блага впливає на кількість спожитого; існування стадного інстинкту; озвучений вибір має більшу вагу; контекст i «малозначні» атрибути обумовлюють вибір; ми схильні довіряти підсвідомим сигналам більше, ніж досвіду; самостійний вибір не завжди гарантує ефективне рішення.

Спрощуючи вибір між різними перспективами, економічні суб'єкти ігнорують загальні риси, зосереджуючи увагу на відмінностях, що представляє собою ефект ізоляції. Для того щоб спростити вибір між альтернативами, люди часто абстрагуються від їх загальних компонент, концентруючи увагу на відмінностях. Подібний «ефект ізоляції» часто призводить до непослідовності в їх перевагах.

В економічній поведінці можна простежити таку тенденцію, коли господарюючі суб'єкти, ухвалюючи рішення, схильні більше ризикувати в тій сфері, де вони більш компетентні. Цей ефект отримав назву «ефект компетентності», та як виявили численні дослідження, він не обов'язково має залежати від того, чи може їх обізнаність та професіоналізм якимось чином вплинути на ймовірність певного результату.

Але в той же час, економічні суб'єкти мають певну чутливість до впливу сторонньої думки, через що рішення ухвалюються не тільки на основі особистої думки та інформації, а й з огляду на таку сторонню думку. В результаті виникає ефект інформаційного каскаду, в моделі якого економічні агенти ухвалюють рішення послідовно один за іншим, спостерігаючи за рішеннями попередніх агентів. Але при цьому жоден з суб’єктів не володіє повною інформацією про результати всіх попередніх рішень. Ефект каскаду виникає тоді, коли певна кількість агентів застосували ідентичні рішення для розв'язання цієї проблеми, особливо якщо в каскаді бере участь агент, що вважається професіоналом. В цьому випадку існує висока вірогідність ухвалення раціонального рішення, до того ж мінімізуються витрати на особистий збір та обробку інформації.

Ухвалення рішення суб'єктом господарювання базується на переконанні про те, що інші суб'єкти ринку володіють більшими обсягами інформації. Каскад 
послідовного ухвалення ідентичних рішень створює тенденцію, до якої починають приєднуватись інші агенти, ігноруючи власну інформацію.

Інформаційний каскад дозволяє глибше проникнути в сутність стадної поведінки, оскільки, маючи високу ступінь взаємовпливу та взаємозалежності, вони в сукупності обумовлюють механізм наслідування поведінки більш досвідчених i авторитетних учасників ринку. Здебільшого цей механізм базується на недооцінці власних розумових та аналітичних здібностей для ухвалення рішення та переоцінка, відповідно, здібностей інших учасників ринку. Особливо яскраво ці взаємопов'язані поведінкові ефекти проявляються на фінансовому ринку, де повнота інформації та здатність до іiі обробки мають критичну важливість як с точки зору економічної ефективності, так і з точки зору репутації. Фінансист Джордж Copoc (George Soros) зазначає, що стадність «висловлює властивість масових інвестиційних процесів, коли всі орієнтуються один на одного і одночасно купують і продають одні й ті ж активи» [599].

Щодо раціональності такої поведінки, то вона може бути сумнівною, оскільки не гарантує продукування та дублювання «колективної мудрості», оскільки існує ймовірність, що первісне рішення буде хибним, i в тому ж напрямку підуть всі рішення в інформаційному каскаді. При цьому, відповідно до теорії інформаційних каскадів, стадну поведінку запускають перші кілька людей, які ухвалили однакове рішення.

Коли економічний суб’єкт вже здійснив вкладення коштів, зусиль в певний інвестиційний проект, він може ухвалювати рішення про його продовження навіть за умови погіршення його перспектив та зростання ризику заради своїх первинних вкладень. В цьому випадку мова йде про виникнення ефекту капкану.

До того ж, ухвалюючи рішення, економічний суб’єкт має схильність досить повільно змінювати свої переконання під впливом нової інформації, оскільки це зазвичай вимагає докладати додаткові зусилля для iï освоєння. В цьому проявляється ефект консерватизму, який в той же час може бути також пов’ язаний з небажанням суб’єкта докладати зусилля для освоєння інноваційних 
видів діяльності, налагодження перспективних комунікацій тощо, незважаючи на очевидність їх ефективності.

Приклад уповільненої зміни суб'єктами своїх переконань під впливом нової інформації навів американський психолог Вільям Едвардс (Edwards W.) в роботі «Консерватизм в процесі обробки людської інформації» [600]. Як показали експерименти, щоб людина змінила свою думку про певний об'єкт, їй потрібно не менше 2-5 нових ознак, що свідчать про необхідність коригування установок. Ефект консерватизму пояснює різні приклади нераціональної поведінки на фінансовому ринку.

Сам консерватизм як поведінкова особливість породжує такий ефект, як ефект схильності, що Д. Канеман і А. Тверскі (Kahneman Daniel, Tversky Amos) [601] визначають, як більшу схильність людей до збереження досягнутого фінансового рівня, ніж до його підвищення за однакових ризиків. Ця аномалія пояснюється тим, що людська психіка сприймає не стільки абсолютне значення свого багатства, скільки його зміни, причому радість від виграшу є набагато меншою, ніж гіркота від програшу. Збитки завжди здаються істотніше, ніж еквівалентний дохід.

Консерватизм же змушує економічного суб’єкта в процесі ухвалення рішення виділяти й використовувати для аналізу саме ту інформацію, яка прямо чи опосередковано підтверджує точку зору, що раніше склалась у нього про якийсь фінансовий інструмент чи суб’єкт фінансових відносин, внаслідок чого виникає ілюзія значущості. Виникнення цього ефекту має певний механізм: отримуючи нові факти, економічний суб’єкт намагається їх вбудувати в існуючий логічний ланцюжок своїх міркувань - переконань, створюючи їх значимість, а ті факти, які суперечать існуючим переконанням, просто відкидаються. Так само вибіркова значущість надається висловленим думкам експертів, аналітичній інформації тощо.

На більшість економічних суб’єктів впливає такий поведінковий ефект, як ефект готівкових коштів. Його сутність полягає в тому, що людям простіше розлучитися з безготівковими коштами, що зберігаються на картці, ніж 3 
готівковими грошима. Тісно пов'язана з цим нездатність економічних суб'єктів правильно оцінити вплив інфляційних процесів та зміну купівельної спроможності своїх доходів.

Узагальнюючи результати робіт дослідників, всі суб'єктивні фактори, що визначають нераціональну поведінку учасників ринку, з численними аномаліями та ефектами, можна поділити на дві групи:

- фактори неправильної оцінки наявної інформації, а також пов'язані 3 помилковим сприйняттям дійсності;

- емоційні (психологічні) фактори, що закладені в людській природі й впливають на поведінку людей.

Отже, ухвалюючи рішення людина керується не абстрактними принципами максимізації задоволень і мінімізації втрат, а діє під впливом психологічних, соціальних аномалій та ефектів в умовах обмеженої інформації, оперуючи відносними, а не абсолютними величинами. 


\section{REFERENCES}

1. National Bank of Ukraine URL: https: //bank.gov.ua/ua/news/all/spilnazayava-finansovih-regulyatoriv-schodo-statusu-kriptovalyut-v-ukrayini.

2. Futures contracts for BRENT and BITCOIN (Fin.Org.UA) will be launched on December 19 URL: http://www.fin.org.ua/news/1223260

3. Nakamoto, Satoshi (24 May 2009). Bitcoin: A Peer-to-Peer Electronic Cash System URL: https: //bitcoin.org/bitcoin.pdf

4. Tax Code of Ukraine URL: https: //zakon.rada.gov.ua/laws/show/2755-17

5. Joint statement of financial regulators on the status of cryptocurrencies in Ukraine URL: https://bank.gov.ua/ua/news/all/spilna-zayava-finansovih-regulyatorivschodo-statusu-kriptovalyut-v-ukrayini

6. $\mathrm{P} \quad(\mathrm{S}) \quad \mathrm{BU} \quad 8 \quad$ "Intangible assets" https://zakon.rada.gov.ua/laws/show/z0750-99

7. On approval of Methodical recommendations on accounting of intangible assets. URL: https://zakon.rada.gov.ua/rada/show/v1327201-09

8. On approval of the Regulations on documentary support of records in accounting. URL: https://zakon.rada.gov.ua/laws/show/z0168-95

9. Закон України «Про цінні папери i фондовий ринок» URL: https://zakon.rada.gov.ua/laws/show/3480-15/print1491296480899025\#Tеxt (дата звернення 20.02.2021p.)

10. Закон України «Про фінансові послуги та державне регулювання ринку фінансових послуг» URL: https://zakon.rada.gov.ua/laws/show/2664-14\#Техt (дата звернення 22.02.2021p.)

11. Цивільний Кодекс України URL: https://ips.ligazakon.net/document/T030435 (дата звернення 21.02.2021p.)

12. Про бухгалтерський облік та фінансову звітність в Україні - Закон України №996-XIV від 16.07.1999p. URL: http://zakon4.rada.gov.ua/laws/show/996-14 (дата звернення 24.02.2021p.) 
13. Проєкт Закону України «Про похідні (деривативи)» URL: https://ips.ligazakon.net/document/JF6M800A?an=28 (дата звернення 20.02.2021p.)

14. Закон України «Про товарну біржу» URL: https://zakon.rada.gov.ua/laws/show/1956-12\#Text (дата звернення 22.02.2021p.)

15. Закон України «Про ринок капіталу та організовані товарні ринки» URL: https://zakon.rada.gov.ua/laws/show/738-20\#Text (дата звернення 23.02.2021p.)

16. Маршалл Дж. Ф. Финансовая инженерия: Полное руководство по финансовым нововведениям. Пер. с. англ. / Маршалл Дж. Ф., Бансал В.К. М.: ИНФРА-М, 1998. 784с.

17. Біржова справа: підручник/ за наук. редакцією докт. екон. наук проф. О.М. Сохацької. Тернопіль: ТНЕУ 2014. 655с.

18. Офіційний сайт Біржового холдингу CMEGROUPURL: https://www.cmegroup.com/trading/agricultural/grain-and-oilseed/black-sea-wheatcorn-and-sunflower-oil-fob-platts-futures.html?redirect=/bsw (дата звернення 25.02.2021p.)

19. Положення (стандарт) бухгалтерського обліку 7 „Основні засоби”: наказ Міністерства фінансів України від 27 квітня 2000 р. N 92.

20. Податковий кодекс України від 2 грудня 2010 року № 2755(VI ст..14,ст.138.

21. Цивільний кодекс України від 16.01.2003 № 435-IV, ст.718-720.

22. Положення (стандарт) бухгалтерського обліку 19 "Об'єднання підприємств": наказ Міністерства фінансів України від 7 липня 1999 року N 163

23. Про оцінку майна, майнових прав та професійну оціночну діяльність в Україні: Закон України від 12.07.2001 p. № 2658-III.

24. Положення (стандарт) бухгалтерського обліку 15 «Дохід»: наказ Міністерства фінансів України від 29 листопада 1999 р. N 290

25. Національне положення (стандарт) бухгалтерського обліку 1 "Загальні вимоги до фінансової звітності": наказ Міністерства фінансів України від 07.02.13 p. №73. 
26. Закон України «Про бухгалтерський облік та фінансову звітність в Україні»: Закон України від 16.07.99 р. № 996-XIV.

27. Міжнародний стандарт бухгалтерського обліку 18 «Дохід» від $01.01 .2014 \mathrm{p}$.

28. Концептуальна основа фінансової звітності IASB; Стандарт, Міжнародний документ, Концепція від 01.09.2010

29. Жиглей І.В. Соціальна звітність: аналіз підходів та перспективи для України / І.В. Жиглей // Проблеми теорії иа методології бухгалтерського обліку, контролю i аналізу: міжнародний збірник наукових праць. - (Серія «Бухгалтерський облік, контроль і аналіз»). - Житомир: ЖДТУ. - 2007. - №3(9). $-246 \mathrm{c}$.

30. Стрибулевич Т.О. Зарубіжний та вітчизняний досвід ідентифікації соціальних витрат в обліково-аналітичних системах [Електронний ресурс] / Т.О. Стрибулевич // Вісник Національного університету водного господарства та природокористування.

Режим доступу: http://nuwm.rv.ua/metods/asp/vd/v39ek38.doc.

31. Альфа і омега бухгалтерського обліку або моя болісна несповідь / За ред. Ф.Ф. Бутинця. - Житомир: Рута, 2007. - 328 с.

32. Ciuhureanu A.N. Studyon Accounting Organization: Options and Influence Factors.Internationalconferenceknowledge-basedorganization. 2018. №24(2). Pp. 3136.

33. Про бухгалтерський облік та фінансову звітність: Закон України [прийнятий Верховною Радою України від 16.07.1999 р., № 996]. URL: http://zakon.rada.gov.ua.

34. Кулик В. А., Любимов М. О. Організація обліку на підприємствах України: розробка внутрішніх регламентів. Бухгалтерський облік і аудит. 2013. № 6. С. $12-18$.

35. Макаренко А.П., Босенко Е.О. Організація та методика аудиту готової продукції. Електронне наукове фахове видання «Ефективна економіка». 2019. №1. - URL:: www.economy.nauka.com.ua. 
36. Національний стандарт (положення) бухгалтерського обліку 1 «Загальні вимоги до фінансової звітності» від лют. 2013 р. № 73. - URL: http: //zakon.rada.gov.ua.

37. Коцеруба H.B. Organization and planning of audit of the enterprise of profitability. «Формування ринкових відносин»: Збірник наукових праць. 2020. Вип. 9 (232). С. 56-61.

38. Лобачева І.Ф., Коцеруба Н.В. Organizacion and planning audit of financial sustainability and solvency of the enterprise Competitiveness of Entrepreneurial Structures: Features and Prospects /Collective monograph. - Agenda Publishing House United Kingdom 2018. C. 143-154.

39. Тарнавська (Волянюк) М.О. Облік, аналіз і аудит готової продукції та iï реалізації. Магістерська робота. 2018. - URL: http://dspace.tneu.edu.ua/bitstream.

40. 1.Пушкар. М.С. Креативний облік (створення інформації для менеджерів): Монографія. - Тернопіль, Карт-бланш, 2006. 334 с.

41. Бухгалтерський управлінський облік: Підручник / Ф.Ф. Бутинець, Т.В. Давидюк, 3.В. Канурна та ін. - Житомир: ПП «Рута», 2005. 480 с.

42. Інформаційні системи бухгалтерського обліку: Підручник / Ф.Ф. Бутинець, С.В. Івахненков, Т.В. Дави дюк та ін. - Житомир: ПП «Рута», 2002. $544 \mathrm{c}$.

43. Вахрушина М.А. Бухгалтерский управленческий учет: Учеб. пособ. - М.: ЗАО «Финстатинформ», 1999. 359 с.

44. Голов С.Ф. Управленческий бухгалтерский учет.- К.: Скарбы, 1998.377 c

45. Гончарук Я.А., Рудницький В.С. Аудит: Навч. посіб. К.: Знання, 2007. $443 \mathrm{c}$.

46. Кутер М.И. Теория бухгалтерского учѐта: Учебник. -М.: «Финансы и статистика», 2002. -640 с.

47. Мишин Ю.А. Управленческий учет: управление затратами и результатами производственной деятельности: (Монография). - M.: Издательство «Дело и Сервис», 2002. - 176 с. 
48. Нидлз Б. и др. Принципы бухгалтерского учета / Б. Нидлз, Х. Андерсон, Д. Колдуэлл: Пер. с англ. - М.: Финансы и статистика, 1994. 496 с.

49. Попова П.В., Маслов Б.Г., Маслова И.А. Основные теоретические принципы построения учетно-аналитической системы. Финансовый менеджмент. 2003. № 5. С. 8-15.

50. Пушкар. М.С. Креативний облік (створення інформації для менеджерів): Монографія. - Тернопіль, Карт-бланш, 2006. - 334 с.

51. Сопко В.В. Бухгалтерський облік в управлінні підприємством: Навч. посіб. - К.: КНЕУ, 2006. 526 с.

52. 13 Управленческий учет: Учеб. пособ. / Под редакцией А.Д. Шеремета. - М.: ФБК-ПРЕСС, 1999. 512 с.

53. Хорнгрен Ч.Т., Фостер Дж. Бухгалтерский учет: Управленческий аспект / Пер. с англ. - М.: Финансы и статистика, 1995. - 416 с.

54. Сакун А.Ж Вплив інформаційного фактора на розвиток системи бухгалтерського обліку // Science, trends and perspectives. Abstracts of XVII international scientific and practical conference. Tokyo, Japan 2020. Pp. 341-343. URL: http://isg-konf.com .

55. Югас Е.Ф. Економічна сутність договірних відносин підприємства та форми розрахунків з постачальниками і підрядниками. Економічний вісник університету. 2011. № 17/2. URL: http://www.nbuv.gov.ua/portal/ soc_gum/Evu/2011_17_2/Yugas.pdf

56. Hilorme T., Perevozova I., Sakun A., Reznik O., Khaustova Ye. (2020). Accounting model of human capital assessment within the information space of the enterprise. Academy of Accounting and Financial Studies Journal, Volume 24, Issue 3, pp. 1-7. URL: https://www.abacademies.org/journals/month-june-year-2020-vol24-issue-3-journal-aafsj-past-issue.html

57. Міжнародні стандарти бухгалтерського обліку 2000: пер. з англ. / за ред. С.Ф. Голова. - К.: Федерація професійних бухгалтерів та аудиторів України, 2000. -1272 c. 
58. Фатенок-Ткачук, А. О., Данилко, А. Р. (2016). Облікові процедури контролю зобов'язань перед постачальниками та підрядниками. Економічний аналіз: зб. наук. праць (Т. 26, (1), с. 179-187).

59. Сирцева, С. В., Щербак, М. М. (2016). Напрями вдосконалення обліку, аналізу та аудиту розрахунків із контрагентами. Глобальні та національні проблеми економіки: Електронне наукове видання, (14). http:/globalnational.in.ua.

60. Сакун А., Юрченко А. Інформаційний потік в системі бухгалтерського обліку як вид загальної інформаційної сукупності.// VIII International Scientific and Practical Conference. Prague, Czech Republic 2020. Pp. 160-163 URL: https://isgkonf.com

61. Лігоненко Л., Хріпко А., Доманський А. Зміст та механізм формування стратегії діджиталізації в бізнес-організаціях. Міжнародний науковий журнал «Інтернаука». Економічні науки. Випуск № 22 (62), 2 т., 2018 р. С. 21-24.

62. Гуренко А., Гашутіна О. Напрями розвитку систем управління в умовах діджіталізації бізнесу в Україні. Економіка і суспільство. Випуск №19. Мукачівський державний університет, 2018 р. С.739-745.

63. Варга В. П. Діджиталізація як один з чинників конкурентоспроможності підприємства. Ефективна економіка. 2020. № 8. URL: http://www.economy.nayka.com.ua/?op=1\&z=8121

64. Про схвалення Концепції розвитку цифрової економіки та суспільства України на 2018-2020 роки та затвердження плану заходів щодо їі реалізації URL: https://cutt.ly/wcEYQXm

65. Лобода Н.О., Чабанюк О.М., Кольба Р.М. Діджиталізація як функція облікової діяльності: коронакриза як контекст. URL: https://conf.ztu.edu.ua/wpcontent/uploads/2021/01/337.pdf

66. Цегельник H.I., Василенко T.M. Використання Digital технологій в бухгалтерському обліку. Облік, аналіз, аудит та оподаткування: сучасна парадигма в умовах сталого розвитку: зб. тез доп. Міжнар. наук.-практ. конф., 10 груд. 2020 р. Київ : КНЕУ, 2020. С. 55-56. 
67. Шишкова Н. Л. Перспективи IT-модернізації бухгалтерського обліку: актуалізація теорії і практики. URL: https://ev.nmu.org.ua/docs/2019/3/ EV20193_146-159.pdf

68. Panchenko H. (2008). Controlling the formation and use of human resources: Candidate's thesis. Donetsk.

69. Szejniuk A. (2015) Personnel controlling in human resources management. Journal of Modern Science, 2 (25).

70. Sytnyk A. (2013) Evaluation of the effectiveness of the personnel management system. Efektyvna ekonomika, 12.

71. Riabtseva O., Riabtsev O. (2016) Modern methods of evaluating the effectiveness of the personnel management department. Ekonomichnyi visnyk, 1 (13), 102-107.

72. Balabanova L., Lykhoiedova O. (2016) Personnel controlling: concept, methodology, tools. Kh.: Vodnyi spektr.

73. Lukianykhin V., Pavlenko D. Introduction of HR-analytics into the personnel controlling system. Retrieved from https://me.fem.sumdu.edu.ua/docs/d175.pdf.

74. The 8 HR Analytics Every Manager Should Know About. Retrieved from: https://www.forbes.com/sites/bernardmarr/2016/03/01/the-8-hr-analytics-everymanager-should-know-about/?sh=2cce415b788f.

75. Global Human Capital Trends (2020). Retrieved from: https://www2.deloitte.com/us/en/insights/focus/human-capital-trends.html.

76. 70 HR Metrics with Examples (Build your own HR Dashboard). Retrieved from: https://humanengineers.com/70-hr-metrics-examples-build-hr-dashboard/.

77. Moroz L.I. (2010). Theoretical and practical aspects of improving the personnel policy of Ukrainian enterprises. Scientific Bulletin of Volyn National University. L.Ukrainka. Economic sciences. Lutsk: RVV "Tower". № 4. - P. 36-41. [in Ukrainian].

78. Shchokin G.V. (1997). Theory of personnel policy: Monograph. Kyiv: MAUP. [in Ukrainian]. 
79. Arzamasova O.V. (2010) Personnel policy of an industrial enterprise in market conditions [Electronic resource]. - Access mode: http://www.nbuv.gov.ua/portal/natural/Nvuu/Ekon/2008_26/statti/3_4.htm

80. (14.02.2010). [in Ukrainian].

81. Moroz L.I. (1999). Choice of processes and methods of making optimal economic decisions. Coll. Science. Proceedings: Bulletin of Lviv Polytechnic National University "Problems of Economics and Management". Lviv: NU LP Publishing House. № 363.P. 149-153. [in Ukrainian].

82. Moroz L.I. (2003). Management decisions of a modern manager and evaluation of his activity. Zb. Science. Proceedings: Bulletin of NU "Lviv Polytechnic": "Problems of Economics and Management" . Lviv: Publishing House of NU LP. № 484. P. 329-334. [in Ukrainian].

83. Moroz LI (2019). Psychophysiological factors of management of working capacity of industrial and production personnel of the enterprise. Project SWorld: Collective monograph "Innovative economy and management in the modern world". Odesa: Kuprienko S.V. Part 2. - Sec. 1. PP. 6-21. [in Ukrainian].

84. Korolchuk M.S. (2012). Theory and Practice of Professional Psychological Investigation - Kyiv.: Nika-Center. [in Ukrainian].

85. Krushelnitska Ya.V. (2003). Physiology and psychology of practice. - Kyiv.: KNEU. [in Ukrainian].

86. Moroz LI (2019). Working capacity and labor productivity as components of a competitive employee of the enterprise. Scientific economic journal Intellect XXI. Kyiv: National University of Food Technologies, NGO "Institute of Competition Problems. N 4. - P. 58-63. [in Ukrainian].

87. Varij M.I. (2016). Psychology of personality. Lviv: Lviv Polytechnic Publishing House. [in Ukrainian].

88. Vollmer Ch. Jobenomics U.S. Unemployment Analysis. 2016. http://Jobenomics.com. P. 1-4. 
89. Лук'янова, К.К. Зарубіжний досвід регулювання зайнятості населення / К.К. Лук'янова // Вісник ЮУрДУ. Серія «Економіка і менеджмент». - 2016. - Т. 10, №3. - C. 109-115.

90. http://advanced-science.ru/petuhova-e.-s.-3(2017)?cultureKey=ru

91. Ващенко В.В. Управління процесом рекрутингу персоналу промислових підприємств : дис. . канд екон. наук : 08.00.04. Маріуполь, 2017. 208 с.

92. https://www.prostir.ua/?news=shkilnyj-kovorkinh-yak-instrumentstymulyuvannya-molodizhnoho-pidpryjemnytstva

93. https://uk.wikipedia.org/wiki/\%D0\%9A\%D0\%BE\%D0\%B2\%D0\%BE\%D1\%80\%D0 $\%$ BA\%D1\%96\%D0\%BD\%D0\%B3

94. Горобець Н. М., Савенко О. А., Лапа В. О. Вплив професійного розвитку на трудову активність персоналу підприємства. Агросвіт. 2014. № 5. С. 48-53.

95. Горобець Н. М., Савенко О. А., Лапа В. О. Особливості мотиваційного механізму управління якістю трудового життя аграрних працівників. Агросвіт. 2015. № 8. C. 49-53.

96. Должанський І.З., Загорна Т.О., Удалих О.О. Управління потенціалом підприємства. Навч. посіб. К.: Центр навч.літератури, 2006. 362 с.

97. DSTU 4281: 2004. Restaurants. Classification [Electronic resource]. Access mode: http://eztuir.ztu.edu.ua/1097/1/59.pdf. (application date 10.02.2021)

98. Didenko E., Diduk O. (2015). Types of competitive advantages of restaurant enterprises and features of their management. Formation of market relations in Ukraine. №12 (175). [in Ukrainian].

99. Druzhinina V., Sosnovskaya Y. (2018). Determining the significance of indicators of competitiveness of restaurants. Bulletin of Khmelnytsky National University, № 2. [in Ukrainian].

100. Zadneprovskaya E. (2008). Marketing strategies of the restaurant business as a basis for ensuring its competitiveness: dis.... BC N. / Zadneprovskaya E. Moscow, $163 \mathrm{p}$. 
101. Competitiveness of the enterprise: assessment of the level and directions of increase: monograph / for general. ed. O. Yankov. Odessa: Atlant, 2013. 470 p.

102. Litvinenko, Ya., Litvinenko T. (2013). Directions of increase of competitiveness of establishments of hotel and restaurant economy in Ukraine. Economics of market relations. № 12. pp. 50-53. [in Ukrainian].

103. Nikolyuk O. (2008). Etymology and essence of the concept of "enterprise competitiveness" [Electronic resource]. Bulletin of ZhSTU. Economic Sciences Series. № 1 (55). Access mode: http://normativ.com.ua/types/tdoc2728.php. (appeal date 11.02.2021)

104. Panasenko D. (2012). Competitiveness of the enterprise: essential and functional characteristics. Bulletin of the National University "Lviv Polytechnic". Series "Management and Entrepreneurship in Ukraine: Stages of Formation and Problems of Development". № 727. pp. 270-275. [in Ukrainian].

105. Rasulova A. (2006). Management of competitiveness of restaurants: dis. ... cand. econ. Science: 08.06.01. Kiev. nat. trade and economy un-t. Kyiv, 167 p. [in Ukrainian].

106. Tkachuk G. (2012). Formation of competitiveness of small agribusiness enterprises: current state and prospects of development: monograph. G. Tkachuk. Zhytomyr: ZhSTU, 200 p. [in Ukrainian].

107. The official site of TGConsulting (2020), "SAP-based agribusiness solutions", available at: https://sb1.com.ua/cases/agro/ (Accessed 10 May 2020).

108. The official site of CenterProgrammSystem (2021), "Agriculture automation: industry solutions", available at: https://1 cps.ru/products_line/avtomatizaciyaselskogo-hozyaystva-otraslevye-resheniya (Accessed 10 Mar 2021).

109. The official site of MASTER (2021), "Master: AGRO", available at: https://masterbuh.com/product/4 (Accessed 10 Mar 2021).

110. The official site of AgroGeneration (2018), "Production management and information systems", available at: https://agrogeneration.com/files/photos/news/\%D0\%A3\%D0\%BF\%D1\%80\%D0\%B 0\%D0\%B2\%D0\%BB\%D1\%96\%D0\%BD\%D0\%BD\%D1\%8F_\%D0\%B2\%D0\%B8 
\%D1\%80\%D0\%BE\%D0\%B1\%D0\%BD\%D0\%B8\%D1\%86\%D1\%82\%D0\%B2\%D0 \%BE\%D0\%BC_\%D0\%A2\%D0\%97.pdf (Accessed 10 Mar 2021).

111. Titova, O. (2012) Peculiarities and preferences of using modern information technologies in agroholding "Ukrlandfarming" management, Visnyk Zhytomyrskoho natsionalnoho ahroekolohichnoho universytetu, [Online], vol. 2, available at: http://ir.znau.edu.ua/bitstream/123456789/102/1/Titova_O_Peculiarities_and_prefere nces.pdf (Accessed 31 Mar 2021).

112. Ринок е-соmmerce в Україні в 2020 році зріс на 40\% - до 107 млрд грн (+інфографіка). URL: https://rau.ua/novyni/e-commerce-v-ukrayini-2020/

113. Цифрова трансформація рітейлу: ретроспектива і прогнози розвитку на 2021 рік URL: https://rau.ua/novyni/tsyfrova-transformatsiya-ritejlu/

114. Погляд в майбутнє: П'ять викликів для електронної комерції в 2021 pоці. URL: https://rau.ua/novyni/pyat-trendiv-e-commerce-2021/

115. Кобилюх О.Я., Гірна О.Б. Тренди трансформації логістики на ринку ЕCOMMERCE. Маркетинг і логістика в системі менеджменту: тези доповідей XIII Міжнародної науково-практичної конференції (жовтень 22 - 24, 2020, Львів). Львів: Видавництво Львівської політехніки, 2020. С.69-71.

116. Эти 6 трендов в логистике окажут влияние на отрасли в 2021 году URL: https://b-mag.ru/jeti-6-trendov-v-logistike-okazhut-vlijanie-na-otrasli-v-2021-godu/

117. ТОП-10 інновацій, які змінять логістику в 2020 році. URL: https://elnews.com.ua/uk/top-10-innovaczij-yaki-zminyat-logistyku-v-2020-roczi/

118. Кобилюх О.Я., Гірна О.Б., Гаєва Л.І. Ключові аспекти транспортної логістики в умовах пандемії COVID-19. Вчені записки ТНУ ім. В.I. Вернадського. Серія: Економіка і управління". 2020. Том 31 (70). N 4. C.117-122. ( DOI: https://doi.org/10.32838/2523-4803/70-4-21).

119. П'ять трендів міжнародної логістики у 2021-му URL: https://nv.ua/ukr/biz/experts/mizhnarodna-dostavka-trendi-i-prognoz-2021-ostanninovini-50141962.html 
120. Гладка I.В. Сучасні тенденції та особливості розвитку туризму в Україні// Економіка. Проблеми економічного становлення. Вісник 1-2, 2015. - С. 64-67

121. Марценюк Л.В. Проблеми та перспективи розвитку туризму в Україні// Економічний вісник. Секція: Економічна теорія. - 2015. - №3. - С.76-82

122. Державний комітет статистики України. Туристична діяльність в Україні [Електронний ресурс]. - Режим доступу: http://www.ukrstat.gov.ua/operativ/operativ2019/tyr/tyr_dil/arch_tyr_dil.htm

123. Державний комітет статистики України. Туризм [Електронний ресурс]. — Режим доступу: http://www.ukrstat.gov.ua/operativ/menu/menu_u/tur.htm

124. Офіційний сайт Світової металургійної асоціації [Електронний ресурс]. - Режим доступу: https://www.worldsteel.org/

125. Офіційний сайт Аналітичного порталу Слово і Діло [Електронний pecypc]. - Режим доступу: https://www.slovoidilo.ua

126. Карплюк С.О. Особливості цифровізації освітнього процесу у вищій школі. Інформаційно-цифровий освітній простір України: трансформаційні процеси і перспективи розвитку. Матеріали методологічного семінару НАПН України. 4 квітня 2019 р. / за ред. В. Кременя, О. Ляшенка ; укл. А.В. Яцишин, О.М. Соколюк. Київ, 2019. - С. 188-197.

127. A Digital Agenda for Europe: Communication from the commission to the European Parliament, the Council, the European Economic and Social Committee and the Committee of the Regions, Brussels. 2010. URL: http://eur-lex.europa.eu/ legalcontent/EN/TXT/HTML/?uri=CELEX:52010DC02 45R(01)\&from=EN.

128. Smart-освіта: ресурси та перспективи : матеріали III Міжнар. наук.метод. конф. (Київ, 7 грудня 2018 р.) : тези доповідей. Київ : Київ. нац. торг.-екон. ун-т. 2018. - 252 с.

129. Про затвердження Положення про Національну освітню електронну платформу: наказ № 523 від 22 травня 2018 р. / Міністерство освіти і науки України. (Дата звернення 23.03.21 p.) https://zakon.rada.gov.ua/laws/show/z070218\#Text. 
130. Фамілярська Л.Л. Модель навчального середовища у післядипломній педагогічній освіті. URL: http://www.confcontact.com/2016-specproekt/ familyarskaya.html.

131. Туризм, общий вклад в ВВП (доля, \%). URL: https://knoema.ru/ atlas/topics/Туризм/Общий-вклад-туризма-в-ВВП/Общий-вклад-в-ВВП-доляpercent

132. Туризм, прямой вклад в занятость (доля, \%). URL: https://knoema.ru/ atlas/topics/Туризм/Прямой-вклад-туризма-в-занятость/Прямой-вклад-взанятость-доля-percent

133. Туристична діяльність в Україні у 2019 році. URL: http://www.ukrstat.gov.ua/operativ/operativ2020/tyr/tyr_dil/tur_d_19_u.xlsx

134. Внутрішній туризм в Україні мав би рости: як змінилась галузь і куди зник «бюджетний» мандрівник. URL: https://www.epravda.com.ua/publications/ 2020/09/23/665405

135. Шевченко О.М. Розвиток фінансових технологій в умовах цифровізації економіки України. Ефективна економіка. 2020. № 7. - URL: http://www.economy.nayka.com.ua/?op=1\&z=8053 (дата звернення: 24.03.2021).

136. ФінТех в Україні: звіт Проекту USAID “Трансформація фінансового сектору" та інноваційного парку UNIT.City. URL: http://data.unit.city/fintech/fgt34ko67mok/fintech_in_Ukraine_2018_ua.pdf (дата звернення: 25.03.2021).

137. Дудинець Л.А. Розвиток фінансових технологій як фактор модернізації фінансової системи. Глобальні та національні проблеми економіки. 2018. Вип. 22. C. $794-798$.

138. Калашнікова Т.В., Самохіна С.А. Розвиток ринку фінансових технологій в Україні як фактор сприяння фінансовій інклюзивності. Вісник ХНАУ ім. В.В. Докучаєва. 2018. № 3. Серія Економічні науки. С. 201-210.

139. Марамыгин М.С., Чернова Г.В., Решетникова Л.Г. Цифровая трансформация российского рынка финансовых услуг: тенденции и особенности. Управленец. 2019. Т. 10. № 3. С. 70-82. 
140. Волосович С.В., Василенко А.В. Regtech в екосистемі фінансових технологій. Modern Economics. 2019. №15. С 62-68.

141. Лисицын А. Риски применения финансовых технологий и создание условий для их снижения

URL: http://rfinance.ru/magazine/?id=19769\&aid=19885\&tid=18 (дата звернення: 29.03.2021).

142. Reagan J. R., Raghavan A., Thomas A. Quantifying risk: What can cyber risk management learn from the financial services industry? URL: https://www2.deloitte.com/insights/us/en/deloitte-review/issue- 19/quantifying-risklessons-from-financial-services-industry.html (дата звернення: 29.03.2021).

143. Сайт агентства Javelin Research. URL: https://www.digitaltransactions.net/the-fallout-from-id-fraud-and-account-takeoversincludes-a-lot-more-p2p-payment-fraud/ (дата звернення: 30.03.2021).

144. Балийская повестка дня в области финансовых технологий. Вводный документ.

URL: http://webcache.googleusercontent.com/search?q=cache:Pa7mvFZoYycJ:documents1 .worldbank.org/curated/en/457731539098097137/pdf/The-Bali-Fintech-AgendaChapeau-Paper.pdf $+\& \mathrm{~cd}=2 \& \mathrm{hl}=\mathrm{uk} \& \mathrm{ct}=\mathrm{clnk} \& \mathrm{gl}=\mathrm{ua}$ (дата звернення: 31.03 .2021 ).

145. Концепція розвитку фермерських господарств та сільськогосподарської кооперації в Україні: Розпорядження Кабінету Міністрів України № 664-2017-р від 13 вересня 2017 року. URL: https://zakon.rada.gov.ua/laws/show/664-2017-\%D1\%80\#Text (дата звернення: 05.03.2021).

146. Концепція Державної цільової програми розвитку аграрного сектору економіки на період до 2022 року: Розпорядження Кабінету Міністрів України № 1437-2015-p від 30 грудня 2015 року. URL: https://zakon.rada.gov.ua/laws/show/1437-2015-\%D1\%80\#Text (дата звернення: 05.03.2021). 
147. Про фермерське господарство: Закон України від 19 червня 2003 року № 973-IV, зі змінами на 15 серпня 2020 року. URL: https://zakon.rada.gov.ua/laws/show/973-15\#Text (дата звернення: 05.03.2021).

148. Реалізація продукції сільського господарства підприємствами та господарствами населення: Державна служба статистики України. URL: http://www.ukrstst.gov.ua (дата звернення: 05.03.2021).

149. Мельников О.Ф. Теорія та методологія фахової підготовки державних службовців: дис. ... доктора наук з держ. упр. : 25.00 .03 / О.Ф. Мельников; Харків. регіон. ін-т держ. упр. НАДУ при Президентові України. -Х., 2009. - 495 с.

150. Мельников О.Ф. Парадигми фахової підготовки державних службовців: [монографія] / О.Ф. Мельников. - Х.: Вид-во ХарРІ НАДУ “Магістр”, 2007. - 424 c.

151. Мельников О.Ф. Кар'єра в системах державної служби різних країн / О.Ф. Мельников // Державне будівництво [електронне видання ХарРІ НАДУ]. 2008. - № 2. - Режим доступу до журн.: http://www.kbuapa.kharkov.ua.

152. Серьогін С.М. Державне управління та державна служба: навчальний посібник / С.М. Серьогін, Л.Л. Прокопенко, Н.К. Рашитова; за заг. ред. Є.І. Бородіна, О.Ф. Мельникова. - Х. : Вид-во ХарРІ НАДУ “Магістр”, 2003. - 160 с.

153. Латинін М.А. Організація професійної підготовки державних службовців: системний погляд / І.В. Кобзев, В.В. Косенко, М.А. Латинін, О.Ф. Мельников // Scientific Collection «InterConf», (44): with the Proceedings of the 8th International Scientific and Practical Conference «Scientific Research in XXI Century» (March 6-8, 2021). Ottawa, Canada: Methuen Publishing House, 2021.784 p. (P. $256-266)$.

154. Бураковська А.В. Нові освітні технології професійної підготовки державних службовців / А.В. Бураковська, О.Ф. Мельников, В.О. Шайдеров // Вісник УАДУ. - 2003. - № 1. - С. 74 - 80.

155. Kobzev I.V. Labor resource management: a modern look / I.Kobzev, A.Melnikov, A.Orlov // Methodology and science foundation of modern jurisprudence: 
collective monograph / - International Science Group. - Boston: Primedia eLaunch, 2020. 264 p. (Pp. 53-58).

156. Косенко В.В. Стратегічне управління трудовими ресурсами [Електронний ресурс] / I.В. Кобзев, В.В. Косенко, О.Ф. Мельников // The IX th International scientific and practical conference «Science and practice of today» November 16-19, 2020 London, Ankara, Turkey. - 695 p. (С. 111-115) Режим доступу до ресурса: https://isg-konf.com/wp-content/uploads/IX-Conference-16-19Ankara-Turkey-Book.pdf.

157. Kolot A., Gerasimenko O. The sphere of labor in the global socio-economic reality 2020: challenges for Ukraine. URL: http://library.fes.de/pdffiles/bueros/ukraine/16344.pdf

158. Pankova O.V., Kasperovich O.Yu. The potential of digitalization in the restoration of labor and employment in Ukraine in a pandemic COVID-19 // Theoretical and empirical scientific research: concept and trends. Volume 1. Oxford, UK. July 24, 2020. pp. 72-76 doi.org/10.36074/24.07.2020.v1.26. URL: https://ojs.ukrlogos.in.ua/index.php/logos/article/download/3990/3924/

159. Novikova O.F. Assessment of the impact of the COVID-19 pandemic on the state of the labor market of Ukraine and the EU: policy to overcome risks and dangers // Socio-labor sphere in the coordinates of the new economy and global socio-economic reality: challenges, ways of development / Kyiv: KNEU named after Vadim Hetman, 2020. pp. 118-122. URL: https://ir.kneu.edu.ua/bitstream/handle/2010/35101/205648.pdf?sequence $=3$

160. Ukraine's government puts oligarchs and multinational enterprises ahead of its own people. International Trade Union Confederation, 30.12.2019. URL: https://www.ituc-csi.org/ukraine-

draftlaw?fbclid=IwAR39sA71NCt_GSXA7cZT0eyfY9YgYs5cpExkA2nNNp61oaB 3gthgofOqrY\&lang=en\#.X gn2aQ7TekQ.facebook

161. Kostritsa V.I., Burlay T.V. Imbalances and divergence in employment: the approaches of the EU and Ukraine to overcome them // Ukrainian Society. - 2020. №1. - pp. 83-109. URL: https://doi.org/10.15407/socium2020.01.083 
162. Audit of the economy of Ukraine 2030. URL: https://nes2030.org.ua/docs/doc-audit.pdf

163. Vectors of economic development until 2030. URL: https://nes2030.org.ua/?fbclid=IwAR2n7HwFWa2nptw7alD_If6j8neTGLRaMJOX yV1OQcmCf34NHsjAXiw9YM\#rec245890384

164. The Government has published a "National Economic Strategy 2030" on the platform of the Center for Economic Recovery. URL: https://www.ukrinform.ua/rubric-economy/3131102-kabmin-opublikuvavnacionalnu-ekonomicnu-strategiu-do-2030-roku.html

165. Inflation Report of the National Bank of Ukraine, January 2021. URL: https://bank.gov.ua/admin_uploads/article/IR_2021-Q1.pdf?v=4

166. Pankova O.V., Shastun A.D. From the challenges of the COVID-19 pandemic in the field of labor and employment of Ukraine to the risk-based model of economic and labor development // Socio-labor sphere in the coordinates of the new economy and global socio-economic reality: challenges, ways of development / Kyiv: KNEU named after Vadim Hetman, 2020. pp. 131-136. URL: https://ir.kneu.edu.ua/bitstream/handle/2010/35101/20-5648.pdf?sequence=3

167. Porter, M. E. (1990). The Competitive Advantage of Nations. New York: Free Press.

168. The Global Competitiveness Report 2018-2019. World Economic Forum. Retrieved from: http://www3.weforum.org/docs/ WEF _ GCR _ Report_20182019.pdf.

169. The Global Competitiveness Report 2019. World Economic Forum. Retrieved from: https://reports.weforum.org/global-competitiveness-report-2019.

170. Global Competitiveness Index 4.0. World Economic Forum. Retrieved from: http://www3.weforum.org/docs/WEF_GCI4_2019_Profile_Ukraine.pdf

171. Заставецька Л.Б. Системи розселення i геопросторові проблеми вдосконалення адміністративно-територіального устрою України: Монографія. Тернопіль: ТНПУ ім. В. Гнатюка, 2013. 331 с. 
172. Kartashov E. G. European lessons of decentralization // Public management: collection, № 1 (11) January 2018. Kуіv: ДП "Видавничий дім «Персонал», 2018. Р. 175-184.

173. Міжмуніципальне співробітництво: вітчизняний та зарубіжний досвід: Навчально-практичний посібник / За заг. редакцією Толкованова В.В., Журавля T.В. Київ, Deutsche Gesellschaft fur Internationale Zusammenarbeit (GIZ) GmbH, проект «Реформа управління на сході України», 2017. 202 с.

174. Нападовська Г. Ю. Міжнародний досвід формування та просторове впорядкування територіальних громад, 2017. // Електронний ресурс. Режим доступу: http://ekhsuir.kspu.edu/handle/

175. Пігуль Н. Зарубіжний досвід проведення децентралізаційних реформ // Глобальні та національні проблеми економіки. Випуск 9. 2016. С.684-688.

176. Технічне регулювання у сфері стандартизації «розумних громад» та «розумних міст»: європейський досвід // Електронний ресурс. Режим доступу: http://www.niss.gov.ua/articles/2338/

177. Свропейська хартія місцевого самоврядування // Електронний ресурс. Режим доступу: https://rm.coe.int/-pdf-a6-59-pages/168071a536

178. Chinardet, C. Le trade marketing: Marques et enseignes: agir ensemble? / C.Chinardet. - Paris : Les Éd. d'organisation, 2004. - 175 p.

179. Dupuis, M. Trade marketing and retailing: a European approach / M. Dupuis, E. Tissier-Desbordes // Journal of Retailing and Consumer Services. - 1996. - Vol 3, № 1. - pp. 43-51.

180. Morales, D. A. Gestión por categorías y trade marketing. Madrid: Prentice Hall, 2000. - 208 p.

181. Брундтланд Г. Х. Наше Спільне Майбутнє: доповідь. Режим доступу: http://www.esz.org.ua/?page_id=3129

182. Порядок денний на XXI століття. Режим доступу: http://www.esz.org.ua/?page_id=3672 
183. Вдовенко Н. М., Сокол Л. М. Макроекономічна оцінка аграрного сектору економіки України за умов інтеграційних процесів. Науковий вісник Полісся. 2016. № 3 (7). С. 22-28.

184. Vdovenko N. M. Mechanisms of regulatory policy application in agriculture. Economic Annals-XXI. 2015. № 5-6. C. 53-56. DOI: http://dx.doi.org/10.21003/ea Режим доступу: http://soskin.info/userfiles/file/2015/5-6\%202015/Vdovenko.pdf

185. Вдовенко Н. М., Маргасова В. Г., Шарило Ю. С. Михальчишина Л. Г., Конкурентоспроможність рибного господарства та аквакультури як складова ефективності національної економіки. Біоекономіка і аграрний бізнес. 2019. Вип. 1. C. 204-211.

186. Вдовенко Н. М., Павленко М. М. Стан та тенденції регулювання розвитку галузей морського господарства та круїзного туризму. Проблеми i перспективи економіки та управління. № 3 (15). 2018. С. 55-62.

187. Vdovenko N., Baidala V., Burlaka N., Diuk A. Management mechanism of agrarian economic system: composition, functioning and factors of development in Ukraine. Problems and Perspectives in Management, 2018. Vol. 16. Issue 2. P. 179189. DOI: http://dx.doi.org/ 10.21511/ppm.16 (2).2018.16

188. Markina I., Diachkov D. Entropy Model Management of Organization. Management, Economics, $\quad$ Technology, $\quad$ Tourism: 2014. DOI:10.5829/idosi.wasj.2014.30.mett.66

189. Кальмук О. Механізми забезпечення економічної безпеки України. URL: http://www.experts.in.ua/baza/analitic/index.php?ELEMENT_ID=81077.

190. Статкевич М. Тіньова економіка і національна безпека - загрози i способи захисту. URL: http://dialogs.org.ua/ru/project/page7924.html.

191. Користін O.C. Економічна безпека. URL: https://pidru4niki.com/1584072021588/ekonomika/ekonomichna_bezpeka.

192. Гетьманчук М.П. Політологія. URL: http://pidruchniki.ws/10310208/politologiya/natsionalna_bezpeka_ukrayini. 
193. Уманців Ю.М. Об'єкти і предмет економічної безпеки. URL: http://pidruchniki.ws/18210712/ekonomika/obyekti_predmet_ekonomichnoyi_bezpe ki.

194. Тіньова економіка - основне підгрунтя економічної злочинності в Україні. URL: http://radnuk.info/pidrychnuku/kruminologiua/458-nevmersh/7571-3.html.

195. Методичні рекомендації розрахунку рівня тіньової економіки / Наказ Міністерства економіки України від 18.02.2009 № 123 URL: http://me.kmu.gov.ua/file/link/135879/file/Metod_TinEk.doc.

196. Тіньова економіка, структура й природа іiі виникнення. URL: http://pidruchniki.com/15800119/ekonomika/tinova_ekonomika_struktura_priroda_vi niknennya.

197. Рівень тіньової економіки в Україні перевищив 30\%. URL: https://smida.gov.ua/news/allnews/riventinovoiekonomikivukrainiperevisiv30.

198. Дослідження тіньової економіки в Україні: майже чверть ВВП - або 846 млрд гривень - перебуває в тіні. URL: https://www.me.gov.ua/News/Detail?lang=uk-UA\&id=b2fe7b9f-4e8a-487f-b3f7ecd29c1c79c6\&title=DoslidzhenniaTinovoiEkonomikiVUkrainiMaizheChvertVvpAbo846-MlrdGrivenPerebuvaVTini.

199. Нордвік М. Тіньова економіка i ми. URL: http://realeconomy.com.ua/publication/22/31782.html.

200. Україна стала європейським лідером за обсягом тіньової економіки URL: http://www.newsru.ua/finance/23nov2012/tenn_2.html.

201. Денисенко М.П., Бреус С.В. Економічна безпека держави та деструктивний вплив на неї тіньової економіки. Вчені записки Університету «КРОК». 2014. Вип. 37. С. 25-31.

202. Денисенко М.П., Бреус С.В. Тіньова економіка як чинник зниження рівня економічної безпеки держави. Стратегічні пріоритети детінізації економіки України у системі економічної безпеки: макро та мікро вимір : Монографія / За ред. Черевка О.В. ПП Чабаненко Ю.А. Черкаси, 2014. 442 с. С. 336-351. 
203. Бреус С.В. Роль інновацій у забезпеченні конкурентоспроможності машинобудівного комплексу України. Актуальні проблеми економіки. 2006. № 1. C. $162-169$.

204. Дубенська «E-commerce в Україні: розвиток попри кризу» [Електронний ресурс] Економічна правда, 2017 [Режим доступу] https://www.epravda.com.ua/publications/2017/10/27/564857/

205. Желіховський В.М. Електронна комерція як стимулятор розвитку правовідносин у мережі Інтернет // Правова інформатика: Наук. журн. $з$ питань правової інформатики, інформаційного права та інформаційної безпеки. - 2006. - № 4 (12) . - С. 68-73.

206. Желіховський В.М. Організаційні та правові засади підвищення ефективності розвитку електронної комерції в Україні // Наук. вісн. Нац. акад. внутр. справ України. - К., 2005 .- № 6 . - С. 259-263.

207. Желіховський В.М. Правове регулювання електронної комерції: досвід окремих країн світу // Боротьба з організованою злочинністю і корупцією (теорія і практика). Міжвід. наук-дослід. центр з проблем боротьби з організованою злочинністю. - 2004. - № 10. - С. 195-203.

208. Желіховський В.М. Поширення електронної комерції в Україні // Правова інформатика: Наук. журн. 3 питань правової інформатики, інформаційного права та інформаційної безпеки. - 2007. - № 2 (14) . - С. 52-56.

209. Генеральна угода по торгівлі послугами від 15.04.1994 року [Електронний ресурс] Верховна Рада України. Офіційний веб-портал. - Режим доступу : http://zakon4.rada.gov.ua/laws/show/981_017.

210. Directive 1999/93/EC of the European Parliament, and of the Council of 13 December 1999 on a Community Framework for Electronic Signatures (Electronic Signatures Directive) [Text] // Official journal. - 1999. - L 13. - 23.10.1998. - P. 5.

211. Антохонова I. Про використання інформаційних технологій і їх вплив на розвиток економіки / І. Антохонова, О. Полухіна // Питання статистики. - 2010. - № 5. 
212. Балик, М. В. Колісник. Електронна комерція як елемент системи світового господарства, 2016. № 2.

213. Наукові засади розвитку зрошення земель в Україні. - К.: Аграр. наука, 2012. $-28 \mathrm{c}$.

214. Адаптація агротехнологій до змін клімату: грунтово - агрохімічні аспекти: колективна монографія / за наук.ред. С.А. Балюка, В.В. Медведєва, Б.С. Носка. (Авторський колектив: Вожегова Р.А., Малярчук М.П., Морозов О.В., Біднина І.О. та ін.). Харків: Стильна типографія, 2018. 364 с.

215. Наукові основи адаптації систем землеробства до змін клімату в Південному Степу України: Монографія / за наук. ред.. член. - кор. НААН Р.А. Вожегової. Розділ 2. Теоретичні аспекти удосконалення водогосподарської діяльності на зрошуваних землях (Вожегова Р.А., Морозов О.В., Коковіхін С.В. та ін.). - Херсон: ОЛДІ-ПЛЮС, 2018. - 752 с.

216. AlexeiMorozov, VladimirMorozov, PeterLazer, NataliyBeznitska. Formation of fertility and productivity indices of reclaimed soils under conditions of regional climate change of the south of Ukraine // Book of Proceedings. Green Room and University of Montenegro. Green Room Sessions 2018 International GEA (Geo Eco-Eco Agro) Conferece. Podgorica, Montenegro. - 2018. - C. 152-163.

217. Формування показників родючості меліорованих грунтів в умовах регіональних змін клімату в Південному регіоні / Морозов О.В., Морозов В.В., Пічура В.І., Безніцька Н.В. // Таврійський науковий вісник: Сільськогосподарські науки. - 2018. № 100. Том 2. - С. 236-244.

218. https://www.agronom.com.ua/vyroshhuvannya-sonyashnyku-v-umovahposuh/

219. https://propozitsiya.com/ua/optimizaciya-strokiv-sivbi-sonyashniku

220. https://agroexp.com.ua/uk/optimalnye-sroki-poseva-podsolnechnika-vukraine

221. TRAVEL, TOURISM \& HOSPITALITY SPOTLIGHT. The Travel, Tourism and Hospitality Industry in the United States// SELECTUSA. URL: https://www.selectusa.gov/travel-tourism-and-hospitality-industry-united-states 
222. Global Food Service Industry Market Trajectory \& Analytics 2020-2027 URL: $\quad$ https://www.prnewswire.com/news-releases/global-food-service-industrymarket-trajectory--analytics-2020-2027-301196708.html

223. Бровинская М.Коронавирус. Карантин, банкротство...Рестораны учатся выживать без посетителей. Получится? URL: https://biz.liga.net/all/prodovolstvie/article/karantin-bankrotstvo-zadnitsa-restoranyuchatsya-vyjivat-bez-posetiteley-poluchitsya

224. Pam Tau Lee. Chapter 98 - Hotels and Restaurants / the Encyclopaedia of Occupational Health and Safety. URL: http://www.ilocis.org/documents/chpt98e.htm

225. Организационная структура гостиницы // Портал для профессионалов гостиничного И ресторанного бизнеса. URL: http://prohotelia.com/2009/08/organizational-structure-of-the-hotel/

226. HoReCa определение. Что такое HoReCa термины / Школа Интернет Маркетинга. URL: https://marketingonline.com.ua/horeca/

227. Manish Gupta. Step by Step approach control Food and Beverage cost of your hotel or restaurant. URL: https://www.speakin.co/edit/step-by-step-approachcontrol-food-and-beverage-cost-of-your-hotel-or-restaurant/

228. Food and Beverage Services - Basics/ Tutorials Point . URL: https://www.tutorialspoint.com/food_and_beverage_services/food_and_beverage_ser vices_quick_guide.htm

229. Менеджмент готельно-ресторанного господарства: підручник / I. Б. Андренко, О. М. Кравець, I. М. Писаревський ; Харк. нац. ун-т міськ. госп-ва ім. О. М. Бекетова. - Х. : ХНУМГ, 2014. - 431 с.

230. Different Types of Food and Beverage Services in Hotels | Restaurants / Setup my Hotel. URL: https://setupmyhotel.com/train-my-hotel-staff/f-and-b/591types-of-f-b-service.html.

231. Different Types of Food and Beverage Services in Hotels | Restaurants. URL: https://setupmyhotel.com/train-my-hotel-staff/f-and-b/591-types-of-f-b-service.html 
232. Туризм, находчивость и пандемия. ТОП-10 новых подходов к бизнесу от лучших отелей и ресторанов. URL: https://vitiana.com/turizm-nahodchivost-ipandemiya-top-10-novyh-podhodov-k-biznesu-ot-luchshih-otelej-i-restoranov/

233. Drone food delivery: why our restaurant is going all in by brody Sweeney. URL: https://www.camile.co.uk/brody-sweeneys-fast-casual-drone/

234. Управление IT-персоналом. Центр развития компетенций в бизнесинформатике Высшей школы бизнеса. 2021. URL: https://hsbi.hse.ru/articles/upravlenie-it-personalom/ (Last accessed: 5.02.2020).

235. Айвазян, 3. С. Антикризисное управление: принятие решений на краю пропасти / 3. С. Айвазян, В. П. Кириченко //Проблемы теории и практики управления. - 1999. - No4. - C.14.

236. Андрійчук В. Г. Аналіз методології визначення вартості підпри-ємства в межах дохідного підходу / В.Г. Андрійчук, Р.В. Андрійчук // Економіка АПК. - 2012. - № 9. - С. 40-47.

237. Андрусів У.Я. Контролінг як ефективна технологія антикризового управління / Андрусів У.Я., Атаманюк I.І.// Причорноморські економічні студії. Випуск 25. 2018.

238. Антикризисное управление / Под ред проф. С. С. Ильина / Национальный институт бизнеса. - Ростов-на-Дону: Феникс, 2004. - 512 с.

239. Антикризисное управление: учеб. пособие для техн. вузов/ Под ред проф. Э. С. Минаева и проф. В. П. Панагушина. - М. : Изд-во ПРИОР, 1998. $432 \mathrm{c}$.

240. Антикризисный менеджмент / Под ред проф. А. Г. Грязновой. - М.: “Тандем”; Ассоциация авторов и издателей “Тандем” Изд-во ЭКМОС, 1999. $368 \mathrm{c}$.

241. Антикризове управління підприємством: навч. посіб. / I.М. Мазур, У.Я. Анрусів, О.Л. Гальцова, Т.П. Кулик; за ред. У.Я. Андрусів. Івано-Франківськ: HAIP, 2017. 348c. 
242. Антикризове управління підприємством: Навч. посіб./ 3.С. Шершньова, В.М. Багацький, Н.Д. Гетманцева; За заг. ред. 3.С. Шершньової. - К.: КНЕУ, 2007. $-680 \mathrm{c}$.

243. Лігоненко Л. О. Антикризове управління підприємством : навч. посіб. / Л. О. Лігоненко, М. В. Тарасюк, О. О. Хіленко. - К. : Київ. нац. торг.-екон. ун-т, 2005. $-377 \mathrm{c}$.

244. Орехов В. И. Антикризисное управление: учебное пособие / В. И. Орехов, К. В. Балдин, Н. П. Гапоненко. - М.: ИНФРА-М, 2008. - 544 с.

245. Гавриш О.А. Антикризове управління підприємством/ Гавриш О.А., Овчаренко А.Ю// Збірник наукових праць НТУУ «КПІ» «Сучасні проблеми економіки і підприємництво. К.: Випуск 5,-2010.

246. Мищенко В.А. Развитие концепций управления предприятием с применением контроллинга / Мищенко В.А., Другова Е.С.// - Харків: НТУ « ХПІ». - 2018. - № 20. - c. 111 - 117

247. Терещенко О. О. Антикризове фінансове управління на підприємстві: монографія / О. О. Терещенко./ - К.: КНЕУ, 2008. - 272 с.

248. Тюріна Н. М. Антикризове управління: навч. посіб. / Н. М. Тюріна, Н. С. Кравацка, І. В. Грабовська. - К.: Центр навчальної літератури, 2012. - 448 с.

249. Міщенко В.А. Актуалізація понять контролінгу та менеджменту /Міщенко В.А., Домніна I.I. //Регулювання,значення та ефективність міжнародного науково-економічного співробітництва: збірник матеріалів Всеукраїнської науково-практичної конференції (м. Київ, 19 січня 2019 р).-К.: «Київський економічний науковий центр».2019.-с.46-50.

250. Коротков Е.М. Антикризисное управление : учебник / Под ред. Э.М.Короткова. -М. : Инфра-М, 2000. - 432 с

251. Шварц I. В. Механізм забезпечення ефективності антикризового управління підприємством (на прикладі машинобудівних підприємств) : дис. ... канд. екон. наук : 08.00.04. Хмельницький, 2008. 229 с.

252. Василенко В.О. Антикризове управління підприємством/ Василенко В.О. / К.: Центр навчальної літератури. 2003.-504 с. 
253. Ситник Л. С. Організаційно-економічний механізм антикризового управління підприємством / Л. С. Ситник. - Донецьк : ІЕП НАН України, 2000. $-503 \mathrm{c}$.

254. Минаев Э.С. Антикризисное управление: учебник/ Э.С. Минаев, В.П. Панагушина; под ред. Э.С. Минаева . М.: ПРИОР, 1998.-432 с.

255. Ткаченко Н.В. Базові засади фінансового контролінгу стійкості суб'єктів господарювання/ Ткаченко Н.В/Проблеми і перспективи економіки та управління 2019.№ 3

256. Коваленко О.В. Інновації та бізнес у харчовій промисловості: монографія / О.В. Коваленко. - К: ННЦ IAЕ, 2015. - 300 с

257. Островська О.А. Інновації у фінансовій діагностиці вітчизняних підприємств / О.А. Островська // Фінанси України. - 2011. - №9. - С. 110- 119.

258. Старинець О.Г. Антикризове управління вітчизняними телекомунікаційними підприємствами : сучасний стан, тенденції та перспективи/. Старинець О.Г./ Ефективна економіка. 2019.-№7.

259. Пілецька С.Т. Контролінг в антикризовому управлінні / С.Т. Пілецька. Управління стійким розвитком економіки: теоретичні і практичні аспекти: кол. моногр. За ред. д.е.н., проф. Прохорової В.В. - Х.: Видавництво Іванченка I.С., 2018. - C. $181-188$

260. Міщенко В.А., Концепція антикризового контролінгового вартісноорієнтованого менеджменту на підприємстві/ Домніна I.I., Міщенко В.А./ Збірник матеріалів IV Міжнародної науково-практичної конференції (м.Запоріжжя, 26 грудня 2020 року). Східноукраїнський інститут економіки та управління. Запоріжжя: ГО "СІЕУ", 2020. С.175-179.

261. Forgue B. Nouvelles approaches de la gestion des crises [Text] /B. Forgue // Rev francaise de gestion. - Paris, 1996. - Vol. 108. - P. 72-73.

262. Туленков М. Концепція понять «менеджмент» i «управління» в сучасному науковому дискурсі /. Туленков М./. Політичний менеджмент. 2009. №3. C.101-111 
263. Ареф’єва О.В., Кузенко Т.Б. Планування економічної безпеки підприємств. Київ : Вид-во Європ. ун-ту, 2004. 170 с.

264. Кракос Ю. Подход к оценке уровня финансовой составляющей экономической безопасности предприятия. Економіка. Фінанси. Право. 2006. № 12. C. $7-12$.

265. Донець Л. І., . Ващенко Н. В. Економічна безпека підприємства : навч. посібн. К: Центр учбової літератури, 2008. 240 с.

266. Бланк И. А. Управление финансовой безопасностью предприятия. К.: Эльга, Ника-центр, 2004. 784 с.

267. Фінансова безпека підприємств і банківських установ : моногр. / за заг. редакцією д-ра екон. наук, проф. А. О. Спіфанова. Суми: ДВНЗ «УАБС НБУ», 2009. 295 c.

268. Горячева К. С. Фінансова безпека підприємства, сутність та місце в системі економічної безпеки. Економіст. 2003. № 8. С. 65-67.

269. Кириченко О. А., Кудря І. В. Вдосконалення управління фінансовою безпекою підприємств в умовах фінансової кризи. Інвестиції: практика та досвід. 2009. № 10. С. 22-26.

270. Мандзіновська Х. О. Формування інформаційної бази для оцінки рівня фінансової безпеки підприємства. Наукові записки. (Українська академія друкарства). 2015. №2. 70-78.

271. Александров И. А. Оценка финансовой безопасности промышленного предприятия. Наукові праці Донецького державного технічного університету. 2002. № 46. C. 12-19.

272. Концепція економічної безпеки України / НАН України; Ін-т економ. прогнозування / В. М. Геєць (підгот). К.: Логос, 1999. 56 с.

273. Барановський О. Визначення показників фінансової безпеки. Економіка. Фінанси. Право. 1999. №8. С. 14-16.

274. Гладченко Т. М. Економічна безпека підприємницької діяльності. Актуальні проблеми міжнародних відносин. 2001. Вип. 26. С. 295-299. 
275. Дмитриева М. Ю. Безопасность финансового рынка России. URL: www.sbcinfo.ru.

276. Забродский В., Капустин Н. Теоретические основы оценки экономической безопасности отрасли и фирмы. Бизнес Информ. 2008. №15-16. C. 35-37.

277. Пойда-Носик Н. Н. Науково-методичні підходи до оцінки рівня фінансової безпеки підприємства. Теоретичні та практичні аспекти економіки та інтелектуальної власності. 2013. № 11. С. 288-292.

278. Rushchyshyn N., Nikonenko U., Kostak Z. Formation of financial security of the enterprise based on strategic planning. Baltic Journal of Economic Studies. 2017. Vol. 3, № 4. P. 231-237.

279. Халіна О. В. Ключові аспекти забезпечення фінансової безпеки підприємства. Бізнес Інформ. 2015. №1. С. 263-268.

280. Беззубко Л.В. Трудовий і кадровий потенціали: монографія / Л.В. Беззубко, Л.О. Гончарова, Б.І. Беззубко. - Донецьк: Норд прес, 2008.

281. Безсмертна В.В. Стратегічне управління кадровим потенціалом підприємства / В.В. Безсмертна // Экономика и управление, 2007. - № 3. - с. 4853.

282. Беляцкий Н.П. Управление персоналом : учеб. пособие / Н.П. Беляцкий, С.Е. Велесько, П. Ройш. - Мн.: Интерпрессервис, Экоперспектива, 2003.

283. Одегов Ю.Г. Аудит и контроллинг персонала : учебник / Ю.Г. Одегов, Т.В. Никонова. - М.: Издательство «Альфа-пресс», 2006.

284. Экономика труда: (социально-экономические отношения): Учебник / Под ред. Н.А. Волгина, Ю.Г. Одегова. - М.: Экзамен, 2004. - 736 с.

285. Бухалков М.И. Управление персоналом : развитие трудового потенциала : учеб. пособ. / М.И. Бухалков. - М.: ИНФРА-М, 2005. - (Высшее образование). - ISBN 5-16-002464-6 - с. 30-38.

286. Беззубко Л.В. Трудовий і кадровий потенціали: монографія / Л.В. Беззубко, Л.О. Гончарова, Б.І. Беззубко. - Донецьк: Норд прес, 2008. 
287. Рябоконь Н.П. Сучасні проблеми формування вітчизняного кадрового потенціалу / Н.П. Рябоконь, А.С. Деркач // Формування ринкових відносин в Україні : зб. наук. праць. - К.: НДЕІ, 2007. - Вип. 4 (71). - с. 173-180.

288. Коломоец Е.Н. Управление кадровым потенциалом организации / Е.Н. Коломоец [Електронний ресурс].- Доступен: <http://www.mail.ru/events/sfiro/articles/sec5/kolomoec.doc> - c. 140-144.

289. Лукашевич Н.П. Теория и практика самоменеджмента : учеб. пособие / Н.П. Лукашевич. - 2-е изд., испр. - К.: МАУП, 2002.

290. Слиньков В.Н. Персонал и его менеджмент : практические рекомендации / В.Н. Слиньков. - К.: КНТ, 2007.

291. Якуба М.М. Кадровий потенціал як ключовий елемент потенціалу підприємства в умовах глобалізації / М.М. Якуба, У.В. Павлюк // Науковий вісник НЛТУ України. - 2009. - Вип. 19.7. - с. 302-305.

292. Устойчивое экономическое развитие в условиях глобализации и экономики знаний: концептуальные основы теории и практики управления: научное издание; под ред. В. В. Попкова. М.: ЗАО «Издательство «Экономика», 2007. 295 c.

293. Бондаренко С.А. Теоретико-методологічні засади системного забезпечення стійкого інноваційного розвитку виробничих підприємств: дис. на здоб. наук.ступ. д.е.н. зі спеціальності 08.00.04, Одеса, 2018. 632 с.

294. Ilchenko V., Goryaschenko Y., Zhadko K., Nekhay O. Methodology of complex estimation level of socio-ecological and economic development of industrial regions of Ukraine. Problems and Perspectives in Management. Volume 17 Issue 2, 2019. P. 277-288.

295. Жадько К.С., Падерін І.Д., Гуртова Н.В. Теоретико-методологічні засади маркетингової діяльності на промислових підприємствах. Вісник економічної науки України. 2018. № 2 (35). С. 57-61.

296. Жидовська Н.М. Форми державної підтримки бурякоцукрового підкомплексу АПК. Матеріали II Міжнародної науково-практичної конференції (заочна форма) «Формування та перспективи розвитку підприємницьких 
структур в рамках інтеграції до європейського простору». Полтава, 2019. С. 180183.

297. Жидовська Н.М., Галац В.О. Основні напрями функціонування та регуляційних дій держави на ринку цукру. Трансформаційні зміни національної економіки в умовах євроінтеграції: збірник тез Міжнародної науково-практичної конференції . Дубляни, 2019. С.67-69.

298. Жидовська H.M. Economic mechanism of sugar and beet sub - complex of agribusiness and its improvement. Science and innovation: Collection of scientific articles. - Publishing house «BREEZE», Montreal, Canada, 2018. p. 15-18.

299. Конституція України. Основний закон. - К., 1996.

300. Закон України «Про державне прогнозування і розробку програм економічного і соціального розвитку України» // Голос України. - 2000, 5 травня. - № 79.

301. Закон України «Про захист населення і територій від надзвичайних ситуацій техногенного та природного характеру» від 16.09.2000 № 149.

302. Закон України «Про охорону навколишнього природного середовища». - К.: Відомості Верховної Ради України, 1991, № 41.

303. Кодекс законів про працю України з постатейними матеріалами/ за ред. В.М. Вакуленко - К.: Юрінком Інтер, 19998. - 1040 с.

304. Про охорону праці: Закон України від 14.10 .1992 р. №2694 - ХІІ// від. Вер. Ради України - 1992. - № 49. - с. 668.

305. Гнатієнко Г. М. Експертні технології прийняття рішень: монографія / Г. М. Гнатієнко, В. Є. Снитюк. - К.: ТОВ «Маклаут», 2008. - 444 с.

306. В.О. Михайлюк, Б.Д. Халмурадов Цивільна безпека, навчальний посібник, Київ, «Центр учбової літератури», 2019. -158 с.

307. Г.Г.Гогіташвілі, Є.Т. Карчевські, В.М. Лапін Управління охороною праці та ризиком за міжнародними стандартами, навчальний посібник, Київ: «Знання», 2007. - 368 с.

308. Цыгичко В. Н. Прогнозирование социально-экономических процессов / В. Н. Цыгичко. - М.: Финансы и статистика, 1986. - 207 с. 
309. Рекомендації щодо побудови системи управління охороною праці на виробництві. Наказ МНС № 398 від 27.06.2006 p.

310. Грабовецький Б.С. Особливості маркетингу нововведень наукоємних виробництв / Б.С. Грабовецький, С.В. Голодняк // Економіка і регіон: Науковий вісник Полтавського національного технічного університету ім. Юрія Кондратюка. - 2008. - № 2. - С. 152 - 155.

311. Добров Г.М. Экспертные оценки в научно-техническом прогнозировании / Г.М. Добров, Ю.В. Ершов, Е.И. Левин, Л.П. Смирнов. - К.: Наукова думка, 1974. - 160 с.

312. Геєць В.М. Моделі і методи соціально-економічного прогнозування: підручник / В.М. Геєць, Т.С. Клебанова, О.І. Черняк та ін. - Х.: ВД «ІНЖЕК», 2005. - 396c.

313. Бешелев С.Д. Математико-статистические методы экспертных оценок. 2-е изд., перераб. и доп. / С.Д. Бешелев, Ф.Г. Гурвич. - М.: Статистика, 1980. $263 \mathrm{c}$.

314. Zhuravska N. Environmental management of production processes in heating systems when receiving magnetic water in reagent-free method with the aim of environmentalization / P. Kulikov etc. // International Journal of Engineering and Technology (UAE). Vol. 7, No 3.2. - 2018. - pp.621 - 625.

315. Методичні рекомендації для проведення атестації робочих місць за умовами праці: із змінами і доповненнями, внесеними М-ва праці України, М-ва охорони здоров’я України від 22.03.1993 р, № 06-960. Право і практика. - 2000. - № $17 .-$ c. 62 .

316. Kulikov P. Modern Possibilities of Management of Technogenic-Natural Systems of Heat-Energy Objects of Industrial and Construction Industry / P. Kulikov, N.Zhuravska // In: V.Onyshchenko etc (eds) Proceedings of the 2-International Conference on Building Innovations. ICBI 2019. Lecture Notes in Civil Engineering,73. Springer. - pp. 115-121.

317. Karczewski J., Raczkowski B. Ocena rysyka zawodowego na stanowisku tokarz, freezer. - Gdansk, 2000. - 61 s. 
318. Karczewski Jerzy Tadeusz. Safety Science Group Delft University of Tecnology. System zarzadzania bezpieczenstwem pracy. - Gdansk, 2000. - 310 p.

319. Касьянов М.А. та інші, Цивільний захист, навчальний посібник, СНУ ім В.Даля, Луганськ, 2008. - с. 208.

320. Журавська Н. Є. Наукові принципи інтегрованого управління системами теплопостачання при використанні підготовки води в електромагнітних полях [Текст] / Н. С. Журавська // Будівельне виробництво: міжвідомчий наук. журнал. Серія: «Економіка» - К.: НДІБВ, 2020. - № 70. - с. 98-101.

321. Стефанович I.C., Стефанович П.І. Виробничий ризик з урахуванням системи управління охорони праці. Зб.наук.праць між.нар наук.прак. конф.-UDC 001.1 BBK 87 Abstracts of VIII International Scientific and Practical Conference Vancouver, Canada 15-17 April 2020 ISBN 978-1-4879-3791-1, Р, ст.846-849.

322. Китаев Н.Н. Групповые экспертные оценки / Н.Н. Китаев. - М: Знание, 1975. $-64 \mathrm{c}$.

323. Бриль К. Г. Опорний конспект лекцій з курсу «Туроперейтинг» для студентів всіх форм навчання напряму підготовки 242 «Туризм» - Чернігів: ЧНТУ, $2017-249$ c.

324. Дурович А.П. Маркетинг в туризме: Учебное пособие. - Минск: Новое знание, 2003. - 496 c.

325. Любіцева О.О. Методика розробки турів : навч. посіб. - К. : Альтерпрес, 2003. - 104 c.

326. Михайліченко Г.І. Практика організації туристичних подорожей : навч. посіб. - К.:КНТЕУ, 2003 р.-156 c.

327. http://www.arrivo.ru/germaniya/gornolyzhnyiy-kurort-oberiyoh.html

328. Бравар Жан-Луї. Ефективний аутсорсинг: Розуміння, планування та використання успішних аутсорсингових відносин / Бравар Жан-Луї, Морган Роберт; Пер. $з$ англ. -Дніпропетровськ. Баланс Бізнес Букс, 2007. - 288c.

329. Микало О.І. Підходи до визначення терміна «аутсорсинг»/ О.І. Микало // Економічний вісник НТУУ «КПІ». - Київ, 2010. - С.111-115. 
330. Hira Ron. Outsourcing America: What's behind Our National Crisis and How We Can Reclaim American Jobs? - New York: AMACOM, 2008. - P. 67-96.

331. Davies, Paul. What's This India Business?: Offshoring, Outsourcing, and the Global Services Revolution. - London: Nicholas Brealey International, 2004. Print.

332. Филина Ф.Н. Аутсорсинг бизнес-процесов. Проблемы и решения / Ф.Н. Филина. -М.: Гросс Медиа, 2008. - 85с.

333. Аникин Б.А. Аутсорсинг: создание высокоэффективных и конкурентоспособных организаций: учеб. пособие / под ред. Б.А. Аникина. - М.: ИНФРА-М, 2003. - 187c.

334. Загородній А. Г. Аутсорсинг та його вплив на витрати підприємства / А.Г. Загородній, Г.О. Партин // Фінанси України. - 2009. - № 9. - С.87-97.

335. Тищенко O.M. Аутсорсинг як фактор ефективності підприємств будівельної галузі / О.М. Тищенко, В.С. Хаустова // Проблеми економіки. -2012. - № 4. - C.129-135.

336. Кросс Дж. Аутсорсинг: British Petroleum's / Дж. Кросс // Гарвард Бизнес ревю. - № 73(3).

337. Ермошина Е.А. Что такое аутсорсинг? [Електронный ресурс] / Е.А. Ермошина. - Режим доступу: http: inkakhrun.ru/money.asp.

338. Handfield R. A brief history of outsourcing [Електронный ресурс] / R. Handfield. - Режим доступу: https://scm.ncsu.edu/scm-articles/article/a-briefhistory-of-outsourcing.

339. Матвій I.Є. Аутсорсинг в діяльності промислових підприємств: основні переваги та загрози / I.Є. Матвій // Прометей: регіональний збірник наукових праць з економіки. - Донецьк: ДЕГІ, 2008. - №1(25). - С.184-189.

340. Денисов С.Б. Концепция аутсорсингового менеджмента: актуальность и степень разработанности / С.Б. Денисов // Економика и управление . - 2012. № 7(92). - C.83-86.

341. Хейвуд Дж.Б. Аутсорсинг: в поисках конкурентных преимуществ / Дж.Б. Хейвуд; Пер. с англ. - М.: Изд. дом «Вильямс», 2004. - 176с. 
342. Календжян С.О. Аутсорсинг и делегирование полномочий в деятельности компаний / С.О. Календжян. - М.: Дело, 2003. - 272с.

343. Бойчук I.В. Аутсорсинг у маркетинговій діяльності підприємств / І.В. Бойчук [Електронний ресурс]. - Режим доступу: //http://www.rusnauka.com/30_OINXXI_2013/Economics/6_147161.doc.htm

344. Закарян I., Філатов I. Інтернет як інструмент Інтернет-маркетингу / I. Закарян, І. Філатов. - СПб.: ВНV, 2006. - 302 с.

345. Ринок дитячого одягу [Електронний ресурс]. - Режим доступу: http://sd.net.ua/2019/01/19/rynok-detskoy-odezhdy-vstupil-v-2019-soptimistichnym-nastroeniem.html

346. Офіційний сайт Інтернет-магазину «Luxik» [Електронний ресурс]. Режим доступу: https://luxik.ua/uk/o-nas4

347. Що таке лід реклами [Електронний ресурс]. - Режим доступу: https://aboutmarketing.info/internet-marketynh/shcho-take-lid/

348. Бутинець Ф.Ф. Теорія бухгалтерського обліку: Підручник / Ф.Ф. Бутинець. - Житомир: ПП "Рута", 2006. - 440 с.

349. Про бухгалтерський облік і фінансову звітність в Україні: Закон України від 16.07.1999 р. № 996-XIV // Національні положення (стандарти) бухгалтерського обліку. - Житомир: ЖІТІ, 2000. - 112 с.

350. Житний П. Системний аспект облікової політики / П. Житний // Бухгалтерський облік і аудит. - 2006. - № 1. - С.62-65.

351. Кондраков Н.П. Бухгалтерский учет: Учебное пособие / Н.П. Кондраков. - М.: ИНФРА-М, 2007. - 592 с.

352. Kyoto Protocol. The United Nations Framework Conventionon Climate Change. Retrieved from: http://unfccc.int/kyoto_protocol/items/ 3145.php (accessed 21 January 2021).

353. Ohliad 20-ii konferentsii storing Ramkovoii konventsii OON ta Kiotskoho protokolu [Review of the 20th Conference of the Parties to the UN Framework Convention and the Kyoto Protocol]. Working Group of Non-Governmental Environmental Organizations of Ukraine on Climate Change. Retrieved from: 
http://climategroup.org.ua/wp-content/uploads/2007/02/Lima_conference_review.pdf. (in Ukrainian) (accessed 23 January 2021).

354. Conference of the Parties, Twenty-first session Paris, 30 November to 11 December 2015. Durban Platform for Enhanced Action (decision 1/CP.17) Retrieved from: http://unfccc.int/resource/docs/2015/cop21/eng/109r01.pdf.। (accessed 03 February 2021).

355. Stratehiia staloho rozvytku "Ukraina - 2020" [Sustainable Development Strategy "Ukraine2020”]. Decree of the President of Ukraine No. 5/2015, 12.01.2015, Official Journal “Uriadovyi kurier”, 2015, No.6. (in Ukrainian)

356. Kolot A. (2013) Korporatyvna sotsialna vidpovidalnist: evoliutsia ta rozvytok teoretychnykh pohliadiv [Corporate social responsibility: evolution and development of theoretical views]. Economic theory: scientific journal, No.4, P. 5-27. (in Ukrainian)

357. Bashynskii T.V. (2014) Sotsialna vsdpovidalnist bankivskoho sektoru Ukraiiny [Social responsibility of the banking sector of Ukraine]. Scientific works of Kirovograd National Technical University. Economic sciences, Issue 25, P. 104-110. (in Ukrainian)

358. Lebedevych S.I., Novak U.P. (2012) Ekolohichnyi audit iak nevidiemnyi element nadannia bankivskyh kredytiv [Environmental audit as an integral part of providing bank loans]. Innovative economy. Ukrainian scientific and production journal, No. 11 (37), P. 222-226. (in Ukrainian)

359. Scaling up Finance for the Sustainable Development Goals: Experimenting with Models of Multilateral Development Banking. New York and Geneva (2018). Retrieved from: https://unctad.org/en/PublicationsLibrary/gdsecidc2017d4_en.pdf (accessed 25 January 2021).

360. Hrishnova O., Brintseva O. (2013) Vprovadzhennia ekolohichnii vidpovidalnosti v praktyku menedzmentu vitchyznianykh pidpryiemstv [Introduction of ecological responsibility in the practice of management of domestic enterprises]. Bulletin of Taras Shevchenko National University of Kyiv, No. 151, P. 12-13. (in Ukrainian) 
361. Smolennikov D.O. (2013) Rol ekolohichnoi vidpovidalnosti biznesu na shliakhu do staloho rozvytku [The role of environmental responsibility of business towards sustainable development]. Bulletin of Sumy State University, Economics Series, No. 4, P. 35-39. (in Ukrainian)

362. Demchenko I. Key approaches of financial stability of Ukraine / I. Demchenko // Збірник наукових праць Таврійського державного агротехнологічного університету (економічні науки). - 2014. - № 2. - С. 5-8. Режим доступу: http://nbuv.gov.ua/UJRN/znptdau_2014_2_2.

363. Demchenko I. V. Formation of financial potential of enterprise / I. V. Demchenko // Збірник наукових праць Таврійського державного агротехнологічного університету (економічні науки), - 2018. - № 1. - С. 140-145. - Режим доступу: http://nbuv.gov.ua/UJRN/znptdau_2018_1_21.

364. Демченко I.В. Переваги та ризики європейської інтеграції України. Матеріали III міжнародної науково-практичної конференції (м. Маріуполь, 9-10 жовтня 2019 р.). - Маріуполь ; Кривий Ріг : Вид. Р. А. Козлов, 2019. - с. 260-261. - Режим доступу: https://dsum.edu.ua/wp-content/uploads/2019/10/Konferentsiya2019-1.pdf\#page $=260$

365. I. Demchenko. O. Iatsukh. The problem of unprofitable activity of enterprises in Ukraine. Baltic Journal of Economic Studies, Vol. 4 (2018), No. 2 March, p. 64-69. URL: http://www.baltijapublishing.lv/index.php/issue/article/view/382

366. Дудчик О.Ю., Драна М.С., Кудлай Ю.С. (2014) Тенденції розвитку світового фінансового ринку та місце України в ньому [Trends in the development of the global financial market and Ukraine's place in it]. Економічні студії [Economic studies]. №4 (4), pp. 113-117.

367. Статистика зовнішнього сектору України [Statistics of the external sector of Ukraine]. URL: https://bank.gov.ua/ua/statistic/sector-external/data-sector-external

368. Bojchyk, I. M. (2016), Ekonomika pidpryiemstva [Enterprise economy], Kondor-Vydavnytstvo, Kyiv, Ukraine. 
369. Hrabovetskyj, B.Ye. (2000), Teoretychni i metodolohichni osnovy ekonomichnoho prohnozuvannia [Theoretical and methodological foundations of economic forecasting], VF TANH, Vinnytsia, available at: http://pulib.if.ua/part/9816

370. Ostrovs'kyj, P. I., Hostryk, O. M. and Dobrunik, T. P. (2012), Modeliuvannia ekonomichnykh protsesiv [Modeling of economic processes], ONEU, Odesa, Ukraine.

371. Babtnko A/ (2013) Ekonomichnyy terminolohichnyy slovnyk-dovidnyk [Economic terminological dictionary-reference book]. Dnipropetrovsk, Ukraine.

372. Havryliuk V. (2019) Osoblyvosti systemy upravlinnya kredytnymy ryzykamy na sil's'kohospodars'kykh pidpryyemstvakh [Features of the credit risk management system at agricultural enterprises ]. Naukovyy pohlyad: ekonomika ta upravlinnya - Scientific view: economics and management, 2 (64), 125-130.

373. Gavrilenko, V.O. Oleksyuk, I.V. (2008). Improvement of cash accounting at trade enterprises, Collection of scientific works of ChSTU. Series: Economic Sciences, Issue 21, pp. 151-154.

374. Zhezhel, Yu.V. (2010). Management of the formation of cash flows of enterprises in the wine industry: abstract of dis. for science. degree of Cand. econ. Science: special. 08.00.04 economy and management (by types of economic activity); Nat. University of Bioresources and Nature Management of Ukraine. Kyiv. 22-23 p.

375. Mayboroda, O.E. Mayboroda, O.V. Replyuk, O.V. (2017). Directions of cash flow management of the enterprise, Economy and Society. Issue 10, pp. 305-309.

376. Khalatur, S. (2017). Important provisions for the development of agriculture of Ukraine. Baltic Journal of Economic Studies, 3(2), 147-154. https://doi.org/10.30525/2256-0742/2017-3-2-147-154.

377. Khalatur S., Radzevicius G., Velychko L., Fesenko V., Kriuchko L. (2019) Global deoffshorization and its impact on the national and regional economies of eastern European countries. Problems and Perspectives in Management, 17(3), pp. 293305. URL: http://dx.doi.org/10.21511/ppm.17(3).2019.24

378. Khalatur, S., Trokhymets O., Karamushka O. (2020) Conceptual basis of tax policy formation in the globalization conditions. Baltic Journal of Economic Studies, 6(2), pp. 81-92. URL: https://doi.org/10.30525/2256-0742/2020-6-2-81-92 
379. Khalatur S., Khaminich S., Budko O., Dubovych O., Karamushka O. (2020) Multiple system of innovation investment decisions adoption with synergetic approach usage. Entrepreneurship and Sustainability, Vol. 7, Num. 4, pp. 2745-2763. http://doi.org/10.9770/jesi.2020.7.4(12).

380. Khalatur, S., Kriuchko, L., \& Sirko, A. (2020). World experience adaptation of anti-crisis management of enterprises in the conditions of national economy's transformation. Baltic Journal of Economic Studies, 6(3), 171-182. https://doi.org/10.30525/2256-0742/2020-6-3-171-182

381. Онищенко Ю.І. Проблеми формування ресурсної бази вітчизняних банків/Ю.І. Онищенко/Науковий Вісник Херсонського державного університету. - 2018. - Випуск 30, частина 2. - С. 84-89.

382. Lashchyk I., Bondarenko L. Theoretical approach to the banking crisis management model. 8th International Joint Youth Science Forum 'Litteris et Artibus' \& 13-th International conference «Young Scientists Towards the Challenges of Modern Technology»// The Materials, November 22-24, 2018. Lviv, Ukraine: Lviv Polytechnic National University, 327 pages (166-167).

383. Офіційний сайт НБУ [Електронний ресурс] / Національний банк України. - Режим доступу: https://bank.gov.ua/statistic/supervision-statist/datasupervision\#1

384. Бюлетень Національного банку України. — 2020. — № 1 [Електронний pecypc]/Національний банк України. — Режим доступу: www.bank.gov.ua.

385. Офіцій-ний сайт Державної служби статистики України [Електронний pecypc]. — Режим доступу : www.ukrstat.gov.ua.

386. Статистика Національного Банку України. - Офіційний сайт Національного Банку України URL: https://bank.gov.ua/statistic/.

387. Рейтинг стійкості банків за підсумками 4 кварталу 2020 року. - Мінфін: Фінансовий портал URL: https://minfin.com.ua/banks/rating/?date=2021-02-19.

388. Мороз Н. В., Бондаренко Л. П. Тенденції банківського кредитування в Україні // Міжнародний науковий журнал "Інтернаука". Серія: "Економічні науки". 2020. № 10. https://doi.org/10.25313/2520-2294-2020-10-6412 
389. Офіційний сайт Національного банку України URL: https://bank.gov.ua/ua/news/all/natsionalniy-bank-viznachiv-14-bankiv-sistemnovajlivimi

390. 1.Розпорядження КМУ “Про схвалення Концепції розвитку цифрової економіки та суспільства України на 2018-2020 роки та затвердження плану заходів щодо ії реалізації” №67 від 17 січня 2018p.

391. Проект “Цифрова адженда України - 2020 (“Цифровий порядок денний” - 2020) Концептуальні засади (версія 1.0)”, https://ucci.org.ua/uploads/files/58e78ee3c3922.pdf.

392. Офіційний сайт Національного банку України. Режим доступу : http://www.bank.gov.ua

393. Жекало Г.І. Цифрова економіка України: проблеми та перспективи розвитку. - Науковий вісник Ужгородського національного університету, 2019 р., вип.26, ч.1, http://www.visnyk-econom.uzhnu.uz.ua/ archive/26_1_2019ua/12.pdf.

394. Цифрова трансформація (цифровізація) регіонів України. Аналітична записка, http://academy.gov.ua/ pages/dop/198/files/4ba4c1b4-cefe-4f27-b58b3aee7c8cf152.pd

395. Балджи М.Д. Економічний ризик та методи його вимірювання: навч. посібник. Харьків: Промарт, 2015, 300 с.

396. Бланк И.А. Управление финансовыми рисками: учебный курс. К.: Ника-Центр, 2006. 448 с.

397. Івченко І.Ю. Економічні ризики: навч. посібник. К.: Центр навчальної літератури, 2004. 304 с.

398. Гуменюк В.Я., Міщук Г.Ю., Олійник О.О. Управління ризиками: навч. посіб. Рівне: НУВГП, 2010. 158 с.

399. Загородній А.Г., Пилипенко Л.М. Ризики аудиторської діяльності: методика виявлення й оцінювання: монографія. Львів: ЗУКЦ, 2010. 232 с.

400. Приймак I. Управління ризиком втрати фінансової стійкості підприємства в умовах невизначеності зовнішнього середовища. Формування ринкової економіки в Україні. 2009. Вип. 19. С. 413-419 


\section{SOCIO-ECONOMIC AND MANAGEMENT CONCEPTS}

401. Старостіна А.О. Кравченко В.А. Ризик-менеджмент: теорія та практика: навч. посібник. К., Видавництво «Кондор», 2009. 220 с.

402. Пікус Р.В. Управління фінансовими ризиками: навч. посібник. К.: Знання, 2010. 598 с.

403. Петряєва З.Ф. Методичне забезпечення управління фінансовими ризиками підприємства. Молодий вчений. 2018. №10(62). С.368-374.

404. Кузьмін О.С. Концепція та еволюція процесно-структурованого менеджменту. Економіка: реалії часу. 2012. № 2 (3). С. 7-16.

405. Кузьмін О.С., Волович О.Б. Система управління заборгованістю підприємства. Наукові праці Національного університету харчових технологій. 2013. № 50. C. 243-247.

406. Харакоз Л.В., Вдовіна А.С. Аналіз форм і методів управління дебіторською заборгованістю. Вісник Дніпропетровського університету. Серія: Економіка. 2008. № 1. С. 53-57.

407. Deep Shift Technology Tipping Points and Societal Impact. Survey Report, $\begin{array}{llll}\text { September } & 2015 . & \text { World } & \text { Economic }\end{array}$ http://www3.weforum.org/docs/WEF_GAC15_Technological_Tipping_Points_report _2015.pdf

408. Evans, D. (2011). The Internet of Things: How the Next Evolution of the Internet is Changing Everything. Cisco Internet Business Solutions Group. http://www.cisco.com/web/about/ac79/docs/innov/IoT_IBSG_0411FINAL.pdf (accesessed on 02.04.2021).

409. Karintseva O.I. Economic restructuring in Ukraine in view of destructive effect of enterprises on environment // International Journal of Ecological Economics and Statistics. 2017. Issue 4, Vol. 38. P. 1-11.

410. Melnyk, L., Dehtyarova, I., Kubatko, O., Karintseva, O., \& Derykolenko, A. (2019a). Disruptive technologies for the transition of digital economies towards sustainability. Economic Annals-XXI, 179(9-10), 22-30. doi: https://doi.org/10.21003/ea.V179-02 
411. Melnyk, L.Hr., Dehtyarova I.B., Kubatko O.V., Kharchenko M.O. Economic and Social Challenges of Disruptive Technologies in Conditions of Industries 4.0 and 5.0: the EU Experience. Mechanism of Economic Regulation. 2019b. \#4. P. 32-42. https://doi.org/10.21272/mer.2019.86.04

412. Melnyk, L., Kubatko, O., Dehtyarova, I. Industrial revolutions as the basis for sustainable economy forming: the EU experience and Ukrainian practice. OmniScriptum Publishing. Latvia. Riga. 2020. 199 p.

413. Schwab, K. (2017). The Fourth Industrial Revolution. Davos: World Economic Forum.

414. Sotnyk, I., Volk, O. Chortok, Y. (2013). Increase of ecological-economic efficiency of ICT as a resource saving innovative direction. Actual Problems of Economics. 9. 229-235.

415. Digital Transformation Initiative (DTI) [Electronic source]. - Access mode: http://reports.weforum.org/digital-transformation

416. Schwab K. The Fourth Industrial Revolution / K. Schwab. - Geneva: World Economic Forum, 2016. - 172 p.

417. Schultz T. Investment in Human Capital / T. Schultz // The American Review. - 1961. - 1. - pp. 1-17.

418. Becker G.S. Investment in Human Capital / G.S Becker // Journal of Political Economy. - 1962. - 70 (5). - pp. 9-49.

419. Vasilchenko V.S. Management of labor potential: textbook / V.S. Vasilchenko, A.M. Gtynenko, O.A. Grishnova, L.P. Kerb. - K.: KHNEU, 2005, - 403 p.

420. Khomych S. Historical development of the concept of intellectual capital / S. Khomych // Galician Economic Bulletin (economics and management of the national economy). - 2011. - №3 (32). - pp. 28-33.

421. Edvinsson, L. and Malone, M. S. (1997). Intellectual Capital: Realizing your Company's True Value by Finding Its Hidden Brainpower, Harper Business, New York.

422. Stuart T. Intellectual capital. The new wealth of organizations / T. Stewart; translated by V. Nozdrina. - M.: Pokoleniye, 2007. - 368 p. 
423. Bell D. The Coming of Post-Industrial Society: A Venture in Social Forecasting / D. Bell; translated under ed. by V.L. Inozemtseva. - M.: Academia, 1999. $-786 \mathrm{p}$.

424. Inozemtsev V.L. Beyond economic society / V.L. Inozemtsev. - M.: Academia, 1998. - 640 p.

425. Brooking E. Intellectual Capital: core asset for the third millennium / E. Brooking - SPb, 2001. - $288 \mathrm{p}$.

426. Strategic challenges of the XXI century to society and economy of Ukraine: in 3 volumes / ed. acad. NAS of Ukraine V.M. Geitz, Acad. NAS of Ukraine V.P. Seminozhenko, corresponding member NAS of Ukraine B.E. Kvasniuk. - K.: Phoenix, 2007. - Vol.1. - pp. 194 - 209.

427. Butnik-Siverskiy O. Intellectual capital (theoretical aspect) / O. ButnikSiversky // Intellectual capital - 2002. - № 1. - pp. 16-27.

428. Morozov O.F. The price of thought - intellectual capital: Monograph / Morozov O.F. - Donetsk: Yugo-Vostok, Ltd., 2005. - 352 p.

429. Komarov I. Intellectual capital / I. Komarov // Personal. - 2000. - № 5. - pp. $54-62$.

430. Stryzhak O. Formation of intellectual capital of the enterprise: author's ref. dis. ... cand. econ. science: special. 08.06.01 "Economics, organization and management of enterprises" / O. Stryzhak. H., 2004. - 23 p.

431. Eskindarov M. Development of corporate relations in the modern Russian economy / M. Eskindarov. - M.: Respublica, 1999. - 188 p.

432. Leontiev B.B. The price of intelligence. Intellectual capital in Russian business / B.B. Leontiev - M .: "Shareholder", 2002. - 200 p.

433. Kendyukhov O. Organizational and economic mechanism of management of intellectual capital of the enterprise: author's ref. dis. ... Dr. econ. science: special. 08.00.04 "Economics and management of enterprises (processing industry)" / O. Kendyukhov. - Donetsk, 2007. - 31 p. 
434. Vasylyk A.V. Formation of strategy of management of intellectual capital of the enterprise / A.V. Vasylyk // Scientific Bulletin of Poltava University of Economics and Trade. Series: Economic Sciences. - 2010. - № 4 (2). - pp. 127-132.

435. Pinyak I. Intellectual assets as an effective resource for economic development of the enterprise / I. Pinyak // Galician Economic Bulletin. - 2009. - № 1. - pp. 33-40.

436. Karpenko A.V. Development of intellectual assets of human potential: theory and practice: monograph / A.V. Karpenko. - Zaporizhzhia: individual enterpreneur V.M. Mokshanov, 2018. -510 p.

437. Martynenko M.V. Quantitative approach to determining the impact of intellectual assets on the results of innovation activities of enterprises / M.V. Martynenko // Actual problems of economy. - 2014. - № 6. - pp. 520-529.

438. Корпоральность и развитие. Сборник трудов по философии корпоративного развития / под ред. О.Б.Алексеева и О.И.Генисаретского. - Вып. 2. - М.: Изд-во «Европа», 2007. - 352 с.

439. Boons, F. Business models for sustainable innovation: State-of-the-art and steps to- wards a research agenda / F. Boons, F. Luedeke-Freund // J. Clean. Prod. 2013. - Vol. 45. - P. 9-19.

440. Поспелова И.Н. Инвестиционное обеспечение устойчивого развития сельского хо- зяйства // Экономика и бизнес: теория и практика. - 2018. - №102. - C. 53-57.

441. Судас, Л.Г. Маркетинговые исследования в социальной сфере / Л.Г. Су дас. - М.: ФГУ: Инфра-М, 2004.- 272 с.

442. Data-driven innovation for growth and well-being. URL: https://www.oecd.org/sti/ieconomy/data-driven-innovation.htm (дата звернення: 31.03.2021).

443. Progress Apama Complex Event Processing (CEP). URL: https://www.tadviser.ru/index.php/\%D0\%9F\%D1\%80\%D0\%BE\%D0\%B4\%D1\%83 \%D0\%BA\%D1\%82:Progress_Apama_Complex_Event_Processing_(CEP) (дата звернення: 31.03.2021). 
444. Касян І.Ю. Банківська система за умов становлення та розвитку цифрової економіки/ Інноваційні банківські технології та сучасні форми грошей : матеріали наук.- практ. конф. студ. аспір. і молод. учених. Київ, 05 квітня 2018 р. - К. : КНЕУ, 2018. - C. 24-27.

445. Сідельник О.П. Впровадження сучасних технологій продажу банківських продуктів / О.П. Сідельник, Євтух Л.Б.// Збірник тез XV міжнародної науково-практичної конференції «Інтеграція України в європейський і світовий простір». / Лівіський навчально-науковий інститут ДВНЗ «Університет банківської справи». - Львів, 2020. - С.125-127.

446. Ткаченко Ю. В. Сучасні технології як основа інноваційної моделі розвитку банківського бізнесу / Ю. В. Ткаченко, Л. А. Зверук // Економічна теорія та право. - 2018. - № 2. - С. 26-41. - Режим доступу: http://nbuv.gov.ua/UJRN/Vnyua_etp_2018_2_4.

447. На що перетворяться банки до 2030 року [Електронний ресурс]. Режим доступу: https://www.epravda.com.ua/publications/2019/09/19/651791/

448. Брагінець Я.С. Інноваційні технології в банківській системі США/ Інноваційні банківські технології та сучасні форми грошей : матеріали наук.практ. конф. студ. аспір. і молод. учених. Київ, 05 квітня 2018 р. - К. : КНЕУ, 2018. - C. 41-43.

449. Ministry of Economic Development and Trade of Ukraine (2013), Order "On approval of Methodological recommendations for calculating the level of economic security of Ukraine", available at: http://www.me.gov.ua/Documents/List?lang=ukUA\&tag=MetodichniRekomendatsii

450. The Verkhovna Rada of Ukraine (2020), The Law of Ukraine "About insurance", available at: www.rada.gov.ua

451. National Commission for the State Regulation of Financial Services Markets (2020), "Information on the state and development of the Ukrainian insurance market", available at: https://nfp.gov.ua/

452. Tretiak, K. V. (2016), "Reinsurance market in Ukraine: formation and development prospects", Abstract of $\mathrm{PhD}$ in Economics dissertation, Money, finance 
and credit, Kyiv National Economic University the name of Vadim Hetman, Kyiv, Ukraine.

453. Базилевич В. Д. Страхові послуги. Підручник у 2 ч. Ч.1.К.: Логос, 2014. $424 \mathrm{c}$.

454. Зиль П. Цифрова трансформація банківського обслуговування i платіжної системи. Банківський вісник. 2017. № 11/652. С. 51-55.

455. Гринчишин Я. М. Прокопюк А. В. Стан та перспективи розвитку страхового ринку України. Молодий вчений. 2017. № 3. С. 622-626.

456. Ольвінська Ю. О., Селезньов О.І. Конкурентоспроможність національної економіки як фактор інвестиційної привабливості. Вісник соціально-економічних досліджень: зб. наук. праць. Одеський держ. екон. ун-т. Одеса. 2014. Вип. 17. С. 295-301.

457. Динаміка страхового ринку України.URL: http://forinsurer.com/(дата звернення: 22.03.2021).

458. World Investment, Report 2020: International production beyond the Pandemic URLhttps://unctad.org/system/files/official document/wir2020_en.pdf

459. Kalyuzhna N., Khodzhaian A., Nebotov P. The WTO toolkit in regulating interstate trade and economic cooperation// Naukovyi Visnyk Natsionalnoho Hirnychoho Universytetu. - 2020. - № 2(176). - C. 160-166.

URL https://nvngu.in.ua/jdownloads/pdf/2020/02/02_2020_Kalyuzhna.pdf

460. Worlds Investment Report (2011) Non-equity modes of international production and development / Ed. by Y. Zhan. Switzerland URL https://unctad.org/system/files/official-document/wir2011_en.pdf

461. Casella, B., R. Bolwijn, D. Moran and K. Kanemoto (2019). "Improving the analysis of global value chains: the UNCTAD-Eora database". Transnational Corporations, 26(3):115-142

462. Duginets G., Koval V., Plekhanova O., Antonov A., Petrova M. On the supranational and national level of global value chain management // Entrepreneurship and Sustainability Issues. - 2019. - Volume 6. - Number 4 (June). - P.1922-1937. DOI:https://doi.org/10.9770/jesi.2019.6.4(27) 
463. Altomonte C. Business Groups as Hierarchies of Firms: Determinants of Vertical Integration and Performance / C. Altomonte, A. Rungi., 2013. - 50 c. (Fondazione Eni Enrico Mattei (FEEM)

464. Melnik, T., Kudyrko, L., \& Samsonova, L. (2019). Contractual relations in the new economic competition strategies of TNCS. Baltic Journal of Economic Studies, 5(3), 116-124. URL: https://doi.org/10.30525/2256-0742/2019-5-3-116-124

465. ASEAN Investment Report 2019 [English] - FDI in Services: Focus on Health Care (UNCTAD/ASEAN/AIR2019) 31 Oct 2019 URL https://unctad.org/webflyer/asean-investment-report-2019

466. Buonafede, F., G. Felice, F. Lamperti and L. Piscitello (2018). "Additive Manufacturing and Global Value Chains: an Empirical Investigation at the CountryLevel", in van Tulder, R., A. Verbeke and L. Piscitello. International Business in the Information and Digital Age (Progress in International Business Research, Vol. 13), Emerald Publishing, pp. 295-323.

467. Non-Equity Modes of Operation in ASEAN Promoting new forms of trade between Japan and ASEAN URL https://www.asean.or.jp/ja/wpcontent/uploads/sites/2/NEM_Philippines_Paper-7.pdf

468. Elia, S., S. Massini and R. Narula (2019). "Disintegration, modularity and entry mode choice: Mirroring technical and organizational architectures in business functions offshoring". Journal of Business Research, 103: 417-431

469. Hospodarskyi kodeks Ukrainy vid 16.01.2003 № 436-IV. Data onovlennia 21.07.2020. URL: https://zakon.rada.gov.ua/laws/card/436-15 (data zvernennia 03.01.2021).

470. Hospodarskyi protsesualnyi kodeks Ukrainy vid 06.11.1991 № 1798-XII. Data onovlennia 19.06.2020. URL: https://zakon.rada.gov.ua/laws/show/1798-12 (data zvernennia 03.02.2021).

471. Hutsalenko L.V., Mykhalchyshyna L.H., Sydorchuk V.M., Pentiuk I.K.. Sudovo-bukhhalterska ekspertyza: navch. posibnyk. K.: Tsentr uchbovoi literatury, 2011. $352 \mathrm{~s}$. 
472. Dondyk N.Ia. Spetsialni bukhhalterski znannia ta yikh zastosuvannia pid chas rozkryttia ta rozsliduvannia ekonomichnykh zlochyniv: monohrafiia. K.: Atika, 2007. 144 s.

473. Zavora T. M.Topol. I. S. Metodychne zabezpechennia sudovobukhhalterskoi ekspertyzy. Ekonomika i rehiony : naukovyi visnyk Poltavskoho natsionalnoiu tekhnichnoho universytetu im. Yuriia Kondratiuka. 2008. № 4. S. 149 151.

474. Kodeks Ukrainy z protsedur bankrutstva vid 18.10.2018 № 2597-VIII. Data onovlennia 16.09.2020. URL: https://zakon.rada.gov.ua/laws/show/2597-19 (data zvernennia 01.03.2021).

475. Kryminalnyi Kodeks Ukrainy vid 05.04.2001 № 2341-III. Data onovlennia 03.09.2020. URL: https://zakon.rada.gov.ua/laws/show/2341-14 (data zvernennia 03.03.2021).

476. Kryminalno-protsesualnyi kodeks Ukrainy vid 03.04.2012 № 4651-VI. Data onovlennia 21.07.2020. URL: https://zakon.rada.gov.ua/laws/show/4651-17. (data zvernennia 04.03.2021).

477. Panasiuk V.M., Burdeniuk T.H. Metodyka portfelnoho analizu konkurentospromozhnosti pidpryiemstva / Stan i perspektyvy rozvytku oblikovoinformatsiinoi systemy v Ukraini: materialy VI Mizhnar. nauk.-prakt. konf., 22 travnia 2020 r. Tom 1. Ternopil: TNEU. 2020, C.164-166

478. Panasiuk V.M., Boichak M. V. Vyznachennia sutnosti finansovoho stanu ta finansovoi zvitnosti pidpryiemstva v systemi obliku / Oblik, opodatkuvannia i kontrol: teoriia ta metodolohiia: materialy mizhnarodnoi naukovo- praktychnoi internetkonferentsii (m. Ternopil, 23 hrudnia 2020 r.) - Ternopil: ZUNU, 2021. S.19-22

479. Ponikarov V. D. Sudovo-ekonomichna ekspertyza : navch. posib. X. : VD «INZhEK», 2005. $224 \mathrm{~s}$.

480. Pro bukhhalterskyi oblik i finansovu zvitnist v Ukraini. Zakon Ukrainy vid 16.07.1999 № 996-XIV. Data onovlennia 14.07.2020. https://zakon.rada.gov.ua/laws/show/996-14 ( data zvernennia 11.03.2021). 
481. Pro zatverdzhennia Zmin do Poriadku provedennia analizu finansovohospodarskoho stanu subiektiv hospodariuvannia derzhavnykh pidpryiemstv i pidpryiemstv, u statutnomu kapitali yakykh chastka derzhavnoi vlasnosti perevyshchuie piatdesiat vidsotkiv, ta pidhotovky na zapyty sudu, prokuratury abo inshoho upovnovazhenoho orhanu vysnovkiv pro naiavnist oznak fiktyvnoho bankrutstva, dovedennia do bankrutstva, prykhovuvannia stiikoi finansovoi nespromozhnosti, nezakonnykh dii u razi bankrutstva. Nakaz Ministerstva yustytsii $\begin{array}{lllll}\text { Ukrainy } & \text { vid } & 12.09 .2014 \mathrm{r} \text { № } & \text { 1530/5. } & \text { URL: }\end{array}$ http://zakon2.rada.gov.ua/laws/show/z1124-14 (data zvernennia 27.03.2021).

482. Pro zatverdzhennia instruktsii pro osoblyvosti zdiisnennia sudovo-ekspertnoi diialnosti atestovanymy sudovymy ekspertamy, yaki ne pratsiuiut u derzhavnykh spetsializovanykh ekspertnykh ustanovakh. Nakaz Ministerstva yustytsii Ukrainy vid 24.12.2003 r. № 170/5. Data onovlennia 10.11.2020. URL: http://zakon2.rada.gov.ua/laws/show/z1431-11 (data zvernennia 22.03.2021).

483. Pro zatverdzhennia instruktsii pro pryznachennia ta provedennia sudovykh ekspertyz ta ekspertnykh doslidzhen. Nakaz Ministerstva yustytsii Ukrainy vid 08.10.1998 № 53/5. Data onovlennia 24.02.2020. URL: http://zakon3.rada.gov.ua/laws/show/z0705-98/page (data zvernennia 21.03.2021).

484. Pro zatverdzhennia metodyky intehralnoi otsinky investytsiinoi pryvablyvosti pidpryiemstv ta orhanizatsii. Nakaz Ahentstva z pytan zapobihannia bankrutstvu pidpryiemstv ta orhanizatsii vid 23.02.98r. № 22 URL: https://zakon.rada.gov.ua/laws/show/z0214-98 ( data zvernennia 28.03.2021).

485. Pro zatverdzhennia metodyky provedennia pohlyblenoho analizu finansovoho-hospodarskoho stanu pidpryiemstv ta orhanizatsii. Nakaz Ahentstva z pytan zapobihannia bankrutstvu pidpryiemstv ta orhanizatsii vid 27. 06.97 r. № 81 . URL: https://zakon.rada.gov.ua/laws/show/z0288-97 (data zvernennia 12.03.2021).

486. Pro zatverdzhennia metodychnykh rekomendatsii shchodo vyiavlennia oznak neplatospromozhnosti pidpryiemstva ta oznak dii z prykhovuvannia bankrutstva, fiktyvnoho bankrutstva chy dovedennia do bankrutstva. Nakaz Ministerstva 
ekonomiky Ukrainy vid 19.01.2006 № 14. Data onovlennia 26.10.2010. URL: https://zakon.rada.gov.ua/rada/show/v0014665-06 (data zvernennia 12.03.2021).

487. Pro zatverdzhennia Natsionalnoho polozhennia (standartu) bukhhalterskoho obliku 1 «Zahalni vymohy do finansovoi zvitnosti». Nakaz Ministerstva finansiv Ukrainy vid 07.02.13. № 73. Data onovlennia 31.05.2019r. URL: http://zakon4.rada.gov.ua/laws/show/z0336-13 (data zvernennia 11.03.2021)

488. Pro zatverdzhennia Polozhennia pro poriadok zdiisnennia analizu finansovoho stanu pidpryiemstv, shcho pidliahaiut pryvatyzatsii. Nakaz Ministerstva finansiv Ukrainy, Fondu derzhavnoho maina Ukrainy vid 26.01.2001 r. № 49/121. Data onovlennia 04.01.2013. URL: http://zakon2.rada.gov.ua/laws/show/ru/z0121-01 (data zvernennia 02.03.2021).

489. Pro zatverdzhennia Poriadku provedennia analizu finansovo-hospodarskoho stanu subiektiv hospodariuvannia derzhavnykh pidpryiemstv i pidpryiemstv, u statutnomu kapitali yakykh chastka derzhavnoi vlasnosti perevyshchuie piatdesiat vidsotkiv, ta pidhotovky na zapyty sudu, prokuratury abo inshoho upovnovazhenoho orhanu vysnovkiv pro naiavnist oznak fiktyvnoho bankrutstva, dovedennia do bankrutstva, prykhovuvannia stiikoi finansovoi nespromozhnosti, nezakonnykh dii u razi bankrutstva. Nakaz Ministerstva yustytsii Ukrainy vid 26.02.2013. № 327/5. Data onovlennia 12.09.2014. URL: https://zakon.rada.gov.ua/laws/show/z0331-13\#n14 (data zvernennia 28.03.2021).

490. Pro sudovu ekspertyzu v kryminalnykh i tsyvilnykh spravakh Postanova Plenumu Verkhovnoho Sudu Ukrainy vid 30.05.1997r. № 8. Data onovlennia 25.05.1998. URL: http://zakon2.rada.gov.ua/laws/show/v0008700-97 (data zvernennia 22.03.2021).

491. Pro sudovu ekspertyzu: Zakon Ukrainy vid 25.02.1994 № 4038-XII. Data onovlennia 14.11.2019. URL: https://zakon.rada.gov.ua/laws/show/4038-12 (data zvernennia 14.03.2021).

492. Seredynska V.M., Zahorodna O.M., Fedorovych R.V. Ekonomichnyi analiz: navch. posibnyk; za red. prof.. R.V.Fedorovycha. Ternopil: Vydavnytstvo Aston, 2010. $416 \mathrm{~s}$. 
493. Tsyvilno-protsesualnyi kodeks Ukrainy vid 18.03.2004 № 1618-IV. Data onovlennia 14.07.2020. URL: https://zakon.rada.gov.ua/laws/show/1618-15. (data zvernennia 27.03.2021).

494. Shvets V.Ie. Osnovy bukhhalterskoho obliku ta sudovo-bukhhalterskoi ekspertyzy: pidruchnyk. K.: Karavela, 2008. 240 s.

495. Горбач Л.М., Плотніков О.В. Глобалізація: світова економіка та українські реалії: монографія. - Київ: Видавничий дім «Кондор», 2020. - 224 с. C.100-108.

496. IMF. World Economic Outlook: Policy Support and Vaccines Expected to Lift Activity. - International Monetary Fund. - January 2021. - P.4. - [Електронний pecypc].

доступу: https://www.imf.org/en/Publications/WEO/Issues/2021/01/26/2021-world-economicoutlook-update.

497. Hanson J.A., Honohan P., Majnoni G. Globalization and National Financial Systems: Issues of Integration and Size // Globalization and National Financial Systems. Edited by Hanson J.A., Honohan P., Majnoni G. - Washington D.C., New York: The World Bank, Oxford University Press, 2003. - 296 p. - P.3-4.

498. Плотніков О.В. Проблеми оптимізації взаємовідносин України 3 міжнародними фінансовими організаціями // Актуальні проблеми міжнародних відносин: [зб. наук. праць]; Київський національний університет імені Тараса Шевченка; Інститут міжнародних відносин. - 2004. - Вип. 46. - Ч. І. - С. $21-25$.

499. Плотніков О.В., Іголкін І.В. Вплив доходів бюджету на формування стабілізаційного фонду: світовий досвід // Фінанси України. - 2006. - № 7. - С.311.

500. Плотніков О.В. Розвиток протиріч країн «Великої сімки» в контексті фінансової глобалізації // Економіка України. - 2020. - № 3. - С. 19-25.

501. Новий тлумачний словник української мови в 4-х томах/ укладачі В.В. Яременко, О.М. Сліпушко. К. : «Аконіт», 2001. 911 с. 
502. Большой экономический словар / под. ред. А.Н. Азрина. М.: Институт новой экономики, 2004. 881 с.

503. Філософський енциклопедичний словник / за ред. В. І. Шинкарука. К.: «Абріс», 2002. 742 с.

504. Гераклит Эфесский: все наследие: на языках оригинала и в русс. пер.: крат. изд. / Подгот. С.Н. Муравьев. М.: ООО "Ад Маргинем Пресс", 2012. 416 с

505. Аристотель. Категории. Сочинения: в 4 т. / Аристотель. М.: Мысль, 1978. T. 2. C. $53-90$.

506. Античная философия: Энциклопедический словарь / Отв. ред. М. А. Солопова. М.: Прогресс-Традиция, 2008. 896 с.

507. Касьян B.I. Категорії "рух" і "розвиток" у філософії. URL: http://westudents.com.ua/glavy/94698-27-kategor-quotruhquotquotrozvitokquot-uflosof.htm (дата звернення: 15.08.2020).

508. Великий тлумачний словник сучасної української мови / Уклад. і голов. ред. В.Т. Бусел. К.: Ірпінь: ВТФ "Перун", 2009. 1736 с.

509. Гегель Г.В.Ф. Наука логики. Т.1 // Энциклопедия философских наук / Г.В.Ф. Гегель. М.: Мысль, 1974. 452 с.

510. Історія економіки та економічної думки. Навч. Посібник / за ред. В. Степаненка. К.: КНЕУ. 2010. 743c.

511. Маркс К. Сочинения. М.: Политиздат, 1974. Т. 42.535 с.

512. Ленин В.И. Полное собрание починений. 5 изд. Т. 26. М.: Издательство Политической Литературы. 1969. 590 с.

513. Кларк Дж. Б. Распределение богатства / пер. с англ. М.: Гелиос АРВ, 2000. $336 \mathrm{c}$.

514. Шумпетер Й. Теория экономического развития (Исследование предпринимательской прибыли, капитала, кредита, процента и цикла конъюнктуры) / пер. с англ. М.: Прогресс, 1982. 456 с.

515. Мельник Л.Г. Экономика развития: учебник. Сумы: Университетская книга, 2013. 784 с 
516. Hurwicz L. Mechanism design Theory. URL: http://nobelprize.org/nobel_pri zes/economics/laureates/2007//ecoadv07.pdf. (дата звернення: 25.08.2020).

517. Adaptivny`e vozmozhnosti i mekhanizmy` gorodskogo vodoprovodnokanalizaczionnogo predpriyatiya. Dy`mchenko E.V., Gajdenko S.N., Khajlo T.O. The $3 \mathrm{rd}$ International scientific and practical conference "Science and education: problems, prospects and innovations" (December 2-4, 2020) CPN Publishing Group, Kyoto, Japan. 2020. p. 328-334.

518. Dymchenko O.V., Khailo Ya.M., Khailo T.O. Pidpryiemnytska stratehiia innovatsiinoho rozvytku i reformuvannia komunalnykh pidpryiemstv mista. Dymchenko O.V., Khailo Ya.M., Khailo T.O. Materialy mizh.nar. konferentsii «Current trend sinthe development of science and practice». Khaifa. 15-16 chervnia 2020.S.115-120.

519. Dymchenko O.V., Khailo T.O. Transformatsiia analitychnykh doslidzhen u funktsiiakh upravlinnia. Dymchenko O.V., Khailo T.O. Suchasnyi stan i perspektyvy rozvytku obliku, analizu ta finansovoho zabezpechennia pidpryiemstv ahropromyslovoho vyrobnytstva: materialy Mizhnar. nauk.-prakt. konf., 12 - 13 lystopada 2020 r. / Kharkiv. nats. ahrar. un-t im. V.V. Dokuchaieva. - Kharkiv: KhNAU, 2020. - 270 s.

520. Evolutionary view of the formation of crisis processes at housing and utility enterprises. Olena Dymchenko, Olena Panova, Olga Rudachenko/ Proceeding of the 12 th International Scientific Conference. Public Economics And Administration 2017. Ostrava, Czech Republic. 2017. 391 p.

521. Shvets, Yu. O. \& Hryhorovych, L. S. (2017). Environmental tax as an instrument of the economy of nature use. Economics and Society. Vol. 10. pp. $488-$ 493.

522. Najdenko, O. Ye. (2017) Problems of environmental taxation and ways to solve them. Economy and society. Vol. 8, pp.627-633.

523. Mishenin Ye.V. \& Yarova I.Ye. (2019) Systematic assessment of the effectiveness of environmental taxation in the context of socio-ecological and economic security of spatial development. Balanced nature management. Vol. 1. pp. 
41- 46. DOI: https://doi.org/10.33730/2310-4678.1.2019.170589 URL: https://essuir.sumdu.edu.ua/handle/123456789/82524

524. Lalaeva, V. M. (2002). Tax regulators of environmental safety of transition economy of Ukraine: author's abstract. Dis ... Cand. Econ. Sciences: 08.04.01 / Kharkiv National University by Karazin. Kharkiv, 20 p.

525. Mandryk, V. O. \& Novak, U. P. (2016) Environmental tax in Ukraine: foreign experience, current realities, directions of improvement. Bulletin NLTU of Ukraine. Vol. 26.6. pp. 20 - 26.

526. Mulyk, T. O. (2011) Tax levers of ecological security of the state. Bulletin of scientific works of VNAU. Series: Economic Sciences. Vol. 1(48). pp. $142-147$.

527. Khvesik, M. A., Bystryakov, I. K. \& Klinovoy, D. V. (2016) Spatial organization and directions for the use of natural resources in Ukraine. Economy of Ukraine. Vol. 7. pp. $46-65$.

528. Osipov, Yu. M. (1994) Foundations of the theory of the economic mechanism. Moscow: Moscow State University Publishing House, 368 p.

529. Lyashenko, V. I., Kosheleva, E. G. \& Tolmacheva, A. F. (2008) Mechanisms for regulating the development of small business in Ukraine: monograph. Donetsk: LLC "Yugo-Vostok, Ltd". 495 p.

530. Mishenin, Ye. (2012) Conceptual foundations of the formation of an environmentally oriented mechanism for ecological management. Economist. Vol. 3. pp. $59-65$.

531. Belyaev, A. A. (1990) The mechanism of management: the essence and forms of management. Kiev: Vischa shk., 147 p.

532. Yarova, I. Ye. (2020) Strategic guidelines for state regulation of the effectiveness of environmental taxation in the system of national security of spatial development. State and regions. Series: Economics and Entrepreneursh. Vol. 5 (116), pp. 91-97. URL: https://essuir.sumdu.edu.ua/handle/123456789/82490

533. Mishenin, Ye. V. \& Yarova, I. Ye. (2019) Methodology of formation of economic and socio-ecological indicators of economic activity in the context of national security. Emergence of public development: financial and legal aspects // Yu. 
Pasichnyk and etc.: [Ed. by Doctor of Economic Sciences, Prof. Pasichnyk Yu.]: Collective monograph. Agenda Publishing House, Coventry, United Kingdom, 737 p. (137-151). URL: https://essuir.sumdu.edu.ua/handle/123456789/82557

534. Marekha I., Yarova I. \& Samusevych Y. (2020) Environmental tax policy in the European Union: on the way to inclusive growth. Inclusive Growth: basics, indicators and development priorities: monograph / edited by T. Vasilyeva, S. Lyeonov. Publishing House: Centre of Sociological Research. pp. 259-279. DOI: 10.14254/97883-959336-0-8/2020 URL: https://essuir.sumdu.edu.ua/handle/123456789/80021

535. Mishenin Ye., Yarova, I. \& Koblianska I. (2020) Ecologically Harmonized Agricultural Management for Global Food Security. In Jhariya, M. K., Meena, R. S., Banerjee, A. (Eds.) Ecological Intensification of Natural Resources for Sustainable Agriculture. Springer Nature Singapore Pte Ltd. ISBN 978-981-334-202-6. DOI: 10.1007/978-981-33-4203-3

URL: https://essuir.sumdu.edu.ua/handle/123456789/82768

536. Цілі сталого розвитку та Україна. Урядовий портал. URL: https://www.kmu.gov.ua/diyalnist/cili-stalogo-rozvitku-ta-ukrayina.

537. Про Цілі сталого розвитку України на період до 2030 року : Указ Президента від 30 вер. 2019 p. № 722/2019. URL: https://zakon.rada.gov.ua/laws/show/722/2019\#Text.

538. Про рішення Ради національної безпеки і оборони України від вересня 2020 року «Про Стратегію національної безпеки України»: Указ Президента України від 14 вересня 2020 року № 392/2020. URL: https://www.president.gov.ua/documents/3922020-35037.

539. Третяк Г. С., Бліщук К. М. Державне регулювання економіки та економічна політика : навч. пос. Львів : ЛРІДУ НАДУ, 2011. 128 с.

540. Мельник В. В. Державне регулювання господарської діяльності в умовах сучасної економічної політики України. Глобальні та національні проблеми економіки. 2018. Вип. 23. С. 88 - 90.

541. Ясько Ю. І. Еволюція теоретичних поглядів на роль держави в економіці. Теоретико-методологічні трансформації економічної науки у XXI ст. : 
перспективи нової парадигми: матеріали Всеукр. наук.-практ. конф. (Київ, 28-29 трав. 2019 р.). Київ : НТЕУ, 2019. С. 120 - 123.

542. Бліщук К. М. Інструменти державного впливу на регіональний економічний розвиток. Демократичне врядування. 2010. Вип. 5.

543. Bouckaert G. Modernizing the Rechtsstaat: Paradoxes of the Management Agenda / G. Bouckaert. — Berlin : Duncker \& Humblot, 2002. - P. 26.

544. Чернов С. І. Текст лекцій з дисципліни "Публічне адміністрування" /C. I. Чернов, С. О. Гайдученко; Харк. нац. ун-т міськ. госп-ва ім. О. М. Бекетова. Х. : ХНУМГ,2014. - С. 7.

545. Волков А. М. Публичное управление недропользованием в России (современныйпериод) / А. М. Волков // Правовая инициатива. — 2013. — № 7. - C. 15.

546. Алферов Ж. И. Власть без мозгов. Отделение науки от государства /Ж. И. Алферов. - М. : Алгоритм, 2013. — 250 с.

547. Атаманчук Г. В. Теория государственного управления / Г. В. Атаманчук. учеб. изд. / под общ. ред. Г. В. Атаманчука. — 2-е, доп. и перераб. — М. : Изд-во РАГС, 2007. - С. 107.

548. Михальчишина Л. Г. Стратегія вдосконалення ринку цінних паперів в Україні. Науковий вісник Національного університету біоресурсів і природокористування України. Серія: Економіка, аграрний менеджмент, бізнес. 2016. Вип. 249. С. 306-314.

549. Полюхович В. Удосконалення правового регулювання фондового ринку України з урахуванням вимог документів міжнародних організацій. Юридична Україна. 2010. № 12. С. 57-60.

550. Ромашко О. Ю. Роль державного регулювання фондового ринку в подоланні кризових явищ. Моніторинг. 2008. № 3. С. 9-13.

551. Серебрякова Л. А. Мировой опыт регулирования рынка ценных бумаг. М.: Финансы, 2006. № 4. С. 10-16.

552. Кравчук Я. С. (2005). Геоморфологія Скибових Карпат. .Львів : Видавн. центр ЛНУ ім. Івана Франка. 232 с. 
553. Рудько Г., Кравчук Я. (2002). Інженерно-геоморфологічний аналіз Карпатського регіону України. Львів. 172 с.

554. Герасимов И. П. (1969). Структурные черты рельефа земной поверхности на территории СССР и их происхождение. М. : Изд-во АН СССР. $100 \mathrm{c}$.

555. Боруцька Ю., Сахнюк І., Телегуз О. [та ін.] (2014). Геохімічна характеристика поверхневих вод басейну р. Стрий в умовах техногенезу. Ресурси природних вод Карпатського регіону (Проблеми охорони та раціонального використання): XIII міжнарод. наук.-практ. конф., 29-30 травня 2014 р.: матеріали доповідей. Львів. С. 44-47.

556. Линник П. Н., Набиванец Б. И. (1986) Формы миграции металлов в пресных водах. Л. : Гидрометеоиздат. 272 с.

557. Статистичний збірник "Діяльність суб'єктів великого, середнього, малого та мікропідприємництва", 2019. Режим доступу: https://sme.gov.ua /wpcontent/uploads/2020/12/2_State_Statistics_Service_of_Ukraine_Activity_of_ent itis _ 2019.pdf

558. Медведєва О.М. Особливості малих інноваційних підприємств в аспекті управління проектами та концепції корпоративної соціальної відповідальності / О.М. Медведєва, А.В. Свдокимова // Управління проектами та розвиток виробництва: Зб.наук.пр. - Луганськ: вид-во СНУ ім. В.Даля, 2009. № 3 (31). - С. 120-130. - Режим доступу: http://www.pmdp.org.ua/images/Journal/ 31/09momksv.pdf

559. Власова К. В. Корпоративна соціальна відповідальність - основа інноваційного розвитку підприємств АПК України. Економічний аналіз. Тернопіль, 2018. Том 28. № 3. С. 247-251.

560. Соціальна відповідальність бізнесу: розуміння та впровадження [Електронний ресурс]. - Режим доступу : http://www.brc.undp.org.ua.

561. Кирчата I.M. Соціальна відповідальність як інструмент забезпечення конкурентоспроможності підприємства / Кирчата I.M., Шершенюк O.M. / Проблеми і перспективи розвитку підприємництва: Збірник наукових праць 
Харківського національного автомобільно-дорожнього університету. Харків, 2019. №2 (23). C.46-56.

562. Демкина К. А. Роль профсоюзов в повышении корпоративной социальной ответственности // Бизнес-образование в экономике знаний, №2, 2018. С.26-29.

563. Ковальчук В. Г. Соціальна відповідальність бізнесу як невід’ємна складова загальнодержавного управління / В. Г. Ковальчук, М. І. Вербицький // Фінансово-кредитна діяльність: проблеми теорії та практики. - 2016. - № 2(21). - C.257-263.

564. European Commission. A Clean Planet for All A European Strategic LongTerm Vision for a Prosperous, Modern, Competitive and Climate Neutral Economy; COM(2018) 773 Final; European Commission: Brussels, Belgium, 28 November 2018.

565. Кулик М.Н. Пересмотр возможностей моделей равновесных цен и выпусков в теории межотраслевого баланса. Проблеми загальної енергетики. 2016. № 47. C. 5-22.

566. Математическая экономика на персональном компьютере / Кубонива М. и др. - М.: Финансы и статистика, 1991. С. 179-188.

567. Картер А. Структурные изменения в экономике США. - М.: Статистика, 1974. С. 150-191.

568. Леонтьев В.В. Исследование структуры американской экономики: теоретический и эмпирический анализ по схеме: затраты-выпуск / пер. с англ. М.: Госстатиздат, 1958. 639 с.

569. Леонтьев В.В. Межотраслевая экономика. - М.: Экономика, 1997. 479 c.

570. Кулик М.Н. Новые модели равновесных цен в теории межотраслевого баланса. Проблеми загальної енергетики. 2018. № 52. С. 12-23.

571. Beaujolin, F. (2017). La gestion des compétences. Études de cas commentés. Gestion des ressources humaines, Cahiers № 128. Paris: Nathan Université. - 143 p.

572. Denimal, P. (2016). Classification, qualification, compétences: Pour des actions sur l'organisation et le dialogue social. Éditions: Liaisons, P. - 254 p. 
573. Tresanini, M. (2016). Évaluer les compétences: du recrutement à la gestion de carrière, Éditions Management Société, collection Pratiques d'Entreprises, P. - 275 p.

574. Heal, G. (2005) Corporate Social Responsibility: An Economic and Financial Framework. The Geneva Papers on Risk and Insurance Issues and Practice, 30, 387-409. URL: http://dx.doi.org/10.1057/palgrave.gpp.2510037

575. Sullivan, John D. The Moral Compass of Companies: Business Ethics and Corporate Governance as Anti-Corruption Tools. IFC Corporate Governance FOCUS publication; no. 7. Washington, D.C. : World Bank Group, 2009. P. 13.

576. Yemets, О. Сучасне поняття моралі та моральності. Науковий вісник Національної академії внутрішніх справ. 2018. 107(2), 96-104. URL: https://scientbul.naiau.kiev.ua/index.php/scientbul/article/view/855

577. Котлер Ф. Основы маркетинга. Краткий курс : пер с англ. М: Издательский дом «Вильямс», 2007. 656 с.

578. Пучкова С. І. Методи підвищення етичного рівня бізнес-організації. Ефективна економіка. 2019. № 12. URL: http://www.economy.nayka.com.ua. DOI: 10.32702/2307-2105-2019.12.107

579. Середа Н. М., Бурцева О. Є., Фоміченко І. П. Маркетингові аспекти корпоративної соціальної відповідальності компанії // Міжнародний науковий журнал "Інтернаука". Серія: "Економічні науки". 2020. №9. URL: https://doi.org/10.25313/2520-2294-2020-9-6283

580. Харченко Т. О. Соціально-відповідальний маркетинг як основа розвитку підприємсв. Ефективна економіка. 2019. № 6. URL: http://www.economy.nayka.com.ua/?op=1\&z=7135. DOI: $\quad 10.32702 / 2307-2105$ 2019.6.64

581. Aspinall and As'ad (2016). Understanding Family Politics: Success and Failures of Political Dynasties in Regioanal Indonesia. South East Asia Research, 116, SAGE

582. Choi, Nankyung (2014). Local Politics Elites in Indonesia: Risers and Holdovers. Sojourn Journal of Social Issues in Southeast Asia, 29-2:364-407. 
583. Hadiz, V. R. (2010). Localising Power in Post-Authoritarian Indonesaia: A Southeast Asia Perspective. Stanford, CA: Stanford University Press.

584. Ito, Kunio, 1991. "The Effects of M\&A Activity on Company Value in Japan and the United States: A Comparative Study," Hitotsubashi Journal of commerce and management, Hitotsubashi University, vol. 26(1), pages 1-14, December.

585. Jeffrey A. Winters.(2011). Oligarchy. CLAY G. WESCOTT. URL: https://doi.org/10.1111/j.1468-0491.2011.01547_3.x

586. Rachlin H. Behavioral economics without anomalies. Journal of the Experimental Analysis of Behavior. 1995 Nov; 64(3): 397-404. URL: https://www.ncbi.nlm.nih.gov/pmc/articles/PMC1350146/\#: :text=Behavioral\%20ec onomics $\% 20$ is $\% 20$ often $\% 20$ conceived,superimposed $\% 20$ on $\% 20$ a $\% 20$ rational $\% 20$ sy stem.\&text=It $\% 20$ incorporates $\% 20$ so-

called\%20anomalies, outcomes\%20of\%20nonexponential\%20time\%20discounting.

587. Kuhn, T.S. The Structure of Scientific Revolutions (Chicago: University of Chicago Press, 1962) ISBN 0-226-45808-3. URL: https://plato.stanford.edu/entries/thomas-kuhn/

588. Cherry Kendra, Swaim Emily. How Hindsight Bias Affects How We View the Past. Verywellmind. May 06, 2020. https://www.verywellmind.com/what-is-ahindsight-bias-2795236

589. Sharot Tali. The optimism bias: a tour of the irrationally positive brain. 2012. URL: https://www.theguardian.com/science/2012/jan/01/tali-sharot-the-optimismbias-extract

590. Cherry Kendra, Shereen Lehman. Understanding the Optimism Bias. AKA the Illusion of Invulnerability. Cognitive psychology. May 10, 2020. URL: https://www.verywellmind.com/what-is-the-optimism-bias-2795031

591. Langer, Ellen J. Mindfulness. Reading, Mass. : Addison-Wesley Pub. Co. 1989. 262 p. URL: https://archive.org/details/mindfulnessamerl00elle/mode/2up

592. Taylor, Shelley E.; Brown, Jonathon D. Illusion and well-being: A social psychological perspective on mental health. Psychological Bulletin. 1988. 103 (2). P. 
193-210. URL: http://taylorlab.psych.ucla.edu/1988_Illusion and well-being_A social psychological perspective on mental health.pdf

593. Cherry Kendra. Availability Heuristic and Decision Making. Verywellmind. November, 2019. URL: https://www.verywellmind.com/availability-heuristic2794824

594. Keynes J. M. In A treatise on money. London, UK : Macmillan 1930.

595. Baddeley Michelle. Herding, social influence and economic decisionmaking: socio-psychological and neuroscientific analyses. Philos Trans R Soc Lond B Biol Sci. 2010 Jan 27; 365(1538): 281-290. URL: https://www.ncbi.nlm.nih.gov/pmc/articles/PMC2827453/

596. Іващенко М. В. Панічна економічна поведінка в Україні як прояв споживчої ірраціональності. Соціально-економічні проблеми сучасного періоду України. 2015. Випуск 2. С. 109-112.

597. Алле Морис. Поведение рационального человека в условиях риска: критика постулатов и аксиом американской школы. Перевод к.э.н. И. А. Егорова. THESIS, 1994, вып. 5. С. 217-241.

598. Талер Річард, Санстейн Кас. Поштовх. Як допомогти людям зробити правильний вибір / пер. з. англ.. Ольга Захарченко. Київ : Наш формат, 2017. 312 c.

599. Сорос Джордж. Сорос о Соросе. Опережая перемены: Пер. с англ. Москва: ИНФРА-М, $1996 . \quad 336 \quad$ c. https://www.phantastike.com/exchange/soros_on_soros/pdf/

600. Edwards W. Conservatism in Human Information Processing. - New York: John Wiley \& Sons, 1968.

601. Tversky, Amos \& Kahneman, Daniel, 1992. Advances in Prospect Theory: Cumulative Representation of Uncertainty. Journal of Risk and Uncertainty, Springer, vol. $5(4)$, pages 297-323, October.

URL: https://ideas.repec.org/a/kap/jrisku/v5y1992i4p297-323.html 